PNL- 8148

DE93 003479

\title{
Hanford Site Environmental Report for Calendar Year 1991
}

Scientific Editors

R. K. Woodruff

R. W. Hanf

Technical Editor

R. E. Lundgren

June 1992

Prepared for

the U.S. Department of Energy

under Contract DE-AC06-76RLO 1830

Pacific Northwest Laboratory

Richland, Washington 99352

Battelle

OISTRIGUTIUN OF THIS OOCUMENT IS

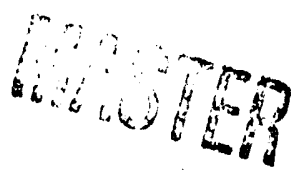




\section{Preface}

U.S. Department of Energy (DOE) Order 5400.1, "General Environmental Protection Program," establishes the requirement for environmental protection programs. These programs ensure that DOE operations comply with applicable federal, state, and local environmental laws and regulations, executive orders, and department policies. The DOE Richland Field Office (RL) has established a plan for implementing this order, United States Department of Energy-Richland Operations Office Environmental Protection Implementation Plan (Brich 1991); this plan is updated annually.

The Hanford Site Environmental Report is prepared annually pursuant to DOE Order 5400.1 to summarize environmental data that characterize Hanford Site environmental management performance and demonstrate compliance status. The report also highlights significant environmental programs and efforts. More detailed environmental compliance, monitoring, surveillance, and study reports may be of value; therefore, to the extent practical, these additional reports have been referenced in the text.
Although this report is written to meet DOE reporting requirements and guidelines, it is also intended to meet the needs of the public. The Summary has been written with a minimum of technical terminology. The Helpful Information section lists acronyms, abbreviations, conversion information, and nomenclature useful for understanding the report.

This report is prepared for the RL Technical Support Division as an activity of the Hanford Environmental Surveillance and Oversight Program, Pacific Northwest Laboratory, Office of Hanford Environment. Pacific Northwest Laboratory is operated for DOE by Battelle Memorial Institute. Battelle Memorial Institute is a not-for-profit independent contract research institute.

Inquiries regarding this report may be directed to the RL Technical Support Division, P.O. Box 550, Richland, Washington 99352, or to Pacific Northwest Laboratory, Office of Hanford Environment, P.O. Box 999, Richland, Washington 99352 


\section{Summary}

The Hanford Site Environmental Report is prepared annually to summarize environmental data and information, describe environmental management performance, and demonstrate the status of compliance with environmental regulations. The report also highlights major environmental programs and efforts.

The report is written to meet reporting requirements and guidelines of the U.S. Department of Energy (DOE) and to meet the needs of the public. This summary has been written with a minimum of technical terminology. The section entitled Helpful Information can also aid in reading and interpreting the body of the report.

The following sections:

- describe the Hanford Site and its mission

- summarize the status in 1991 of compliance with environmental regulations

- describe the environmental programs at the Hanford Site

- present information on environmental surveillance and the ground-water protection and monitoring program

- discuss activities to ensure quality.

More detailed information can be found in the body of the report and in the cited references.

\section{The Hanford Site and its Mission}

The Hanford Site in southcentral Washington State is about $1,450 \mathrm{~km}^{2}$ ( $\left.560 \mathrm{mi}^{2}\right)$ of semiarid snrub-steppe located just north of the confluence of the Snake and Yakima rivers. This land, with restricted public access, provides a buffer for the smaller areas historically used for the production of nuclear materials, waste storage, and waste disposal. About $6 \%$ of the land area has been disturbed and is actively used. This $6 \%$ is divided into operational areas:

- the $100-\mathrm{B} / \mathrm{C}, 100-\mathrm{D}, 100-\mathrm{F}, 100-\mathrm{H}, 100-\mathrm{K}$, and $100-\mathrm{N}$ Areas, which lie along the Columbia River in the northern portion of the Hanford Site

- the 200-East and 200-West Areas, which lie in the center of the Hanford Site nea: the basalt outcrops of Gable Mountain and Gable Butte

- the 300 Area, near the southern border of the Hanford Site

- the 400 Area, between the 300 and 200 Areas (home of the Fast Flux Test Facility)

- the 1100 Area, a corridor northwest of the city of Richland used for vehicle maintenance and other support activities.

The 600 Area is the designation for land between the other operational areas.

The Hanford Site was acquired by the federal government in 1943 and was dedicated for more than 20 years primarily to the production of plutonium for national defense and the management of the resulting wastes. In the following years, missions were diversified to include research and development in the areas of energy, wasie management, and environmental restoration.

The DOE has ended the production of nuclear materials at Hanford for weapons. The mission being implemented by the DOE Richland Field Office (RL) includes:

- waste management

- environmental restoration

- research and development

- technology development. 


\section{Summary}

Current waste management activities at the Hanford Site include primarily managing wastes with high and low levels of radioactivity (from the defense activities) in the 200-East and 200West Areas. Key waste management facilities include the waste storage tanks, Plutonium Uranium Extraction (PUREX) Plant, Plutonium Finishing Plant, Central Waste Complex, Low-Level Burial Ground, B Plant, and 242-A Evaporator. In addition, used fuel is stored in the $100-\mathrm{K}$ fuel storage basins.

Environmeital restoration includes activities to decontaminate and decommission facilities and to clean up or restore inactive waste sites. The Hanford surplus facilities program conducts surveillance and maintenance of such facilities, and has begun to clean up and dispose of more than 100 facilities. Current activities include decommissioning of the 201-C strontium semiworks and the 183-H solar Evaporation Basins.

Research and technology development activities are also conducted on the Hanford Site in the 200,300, and 4.00 Areas and an administrative area south of the Hanford Site boundary. Many of these activities are intended to improve the techniques and reduce the costs of waste management, environmental protection, and Site restoration.

Operations and activities on the Hanford Site are managed by RL through four prime contractors and numerous subcontractors. Each contractor is responsible for the safe, environmentally sound maintenance and management of its facilities and operations, waste management, and monitoring of operations and effluents for environmental compliance.

The principal contractors include:

- Westinghouse Hanford Company

- Battelle Memorial Institute

- Kaiser Engineers Hanford

- Hanford Environmental Health Foundation.

Non-DOE operations and activities include commercial power production by the Washington
Public Power Supply System's WNP-2 reactor (near the 400 Area) and commercial low-level radioactive waste burial by U.S. Ecology (near the 200 Areas). Siemens Nuclear Power Corporation operates a commercial nuclear fuel fabrication facility, and Allied Technology Group Corporation operates a low-level radioactive waste decontamination, supercompaction, and packaging disposal facility adjacent to the southern boundary of the Hanford Site.

\section{Compliance With Environ- mental Regulations}

The DOE Order 5400.1, "General Environmental Protection Program," describes the environmental standards and regulations applicable at DOE facilities. These environmental standards and regulations fall into three categories: 1) DOE directives, 2) federal legislation and executive orders, and 3) state and local statutes, regulations, and requirements. The following subsections sum marize the status of Hanford's compliance with these applicable regulations and list environmental occurrences for 1991.

A key element in Hanford's compliance program is the Hanford Federal Facility Agreement and Consent Order ('Tri-Party Agreement). 'The TriParty Agreement is an agreement among the U.S. Environmental Protection Agency (EPA), Washington State Department of Ecology (Ecology), and DOE for achieving the compliance with the remedial action rovisions of the Comprehensive Environmental Response, Compensation, and Liability Act (CERCLA) lincluding Superfund Amendments and Reauthorization Act (SARA) I and with treatment, storage, and disposal unit regulation and corrective action provisions of the Resource Conservation and Recovery Act (RCRA).

\section{Compliance Status}

This section summarizes the activities conducted to ensure that the Hanford Site is in compliance with environmental protection regulations. 


\section{Comprehensive Environmental Response, Compensation, and Liability Act}

The CERCLA established a program to ensure that sites contaminated by hazardous substances are cleaned up by responsible parties or the government. The SARA broadened CERCLA and established provisions for federal facilities.

The preliminary assessments conducted for the Hanford Site revealed approximately 1,100 known individual waste sites where hazardous substances may have been disposed of in a manner that requires further evaluation to determine impact to the environment.

The DOE is actively pursuing the remedial investigation/feasibility studies (RI/FS) process at some operable units on the Hanford Site. The selection of the operable units currently under investigation is a result of Tri-Party Agreement negotiations. All milestones related to the RI/FS process established for 1991 were achieved, and Hanford was in compliance with these CERCLA/ SARA requirements. This takes into consideration several milestones delayed through the change request process.

\section{Emergency Planning and Community Right-To-Know Act}

The Emergency Planning and Community RightTo-Know Act provides the public with information about hazardous chemicals in the community and establishes emergency planning and notification procedures to protect the public from a release. Subtitle A of the law calls for creation of state emergency response commissions to guide planning for chemical emergencies. State commissions have also created local emergency planning committees to ensure community participation and planning.

The 1990 Hanford Tier Two Emergency and Hazardous Chemical Inventory (DOE 1990a) was issued March 1, 1991, to the State Emergency Response Commission, local county ernergency management committees, and local fire department. The report contained information on hazardous materials in storage across the Hanford Site. Accordingly, during 1991, the Hanford Site was in compliance with the reporting and notification requirements contained in this Act.

\section{Resource Conservation and Recovery Act}

The RCRA establishes regulatory standards for the generation, transportation, storage, treatment, and disposal of hazardous waste. Ecology has been authorized by the EPA to implement its dangerous waste program in lieu of the EPA for Washington State, except for some provisions of the Hazardous Solid Waste Amendments of 1984. Ecology also implements the state's regulations, which are often more stringent.

At the Hanford Site, 63 treatment, storage, and disposal (TSD) units have been identified that must be permitted or closed in accordance with RCRA and Washington State regulations. The TSD units are required to operate under Ecology's interim status compliance requirements. Approximately one-half of the units will be closed.

The Tri-Party Agreement provides the framework for meeting RCRA requirements. Fortyseven of the forty-eight milestones scheduled for 1991 were completed, although some were delayed as approved through the change request process. At the end of 1991, 136 Tri-Party Agreement milestones had been completed on or ahead of schedule over the previous 3 years.

In December 1990, Ecology issued a Notice of Noncompliance to RL regarding the return of 68 drums of packaged waste to the generating site, the 183-H Solar Evaporation Basins. The drums were returned to the Central Waste Complex in January 1991. The inspection, repackaging, and shipping of the 68 drums was completed without any safety-related incidents.

A Part B permit application for the Hanford Site was submitted to the regulators for review in October 1991. As of the end of December 1991, no comments had been received on this submittal.

Quarterly RCRA ground-water sampling was suspended at the Hanford Site in May 1990 when the site analytical services contract with United 
States 'Testing, Ine., was terminated. A special one-time sampling was conducted at selected wells during February and March 1991. This limited effort obtained ground-water data during the period of extended negotiation to replace the analytical services contract. Full-scale RCRA ground-water monitoring activities resumed in June 1991 when an interim contract was established with International Technologies Corporation for analyzing ground-water samples. Fifty ground-water monitoring wells were constructed at seven RCRA TSD facilities in 1991.

Subtitle I of RC:RA deals with regulation of underground storage tank systems. These regulations were added to RCRA by the Hazardous and Solid Waste Amendments of 1984. The EPA has developed regulations imposing technical standards for tank performance and management, including standards governing the cleanup and closure of leaking tanks. These regulations do not apply to the single- and double-shell nuclear waste tanks, which are regulated as TSD facilities.

During 1991, four abandoned tanks located in the 3000 Area were removed and disposed of. Additionally, one gasoline tank was removed from the $100-\mathrm{N}$ Area when a gas station was closed. A total of $14 \mathrm{tank} /$ piping systems were tested. Five systems failed and were taken out of servire.

\section{Clean Air Act}

The purpose of the Clean Air Act is to protect public health and welfare by safeguarding air quality, bringing polluted air into compliance, and protecting clean air from degradation. In Washington State, the provisions of the act are implemented by EPA, Washington State Department of Health $(\mathrm{DOH})$, and local air authorities.

The Hanford Site is operated under a Prevention of Significant Deterioration permit (No. PSDX80-14) issued by the EPA in 1980. The permit sets specific limits for emissions of nitrogen oxides from the Plutonium Uranium Extraction (PUREX) and Uranium Oxide (UO, ${ }_{3}$ ) plants.
The DOH, Division of Radiation Pi stection, has promulgated regulatory controls for radioative air emissions under Section 116 of the Clean Air Act. Washington State regulations ('WAC: 246247) require registration of all radioactive air emission point sources with the DOH. All significant Hanford Site stacks emitting radiation have been registere $d$ in accordance with applicable regulations.

Revised Clean Air Act requirements for radioactive air emissions were issued December 15 , 1989, under National Emission Standards for Hazardous Air Pollutants (NESHAP) 40 (CFR 61, Subpart H. Emissions from the Hanford Site are well within the new EPA offsite emissions standard of $10 \mathrm{mrem} / \mathrm{yr}$ leffective dose equivalent s see Glossary)l. However, Hanford Site sources do not yet meet the new procedural requirements for flow measurement, emissions measurement, quality assurance, and sampling documentation. The RL received a 2-year extension of the Subpart $\mathrm{H}$ requirements until December 15 , 1991. Negotiations are ongoing.

Pursuant to the NESHAP program, EPA has developed regulations specifically addressing asbestos emissions 40 CFR 61, Subpart M. These regulations apply at Hanford in building demolition/disposal and waste disposal operations. During $1991,1,160 \mathrm{~m}^{3}\left(1,517 \mathrm{yd}^{3}\right)$ of asbestos were removed.

The local air authority, the Tri-Counties Air Pollution Control Authority, enforces General Regulation 80-7. This regulation pertains to detrimental effects, fugitive dust, incineration products, odor, opacity, asbestos, and sulfur oxide emissions. The Authority has also been delegated responsibility to enforce the EPA asbestos regulations under NESHAP. The Site remains in compliance with the regulations.

Hanford Site contractors have prepared Facility Effluent Monitoring Plans (FEMPs) specific to various facilities across the Site. The FEMPs include sections that outline compiiance with $40 \mathrm{CFR} 61$ (atmospheric emissions). The preparation of FEMPs was completed in late 1991. A 
summary of each FEMP has been incorporated into a sitewide environmental monitoring plan covering effluent monitoring and environmental surveillance.

\section{Clean Water Act}

The Clean Water Act applies to all discharges to waters of the United States. At the Hanford Site, the regulations are applied through a National Pollutant Discharge Elimination System (NPDES) permit governing effluent discharges to the Columbia River. The NPDES permit (No. WA-000374-3) specifies discharge points (called outfalls, of which there are eight), effluent limitations, and monitoring requirements.

There were four reportable conditions in 1991. Problems were experienced in measuring the flow at Outfall 003 in the $100-\mathrm{K}$ Area. With low flows, rust from the associated piping accumulates in the meters. The design of the system was evaluated, and changes were made to alleviate the problem.

The $\mathrm{pH}$ permit limit was exceeded in the 100-N Area (Outfall 009). The cause of the exceedance was thought to be inlet water with a high $\mathrm{pH}$. Action was taken to isolate the inlet water from the outfall. The 100-K Area outfall (Outfall 004) total suspended solids (TSS) analysis was not performed within the 7-day regulatory sample holding time. Procedures were reviewed with operations personnel.

Quarterly sampling results normally reported in April for an $\mathrm{N}$ reactor outfall were delayed. The wrong test well was sampled and a new sample and analysis had to be conducted.

\section{Safe Drinking Water Act}

The National Primary Drinking Water Regulations of the Safe Drinking Water Act apply to the drinking water supplies at the Hanford Site. These regulations are enforced by the DOH. During 1991, sanitary water was supplied on the Hanford Site by 15 individual drinking water systems. All water systems were in compliance with the requirements of the applicable regulations.

\section{Toxic Substances Control Act}

The application of Toxic Substances Control Act requirements to Hanford essentially involves regulation of $\mathrm{PCBs}$. The Hanford Site is currently in compliance with regulations for nonradioactive PCBs. Effective nationwide treatment and disposal capacity and technologies have not been developed for radioactive PCB waste. These wastes are being stored with EPA approval, pending development of treatment and disposal technologies and capabilities.

\section{Federal Insecticide, Fungicide, and Rodenticide Act (FIFRA)}

The EPA is responsible for ensuring that a chemical, when used according to label instructions, will not present unreasonable risks to human health or the environment. The FIFRA and the Revised Code of Washington 17.21, "Washington Pesticide Application Act," as implemented by WAC 16-228, General Pesticides Regulations, apply to storage and use of pesticides. The Hanford Site is in compliance with the Act's requirements and WAC $16-228$ regulations pertaining to storage and application of pesticides.

\section{Endangered Species Act}

A few rare species of native plants and animals are known to oc zur on the Hanford Site. Some of these are listed by the U.S. Fish and Wildlife Service as en dangered or threatened (federally listed). Others are listed by the Washington State Department of Wildlife as endangered, threatened, or sensitive species. The Site monitoring program is discussed in Section 3.3, "Environmental Studies and Programs." Hanford activities complied with the Endangered Species Act in 1991.

\section{National Historic Preservation Act, Ar- chaeological Resources Protection Act, and American Indian Religious Freedom Act}

Cultural resources on the Hanford Site are subject to the provisions of the National Historic Preservation Act and the Archaeological Resources Protection Act. Compliance with these 
Acts is accomplished through a monitoring program which is described in Section 3.3, "Environmental Studies and Programs." In 1991, Hanford operations complied with these Acts.

\section{National Environmental Policy Act (NEPA)}

The NEPA establishes environmental policy to provent or eliminate damage to the environment and to enrich our understanding of ecological systenis and natural resources. The NEPA requires that major federal projects with significant impacts be carefully reviewed and reported to the public in environmental impact statements (EISs). Other NEPA documents such as environmental assessments are also prepared in accordance with NEPA requirements.

Several EISs related to programs or activities on the Hanford Site are in process or in the planning stage. These are:

- Draft Environmental Impact Statement, Decommissioning of Eight Surplus Production Reactors at the Hanford Site, Richland. Washington

- Programmatic Environmental Impact Statement for the Office of Environmental Restoration and Waste Management Program

- Weapons Complex Modernization Programmatic EIS.

NEPA assessments also included information on floodplain management and protection of wetlands.

\section{Environmental Occurrences}

Onsite and offsite environmental ocurrences (spills, leaks, etc.) of radioactive and nonradioactive effluent materials during 1991 were reported to DOE as specified in DOE Order 5000.3A and to other federal and state agencies as required by law. All emergency, unusual, and off-normal occurrence reports, including event descriptions and corrective actions, are available for review in the RL Public Reading Room, Washington. There were no emergency occurrences reported in 1991.
A large number of off-normal environmental occurrence reports were filed at Hanford during 1991, covering everything from spills of automotive battery acid to leaks from overheated motor vehicle cooling systems. Because of the volume of reported off-normal occurrences, event summaries are not included here.

The 1991 unusual occurrences with the most potential for environmental impact and their occurrence numbers are:

- Release of Contaminated Well Water to the Ground (RL-PNL-P14BOPER-19911004)

- Diesel Fuel Spill (RL-WHC-WHC100ERD1991-1002)

- Radiation Contamination (RL-WHC-PFP1991-1020)

- Purgewater Discharge to the Ground (WHC91-0008-183H).

\section{Environmental Programs}

Environmental programs were conducted at Hanford to restore environmental quality, manage waste, develop appropriate technology for cleanup activities, and study the environment. These programs are discussed below.

\section{Environmental Restoration}

The environmental restoration program has been established to clean up inactive waste sites and decontaminate and decommission surplus facilities. Two major programs will implement these actions:

- environmental restoration remedial action program

- Hanford surplus facilities program.

The environmental restoration remedial action program was established to comply with regulations for characterizing and cleaning up of inactive waste sites. The program specifically includes identification and characterization of 
inactive sites, cleanup design and action, and post-closure activities of inactive radioactive, chemically hazardous, and mixed waste sites. A number of operable units (clusters of waste sites) hive been created. Remedial investigations are being conducted at 16 operable units to determine the need for remediation at these units. Expedited Response Actions were initiated on three individual wastes sites: the 618-9 Burial Ground, the 300 Area Process Trenches, and the 200-West Area carbon tetrachloride site. More than 40 drums containing over $5,678 \mathrm{~L}(1,500$ gal) of solvent and uranium were removed from the 618-9 Burial ground, preventing the liquid from eventually reaching the ground water. Work was completed at the 300 Area Process Trenches where approximately $5,300 \mathrm{~m}^{3}$ $\left(7,000 \mathrm{yd}^{\prime \prime}\right)$ of contaminated soil were removed and isolated. A pilot-scale carbon tetrachloride vapor extraction unit was successfully demonstrated at the 200-West Area.

Many DOE-owned facilities at the Hanford Site that were formerly used for nuclear materials production have been retired from service and declared surplus. The Hanford surplus facilities program manages these facilities for DOE. The program provides for surveillance and maintenance, as well as eventual decommissioning, of these facilities.

The activities currently under way include cleaning sp the 183-H Solar Evaporation Basins, decommissioning of the 201-C Strontium Semiworks, decommissioning of several 100 Areas ancillary facilities, and preparing the final EIS Decommissioning of Eight Surplus Production Reactors at the Hanford Site, Richland. Washington.

\section{Waste Management}

Waste management is the safe and effective management of active and standby facilities and the treatment, storage, and disposal of radioactive, hazardous, and mixed waste. An important component is to minimize the generation of waste. The Site contractors have integrated waste minimization and pollution prevention awareness programs into a single, coordinated initiative.
Waste minimization is being accomplished primarily by source reduction and recycling techniques.

A major strategy for Hanford's waste management is to discontinue discharges of liquid contaminated effluents to the soil column. Effluent streams containing hazardous and/or radioactive wastes will no longer be discharged or will be treated to remove contaminants before discharge. Thirty-two liquid effluent streams have been identified for which action is required. This action is included as a milestone under the TriParty Agreement Action Plan.

The major effort for cleanup of the Hanford Site will be the disposal of the stored wastes resulting from past production operations. The strategies for handling and disposing of these wastes, as well as newly generated wastes, were established through the National Environmental Policy Act (NEPA) process. The resulting record of decision recommends implementing preferred alternatives, described by the Final Environmental Impact Statement, Disposal of Hanford Defense, High-Level Transurrmic and Tank Wastes.

\section{Technology Development}

The Office of Technology Development was formed to consolidate and provide centralized management and oversight for research, development, demonstration, testing, and evaluation activities, and support to DOE Headquarters (HQ, in Washington, D.C.) Offices of Environmental Restoration and Waste Management, Waste Operations, Defense Programs, Nuclear Energy, and Energy Research. The technology development activities seek to coordinate new and more effective technologies to solve environmental restoration and waste management challenges.

During 1991, two integrated demonstrations were assigned to Hanford contractors for lead coordination: 1) for underground storage tan: stabilization and remediation, and closure of high-priority single-shell tank RCRA sites and 2 ) to provide solutions for the Expedited 
Response Action to remediate the carbon tetrachloride plume in the 200-West Area.

\section{Environmental Studies}

Wildlife populations inhabiting the Hanford Site are monitored to measure the status and condition of the populations, and to assess effects of Hanford operations. Particular attention is paid to species that are rare, threatened, or endangered nationally or statewide and those species that are of commercial, recreational, or aesthetic importance statewide or locally. These species include the bald eagle, chinook salmon, Canada goose, several species of hawk, Rocky Mountain Elk, mule deer, white pelican, and other bird species.

Fluctuations in wildlife and plant species on the Hanford Site appear to be a result of natural ecological factors and management of the Columbia River system. The establishment and management of the Hanford Site has had a net positive effect on wildlife relative to probable alternative uses of the Site.

The Hanford Cultural Resources Laboratory was established by the U.S. Department of Energy Richland Field Office in 1987 as part of the Pacific Northwest Laboratory. Cultural resources on the Hanford Site are closely monitored and projects are relocated in cases where there is a possibility of altering any significant historical sites.

It appears that erosive processes are the most significant factors affecting most of the sites. Wind erosion from off-road-vehicle use plays a big part in the deterioration of sites inside and outside of the security perimeter.

Two cultural properties were evaluated for their eligibility to the National Register of Historic Places. The first is a hunting blind and kill site in the Gable Mountain/Gable Butte Archaeological District. Results of test excavitions are being used to support its nomination. The second, White Bluffs Road, an ancient Native American trail, was determined eligible for the National Register of Historic Places.
Technical work done in 1991 on the Hanford Environmental Dose Reconstruction Project (HEDR) consisted of studying data obtained in 1990, restructuring models to enhance their capabilities, developing estimates of releases of radioactive materials, and evaluating additional information needed to produce estimates.

The community-operated environmental surveillance program was initiated in 1990 to increase the public's involvement in and awareness of Hanford's surveillance program. Three surveillance stations began operation in March 1991.

An education outreach program was established with the Yakima Indian National in 1991. This program provided an opportunity for a student to study Columbia River water quality and fish health and environmental monitoring activities conducted at Hanford.

\section{Environmental Monitoring Information}

Environmental monitoring of the Hanford Site consists of 1 ) effluent monitoring and 2) environmental surveillance. Effluent monitoring is performed as appropriate by the Site facility operators at the facility or at the point of release to the environment. Environmental surveillance consists of sampling and analyzing environmental media on and off the Hanford Site to detect and quantify potential contaminants, and to assess their environmental and human health significance.

The overall objectives of the monitoring programs are to demonstrate compliance with federal, state, and local regulations; confirm adherence to DOE environmental protection policies; and support environmental management decisions.

The following sections describe the effluent monitoring and environmental surveillance conducted in 1991 and the results. 


\section{Effluent Monitoring}

Effluent monitoring measures the amounts of radioactive and nonradioactive effluent liquids, gases, and solids released to or disposed of in the Hanford Site environment. Facility operators monitor effluents mainly through sampling and analyzing. The effluent data gathered from monitoring activities are evaluated to determine the degree of compliance with applicable federal, state, and local regulations and permits.

Air emission flows are quantified using a combination of discharge point measurements and calculations based on process information. Emissions can contain volatile forms of radionuclides, noble gases, and radioactive particles. An air emission discharge is monitored when it has the potential of exceeding $10 \%$ of release limits. Stacks and vents are monitored for total alpha and total beta activity and, as warranted, specific radionuclides. A nonradioactive emission is monitored if it could exceed $50 \%$ of applicable standards. Nonradioactive constituents monitored include nitrogen oxides, particulate matter, sulfur oxides, carbon monoxide, hydrocarbons, and ammonia. Air emission discharge points are located in the $100,200,300,400,600$, and 1100 Areas.

Onsite liquid effluents discharge to cribs, ponds, ditches, the City of Richland treatment facility, and the Columbia River. Samples of these effluents are analyzed to demonstrate whether applicable standads are met. Radioactive discharges, following a downward trend, decreased further in the 100 and 300 Areas. Total activity discharged in the 200 Areas did increase, but not substantially. Most nonradioactive liquid discharges also decreased, some significantly, such as sodium sulfate and aluminum sulfate in the 100 Areas. Exceptions, with moderate increases, were total organic carbon in the 200 Areas and nitrates, polyacrylamide, and aluminum sulfate in the 300 Area.

\section{Air Surveillance}

Transport of atmospheric releases of radioactive materials from the Hanford Site to the surrounding region represents a direct pathway for human exposure. Radioactive materials in air were sampled continuously at 47 locations onsite, at the Site perimeter, and in nearby and distant communities. Samples were also collected at three community-operated environmental surveillance stations that were managed and operated by local school teachers. Particulates were filtered from the air at all locations and analyzed for radionuclides. Air was sampled and analyzed for selected gaseous radionuclides at key locations. Several radionuclides released at Hanford are also found worldwide from two other sources: those radionuclides that are naturally occurring and those resulting from the fallout from nuclear weapons testing. The influence of Hanford emissions on local radionuclide concentrations was indicated by the difference between concentrations measured at distant locations within the region and concentrations measured at the Site perimeter.

Average $1991,{ }^{106} \mathrm{Ru},{ }^{12 \%} \mathrm{I}$, total beta, and total alpha radiation concentrations were greater at the Site perimeter than at the distant locations; however, only for ${ }^{12 \%} \mathrm{I}$ was the difference statistically significant ( $5 \%$ significance level). The differences in total beta and alpha radiation were predominantly due to the effects of nataral geological variances. Ruthenium-106 was generally below detectable concentrations both on and off the Hanford Site. Elevated uranium concentrations $\left({ }^{2: 34} U\right.$ and ${ }^{2: 34} U$ ) were reported for 300 Area air samples collected during the third and fourth quarters of 1991. The maximum air concentration $\left(3,450 \mathrm{aCi} / \mathrm{m}^{3},{ }^{23.4} \mathrm{U}\right)$ at the 300 Area was $3.4 \%$ of the derived concentration guide (DCG), the concentration that would result in a dose equal to the DOE standard to protect public health. However, uranium concentrations measured at the downwind Site perimeter locations were not elevated during this time period. For 1991 the overall air pathway resulted in a potential dose to the maximally exposed individual that was $0.07 \%$ of the Clean Air Act standard.

\section{Surface-Water Surveillance}

The Columbia River was one of the primary environmental exposure pathways to the public during 1991 as a result of operations at the Hanford 
Site. Radiological and nonradiological contaminants entered the river along the Hanford Reach as direct effluent discharges and through the seepage of contaminated ground water. Water samples were collected from the river at various locations throughout the year to determine compliance with applicable standards.

Although radionuclides associated with Hanford operations continued to be routinely identified in Columbia River water during the year, concentrations remained extremely low at all locations and were well below applicable standards. Nonradiological water quantity constituents measured in Columbia River water during 1991 were also in compliance with applicable standards.

Samples from three Columbia River shoreline springs, contaminated as a result of past waste disposal practices at Hanford, were collected during 1991. Contaminant concentrations in the springs were similar to those found in the ground water. Radionuclides concentrations were generally below the DOE DCGs. However, " $\mathrm{Sr}$ in $\mathrm{N}$ Springs water was above the DCG as well as the drinking water standard (DWS). Tritium, while below the DCG, was above the DWS at the Hanford townsite springs.

Samples of Columbia River surface sediments were collected from behind McNary and Priest Rapids Dams and from four shoreline locations along the Hanford Reach of the Columbia River during 1991. As in the past, radionuclide concentrations in sediments behind MoNary Dam were generally slightly higher than those observed in sediments collected from behind Priest Rapids Dam and along the Site.

Three onsite ponds were sampled to determine radionuclide concentrations. These ponds are accessible to migratory waterfowl and other animals. As a result, a potential biological pathway exists for the removal and dispersal of contaminants that may be in the ponds. Concentrations of radionuclides in water collected from these ponds during 1991 were similar to those observed during past years. In all cases, radionuclide concentrations in the onsite pond water were below the DOE DCG.
Offsite water, used for irrigation and/or drinking water, was sampled to determine radionuclide concentrations in water used by the nearby public. Elevated total alpha and total beta concentrations, attributed to naturally occurring uranium, were observed at some locations. Average radionuclide concentrations in offsite water during 1991 were within applicable drinking water limits.

\section{Soil and Vegetation Surveillance}

In 1991, 16 soil samples were collected on the Hanford site and 10 were collected offsite. The onsite samples were obtained near major operating areas, where any effects from Hanford operations would be expected to be most apparent. Most of the offsite sampling locations were at the Site perimeter and in a generally downwind direction. Some were collected upwind of the Site at distant locations to establish background concentrations. The offsite soil samples were sorted into four different categories: offsite, community, distant, and perimeter locations. Strontium-90, ${ }^{1: 37} \mathrm{Cs},{ }^{2: 39: 2+11} \mathrm{Pu}$, and uranium were the only radionuclides consistently detected in the samples.

The results were used to make two comparisons. The first comparison, between the onsite and the combined offsite locations, did not indicate a difference between the two groups, but the second comparison, between the perimeter and the background locations, did show a difference, which was due to an apparent decrease in concentra-

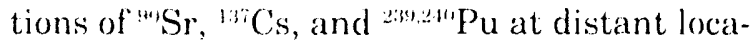
tions and an increase in uranium. These changes may be a result of natural variations in the environment.

In 1991, 13 onsite and 7 offsite veretation samples were collected. Vegetation was sampled using the same rationale as soil sampling. The offsite vegetation sample locations were sorted into two categories: distant and perimeter. Only "'Sr, ${ }^{13 \mathrm{Cs},}$, $2: \mathrm{Pu}$, and uranium were consistently detected in the samples. A comparison between onsite and the combined offsite locations did not show a difference between the two groups

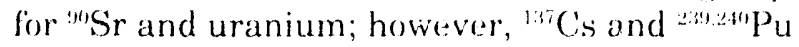
concentrations were higher onsite than offsite. A 
second comparison, between perimeter and distant locations, showed ${ }^{91} \mathrm{Sr}$ and ${ }^{239.240} \mathrm{Pu}$ concentrations in vegetation at the Site perimeter were not different than those at the background locations. Cesium-137 was, in general, not detectable in the vegetation obtained offsite. Uranium concentrations at the perimeter were not compared to those at background locations because the samples were analyzed by different methods.

\section{Wildlife Surveillance}

The Hanford Site contains large tracks of undeveloped land that serve as a refuge for many species of wildlife. The Columbia River, which borders the Site, also providas habitat for wildlife and fish that are of economic and recreational importance to the area. Terrestrial wildlife like deer, rabbits, and upland gamebirds have access to parts of the Site that contain low levels of radionuclides attributable to current and past Site operations. Wildlife are monitored for radionuclides as indicators of possible exposure to the Site surface contamination. Similarly, Columbia River fish are monitored to detect any radioactivity that may arise from Site activities as well as to help estimate the dose to those who may consume these fish.

Analysis of wildlife for radioactivity indicated some exposure of wildlife to contamination. Strontium-90 was found in bone of rabbits at elevated levels. Concentrations of "Sr in deer bone were lower than 1990 levels, which had approached the higher levels observed in rabbit bone. Strontium was also detected in Columbia River fish carcasses at levels in excess of concentrations reported in bass carcasses from a background location. Cesium-137 was also detected in the breast muscle of ducks collected from B Pond, a low-level waste pond located near the 200-East Area. A clam shell from the 100-N Area contained about $270 \mathrm{pCi} / \mathrm{g}$ "Sr. Soft tissue from clams collected below the 300 Area contained $1 \mathrm{pCi} / \mathrm{g}$ of uranium. These observations indicate that wildlife have accumulated some radioactivity originating from the Hanford Site.

The radionuclide concentrations measured in fish and wildlife were used to estimate potential doses to sportsmen who may consume Hanford Site game. The resulting doses were well below applicable standards and guidelines developed to protect the public.

\section{Food and Farm Product Surveillance}

The Hanford Site is surrounded by many farms that produce a number of food products and alfalfa. Milk, eggs, poultry, beef, vegetables, fruit, wheat, and wine collected from downwind (to the south and east) and upwind distant locations are sampled. The principal downwind locations include the Sagemoor and Riverview areas. Crops collected from the Riverview area are irrigated with Columbia River water. Alfalfa and farm products were analyzed for the following radionuclides: ${ }^{3} \mathrm{H},{ }^{611} \mathrm{Co},{ }^{90} \mathrm{Sr},{ }^{499} \mathrm{Tc},{ }^{129} \mathrm{I},{ }^{131} \mathrm{I},{ }^{137} \mathrm{Cs}$, ${ }_{234,235.23 \times} \mathrm{U}$, and ${ }^{239,2411} \mathrm{Pu}$.

Most of the farm products sampled did not contain measurable amounts of the radionuclides that were identified for analysis. Low concentrations of ${ }^{3} \mathrm{H},{ }^{91} \mathrm{Sr},{ }^{129} \mathrm{I},{ }^{137} \mathrm{Cs},{ }^{234} \mathrm{U}$, and ${ }^{238} \mathrm{U}$ were detected in some agricultural media. Tritium in wine was analyzed by two laboratories, and no Hanford effects were indicated. Iodine-129 was found at slightly elevated concentrations in milk collected near the Hanford Site as compared to distant locations. Alfalfa had detectable but low concentrations of ${ }^{\text {") }} \mathrm{Sr}$, but alfalfa irrigated with Columbia River water downstream of the Hanford Site had higher concentrations than alfalfa irrigated with other sources of water. Uranium234 and ${ }^{2: 36} \mathrm{U}$ were also detected in potatoes, but appeared to be a result of natural sources. The potential offsite dose to consumers from food products grown near Hanford is a very small fraction of the public dose standard for exposure to environmental radioactivity.

\section{External Radiation Surveillance}

Dose rates from external radiation were measured at a number of locations in 1991 using thermoluminescent dosimeters (TLDs). Artificial and naturally occurring external radiation sources (cosmic radiation and radionuclides in the air and ground), as well as worldwide fallout, all contributed to the dose rates measured. Dose 
rates at all TLD locations were approximately $15 \%$ higher than those observed during 1990 ; however, these increases can be attributed to variability in naturally occurring dose rates and expected measurement variability at low dose rates.

The background external radiation dose rate, calculated from the annual average results from upwind distant location (Sunnyside, Yakima, and Moses Lake) was $88 \pm 3 \% \mathrm{mrem} / \mathrm{yr}$ as compared to the perimeter average of $100 \pm 6 \% \mathrm{mrem} / \mathrm{yr}$. The difference between these average dose rates is due to both natural geographic variations in terrestrial radiation and variations resulting from human activities. Dose rates at the shoreline of the 100-N Area were approximately two to three times greater than typical shoreline dose rates. This increase is attributed to residual radioactivity from past waste management activities within the 100-N Area. Some onsite dose rates near waste storage and handling facilities were elevated above natural background rates as expected, but agree with historical values. The observations at all TLD locations indicate no increase from typical historical external radiation levels.

Various routine external radiation and contamiration surveys were performed at numerous locations on the Hanford Site. Selected onsite roads, railroads, Columbia River shoreline locations, and areas of the Site perimeter were surveyed for elevated radiation levels. In 1991, two small areas of low-level radioactive contamination |each less than $1 \mathrm{ft}^{2}\left(0.09 \mathrm{~m}^{2}\right)$ ) were detected on an onsite road and at an onsite rail location and removed.

\section{Potential Radiation Doses from 1991 Hanford Operations}

The potential dose to the hypothetical maximally exposed individual (MEI) in 1991 from Hanford operations was $0.02 \mathrm{mrem}\left(2 \times 10^{-4} \mathrm{mSv}\right)$, compared to $0.03 \mathrm{mrem}\left(3 \times 10^{4} \mathrm{mSv}\right)$ reported for 1990. The potential dose to the local population of 380,000 persons from 1991 operations was 0.9 person-rem $(0.009$ person-Sv!, compared to 2 person-rem (0.02 person-Sv) reported for 1990. The 1991 average dose to the population was
$0.002 \mathrm{mrem}\left(2 \times 10^{5} \mathrm{mSv}\right)$ per person. The current $\mathrm{DOE}$ radiation limit for an individual member of the public is $100 \mathrm{mrem} / \mathrm{yr}$ ( $1 \mathrm{~Sv} / \mathrm{yr}$ ), and the national average dose from natural sources is $300 \mathrm{mrem} / \mathrm{yr}(3 \mathrm{mSv} / \mathrm{yr})$. The MEI potentially received $0.02 \%$ of the limit and $0.007 \%$ of the national average dose from natural sources. The average individual potentially received $0.002 \%$ of the standard and $0.0008 \%$ of the $300 \mathrm{mrem} / \mathrm{yr}$ received from typical natural sources.

Special exposure scenarios not included in the above doses include the potential consumption of game residing on the Hanford Site and exposure to radiation at the publically accessible location with the maximum exposure rate. Doses from these sources would also have been small compared to the dose limit.

Dose through the air pathways $\cdots: 20.07 \%$ of the EPA (40 CFR 61) limit.

\section{Ground-Water Protection and Monitoring Program}

Radiological and chemical constituents in ground water were monitored during 1991 throughout the Hanford Site in support of the overall objectives described in "Environmental Program Information," Section 3.0. Monitoring activities were conducted to identify and quantify existing, emerging, or potential ground-water quality problems; assess the potential for contaminants to migrate off the Hanford Site; and prepare an integrated assessment of the condition of ground water on the Site. To comply with the Resource Conservation and Recovery Act, additional monitoring was conducted to assess the impact that specific facilities have had on ground-water quality. During 1991, 528 Harford Site wells were sampled to satisfy ground-water monitoring needs. As discussed in Section 4.3, four additional wells located across the Columbia River and east of the Hanford Site were sampled to determine whether Hanford operations had affected water quality off the Hanford Site.

Analytical results for samples were compared with EPA's DWS (Tables B.2 and B.3, Appendix B) and DOE's DCG (Table B.6, Appendix B). 
Ground water beneath the Hanford Site is used for drinking at five locations. Only the drinking water in the 400 Area at the FFTF Visitors Center is available for public consumption; this source is discussed in Section 4.8. In addition, water supply wells for the city of Richland are located adjacent to the southern boundary of the Hanford Site.

Radiological monitoring results indicated that total alpha, total beta, " $\mathrm{H}$, ${ }^{61} \mathrm{Co},{ }^{90} \mathrm{Sr}$, ${ }^{1 ! !} \mathrm{Tc}$, ${ }^{12 ! 9} \mathrm{I}$, and ${ }^{137} \mathrm{Cs}$ concentrations in wells in or near operating areas were at levels above the DWS. Concentrations of uranium in the 200-West Area were above the DCG. Concentrations of ${ }^{3} \mathrm{H}$ in the 200 Areas and ${ }^{n 1} \mathrm{Sr}$ in the 100-N and 200-East Areas were also above the DCG. Tritium continued to move slowly with the general ground-water flow and discharge to the Columbia River.

Certain chemicals regulated by the EPA and the State of Washington were also present in Hanford ground water near operating areas. Nitrate concentrations exceeded the DWS at isolated locations in the 100,260, and 300 Areas and in several 600 Area locations. Chromium concentrations were above the DWS at the 100-D, $100-\mathrm{H}$, and $100-\mathrm{K}$ Areas, and in the surrounding areas. Chromium concentrations above the DWS were also found in the 200-East and 200-West Areas. Cyanide was present in ground water north of the 200-East Area. High concentrations of carbon tetrachloride and chloroform were found in wells in the 200-West Area. Trichloroethylene was found at levels exceeding the DWS at wells in and near the $100-\mathrm{F}, 200-$ West, and 300 Areas. Trichlorosthylene levels in wells near the Solid Waste Landfill (outside the 200-East Area) have dropped to slightly below the DWS, while tetrachloroethylene levels in those wells remain just above the DWS. Sampling at monitoring wells near Richland water supply wells showed that concentrations of regulated groundwater constituents in this area were below the DWS and, in general, below detection levels.
A comprehensive review of all ground-water monitoring work on the Site is published annually. Before 1989, these reports contained complete listings of all radiological and chemical data collected during the reporting periods. Since 1989, complete listings can be found in a companion volume to this report.

\section{Quality Assurance}

A comprehensive quality assurance (QA) program, which included various quality control (QC) practices and methods to verify data, was maintained to ensure data quality. The QA program is implemented through QA. plans designed to meet the requirements in the American $\mathrm{Na}$ tional Standards Institute/American Society of Mechanical Engineers NQA-1 QA program document and DOE Orders. Quality assurance plans are maintained for all surveillance activities, and conformance is verified by independent auditors. Quality control methods include replicate sampling and analysis, analysis of blanks and reference standards, participation in interlaboratory cross-check studies, and splitting samples with other laboratories. Sample collection and laboratory analyses are conducted using documented and approved procedures. When sample results are received, they are screened for anomalous values by comparing them to recent results and historical data. Analytical laboratory performance on the EPA Laboratory Intercomparison Studies Program and the national DOE Quality Assessment Program indicated that 93\% of the results were within the control limits, a result that ranked very favorably among participating laboratories. 


\section{Report Contributors}

The production of the Hanford Site Environmental Report requires the knowledge, skills, information, and cooperation of many people and several organizations. The contributions and cooperation, often under demanding time constraints, of the following individuals are gratefully acknowledged. The lead authors are listed with the sections they were responsible for producing. (The authors are from the Pacific Northwest Laboratory unless otherwise indicated.)

Siection

Helpful Information

1.0 Introduction

1.1 Site Mission

1.2 Major Operations and Activities

1.3 Site Environment

2.0 Environmental Compliance Summary

2.1 Ovarseeing Hanford's Environmental Compliance and Cleanup

2.2 Compliance Status

2.3 Current Issues and Actions

2.4 Environmental Occurrences

3.0 Environmental Program Information

3.1 Environmental Restoration, Waste Management, and Technology Development

3.2 Environmental Monitoring at Hanford Effluent Mcnitoring

Environmental Surveillance

3.3 Environmental Studies and Programs--Wildlife Resources Cultural Resources

Meteorology and Climatology of the Hanford Area

Hanford Environmental Dose Reconstruction Project

Community-Operated Environmental Surveillance Stations

Other Environmental Activities

4.0 Environmental Monitoring Information

4.1 Effluent Monitoring

4.2 Ajr Surveillance

4.3 Surface-Water Surveillance

4.4 Food and Farm Product Surveillance

4.5 Wildlife Surveillance

4.6 Soil and Vegetation Surveillance

4.7 External Radiation Surveillance

4.8 Potential Radiation Doses from 1990 Hanford Operations

5.0 Ground-Water Protection and Monitoring Program

6.0 Quality Assurance

7.0 References

Appendix A - Glossary

Appendix B - Applicable Standards and Permits

Appendix C - Dose Calculations

Appendix D - RCRA and CERCLA Monitoring Documents

Appendix E - Radionuclides Detected by Gamma Spectroscopy
Authors

R. W. Hanf

R. K. Woodruff

R. K. Woodruff

P. J. Davis, WHC

C. E. Cushing

P. J. Davis, WHC

P. J. Davis, WHC

P. J. Davis, WHC

P. J. Davis, WHC

R. W. Hanf

R. K. Woodruff

P. J. Davis, WHC

R. K. Woodruff

L. P. Diediker, WHC

R. K. Woodruff

L. E. Eberhardt

J. C. Chatters

D. J. Hoitink

D. B. Shipler

R. K. Woodruff

R. K. Woodruff

R. K. Woodruff

L. P. Diediker, WHC

G. W. Patton

R. L. Dirkes

T. M. Poston

T. M. Poston

E. J. Antonio

G. A. Simiele

J. K. Soldat

R. W. Bryce

G. A. Simiele;

L. P. Diediker, WHC

Staff

Staff

Staff

J. K. Soldat

P. J. Davis, WHC

W. M. Poston 


\section{Acknowledgments}

The programs described in this report were managed by the Office of Hanford Environment under the direction of R. E. Jaquish The authors appreciate the reviews by R. F. Brich, R. D. Hildebrand, and E. B. Dagan of the U.S. Department of Energy Richland Field Office, and T. A. Ikenberry, L. L. Cadwell, G. L. Harvey, P. C. Hays, E. B. Moore, and P. D. Thorne of the Pacific Northwest Laboratory.

Environmental samples were collected by Radiation Protection Technologists M. E. Almarode, G. L. Andersen, L. L. Belt, J. A. Jahnke, T. R. Lakey, J. J. Lopez, D. L. Mackliet, D. L. Merrill, and D. A. Mueller. The environmental monitoring supervisor is E. W. Lusty.

Community-operated environmental surveillance stations were managed by local teachers who were responsible for collecting the samples and maintaining the stations. The managers and alternate managers for each station included:

C. A. Wagner, Manager

T. E. Gilmore, Alternate Manager

C. L. Stevenson, Manager

M. P. Madison, Manager

K. A. Darrington, Alternate Manager
Leslie Groves Park, Richland

Basin City Elementary School, Basin City

Edwin Markham Elementary School, North Franklin County

This report was produced on MacIntosh using Aldus Pagemaker. Valuable text processing support was provided by L. M. Andor, K. K. Chase, J. E. Gority, D. J. Kennedy, and J. L. Moore. Publication assistance was provided by M. K. DeSmet. Graphics for the report were designed by J. P. Noland, K. A. Corcoran, K. K. Kachele, and L. G. Wattenburger (Boeing Computer Services, Richland) and W. R. Gorst using Aldus Freehand and DeltaPoint Inc. Delta Graph. Cover and dividers were designed by C. T. Sarton (Boeing Computer Services, Richland). 


\section{Contents}

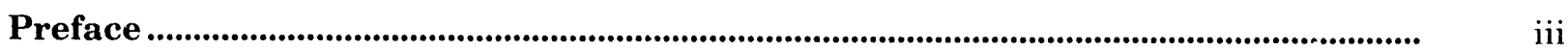

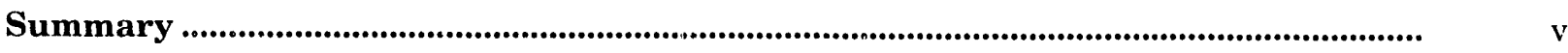

The Hanford Site and its Mission .......................................................................... v

Compliance with Environmental Regulations ..................................................... vi

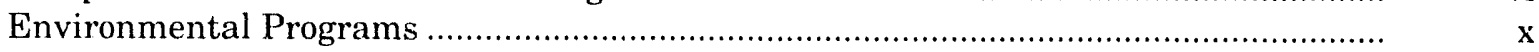

Environmental Monitoring Information ..............................................................

Ground-Water Protection and Monitoring Program ............................................ xvi

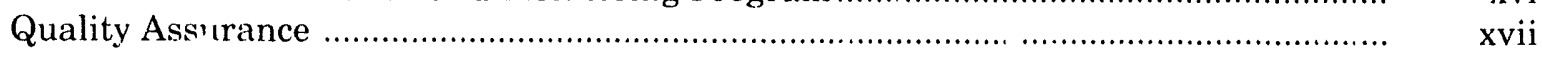

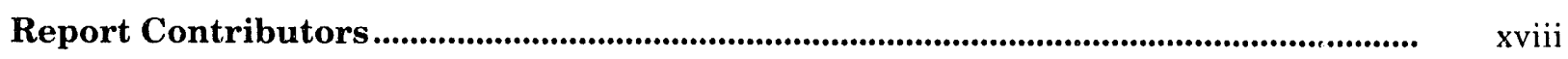

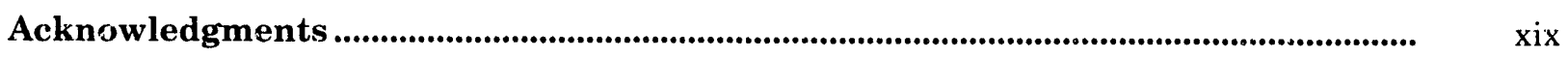

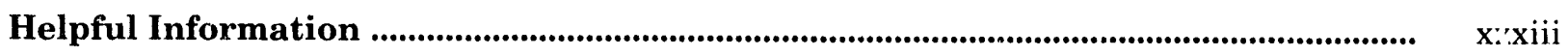

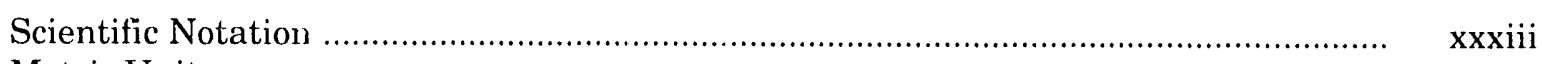

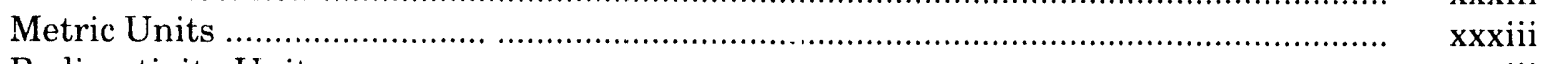

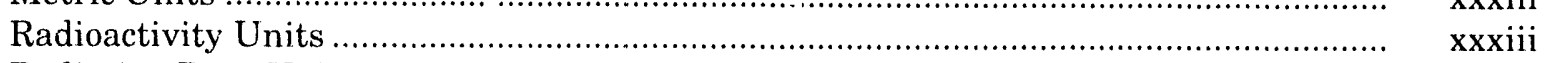

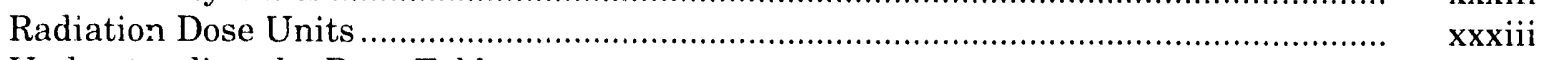

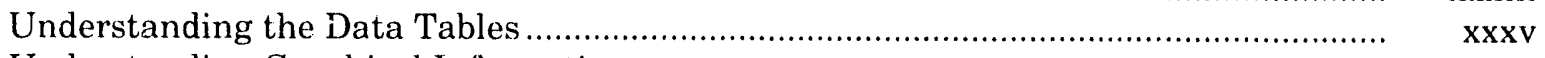

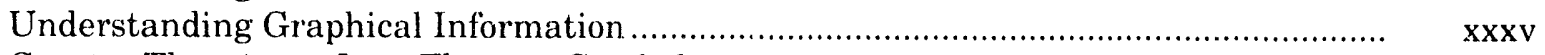

Greater Than $(>$ ) or Less Than $(<)$ Symbols ........................................................... xxxvi

Radionuclide Nomenclature ............................................................................. $\quad$ xxxvii

Elemental and Chemical Constituent Nomenclature …............................................ $\quad$ xxxviii

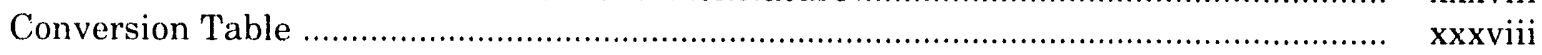

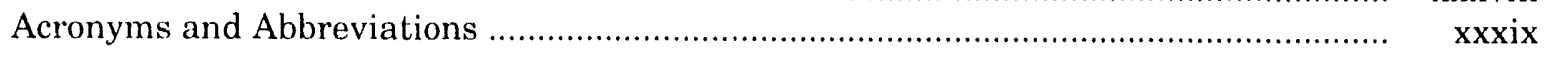

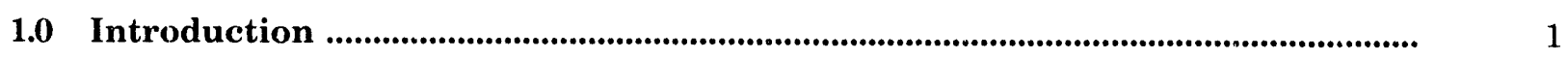

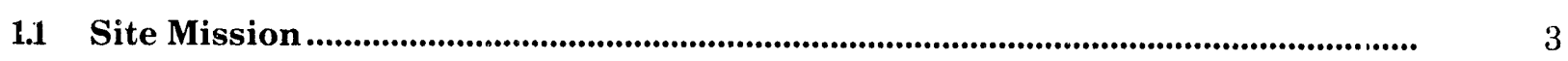

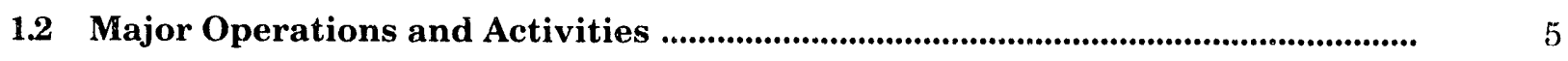

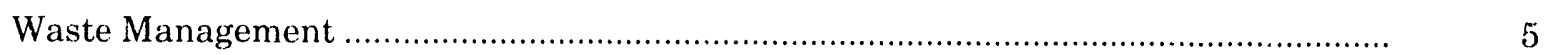

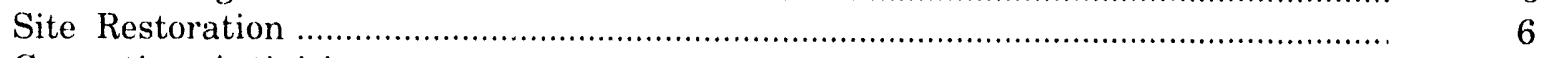

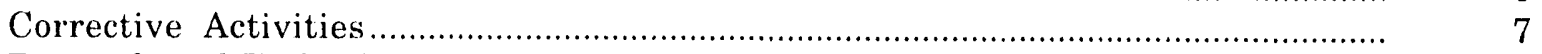

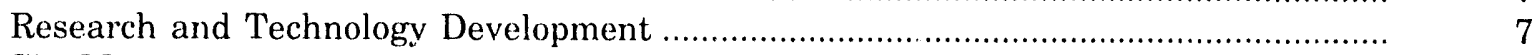

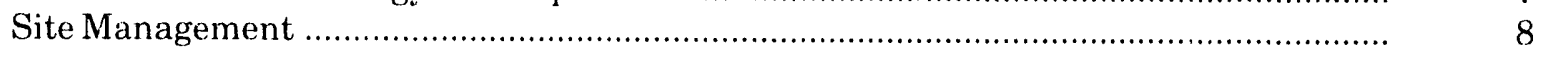

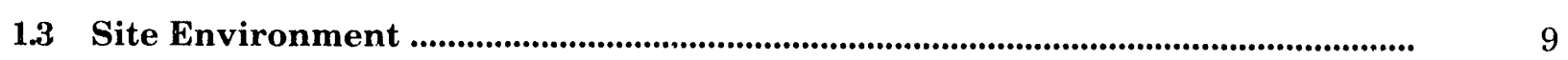

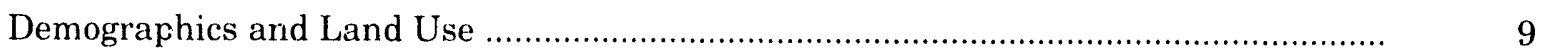

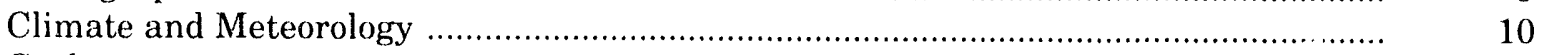

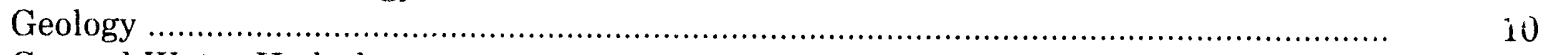

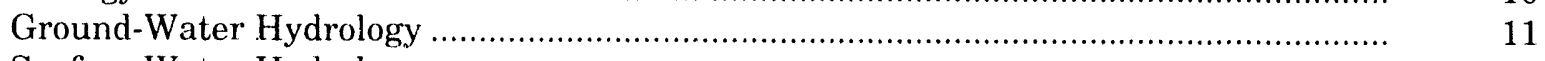

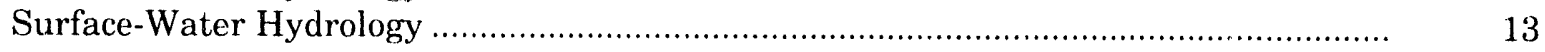


Ecology

Archaeology and Cultural Resources

2.0 Environmental Compliance Summary

2.1 Environmental Compliance and Cleanup

The Regulating Agencies

The Tri-Party Agreement

The Role of Oregon State at the Hanford Site .................................................... 20

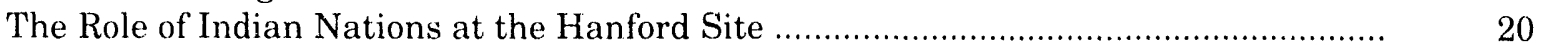

Public Participation ................................................................................

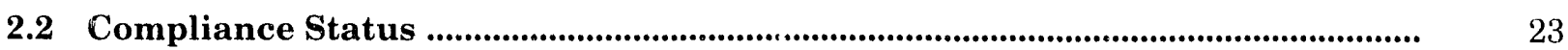

Comprehensive Environmental Response, Compensation, and Liability Act ............... 23

Emergency Planning and Community Right-To-Know Act.................................... 24

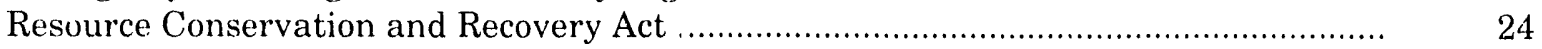

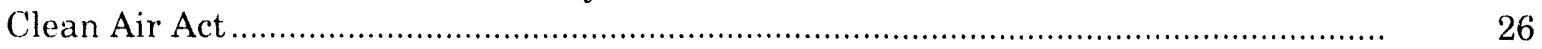

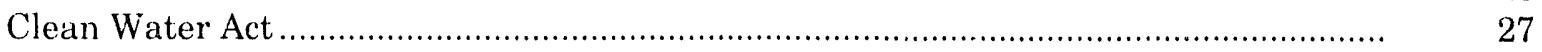

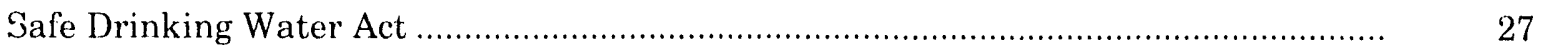

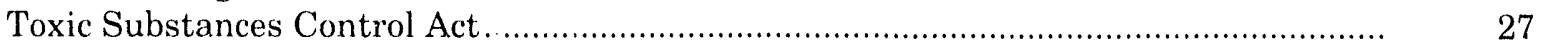

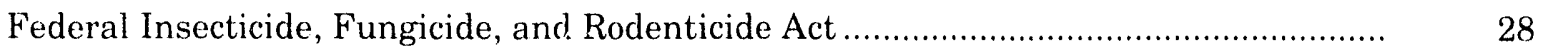

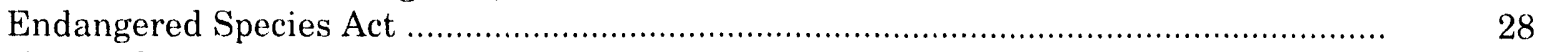

National Historic Preservation Act, Archaeological Resources

Protection Act, and American Indian Religious Freedom Act ................................

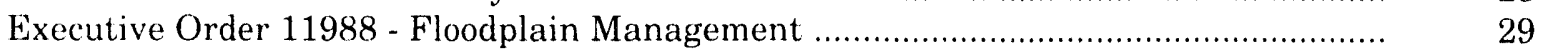

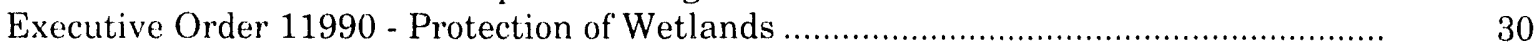

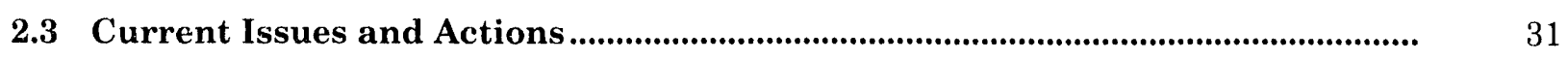

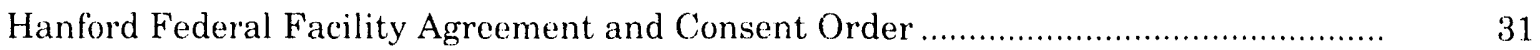

Hanford Future Site Use/Cleanup Strategy .................................................... 33

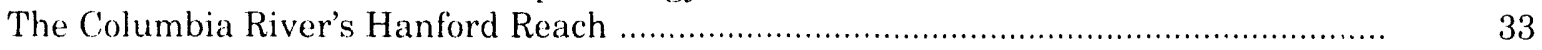

Tiger Team Assessment Corrective Actions ....................................................... 34

Plutonium Uranium Extraction and Uranium Oxide Plants Status ......................... 35

Plutonium Finishing Plant Restart ............................................................. 35

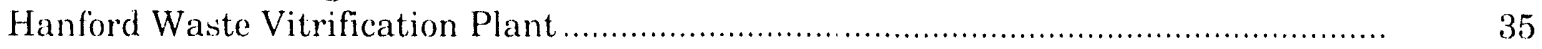

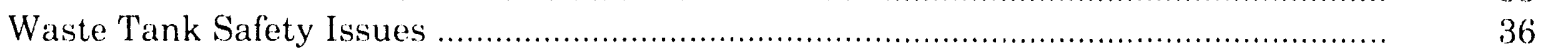

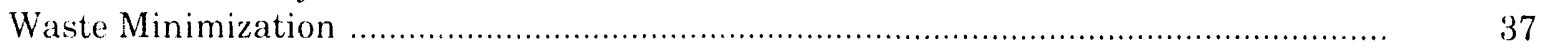

General Accounting Office Audit of Ground-Water and Soil Monitoring .................... 37

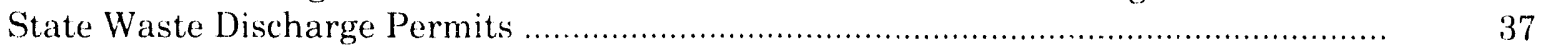

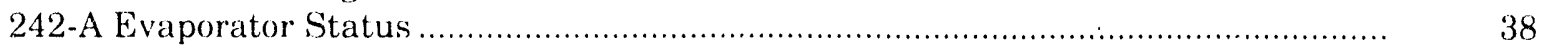

Submarine Reactor Compartments ......................................................... 38

United States Testing Company, Incorporated, Termination ................................. 38

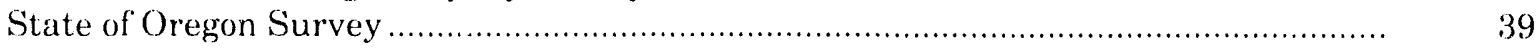

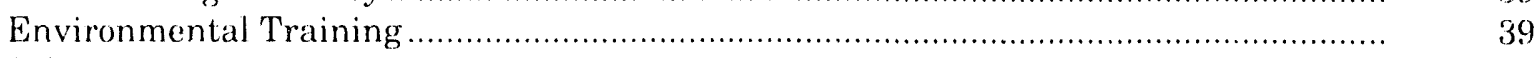

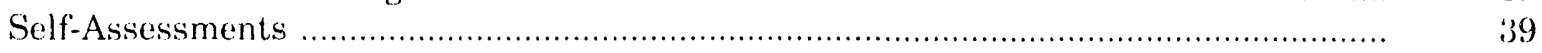

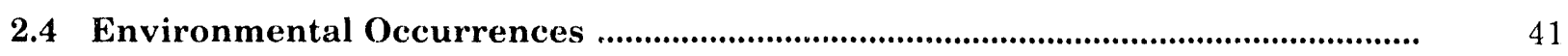

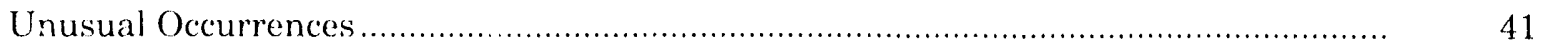




\subsection{Environmental Restoration, Waste Management and Technology}

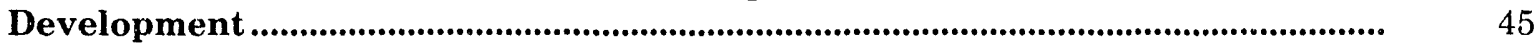

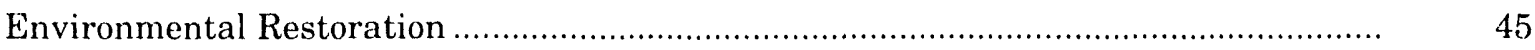

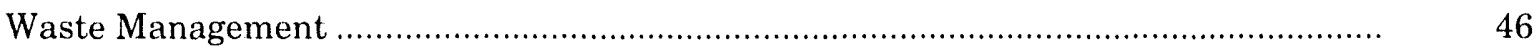

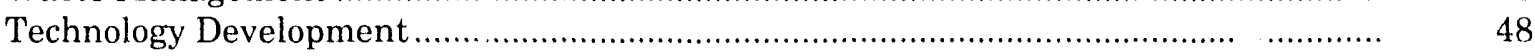

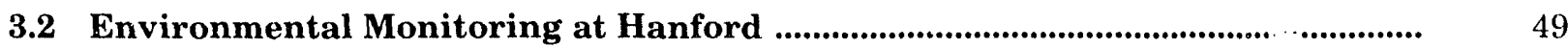

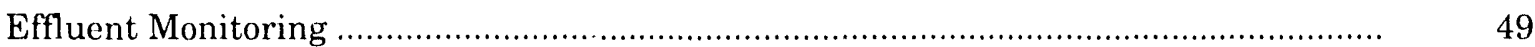

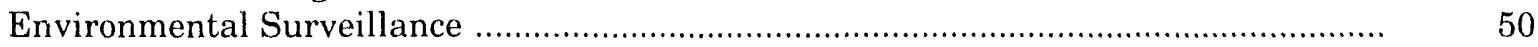

3.3 Environmental Studies and Programs ............................................................

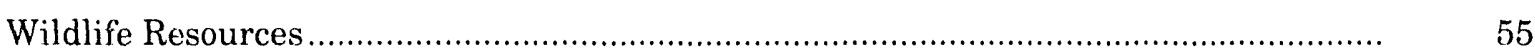

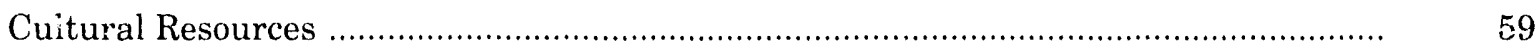

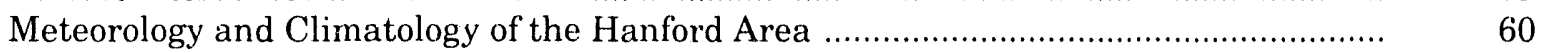

Hanford Environmental Dose Reconstruction Project ................................................. 62

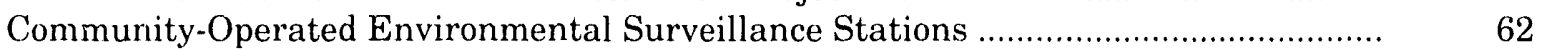

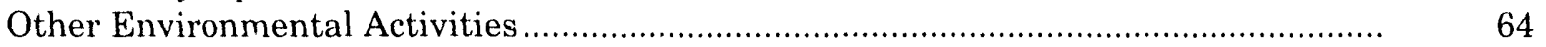

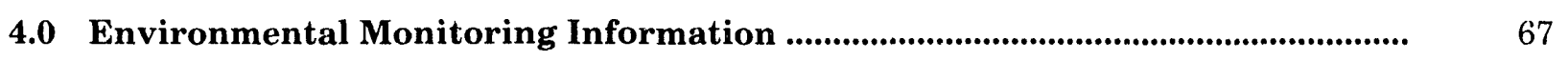

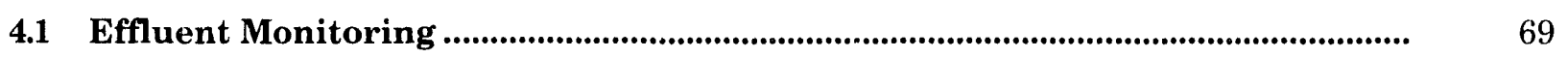

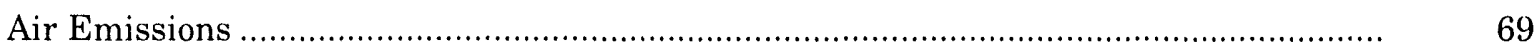

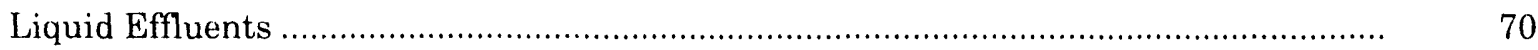

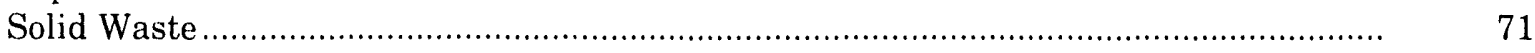

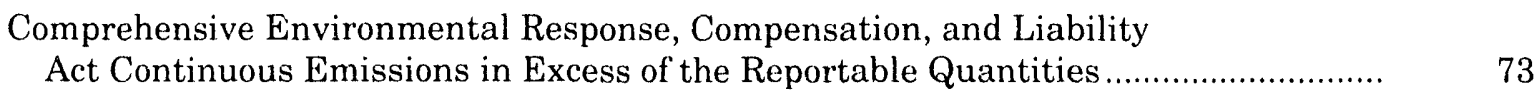

Emergency Planning and Community Right-to-Know Act .......................................

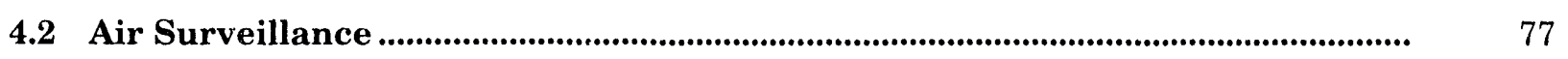

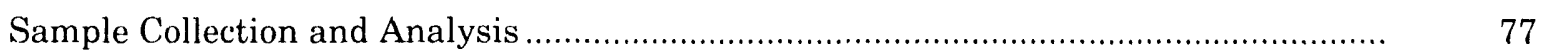

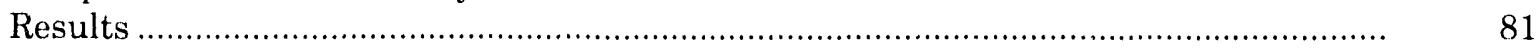

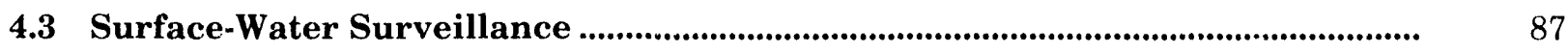

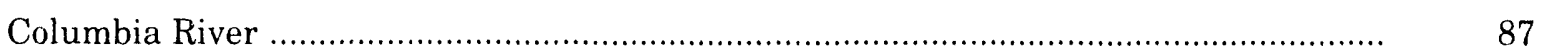

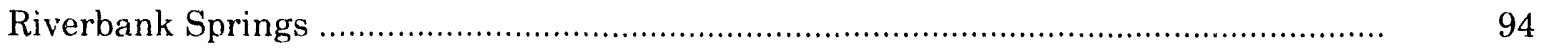

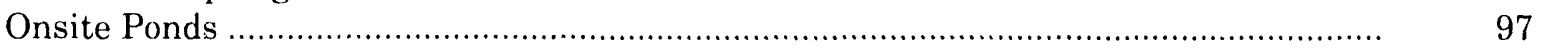

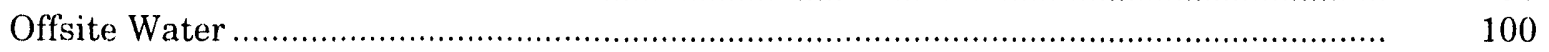

4.4 Food and Farm Product Surveillance ..........................................................................

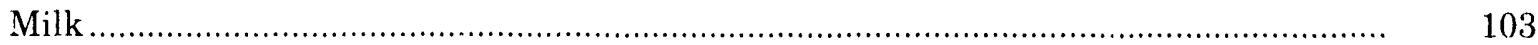

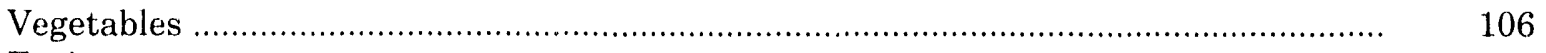

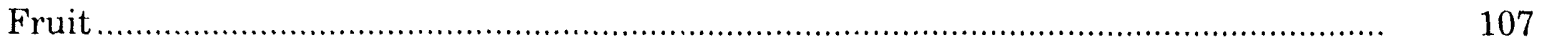


Wine

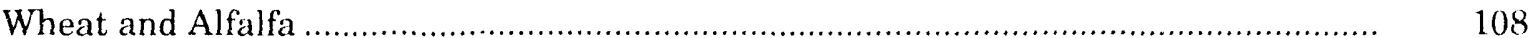

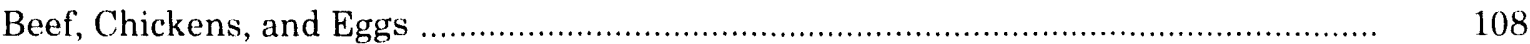

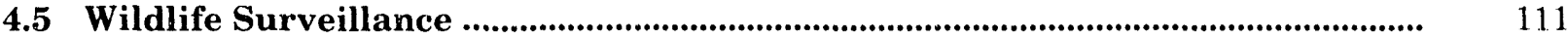

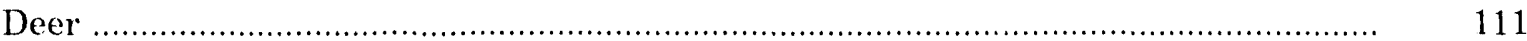

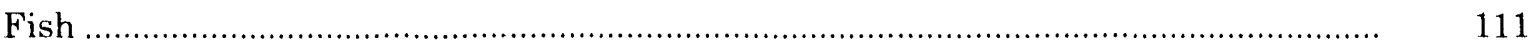

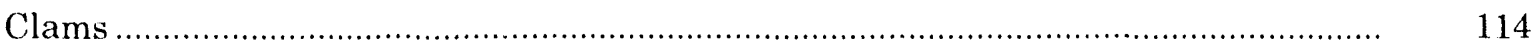

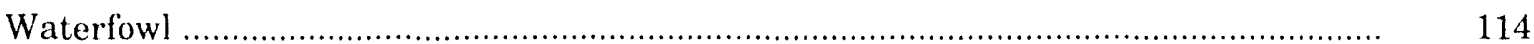

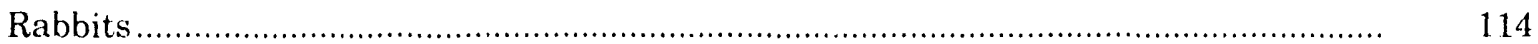

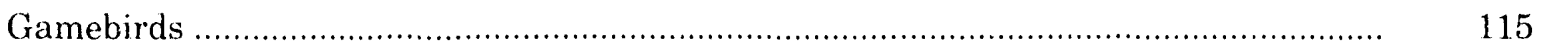

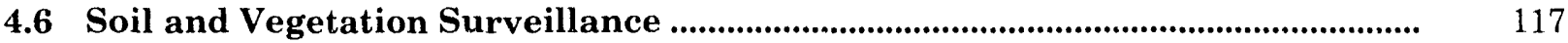

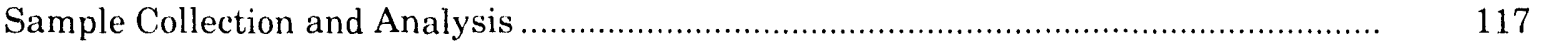

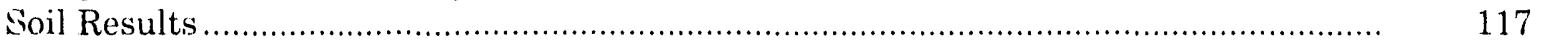

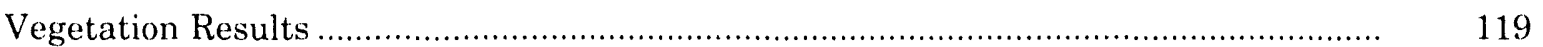

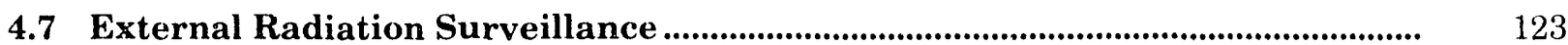

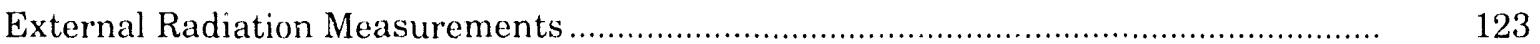

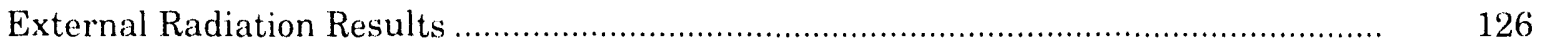

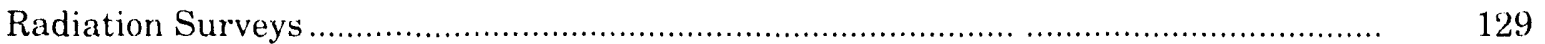

4.8 Potential Radiation Doses from 1990 Hanford Operations ................................... 133

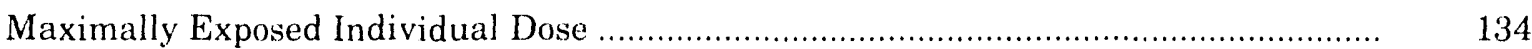

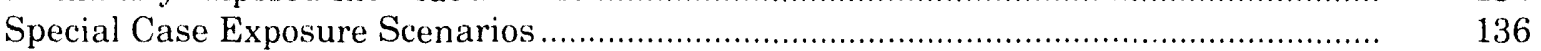

Comparison with Clean Air Act Standards .................................................... 139

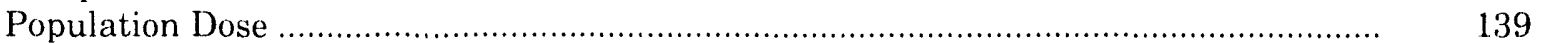

Doses from Other Than DOE Sources ................................................................... 142

Hanford Public Radiation Dose in Perspective ........................................................... 142

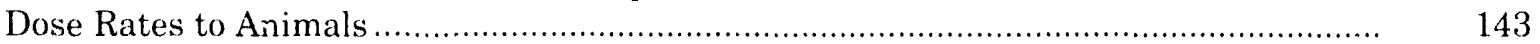

5.0 Ground-Water Protection and Monitoring Program ...................................... 145

Ground-Water Protection .................................................................................... 145

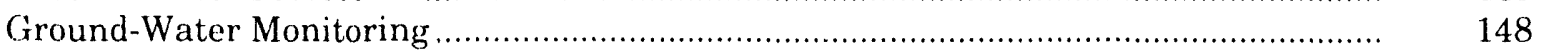

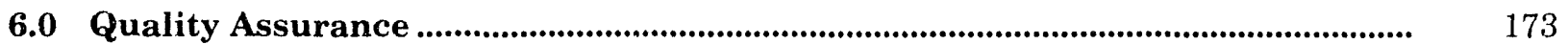

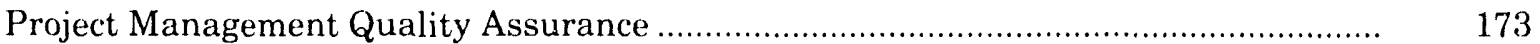

Sample Collection Quality Assurance ................................................................... 174

Analytical Results Quality Assurance ................................................................... 174 
Contents

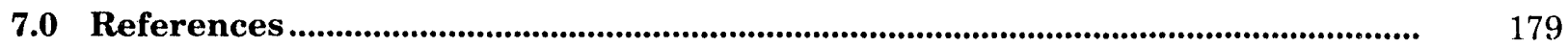

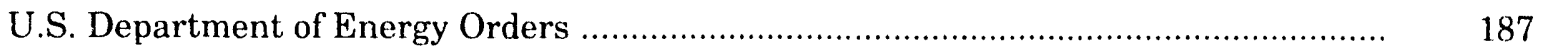

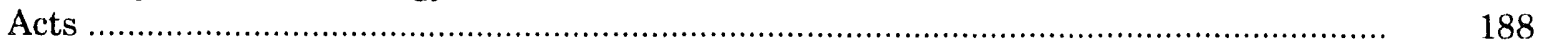

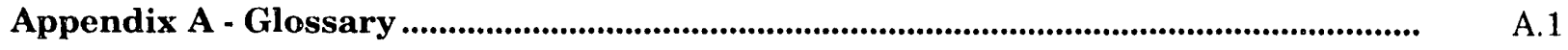

Appendix B - Applicable Standards and Permits ................................................... B.1

Appendix C - Dose Calculations ........................................................................................ C.1

Appendix D - RCRA and CERCLA Monitoring Documents ...................................... D. 1

Appendix E - Radionuclides Detected by Gamma Spectroscopy ….............................. E.1 


\section{Figures}

H.1 Data Plotted Using a Linear Scale

$\mathrm{XXXV}$

H.2 Data Plotted Using a Logarithmic Scale

xxxvi

H.3 Data With Error Bars Plotted Using a 'jinear Scale ........................................... xxxvi

1.1 DOE's Hanford Site

6

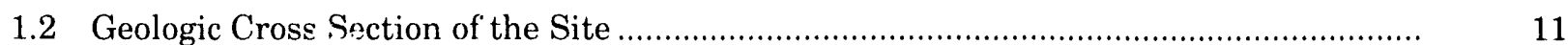

1.3 Water-Table Elevations for the Unconfined Aquifer at Hanford, June 1991

3.1 Primary Exposure Pathways

3.2 Bald Eagles Observed Along the Hanford Reach, Fall and Winter Months 55

3.3 Chinook Salmon Spawning Redds in the Hanford Reach 56

3.4 Canada Goose Nests on Islands in the Hanford Reach 56

3.5 Red-Tailed, Swainson's, and Ferruginous Hawks on the Hanford Site

3.6 Elk on the Hanford Site Counted by Aerial Surveillance During the Post-Calving Period: August Through September; and the Post-Hunting Period: December Through January

3.7 Hanford Meteorological Monitoring Network Wind Roses for 1991

3.8 Counties and Native American Tribes Considered in Estimating Doses from Past Hanford Operations in the Hanford Environmental Dose Reconstructive Project

4.2 Monthly Average Total Beta Radioactivity in Airborne Particulate Samples, 1981 Through 1991

4.3 Annual Average Concentrations of Iodine-129 in Air at the Hanford Environs, 1986 Through 1991

4.4 Annual Average Concentrations of Tritium in Air at the Hanford Environs, 1986 Through 1991

4.5 Annual Average Concentrations of Plutonium-239,240 in Air at Northwest and Hanford Environs, 1986 Through 1991

4.6 Annual Average Concentrations of Uranium in Air at Northwest and Hanford Environs, 1986 Through 1991 
Contents

4.7 Onsite and Otłsite Water and Sediment Sampling Locations, 1991

4.8 Annual Average Total Alpha Concentrations in Columbia River Water, 1986 Through 1991

4.9 Annual Average Total Beta Concentrations in Columbia River Water, 1986 Through 1991

4.10 Annual Average Tritium Concentrations in Columbia River Water, 1986 Through 1991

4.11 Annual Average Strontium-90 Concentrations in Columbia River Water, 1986 Through 1991

4.12 Annual Average Uranium Concentrations in Columbia River Water, 1986 Through 1991

4.13 Columbia River Water Quality Measurements, 1986 Through 1991

4.14 Monthly Average Columbia River Flow Rates During 1991

4.15 Monthly Average Columbia River Water Temperatures During 1991

4.16 Radionuclide Concentrations in Columbia River Sediments at Priest Rapids Dam and McNary Dam, 1986 Through 1991

4.17 Radionuclide Concentrations in N Springs, 1988 Through 1991

4.18 Radionuclide Concentrations in Riverbank Springs Near the Hanford

Townsite, 1988 to 1991

4.19 Constituents of Concern in 300 Area Riverbank Springs, 1988 to 1991

4.20 Annual Average Radionuclide Concentrations in B Pond, 1986 Through 1991

4.21 Average Total Beta and Tritium Concentrations in FFTF Pond, 1986 Through 1991

4.22 Annual Average Radionuclide Concentrations in West Lake, 1986

Through 1991

4.23 Food and Farm Product Sampling Locations, 1991

4.24 Average Iodine-129 Concentrations in Milk at Sagemoor and Sunnyside, 1986 Through 1991

4.25 Annual Average Strontium-90 Concentrations in Milk for All Sampling Locations, 1987 Through 1991 
4.26 Annual Average Strontium-90 Concentrations in Leafy

Vegetables for All Sampling Locations, 1987 Through 1991

4.27 Strontium-90 Concentrations in Alfalfa Collected at Rivervicw and

Richland and All Other Sampling Locations, 1987 'Through 1991

4.28 Wildlife Sampling Locations, 1991

4.29 Mean Concentrations of Strontium-90 in Whitefish and Carp Carcasses

Collected from the Columbia River, and Bass from Sunnyside, 1991

4.30 Mean Concentrations of Cesium -137 in Mallard Duck Muscle Collected

from B Pond, 1987 Through 1991

4.31 Sampling Locations for Soil and Vegetation, 1991

4.32 Medium, Maxinıum and Minimum Strontium-90, Cesium-137,

Plutonium-239,240, and Uranium Concentrations Measured in

Soil On and Off the Hanford Site, 1986 Through 1991

4.33 Medium, Maxımum and Minimum Strontium-90, Cesium-137,

Plutonium-239,240, and Uranium Concentrations Measured in

Soil at the Hanford Site Perimeter and Distant Locations,

1986 Through 1991

4.34 ? Tedium, Maximum and Minimum Strontium-90, Cesium-137,

Pluinnium-239,240, and Uranium Concentrations Measured in

Veget:ation at Onsite and Offsite Locations, 1986 Through 1991

4.35 Thermoluminescent Dosimeters Measurement Locations and Station

Numbers for Perimeter and Community Sites, 1991

4.36 Thermoluminescent Dosimeter Locations and Station Numbers on the

Hanford Reach of the Columbia River, 1991

4.37 Annual Average Dose Rates at Perimeter and Distant Location:s, 1986 Through 1991

4.38 Thermoluminescent Dosimeter Locations and Station Number on the

Hanford Site, 1991

4.39 Road and Railroad Survey Routes, 1991

4.40 Locations Important to Dose Calculations

4.41 Calculated Effective Dose Equivalent to the Hypothetical Maximally

Exposed Individual, 1987 Through 1991

4.42 Calculated Effective Dose Equivalent to the Population Within $80 \mathrm{~km}$

of Hanford, 1987 Through 1991 
Contents

4.43 National Annual Average Radiation Doses from Various Sources ............................ 141

5.1 Location of $100,200,300$ and 1100 Aggregate Areas of the

National Priorities List for the Hanford Site ....................................................... 146

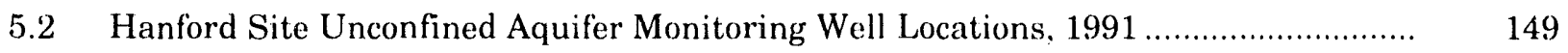

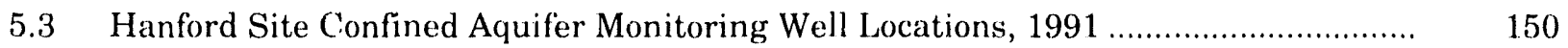

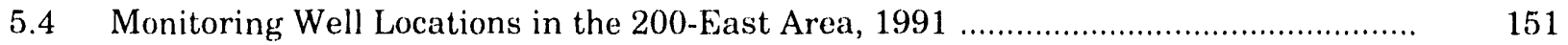

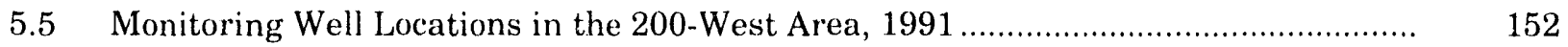

5.6 Locations of RCRA Ground-Water Monitoring Projects and Landmarks on

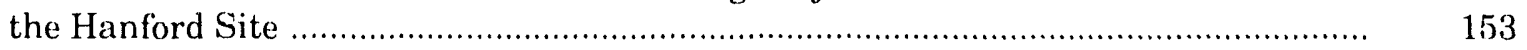

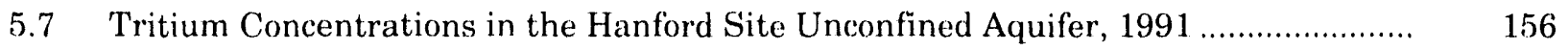

5.8 Trend Plot of Tritium Concentrations in Well 699-24-33 ......................................... 157

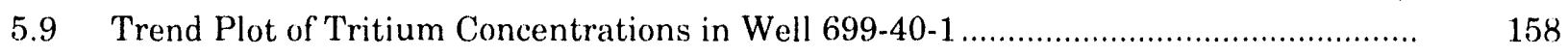

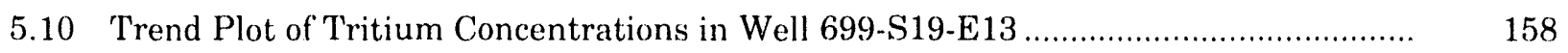

5.11 Trend Plot of Tritium Concentrations in Well 699-35-70 ........................................... 159

5.12 Distribution of Radionuclides Except Tritium at Concentrations Above the Drinking Water Standard in the Vicinity of the 200 Areas, 1991

5.13 Trend Plot of Strontium-90 Concentrations in Well 199-N-67 ................................ 161

5.14 Trend Plot of Strontium-90 Concentrations in Wells Near Gable Mountain Pond.

5.15 Distribution of Radionuclides and Hazardous Chemicals at Concentrations Above the Drinking Water Standard in the Vicinity of the 100 Areas, 1991

5.16 Trend Plot of Uranium Concentrations in Well 299-W19-18 ....................................

5.17 Trend Plot of Uranium Concentrations in Well 399-1-17A ......................................... 164

5.18 Nitrate Concentrations in the Hanford Site Unconfined Aquifer, 1991 ..................... 166

5.19 Trend Plot of Nitrate Concentrations in Well 699-36-93 _......................................... 167

5.20 Trend H'ot of Nitrate Concentrations in Well 299-W19-18 ..................................... 168

5.21 Distribution of Hazardous Chemicals Except Nitrate Above the Drinking Water Standard in the Vicinity of the 200 Arcas, 1991 
5.22 Trenả Plot of Carbon Tetrachloride Concentrations Near the 200-West Area .............

6.1 Comparison of Thermoluminescent Dosimeter Results With Known Exposures 


\section{Tables}

H.1 Names and Symbols for Units of Measure ….............................................................. xxxiv

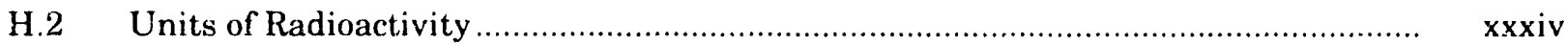

H.3 Units of Radiation Dose ..................................................................................... x

3.1 Near-Facility Routine Environmental Samples and Locations ............................... 51

3.2 Environmental Surveillance Sample Types and Measurement Locations, $1991 \ldots \ldots . \quad 54$

3.3 Monthly Climatological Data from the Hanford Meteorology Station, $1991 \ldots \ldots \ldots \ldots \ldots$

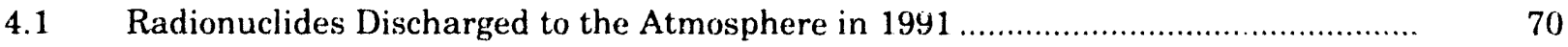

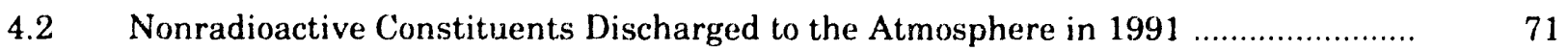

4.3 Radionuclides in Liquid Effluents Discharged to Ground Disposal

Facilities in 1991

4.4 Nonradioactive Liquid Constituents Discharged to Ground Disposal

Facilities in 1991

4.5 Radionuclides in Liquid Effluents Discharged to the Columbia River

from the 100 Areas in 1991

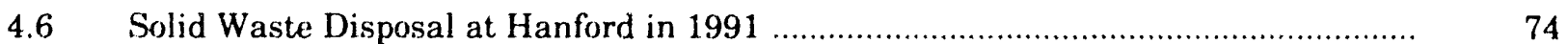

4.7 Hanford Site Tier-Two Emergency and Hazardous Chemical Inventory

Average Balance of Ten Chemicals Stored in Greatest Quantities in 1991

4.8 Air Sampling Locations and Sample Composite Groups ....................................

4.9 Sampling Frequency by Location for Air Samples Collected in $1991 \ldots \ldots \ldots \ldots \ldots \ldots \ldots \ldots \ldots \ldots \ldots \ldots$

4.10 Airborne Radionuclide Concentrations in the Hanford Environs, 1991 ..................... 82

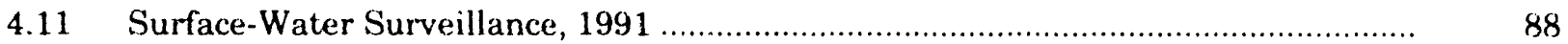

4.12 Numbers of Locations, Sampling Frequency and Analyses Performed

for Food and Farm Products for 1991.

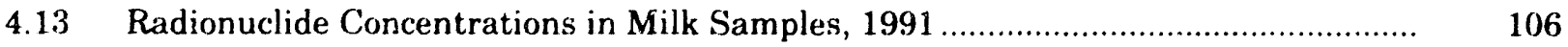

4.14 Concentrations of Tritium and Cesium-137 in Columbia Basin and Yakima Valley Wines 
4.15 Number and Species and Locations Sampled and Analyzed for

Fish and Wildlife, 1991

4.16 Soil and Vegetation Samples Collected in 1991

4.17 Dose Rates for Thermoluminescent Dosimeters at Perimeter and

Community Locations, 1991

4.18 Dose Rates Measured by Thermoluminescent Dosimeter Along the Hanford Reach of the Columbia River, 1991

4.19 Dose Rates for Thermoluminescent Dosimeter Locations on the Hanford

Site, 1991

4.20 Doses to the Hypothetical Maximally Exposed Individual from 1991

Hanford Operations

4.21 Population Doses from 1991 Hanford Operations

4.22 Summary of Doses to the Public in the Vicinity of Hanford from Various

Sources, 1991

4.23 Estimated Risk from Various Activities and Exposures

4.24 Activities Comparable in Risk to that from the 0.02-mrem Dose

Calculated for the 1991 Maximally Exposed Individual

5.1 Radionuclides and Chemicals Analyzed for in Ground Water

5.2 Major Chemical and Radiological Ground-Water Contaminants and

Their Link to Site Operations

6.1 International Technology Corporation Performances on DOE Quality

Assessment Program Samples in 1991

6.2 International Technology Corporation Performances on EPA

Intercomparison Program Samples in 1991

B.1 Washington State Water Quality Standards for the Hanford Reach of the

Columbia River

B.2 Radiological Drinking Water Standards: U.S. Environmental Protection Agency, National Primary Drinking Water Regulations; and State of Washington, Rules and Regulations of the State Board of Health Regarding Public Water Systems

B.3 Chemical Drinking Water Standards: U.S. Environmental Protection Agency, National Primary Drinking Water Regulations; and State of Washington, Public Water Supplies

B.4 Benton-Franklin-Walla Walla Counties Air Pollution Control Authority Ambient Air Quality Standards 
Contents

B.5 Radiation Standards for Protection of the Public from All Routine

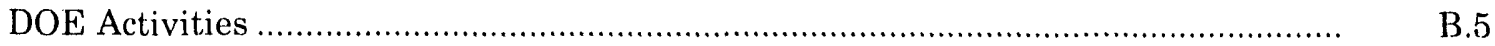

B.6 Derived Concentration Guides …......................................................................... B. 6

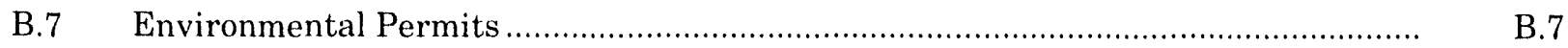

C.1 Food Pathway Parameters Used in the 1991 Dose Calculations ................................ C.4

C.2 Dietary Parameters Used in the 1991 Dose Calculations .......................................... C.4

C.3 Residency Parameters Used in the 1991 Dose Calculations ..................................... C.5

C.4 Recreational Parameters Used in the 1991 Dose Calculations .................................. C.5

E.1 Radionuclide Analyzed by Gamma-Spectroscopy ................................................. E.1 
Helpful Information 


\section{Helpful Information}

The following information is provided to assist the reader in understanding the report. Definitions of technical terms can be found in Appendix A, "Glossary."

\section{Scientific Notation}

Scientific notation is used in this report to express very large or very small numbers. For example, the number 1 billion could be written as $1,000,000,000$ or using scientific notation as $1 \times 10^{\prime \prime}$. Translating from scientific notation to a more traditional number requires moving the decimal point either left or right from the number. If the value given is $2.0 \times 10^{3}$, the decimal point should be moved three numbers (insert zeros if no numbers are given) to the right of its present location. The number would then read 2,000 . If the value given is $2.0 \times 10^{5}$, the decimal point should be moved five numbers to the left of its present location. The result would become 0.00002 .

\section{Metric Units}

The primary units used in this report are metric. Table H.1 summarizes and defines the terms and corresponding symbols (metric and nonmetric) found throughout this report.

\section{Radioactivity Units}

Much of this report deals with levels of radioactivity in various environmental media. Radioactivity in this report is usually discussed in units of curies (Ci) (Table H.2). The curie is the basic unit used to describe the amount of radioactivity present, and concentrations are generally expressed in terms of fractions of curies per unit mass or volume. One curie is equivalent to 37 billion disintegrations per second or is a quantity of any radionuclide that decays at the rate of 37 billion disintegrations per second. Disintegrations generally produce spontaneous emissions of alpha or beta particles, gamma radiation, or combinations of these. In some instances in this report, radiation values are expressed with two sets of units. One set of units is usually included in parenthesis or footnotes. These units belong to the International System of Units (SI), and their inclusion in this report is mandated by DOE. SI units are the "new" internationally accepted units and will eventually be the standard for reporting radioactivity and radiation dose in the United States. The basic unit for discussing radioactivity, the curie, can be converted to the equivalent SI unit, the becquerel $(\mathrm{Bq})$, by multiplying by $3.7 \times 10^{\prime \prime \prime}$. One becquerel is equivalent to one nuclear disintegration per second.

\section{Radiation Dose Units}

The amount of radiation received by a living organism is expressed in terms of radiation dose. Radiation dose in this report is usually written in terms of effective dose equivalent and reported numerically in units of rem or in the SI unit, sievert ( $\mathrm{Sv}$ ) (Table H.3). Rem (sievert) is a term that relates ionizing radiation and biological effect or risk. A dose of 1 millirem has a biological effect similar to the dose received from about one day's exposure to natural background radiation (see "Hanford Environmental Radiation Public Dose in Perspective" in Section 4.8 for a more in-depth discussion of risk comparisons). To convert the most commonly used dose term in this report, the millirem, to the SI equivalent, the sievert, multiply millirem by $10^{5}(1$ sievert is equal to $1.0 \times 10^{5}$ millirem).

Additional information on radiation and dose terminology can be found in the glossary of this report (Appendix A). A list of the radionuclides discussed in this report and their half-lives is included on page xxxvii of this section.

General information on radiation and radiation dose (as well as Hanford's Environmental Monitoring Program, Hanford's Cultural Resource Program, and Hanford's wildlife) has been compiled in informational pamphlets that can be 
Table H.1. Names and Symbols for Units of Measure

\begin{tabular}{cllll}
\multicolumn{2}{c}{ Length } & \multicolumn{2}{c}{ Time } \\
\cline { 1 - 1 } Symbol & \multicolumn{1}{c}{ Name } & & Symbol & Name \\
\cline { 1 - 1 } $\mathrm{cm}$ & centimeter $\left(1 \times 10^{-2} \mathrm{~m}\right)$ & & $\mathrm{d}$ & day \\
$\mathrm{ft}$ & foot & $\mathrm{h}$ & hour \\
$\mathrm{in}$. & inch & $\mathrm{min}$ & minute \\
$\mathrm{km}$ & kilometer $\left(1 \times 10^{3} \mathrm{~m}\right)$ & $\mathrm{s}$ & second \\
$\mathrm{m}$ & meter & $\mathrm{yr}$ & year \\
$\mathrm{mi}$ & mile & & \\
$\mathrm{mm}$ & millimeter $\left(1 \times 10^{-3} \mathrm{~m}\right)$ & & \\
$\mu \mathrm{m}$ & micrometer $\left(1 \times 10^{-6} \mathrm{~m}\right)$ & &
\end{tabular}

\begin{tabular}{|c|c|}
\hline \multicolumn{2}{|r|}{ Area } \\
\hline Symbol & Name \\
\hline $\begin{array}{l}\mathrm{ha} \\
\mathrm{km}^{2} \\
\mathrm{mi}^{2}\end{array}$ & $\begin{array}{l}\text { hectare }\left(10,000 \mathrm{~m}^{2}\right) \\
\text { square kilometer } \\
\text { square mile }\end{array}$ \\
\hline
\end{tabular}

\begin{tabular}{|c|c|}
\hline \multicolumn{2}{|r|}{ Volume } \\
\hline Symbol & Name \\
\hline $\begin{array}{l}\mathrm{cm}^{3} \\
\mathrm{gal} \\
\mathrm{L} \\
\mathrm{mL} \\
\mathrm{m}^{3} \\
\mathrm{ppmv} \\
\mathrm{qt} \\
\mathrm{yd}^{3}\end{array}$ & $\begin{array}{l}\text { cubic centimeter } \\
\text { gallon } \\
\text { liter } \\
\text { milliliter }\left(10^{-3} \mathrm{~L}\right) \\
\text { cubic meter } \\
\text { parts per million volume } \\
\text { quart } \\
\text { cubic yard }\end{array}$ \\
\hline \multicolumn{2}{|r|}{ Rate } \\
\hline Symbol & Name \\
\hline $\begin{array}{l}\mathrm{cfs} \\
\mathrm{mi} / \mathrm{h}\end{array}$ & $\begin{array}{l}\text { cubic feet per second } \\
\text { miles per hour }\end{array}$ \\
\hline
\end{tabular}

\begin{tabular}{|c|c|}
\hline \multicolumn{2}{|r|}{ Mass } \\
\hline Symbol & Name \\
\hline $\begin{array}{l}\mathrm{g} \\
\mathrm{Gg} \\
\mathrm{kg} \\
\mathrm{mg} \\
\mu \mathrm{g} \\
\mathrm{ng} \\
\mathrm{t}\end{array}$ & $\begin{array}{l}\text { gram } \\
\text { gigagram }\left(10^{9} \mathrm{~g}\right) \\
\text { kilogram }\left(10^{3} \mathrm{~g}\right) \\
\text { milligram }\left(10^{-3} \mathrm{~g}\right) \\
\text { microgram }\left(10^{-6} \mathrm{~g}\right) \\
\text { nanogram }\left(10^{\cdot 9} \mathrm{~g}\right) \\
\left.\text { metric ton (or tonne; } 10^{3} \mathrm{~kg}\right)\end{array}$ \\
\hline \multicolumn{2}{|r|}{ Temperature } \\
\hline Symbol & Name \\
\hline $\begin{array}{l}{ }^{\circ} \mathrm{C} \\
{ }^{\circ} \mathrm{F}\end{array}$ & $\begin{array}{l}\text { degrees Centigrade } \\
\text { degrees Fahrenheit }\end{array}$ \\
\hline
\end{tabular}

Table H.2. Units of Radioactivity

Table H.3. Units of Radiation Dose

\begin{tabular}{ll}
\multicolumn{2}{c}{ Radioactivity } \\
\hline$\underline{\text { Symbol }}$ & $\frac{1}{\text { Name }}$ \\
$\mathrm{Ci}$ & $\quad$ curie \\
$\mathrm{mCi}$ & millicurie $\left(10^{-3}(\mathrm{Ci})\right.$ \\
$\mu \mathrm{Ci}$ & microcurie $\left(10^{-6} \mathrm{Ci}\right)$ \\
$\mathrm{nCi}$ & nanocurie $\left(10^{-9} \mathrm{Ci}\right)$ \\
$\mathrm{pCi}$ & picocurie $\left(10^{-12} \mathrm{Ci}\right)$ \\
$\mathrm{fCi}$ & femtocurie $\left(10^{-15} \mathrm{Ci}\right)$ \\
$\mathrm{aCi}$ & attocurie $\left(10^{-11} \mathrm{Ci}\right)$ \\
$\mathrm{Bq}$ & becquerel
\end{tabular}

\begin{tabular}{|c|c|}
\hline \multicolumn{2}{|c|}{ Radiation Dose } \\
\hline Symbol & Name \\
\hline mrad & millirad \\
\hline mrem & millirem $\left(10^{-3} \mathrm{rem}\right)$ \\
\hline $\mathrm{Sv}$ & sievert \\
\hline $\mathrm{mSv}$ & millisievert $\left(10^{-3} \mathrm{~Sv}\right)$ \\
\hline$\mu \mathrm{Sv}$ & microsievert $\left(10^{-6} \mathrm{~Sv}\right)$ \\
\hline $\mathrm{mR}$ & milliroentgen \\
\hline
\end{tabular}


obtained, free, by writing to Dr. Robert H. Gray, Manager, Hanford Environmental Surveillance and Oversight, P.O. Box 999, Richland, Washington 99352. More comprehensive readings on radiation and radiation dose can be found in most public libraries and in many local book stores.

\section{Understanding the Data Tables}

Measuring any physical quantity (for example, temperature, distance, time, or radioactivity) has some degree of inherent uncertainty. This uncertainty results from the combination of all possible inaccuracies in the measurement process, including such factors as the reading of the result, the calibration of the measurement device, and numerical rounding errors. In this report, individual radioactivity measurements are accompanied by a plus or minus ( \pm ) value (sometimes expressed as a percentage of the related concentration value), which is the uncertainty term known as a two-sigma counting error. Because measuring a radionuclide requires a process of counting random radioactive emissions from a sample, the twosigma counting error gives information on what the measurement might be if the same sample were counted again under identical conditions. The two-sigma counting error implies that approximately $95 \%$ of the time, a recount of the same sample would give a value somewhere between the reported value minus the two-sigma counting error and the reported value plus the two-sigma counting error. Values in the tables that are less than the two-sigma counting error indicate that the reported result might have come from a sample with no radioactivity. Such values are considered as below detection. Also note that each radioactive measurement must have the random background radioactivity of the measuring instrument subtracted; therefore, negative results are possible, especially when the sample has very little radioactivity.

Just as individual values are accompanied by two-sigma counting errors, reported means $(\bar{X})$ are accompanied by two standard errors of the calculated mean (SEM). In this report, SEM is expressed as a percentage of the mean concentration value. If the data fluctuate randomly, then the SEM is a measure of the uncertainty in the estimated mean of the data from this randomness. If trends or periodic (for example, seasonal) fluctuations are present, then the SEM is primarily a measure of the variability in the trends and fluctuations about the mean of the data.

\section{Understanding Graphical Information}

Presenting data on a graph is useful when comparing numbers collected at several locations or at one location over time. Graphs make it easier to visualize differences where they exist. However, while graphs may make it easier to evaluate data, they may also lead the reader to incorrect conclusions if they are not interpreted correctly. Careful consideration should be given to the scale (linear or logarithmic) and concentration units being used.

Some of the data graphed in this report are plotted using logarithmic (or compressed) scales. Logarithmic scales are useful when plotting two or more numbers that differ greatly in size. For example, a sample with a concentration of $5 \mathrm{~g} / \mathrm{L}$ would get lost at the bottom of the graph if plotted on a linear scale with a sample having a concentration of $300 \mathrm{~g} / \mathrm{L}$ (Figure H.1). A logarithmic plot of these same two numbers allows the reader to see both data points and compare their relative concentrations (Figure H.2).

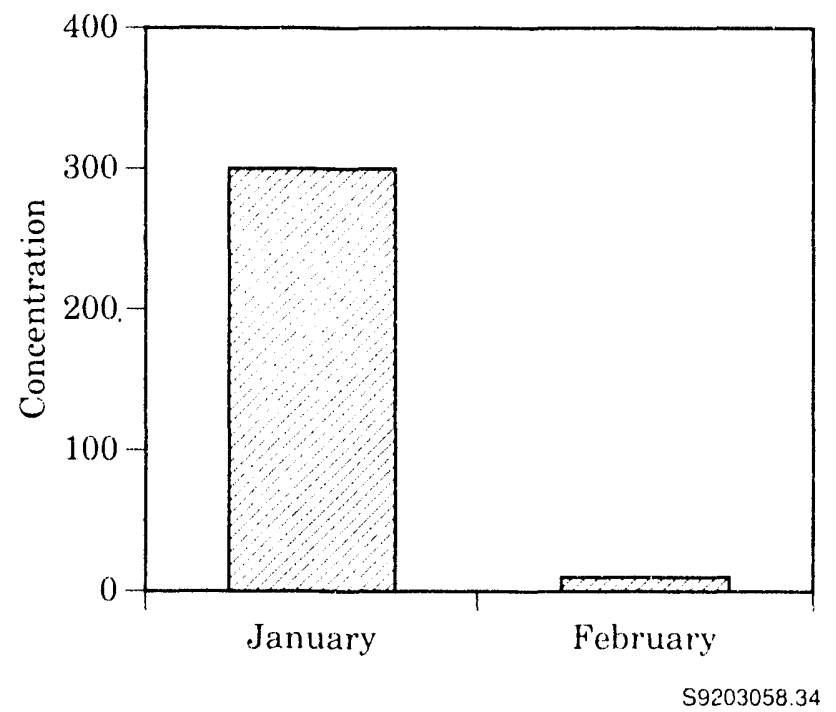

Figure H.1. Data Plotted Using a Linear Scale 


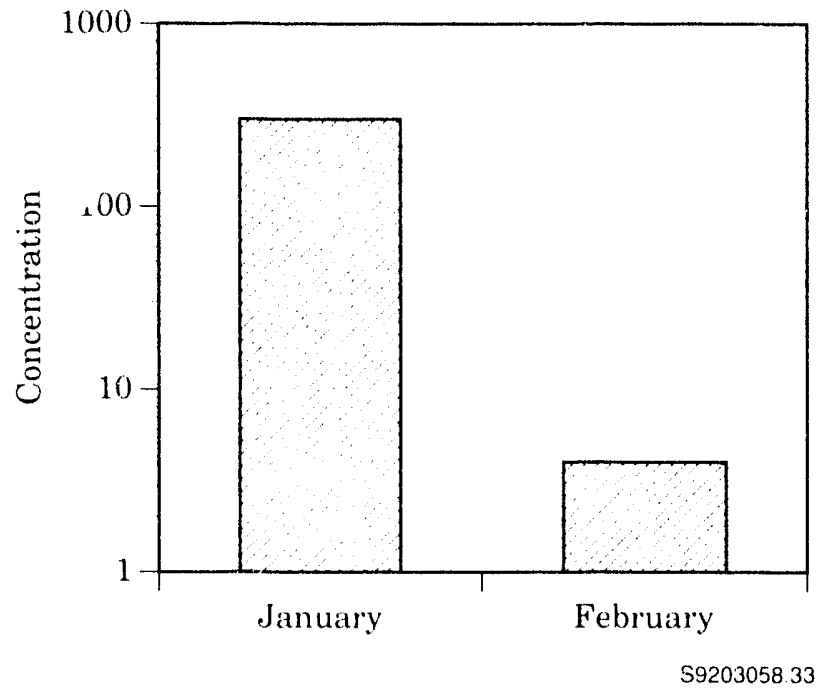

Figure H.2. Data Plotted Using a Logarithmic Scale

Many of the mean values graphed in this report have vertical lines extending above and below the data point. These lines (called error bars), which are usually capped at both ends with a short horizontal line, indicate the amount of uncertainty in the reported result. The error bars in this report represent a $95 \%$ chance that the result is between t: e upper and lower ends of the error bar, and a $5 \%$ chance that the actual result is either lower or higher than the error bar." "For example, in Figure H.3, the first plotted value has a result of $2.0 \pm 1.1$, so there is a $95 \%$ chance that the actual result is between 0.9 and 3.1 , a $2.5 \%$ chance it is less than 0.9 , and a $2.5 \%$ chance it is greater than 3.1. Error bars are computed statistically employing all of the information used to generate the data point plotted on the graph. These bars indicate whether one value is statistically similar to or different from another value. If the error bars (or range of values) of two or more values overlap, as is the case with values 1 and 3 and values 2 and 3 , the values are considered to be similar, statistically. If the error

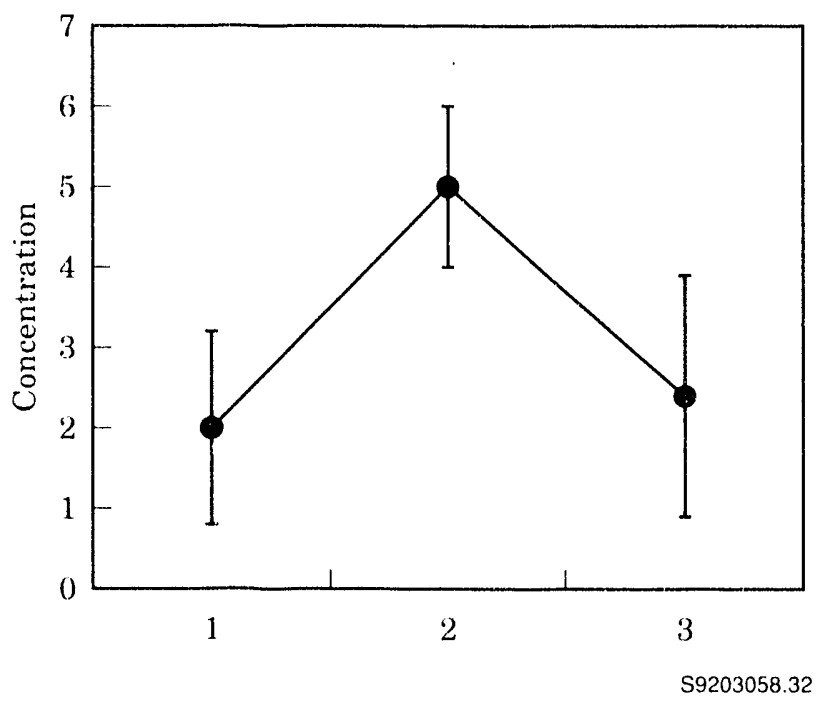

Figure H.3. Data With Error Bars Plotted Using a Linear Scale

bars do not overlap (values 1 and 2), the values are considered to be statistically different. Values that appear to be very different visually (values 2 and 3 ) may actually be quite similar when compared statistically.

\section{Greater Than $(>)$ or Less Than (<) Symbols}

Greater than ( $>$ ) or less than $(<)$ symbols are used to indicate that the actual value may either be larger than the number given or smaller than the number given. For example, $>0.09$ would indicate that the actual value is greater than 0.09 . An inequality symbol pointed in the opposite direction $(<0.09)$ would indicate that the number is less than the value presented. If an inequality symbol is used in association with an underscore $(\leq$ or $\geq$ ), his indicates that the actual value is less-than-or-equal-to or greater-than-or-equal-to the number given, respectively.

(a) Assuming the Normal statistical distribution of the data. 


\section{Radionuclide Nomenclature}

\begin{tabular}{|c|c|c|}
\hline Radionuclide & Symbol & Half-Life \\
\hline tritium & "H & $12.3 \mathrm{yr}$ \\
\hline beryllium-7 & ${ }^{7} \mathrm{Be}$ & $53.28 \mathrm{~d}$ \\
\hline carbon-14 & ${ }^{1.1} \mathrm{C}$ & $5730 \mathrm{yr}$ \\
\hline sodium-22 & ${ }^{2}: \mathrm{Na}$ & $2.6 \mathrm{yr}$ \\
\hline potassium-40 & ${ }^{40} \mathrm{~K}$ & $1.26 \times 10^{9} \mathrm{yr}$ \\
\hline $\operatorname{argon}-41$ & ${ }^{41} \mathrm{Ar}$ & $1.8 \mathrm{~h}$ \\
\hline chromium-51 & ${ }^{51} \mathrm{Cr}$ & $27.7 \mathrm{~d}$ \\
\hline manganese-54 & ${ }^{5.4} \mathrm{Mn}$ & $312 \mathrm{~d}$ \\
\hline cobalt-57 & ${ }^{57} \mathrm{Co}$ & $271.8 \mathrm{~d}$ \\
\hline cobalt-60 & ${ }^{60} \mathrm{Co}$ & $5.3 \mathrm{yr}$ \\
\hline nickel-63 & ${ }^{6 i 3} \mathrm{Ni}$ & $92 \mathrm{yr}$ \\
\hline zinc-65 & ${ }^{6} \mathrm{Zn}$ & $243.8 \mathrm{~d}$ \\
\hline krypton-85 & ${ }^{85} \mathrm{Kr}$ & $10.7 \mathrm{yr}$ \\
\hline strontium-89 & ${ }^{49} \mathrm{Sr}$ & $52 \mathrm{~d}$ \\
\hline strontium-90 & ${ }^{9} \mathrm{Sr}$ & $28.8 \mathrm{yr}$ \\
\hline niobium-95 & ${ }^{95} \mathrm{Nb}$ & $36 \mathrm{~d}$ \\
\hline zirconium-95 & ${ }^{95} \mathrm{Zr}$ & $64.0 \mathrm{~d}$ \\
\hline molybdenum-99 & ${ }^{9 ! 9} \mathrm{Mo}$ & $66.0 \mathrm{~h}$ \\
\hline technetium-99 & $\mathrm{Tc}$ & $2.12 \times 10^{5} \mathrm{yr}$ \\
\hline ruthenium-103 & ${ }^{103} \mathrm{Ru}$ & $39.4 \mathrm{~d}$ \\
\hline ruthenium-106 & ${ }^{106} \mathrm{Ru}$ & $367 \mathrm{~d}$ \\
\hline $\operatorname{tin}-113$ & ${ }^{11: 3 \mathrm{Sn}}$ & $115 \mathrm{~d}$ \\
\hline antimony-125 & ${ }^{125} \mathrm{Sb}$ & $2.7 \mathrm{yr}$ \\
\hline iodine-129 & ${ }^{129} \mathrm{I}$ & $1.6 \times 10^{7} \mathrm{yr}$ \\
\hline iodine-131 & ${ }^{131} \mathrm{I}$ & $8.0 \mathrm{~d}$ \\
\hline barium-133 & ${ }^{13: 3} \mathrm{Ba}$ & $10.53 \mathrm{yr}$ \\
\hline cesium-134 & ${ }^{134} \mathrm{Cs}$ & $2.1 \mathrm{yr}$ \\
\hline
\end{tabular}

\begin{tabular}{|c|c|c|}
\hline Radionuclide & Symbol & Half-Life \\
\hline cesium-137 & ${ }^{1: 37} \mathrm{Cs}$ & $30.2 \mathrm{yr}$ \\
\hline cerium-144 & ${ }^{14.4} \mathrm{Ce}$ & $284 \mathrm{~d}$ \\
\hline promethium-147 & ${ }^{1.17} \mathrm{Pm}$ & $2.62 \mathrm{yr}$ \\
\hline europium-i52 & ${ }^{152} \mathrm{Eu}$ & $12 \mathrm{yr}$ \\
\hline europium-154 & ${ }^{154} \mathrm{Eu}$ & $16 \mathrm{yr}$ \\
\hline europium-155 & ${ }^{155} \mathrm{Eu}$ & $1.8 \mathrm{yr}$ \\
\hline thallium-208 & ${ }^{2018} \mathrm{Tl}$ & $3.1 \mathrm{~min}$ \\
\hline bismuth-212 & ${ }^{212} \mathrm{Bi}$ & $60.6 \mathrm{~min}$ \\
\hline lead-212 & ${ }^{212} \mathrm{~Pb}$ & $10.6 \mathrm{~h}$ \\
\hline polonium-212 & ${ }^{212} \mathrm{Po}$ & $0.3 \times 10^{-6} \mathrm{~s}$ \\
\hline polonium-216 & ${ }^{216} \mathrm{Po}$ & $0.15 \mathrm{~s}$ \\
\hline radon- 220 & ${ }^{220} \mathrm{Rn}$ & $55.6 \mathrm{~s}$ \\
\hline radium-226 & ${ }^{226} \mathrm{Ra}$ & $1600 \mathrm{yr}$ \\
\hline radium-228 & ${ }^{228} \mathrm{Ra}$ & $5.75 \mathrm{yr}$ \\
\hline thorium-232 & $2: 2 \mathrm{Th}$ & $1.4 \times 10^{10} \mathrm{yl}$ \\
\hline uranium total & $\mathrm{U}$ or uranium & -- \\
\hline uranium-234 & ${ }^{234} \mathrm{U}$ & $2.4 \times 10^{5} \mathrm{yr}$ \\
\hline uranium-235 & ${ }^{235} \mathrm{U}$ & $7 \times 10^{7} \mathrm{yr}$ \\
\hline uranium-236 & ${ }^{236} \mathrm{U}$ & $2.3 \times 10^{7} \mathrm{yr}$ \\
\hline uranium-238 & ${ }^{2334} \mathrm{U}$ & $4.5 \times 10^{9} \mathrm{yr}$ \\
\hline plutonium-238 & ${ }^{234} \mathrm{Pu}$ & $87.7 \mathrm{yr}$ \\
\hline neptunium-239 & ${ }^{239} \mathrm{~Np}$ & $2.4 \mathrm{~d}$ \\
\hline plutonium-239 & ${ }^{239} \mathrm{Pu}$ & $2.4 \times 10^{4} \mathrm{yr}$ \\
\hline plutonium-240 & ${ }^{240} \mathrm{Pu}$ & $6537 \mathrm{yr}$ \\
\hline plutonium-241 & ${ }^{241} \mathrm{Pu}$ & $14.4 \mathrm{yr}$ \\
\hline americium-241 & ${ }^{241} \mathrm{Am}$ & $433 \mathrm{yr}$ \\
\hline
\end{tabular}




\section{Elemental and Chemical Constituent Nomenclature}

Constituent
aluminum
ammonia
ammonium
antimony
arsenic
barium
beryllium
bicarbonate
boron
cadmium
calcium
calcium fluoride
carbon
carbonate
carbon tetrachloride
chloride
chromium (species)
chromium (total)
cobalt
copper
cyanide
fluoride

\section{Conversion Table}

\begin{tabular}{|c|c|c|}
\hline Multiply & By & To Obtain \\
\hline in. & 2.54 & $\mathrm{~cm}$ \\
\hline $\mathrm{ft}$ & 0.305 & $\mathrm{~m}$ \\
\hline $\mathrm{mi}$ & 1.61 & $\mathrm{~km}$ \\
\hline lb & 0.454 & $\mathrm{~kg}$ \\
\hline $\operatorname{liq} q t$ & 0.946 & $\mathrm{~L}$ \\
\hline $\mathrm{ft}^{2}$ & 0.093 & $m^{2}$ \\
\hline acres & 0.405 & ha \\
\hline $\mathrm{mi}^{2}$ & 2.59 & $\mathrm{~km}^{2}$ \\
\hline $\mathrm{ft}^{3}$ & 0.028 & $\mathrm{~m}^{3}$ \\
\hline $\mathrm{dpm}$ & 0.450 & $\mathrm{pCi}$ \\
\hline $\mathrm{nCi}$ & 0.001 & $\mathrm{pCi}$ \\
\hline $\mathrm{pCi} / \mathrm{L}$ & $10^{\cdot 9}$ & $\mu \mathrm{Ci} / \mathrm{mL}$ \\
\hline $\mathrm{pCi} / \mathrm{m}^{3}$ & $10^{-12}$ & $\mathrm{Ci} / \mathrm{m}^{3}$ \\
\hline $\mathrm{pCi} / \mathrm{m}^{3}$ & $10^{15}$ & $\mathrm{mCi} / \mathrm{cm}^{3}$ \\
\hline $\mathrm{mCi} / \mathrm{km}^{2}$ & 1.0 & $\mathrm{nCi} / \mathrm{m}^{2}$ \\
\hline becquerel & $2.7 \times 10^{-11}$ & curie \\
\hline gray & 100 & $\mathrm{rad}$ \\
\hline sievert & 100 & rem \\
\hline $\mathrm{ppb}$ & 0.001 & ppm \\
\hline ppm & 1.0 & $\mathrm{mg} / \mathrm{L}$ \\
\hline${ }^{\circ} \mathrm{F}$ & $\left(\mathrm{F}^{\circ}-32\right) \div 9 / 5$ & ${ }^{\circ} \mathrm{C}$ \\
\hline
\end{tabular}

\begin{tabular}{ll}
\multicolumn{1}{c}{ Constituent } & Symbol \\
\cline { 1 - 2 } iron & $\mathrm{Fe}$ \\
lead & $\mathrm{Pb}$ \\
lithium fluoride & $\mathrm{LiF}$ \\
magnesium & $\mathrm{Mg}$ \\
manganese & $\mathrm{Mn}$ \\
mercury & $\mathrm{Hg}$ \\
nickel & $\mathrm{Ni}$ \\
nitrate & $\mathrm{NO}_{3}^{-}$ \\
nitrogen & $\mathrm{N}$ \\
nitrogen dioxide & $\mathrm{NO}$ \\
phosphate & $\mathrm{PO}_{4}{ }^{\prime}$ \\
phosphorus & $\mathrm{P}$ \\
potassium & $\mathrm{K}$ \\
selenium & $\mathrm{Se}$ \\
silver & $\mathrm{Ag}$ \\
sodium & $\mathrm{Na}$ \\
strontium & $\mathrm{Sr}$ \\
sulfate & $\mathrm{SO}{ }_{4}^{2}$ \\
thallium & $\mathrm{Tl}$ \\
trichlorylmethane & $\mathrm{CHCl}{ }_{3}$ \\
vanadium & $\mathrm{V}$ \\
zinc & $\mathrm{Zn}$
\end{tabular}




\section{Acronyms and Abbreviations}

ALARA

as low as reasonably achievable

ALE

ANSI

ASME

ASTM

CERCLA

CFR

DCE

DCG

DOE

DOE-HQ

DOH

DOI

DWS

EDE

EIS

EPA

ERDA

ERRA

ES\&H
Arid Lands Ecology (Reserve)

American National Standards

Institute

American Society of Mechanical Engineers

American Society for Testing and Materials

Comprehensive Environmental

Response, Compensation, and

Liability Act

Code of Federal Regulations

dichloroethylene

Derived Concentration Guide

U.S. Department of Energy

U.S. Department of Energy-

Headquarters

State of Washington Department of Health

U.S. Department of the Interior

drinking water standards

effective dose equivalent

environmental impact statement

U.S. Environmental Protection Agency

U.S. Energy Research and

Development Administration

Environmental Restoration

Remedial Action (Program)

environment, safety, and health
FDA

U.S. Food and Drug

Administration

FEMP

Facility Effluent Monitoring Plan

FFTF Fast Flux Test Facility

FIFRA Federal Insecticide, Fungicide, and Rodenticide Act

FONSI

FR

FY

GAO

HCRL

HDW

HEDR

HMS

ICRP

ISV

IT

LLBG

LWDF

MASF

MCL

MDA

MDC
Finding of No Significant Impact

Federal Register

fiscal year

General Accounting Office

Hanford Cultural Resources Laboratory

Hanford Defense Waste

Hanford Environmental Dose Reconstruction (Project)

Hanford Meteorological Station

International Commission on

Radiological Protection

in situ vitrification

International Technology

Corporation

Low-Level Burial Ground

Liquid Waste Disposal Facility

Maintenance and Storage Facility

maximum contaminant level

minimum detectable activity

minimum detectable

concentration 
MEI

NCRP

NEPA

NESHAP

NPDES

NPR

NPS

NRC

NS

NTU

NWR

PCB

PEIS

PFP

PNL

PSD

PUREX

QA

QC

RCRA

RCW

REDOX maximally exposed individual

National Council on Radiation

Protection and Measurements

National Environmental Policy

Act

National Emission Standards for Hazardous Air Pollutants

National Pollutant Discharge

Elimination System

New Production Reactor

National Park Service

U.S. Nuclear Regulatory

Commission

no standard

nephelometric turbidity unit

National Wildlife Refuge

polychlorinated biphenyl

Programmatic Environmental

Impact Statement

Plutonium Finishing Plant

Pacific Northwest Laboratory

prevention of significant

deterioration

Plutonium Uranium Extraction

(Plant)

quality assurance

quality control

Resource Conservation and

Recovery Act

Revised Code of Washington

Reduction Oxidation (Plant)
SARA Superfund Amendments and

RI/FS

RL

U.S. Department of Energy

Richland Field Office Reauthorization Act

SE

SEM

SEN

SI

SOF

TCE

TLD

TOX

TRU

TSD

UNSCEAR

UO $O_{3}$ Plant

USC

USGS

UST

VOA

WAC

WIPP

WHC

WRA standard error

standard error of the mean

Secretary of Energy Notice

International System of Units

Statement of Findings

trichloroethylene

thermoluminescent dosimeter

total organic halogens

transuranic

treatment, storage, and disposal

United Nations Science

Committee on the Effects of

Atomic Radiation

Uranium Oxide Plant

United States Code

U.S. Geological Survey

U.S. Testing Company, Inc.

volatile organic analyses

Washington Administrative Code

Waste Isolation Pilot Plant

Westinghouse Hanford Company

Wildlife Recreation Area 
Introduction 


\subsection{Introduction}

The purpose of this report is to summarize information and $d$ ta that characterize Hanford Site environmen al management performance and demonstrate the status or compliance with applicable federal, state, and local environmental laws and regulations. The report also highlights significant environmental programs and efforts.

The report describes the Site mission and activities, general environmental features, radiological and chemical releases from operations, status of compliance with environmental regulations, status of programs to accornplish compliance, and environmental monitoring activities and results.
Those interested in more detail than the summary information presented in this report are referred to the technical reports cited in the text. Report sources include local community libraries and the National Technical Information Center, Springfield, Virginia 22161. Descriptions of analytical and sampling methods, formerly part of this report, are contained in the Hanford Site Environmental Monitoring Plan (DOE 1991b). Readers less familiar with the concepts, terminology, and units used in this report may find the preceding Helpful Information section useful. 


\subsection{Site Mission}

The Hanford Site was acquired by the federal government in 1943. For more than 20 years, Hanford Site facilities were dedicated primarily to the production of plutonium for national defense and management of the resulting wastes. In later years, programs at the Hanford Site were diversified to include research and development for advanced reactors, renewable energy technologies, waste disposal technologies, and cleanup of contamination from past practices.

The U.S. Department of Energy (DOE) is establishing a new mission for Hanford including:

- Waste Management of stored defense wastes and the handling, storage, and disposal of radioactive, hazardous, mixed, or sanitary wastes from current operations

- Environmental Restoration of approximately 1,100 inactive radioactive, hazardous, and mixed waste sites and about 100 surplus facilities
- Research and Development in energy, health, safety, environmental sciences, molecular sciences, environmental restoration, waste management, and national security

- Technology Development of new environmental restoration and waste management technologies, including site characterization and assessment methods; waste minimization, treatment, and remediation technology; and education outreach programs.

The DOE has set a goal of cleaning up Hanford's waste sites and bringing its facilities into compliance with local, state, and federal environmental laws by 2018 . 


\subsection{Major Operations and Activities}

The primary DOE operations and activities on the Hanford Site in 1991 included waste management, site restoration, environmental corrective actions, research and technology development, and site management. The majority of these activities were conducted under the Environmental Restoration and Waste Management Program for the Hanford Site. The overall program plan is discussed in Section 3.0, "Environmental Program Information."

\section{Waste Management}

Current waste-management activities at the Site primarily include the management of high- and low-activity defense wastes in the 200-East and 200-West Areas (Figure 1.1) and the storage of spent defense fuel in the 100-K Area. Key wastemanagement facilities include the waste storage tanks, Central Waste Complex, Low-Level Burial Ground (LLBG), 100-K Fuel Storage Basins, Plutonium Uranium Extraction (PUREX) Plant, Plutonium Finishing Plant (PFP), B Plant, and 242-A Evaporator.

Waste-management activities involving singleshell and double-shell tanks currentily include ensuring safe storage of wastes through surveillance and monitoring of the tanks and upgrading monitoring instrumentation. Concerns have been raised about the potential of a ferrocyanide explosion and hydrogen gas accumulation in the waste tanks. One issue is that under certain conditions of chemical concentration, moisture, and temperature, ferrocyanide and nitrates in the singleshell tanks could release heat and potentially become explosive. The other issue is that flammable hydrogen gases may be trapped beneath the crust in five double-shell tanks and 18 singleshell tanks. The DOE and external oversight groups have concluded that there is no imminent danger to the public from either situation. A Tank Waste Remediation System Division has been formed that has the responsibility to identify any hazards associated with the waste tanks and implement the necessary actions to mitigate or remediate those hazards. Studies are also being conducted to address the risks of chemical explosions in tanks.

The 100-KE and 100-KW Fuel Storage Basins are currently being used to store N Reactor spent fuel. In October 1990, DOE announced that an environmental impact statement would be prepared to evaluate options for disposition of the remaining fuel.

The PUREX Plant formerly processed irradiated reactor fuel to extract plutonium. Operation of the plant was stopped on December 7, 1988, for safety reasons. From December 1989 through March 1990, the facility completed a stabilization run to process fuel remaining in the plant. The PUREX Plant did not operate in 1990 after the stabilization run. Inventories of solvent and nuclear materials remain, including liquid uranyl nitrate hydrates, fuel from Hanford single-pass reactors, and organic materials. During FY 1991, transition of the PUREX Plant to a minimum safe standby condition began. It is anticipated that no decision on further operation of the PUREX Plant will be made for as long as 3 years.

The PFP was used to convert liquid plutonium from the PUREX Plant to plutonium oxide or metal. The PFP has not produced a product since 1987. The plant also processes and stabilizes scrap plutonium materials. Reactivation of the Plutonium Reclamation Facility, one of the operations at the PFP, is scheduled for late in FY 1992. Operations beyond this materials stabilization campaign will depend on the conclusions from an appropriate NEPA assessment.

There are no production activities currently taking place at B Plant but several operating systems are required to accomplish the $\mathrm{B}$ Plant $\mathrm{Fa}$ cility mission, which is to ensure safe storage and management of radiological inventories.

The Grout Treatment Facility will treat and dispose of low-level mixed waste liquid removed from the double-shell tanks. The facility combines liquid wastes with dry materials such as 


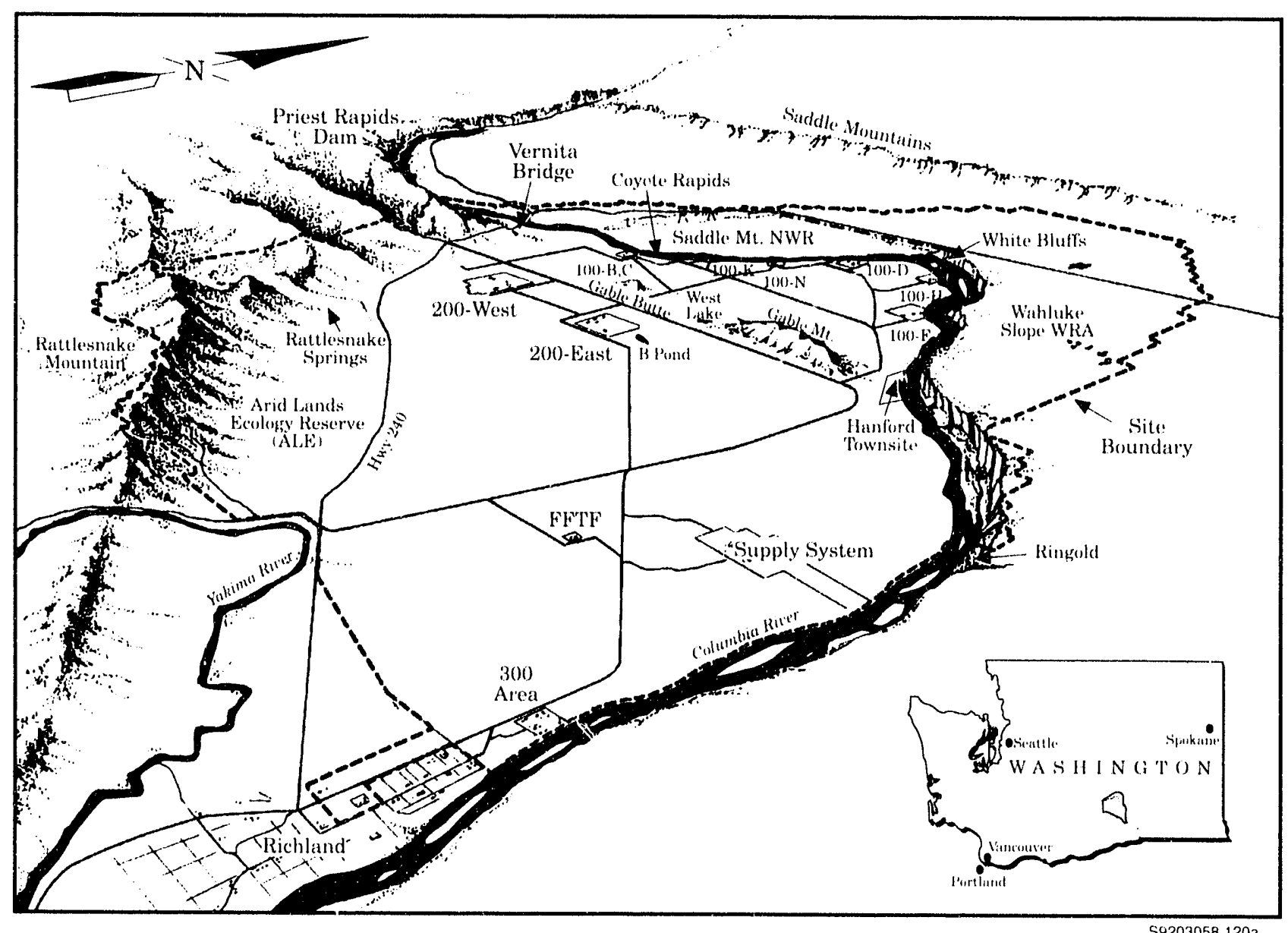

Figure 1.1. DOE's Hanford Site

cement, limestone, fly ash, and blast furnace slag to produce a grout slurry that is pumped into underground concrete vaults, where it solidifies. Approximately $6.1 \times 10^{\times} \mathrm{L}$ (160 million gal) of mixed waste are planned to be processed between 1992 and 2014. In 1991, facility systems were being prepared for start up in 1992. Construction is continuing on four new vaults with scheduled operation for October 1992.

The 242-A Evaporator is used to reduce the volume of liquid wastes from double-shell waste tanks. The process condensate will then be stored in liquid effluent retention facilities until the liquid effluent treatment facility is complete. The concentrated double-shell tank waste will be returned to the double-shell tanks. The retention facilities are scheduled for completion in August 1992. The treatment facility is being designed and constructed in the 200-East Area to remove listed chemical constituents from the 242-A Evaporator process condensate.

\section{Site Restoration}

Site restoration includes activities to decontaminate and decommission facilities and to clean up or restore inactive waste sites.

The Hanford surplus facilities program conducts surveillance and maintenance of surplus facilities, and has begun to clean up and dispose of more than 100 facilities. Current activities include decommissioning of the 201-C Strontium Semiworks and the 183-H Solar Evaporation Basins. The final environmental impact statement (EIS), Decommissioning of Eight Surplus 
Production Reactors at the Hanford Site, Richland, Washington, and subsequent Record of Decision are expected at any time.

The environmental restoration remedial action program was established to clean up avout 1,100 inactive waste sites. The Environmental Restoration Program initiated Expedited Response Actions on three individual waste sites. Over 40 drums containing more than $5,678 \mathrm{~L}$ $(1,500 \mathrm{gal})$ of solvent were removed from the 618-9 Burial Ground, preventing the solvent from reaching the ground water. Work was completed at the 300 Area Process Trench, with approximately $5,300 \mathrm{~m}^{3}\left(7,000 \mathrm{yd}^{3}\right)$ of contaminated soil being removed and isolated. A pilotscale carbon tetrachloride vapor extraction unit was successfully demonstrated at the 200 -West Area site, and procurement of a full-scale system was initiated.

\section{Corrective Activities}

Corrective activities consist of actions to comply with regulatory requirements or compliance agreements with federal, state, or local regulatory agencies. Corrective actions in 1991 are addressed in Section 2.0, "Environmental Compliance Summary."

\section{Research and Technology Development}

Research and technology development activities on the Hanford Site are a relatively minor contributor to Site releases. Most of these activities are located in the 200,300,400, and 3000 Areas, and releases occur primarily from the operation of research laboratories and pilot facilities. Many of these activities are intended to improve the techniques and reduce the costs of waste management, environmental protection, and Site restoration.

The Fast Flux Test Facility (FFTF) continued operations in 1991 conducting irradiation experiments. In 1991, the FFTF produced gadolinium153 for use in medical applications for detection of osteoporosis. While continued operation is in question, Congress has authorized $\$ 84$ million for operation in FY 1992.

The in situ vitrification (ISV) process is a technology for remediating contaminated soils. In the process, organic materials are destroyed by extreme heat and inorganic materials are immobilized for geologic periods in a highly durable glass and crystalline block.

During July 1991, a large-scale ISV test was conducted involving a 22,700-L (6,000-gal) underground storage tank. The test was staged so that the tank and surrounding soil could be instrumented for data collection during the test. The steel and concrete tank was designed to represent typical tank configurations throughout the DOE complex. A $0.3-\mathrm{m}(1-\mathrm{ft})$ layer of simulated sludge consisting only of Hanford soil saturated with water was placed on the bottom of the $3-\mathrm{m}$ (10-ft-) deep tank, and the remaining volume was backfilled with a low-density soil-like material to enhance subsidence during the melting process. No hazardous or radioactive materials were involved in the test. Powered operations of the test occurred over a 6-day period and melted from the

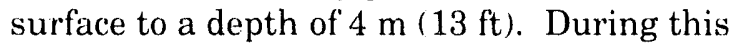
period the electrode feed system, which allows operators to adjust the position of the electrodes in the melt, was successfully demonstrated for the first time on the large-scale. The test was terminated earlier than planned when a rapid release of steam from the partially vitrified tank displaced a large volume of molten soil resulting in some damage to equipment. While precautions had been taken to mitigate against such transient vapor releases from the melt, the magnitude of the event was unforeseen. Data collected during the test and the event are being analyzed so that the cause of the event can be better understood.

\section{Site Management}

Hanford Site operations and activities are managed by RL through four prime contractors and numerous subcontractors. Each contractor is responsible for safe, environmentally sound 
maintenance and management of its facilities and operations; for waste management; and for monitoring of operations and effluents to ensure environmental compliance.

The principal responsibilities of these contractors include the following:

- Westinghouse Hanford Company, the operating and engineering contractor, conducts environmental restoration, reprocesses fuel and manages wastes, decommissions facilities, operates the FFTF reactor, maintains $\mathrm{N}$ Reactor and its fuel fabrication facilities, and provides support services such as security, fire protection, stores, and electrical power distribution.

- Battelle Memorial Institute, the research and development contractor, operates the Pacific Northwest Laboratory for DOE, conducting research and development in environmental restoration and waste management, environmental science, molecular science, energy, health and safety, and national security.
- Kaiser Engineers Hanford, the engineering and construction services contractor, provides architectural, construction, and engineering services.

- Hanford Environmental Health Foundation is the occupational and environmental health services contractor.

Non-DOE operations and activities on the Hanford Site include commercial power production by the Washington Public Power Supply System WNP-2 reactor and commercial low-level radioactive waste burial by U.S. Ecology. Siemens Nuclear Power Corporation operates a commercial nuclear fuel fabrication facility, and Allied Technology Group Corporation operates a lowlevel radioactive waste decontamination, supercompaction, and packaging disposal facility immediately adjacent to the southern boundary of the Site. 


\subsection{Site Environment}

The Hanford Site lies within the semiarid Pasco Basin of the Columbia Plateau in southeastern Washington State (see Figure 1.1). The Site occupies an area of about $1,450 \mathrm{~km}^{2}$ (approximately $560 \mathrm{mi}^{2}$ ) north of the confluences of the Snake and Yakima rivers with the Columbia River. This land, with restricted public access, provides a buffer for the smaller areas histori. cally used for production of nuclear materials, waste storage, and waste disposal; about $6 \%$ of the land area has been disturbed and is actively used. The Columbia River flows eastward through the northern part of the Hanford Site and then turns south, forming part of the eastern boundary. The Yakima River runs along part of the southern boundary and joins the Columbia River below the city of Richland. Adjoining lands to the west, north, and east are principally range and agricultural land in Benton and Franklin Counties. The cities of Richland, Kennewick, and Pasco (Tri-Cities) constitute the nearest population center and are located southeast of the Hanford Site.

\section{Demographics and Land Use}

Estimates by the U.S. Bureau of the Census for 1990 place the population totals for Benton and Franklin Counties at 112,560 and 37,473 , respectively. The 1990 estimates for the Tri-Cities populations are Richland, 32,315; Kennewick, 42,159; and Pasco, 20,337. The populations of Benton City, Prosser, and West Richland totaled 10,244 in 1990. The population of Benton and Franklin Counties is young, with $56 \%$ of the total population under the age of 35 , compared with $54 \%$ of the total state population. An examination of age groups in 5-year increments reveals that the largest age group in Benton and Franklin Counties ranges from 5 to 9 years old, representing $9.3 \%$ of the total bicounty population; the largest group in the state ranges from 30 to 34 years, which represents about $9 \%$ of the total state population.
The Hanford Site lands embrace several DOE operational areas. The major areas are as follows:

- The entire Hanford Site has been designated a National Environmental Research Park.

- T'he 100 Areas, bordering on the right bank (south shore) of the Columbia River, are the sites of the eight retired plutonium production reactors and the N Reactor, which is currently in retired status. The 100 Areas occupy about $11 \mathrm{~km}^{2}\left(4 \mathrm{mi}^{2}\right)$.

- The 200-West and 200-East Areas are located on a plateau about 8 and $11 \mathrm{~km}$ ( 5 and $7 \mathrm{mi}$ ), respectively, south of the Columbia River. These areas historically have been dedicated to fuel reprocessing and waste processing management and disposal activities. The 200 Areas cover about $16 \mathrm{~km}^{2}\left(6 \mathrm{mi}^{2}\right)$.

- The 300 Area, located just north of the city of Richland, is the site of nuclear research and development. This area covers $1.5 \mathrm{~km}^{2}\left(0.6 \mathrm{mi}^{2}\right)$.

- The 400 Area is about $8 \mathrm{~km}$ (5 mi) northwest of the 300 Area and is the site of the FFTF, used in the testing of breeder reactor systems. Also included in this area is the Fuels and Materials Examination Facility.

- The 1100 and 3000 Areas are located in north Richland and include site support services such as general stores and transportation maintenance.

- The 600 Area includes all of the Hanford Site not occupied by the 100, 200,300, 400, 1100, or 3000 Areas.

Several areas of the Site, totaling $665 \mathrm{~km}^{2}\left(257 \mathrm{mi}^{2}\right)$, have been designated as the Arid Lands Ecology (ALE) Reserve, the U.S. Fish and Wildlife Service Saddle Mountain National Wildlife Refuge (NWR), and the Washington State Department of Game Reserve area (Wahluke Slope WRA)(DOE 1986). 
Land use in surrounding environs includes urban and industrial development, irrigated and dryland farming, and grazing. In 1989, wheat represented the largest single crop in terms of area planted in Benton and Franklin Counties, with 87,412 ha $(216,000$ acres $)$. Corn, alfalfa, potatoes, asparagus, apples, cherries, and grapes are other major crops in Benton and Franklin Counties. More than 20 processors in Benton and Franklin Counties produce food products including potato products, canned fruits and vegetables, wine, and animal feed.

Much of the above information is from Cushing (1991), where more detailed information can be found.

\section{Climate and Meteorology}

The Cascade Mountains beyond Yakima to the west greatly influence the climate of the Hanford Site. This range creates a rain shadow effect and also serves as a source of cold air drainage, which has a considerable effect on the wind regime.

The prevailing wind direction on the 200 Area plateau is from the northwest in all months of the year. The secondary wind direction is from the southwest. Summaries of wind direction indicate that winds from the northwest quadrant occur most often during the winter and summer. During the spring and fall, the frequency of southwesterly winds increases with a corresponding decrease in northwest flow. Monthly average wind speeds are lowest during the winter months, averaging 10 to $11 \mathrm{~km} / \mathrm{h}(6$ to $7 \mathrm{mi} / \mathrm{h}$ ), and highest during the summer, averaging 14 to $16 \mathrm{~km} / \mathrm{h}$ (9 to $10 \mathrm{mi} / \mathrm{h}$ ). Wind speeds that are well above average are usually associated with southwesterly winds. However, the summertime drainage winds are generally northwesterly and frequently reach $50 \mathrm{~km} / \mathrm{h}(30 \mathrm{mi} / \mathrm{h})$. These winds are most prevalent over the northern portion of the Site.

Diurnal and monthly averages and extremes of temperature, dew point, and humidity are given by Stone et al. (1983). The record maximum temperature is $46^{\circ} \mathrm{C}\left(115^{\circ} \mathrm{F}\right)$, and the record minimum temperature is $-32.8^{\circ} \mathrm{C}\left(-27^{\circ} \mathrm{F}\right)$. For the period
1912 through 1980 , the average monthly temperatures ranged from a low of $-1.5^{\circ} \mathrm{C}\left(29.3^{\circ} \mathrm{F}\right)$ in January to a high of $24.7^{\circ} \mathrm{C}\left(76^{\circ} \mathrm{F}\right)$ in July. During the winter, the highest monthly average temperature at the Hanford Meteorological Station (HMS) was $6.9^{\circ} \mathrm{C}\left(44.4^{\circ} \mathrm{F}\right)$, and the record lowest was $-5.9^{\circ} \mathrm{C}\left(21.4^{\circ} \mathrm{F}\right)$; both occurred during February. During the summer, the record maximum monthly average temperature was $27.9^{\circ} \mathrm{C}\left(82.2^{\circ} \mathrm{F}\right)$ (in July), and the record lowest was $17.2^{\circ} \mathrm{C}\left(63^{\circ} \mathrm{F}\right.$ ) (in June). The annual average relative humidity at the HMS is $54 \%$. It is highest during the winter months, averaging about $75 \%$, and lowest during the summer, averaging about $35 \%$. Average annual precipitation at the HMS is $16 \mathrm{~cm}$ ( 6.3 in.). Most of the precipitation occurs during the winter, with nearly half of the annual amount occurring in the months of November through February.

Atmospheric dispersion is a function of wind speed, duration and direction, atmospheric stability, and mixing depth. Dispersion conditions are generally good if winds are moderate to strong, the atmosphere is of neutral or unstable stratification, and there is a deep mixing layer. Good dispersion conditions associated with neutral and unstable stratification exist about 57\% of the time during the summer. Less favorable dispersion conditions may occur when the wind speed is light and the mixing layer is shallow. These conditions are most common during the winter, when moderately to extremely stable stratification exists about $66 \%$ of the time. Occasionally there are extended periods, primarily during winter months, of poor dispersion conditions that are associated with stagnant air in stationary high-pressure systems.

\section{Geology}

The Hanford Site lies within the Pasco Basin, one of many topographic and structural basins within the Columbia Plateau. Principal geologic units beneath the Hanford Site include, in ascending order, the Columbia River Basalt Group, the Ringold Formation, and : series of deposits informally referred to as the Hanford formation. These units are covered locally by a few meters or less of recent alluvial or windblown deposits. Older geologic units have been deformed into a series 
of roughly east-west trending folds. The stratigraphic and structural relationships between these units are displayed in Figure 1.2.

The Columbia River Basalt Group is composed of numerous basaltic lava flows. River and lake sediments of the Ringold Formation contain a wide range of sediment types, with beds ranging from weakly cemented coarse sandy gravel to compacted silt and clay. Within the Pasco Basin, the Hanford formation consists of mostly coarse gravel and sand that overlie the eroded surface of the Ringold Formation, but in places the Hanford formation directly overlies basalt. Near the 200West Area, the Ringold and Hanford formations are separated by a well-developed buried soil (Plio-Pleistocene unit) and fine-grained wind deposits (early "Palouse" soil) (Last et al. 1989).
Hajek (1966) lists and describes 15 different soil types on the Site, varying from sand to silty and sandy loam.

\section{Ground-Water Hydrology}

Both confined and unconfined aquifers are present beneath the Hanford Site. The confined aquifers, where ground water is under pressure greater than that of the atmosphere, are found primarily within the Columbia River basalts. In general, the unconfined or water-table aquifer is located in the Ringold Formation and glaciofluvial sediments, as well as some more recent alluvial sediments in areas adjacent to the Columbia River (Gephart et al. 1979). This relatively shallow aquifer has been affected by waste-water disposal

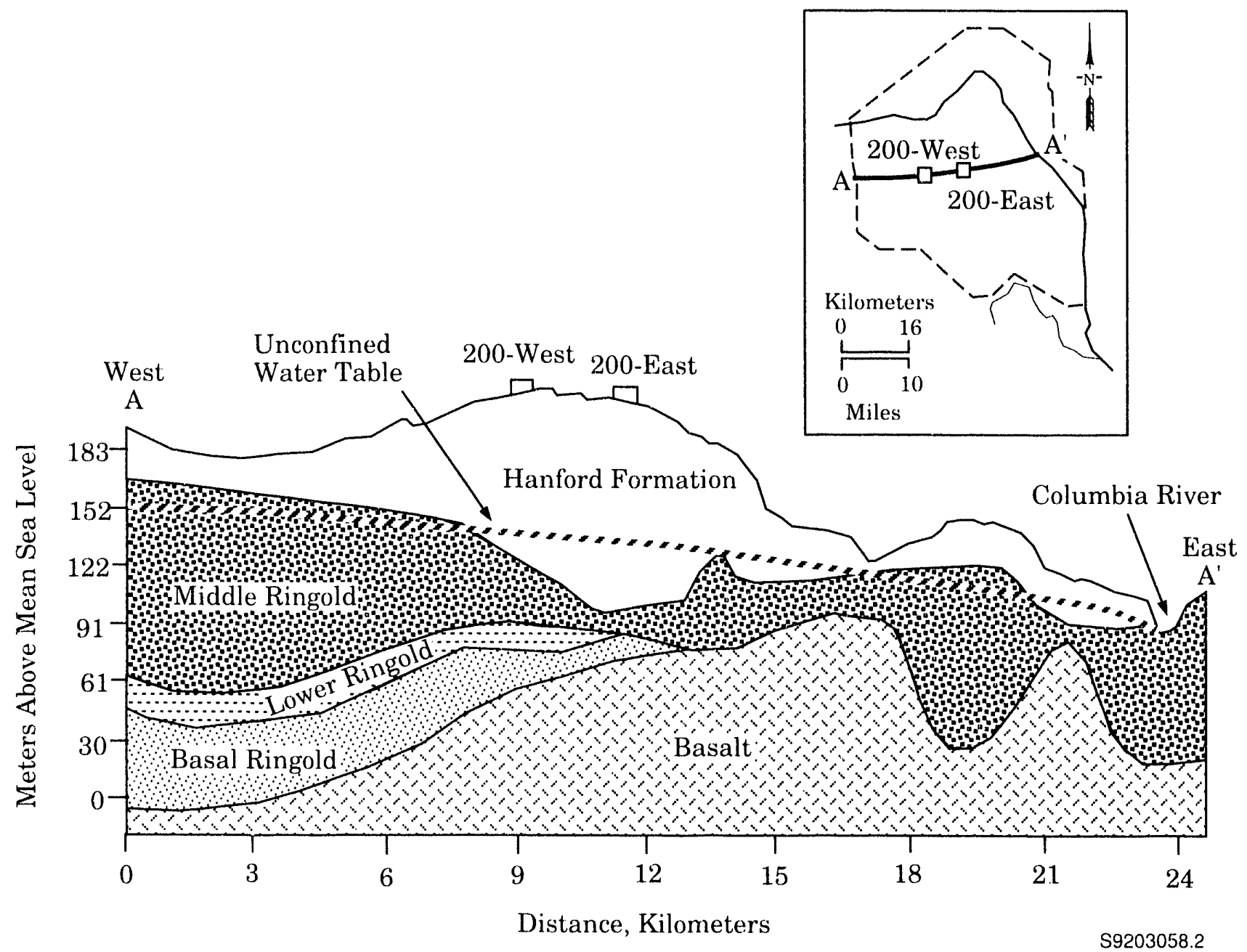

Figure 1.2. Geologic Cross Section of the Site (modified from Tallman et al. 1979) 
at Hanford (Graham et al. 1981). Therefore, the unconfined aquifer is the most thoroughly monitored aquifer beneath the Site.

The unconfined aquifer is bounded below by either the basalt surface or, in places, the relatively impervious clays and silts of the Ringold Formation. The water table defines the upper boundary of the unconfined aquifer. Laterally, the unconfined aquifer is bounded by the basalt ridges that surround the basin and by the Yakima and Columbia rivers. The basalt ridges have a low permeability and act as a barrier to lateral flow of ground water (Gephart et al. 1979) where they rise above the water table. The saturated thickness of the unconfined aquifer is greater

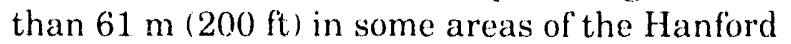
Site and pinches out along the flanks of the basalt ridges. Depth from the ground surface to the

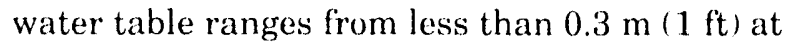
the Columbia River to more than $106 \mathrm{~m} \mathrm{(348 \textrm {ft } )}$ in the center of the Site. Elevation of the water table in meters above mean sea level for the Hanford Site and adjacent portions of Franklin County is shown in Figure 1.3.

Recharge to the unconfined aquifer originates from several sources (Graham et al. 1981). Natural recharge occurs from precipitation at higher elevations and runoff from intermittent streams, such as Cold Creek and Dry Creek on the western margin of the Site. The unconfined aquifer is recharged by the Yakima River as it flows along the southwest boundary of the Hanford Site. The Columbia River recharges the unconfined aquifer during high stages when river water is transferred to the aquifer along the river bank. The unconfined aquifer receives little, if any, recharge from precipitation directly on vegetated areas of the Hanford Site because of a high rate of evapotranspiration from native soil and vegetation.

Large-scale artificial recharge occurs from offsite agricultural irrigation and liquid-waste disposal in the operating areas. Recharge from irrigation in the Cold Creek Valley enters the Hanford Site as ground-water flow across the western boundary. Recharge to ground water across the Columbia River from the Hanford Site is primarily from irrigation and irrigation canal leakage. As indicated in Figure 1.3, the water-table elevation in this area is from 100 to $150 \mathrm{~m}$ (328 to $492 \mathrm{ft}$ ) higher than the water-table elevation on the Hanford Site.

The operational discharge of' water has created ground-water mounds near each of the major waste-water disposal facilities in the 200 Areas. These mounds have altered the aquifer's local flow pattern, which is generally from the recharge areas in the west to the discharge areas (primarily the Columbia River) in the east. Water levels in the unconfined aquifer have changed continually during site operations because of variations in the volume of waste water discharged. Consequently, the movement of ground water and its associated constituents has also changed with time.

Ground-water mounding also occurs in the 100 and 300 Areas. Ground-water mounding in these areas is not as significant as in the 200 Areas because of differences in discharge volumes and subsurface geology. In the 100 and 300 Areas, water levels are also greatly influenced by river stage.

As significant quantities of liquid effluents are discharged to the ground at Hanford facilities, these effluents percolate downward through the unsaturated zone to the water table. As effluents move through the unsaturated zone, adsorption onto soil particles, chemical precipitation, and ion exchange attenuate or delay the movement of some radionuclides, such as ${ }^{90} \mathrm{Sr},{ }^{137} \mathrm{C} / \mathrm{s}$, and 23:124" $\mathrm{Pu}$. These constituents move through the soil column at varying rates and eventually enter the ground water. Other ions, such as nitrate, and radionuclides, such as ${ }^{~} \mathrm{H},{ }^{96,} \mathrm{Tc}$, and ${ }^{12 \cdot 1} 1$, are not as readily retained by the soil and move downgradient in the same direction as, and at a rate nearly equal to, the flow of ground water. When the liquid effluents reach the ground water, their concentrations are reduced by dilution. As these constituents move with the ground water, radionuclide and chemical concentrations are further reduced by spreading (dispersion), and radionuclide concentrations are reduced by radioactive decay. 
Site Environment

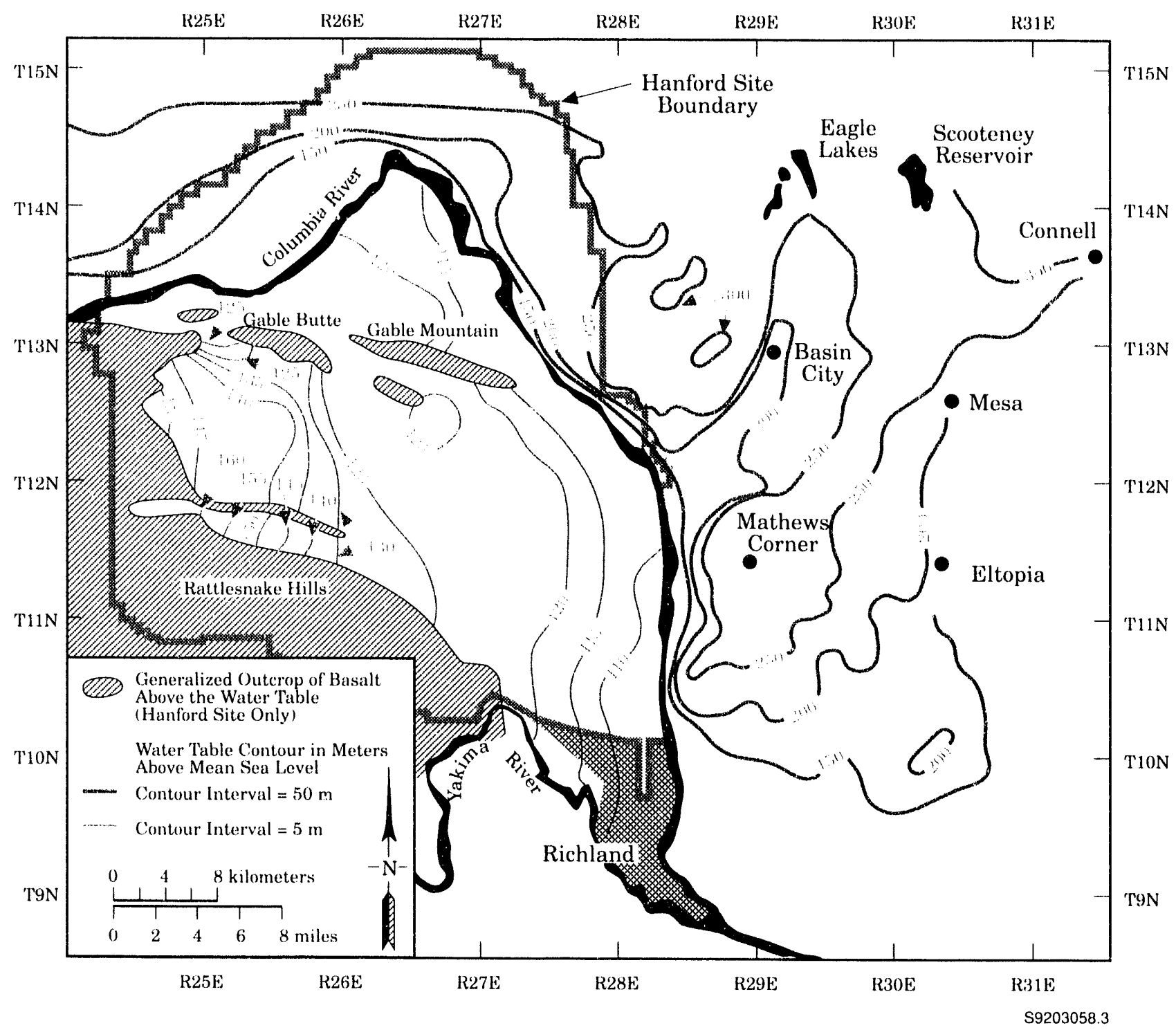

Figure 1.3. Water-Table Elevations for the Unconfined Aquifer at Hanford, June 1991

\section{Surface-Water Hydrology}

The Columbia River is the dominant surfacewater body on the Site. The Columbia, which originates in the mountains of eastern British Columbia, Canada, drains a total area of approximately $70,800 \mathrm{~km}^{2}\left(27,300 \mathrm{mi}^{2}\right)$ en route to the Pacific Ocean. Flow of the Columbia River is regulated by 11 dams within the United States, 7 upstream and 4 downstream of the Site. Priest Rapids is the nearest dam upstream of the Site, and McNary is the nearest dam downstream. The Hanford Reach of the Columbia River extends from Priest Rapids Dam to the head of Lake Wallula (created by McNary Dam), near Richland. This Reach is the last stretch of the Columbia River in the United States above Bonneville Dam that remains unimpounded. The width of the river varies from approximately $300 \mathrm{~m}(984 \mathrm{ft})$ to $1,000 \mathrm{~m}(3,281 \mathrm{ft})$ within the Hanford Site.

Flows in the Hanford Reach fluctuate significantly because of the relatively small storage capacities 
and the operational practices at upstream dams. Flow rate of the Columbia River through the Site is regulated primarily by Priest Rapids Dam. Typical daily flows range from $1,000 \mathrm{~m}^{3} / \mathrm{s}(35,310 \mathrm{cfs})$ to $7,000 \mathrm{~m} / 3 / \mathrm{s}(247,170 \mathrm{cfs})$, with peak spring runoff flows of up to $12,600 \mathrm{~m}^{3} / \mathrm{s}(444,906 \mathrm{cfs})$. The minimum regulated flow is $1,020 \mathrm{~m}^{3 /} / \mathrm{s}(36,016 \mathrm{cfs})$. Typical annual average flows at Friest Rapids Dam are $2,800 \mathrm{~m}^{3} / \mathrm{s}\left(99,000 \mathrm{cf}\right.$ 's) to $3,100 \mathrm{~m}^{3 /} / \mathrm{s}$ $1120,000$ cfs $)$. Monthly mean flows typically peak from April through June and are lowest from September through October.

The temperature of the Columbia River varies seasonally. Minimum temperatures are observed during January and February, and maximum temperatures typically occur during August and September. Mean monthly temperatures for the river range from approximately $3^{\circ} \mathrm{C}\left(37^{\circ} \mathrm{F}\right)$ to about $20^{\circ} \mathrm{C}\left(68^{\circ} \mathrm{F}\right)$ during a year. Solar radiation, water storage management practices at upstream dams, and water flow rate dictate, to a large extent, the thermal characteristics of the Columbia River along the Hanford Reach.

The Columbia River has been developed extensively for hydroelectric power, flood control, navigation, irrigation, and municipal and industrial water supplies. In addition, the Hanford Reach is used for a variety of recreational activities, in iluding fishing, hunting, boating, water skiing, and swimming. The State of Washington has classified the stretch of the Columbia River from the Washington-Oregon border to Grand Coulee Dam (which includes the Hanford Reach) as Class A (Excellent) and has established water quality criteria and water use guidelines for this class designation.

\section{Ecology}

The Hanford Site is a relatively large, undisturbed area of shrub-steppe that contains numerous plant and animal species adapted to the region's semiarid environment. The vegetation mosaic of the Site consists of eight major plant communities: 1) sagebrush/bluebunch wheatgrass, 2) sagebrush/cheatgrass or sagebrush/Sandberg's bluegrass, 3) sagebrush-bitterbrush/cheatgrass, 4) greasewood/cheatgrass-saltgrass, 5/ winterfat/ Sandberg's bluegrass, 6) thyme buck wheat/ Sandberg's bluegrass, 7) chratgrass-tumble mustard, and 81 willow. More than 240 species of plants have been identified on the Hanford Site (ERDA 1975), and cheatgrass is the dominant plant on fields that were cultivated 40 years ago.

More than 300 species of terrestrial and aquatic insects, 12 species of reptiles and amphibians, 44 species of fish, 187 species of hirds, and about 39 species of mammals have been found on the Hanford Site (Cushing 1991). Deer and elk are the major large mammals on the Site; coyotes are plentiful, and the Great Basin pocket mouse is the most abundant mammal. Waterfowl are numerous on the Columbia River, and the bald eagle is a regular winter visitor along the river. Salmon and steelhead are the fish species of most interest.

There are two types of natural aquatic habitats on the Hanford Site; one is the Columbia River, and the other is provided by the small springstreams and seeps located mainly on the ALE Reserve in the Rattlesnake Hills. These include Rattlesnake Springs, Dry Creek, Snively Springs, and West Lake, a small, natural pond near the 200 Areas. Several artificial water bodies, both ponds and ditches, have been formed as a result of waste-water disposal practices associated with the operation of the reactors and separation facilities; these water bodies form established aquatic ecosystems complete with representative flora and fauna (Emery and McShane 1980).

No plants or manmals on the federal list of Endangered and 'Threatened Wildlife and Plants (DOI 1986; 50 CFR 17.11, 17.12) are known to reside fulltime on the Hanford Site. However, three plant species, three mammals, eight birds, and two molluscs occurring on the Hanford Site 
are currently candidates for formal listing by the federal government and/or Washington State. The federal government lists the peregrine falcon ( Falco peregrinus) as endangered and the bald eagle (Haliaeetus leucocephalus) and Aleutian Canada goose (Branta canadensis leucopareia) as threatened. The peregrine falcon and Aleutian Canada goose are migrants through the Hanin. id Site, and the bald eagle is a common winter resident.

\section{Archaeology and Cultural Resources}

The Hanford Site is rich in cultural resources. It contains numerous, well-preserved archaeological sites representing the prehistoric and historic periods and is still thought of as a homeland by many Native Americans (Chatters 1989). 


\section{Environmental Compliance Summary}




\subsection{Environmental Compliance Summary}

This section briefly describes how environmental compliance is being achieved for the Hanford Site. Included are subsections describing 1) the regulations and oversight of compliance at the Site, 2 ) the current status of the Site's compliance with the principal regulations, 3 ) the issues and actions arising from these compliance efforts, and 4) the environmentally significant unusual occurrences. 


\subsection{Environmental Compliance and Cleanup}

Many entities have a role in the U.S. Department of Energy's (DOE's) new mission of environmental restoration and waste management. These include federal, state, and local regulatory agencies; environmental groups; regional communities; Indian nations; and individual citizens. The following section describes the roles of the principal agencies, organizations, and public in the environmental compliance and cleanup of the Hanford Site.

\section{The Regulating Agencies}

Several federal, state, and local government agencies are responsible for enforcing and overseeing environmental regulations at the Hanford Site. These agencies include the U.S. Environmental Protection Agency (EPA), the Washington State Department of Ecology (Ecology), the Washington State Department of Health (DOH), and the Tri-County (Benton-Franklin-Walla Walla Counties) Air Pollution Control Authority. These agencies issue permits, review compliance reports, participate in joint monitoring programs, inspect facilities and operations, and oversee compliance with applicable regulations. The DOE, through its directives to field offices and compliance audits, initiates and assesses actions for conforming to environmental requirements.

The EPA is the principal federal environmental regulator in Washington State. The EPA develops, promulgates, and enforces environmental protection regulations and technology-based standards as directed by statutes passed by Congress. In some instances, the EPA has delegated environmental regulatory authority to the state or authorized the state program to operate in lieu of the federal program when the state's program meets or exceeds the EPA's requirements. For instance, the EPA has delegated or authorized enforcement authority to Ecology for air pollution control and many areas of hazardous-waste management. In other activities, the state program is enforced directly upon federal agencies as provided by federal law. For example, the DOH has authority to implement the state program for radionuclide air emissions to the atmosphere at the Hanford Site in accordance with the federal facilities section of the Clean Air Act. Where regulatory authority is not delegated or authorized to the state, EPA Region 10 is responsible for reviewing and enforcing compliance with EPA regulations as they pertain to the Hanford Site.

\section{The Tri-Party Agreement}

The Hanford Federal Facility Consent and Agreement Order (also known as the Tri-Party Agreement) is an agreement among the EPA, Ecology, and DOE for achieving compliance with the Comprehensive Environmental Response, Compensation, and Liability Act (CERCLA) [including the Superfund Amendment and Reauthorization Act (SARA)] remedial action provisions and with Resource Conservation and Recovery Act (RCRA) treatment, storage, and disposal unit regulation and corrective action provisions. The Tri-Party Agreement 1) defines and ranks RCRA and CERCLA cleanup commitments, 2) establishes responsibilities, 3 ) provides a basis for budgeting, and 4) reflects a concerted goal of achieving full regulatory compliance and remediation, with enforceable milestones, in an aggressive but achievable manner. The Tri-Party Agreement was also established with input from the public. Copies of the agreement and quarterly progress reports of activities are publicly available at the DOE, Richland Field Office (RL) Public Reading Room in Richland, Washington, and at information repositories in Seattle and Spokane, Washington, and Portland, Oregon. To get on the mailing list to obtain Tri-Party Agreement updates, a request may be made to EPA or $\mathrm{RL}$ directly, by calling Ecology on 1-800-321-2008, or by mail to either:

Hanford Mailing List

P.O. Box 1970 B3-35

Richland, WA 99352

or 
Hanford Update

Dept. of Ecology

P.O. Box 47600

Olympia, WA $98504-7600$

The Tri-Party Agreement consists of a legal agreement and an action plan. The legal agreement establishes jurisdictions, authorities, and other legal determinations among the parties. The five specific areas of involvement defined by the legal agreement are the following:

1. Identify RCRA treatment, storage, and disposal units that require permits, and establish schedules to comply with interim and final status requirements. Where applicable, RCRA Part B permit applications will be completed, closures accomplished, and postclosure care implemented.

2. Identify interim action alternatives appropriate to implement the final RCRA corrective and CERCLA remedial actions.

3. Establish requirements for performing investigations to determine the nature and extent of threats to public health or the environment caused by actual or possible releases, and perform studies to identify, evaluate, and select alternatives for controlling possible releases.

4. Identify the nature, objective, and schedule of response actions for cleanup of hazardous material spills.

5. Implement the selected interim and final RCRA corrective and CERCLA remedial actions.

The action plan implements the legal agreement by 1 ) defining how the parties will work together, 2 ) describing the processes and procedures to be followed, 3 l defining the units to be addressed, and 4 s scheduling the work. The action plan, through enforceable milestones, establishes a plan and schedule for bringing the Hanford Site into compliance with applicable requirements of RCRA and all remedial action requirements of CERCLA.

\section{The Role of Oregon State at the Hanford Site}

Although the State of Oregon does not have a direct regulatory role at the Hanford Site, DOE recognizes that Oregon has an interest in Hanford Site cleanup because of the state's location downstream on the Columbia River and because of the potential for shipping radioactive wastes from the Hanford Site through Oregon. Oregon participates in the State and Tribal Government Working Group for the Hanford Site, which reviews the Site's cleanup plans.

The Oregon Department of Energy has the lead in the state's involvement at the Hanford Site. It is performing a 4-year research program on a contract scheduled to expire in 1993 to determine the effects of Hanford Site radioactive waste activities on the environment and on the health of Oregon residents. The Oregon Department of Energy provides information to the public, Oregon's Congressional delegation, and state and local officials on proposed cleanup, transport, and disposal activities and costs. It also supports the Oregon Hanford Waste Board, which recommends policy to the governor and legislature. The board was reauthorized by the 1991 legislature and is composed of agency heads, members of the legislature, and citizens.

\section{The Role of Indian Nations at the Hanford Site}

The Hanford Site is located on land ceded in treaties in the year 1855 with the Yakima Indian Nation and the Confederated Tribes of the Umatilla Indian Reservation (the Umatilla, Cayuse, and Walla Walla Tribess. The Nez Perce Tribe ceded lands east of the Site. The tribes retain rights and privileges in the ceded areas, including the right to take fish at usual and accustomed places.

In addition to the treaties of 1855 , the following laws apply to Native American rights and culture at the Hanford Site: the American Indian Religious Freedom Act, the Archaeological Resources 
Protection Act, the National Historic Preservation Act, and the American Antiquities Preservation Act. The RL implementation program is described in Section 3.3, "Environmental Studies and Programs."

RL provides a grant to the Yakima Indian Nation and the Confederated Tribes of the Umatilla Indian Reservation to ensure their involvement in the Environmental Restoration and Waste Management Five-Year Plan activities for cleanup of the Hanford Site (DOE 1990b). A similar grant is being considered for the Nez Perce Tribe. Members of the Confederated Tribes have a grant to address their concerns about transporting wastes to the Waste Isolation Pilot Plant in New Mexico.

\section{Public Participation}

Individual citizens of Washington State and neighboring states may participate in determining how Hanford Site cleanup is conducted. A plan for community relations and public involvement is included in the Tri-Party Agreement. The community relations plan was developed and negotiated among DOE, Ecology, and EPA Region 10 with public comment and was jointly approved in 1990.

Quarterly information meetings are held in the Tri-Cities (Kennewick, Pasco, and Richland), Washington, and one other city alternated within the Northwest to update the public on Tri-Party
Agreement activities. Meeting dates are announced approximately 3 weeks in advance through the quarterly Hanford Update newsletter, news releases, and newspapers. The DOE has also encouraged public participation in the Hanford Five-Year Plan. Before each meeting, the press is informed of the issues to be discussed, and notices are sent to elected officials, community leaders, and special interest groups.

The public can obtain up-to-date information on the Hanford Site cleanup effort at the following four repositories:

1. the RL Public Reading Room, Richland, Washington

2. University of Washington Library, Seattle, Washington

3. Crosby Library, Gonzaga University, Spokane, Washington

4. Portland State University Library, Portland, Oregon.

The repositories receive copies of Tri-Party Agreement action plan quarterly progress reports, CERCLA/SARA and RCRA environmental restoration activities reports, closure and postclosure plans, RCRA permit applications, meeting summaries, and other publications related to the Site's cleanup. 


\subsection{Compliance Status}

This section summarizes the activities conducted to ensure the Hanford Site is in compliance with federal environmental protection statutes and related Washington State and local environmental protection regulations, and the status of Hanford's compliance with these requirements. Environmental permits required under the environmental protection regulations are discussed under the applicable statute. Appendix B lists environmental permits currently issued for the Hanford Site.

\section{Comprehensive Environmental Response, Compensation, and Liability Act}

The CERCLA requires that specific proceciures be implemented to assess inactive waste sites for the release of hazardous substances. The evaluation procedure is divided into three tiers of activity: 1) preliminary assessments, 2) remedial investigation/feasibility studies (RI/FS), and 3 ) remedial actions. The EPA has established procedures that the Hanford Site must comply with to conduct the three-tiered process.

Preliminary assessments conducted for the Hanford Site revealed that there are approximately 1,100 known individual waste sites where hazardous substances may have been disposed. These 1,100 sites have been grouped into 78 operable units, which have been further grouped into 4 aggregate areas using identifiable geographic boundaries. The four aggregate areas have been placed on the EPA's National Priorities List, which requires a schedule and actions for their remediation.

The DOE is actively pursuing the RI/FS process at some operable units on the Hanford Site. The selection of the operable units is a result of TriParty Agreement negotiations. The Tri-Party Agreement provides the framework for meeting CERCLA cleanup requirements. All milestones related to the RI/FS process established for 1991 were achieved, and the Hanford Site was in compliance with these CFRCLA/SARA requirements. This takes into consideration several milestones delayed through the change request process.

In October 1990, Secretary of Energy Watkins proposed three accelerated cleanup actions. These actions would be completed as Expedited Response Actions (a way to hasten cleanup at sites to prevent further spread of contamination). The three actions would 1) remove drums thought to contain hexone and uranium from a burial ground in the 300 Area, 2) remove carbon tetrachloride from the vadose zone of two ground disposal sites in the 200-West Area, and 3) remove contaminated sediments from the bottom of 300 Area Process Trench. All of these Expedited Response Actions were initiated in 1990. The status is as follows:

- The response action of removing the buried drums containing hexone and uranium has been completed. The final report for the response action was issued (October 1991) and was also issued for public comment and review (DOE 1992f).

- Work to remove carbon tetrachloride from the vadose zone of two ground disposal sites in the 200 -West Area is in progress. The treatability test for the vapor extraction system is complete, and the system has been upgraded as necessary. The engineering evaluation/cost analysis document has been finalized. The Action Memorandum, which documents actions approved for the project, was issued.

- Excavating and consolidating the contaminated soil from the bottom of the 300 Area Process Trench has been completed. Data that were collected during the activity are being validated. Work on the final report is ongoing.

Under Section 103(a), the Emergency Release Notification provision of CERCLA, releases exceeding reportable quantity limits for regulated 
chemicals were reported. Further details of the 1991 releases are contained in Section 4.1, "Effluent Monitoring," of this report.

Ground-water monitoring of the 1100-EM-1 operable unit has been performed and information on the subject can be found in the documents listed in Appendix D.

\section{Emergency Planning and Community Right-To-Know Act}

The Emergency Planning and Community RightTo-Know Act provides the public with information about hazardous chemicals in the community and establishes emergency planning and notification procedures to protect the public from a release. Subtitle A of the law calls for creation of state emergency response commissions to guide planning for chemical emergencies. State commissions have also created local emergency planning committees to ensure community participation and planning.

The 1990 Hanford Tier Two Emergency and Hazardous Chemical Inventory (DOE 1990a) was issued March 1, 1991, to the State Emergency Response Commission, local county emergency management committees, and local fire department. The report contained information on hazardous materials in storage across the Hanford Site. Accordingly, during 1991, the Hanford Site was in compliance with the reporting and notification requirements contained in this Act.

\section{Resource Conservation and Recovery Act}

The RCRA establishes regulatory standards for the generation, transportation, storage, treatment, and disposal of hazardous waste. Ecology has been authorized by the EPA to implement its dangerous waste program in lieu of the EPA for Washington State, except for some provisions of the Hazardous Solid Waste Amendments of 1984 . While Ecology's Dangerous Waste Regulations, contained in the Washington Administrative Code (WAC) 173-303, must be at least as stringent as the RCRA requirements, these regulations are often more stringent.

Approximately 63 treatment, storage, and/or disposal (TSD) units that must be permitted or closed in accordance with RCRA and WAC 173303 have been identified on the Hanford Site. Some of the TSD units contain numerous individual components (for example, the single-shell tank unit includes 149 separate tanks). The existing TSD units are required to be operated under Ecology's interim status compliance requirements. Approximately one-half of the TSD units will be closed.

The Tri-Party Agreement provides the framework for meeting RCRA requirements. Fortyseven of the forty-eight milestones scheduled for 1991 were completed, although some were delayed as approved through the change request process. At the end of 1991, 136 Tri-Party Agreement milestones had been completed on or ahead of schedule over the previous 3 years. For more information on these milestones, see Section 2.3 .

\section{Enforcement Action}

No enforcement actions resulted from inspections conducted by Ecology at the treatment, storage, and disposal facilities on the Hanford Site for 1991. All corrective actions from earlier enforcement actions were completed.

\section{Resource Conservation and Recov- ery Act Part A Interim Status}

In December 1990, Ecology issued a Notice of Noncompliance to RL regarding the return of 68 drums of packaged waste to the generating site, the 183-H Solar Evaporation Basins.

The drums were returned to the Central Waste Complex in January 1991. The inspection, repackaging, and shipping of the 68 drums was completed without any safety-related incidents.

\section{Hanford Part B Permit}

Meetings were held in February and March 1991 among RL, Ecology, and EPA Region 10 to 
discuss the content and schedule for issuance of the Hanford Site Part B Permit. Issue resolution meetings continued through July 1991. Of 38 issues raised, 27 were resolved at least in principle, and 11 remained unresolved. A Part B permit application for the Hanford Site was submitted to the regulators for review in October 1991, identifying the RL position on all remaining unresolved issues. As of the end of December 1991, no comments had been received from Ecology in response to this submittal.

\section{Resource Conservation and Recov- ery Act Ground-Water Monitoring}

Quarterly RCRA ground-water sampling was discontinued at the Hanford Site in May 1990 when the Site analytical services contract with United States Testing, Inc., was terminated. A special one-time sampling was conducted at selected wells during February and March 1991. This limited effort obtained ground-water data during the period of extended negotiation to replace the analytical services contract. In an April 1991 letter to RL, Ecology requested that fullscale RCRA monitoring activities be reinitiated within 45 days. Ecology noted that failure to comply would trigger "other administrative alternatives" to ensure compliance with state and federal hazardous waste regulations.

Full-scale RCRA ground-water monitoring activities resumed in June 1991. All data received from the analytical laboratory through November 18 were compiled into the RCRA ground-water quarterly report for the period July through September 1991.

In June 1991, an interim contract was established with International Technologies Corporation for analyzing ground-water samples. In October 1991, a final contract was established with DataChem Laboratories of Salt Lake City to perform hazardous analyses. All data reported in the July through September RCRA ground-water quarterly report were from analyses under the interim contract with International Technologies Corporation.
Although full-scale sampling was resumed, timely receipt of analytical results was a problem. Improvements are anticipated from the laboratories under the final contract.

Fifty ground-water monitoring wells were constructed at seven RCRA TSD facilities in 1991. This met the Tri-Party Agreement Milestone M-24-00.

For additional information on the ground-water monitoring activities that occurred in 1991, see Appendix D for a list of published reports.

\section{Resource Conservation and Recov- ery Act Underground Storage Tanks}

Subtitle I of RCRA deals with regulation of underground storage tank systems. These regulations were added to RC'RA by the Hazardous and Solid Waste Amendments of 1984. The EPA has promulgated regulations imposing technical standards for tank performance and management, including standards governing the cleanup and closure of leaking tanks. These regulations do not apply to the single- and double-shell nuclear waste tanks, which are regulated as TSD facilities. Tho EPA has authorized Ecology to implement the underground storage tank rules.

During 1991, four abandoned tanks located in the 3000 Area were removed and disposed of. Additionally, one gasoline tank was removed from the 100-N Area when a gas station was closed. A total of $14 \mathrm{tank} /$ piping systems was tested. Five systems failed and were taken out of service.

\section{Clean Air Act}

The EPA has established the Prevention of Significant Deterioration (PSD) program (40 CFR 52) to protect air quality while allowing a margin for future growth. The EPA has delegated authority to Ecology for regulation of new emission sources under the PSD program.

The DOE was issued a PSD permit by the EPA in 1980 for the Hanford Site. The permit sets 
specific limits for nitrogen oxides emissions from the Plutonium Uranium Extraction (PUREX) and Uranium Oxide $\left(\mathrm{UO}_{i:}\right)$ Plants. Significant increases in emissions from the Hanford Site of any criteria pollutant regulated by the Clean Air Act require agency review of potential impacts to regional air quality. Additional limits may be necessary in accordance with the PSD permit.

The DOH, Division of Radiation Protection, has promulgated regulatory controls for radioactive air emissions under Section 118 of the Clean Air Act. These controls are applicable to federal facilities such as the Hanford Site. WAC 246-247 requires registration of all radioactive air emission point sources with the DOH.

The EPA has retained authority for regulating certain hazardous pollutants under the National Emission Standards for Hazardous Air Pollutants (NESHAP), in accordance with 40 CFR 61. These standards are designed to protect the public from hazardous air pollutants (for example, arsenic, asbestos, beryllium, mercury, radionuclides, and vinyl chloride.

Pursuant to the NESHAP program within the Clean Air Act, the EPA has promulgated regulations specifically addressing asbestos emissions. These regulations apply at the Hanford Site in building demolition and/or disposal and waste disposal operations. Approximately 1,400 facilities on the Hanford Site have asbestos-containing material. During 1991, $1,160 \mathrm{~m}^{3}(1,520 \mathrm{yd})$ of asbestos were removed and disposed of in the Hanford Central Landfill in accordance with applicable regulations.

Revised Clean Air Act requirements for radioactive air emissions were issued in December 1989 under 40 CFR 61, Subpart H. Emissions from the Hanford Site are within the new EPA offsite emission standards of $10 \mathrm{mrem} / \mathrm{yr}$ (effective dose equivalent). The 1989 requirements for flow and emissions measurements, quality assurance, and sampling documentation are in the process of being implemented at all Hanford Site sources.

These specific reporting and monitoring requirements necessitate additional effort. RL received a 2-year compliance extension for the Subpart $H$ requirements until December 15, 1991. During this extension period, ongoing evaluations were conducted to determine the need for any additional continuous sampling equipment and other actions to meet EPA criteria. Negotiations are under way with the EPA toward the development of a federal facilities compliance agreement regarding continued evaluations and scheduling of any required equipment upgrades.

Hanford Site contractors have prepared Facility Effluent Monitoring Plans (FEMPs) specific to various facilities across the Site. The FEMPs include sections that outline compliance with 40 CFR 61 (atmospheric emissions). The preparation of FEMPs was completed in late 1991. A summary of each FEMP has been incorporated into a sitewide environmental monitoring plan covering effluent monitoring and environmental surveillance (DOE 1991b).

The local air authority, Tri-County Air Pollution Control Authority, enforces General Regulation 80-7, which pertains to detrimental effects, fugitive dust, incineration products, odor, opacity, asbestos, and sulfur oxide emissions. They have been delegated authority to enforce EPA asbestos regulations under NESHAP. The Site is in compliance with the regulations.

During 1991, Hanford Site air emissions remained below all regulatory limits set for radioactive and other pollutants. Routine reporting of air emissions was provided to each air quality agency, in compliance with requirements.

\section{Clean Water Act}

The Clean Water Act applies to all discharges to waters of the United States. At the Hanford Site, the regulations are applied through a National Pollutant Discharge Elimination System (NPDES) permit governing effluent discharges to the Columbia River.

Conditions resulting from retirement of the $\mathrm{N}$ Reactor have affected the sampling and recording procedures associated with the Hanford Site's NPDES permit. Primarily there are reduced flows at the $N$ Reactor outfalls, and in some cases 
no flow at all. The situation is being noted on the monthly discharge monitoring reports submitted to the EPA.

Problems were experienced in measuring the flow at Outfall 003 in the 100-K Area. The discharge at this outfall is the $181-\mathrm{KE}$ inlet screen backwash. The monthly flow ranges from 19,000 to $75,000 \mathrm{~L}$ ( 5,000 to 20,000 gal) compared to a permit limit of more than $15,000,000 \mathrm{~L} / \mathrm{mo}$ $(4,000,000 \mathrm{gal} / \mathrm{mo})$. With the low flows, rust from the associated piping accumulates in the meters. The design of the system was evaluated, and changes were made to alleviate the problem.

An excursion and two other conditions were reported to the EPA in June 1991. The $\mathrm{pH}$ permit limit was exceeded in the 100-N Area (Outfall 009). The $\mathrm{pH}$ was measured at 9.2 , which exceeded the permit limit of 9.0. The cause of the exceedance was thought to be inlet water with a high $\mathrm{pH}$. Action was taken to isolate the inlet water from the outfall. Additionally in June, the 100-K Area outfall (Outfall 004) total suspended solids (TSS) analysis was not performed within the 7-day regulatory sample holding time. Procedures were reviewed with operations personnel. The last condition reported in June was the delay in reporting quarterly sampling results normally reported in April for N Springs. N Springs were sampled at the wrong test well; therefore, a new sample and analysis had to be conducted.

Permit modifications were discussed with the EPA Region 10 water permit writer regarding new waste-water treatment facilities planned for the 300 Area. These new facilities include a treatment facility for process waste water, as well as filter backwash waste water and ash sluice waste water.

\section{Safe Drinking Water Act}

The National Primary Drinking Water Regulations of the Safe Drinking Water Act apply to the drinking water supplies at the Hanford Site. These regulations are enforced by the $\mathrm{DOH}$.

During 1991, potable water was supplied to the Hanford Site by 15 individual drinking water systems. Fourteen are DOE-owned systems; the other is the city of Richland municipal system, which provides water to the 700,1100 , and 3000 Areas. Ten of the systems use Columbia River water as a raw water source, four systems use ground water, and one system uses a combination of the two.

The water supplies are monitored for the contaminants listed in the rules and regulations of the DOH regarding public water systems. In 1991 all water systems were in compliance with requirements and agreements.

\section{Toxic Substances Control} Act

The application of Toxic Substances Control Act requirements to the Hanford Site essentially involves regulation of polychlorinated biphenyls (PCBs). Federal regulations for use, storage, and disposal of PCBs are found in 40 CFR 761. State of Washington dangerous waste regulations for managing PCB waste are listed in WAC 173-303.

Various concentrations of PCBs are found in electrical equipment throughout the Hanford Site. The majority of transformers have been sampled and characterized. Many PCB-containing (those with greater than $500 \mathrm{ppm}$ ) transformers and large capacitors have been replaced or modified. A risk assessment has been completed for all but one of the remaining PCB transformers to aid in removal of the PCBs.

Defueled, decornmissioned submarine reactor compartments shipped by the U.S. Navy to the Hanford Site for disposal contain small quantities of PCBs bound within the matrix of nonmetallic materials such as thermal insulation, electrical cables, and some rubber items. Because of the presence of $\mathrm{PCBs}$, the reactor compartments are regulated under this Act. A compliance agreement between EPA and DOE defines the process by which a permit under this Act will be issued for the disposal trench.

Nonradioactive PCB waste is stored and disposed of in accordance with the 40 CFR 761 requirements. Effective nationwide treatment and disposal capacity and technologies have not been 
developed for radioactive PCB waste. This waste remains in storage pending the devolopment of adequate treatment and disposal technologies and capacities.

\section{Federal Insecticide, Fungi- cide, and Rodenticide Act}

Ecology administers the Federal Insecticide, Fungicide, and Rodenticide Act of 1975 (FIFRA) certifieation and storage requirements under authority granted by EPA. The FIFRA and the Revised Cude of Washington 17.21, Washington Pesticide Application Act, as implemented by WAC $16-228$, "General Pesticides Regulations," apply to storage and use of pesticides. At the Hanford Site, pesticides are applied by personnel licensed by Ecology ats commercial pesticide applicator's. The Hanford Site is in compliance with the Act's requirements and WAC $16-228$ regulations pertaining to storage and application of pesticides.

\section{Endangered Species Act}

A few rare species of native plants and animals are known to occur on the Hanford site. Some of these are listed by the U.S. Fish and Wildlife Service as endangered or threatened federally: listed . Others are listed by the Washington State Department of Wildlife as endangered, threatened, or sensitive species. The Site monitoring program is discussed in Section 3.3, "Environmental Studies and Programs."

\section{National Historic Preserva- tion Act, Archaeological Resources Protection Act, and American Indian Religious Freedom Act}

Cultural resources on the Hanford Site are subject to the provisions of the National Historic Preservation Act and the Archaeological Resources Protection Act. Compliance with the applicable regulations is accomplished through an active monitoring program that includes:
1) review of all proposed land-disturbing projects to assess potential impacts on cultural resources, and 2 ) periodic inspections of known archaeological and historical sites to determine their condition and the effects of land management policies on the sites. The 1991 program activities are described in Section 3.3, "Environmental Studies and Programs."

The American Indian Religious Freedom Act requires federal agencies to help protect and preserve the Native American's right to practice their traditional religion. RL cooperates with the Native Americans by providing Site aecess for organized religious activities.

\section{National Environmental Policy Act}

The National Environmental Policy Act (NEPA) establishes a national environmental policy. The Act requires major federal projects with potential to significantly impact the environment to be carefully reviewed and reported to the public through environmental impact statements (EIS). Other documents such as environmental assessments are also prepared in accordance with NEPA requirements. Such NEPA documents are prepared and reviewed in accordance with the Council on Environmental Quality regulations in 40 CFR 1500 to 1508,10 CFR 1021, DOE Order 5440.1D (dated February 22, 1991), the DOE NEPA Guidelines 152 FR 47662, December 15, 1987), and SEN-15-90, "National Environmental Policy Act" (dated February 5, 1990).

The SEN-15-90 documentation directs IOOE field offices to conduct early and adequate NEPA planning, and to designate an official to be responsible for overall NEPA compliance. It also terminated the use of memos to document NEPA reviews of certain activities and projects as of September 30, 1990. The RL has cromplied with these, as well as other requirements of the notice.

Several related programmatic and site-specific EISs are in process or in the planning and scoping stages. These are summarized below. 


\section{Environmental Impact Statement, Decommissioning of Eight Surplus Production Reactors at the Hanford Site, Richland, Washington}

Eight plutonium production reactors were built and operated at the Hanford Site between 1943 and 1971. These reactors have been declared surplus by DOE and are now available for decommissioning. The first reactor to operate,

B Reactor, is eligible for listing as a National Historic Site.

The draft ElS (DOE 1989a) was published in March 1989 and subsequently went through the required review process. During 1990, responses to agency and public comments on the draft were prepared. The final EIS and record of decision are expected to be available in 1992.

\section{Programmatic Environmental Im- pact Statement for the Environmen- tal Restoration and Waste Manage- ment Program}

This EIS will evaluate the potential environmental impacts of DOE's national environmental restoration and waste management program. It will include actions for remediation, compliance with RCRA and CERCLA, restoration, waste management, and repositories.

\section{Weapons Complex Modernization Programmatic Environmental Im- pact Statement}

The RL contractor's assisted Argonne National Laboratory in preparing a draft EIS, published in April 1991, for siting, construction, and operation of a New Production Reactor (NPR) to produce "H. The draft compares potential environmental and socioeconomic impacts from the siting of an NPR at the Hanford Site, Idaho National Engineering Laboratory, and the Savannah River Plant. The technologies proposed for "H production are the light-water reactor, modular hightemperature gats-cooled reactor, and heavy-water reactor. The sites were evaluated regarding each of the three technologies. At the Hanford Site, the light-water reactor would be the WNP-1, which is $63 \%$ complete. The fuel/tritium target fabrication and "H processing would be housed in the existing Fuels and Materials Examination Facility in the 400 Area.

In November 1991, DOE announced that it will incorporate the environmental impact analysis for the DOE NPR capacity proposal into the Weapons Complex Modernization Programmatic Environmental Impact Statement (PEIS) and include NPR siting and technology decisions in the Weapons Complex Modernization Record of Decision. The DOE invited the public to comment on incorporating the ${ }^{3} \mathrm{H}$ capacity analysis into the Weapons Complex Modernization PEIS on November 29, 1991 (56 FR 60985). The implementation plan takes the resulting comments into account.

\section{Executive Order 11988 - Floodplain Management}

'To minimize potential harm to or within the 100 year floodplain, the potential effects of actions taken in the floodplain at Hanford are evaluated and alternatives are considered when necessary to avoid adverse effects and incompatible development within the floodplain. The evaluations are made in one of two ways: either concurrently with the NEPA process, or separately, with the required Public Notice and Statement of Findings (SOF) published in the Federal Register. If the action requires an environmental assessment, the floodplain assessment must be incorporated. The SOF may be incorporated in a Finding of No Significant Impact (FONSI). If the action does not require an environmental assessment, the floodplain assessment accompanies an information bulletin. Two floodplain/wetlands assessments were written in 1991 and included in NEPA documentation for CERCLA actions.

\section{Executive Order 11990 - Protection of Wetlands}

Protection is considered for any action and new construction proposed in a wetland at Hanford to minimize the destruction, loss, or degradation of those wetlands. An evaluation takes into account economic and environmental concerns and is 
conducted either concurrently with the NEPA process or separately, with the required Public Notice and SOF published in the Federal Register. If the action requires an environmental assessment, the wetlands assessment must be incorporated. The SOF may be incorporated in the
FONSI. If the action does not require an environmental assessment, the wetlands assessment accompanies an information bulletin. Two floodplain/wetlands assessments were written in 1991 and included in NEPA documentation for CERCLA actions. 


\subsection{Current Issues and Actions}

Progress has been made toward achieving full regulatory compliance at the Hanford Site. Ongoing self-assessments of the compliance status, implementation of the Tri-Party Agreement, and public meetings continue to identify environmental compliance issues. These issues are discussed openly with the regulatory agencies and with the public to ensure that all environmental compliance issues are addressed.

\section{Hanford Federal Facility Agreement and Consent Order (Tri-Party Agreement)}

Forty-seven of 48 milestones scheduled for 1991 were completed, although some were delayed as approved through the change request process. Included in these completed milestones were the following activities:

- Six RCRA Part B permit applications and two closure plans for Hanford TSD facilities were submitted.

- Eleven CERCLA RI/FS or RCRA facility investigation/corrective measures study (RFI/CMS) work plans for inactive waste sites were submitted.

- Actions to meet 15 Tri-Party Agreement milestones dealing with management of liquid effluents at the Hanford Site were completed.

- Sixty-one RCRA ground-water monitoring wells were installed.

At the end of 1991 a total of 136 Tri-Party Agreement milestones | for fiscal years (FY) 1989, 1990, and 1991/ had been completed on or ahead of schedule. One milestone (M-05-03) was not met.

Milestone M-05-(03, "Interim stabilize an additional four single-shell tanks," due in September 1991, has yet to be completed. Progress on stabilizing the tanks was halted by DOE-HQ in August 1991, to resolve the issue of potentially adding liquid to "watchlist" tanks |Public Law 101510, Section 3137 (Wyden Amendment)l.

"Watchlist" tanks include those that contain ferrocyanides, hydrogen-gas generating waste, high-heat generating waste, and waste with high concentrations of organic chemicals. Five singleshell tanks are in the process of being stabilized at this time. This milestone will be complete when the process is complete.

The Tri-Party Agreement requires the preparation of individual work plans for conducting remedial investigation and feasibility study work on the 78 designated operable units. The work is being actively conducted at selected operable units on the Site in accordance with the schedules stipulated in the Tri-Party Agreement Action Plan.

The liquid effluent study (WHC 1990), which was agreed to as part of the Tri-Party Agreement negotiation, was transmitted to EPA Region 10 and Ecology in the third quarter of 1990. EPA and Ecology reviewed the liquid effluent study documents and provided comments in February and April 1991, respectively. The $\mathrm{N}$ Reactor effluent stream was identified as one of seven high-priority streams at the Hanford Site. The EPA regards this effluent as the most environmentally significant continuing release at the Hanford Site. EBASCO Services, Inc., has been contracted to report on alternative containment methods for the radioactive ground-water plume that was created by the $\mathrm{N}$ Reactor effluent.

On or before February 6, 1991, DOE submitted 10 change request packages for several major and interim milestones contained in the Tri-Party Agreement. On April 8, 1991, EPA and Ecology denied eight of the submitted change packages, conditionally accepted one, and deferred action on another. Public meetings were held on April 16 and 17 to discuss the denials and status of the change packages. Intense negotiations were entered into in May 1991 to reach acceptable agreement between the three parties on the changes. On May 15, 1991, tentative agreement was reached by the three parties regarding the 
proposed changes to the Tri-Party Agreement. The tentatively agreed changes were submitted to the public for a comment period from May 22 to July 5,1991 , with public meetings held in June to discuss the changes.

The EPA, Ecology, and DOE, after considering public comments, approved the change packages in September 1991.

Below is a summary of the approved changes by major milestone:

- Milestone M-01-00, "Complete 14 grout campaigns of double-shell tank waste by September 1994 and maintain currency with waste feed thereafter," has been delayed 27 months to December 1996.

- New milestones and due dates will be established for Milestone M-02-00, "Initiate B Plant operations for pretreatment of double-shell tank waste," in January 1992.

- Interim Milestone M-03-01, "Initiate Hanford Waste Vitrification Plant (HWVP) construction," has been delayed 9 months, while Milestone M-03-00, "Initiate Hanford Waste Vitrification Plant operations," has not been changed at this time.

- Adjustments to the number of tanks to be stabilized under the interim milestones supporting Major Milestone M-05-00, "Complete single-shell tank interim stabilization," were approved (from 9 in 1991 to 4; from 9 in 1993 to 11 ; from 9 in 1994 to 8 , and from 5 in 1995 to 10). The major milestone date of September 1995 to complete the interim stabilization of all but the two high-heat tanks was not changed.

- Adjustments were made to Interim Milestones M-10-04 (extend due date from December 1990 to September 1991) and M-10-06 (reduction from 24 samples to 20 samples). Interim Milestone M-10-05 was redefined to cover the preparation of an integrated waste sampling plan. No changes were made to the September 1998 Major Milestone M-10-00, "Complete analyses of at least two complete core samples from each single-shell tank."
- M-12-0(), "Submit RI/FS or RFI/CMS work plans for 20 operable units," has been changed to 15 work plans, and the due date for M-13-00, "Submit six RI/FS' or RFI/CMS work plans per year," has been revised to begin in 1993. Additionally, the interim milestones under M-12-00 have been revised to require rescoped work plans reflecting revised past practice strategy. Four new major milestones have been added (M-27-00, M-28-(0), M-29-()0, and $M-30-00)$ requiring aggregate area management study reports, soils and groundwater background determinations, the Hanford Site risk assessment methodology, and integrated general investigations and studies for the 100 Areas. Under these new major milestones are 23 new supporting interim milestones.

- Three new interim milestones have been added to Major Milestone M-17-00, "Complete liquid effluent treatment facilities/upgrades for all Phase I streams," requiring the development of sampling and analysis plans, implementation of interim operating restrictions on facility effluents, and submittal of a methodology for assessing the impact of liquid discharges.

- M-20-21 (submittal of a permit application for $B$ Plant) is revised to require the establishment of a due date for submittal of a permit application or a closure plan The new date will be established by January 1992 .

- Interim Milestone M-24-07 and Major Milestone M-24-(0), "Install RCRA ground-water monitoring wells at the rate of 30 in (Y 1990," were extended 280 days making them due October 7, 1991.

- A newly established milestone (M-31-(0)) requires the construction of up to four new double-shell tanks with interim nilestones requiring the completion of conceptual design (M-31-01) and establishment of additional milestones (M-31-02) by September 1992.

A complete renegotiation of Major Milestone M-17-00, "Complete liquid effluent treatment facilities/upgrades for all Phase I streams," was completed in October 1991. The resulting change 
package will modify the existing Tri-Party Agreement Major Milestone M-17-00 and the interim milestones M-17-02, M-17-04, M-17-08, M-17-09, M-17-10, M-17-11, M-17-12, and M-17-13. As a result of the negotiations 86 new interim milestones and 1 new major milestone will be added to the Tri-Party Agreement dealing with liquid effluents. This change package will undergo public review along with the Tri-Party Agreements annual update and be approved after resolution of any comments.

As required by Amendment 2 to the Tri-Party Agreement, negotiations occurred from May through September 1991. These negotiations resulted in an agreement (Consent Order) between RL and Ecology for obtaining state permits for liquid effluents at the Hanford Site. The actions and schedules put forth in the agreement for obtaining state permits will be consistent with the interim Tri-Party Agreement milestones. The permit, in addition, will address those deliverables specifically required for compliance with the State permitting program (engineering reports, etc.), a schedule for permit submittals, and a schedule for identification and disposition of miscellaneous liquid effluent streams.

The 1992 annual update to the Tri-Party Agreement has been prepared and will undergo public comment during the period of March and April 1992. The annual update to the Tri-Party Agreement was delayed this year to incorporate the new M-17-00 milestones, which were negotiated during the period from June through October 1991.

Milestone M-14-00, “Complete construction and initiate operations of a low-level mixed waste laboratory," was included in the Agreement to ensure that projected analytical needs at the Hanford Site would be met. Subsequent to the signing of the Tri-Party Agreement, the DOE determined that analytical needs at the Hanford Site would be better satisfied through the use of commercial laboratory facilities. Activities associated with the laboratory project were halted while an evaluation was conducted to determine whether new laboratory capabilities were still necessary if commercial laboratories performed the bulk of the low-level mixed-waste sample analyses. The results of that evaluation determined that additional capabilities were necessary to analyze process control samples and perform quality c.ntrol checks on the analyses conducted by commercial laboratories.

The DOE currently has several small contracts in place with commercial laboratories. 'These laboratories will continue to be used pending the placement of multiyear, multimillion dollar contracts for long-term laboratory services. The DOE also is working closely with the laboratories currently being used to expedite the sample turnaround times. A change package was submitted to Ecology and EPA in November 1991 to redefine the major milestone; the change package was denied and at year's end was in dispute resolution.

\section{Hanford Future Site Use/ Cleanup Strategy}

Potential long-term future uses of Hanford Site land strongly influence decisions about cleanup strategies and cleanup standards. Understanding public and other affected parties' visions of potential future site uses will help DOE make cleanup decisions that will be publicly supported and that will stand the test of time.

The DOE, in cooperation with other interested participants, is supporting a process to actively seek public input to the development of cleanup strategies, taking into consideration potential future site uses.

\section{The Columbia River's Hanford Reach}

The Hanford Reach is an 84-km (52-mi) stretch of the Columbia River from Priest Rapids Dam to the head of Lake Wallula near Richland. Congress passed a law (Public Law 100-605) in 1988 requiring a comprehensive study of the Hanford Reach. The Secretary of Interior, in consultation with the Secretary of Energy, was to take two actions: 1) inventory and evaluate the river's resources, and 2) develop and analyze a series of protection alternatives, including designation of 
the Reach in the National Wild and Scenic Rivers system. The Department of Interior was to have presented its study and an EIS to Congress by November 1991; however, this has not yet occurred.

The law states that for 8 years, no federal agency may construct any dam, channel or navigation project. It also requires all other activities, to the extent practicable, be planned and implemented to minimize adverse impacts on the river's resources. As a means of complying with the law, RL notifies the National Park Service (NPS) of all proposed activities subject to the NPS consultation and coordination process agreed upon by the two involved agencies.

Analysis of the alternatives began in May 1990. Options range from establishing a resource protection area, to taking no action. Which state or federal agencies would manage the area, whether development would be limited, and how far from the shore the protection would extend are among other issues to be addressed in the EIS. For example, if the Hanford Reach were declared a National River, the NPS would preserve the river in its natural state and allow its resources to be used but not changed, altered, or depleted.

The NPS is the lead agency for the Department of Interior and plans to announce its preferred alternative in a draft EIS in the spring of 1992. A public comment period will follow, and public hearings are planned. The final report to Congress will present the study team's final recommendation.

\section{Tiger Team Assessment Corrective Actions}

In June 1989, Secretary of Energy James D. Watkins announced a 10-point initiative to strengthen safety, environmental protection, and waste management activities at DOE production, research, and testing facilities. The Initiative is part of the Secretary's overall plan to ensure full accountability in the areas of environment, safety, and health (ES\&H), and ensure that all DOE facilities achieve and maintain full compliance with applicable federal and state ES\&H requirements.
Tiger Team assessments, one of the 10 points in the initiative, are one of Secretary Watkins' highest priorities for DOE. The assessments include, but are not limited to, the following ES\&H areas:

- compliance with applicable federal, state, and local regulations; permit requirements; agreements; orders; and consent decrees

- compliance with DOE order requirements for ES\&H activities

- adequacy of DOE and site contractor ES\&H management programs, including planning, organization, resources, training, and relationship with regulatory agencies

- conformance with applicable best and accepted industry practices

- identification of root causes.

The Hanford Site Tiger Team began evaluating Site operations in May 1990. The Tiger Team presented its findings to RL and state officials in July 1990. The team's report listed 371 separate findings, and 4 special issues; no findings were characterized as representing an imminent danger. Eighty-four findings related to environmental issues. The documentation of the results of the assessment is published in Tiger Team Assessment of the Hanford Site (DOE 1990e). A copy of this document is available at the RL Public Reading Room.

In January 1991, RL submitted the draft of the Hanford Site Preliminary Action Plan to U.S. Department of Energy-Headquarters (DOE-HQ). Comments were subsequently received from DOE-HQ reviewers. The RL and Hanford Site contractors have responded to thos? comments. Through March 1991, resolution had been achieved on $95 \%$ of all comments received. The Hanford Readiness Task Force, composed of RL and Site contractor personnel, submitted a revised Hanford Site Preliminary Action Plan in April 1991.

Anticipating formal approval of the plan, actions were initiated in accordance with the plan and the priority levels were assigned to each action. Progress has been carefully tracked on closeout 
and interim milestones. Delinquent actions have been carefully analyzed to ensure no environmental or safety impact. Currently, 584 actions out of 766 have been completed and are awaiting closure by DOE-HQ. The draft plan was formally approved in December 1991.

\section{Plutonium Uranium Extraction and Uranium Oxide Plants Status}

Operation of the PUREX process to stabilize certain liquid inventories was completed in FY 1990. Inventories of solvent and nuclear materials remain, including liquid uranyl nitrate hydrates and fuel from Hanford Site production reactors and organic materials. Transition of the PUREX Plant to a minimum safe standby condition began in FY 1991. Tanks and transfer routes were closed off to prevent spills of remaining liquids and to isolate incoming utilities from the process area.

Preparation of the $\mathrm{UO}_{3}$ Plant to process remaining inventories of liquid uranyl nitrate hydrates continues. An operational readiness review team was established, and mechanical work was initiated to ensure safe operations.

It is anticipated that no decision on further operation of the PUREX Plant will be made until an EIS is complete.

\section{Plutonium Finishing Plant Restart}

Reactivation of two process areas in the Plutonium Finishing Plant (PFP) will stabilize materials held in the facility. This materials stabilization campaign is in response to direction from DOE-HQ to operate PFP as necessary to stabilize and prepare materials for long-term storage and to conduct cleanout activities needed to improve the safety of the facility.

Operation of the Plutonium Reclamation Facility, one of two active process facilities and the first step in the stabilization process, will be resumed following completion of the readiness review process. Residual in-process chemically active recyclable liquids, sludges, fluoride powder, and rags containing plutonium will be processed to produce plutonium nitrate solutions. These plutonium nitrate solutions will then be converted in the other process facility, the Remote Mechanical C Line, to an oxide form. Plutonium oxide is a stable form suitable for extended storage. Reactivation of the Plutonium Reclamation Facility is scheduled for late in FY 1992.

Evaluation of the PFP status with respect to selected DOE orders and implementation of the new PFP final safety analysis report will also be performed before Plutonium Reclamation Facility restart.

\section{Hanford Waste Vitrification Plant}

The Hanford Waste Vitrification Plant will be constructed to treat much of the waste currently stored in double-shell tanks. The high-activity fraction of waste resulting from pretreatment of the stored waste will be immobilized into borosilicate glass and stored until a repository is ready to receive this waste.

The RL advised Ecology in December 1990 of technical and programmatic concerns that may delay the start of plant construction. To address these technical and programmatic concerns, RL initiated a systems engineering risk assessment to evaluate the technical, safety, and regulatory uncertainties in the Hanford Waste Vitrification Program.

Review of the draft findings from the vitrification systems risk assessment and negotiations between DOE, Ecology, and EPA resulted in a decision that the program for remediation of the Hanford Site tank wastes needed to be redefined.

The redefinition of this program resulted in a reestablishment of the programmatic baseline for the project. As a result, the start of construction on the plant was delayed by 9 months, but the date for starting operations remained unchanged (December 1999). The definitive design, approximately $35 \%$ complete, is scheduled for completion in June 1994. 


\section{Waste Tank Safety Issues}

Several watste tank safety issues have potential impacts on environmental restoration work planned for the Hanford Site. Funding to perform environmental activities has been redirected to resolve safety issues regarding the tanks. Also, because of these safety issues, work control restrictions have been implemented, which has slowed work in and around the tanks.

A supplement to the Hanford Defense Waste (HDW) EIS (DOE 1987b) is planned to evaluate options for disposing of single-shell tank wastes. In the record of decision for the HDW EIS, the decision about how to handle the wastes in the single-shell tanks was deferred. Before a decision can be made, the wastes will need to be characterized and technology will need to be developed for disposing of the wastes. Because of Tri-Party Agreement milestones, this supplemental EIS's schedule is proposed for acceleration.

In December 1991, it was determined by DOEHQ that this supplemental EIS should be combined with the waste tank safety supplemental EIS. The combined supplement will reassess the entire tank safety and tank waste treatment and disposal program.

\section{Background}

Between 1943 and 1964, 149 single-shell tanks were built to store liquid radioactive wastes. Their capacities range from approximately $2.08 \times 10^{5} \mathrm{~L}\left(5.5 \times 10^{4}\right.$ gal $)$ to $3.78 \times 10^{6} \mathrm{~L}$ $\left(1 \times 10^{5} \mathrm{gal}\right)$. Some of the tanks have leaked. No wastes have been added since November 1980 , and much of the originally stored waste has been pumped out. Today, the 149 tanks hold about $1.4 \times 10^{\star} \mathrm{L}\left(3.7 \times 10^{\circ} \mathrm{gal}\right.$ ) of waste. The waste is in three general forms: sludge, salt cake, and liquid. The waste is a variety of types: low-activity, high-activity, hazardous, or plutonium-contaminated salt cake and sludge.

Twenty-eight double-shell tanks have been built since 1968 and used since 1970. The double-shell tanks now contain about $7.6 \times 10^{7} \mathrm{~L}\left(2.0 \times 10^{7} \mathrm{gal}\right)$ of liquid radioactive waste. These tanks have a second steel wall, and the space between the two walls is monitored for leaks. None of these tanks is known to have leaked to date.

Sixty-six of the single-shell tanks have been classified as suspected leakers. In 1979, to halt or reduce effects of current and future leaks, removal of pumpable liquids from the single-shell tariks to the double-shell tanks began and continues today. Recent research shows that more studies are needed before more liquids containing ferrocyanide or large amounts of ignitable materials are pumped from the single-shell tanks to the double-shell tanks. The risks of concentrating waste in double-shell tanks must also be evaluated.

\section{Safety Issues}

Concerns have been raised about the potential of a ferrocyanide explosion and hydrogen gas accumulation in the Hanford Site waste tanks. One issue is that under certain conditions of chemical concentration, moisture, and temperature, ferrocyanide and nitrates in the singleshell tanks could release heat and potentially become explosive. The other issue is that flammable hydrogen gases may be trapped beneath the crust in five double-shell tanks and 18 singleshell tanks. One tank in particular, 101-SY (a double-shell tank), shows the largest accumulation of trapped gases. The DOE and external oversight groups have concluded there is no imminent danger to the public from either situation.

Westinghouse Hanford Company has formed a Tank Waste Remediation System Division that has the responsibility to identify any hazards associated with the waste tanks and implement the necessary actions to mitigate or remediate those hazards. Instrumentation to assist in these efforts is being developed for placement in the hydrogen and the ferrocyanide tanks, and ultimately in the tanks containing unstable organic compounds, on an as-needed basis.

Information obtained from core samples, video pictures, and monitoring of 'Tank 101-SY as well as information from detailed studies on the mechanism of flammable gas formation and retention assists in understanding the behavior of 
Tank 101-SY. This understanding supports the development of detailed mitigation strategies for that tank. Work is being initiated to characterize the other flammable-gas tanks to determine the severity of the hazard.

Studies with synthetic waste that duplicate the waste streams that generated ferrocyanide wastes minus radionuclides have increased the understanding of the risk from the ferrocyanidecontaining tanks. This understanding has been summarized in a "position paper" on ferrocyanide that is currently undergoing DOE-HQ peer review. Work is just being initiated on assessing the risk from organic-containing tanks.

\section{Waste Minimization}

The Hanford Waste Minimization Program was designed to meet the requirements of $\mathrm{DOE}$ Orders 5400.1 and 5820.2A, and DOE-HQ guidance consistent with EPA guidelines. The major elements of the program are 1) management support; 2 ) employee training, awareness, and incentives; 3 ) program scope, objectives, and goals; 4 ) waste minimization assessments/audits; 5) accurate cost accounting; 6 ) accurate waste accounting; 7) technology transfer; and 8) program evaluation.

The program focuses on preventing the generation of waste but also implements a strategy to reduce the volume and toxicity of wastes that are nevertheless generated. In order of priority, the program advocates waste prevention using source reduction and recycling techniques, treatment, and disposal of wastes. Wastes targeted for minimization include radioactive / high-activity, transuranic (TRU), low-activityl, radioactive mixed, hazardous (RCRA), and non-hazardous solid wastes. The Site waste minimization program is discussed in further detail in Section 3.1.

\section{General Accounting Office (GAO) Audit of Ground- Water and Soil Monitoring}

The GAO is reviewing environmental monitoring at the Hanford Site at the request of Senator
John Glenn of Ohio. The GAO will be conducting this review over several months and meeting with all Site contractors and the State of Washington. The GAO has initiated the review with an audit of ground-water and soil monitor. ing at the Hanford Site. Meetings with RL and Site contractors occurred in February and March 1991. The GAO review includes well management and vadose zone monitoring. The GAO has requested a copy of the charter for well management that was prepared in response to two Tiger Team findings, and a copy of the vadose zone monitoring plan that discusses the use of a spectral gamma logging system.

\section{State Waste Discharge Permits}

RL has been authorized by DOE-HQ to apply for permits to comply with Washington State requirements for regulating effluent streams discharging to the soil column. A compliance order was signed with Ecology in December 1991. The compliance order establishes a schedule for complying with state permitting requirements for liquid waste discharges to underground waters. This consent order subjects the Hanford Site liquid waste effluents to regulatory milestones, which include submission of engineering reports, design reports, permit applications, sampling and analysis plans, construction schedules, impact assessments, and interim operating restrictions.

\section{2-A Evaporator Status}

The 242-A Evaporator remains in standby status pending construction of four liquid effluent retention facilities. Planned use of the first of three retention facilities is scheduled for the second half of 1992. The PUREX Plant shutdown eliminates the need for one retention facility.

The 242-A Evaporator is used to reduce the volume of liquid wastes that are placed in storage in the double-shell tanks. The retention facilities will be used for the temporary storage of liquid condensate from the 242-A Evaporator until the liquid effluent treatment facility is complete. The 
treatment facility is being designed and constructed in the 200-East Area to remove listed chemical constituents from the 242-A Evaporator process condensate.

\section{Submarine Reactor Com- partments}

Six defueled submarine reactor compartment disposal packages were received and placed in Trench 94 during calendar year 1991.

The reactor compartment disposal packages are being regulated by the Washington State Department of Ecology as dangerous waste because of the presence of lead used as shielding, per agreement with the state. In December 1989, DOE submitted to the state a draft Part B permit application for low-level waste burial grounds, including Trench 94. DOE is addressing questions and comments from the state, including several related to Trench 94 , before submitting a revised permit application.

\section{United States Testing Company, Incorporated, Termination}

Previously, the United States Testing Company, Incorporated (US'I), performed the majority of radiochemical analyses contained in the Hanford Site Annual Environmental Reports. This contract was terminated in June 1990.

For some of the analytical services required by PNL contracts, contracts were placed with Los Alamos National Laboratory and TMA/NorCal Laboratories and an interim contract was awarded to International Technology Corporation's Richland laboratory, who purchased the UST facilitiss in Richland. Four separate longterm analytical contracts were established in September and October as follows:

- Bioassay - International T'echnology Corporation

- Surface Environmental Radiochemistry International Technology Corporation
- Radiochemistry in Ground Water and Solids International Technology Corporation

- Hazardous Chemistry (Ground Water and Solids) - DataChem Laboratories, Salt Lake City

Westinghouse Hanford Company currently has a contract in place with the Martin Marietta Energy Systems K-25 laboratory in Oak Ridge, Tennessee.

\section{State of Oregon Survey}

As part of the DOE plan to clean up the Hanford Site, transuranic wastes will be shipped to a repository near Carlsbad, New Mexico, over a period of approximately 20 years. To gauge public opinion regarding this transport plan, 402 adults living in the four Oregon counties along the Interstate 84 corridor planned for the transport route, and 604 adults living elsewhere in Oregon were surveyed in June and July 1990.

The survey was conducted for the Oregon Department of Energy. The survey was administered by telephone to a randomly selected set of households. Within each household selected, the available household member over 18 years of age with the most recent birthday was interviewed. Survey results were reported in early February 1991 to the Oregon Hanford Waste Board and Hanford Advisory Committee. The Board is Oregon's policy forum for the Hanford Site issues that impact the state. The Advisory Committee is the Board's liaison to citizens and local governments.

More than half ( $56 \%$ ) of those surveyed believe nuclear weapons waste transport poses a greater risk than continuing to store the waste at the Hanford Site. About one-fifth $(18 \%)$ believe the risk is the same. Key findings of the analysis include:

- Most Oregonians worry about the effects of nuclear waste transport, but niore than half believe the job can be done safely.

- Of those who live along a likely transport route in Eastern Oregon, $80 \%$ fear that radioactive waste transport might harm public 
health and safety. Statewide, 64\% agree. More than two out of three Oregonians $(69 \%)$ believe hazardous material transport mishaps will happen.

- Respondents tended to rate the hazards of nuclear waste transport on a par with transport of toxic chemicals and explosives on Oregon highways.

- Respondents were far more likely to see more harmful consequences than benefits as a result of the transport program.

\section{Environmental Training}

Training is provided for contractor employees, DOE, EPA, Washington State, vendors, and others requesting training required for entry onto the Hanford Site. Training is provided in the areas of hazardous waste site operations (initial and refresher), hazard communications, waste minimization and waste management, waste designation, hazardous waste shipment, facility waste sampling, and respiratory protection.

During 1991, eight instructors trained approximately 5,650 individuals in hazardous waste operations and approximately 400 in the technical courses dealing with sampling, designating, and shipping waste. Along with providing classroom instruction, new courses were developed or refined/redesigned and were presented or shared with other DOE sites.

\section{Self-Assessments}

Several types of environmental self-assessments were performed at Hanford in 1991. These assessments evaluated compliance with local, state, and federal requirements as well as self-imposed requirements. The major focuses of the assessments were to:

- review laboratory operations against EPA's SW-846 test methods (EPA 1982)

- routinely assess permitted activities for compliance

- assess satellite accumulation and 90-day storage areas for compliance with waste storage requirements

- routinely audit the low-activity waste generators' program for organizational structure, methods used to characterize waste, methods of packaging waste, and methods used to store and accumulate waste.

In the future, the subject of these self-assessments are expected to be incorporated into and implemented by the comprehensive self-assessment program being developed at the direction of the Secretary of Energy. 


\subsection{Environmental Occurrences}

Onsite and offsite environmental occurrences (spills, leaks, etc.) of radioactive and nonradioactive materials during 1991 were reported to DOE as specified in DOE Order 5000.3A and to other federal and state agencies as required by law. The specific agencies notified depended on the type, amount, and locatiun of the individual occurrences. Generally, these materials either dispersed naturally, were stabilized in existing waste disposal sites, or were controlled and cleaned up. In some cases an occurrence may be under continuing observation and evaluation. During 1991, all Emergency, Unusual and Offnormal occurrences at Hanford were reported to the Hanford Site Occurrence Notification Center. This Center is responsible for maintaining both a computer database and a hardcopy file of event descriptions and corrective actions. Copies of occurrence reports are available for public review in the DOE Richland Operations Office (RL) Public Reading Room located on the Washington State University campus in Richland, Washington.

As defined in DOE Order 5000.3A, emergency occurrences "are the most serious occurrences and require an increased alert status for onsite personnel and, in some specified cases, for offsite authorities." There were no Emergency Occurrence Reports filed in 1991.

Unusual occurrences are defined as non-emergency occurrences that have a "significant impact or potential for impact on safety, environment, health, security, or operations." There were 115 unusual occurrence reports filed during 1991. Many of these included minor leaks and spills because initial reporting requirements for 1991 specified that any events reportable to offsite agencies be classified as unusual. This requirement was modified several months into the year and for the remainder of the year only those leaks, spills and releases that exceeded state and federal reportable quantities were classified as unusual. Several unusual occurrences of environmental significance are summarized below.

Off-normal environmental occurrences are referred to as "abnormal or unplanned events or conditions that adversely affect, potentially affect, or are indicative of degradation in, the safety, security, environmental or health protection performance or operation of a facility." There were 1,277 off-normal environmental occurrence reports filed at Hanford during 1991 covering everything from battery acid spills and leaks from overheated motor vehicle cooling systems to minor radiation contamination problems. Because of the volume of reported off-normal occurrences, event summaries are not included here.

\section{Unusual Occurrences}

\section{Release of Contaminated Well Water to the Ground (RL-PNL-P14BOPER- 1991-1004)}

About 50 gal ( $189 \mathrm{~L}$ ) of well water containing approximately $190 \mathrm{mg}$ of cyanide, $101,000 \mathrm{pCi}$ of ${ }^{\text {(i) }} \mathrm{Co}$ and $5.7 \mu \mathrm{Ci}$ of "No $\mathrm{Tc}$ were mistakenly discharged to the soil during routine ground-water sampling and purging operations. Purgewater from contaminated wells is normally deposited in temporary containment vessels and then transferred to permanent storage facilities at a later date. Labels on well water sample containers are usually coded so that field personnel can identify contaminated wells before they begin sampling. In this case, however, sample containers were improperly labeled and the purgewater was pumped onto the ground. As a result, groundwater sampling was halted for a time. Sampling was restarted under an administrative procedure requiring the containment of all purgewater. Investigation of this occurrence determined that improved procedure documentation, training, and communication of instructions was required.

\section{Diesel Fuel Spill (RL-WHC- WHC100ERD-1991-1002)}

Approximately 25 gal ( $95 \mathrm{~L}$ ) of diesel fuel were leaked to the soil from a generator operating at a core drilling site inside the 183-H Solar Evaporation Basins. It was initially thought that the leak was due to a loose fuel filter but a closer inspection revealed a crack in one of the fuel filter 
gaskets. This generator had recently been serviced and was operating for the first time since servicing. A large volume of fuel escaped because the unit was located out of view of the employees working at the site and was not checked during the shift. The leak was not discovered until the end of the shift when the unit was being shut off. This incident could have been avoided if the filter had been inspected before installation and the equipment had been periodically inspected during operation. Cleanup was started immediately and completed by $6: 00 \mathrm{pm}$ on the day of the occurrence. Twenty-three drums of contaminated soil were generated.

\section{Radiation Contamination (RL-WHC- PFP-1991-1020)}

Personnel excavating two abandoned 2-in. (5-cm) stainless steel plutonium bearing transfer lines in an uncontrolled area outside the 241-Z Building at the Plutonium Finishing Plant were found to be contaminated with low-level radiation. Excavation work was discontinued and preliminary surveys were conducted when workers noticed discolored soil as they were hand-digging down to the transfer lines. A Health Physics Technician was instructed to enter the pit and remove soil for analysis. At that time the contamination levels in the pit were determined to be $30,000 \mathrm{dpm}$ beta/gamma and $350,000 \mathrm{dpm}$ alpha. As a precautionary measure, extensive surveys were conducted on all personnel and equipment associated with the excavation. In addition to onsite facilities and equipment, the personal vehicles and homes of the individuals involved were also inspected. All results were less than detectable. At the request of a family member of one employee, the State of Washington Department of Health also surveyed one home but no contamination was detected. Analysis results for the soil sample obtained from the pit indicated concentrations of $\stackrel{1}{*} \mathrm{Am}$ and ${ }^{2 * 3} \mathrm{Pu}$ at $5.3 \times 10^{-1} \mu \mathrm{Ci} / \mathrm{g}$ and $5.98 \mathrm{x}$ $10^{-1} \mu \mathrm{Ci} / \mathrm{g}$, respectively. The pit was wet down and covered with plastic to prevent the spread of contamination and a new radiation work permit was written requiring intermittent radiological surveys when excavation activities progressed to within $18 \mathrm{in} .(46 \mathrm{~cm})$ of any known piping, and/or any unknown piping or wiring is encountered, or abnormal soil coloration or conditions are discovered.

\section{Purgewater Discharge to the Ground (WHC-91-0008-183H)}

Twenty gallons (76 L) of purgewater contaminated with $\mathrm{Cr}^{+\mathrm{ti}}$ were discharged to the ground from a well at the 183-H Solar Evaporation Basins. A code letter indicating that this water should be contained was not included on the sample bottle label so the field personnel did not know that containment was required. This omission was caused by human oversight and was compounded by the use of an outdated checklist to generate the label for the sample bottle. The nonroutine scheduling of the sampling activity may have contributed to the error. In the future, all outdated lists of wells requiring purgewater containment will be destroyed, and computer generated labels will be used for both routine and nonroutine sampling. Field personnel will also be required to verify the purgewater requirements for each well before purging the well.

\section{Alpha Release to the Atmosphere (WHC-PUREX-1991-0223)}

Air samples collected from the main stack of the PUREX Plant in the 200-East Area indicated that alpha releases exceeded WHC weekly guidelines during the week of February 8 to 15, 1991. Subsequent sampling continued to show higher than expected levels. Using worst-case assumptions, preliminary calculations indicated that the total weekly release of ${ }^{2+11} \mathrm{Am}\left(4.06 \times 10^{-12} \mu \mathrm{Ci} / \mathrm{mL}\right)$, an alpha emitter, was in excess of the established weekly limit of $2.0 \times 10^{12} \mu \mathrm{Ci} / \mathrm{mL}$. No regulatory limits had been or were expected to be exceeded. However, it appeared likely that the WHC Operational Safety Requirement for annual releases would be exceeded. The annual average concentration limit for ${ }^{2+1} \mathrm{Am}$ at the point of release to the environment is $2 \times 10^{1: 1} \mu \mathrm{Ci} / \mathrm{mL}$. A contributing cause was probably floodwaters from a frozen, broken pipe in the 293-A Building in January 1991 (WHC-91-0035-PUREX), which carried radioactivity into a ventilation exhaust duct downstream of the duct's filters. Actions undertaken to limit additional releases included reducing the air flow through the stack, cleaning up the contaminated ductwork, and increasing sampling from once a week to every 24 hours. Routine monitoring has indicated a return to normal levels of " ${ }^{2+1} \mathrm{Am}$. The final report for this occurrence had not been completed at the time this summary was prepared. 
Environmental

Program Information 


\subsection{Environmental Program Information}

It is DOE policy to conduct its operations in an environmentally responsible manner and comply with applicable environmental standards. At Hanford, a variety of environmental activities are performed to comply with laws and regulations, enhance environmental quality, and monitor the impact of environmental pollutants from Site operations.

Section 2.0 summarized the status of Hanford's compliance with applicable regulations, activities under way to achieve compliance, and programs to manage and improve environmental quality.
This section summarizes significant activities conducted in 1991 to manage waste, restore contaminated inactive waste sites and facilities, develop new cleanup technologies, monitor the release of pollutants from facilities, conduct sampling and analysis of environmental media for pollutants, assess the status of wildlife and cultural resources, monitor the meteorology and climatology of the Site, and conduct special environmental programs. 


\subsection{Environmental Restoration, Waste Management, and Technology Development}

The cornerstone and framework for DOE's strategy for department-wide environmental restoration, waste management, and technology development is the DOE Environmental Restoration and Waste Management Five-Year Plan (DOE 1990b). This annually updated document was reissued in August 1991. The DOE 5-year plan addresses overall philosophy and environment- and wasterelated activities that are the responsibility of the Office of Environmental Restoration and Waste Management.

The Environmental Restoration and Waste Management Site-Specific Plan for the Richland $O p$ erations Office (DOE 1989b) implements and supports the DOE 5-year plan. This detailed information volume is prepared so it can be used as a stand-alone document. The Hanford Site Five-Year Plan (DOE 1990b) is supported by two companion documents, the Overview of the Hanford Cleanup Fise. Year Plan and the Hanford Site Environmental Restoration and Waste Management Five-Year Plan Activity Data Sheets (DOE 1990d). The overview provides a general plan description, and the activity data sheets provide supplemental data to the detailed information document.

\section{Environmental Restoration}

The environmental restoration program has been established to remediate inactive waste sites, and to decontaminate and decommission surplus facilities. The Hanford Site has established the following two major programs for implementing these actions:

1. Environmental Restoration Remedial Action (ERRA) Program

2. Hanford Surplus Facilities Program.

Activities conducted within these programs are summarized in the following subsections.

\author{
Environmental Restoration \\ Remedial Action Program
}

The ERRA Program was established to comply with regulations for characterization and cleanup of inactive waste sites. The program specifically includes identification and characterization of inactive sites, remedial design and cleanup action, and post-closure activities of inactive radioactive, chemically hazardous, and mixed waste sites.

All of the waste disposal sites at the Hanford Site have been grouped into 78 operable units. An operable unit is a grouping of waste sites for conducting a remedial investigation and carrying out remedial actions. Operable units form the basis for planning, scheduling, budgeting, and establishing the working order for some of the environmental restoration milestones for the TriParty Agreement. Remedial investigations are being conducted at 16 operable units to determine the need for remediation at these units. The ERRA Program also initiated Expedited Response Actions on three individual waste sites: the 618-9 Burial Ground, the 300 Area Process Trenches, and the 200-West Area carbon tetrachloride site. More than 40 drums containing over $5,678 \mathrm{~L}$ ( $1,500 \mathrm{gal})$ of solvent and uranium were removed from the 618-9 Burial Ground, preventing the liquid from eventually reaching the ground water. Work was completed at the 300 Area Process Trenches where approximately $5,300 \mathrm{~m}^{3}\left(7,000 \mathrm{yd}^{3}\right)$ of contaminated soil were removed and isolated. A pilot-scale carbon tetrachloride vapor extraction unit was successfully demonstrated at the 200-West Area, and procurement of a full-scale system was initiated.

\section{Hanford Surplus Facilities Program}

Many DOE-owned facilities at the Hanford Site that were used for nuclear materials production have been retired from service and declared 
surplus. The Hanford Site Surplus Facilities Program manages these facilities for DOE. The program provides for surveillance and maintenance, as well as eventual decontamination and decommissioning of these facilities.

The program manages about 100 separate facilities including large concrete and cement block structures that formerly housed chemical separations processes, decommissioned nuclear reactors, underground effluent water systems and storage tanks, and ancillary buildings. Included also are the eight graphite-moderated plutonium production reactors constructed between 1943 and 1955 . These reactors have now been shut down for more than 20 years.

Activities currently under way include surveillance and maintenance of surplus facilities, decommissioning of the 201-C Strontium Semiworks, and preparation of the final EIS, Decommissioning of Eight Surplus Production Reactors at the Hanford Site, Richland, Washington. The draft EIS (DOE 1989a), which has been released for public review, discusses various alternatives for decommissioning these reactors. The final EIS and record of decision are scheduled to be published in FY 1992. Decommissioning of the current inventory of surplus facilities by the year 2018 is estimated to cost approximately $\$ 1$ billion.

\section{Waste Management}

Waste management is the safe and effective management of active and standby facilities and the treatment, storage, and disposal of radioactive, hazardous, and mixed waste. The waste management goals of RL are to minimize the generation of waste, and to maintain safe and environmentally sound programs for treatment, storage, and disposal of newly generated and stored wastes. The Hanford Site Five-Year Plan (DOE 1990b) provides de'ailed descriptions of the Site's waste management programs and other activities. Summary descriptions of major programs and activities are presented here.

\section{Waste Minimization}

The Hanford Waste Minimization Program was designed to meet DOE Orders 5400.1 and $5820.2 \mathrm{~A}$, and DOE guidance, consistent with EPA guidelines. The major elements of the program are 11 management support; 2 ) employee training, awareness, and incentives; 3 ) program scope, objectives, and goals; 4 ) waste minimization assessments/audits; 5) accurate cost accounting; 6) accurate waste accounting; 7) technology transfer; and 8) program evaluation.

The program focuses on preventing and minimizing the generation of waste. The program implements a strategy to reduce the volume and toxicity of wastes that are nevertheless generated. In order of priority, the program advocates waste prevention using source reduction and recycling techniques, treatment, and disposal of wastes. Wastes targeted for minimization include radioactive (high-activity, transuranic, low-activity), radioactive mixed, hazardous, and nonhazardous regulated wastes.

Requirements for the Hanford Site program now include the following:

- an an nual DOE waste reduction report (first issue to be completed in March 1992)

- a biennial EPA waste minimization report (completed in March 1991)

- an annual EPA source reduction and recycling report attached to the SARA 313 Report (first issue to be completed in July 1992)

- an annual DOE-required Hanford Site and contractor-specific waste minimization plan review and update (completed in May 1991)

- update of the Sitewide and specific RCRA Part B permits

- DOE-required process waste assessments 
- waste minimization and pollution prevention program plans (updated for the Hanford Site and each contractor May and August 1991, respectively).

Waste minimization efforts have reduced the volume of wastewater discharged to process trenches in the 300 Area of the Site by more than $5.7 \mathrm{million} \mathrm{L} / \mathrm{d}$ ( $1.5 \mathrm{million} \mathrm{gal} / \mathrm{d})$ to meet a TriParty Agreement milestone. Modifications included installing closed-loop cooling, plugging drains, lowering thermostats in steam-heated buildings, using water in water-cooled equipment only when required, and putting administrative controls in place where possible.

In addition, a multifunction Tank Space Management Board consisting of plant managers was established to review efforts to reduce wastes generated and sent to the tank farms for storage. Task teams imposed maximum waste generation limits for each plant, and approval from the Management Board was necessary to exceed the established volumes. The volume of liquid waste avoided through waste reduction efforts to date exceeds 22 million L (5.8 million gal).

A paper recycling program has expanded to include 194 buildings onsite. In 1991, approximately 150 tons of paper were recycled.

\section{Soil Column Discharges}

A major strategy for the Hanford Site's waste management is to discontinue discharges of contaminated liquid effluents to the soil column. Effluent streams containing hazardous and/or radioactive wastes will no longer be discharged or will be treated to remove contaminants before discharge. Thirty-two liquid effluent streams have been identified for which action is required. This action is included as a milestone under the Consent Order DE 91NM-177 and the Tri-Party Agreement action plan.

A plan and schedule have been prepared in accordance with DOE Order 5400.5, "Radiation Protection of the Public and the Environment," and have been implemented to discontinue the disposal of contaminated liquids into the soil at the Hanford Site. Discharge of contaminants in the major waste streams will be discontinued by 1995 either by stopping the discharge or treating the effluent stream to remove contaminants. Technology for treating the effluent streams is being evaluated to determine which would best meet regulatory requirements.

\section{Stored Wastes}

The major effort for cleanup of the Hanford Site will be the disposal of stored wastes generated from past production operations. The strategies for handling and disposing of these wastes, as well as newly generated wastes, have been documented through the National Environmental Policy Act process. The resulting record of decision recommends implementing preferred alternatives, described by the Final Environmental Impact Statement, Disposal of Hanford Defense High-Level, Transuranic and Tank Wastes (DOE 1987b). The preferred alternatives recommend disposal of double-shell tank waste, retrievably stored and newly generated transuranic waste, and encapsulated cesium and strontium waste as follows.

Double-sheli tank waste will be separated into three fractions: high-activity waste, transuranic waste, and low-aciivity waste. The 28 doubleshell tanks store more than 91 million L ( $2.4 \mathrm{x}$ $10^{7}$ gal) of radioactive liquid and slurry, much of which has been transferred and concentrated from single-shell tanks. The high-activity waste and transuranic waste will be processed into a solid, vitrified material similar to glass and disposed of in a repository. The low-activity waste will be mixed with a cement-like material and allowed to harden in near-surface concrete vaults.

Solid transuranic waste that has been retrievably stored since 1970 or has been newly generated will be sorted and packaged in the proposed Waste Receiving and Processing Facility for shipment to the Waste Isolation Pilot Plant (WIPP) in New Mexico. WIPP certified transuranic wastes are currently being stored in the Transuranic Waste Storage and Assay Facility.

Cesium and strontium capsules will continue to be stored for eventual disposal in a repository. 
The cesium and strontium were removed from single-shell tank wastes to reduce heat generation; 1,577 cesium capsules and 640 strontium capsules were produced. There are currently 961 cesium capsules and 597 strontium capsules stored at the Hanford Site $(41,718,000 \mathrm{Ci}$ of cesium and 24,532,000 $\mathrm{Ci}$ of strontium).

For single-shell tank waste, transuranic-contaminated soil sites, and pre-1970 buried, suspect, transuranic-contaminated solid waste, the recommended strategy is to continue the development and evaluation of disposal technology before making a disposal decision. Wastes will continue to be stored in a manner that protects the environment and human health.

Storage will continue until treatment and disposal facilities are constructed and treatment processes are implemented. An environmental impact statement supplemental to DOE (1987b) will be prepared for disposal of the single-shell tank wastes.

\section{Technology Developrnent}

The DOE Office of Technology Development was formed to consolidate and provide centralized management and oversight for research, development, demonstration, testing, evaluation activities, and si $\ldots t$ to the Office of Environmental Restoration and Waste Management. The technology development activities are targeted toward coordination of new and more effective technologies to solve environmental restoration and waste management challenges.

The Office of Technology Development's programmatic implementation strategy is founded on the concept of integrated demonstrations, integrated programs, and supporting technology programs. An integrated demonstration is a cost-effective mechanism that assembles a group of related and synergistic technologies. Their performance is then evaluated individually and as part of a complete systern in correcting environmental restoration and waste management problems from waste generation to disposal. An integrated program is a group of research, development, and/or demonstration tasks that relate to a single environmental restoration or waste management issue or function. Supporting technology programs, such as robotics and analytical laboratory management, are technical disciplines that support several integrated demonstrations and integrated programs.

The technology development program is implemented at the Hanford Site through technical program managers at both Pacific Northwest Laboratory and Westinghouse Hanford Company. Two integrated demonstrations were assigned to the program managers for lead coordination: demonstrate technologies for stabilization and remediation of underground storage tanks and closure of high-priority single-shell tank RCRA sites; and provide technology options for the expedited response action to remediate the carbon tetrachloride plume in the 200-West Area. 


\subsection{Environmental Monitoring at Hanford}

Environmental monitoring of the Hanford Site consists of 1) effluent monitoring and 2) environmental surveillance. Effluent monitoring is performed as appropriate by the Site operators at the facility or point of release to the environment. Environmental surveillance consists of sampling and analyzing environmental media on and off the Hanford Site to detect and quantify potential contaminants and assess their environmental and human health significance.

The overall objectives of the monitoring programs are to demonstrate compliance with federal, state, and local regulations; confirm adherence to DOE environmental protection policies; and support environmental management decisions.

The effluent monitoring and environmental surveillance programs are summarized in this section. Effluent monitoring data, environmental surveillance data, and dose assessment results appear in Section 4.0, "Environmental Monitoring Information."

\section{Effluent Monitoring}

Effluent releases at the Hanford Site are reported to the DOE Richland Field Office (RL) and the public. Reporting these releases is required by DOE Orders 5484.1, "Environmental Protection, Safety, and Health Protection Information Reporting Requirements," and 5400.1, "General Environmental Protection Program." Analytical data on samples taken from effluent releases include the types and quantities of constituents, both radioactive and nonradioactive, that facilities discharge to the air, soil, and Columbia River. These data are evaluated to determine the state of compliance with applicable regulations.

\section{Airborne Effluent Monitoring}

\section{Nonradioactive}

Nonradioactive air pollutants from powergenerating and chemical-processing facilities are molitored. In compliance with the existing Prevention of Significant Deterioration (PSD) permit (No. PSD-X80-14) issued for the Plutonium-Uranium Extraction (PUREX) and Uranium-Oxide $\left(\mathrm{UO}_{3}\right)$ Plants, air emissions from these facilities are monitored for nitrogen oxides. At the PUREX Plant, the main discharge stack is continuously monitored. The calciner exhaust at the $\mathrm{UO}_{3}$ Plant is equipped with a nitrogen oxides monitor. In compliance with air quality standards established by the Benton-Franklin-Walla Walla Counties Air Pollution Control Authority, particulate matter, sulfur oxides, nitrogen oxides, carbon monoxide, and hydrocarbon emissions from the powerhouses are reported. These emissions are calculated from tons of fuel consumed, using calculations approved by the U.S. Environmental Protection Agency (EPA). Emissions of ammonia and ammonium hydroxide from the 200 Areas are reported annually to EPA Region 10 if they exceed quantities listed in the Comprehensive Environmental Response, Compensation, and Liability Act (CERCLA).

\section{Radioactive}

Radioactive releases are monitored by analyzing samples collected froin stack or vent emissions and liquid effluents. Samples are analyzed for total alpha and beta activity and specific radionuclides. Continuous radiation monitoring systems are used when the potential exists for releases to exceed normal operating ranges by amounts that would require personnel to be alerted. Selection of the specific radionuclides for sampling, analysis, and reporting is based on 1) an evaluation of emissions expected from the known radionuclide inventories in the facility, 2) criteria for sampling given in the contractor environmental compliance manual, and 3) the potential contribution to the offsite dose received by members of the public from radioactive effluent constituents.

\section{Liquid Effluent Monitoring}

\section{Nonradio_ctive}

Liquid effluents from Site facilities discharge to cribs, ponds, ditches, drain pipes, trenches, the City of Richland Publicly Owned T'reatment Works (from the 1100 Area), and the Columbia 
River (from the 100 and 300 Areas). Where designated discharge points exist for effluents to enter the Columbia River, samples are collected to determine compliance with the National Pollutant Discharge Elimination System (NPDES) permit for the Site. In the 200 Areas, liquid effluent releases of ammonia and ammonium hydroxide in excess of reportable quantities are reported to EPA Region 10 annually.

\section{Radioactive}

Those effluents that normally or potentially contain radionuclides include cooling water, steam condensates, process condensates, laundry wastewater, and wastewater from laboratories and chemical sewers. Samples from these wastewater streams are sampled and analyzed for radionuclides present in the facilities where the stream originated.

\section{Near-Facility Environmental Monitoring}

Near-facility environmental monitoring is defined principally as routine monitoring near Site facilities discharging or having discharged radioactive or hazardous contaminants. The monitoring locations are associated mostly with major operations facilities, such as the PUREX Plant and $\mathrm{N}$ Reactor, and waste disposal facilities, such as burial grounds, ponds, cribs, trenches, and ditches.

The purpose of the near-facility environmental monitoring program is to ensure employee and environmental protection and determine the status of compliance with local, state, and federal regulations. Much of the program consists of collecting and analyzing environmental samples and methodically surveying areas near facilities releasing effluents. The program also evaluates acquired analytical data, determines the effectiveness of facility effluent monitoring, measures the adequacy of containment at waste disposal units, detects and monitors unusual conditions, and identifies needed upgrades to effluent monitoring capabilities. The program inmplies with applicable portions of DOE Orders 5400.1; 5484.1; 5400.5, "Radiation Protection of the Public and the Environment;" and 5820.2A, "Radioactive Waste Management."
Monitoring activities routinely include sampling and monitoring near-facility ambient air, surface water, ground water, external radiation dose, soil, sediment, vegetation, and animals. Some of the parameters typically monitored are $\mathrm{pH}$, water temperature, radionuclides, radiation exposure, and hazardous constituents. Samples are collected in known or expected effluent pathways. These pathways generally are downwind of potential or actual airborne releases and downgradient of liquid discharges. The annual routine activities of ne:ur-facility monitoring are summarized in Table 3.1, which shows the type, quantity, and area location of samples collected.

Liquid waste disposal sites and the terrain surrounding them are surveyed to detect and characterize any radioactive surface contamination. The locations of these surveys include cribs, trenches, drains, retention basin perimeters, pond perimeters, ditch banks, solid waste disposal sites (for example, burial grounds, trenches), unplanned release sites, tank farm perimeters, stabilized waste disposal sites, roads, and firebreaks in and around the Site operations areas. Radiological surveys are conducted at 391 sites in the operations areas (100 in 100 Areas; 273 in 200 and 600 Areas; 18 in 300 and 400 Areas) (DOE 1991a).

\section{Environmental Surveillance}

Environmental surveillance of the Hanford Site and surrounding region is conducted to demonstrate compliance with environmental regulations, confirm adherence to DOE environmental protection policies, support DOE environmental management decisions, and provide information to the public. Surveillance is conducted as an independent program under DOE Orders 5400.1, "General Environmental Protection Program," and 5400.5, "Radiation Protection of the Public and Environment," and the guidance in Environmental Regulatory Guide for Radiological Effluent Monitoring and Environmental Surveillance (DOE 1991a). The scope, objectives, criteria, design, and description of the program are summarized below and provided in detail in Environmental Monitoring Plan, United States Department of Energy, Richland Field Office (DOE 1991b). 
Table 3.1. Near-Facility Routine Environmental Samples and Locations

\begin{tabular}{lrccc}
\multicolumn{1}{c}{ Samples } & Total & 100 Areas & 200 Areas & $300 / 400$ Areas \\
Air & 38 & 4 & 34 & \\
Surface Water & 37 & 22 & 15 & \\
Ground Water from & & & & \\
$\quad$ Monitoring Wells & 110 & 20 & 89 & 1 \\
External Radiation & & & & 15 \\
$\quad$ Monitors & 289 & 213 & 61 & 15 \\
Soil & 157 & 32 & 110 & 15 \\
Vegetation & 95 & 40 & 40 &
\end{tabular}

\section{Scope}

Site surveillance encompasses sampling and analysis for potential radiological and chemical contaminants on and off the Hanford Site. Emphasis is placed on surveillance of those pathways and radionuclides, or chemicals, constituting the greatest pctential risk to humans. Surveillance is focused on routine releases from Hanford's DOE operations, out also reflects the need to respond to unusual releases and the existence of non-DOE nuclear operations on or near the Hanford Site. Surveillance results are formally reported annually through this report series, although unusual results or trends also are reported to DOE and the appropriate facility managers when they occur. Whereas effluent and near-facility monitoring is conducted by the facility operating contractor, environmental surveillance is conducted under an independent program.

\section{Objectives}

Key surveillance objectives in 1991 included:

- verifying compliance with DOE and EPA radiological dose standards for public protection

- measurirg radionuclides, radiation, and chemicals in the onsite and offsite environnent to

- independently assess the adequacy of facility pollution controls
- assess the environmental and public health impacts of Hanford operations

- identify and quantify potential environmental quality problems

- provide information to DOE for environmental management of the Site, and for the public and regulatory agencies.

\section{Criteria}

The criteria for environmental surveillance ar: derived from DOE Order 5400.1, guidance published for DOE sites (DOE 1991a) and the abovestated objectives. These criteria, pathway analyses to determine the radionuclides and media contributing to the dose to humans, and local needs and interests have been used in establishing the surveillance program. Experience gained from environmental surveillance activities and stu' 'ies conducted at Hanford for more than 45 y cars have provided valuable technical background for planning and data interpretation.

\section{Surveillance Design}

Environmental surveillance at Hanford is designed to meet the previously listed objectives, considering the environmental characteristics of the Site and its operating facilities. Its main focus is on determining environmental impacts and compliance with public health standards rather than on detailed radiological and chemical characterization. 
The prirnary pathways for movement of radioactive materials and chemicals from the Site to the public are the atmosphere, surface water, and ground water. Figure 3.1 illustrates these potential primary routes and the possible exposure pathways to humans. The significance of each pathway is determined from measurements and calculations that estimate the amount of radioactive material transported along each pathway and by comparing the concentrations or dose to environmental and public health protection standards. Pathways are also evaluated based on prior studies and observations of radionuclide and chemical movement through the environment and food chains. Calculations based on effluent data show the expected concentrations off the Hanford Site to be low for most radionuclides and generally below the level that can be detected by monitoring technology. To ensure that radiological analyses of samples are sufficiently sensitive, minimum detectable concentrations of key radionuclides in air, water, and food are established at levels well below the levels that correspond to the standards.

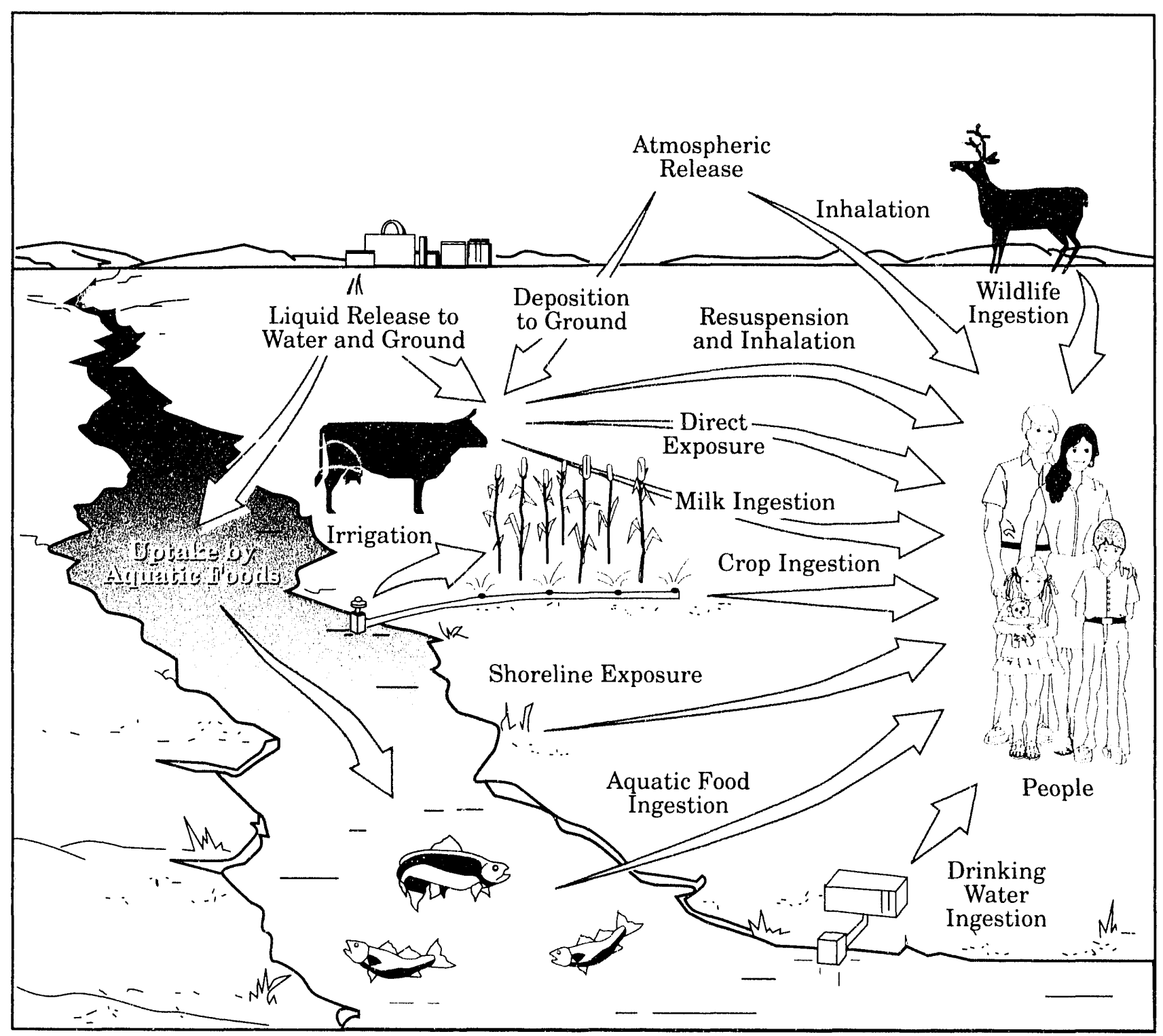

S9203058.131C

Figure 3.1. Primary Exposure Pathways 
Environmental and food-chain pathways are monitored near the facilities releasing effluents and at offsite receptor locations. The surveillance design at Hanford uses a stratified sampling approach to monitor these pathways. Samples are collected and radiation is measured according to three surveillance zones that extend from onsite operating areas to the offsite environs.

The first zone extends from near the operating facilities to the Site perimeter. The environmental concentrations of releases from facilities will generally be the highest in this zone and will be most easily detected before being transported off the Site. The second surveillance zone consists of a series of perimeter sampling stations positioned near or just inside the Site boundary. Data from these stations document or represent conditions at the nearest points at which members of the public reside or could reside. Exposures at these locations are typically the maximum that any member of the public could receive. The third surveillance zone consists of nearby and distant community locations within an $80-\mathrm{km}$ (50-mi) radius of the Site. Surveillance is conducted in communities to provide measurements at those locations where the most people are potentially exposed and to provide assurance to the communities that levels are well below standards established to protect public health.

Finally, background concentrations are measured at distant locations and compared with onsite, perimeter, and community locations as an indicator of the effects of Hanford operations. Background locations are locations that are essentially unaffected by Hanford effluents, but which could be expected to contain low levels of natural and nuclear testing fallout nuclides in environmental media.

To the extent possible, radiation dose assessments should be based on direct measurements of radiation dose rates and radionuclide concentrations in the surrounding environment. The amounts of most radioactive materials released in recent years have generally been too small to be measured directly once they were dispersed in the offsite environment. For many of the measurable radionuclides, it is often not possible to distinguish levels that resulted from worldwide fallout from those that resulted from Hanford releases. Therefore, in nearly all instances, potential offsite doses are estimated using environmental pathway models that calculate concentrations of radioactive materials in the environment from effluent releases reported by the operating contractors.

\section{Program Description}

The surveillance program in 1991 utilized both measurements and modeling to assess the effects of Hanford operations. Key media and locations were sampled and the samples analyzed for selected contaminants according to a predefined sampling plan. The data were interpreted primarily in terms of combined radiological exposure from all pathways and by comparing chemical contaminants to standards.

In the first zone, between the facilities and the perimeter, air monitoring stations were located around each operating area (see Figure 4.1) because air transport is a potential key pathway for transport of radioactive materials off the Site. Surface-water impoundments potentially accessible to wildlife and drinking water sources were also sampled (see Figure 4.7). Ground water was sampled from wells located near operating areas and along potential transport pathways (see Figures 5.2 through 5.5 ). In addition to air and water surveillance, samples of soil, native vegetation, and wildlife were collected (see Figures 4.28 and 4.31). Radiation was measured to determine the effectiveness of effluent controls and ascertain any long-term build up of contaminants from past and current operations (Figures 4.35, 4.36, and 4.38). Selected onsite roads and rails were also surveyed (see Figure 4.39).

In the second or perimeter zone, air monitoring stations, radiation measurement locations and ground-water surveillance wells were located near or just inside the Site boundary. Both hazardous chemical and radiological contaminants are measured in ground-water samples. Agriculture is an important industry near the Site; therefore, milk, crops, soil, and native vegetation are monitored (see Figures $4 . \dot{\varepsilon} 3$ and 4.31) to detect any influence from Hanford on locally produced food and farm products. The Columbia River is included in the second zone. River water is monitored upstream of the Site at Priest 
Rapids Dam and at Richland, Washington, where it is used for public drinking water. Water pumped from the Columbia River for irrigation is also monitored.

Surveillance in the third zone, consisting of nearby and distant communities, includes air, soil, water supplies, vegetation, and food products sampling, and radiation measurements.

Table 3.2 summarizes the geographic distribution of scheduled sample types and measurement locations. Details of sampling locations, frequencies, media and analyses, and significant results of scheduled and special sampling are discussed in Section 4.0, "Environmental Monitoring Iníurmation." Most 1991 samples were ansiyzed and are reported. Some samples remained to be analyzed as the new analytical contractor finished the backlog of samples following termination of the prior analytical contract.

Surveillance is conducted under established quality assurance plans and written procedures. Sample scheduling, accountability, data storage, and data screening were managed and controlled by computerized systems. Laboratory analyses of samples for radioactivity and chemicals were conducted principally by International Technology Corporation, the Pacific Northwest, Laboratory, and the Hanford Environn "ualth Foundation, all in Richland, W ....ng .un. Selected river water quality and chemistry analyses, and temperature and flow measirrements were performed by the U.S. Geological Survey, Denver, Colorado.

Table 3.2. Environmertal Surveillance Sample Types and Measurement Locations, 1991

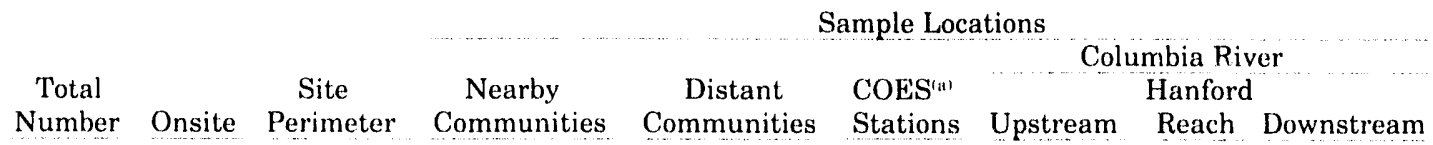

\begin{tabular}{|c|c|c|c|c|c|c|c|c|c|}
\hline Air & 50 & 23 & 13 & 8 & 3 & 3 & & & \\
\hline Ground Water & 528 & 528 & & & & & & & \\
\hline Springs & 3 & & & & & & & & 3 \\
\hline Columbia River & 4 & & & & & & 2 & 1 & 1 \\
\hline Irrigation Water & 1 & & 1 & & & & & & \\
\hline Drinking Water & 13 & 8 & $5^{(b)}$ & & & & & & \\
\hline \multicolumn{10}{|l|}{ Columbia River } \\
\hline Sediments & 6 & & & & & & 1 & 3 & 2 \\
\hline Ponds & 3 & 3 & & & & & & & \\
\hline Foodstuffs & 13 & & 6 & 5 & 2 & & & & \\
\hline Wildlife & 13 & 9 & 1 & & 3 & & & & \\
\hline \multicolumn{9}{|l|}{ Soil and } & \\
\hline Vegetation & 46 & 29 & 11 & 1 & 5 & & & & \\
\hline TLDs ${ }^{\mid \mathrm{C}^{\prime}}$ & 73 & 28 & $31^{\text {td }}$ & 8 & 3 & 3 & & & \\
\hline \multicolumn{9}{|l|}{ Waste Site } & \\
\hline Surveys & 75 & 75 & & & & & & & \\
\hline \multicolumn{9}{|l|}{ Railroad/Roadway } & \\
\hline Surveys & 17 & 16 & 1 & & & & & & \\
\hline Shoreline Surveys & 14 & & 14 & & & & & & \\
\hline Aerial Survey & 1 & & 1 & & & & & & \\
\hline
\end{tabular}

(a) Community-Operated Environmental Surveillance Stations.

(b) Includes four offsite water supplies.

(c) Thermoluminescent dosimeters.

(d) Includes locations in and along the Columbia River. 


\subsection{Environmental Studies and Programs}

\section{Wildlife Resources}

Wildlife populations inhabiting the Hanford Site are monitored to measure the status and condition of the populations and assess effects of Hanford operations. Particular attention is paid to species that are rare, threatened, or endangered nationally or statewide and those species that are of commercial, recreational, or aesthetic importance statewide or locally. These species include the bald eagle, chinook salmon, Canada goose, several species of hawk, Rocky Mountain elk, mule deer, white pelican, and other bird species.

Fluctuations in wildlife and plant species on the Hanford Site appear to be a result of natural ecological factors and management of the Columbia River system. The establishment and management of the Hanford Site has had a net positive effect on wildlife relative to probable alternative uses of the Site.

\section{Bald Eagle}

Bald eagles are listed by the U.S. Fish and Wildlife Service as endangered in most states and as threatened in the State of Washington. Historically, bald eagles have wintered along the Hanford Reach of the Columbia River. However, when monitoring began in the early 1960s, numbers were very low (Figure 3.2). Following the passage of the Endangered Species Act in 1973, the number of wintoring bald eagles increased. Possible reasons for the observed increase are the added protection of bald eagles at nesting locations off the Hanford Site and the nationwide elimination of DDT as an agricultural pesticide in 1972. On a local scale, changes in the number of eagles on the Hanford Site generally correspond to changes in the number of salmon carcasses, a major fall and winter food source for eagles (Figure 3.2). Most of the eagles using the Hanford Reach are concentrated in the section between the abandoned Hanford townsite and the 100-K Area.

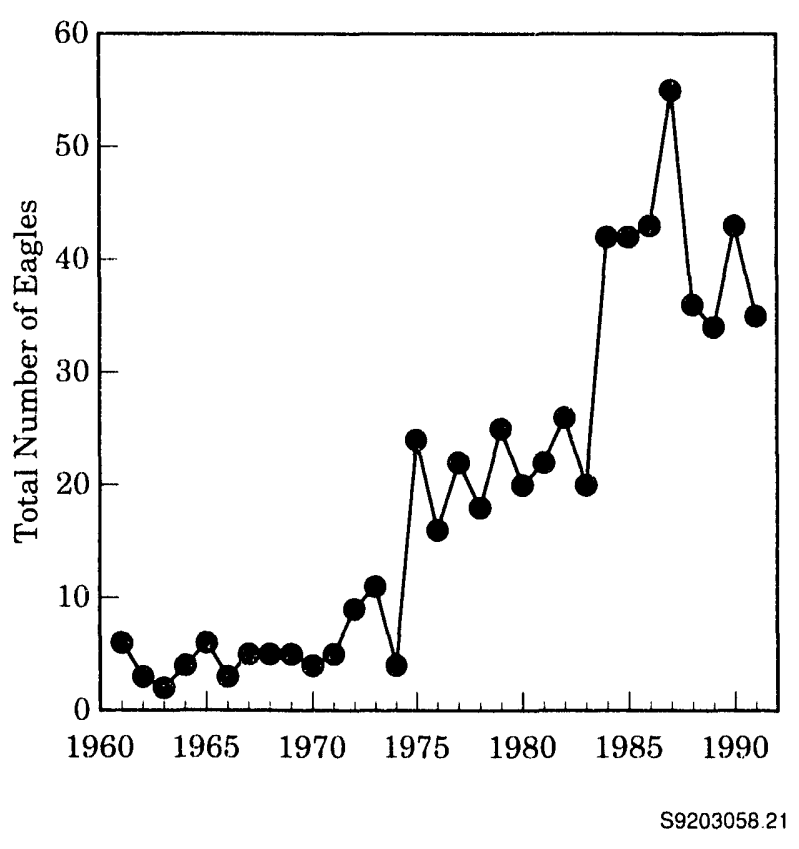

Figure 3.2. Bald Eagles Observed Along the Hanford Reach, Fall and Winter Months

The number of bald eagles wintering along the Hanford Reach varies each ycar in response to weather and food availability elsewhere in eastern Washington. The Hanford Reach is expected to continue providing wintering habitat, as long as the critical resources such as food, perches, and relative freedom from human activities are maintained.

\section{Chinook Salmon}

Chinook salmon are an important resource to the citizens of Washington. Salmon are caught commercially and for recreation. The commercial and recreational catch is carefully managed to sustain the resource. Today the most important natural spawning area in the mainstream Columbia ? iver for the fall chinook race is found in the free-flowing Hanford Reach. In the early years of the Hanford Site, there were few spawning nests (redds) in the Hanford Reach (Figure 3.3). 


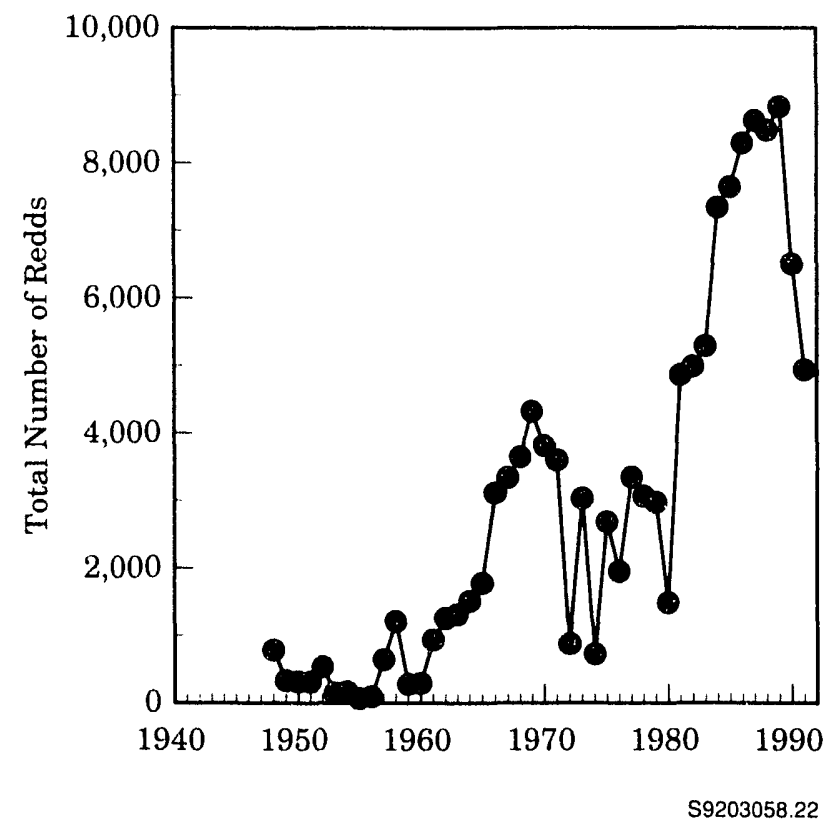

Figure 3.3. Chinook Salmon Spawning Redds in the Hanford Reach

In the years between 1943 and 1971, a number of dams were constructed on the Columbia River. The reservoirs created behind the dams eliminated most mainstem spawning areas and increased salmon spawning in the Hanford Reach. Fisheries management strategies aimed at maintaining spawning populations in the mainstem Columbia River have also contributed to the observed increases. In recent years, numbers of fall chinook salmon spawning in the Hanford Reach have declined consistent with reduced run sizes returning to the Columbia River. The number of salmon varies each year depending on hatching success, survival of downstream juveniles, and the size of the commercial and recreational catches. The Hanford Reach under existing management practices continues to provide valuable salmon spawning habitat.

\section{Canada Goose}

Nesting Canada geese are valuable recreational and aesthetic resources along the Snake and Columbia rivers in eastern Washington. Goose nesting surveys began in the 1950 s to monitor changes in response to reactor operations (Figure 3.4). The nesting population in the Hanford
Reach has recently surpassed the high levels observed during the early $1950 \mathrm{~s}$. The gradual decline observed in the late 1960s and early 1970 s is attributed to persistent coyote predation, mostly on the Columbia River islands upstream from the Hanford townsite. Since the 1970s, the center of the nesting population has shifted from upstream to downstream islands near Richland, which in recent years have been relatively free fror. coyote predation.

Canada goose populations are successful on the Hanford Reach because the islands are restricted from human uses during the nesting period and because shoreline habitats provide adequate food and cover for broods (Eberhardt et al. 1989).

\section{Hawks}

The undeveloped land of the semiarid areas of the Hanford Site provides nest sites and food for three species of migratory buteo hawks: Swainson's, red-tailed, and ferruginous. Under natural conditions, these hawks nest in trees, on cliffs, or on the ground. Powerline towers and poles also can serve as nest sites. The ferruginous hawk is a

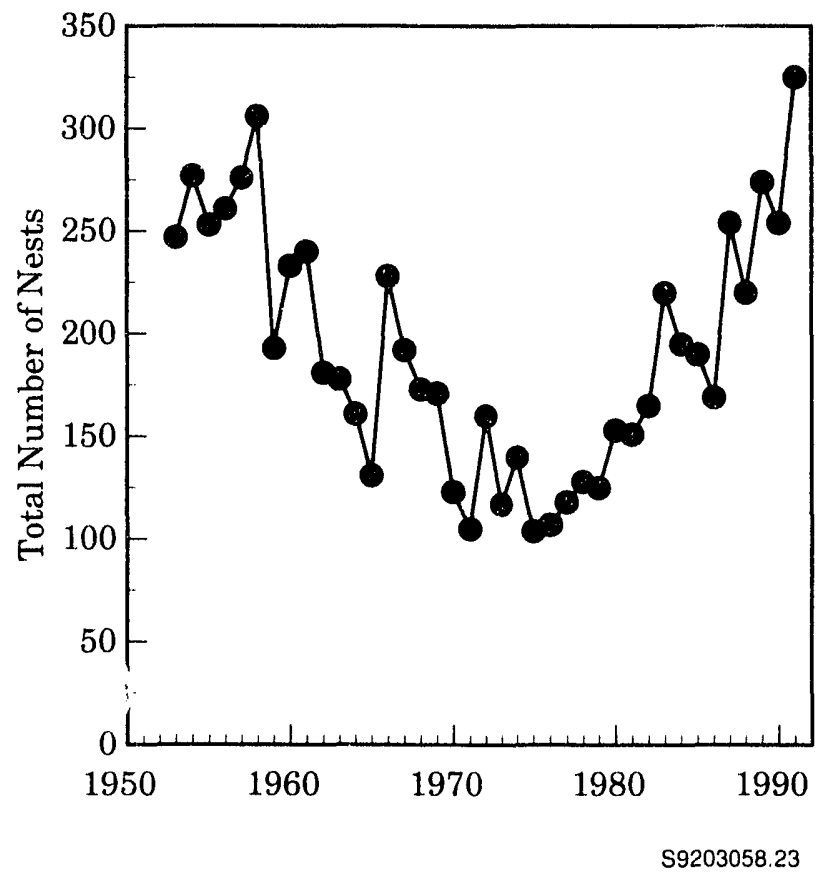

Figure 3.4. Canada Goose Nests on Islands in the Hanford Reach 
U.S. Fish and Wildlife Service candidate species for listing as threatened and/or endangered. In recent years, the number of ferruginous hawks nesting on the Hanford Site has increased (Figure 3.5). Hawks raised on the Hanford Site die during offsite migration and while wintering on ranges far from the Hanford Site. The Site continues to provide hawk nesting habitats administratively protected from human intrusions, as well as providing suitable foraging areas. The sharp declines in red-tailed and Swainson's hawk nests in the late $1980 \mathrm{~s}$ are probably not a result of Hanford Site activities because the number of nests for the very sensitive ferruginous hawk did not decline (Figure 3.5). Decreases in nesting red-tailed and Swainson's hawks were probably related to impacts that occurred during their migration and/or while they were on their wintering grounds.

\section{Rocky Mountain Elk}

Rocky Mountain elk did not inhabit the Hanford Site when it was established in 1943. Elk appeared on the Arid Lands Ecology (ALE) Reserve in the winter of 1972. A few animals stayed and reproduced. The greatest number of elk recorded was

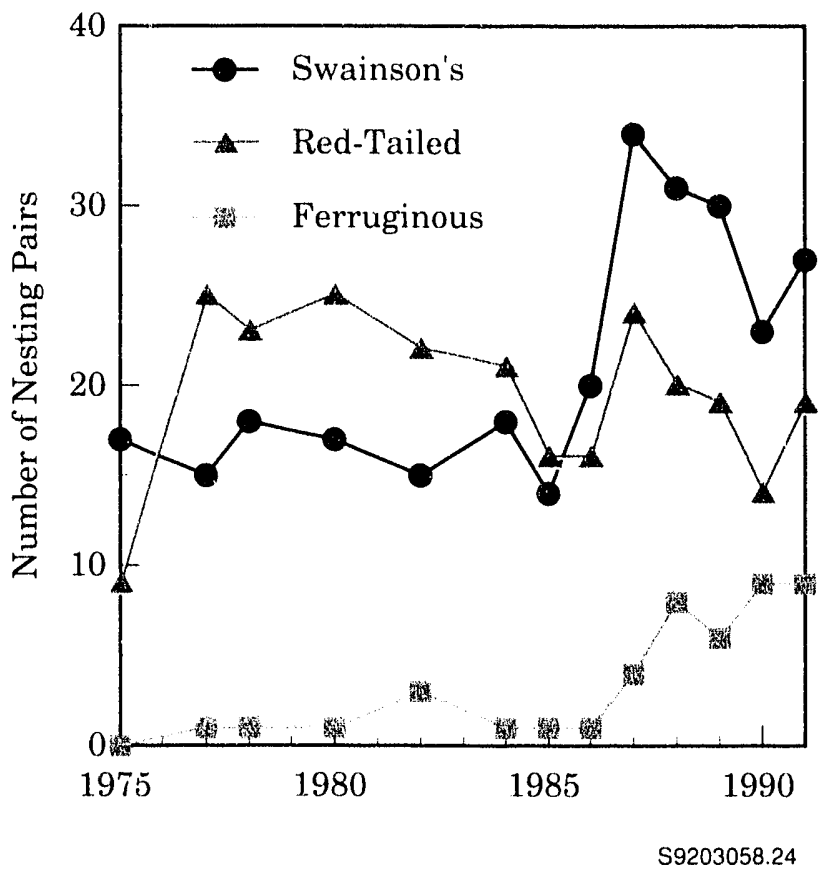

Figure 3.5. Red-Tailed, Swainson's, and Ferruginous Hawks on the Hanford Site
133, before the 1991 offsite hunting season (Figure 3.6 ). With a regulated hunting season on private lands adjoining the ALE Reserve, the elk population appeared to be holding at less than 100 animals until the spring of 1990 . However, comparatively few elk were killed during the 1990 and 1991 offsite hunting seasons, and the herd has expanded to its current population of 119 animals.

Elk are successful on the ALE Reserve because of 1) available forage without competition from domestic livestock; 2) unrestricted access to drinking water at springs located on the ALE Reserve; 3 ) relatively mild winters; 4) ability to accommodate extreme summer temperatures, even in the absence of shade; and 5) absence of hunting on the Site.

\section{Mule Deer}

Mule deer are a common resident of the Hanford Site and are important because of the recreational (offsite hunting) and aesthetic values they provide. Because mule deer have been protected from hunting on the Hanford Site for approximately 50 years, the herd has developed a number of

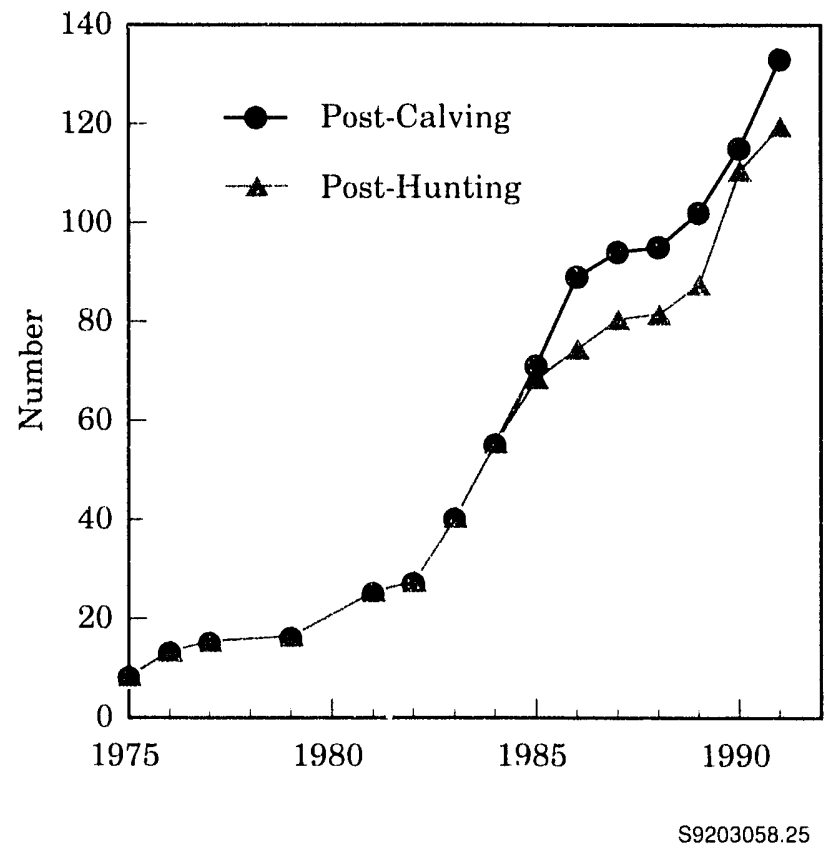

Figure 3.6. Elk on the Hanford Site Counted by Aerial Surveillance During the Post-Calving Period: August Through September; and the Post-Hunting Period: December Through January 
unique population characteristics that are in contrast to most other herds in the semiarid region of the Northwest. These characteristics include a large proportion of old-age animals and large-antlered males. This herd provides a unique opportunity for comparison to other more heavily harvested herds in this region.

Because of the unique nature of the herd and high degree of public interest, a study was initiated in 1990 to 1 ) obtain estimates of the number of deer on the Hanford Site, 2) determine the extent and frequency of offsite movements by Hanford Site deer, and 3) evaluate the level of ${ }^{90} \mathrm{Sr}$ in deer from the 100 Areas (see Section 4.5, "Wildlife Surveillance").

Thirty-six mule deer were captured and fitted with ear tags and/or radio collars in 1990 between the Hanford townsite and the N Reactor. Frequent offsite movements were made by these deer during the year, and one animal was killed by a hunter during one of these movements. In general, the mule deer population on the Hanford Site appears to be healthy. The numbers of deer on the Hanford Site do not appear to have changed dramatically over the last few decades, and many very old ( $>5$ years) animals are present.

\section{White Pelican}

Historically, the white pelican has visited the Hanford Reach of the Columbia River in small numbers each winter. This large, fish-eating bird has only recently been listed by the Washington State Department of Wildlife as endangered. Therefore, they have not been monitored as extensively as bald eagles. Many of the features of the Hanford Reach that make it attractive to wintering bald eagles also make it attractive to white pelicans.

\section{Shrub-steppe Birds of Special Concern}

The Washington Department of Wildlife has listed several shrub-steppe birds as species of special concern because their populations have been diminished by massive losses of native shrub-steppe habitat as a result of expanding agriculture and urbanization. The Hanford Site contains large contiguous areas of relatively undisturbed shrub-steppe habitat that provides nesting habitat for these birds. To determine the spatial distribution and relative abundance of species of special concern (sage sparrows, sage thrashers, loggerhead shrikes, and long-billed curlews), two transects have been monitored on the Hanford Site over the past 4 years using U.S. Fish and Wildlife Service procedures. These transects cross a variety of habitats including relatively undisturbed shrub-steppe, recently burned shrub-steppe, and agricultural fields that were abandoned in the early 1940s and are now dominated by cheatgrass.

The only shrub-steppe species of special concern that nested in the abandoned fields was the longbilled curlew. The sage thrasher was seldom seen along both transect routes, which is in agreement with other studies of shrub-steppe birds that indicate that sage thrashers are not abundant in lowelevation shrub-steppe habitats. Sage sparrows were most common in places that supported stands of sagebrush which had escaped burning by recent wildfires. Loggerhead shrikes were less plentiful than sage sparrows and occurred in places that supported either sagebrush or bitterbrush shrubs.

The lower elevations of the Hanford Site provide habitat suitable for viable populations of longbilled curlews, sage sparrows, and loggerhead shrikes but not sage thrashers. The long-billed curlew nests on the ground and is not dependent on desert shrubs for nest placement. However, sage sparrows and loggerhead shrikes place their nests in the branches of desert shrubs; thus, the loss of sagebrush and bitterbrush shrubs through burning is detrimental to these species.

\section{Special Plants and Invertebrate Animals}

The Washington Natural Heritage Program (1990) has identified three species of vascular plants that could be jeopardized by construction and/or cleanup activities performed on the Hanford Site. These species are Columbia yellowcress, Columbia milk vetch, and Hoover's desert parsley. Columbia yellowcress is listed as an 
endangered taxon in Washington State. It occurs along the shoreline of the Columbia River on the Hanford Site. Columbia milk vetch is listed as a threatened taxon and occurs on dry land of the Hanford Site upstream from the Vernita Bridge. Hoover's desert parsley, also listed as a threatened taxon, occurs on talus slopes of the Hanford Site in the same general area as Columbia milk vetch.

The U.S. Fish and Wildlife Service lists the Columbia pebblesnail and shortface limpet as candidate species for protection as threatened or endangered species. Both inhabit the Hanford Reach of the Columbia River and appear to have been widespread historically in the mainstem Colurnbia River Basin before the installation of dams. Both species are now apparently reduced within the Columbia Basin to isolated populations that are separated by large areas of unsuitable habitat.

Only two sizable populations of Columbia pebblesnail remain: those in the Methow and Okanogan rivers of north central Washington. Neither of these larger populations are protected. Smaller populations survive in the Hanford Reach and elsewhere. Eecause of the lack of habitat protection and the substantial reduction in the species' historical range, the Columbia pebblesnail will probably be listed federally as endangered.

Currently, large populations of shortface limpets persist in four streams: the Deschutes River, Oregon; the Hanford Reach of the Columbia River, Washington; Hells Canyon, Idaho and Oregon; and the Okanogan River, Washington. Smaller populations exist elsewhere. While substantial range reduction has occurred in this species, and the large populations are not protected, the shortface limpet will probably be listed federally as threatened.

\section{Cultural Resources}

The Hanford Cultural Resources Laboratory (HCRL) was established by RL in 1987 as part of the Pacific Northwest Laboratory. The HCRL provides support for managing the archaeological, historical, and cultural resources of the Hanford Site in a manner consistent with the National
Historic Preservation Act, the Archaeological Resources Protection Act, and the American Indian Religious Freedom Act.

Pursuant to Section 106 of National Historic Preservation Act, cultural resource reviews are conducted before each proposed ground-disturbing or building alteration/demolition project on the Hanford Site. During the FY 1991, Hanford contractors requested 102 such reviews, 22 of which required archaeological surveys. The surveys covered a total of 302 ha ( 746 acres) and resulted in discovery of 18 prehistoric archaeological sites and four historic archaeological sites. Projects were relocated to avoid any potential impact to two significant sites near the 300 Area.

The archaeological site monitoring program, devised to comply with Section 110 of the National Historic Preservation Act, is designed to determine the current condition of cultural resources, and thus to determine whether RL's cultural resource management and protection policies are effective. Results of monitoring are used in planning cultural resource site management and protection. Following procedures established in the Hanford Cultural Resources Management Plan (Chatters 1989), staff monitored the condition of 41 sites. The conclusions from this year's monitoring are very similar to those of previous years. Natural erosive processes are the most significant factors impacting the majority of sites and could be reduced by revegetation. Sites outside the security fence continue to receive the heaviest impacts from looters and vandalism. A more recently recognized impact on sites inside and outside the security perimeter is wind erosion enhanced by off-road vehicle use.

Two cultural properties were evaluated for their eligibility to the National Register of Historic Places. Test excavations were conducted at a hunting blind and kill site in the Gable Butte vicinity dating within the last 2000 years. Results of this effort are being used to support the nomination of the Gable Mountain/Gable Butte Archdeological District to the National Register. Also, a Request for Determination of Eligibility was prepared for the White Bluffs Road, an 
ancient Native American trail and freight road important to the settlement of central

Washington. The Washington State Historic Preservation Officer determined that the road was eligible for the National Register of Historic Places.

Activities for the cultural resources education program included presenting lectures to groups of all ages and developing a series of displays to be used in Hanford Site facilities for worker education. Lectures were presented to groups ranging from primary school rockhounds to civic groups, and two local television spots featured the HCRL or its activities.

The archaeological survey of areas of the Hanford Site that are not targeted for development is a requirement of Section 110 of the National Historic Preservation Act and of 1988 amendments to Archaeological Resources Protection Act. The Hanford Cultural Resources Management Plan specifies that a $10 \%$ stratified random sample of Hanford Site lands will be surveyed to refine an existing model of archaeological site distributions. Twenty sample plots covering $3.2 \mathrm{~km}^{2}\left(1.24 \mathrm{mi}^{2}\right)$ were surveyed in FY 1991. Fourteen archaeological sites and ten isolated artifacts were recorded.

Research activities were conducted when possible as part of compliance work. These included collection and analysis of data from the 2,100-yearold Tsulim bison kill site. Studies of the landscape and tooth and shell fragments from the site revealed that during December or January, hunters drove a bison herd into the apex of a parabolic dune, where they killed and butchered eight animals (Chatters et al. 1992). Research activities also included modeling of fishing site distributions, which showed that salmon behavior and channel shape could be used to accurately predict the location of fishing sites on Hanford (Gard 1992).

\section{Meteorology and Climatology of the Hanford Area}

Meteorological measurements are conducted to support 1) Hanford Site emergency preparedness and response, 2 ) atmospheric dispersion calculations, and 3) Hanford Site operations. Support is provided through weather forecastirg and the maintenance and distribution of climatological data. Forecasting is provided to help manage weather-dependent operations. Climatological data are provided to help plan weather-dependent activities and are used as a resource to assess the environmental effects of operations.

The weather in 1991 was warmer and slightly wetter than normal. In fact, 1991 was the sixth consecutive year with an above-normal annual average temperature. The average temperature for 1991 was $12.6^{\circ} \mathrm{C}, 0.7^{\circ} \mathrm{C}$ above normal $\left(11.9^{\circ} \mathrm{C}\right)$. Seven months during 1991 were warmer than normal, each averaging at least $0.6^{\circ} \mathrm{C}$ above normal. Four months were colder than normal, each averaging at least $0.5^{\circ} \mathrm{C}$ below normal. February (a record warm month) and December had the largest positive departures, both $3.6^{\circ} \mathrm{C}$ above normal; while June, at $2.3^{\circ} \mathrm{C}$ below normal, had the largest negative departure.

Precipitation for 1991 totaled $17.1 \mathrm{~cm}$ (6.75 in.), $108 \%$ of normal $[15.9 \mathrm{~cm}$ (6.3 in.)], with only $14.5 \mathrm{~cm}(5.7 \mathrm{in}$.) of snow [compared to an annual normal of $35.1 \mathrm{~cm}$ (13.8 in.)]. Because 1991 was warmer than normal, with above normal precipitation, and no significant cold outbreaks, little adverse impact to either flora or fauna would be anticipated.

During 1991, meteorological conditions effecting atmospheric diffusion were more typical of climatological normals. Average wind speeds during the months of January, February, November, and December (typically the lowest of the year) were near or below climatological normals, whereas during 1990 they were considerably higher than normal for these months, and in fact, were the highest speeds of the year. This decreased the incidence of fog and stagnant air conditions during 1990 to near record lows, and allowed for much better dispersion than normal.

The average wind speed for 1991 was $11.9 \mathrm{~km} / \mathrm{h}$, $(7.4 \mathrm{mi} / \mathrm{h}), 0.5 \mathrm{~km} / \mathrm{h}(0.3 \mathrm{mi} / \mathrm{h})$ below normal, and the peak gust for the year was $98 \mathrm{~km} / \mathrm{h}(61 \mathrm{mi} / \mathrm{h})$ recorded on March 3. Figure 3.7 shows the 1991 wind ros as (diagrams showing direction and frequencies of wind) for meteorological monitoring stations located on and around the Hanford Site. 


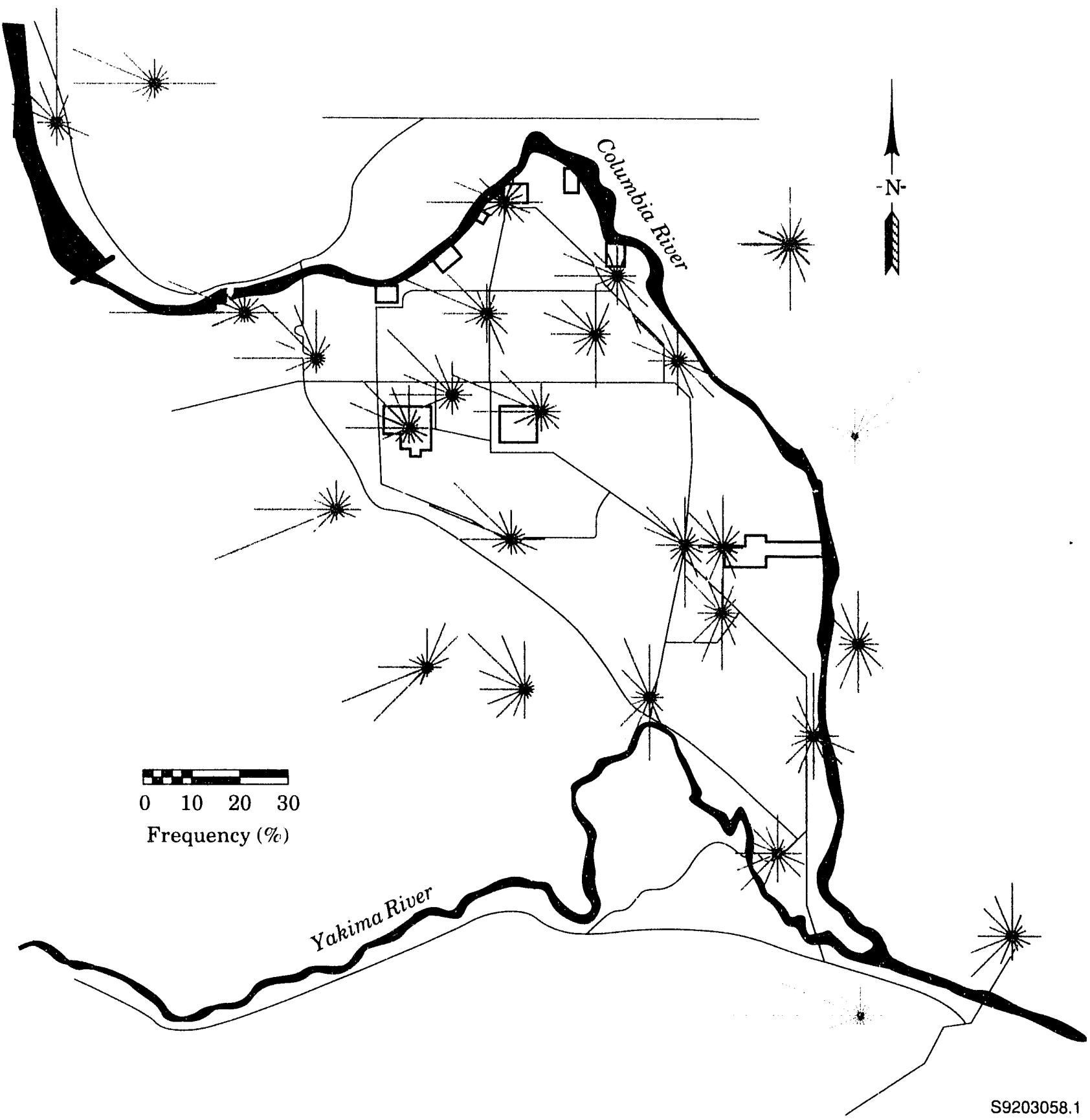

Figure 3.7. Hanford Meteorological Monitoring Network Wind Roses for 1991. Individual lines indicate direction from which wind blows. Length of line is proportional to frequency of occurrence from a particular direction. 
Table 3.3 provides monthly climatological data from the Hanford Meteorology Station for 1991.

\section{Hanford Environmental Dose Reconstruction Project}

In 1987. after receiving a recommendation by the Hanford Health Effects Review Panel the previous year, DOE directed PNL to begin the Hanford Environmental Dose Reconstruction (HEDR) Project. (The Hanford Health Effects Review Panel had been formed to consider the potential health implications of historic Hanford Site releases of radioactive materials.) The objective of the HEDR Project is to develop estimates of the radiation doses that people may have received from Hanford operations. An independent Technical Steering Panel was selected by the Vice Presidents for Research at major universities of Washington and Oregon to direct the work of the project. The 18-member panel consists of experts in various technical fields relevant to HEDR Project work and representatives from the states of Washington, Oregon, and Idaho; Native American tribes; and the public. In 1991, responsibility for managing the HEDR Project transferred to the U.S. Department of Health and Human Services through the Center for Disease Control. The Technical Steering Panel will continue its role as the technical director of the work.

In 1990 , scientists completed the first phase of the HEDR Project, which was to determine whether enough information of sufficient quality existed to develop and demonstrate a dose-estimating method. The product of this phase was a set of more than 20 documents that describe:

- the preliminary information found or reconstructed

- preliminary dose-estimating models and computer codes

- preliminary estimates of dose and their uncertainties for representative individuals who may have lived near the Hanford Site during early years of operations.
Technical work for 1991 consisted of evaluating data from the first phase, restructuring models to enhance their capabilities, developing detiiled estimates of releases of radioactive materials, and identifying, acquiring, and evaluating additional information needed to produce estimates. This information is being developed for the 19 counties highlighted in Figure 3.8, for major exposure pathways, and for the full history of the Hanford Site-1944 through 1991.

In addition to work being performed at PNL, eight northwest Native American tribes are conducting research to support dose estimates for their tribal members.

Future plans include the use of more complete dose models to make more refined estimates of doses to individuals sharing a common set of characteristics in each of the 19 counties. This work is scheduled to be completed by September 1993 .

\section{Community-Operated Environmental Surveillance Stations}

A community-operated environmental surveillance program was initiated in 1990 to increase the public's involvement in and awareness of Hanford's surveillance program. It is hoped that this program will increase public understanding of surveillance results, provide a mechanism for the public to raise surveillance issues, and facilitate public education.

Three community-operated environmental surveillance stations began operation in March 1991. The stations are located downwind of the Hanford Site at Basin City Elementary School in Basin City, Edwin Markham Elementary School in north Franklin County, and Leslie Groves Park in Richland (see Figure 4.1). Local residents have access to the monitoring stations to observe the instruments and results.

Schools use the stations in their science cu:ricula. Local teachers manage the stations and have been trained to operate them. The station 


\begin{tabular}{|c|c|c|c|c|c|c|c|c|c|c|c|c|c|c|}
\hline \multirow{5}{*}{ 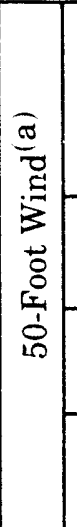 } & \multirow{2}{*}{ 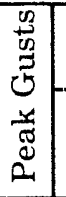 } & әาย С & $\stackrel{m}{\stackrel{+}{\sim}}$ & $\infty$ & $\infty$ & $\stackrel{\rho}{\circ}$ & ని & $\vec{m}$ & $\stackrel{\infty}{\rightarrow}$ & 勇 & $\stackrel{\varphi}{-1}$ & $\begin{array}{c}+ \\
\stackrel{N}{N}\end{array}$ & $\stackrel{\sim}{\sim}$ & $\sum^{\bar{E}} \infty$ \\
\hline & & นо!วววג!๔ & 称完 & 录 & $\infty$ & z & 3 & 之 & $\frac{3}{02}$ & $\sum_{3}^{k}$ & 3 & Z & 3 & 莎 \\
\hline & & $\begin{array}{l}\text { (y/uy) } \\
\text { pəəds }\end{array}$ & $8 E$ & $\stackrel{\infty}{\infty}$ & $\infty$ & $\stackrel{N}{i}$ & $\stackrel{6}{1}$ & \pm & $\mathscr{8}$ & 8 & $\begin{array}{l}\infty \\
\infty\end{array}$ & N & \& & $\stackrel{\infty}{\sigma}$ \\
\hline & & ә.nһxedəQ & 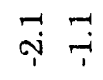 & $\underset{1}{0}$ & $\stackrel{0}{+}$ & $\stackrel{m}{\varphi}$ & $\stackrel{+}{-}$ & ب़ & $\stackrel{m}{0}$ & ọ & $\stackrel{m}{0}$ & $\stackrel{0}{0}$ & $\stackrel{N}{0}$ & بִ \\
\hline & & 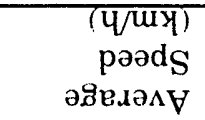 & $\begin{array}{ll}4 & 20 \\
\infty & 0\end{array}$ & $\underset{\stackrel{H}{H}}{\stackrel{H}{*}}$ & ف․ & $\stackrel{n}{\unlhd}$ & $\stackrel{4}{\mathscr{-}}$ & $\ddot{\theta}$ & $\stackrel{+}{\stackrel{H}{H}}$ & $\stackrel{\stackrel{H}{二}}{=}$ & $\stackrel{\infty}{\circ}$ & $\stackrel{\varphi}{\dot{\theta}}$ & 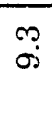 & $\stackrel{\text { g] }}{\Rightarrow}$ \\
\hline$\stackrel{3}{.0}$ & $=$ & ә.มกน.มอdә & 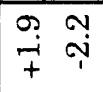 & $\begin{array}{l}\infty \\
\stackrel{\infty}{+} \\
+\end{array}$ & $\ddot{p}$ & $\stackrel{\dddot{p}}{+}$ & $\stackrel{m}{q}$ & ri & $\dot{0}$ & $\overrightarrow{0}$ & $\stackrel{4}{r}$ & $\stackrel{\infty}{+\infty}+$ & $\stackrel{\infty}{+}$ & $\begin{array}{l}0 \\
\dot{0}\end{array}$ \\
\hline 离 & & әภัв.әА & $\begin{array}{cc}\infty & -1 \\
\infty & \infty \\
⿱ & 0\end{array}$ & ro & $\stackrel{\sim}{\ddot{q}}$ & $\begin{array}{l}\infty \\
10 \\
i\end{array}$ & $\stackrel{+\infty}{+\infty}$ & m. & 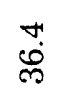 & $\begin{array}{l}0 \\
\dot{0}\end{array}$ & $\stackrel{\infty}{\stackrel{\sim}{+}}$ & $\begin{array}{l}N \\
\infty \\
1\end{array}$ & 落 & $\underset$\[ \]${\mathscr{1}}$ \\
\hline$\Xi$ & $\frac{\bar{\pi}}{3}$ & \text {$әมnวนеdә }$ & \text {$هִ }$ & \text {$بُ }$ & $\overline{\underline{\sigma}}$ & $\Theta_{1}$ & 1 & \text {$' }$ & \text {$. }$ & \text {$' }$ & $\begin{array}{l}\infty \\
i j \\
+\end{array}$ & $\begin{array}{l}0 \\
\dot{r}\end{array}$ & $\begin{array}{l}\stackrel{\circ}{9} \\
\stackrel{1}{7}\end{array}$ & $\stackrel{0}{\stackrel{N}{*}}$ \\
\hline$.$ & \text {$in }$ & {$[870 \mathrm{~L}$} & $\stackrel{s}{\sigma} 0$ & $\ddot{0}$ & 0 & 0 & 0 & 0 & 0 & 0 & $\stackrel{\circ}{\circ}$ & $E$ & \text {$- }$ & \text {$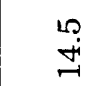 }$ \\
\hline$\overline{\bar{y}}$ & & \text {$อ.ınน.ภeda }$ & \text {$זי- }$ & $\stackrel{0}{+}$ & \text {$ஜே }$ & $\ddot{1}$ & $\stackrel{N}{i}$ & $\stackrel{m}{0}$ & $\stackrel{10}{9}$ & $\stackrel{\infty}{\dot{1}}$ & $\stackrel{+}{+}$ & $\stackrel{+r}{+}$ & $\stackrel{0}{1}$ & $\stackrel{\vartheta}{+}$ \\
\hline & & {$[870 \mathrm{~L}$} & $\begin{array}{ll}\infty & 10 \\
0 & 0 \\
0 & 0\end{array}$ & $\begin{array}{l}\infty \\
\dot{v}\end{array}$ & $\stackrel{-1}{-1}$ & $\stackrel{N}{M}$ & \text {$is }$ & $\dot{0}$ & $\ddot{0}$ & 0 & $\stackrel{4}{-i}$ & $\ddot{n}$ & $\stackrel{\circ}{\circ}$ & \text {$I }$ \\
\hline & & \text {$ә)еव }$ & \text {$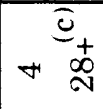 }$ & $o$ & $\stackrel{+}{\infty}$ & \text {$点 }$ & \text {$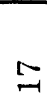 }$ & $\stackrel{+}{\circ}$ & $\stackrel{0}{0}$ & \text {$ลิ }$ & \text {$요 }$ & \text {$†े }$ & $\stackrel{+}{\stackrel{9}{-1}}$ & $\underset{\widetilde{\sigma}}{\longmapsto}+$ \\
\hline & \text {$悉 }$ & \text {$7samoT }$ & $\begin{array}{ll}0 & m \\
10 & 0 \\
1 & 0\end{array}$ & $\begin{array}{l}0 \\
10\end{array}$ & $\begin{array}{l}\varphi \\
\because\end{array}$ & $m$ & 6 & \text {$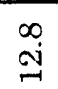 }$ & $\infty$ & $\begin{array}{l}0 \\
\text { Li }\end{array}$ & \text {$م) }$ & 0 & \text {$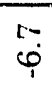 }$ & $\begin{array}{l}0 \\
0 \\
\end{array}$ \\
\hline & \text {$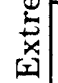 }$ & \text {$әาеव }$ & $\stackrel{9}{-}$ & $\vec{n}$ & $\vec{N}$ & $\bar{N}$ & \text {$엄 }$ & $m$ & $\frac{t}{N}$ & $t$ & $\mapsto$ & $\stackrel{\cong}{\sim}$ & \text {$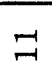 }$ & 5 \\
\hline $0_{0}^{0}$ & & \text {$7รәบภ! }$ & $\begin{array}{ll}0 & 0 \\
10 & \infty \\
-1 & \infty\end{array}$ & $\stackrel{0}{\circ}$ & \text {$交 }$ & $\stackrel{\infty}{\infty}$ & \text {$के }$ & $\stackrel{6}{\mathscr{q}}$ & \text {$मேं }$ & $\underset{0}{0}$ & $\stackrel{-1}{\infty}$ & $\stackrel{\infty}{\infty}$ & $\stackrel{0}{10}$ & $\stackrel{0}{\dot{0}}$ \\
\hline \text {$कृ }$ & & \text {$(q) }$ & $\begin{array}{ll}\forall & 0 \\
i & \stackrel{p}{+}\end{array}$ & $\stackrel{\infty}{0}$ & \text {$t) }$ & $\stackrel{10}{9}$ & $\stackrel{m}{i}$ & $\stackrel{0}{+}$ & $\begin{array}{l}a j \\
+\end{array}$ & $\begin{array}{r}y \\
i j \\
+\end{array}$ & 0 & $\stackrel{0}{0}$ & $\stackrel{0}{90}+$ & $\stackrel{1}{+}$ \\
\hline$E^{\overline{0}}$ & $\mathbb{D}_{00}^{2}$ & \text {$КчาUоW }$ & $\begin{array}{ll}\infty & 0 \\
-1 & 0 \\
& 0\end{array}$ & $\ddot{0}$ & $\stackrel{\vartheta}{\mathscr{v}}$ & $\stackrel{\infty}{10}$ & $\stackrel{-}{\infty}$ & \text { } & \text {$ન્ }$ & $\stackrel{9}{\subseteq}$ & $\stackrel{0}{\stackrel{-}{-1}}$ & \text {$טִ }$ & \text {$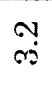 }$ & $\stackrel{0}{\sim}$ \\
\hline & \text {$焉 }$ & $\begin{array}{r}\text { unum!u!W } \\
\text { S!!e }_{\text {I! }}\end{array}$ & $\begin{array}{ll}m & 0 \\
\dot{\varphi} & -\end{array}$ & $\stackrel{4}{0}$ & \text {$웅 }$ & $\begin{array}{l}\infty \\
\infty\end{array}$ & $\stackrel{20}{ت}$ & $\stackrel{N}{N}$ & $\underset{\sim}{\infty}$ & $\stackrel{\mathscr{P}}{\stackrel{\infty}{-1}}$ & $\stackrel{n}{*}$ & $\stackrel{10}{10}$ & $\begin{array}{l}20 \\
0 \\
0\end{array}$ & \text {$c. }$ \\
\hline & & $\begin{array}{r}\text { unumexew } \\
\kappa_{\text {l!e }} \text { (I }\end{array}$ & $\begin{array}{ll}0 & \infty \\
\sim & \stackrel{\nu}{\sim}\end{array}$ & $\ddot{n}$ & $\stackrel{10}{9}$ & \text {$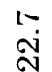 }$ & $\stackrel{\infty}{\stackrel{10}{N}}$ & \text {$के }$ & $\stackrel{m}{m}$ & \text {$के }$ & $\begin{array}{l}0 \\
\infty \\
\infty\end{array}$ & $\infty$ & $\stackrel{9}{0}$ & $\ddot{\sigma}$ \\
\hline & & \text {$4าuoW }$ & $\checkmark x$ & $\Sigma$ & 4 & $\sum$ & \text {$T }$ & \text {$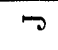 }$ & $\varangle$ & $\Omega$ & 0 & $Z$ & \text {$A }$ & $E$ \\
\hline
\end{tabular}

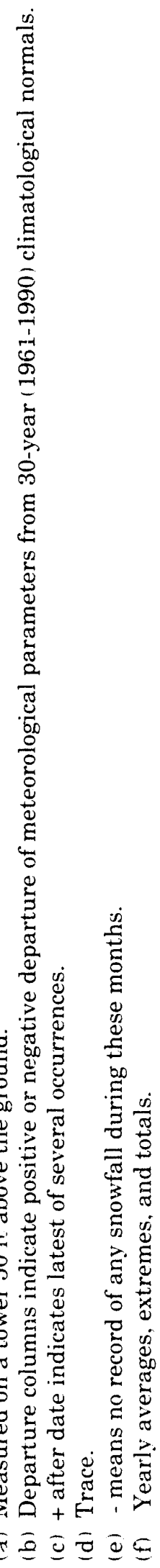




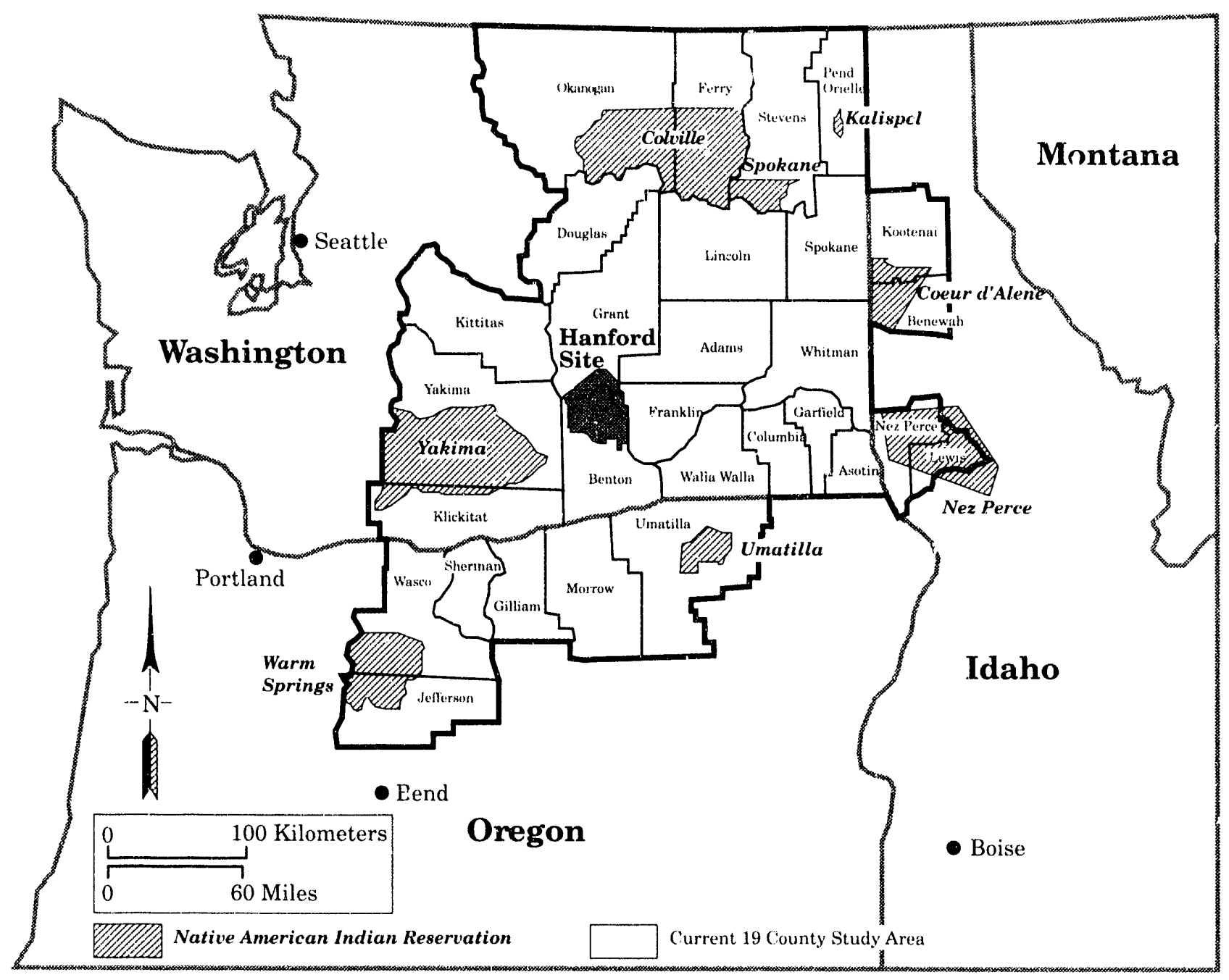

$\$ 9203058.122$

Figure 3.8. Counties and Native American Tribes Considered in Estimating Doses from Past Hanford Operations in the Hanford Environmental Dose Reconstruction Project

managers collect samples and submit them for laboratory analysis. Staff from PNL work with the station managers to maintain the equipment and coordinate sampling and analytical procedures with Hanford Site environmental surveillance operations.

Results from these stations are discussed in Sections 4.2, "Air Surveillance," and 4.7, "External Radiation Surveillance."

\section{Other Environmental Activities}

Other significant environmental activities during 1991 included continuation of a Hanford Site land use planning initiative, the continuation of a National Park Service study to consider environmental protection alternatives for the Hanford 
Rea:h, and environmental reviews under the National Environmental Policy Act. Each of these activities is summarized in Section 2.0, "Environmental Compliance Summary."

An education outreach program was established with the Yakima Indian Nation in 1991. This program provided an opportunity for a student to study Columbia River water quality, fish health, and environmental monitoring activities conducted at Hanford. As part of the work, a "hot line" was set up to receive reports on and collect fish with diseases or deformities. Three fish were collected in the summer and taken to the U.S. Fish and Wildlife Service for evaluation. 


\section{Environmental \\ Monitoring Information}




\subsection{Environmental Monitoring Information}

Environmental monitoring of the Hanford Site consists of effluent monitoring and environmental surveillance. Section 3.2 described the Site effluent monitoring and environmental surveillance programs. Section 4.0 describes the results of these monitoring and surface surveillance programs for 1991 and includes an assessment of potential radiation doses from all pathways. Subsurface, or ground-water, surveillance is discussed in Section 5.0. Quality assurance and control for monitoring programs are discussed in Section 6.0.

In many places, the uncertainty of a result is reported in the units of the measurement or as a percentage. When attempting to measure extremely small quantities, uncertainties become large. Statistically, there is a high probability
(95\%) that the actual result is within the uncertainty range. When the uncertainty is equal to $(100 \%)$ or larger than the result, the actual value may be zero. The Helpful Information section at the beginning of this document is provided for the reader desiring further explanation of the notation, units, and type of information being reported.

The environmental surveillance data presented in the following sections are summaries prepared to describe the range of conditions observed during the year in different locations. Detailed results by specific sampling location are contained in a data volume, Hanford Site Environmental Data 1991--Surface and Columbia River (Bisping 1992). 


\subsection{Effluent Monitoring}

Radioactive and nonradioactive effluent liquids, gases, and solids are monitored when released from or disposed of at the Hanford Site. Facility operators monitor effluents mainly through sampling and analyzing. The effluent data gathered from monitoring activities are evaluated to determine the degree of compliance with applicable federal, state, and local regulations and permits. Major facilities have specific environmental monitoring plans, which are part of the comprehensive Site environmental monitoring plan required by DOE (DOE 1991b). The effluent data are evaluated to assess the effectiveness of treatment and control systems and practices.

\section{Air Emissions}

Air emission discharge points are located in the 100, 200, 300, 400, 600, and 1100 Areas. The sources for these emissions are summarized below:

- In the 100 Areas, emissions originate from the $\mathrm{N}$ Reactor, now in retired status, and two irradiated-fuel storage basins and a radiochemistry laboratory in the $100-\mathrm{K}$ Area. Active radionuclide emission points decreased from seven to five in 1991. The 184-N powerhouse, the only recent source of nonradioactive emissions, remained shutdown after ceasing operations in March 1990.

- The 200 Areas contain facilities for nuclearfuel chemical separations, processing, waste handling and disposal, and steam generation using coal. Primary sources of radionuclide emissions are the Plutonium Uranium Extraction (PUREX) Plant, Uranium-Oxide $\left(\mathrm{UO}_{3}\right)$ Plant, Plutonium Finishing Plant (PFP), T Plant, 222-S Analytical Laboratory, tank farms for waste storage, underground storage tanks, waste evaporators, and a laundry facility. Nonradioactive pollutants may be emitted from the PUREX Plant, UO, Plant, PFP, and the powerhousés. In 1991, 71 radionuclide and 4 nonradioactive emission points were active in the 200 Areas.
- The 300 Area primarily contains laboratories, research facilities, and a steam plant. Radioactive emissions arise from research and development activities. Nonradioactive emissions originate from the steam plant. During 1991 there were 39 radionuclide and 3 nonradioactive airborne emission sources in the 300 Area. The N Reactor Fuel Fabrications Facility, once a source of radioactive emissions, has been shutdown and had no airborne emissions in 1991.

- The 400 Area has the Fast Flux Test Facility (FFTF), the Maintenance and Storage Facility (MASF), and the Fuels and Materials Examination Facility. Airborne emissions consist of radioactive particulates and gases from operations and support activities at FFTF and MASF. Four additional radionuclide air emissions sources are in the 400 Area, three at FFTF and one at MASF. There are no nonradioactive air emission sources.

- The 600 Area encompasses all the areas of the Hanford Site not assigned to the 100, 200, 300, 400 , and 1100 Areas. Two radioactive air emission discharges are in the 600 Area. There are no nonradioactive air emission sources.

- The 1100 Area contains warehouses, vehicle maintenance shops, excess equipment and materials storage, and office buildings. The 1100 Area emissions are generated from heating plants. The two oil-fired boilers, however, did not operate during 1991.

Radioactive air emissions from facilities at the Hanford Site may consist of radioactive particulates, noble gases, or volatile forms of radionuclides. Radioactive emissions from stacks and vents having the potential of exceeding $10 \%$ of discharge limits are monitored. A nonradioactive emission is monitored when it has the potential of exceeding $50 \%$ of applicable standards for nonradioactive constituents. 
A report detailing radioactive airborne releases from the major operating areas is published annually (for example, Diediker et al. 1992) and submitted to the EPA as required by the Clean Air Act. A report detailing all environmental releases in the major operating areas is published annually (for example, Manley 1992) and submitted to DOE Richland Field Office (RL). In compliance with the National Emissions Standards for Hazardous Air Pollutants statutes, an annual report documenting all radioactive air emissions at the Hanford Site is submitted to the U.S. Environmental Protection Agency (EPA) by $\mathrm{RL}$. These reports are available in RL's public reading room located on the campus of Washington State University Tri-Cities in Richland. Onsite radioactive air emission data are also reported every year to the Idaho National Engineering Laboratory via the Effluent Information SystemOnsite Discharge Information System (DOE 1987a). A summary of radioactive air emissions from the Hanford Site for 1991 is given in Table 4.1. Table 4.2 summarizes the nonradioactive constituents released in gaseous emissions (the 400 and 600 Areas have no nonradioactive emission sources of concern).

\section{Liquid Effluents}

Liquid effluents are discharged from facilities in all areas of the Hanford Site. Liquid effluent sources result in over 350 radioactive and nonradioactive liquid waste streams discharging to the Columbia River, soil column. or sewer disposal systems. Total liquid efflurnt discharge volume was about 13 million $\mathrm{m}^{3}$ (17 million $\left.\mathrm{yd}^{3}\right)$ in 1991 .

Liquid effluents released to the environment are monitored to ensure that applicable limits are not

Table 4.1. Radionuclides Discharged to the Atmosphere in 1991

\begin{tabular}{|c|c|c|c|c|c|}
\hline \multirow[b]{2}{*}{ Radionuclide } & \multirow[b]{2}{*}{ Half-Life } & \multicolumn{4}{|c|}{ Release, $\mathrm{Ci}^{(i n)}$} \\
\hline & & 100 Areas & 200 Areas & 300 Area & 400 Area \\
\hline${ }^{3} \mathrm{H}(\mathrm{as} \mathrm{HTO})$ & $12.3 \mathrm{yr}$ & & 1 & 55 & \\
\hline${ }^{3} \mathrm{H}$ (as HT) & $12.3 \mathrm{yr}$ & & & 29 & \\
\hline${ }^{14} \mathrm{C}$ & $5,730 \mathrm{yr}$ & & $8 \times 10^{2}$ & & \\
\hline${ }^{41} \mathrm{Ar}$ & $1.8 \mathrm{hr}$ & & & & 27 \\
\hline${ }^{6 i)} \mathrm{Co}$ & $5.3 \mathrm{yr}$ & $3.8 \times 10^{-5}$ & & & \\
\hline${ }^{90} \mathrm{Sr}^{\prime \prime \prime \prime}$ & $28.8 \mathrm{yr}$ & $7.6 \times 10^{5}$ & $2.4 \times 10^{-3}$ & $3.8 \times 10^{-4}$ & \\
\hline${ }^{106 i} \mathrm{Ru}$ & $367 \mathrm{~d}$ & $2.5 \times 10^{-4}$ & $2.9 \times 10^{-3}$ & & \\
\hline${ }_{12: 5 b}$ & $2.7 \mathrm{yr}$ & $3.1 \times 10^{5}$ & & & \\
\hline 1:? $\mathrm{I}$ & $1.6 \times 10^{7} \mathrm{yr}$ & & $4.8 \times 10^{2}$ & & \\
\hline${ }_{13.4} \mathrm{Cs}$ & $2.1 \mathrm{yr}$ & $1.3 \times 10^{-5}$ & & & \\
\hline $1: 37 \mathrm{Cs}$ & $30 \mathrm{yr}$ & $7.6 \times 10^{-5}$ & $4.1 \times 10^{-3}$ & & $7.7 \times 10^{-f i}$ \\
\hline 1.14 $\mathrm{Pm}$ & $2.6 \mathrm{yr}$ & & $6.5 \times 10^{-4}$ & & \\
\hline $212 \mathrm{~Pb}$ & $10.6 \mathrm{~h}$ & & $2.7 \times 10^{-3}$ & & \\
\hline 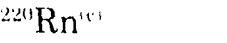 & $55.6 \mathrm{~s}$ & & 33 & & \\
\hline $\mathrm{U}$ (total) & $4.5 \times 10^{9} \mathrm{yr}$ & & $3.0 \times 10^{-i}$ & $3.9 \times 10^{-x}$ & \\
\hline : $: i k \mathrm{Pu}$ & $87.7 \mathrm{yr}$ & $9.2 \times 10^{-7}$ & $3.2 \times 10^{-6}$ & & \\
\hline${ }^{2}-393,2+2+11 \mathrm{Pu}^{\text {td }}$ & $2.4 \times 10^{-4} \mathrm{yr}$ & $5.9 \times 10^{-f i}$ & $4.4 \times 10^{-i}$ & $7.6 \times 10^{-6 i}$ & \\
\hline${ }^{2}+11 \mathrm{Pu}$ & $14.4 \mathrm{yr}$ & & $2.1 \times 10^{-3}$ & & \\
\hline${ }^{241} \mathrm{Am}$ & $433 \mathrm{yr}$ & & $4.5 \times 10^{-4}$ & & \\
\hline
\end{tabular}

(a) $1 \mathrm{Ci}=3.7 \times 10^{\prime \prime \prime} \mathrm{Bq}$.

(b) "'Sr values include total beta activity for those facilities where " $\mathrm{Sr}$ is not measured directly.

(c) ${ }^{2 *} \mathrm{Rn}$ value is calculated from ${ }^{212} \mathrm{~Pb}$ measurements, which account for decay and ingrowth.

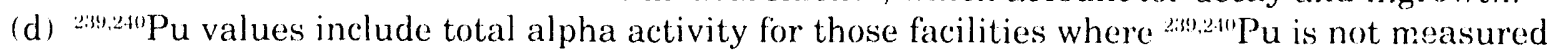
directly. 
Table 4.2. Nonradioactive Constituents Discharged to the Atmosphere in 1991

\begin{tabular}{lllr} 
& \multicolumn{2}{c}{ Release, $\mathrm{kg}$} \\
\cline { 2 - 3 } Constituent & 200Areas & 300 Area \\
\cline { 2 - 3 } Particulates & \multicolumn{2}{c}{$61.59 \times 10^{2}$} & $1.4 \times 10^{4}$ \\
Nitrogen oxides & $12.8 \times 10^{4}$ & $6.4 \times 10^{4}$ \\
Sulfur oxides & $44.8 \times 10^{4}$ & $18.5 \times 10^{4}$ \\
Carbon monoxide & $10.7 \times 10^{4}$ & $5.8 \times 10^{3}$ \\
Hydrocarbons & $14.9 \times 10^{2}$ & $23.3 \times 10^{1}$ \\
Ammonia & $75 \times 10^{1}$ & 0
\end{tabular}

exceeded. Discharges are monitored for both radioactive and nonradioactive constituents. Radioactive and regulated nonradioactive liquid effluents are monitored in the 100,200,300, and 400 Areas. Liquid effluents that contain both radioactive and hazardous constituents are shipped to the 200 Areas for storage in doubleshell tanks or monitored interim-storage facilities. The 600 and 1100 Areas do not generate radioactive or nonradioactive hazardous liquid effluents.

Radioactive liquid effluent monitoring data are reported annually via the Effluent Information System-Onsite Discharge Information System. Monitoring results for liquid effluents regulated by the National Pollutant Discharge El.mination System permit are reported monthly to EPA. A summary of radionuclides in liquid effluents discharged to ground disposal facilities in 1991 is given in Table 4.3. Table 4.4 summarizes the nonradioactive constituents in liquid effluents. Table 4.5 summarizes data on radionuclides from measured liquid effluents released to the Columbia River from the 100 Areas.

Releases entering the river via ground water are not measured directly but are assessed through river water environmental surveillance (see Section 4.3). These surveillance measurements are used in the public dose estimates (see Section 4.8).

\section{Solid Waste}

Solid wastes produced at Hanford are classified as radioactive, nonradioactive, and mixed waste.
Radioactive waste consists of transuranic, highactivity, and low-activity wastes. Mixed waste consists of wastes having both radioactive and hazardous nonradioactive components. Nonradioactive wastes are composed of hazardous or nonregulated wastes. Hazardous waste consists of dangerous wastes or extremely hazardous wastes, as defined in Washington State Department of Ecology Dangerous Waste Regulations.

Radioactive and mixed wastes currently are handled in several ways. High-activity liquid wastes are stored in double-shell tanks. Lowactivity liquid wastes are stored in double-shell tanks or on storage pads, or buried, depending on the source, composition, and concentration. Transuranic wastes are stored in vaults or underground storage pads, from which they can be retrieved.

Approximately 200 facilities on the Hanford Site generate hazardous waste. An annual report lists th "dangerous wastes" and "extremely hazardous wastes" generated, treated, stored, and disposed of onsite and offsite (DOE 1992b). Hazardous wastes are treated, stored, and prepared for disposal at several Hanford Site facilities, or shipped offsite for disposal, destruction, or recycling. In $1991,105,000 \mathrm{~kg}(231,000 \mathrm{lb})$ of dangerous wastes and $302,000 \mathrm{~kg}(665,000 \mathrm{lb})$ of extremely hazardous wastes were shipped offsite for disposal or recycling.

Nondangerous or nonregulated wastes generated at the Hanford Site are buried in the Central Landfill, located in the 200 Areas. Examples of these wastes are construction debris, office trash, cafeteria waste, and packaging materials. Other materials and items classified as waste are solidified filter backwash and sludge from the treatment of river water, failed and broken equipment and tools, air filters, noncontaminated used gloves and other clothing, and certain chemical precipitates such as oxalates. Nonradioactive friable asbestos is buried at designated areas at the Central Lardfill. Ash generated at the 200East and 200-West Areas powerhouses is buried at designated sites near the powerhouses. Demolition waste from 100 Areas decommissioning projects is buried in situ or at designated sites in the 100 Areas. 
Table 4.3. Radionuclides in Liquid Effluents Discharged to Ground Disposal Facilities in 1991

Radionuclide

${ }^{3} \mathrm{H}$

${ }^{54} \mathrm{Mn}$

${ }^{\text {iil } \mathrm{Co}} \mathrm{O}$

" $\mathrm{Sr}$

${ }^{125} \mathrm{Sb}$

${ }^{134} \mathrm{Cs}$

${ }^{13} \mathrm{Cs}$

${ }^{2} 34 \mathrm{U}$

:33 $\mathrm{U}$

${ }^{2: 3 \times} U$

$\mathrm{U}$ (total)

${ }^{2: 34} \mathrm{Pu}$

2319.24110 $\mathrm{Pu}$

${ }^{241} \mathrm{Pu}$

${ }^{241} \mathrm{Am}$

Total Effluent

Volume $\left(\mathrm{m}^{3}\right)$
Half-Life

$12.3 \mathrm{yr}$

$312 \mathrm{~d}$

$5.3 \mathrm{yr}$

$28.8 \mathrm{yr}$

$2.7 \mathrm{yr}$

$2.1 \mathrm{yr}$

$30 \mathrm{yr}$

$2.4 \times 10^{5} \mathrm{yr}$

$7.0 \times 10^{\circ} \mathrm{yr}$

$4.5 \times 10^{9} \mathrm{yr}$

$4.5 \times 10^{9} \mathrm{yr}$

$87.7 \mathrm{yr}$

$2.4 \times 10^{4} \mathrm{yr}$

$14.4 \mathrm{yr}$

$433 \mathrm{yr}$
Release, $\mathrm{Ci}^{i+1 !}$

100 Areas $\quad 200$ Areas $\quad 300$ Area

9.3

22

$4.2 \times 10^{-4}$

$4.8 \times 10^{3}$

$8.5 \times 10^{-1}$

$1.8 \times 10^{-3}$

$6.4 \times 10^{-4}$

$1.3 \times 10^{-1}$

57

$9.4 \times 10^{2}$

$7.2 \times 10^{-1}$

$1.7 \times 10^{-3}$

$7.0 \times 10^{-5}$

$3.7 \times 10^{-4}$

$1.3 \times 10^{-3}$

$2.8 \times 10^{4}$

$1.7 \times 10^{2}$

$2.5 \times 10^{-1}$

$2.7 \times 10^{-1}$

$3.4 \times 10^{-1}$

$1.3 \times 10^{3}$

$1.1 \times 10^{7}$

$1.8 \times 10^{7}$

(a) $1 \mathrm{Ci}=3.7 \times 10^{10} \mathrm{~Bq}$.

(b) Reported as total beta; assumed to be ${ }^{91} \mathrm{Sr}$ for dose calculations.

Table 4.4. Nonradioactive Liquid Discharged to Ground Disposal Facilities in 1991

Release, $\mathrm{kg}$

\begin{tabular}{|c|c|c|c|c|}
\hline \multirow{2}{*}{ Constituents } & & & & \\
\hline & 100 Areas & 200 Areas & 300 Area & 400 Area \\
\hline Total organic carbon & & $1.41 \times 10^{4}$ & $2.6 \times 10^{3}$ & 37 \\
\hline Nitrates & & $3.39 \times 10^{9}$ & $2.5 \times 10^{3}$ & 26 \\
\hline Copper & & & 20 & \\
\hline Aluminum sulfate & $11.37 \times 10^{3}$ & & $5.9 \times 10^{3}$ & \\
\hline Polyacrylamide & $13.8 \times 10^{1}$ & & $3.8 \times 10^{1}$ & \\
\hline Total Effluent & & & & \\
\hline Volume ( $\left.\mathrm{m}^{\prime \prime}\right)$ & $1.2 \times 10^{1}$ & $2.18 \times 10^{6 i}$ & $1.8 \times 10^{6}$ & $1.6 \times 10^{4}$ \\
\hline
\end{tabular}


Table 4.5. Radionuclides in Liquid Effluents Discharged to the Columbia River from the 100 Areas in 1991

\begin{tabular}{l} 
Radionuclide \\
\hline${ }^{3} \mathrm{H}$ \\
${ }^{54} \mathrm{Mn}$ \\
${ }^{60} \mathrm{Co}$ \\
${ }^{90} \mathrm{Sr}$ \\
${ }^{125} \mathrm{Sb}$ \\
${ }^{134} \mathrm{Cs}$ \\
${ }^{137} \mathrm{Cs}$ \\
${ }^{239.2410} \mathrm{Pu}$ \\
Total Effluent \\
Volume $\left(\mathrm{m}^{3}\right)$
\end{tabular}

\begin{tabular}{|c|c|}
\hline Half-Life & Release, $\mathrm{Ci}^{(\mathrm{a})}$ \\
\hline $12.3 \mathrm{yr}$ & 10 \\
\hline $312 \mathrm{~d}$ & $3.5 \times 10^{-3}$ \\
\hline $5.3 \mathrm{yr}$ & $1.2 \times 10^{-2}$ \\
\hline $28.8 \mathrm{yr}$ & $1.3 \times 10^{-1}$ \\
\hline $2.7 \mathrm{yr}$ & $2.5 \times 10^{-4}$ \\
\hline $2.1 \mathrm{yr}$ & $1.8 \times 10^{-4}$ \\
\hline $30 \mathrm{yr}$ & $3.9 \times 10^{2}$ \\
\hline $2.4 \times 10^{4} \mathrm{yr}$ & $4.7 \times 10^{-6}$ \\
\hline
\end{tabular}

(a) $1 \mathrm{Ci}=3.7 \times 10^{10} \mathrm{~Bq}$.

A summary of both nonradioactive and radioactive solid waste disposed of at the Hanford Site is shown in Table 4.6. Solid waste program activities are regulated by the Resource Conservation and Recovery Act and Toxic Substances Control Act, which are discussed in Section 2.0, "Environmental Compliance Summary."

\section{Comprehensive Environmental Response, Compensation, and Liability Act (CERCLA) Continuous Emissions in Excess of the Reportable Quantities}

Section 103(f)(2) of CERCLA, as amended, requires, annual reporting of releases of hazardous substances should they exceed reportable quantities but are continuous and stable in quantity and rate. On the Hanford Site, ammonia emissions from the 200 Areas PUREX rlant, 241-AP Tank Farm, and 241-AW Tank Farm, and ammonia and ammonium hydroxide emissions from the 242-A Evaporator-Crystallizer may exceed reportable quantities during normal operations.
Emissions from all these facilities are monitored, and none exceeded a reportable quantity during 1991. Waste ammonia was not generated at the PUREX Plant because fuel-decladding operations ceased in 1990. Ammonia-bearing waste was not processed at the 242-A Evaporator-Crystallizer; therefore, no waste ammonia was generated. The two tank farms continued operations, storing PUREX Plant ammonia-bearing waste, but not receiving any new waste. The emissions from these two facilities were substantially below applicable reportable quantities.

\section{Emergency Planning and Community Right-To-Know Act}

Title III of the Superfund Amendments and Reauthorization Act (SARA) is a free-standing law, called the Emergency Planning and Community Right-To-Know Act. The purpose of this Act is to provide the public with information about hazardous chemicals in their communities. It also establishes emergency planning and notification procedures to protect the public in the event of a hazardous chemical release. State Emergency Response Commissions have been formed 
Table 4.6. Solid Waste Disposal at Hanford in 1991

\begin{tabular}{|c|c|c|c|c|c|c|}
\hline Constituent & Units & $\begin{array}{c}\text { Transuranic } \\
\text { Waste } \\
\end{array}$ & $\begin{array}{c}\text { Low-Activity } \\
\text { Waste } \\
\end{array}$ & $\begin{array}{c}\text { High-Activity } \\
\text { Waste } \\
\end{array}$ & $\begin{array}{c}\text { Other Solid } \\
\text { Waste } \\
\end{array}$ & Total \\
\hline \multicolumn{7}{|l|}{ Radioactive } \\
\hline $\mathrm{U}$ & $\mathrm{g}$ & 0.0 & $2.6 \times 10^{6}$ & 0.0 & & $2.6 \times 10^{6}$ \\
\hline 列: & $\mathrm{g}$ & 0.0 & $2.1 \times 10^{2}$ & 0.0 & & $2.1 \times 10^{2}$ \\
\hline $\mathrm{Pu}$ & $\mathrm{g}$ & $1.9 \times 10^{3}$ & $2.1 \times 10^{1}$ & 0.0 & & $1.9 \times 10^{3}$ \\
\hline $\mathrm{Am}$ & $\mathrm{g}$ & $5.7 \times 10^{-1}$ & $1.2 \times 10^{-2}$ & 0.0 & & $5.8 \times 10^{-1}$ \\
\hline Th & $\mathrm{g}$ & 0.0 & $3.1 \times 10^{5}$ & 0.0 & & $3.1 \times 10^{5}$ \\
\hline $\mathrm{Sr}^{\prime: 1 /}$ & $\mathrm{Ci}$ & $2.5 \times 10^{-2}$ & $1.0 \times 10^{3}$ & 0.0 & & $1.0 \times 10^{3}$ \\
\hline$R u^{\prime \prime \prime \prime}$ & $\mathrm{Ci}$ & $9.7 \times 10^{-3}$ & 2.8 & 0.0 & & 2.8 \\
\hline $\mathrm{Cs}^{\prime \prime \prime \prime}$ & $\mathrm{Ci}$ & $2.9 \times 10^{-2}$ & $2.9 \times 10^{3}$ & 0.0 & & $2.9 \times 10^{3}$ \\
\hline $\begin{array}{l}\text { Other fission and } \\
\text { activation products }\end{array}$ & $\mathrm{Ci}$ & $2.0 \times 10^{-5}$ & $4.9 \times 10^{5}$ & 0.0 & & $4.9 \times 10^{5}$ \\
\hline
\end{tabular}

\section{Nonradioactive}

Nonradioactive trash, refuse

$\mathrm{m}^{3}$

Asbestos

$\mathrm{m}^{3}$

Septic sludge

$\mathrm{m}^{3}$

$2.1 \times 10^{4}$
$1.2 \times 10^{3}$
$3.3 \times 10^{3}$

(a) Values represent single isotopes only; decay products are included in other fission and activation products.

to guide planning for chemical emergencies, in accordance with Subtitle A of the law. The state creates Local Emergency Planning Committees to assure community participation and planning.

Subtitle B contains the reporting requirements for providing local communities with information on hazardous materials existing in or released from a facility near those locales. The Hanford Site was in compliance with the reporting and notification requirements of this Act. The 1991 Tier Two Emergency and Hazardous Chemical Inventory (DOE 1992d) report was issue

February 1992, to the State Emergency Response Commission, local county emergency management committees, and local fire departments. This report contains information on hazardous materials in storage across the Hanford Site. Table 4.7 summarizes the information reported, listing the 10 chemicals stored in greatest quantity on the Hanford Site.
Field representatives throughout the Hanford Site participate in annual training and recertification on the regulatory requirements of reporting for this Act. They enter information in the Hazardous Material Inventory Database, from which the reported information is obtained.

The annual Toxic Chemical Release Inventory (DOE 1991c) report is provided to EPA as information only, conforming with guidance from DOE-Headquarters. Issuing this report is no longer required because the primary mission of the Hanford Site has shifted from production operations to environmental restoration. Also available to the public, the report has information on toxic chemical releases and transfers at the Site, as well as waste management practices. 
Table 4.7. Hanford Site Tier-Two Emergency and Hazardous Chemical Inventory Average Balance of Ten Chemicals

Stored in Greatest Quantity in 1991

\section{Hazardous Material}

Coal

Mineral oil

Uranium nitrate hexahydrate

Sodium

Fuel oil, No. 6

ivitric acid

Diesel fuel

Nitrogen

Sodium chiuride

Ethylene glyco!
Average Daily

Balance, $\mathrm{kg}$

$4.6 \times 10^{7}$

$1.9 \times 10^{6}$

$1.3 \times 10^{6}$

$1.2 \times 10^{6}$

$5.9 \times 10^{5}$

$5.8 \times 10^{5}$

$4.8 \times 10^{5}$

$3.8 \times 10^{5}$

$3.3 \times 10^{5}$

$2.8 \times 10^{5}$ 


\subsection{Air Surveillance}

Atmospheric releases from Hanford to the surrounding region are a potential source of human exposure. For that reason radioactive materials in air are monitored at a number of locations. This section discusses sample collection, analytical methods, and the results of the air surveillance program. Detailed analytical results are contained in Bisping (1992).

\section{Sample Collection and Analysis}

Radioactivity in air was sampled by a network of continuously operating samplers at 23 locations on the Hanford Site, 13 near the Site perimeter, 8 in nearby communities, and 3 in distant communities (Figure 4.1 and Table 4.8). Samples were also collected at three community-operated environmental surveillance stations (COESS) that were managed and operated by local school teachers. Air samplers on the Hanford Site were located primarily around major operating areas to maximize the ability to detect contaminants resulting from Site operations. Perimeter samplers were located around the Site with emphasis on the prevailing downwind directions to the south and east of the Site. Continuous samplers located in Benton City, Connell, Eltopia, Kennewick, Mattawa, Othello, Pasco, and Richland provided concentrations at the nearest population centers. Samplers at the distant communities of Moses Lake, Sunnyside, and Yakima provided data from communities essentially unaffected by Site operations. Yakima is a distant upwind location that provides reference regional background concentrations.

Samples were collected according to a schedule established before the monitoring year (Bisping 1991). Air sampling locations are listed in Table 4.8. The number of locations sampled for total alpha and total beta radiation and specific radionuclides are summarized in Table 4.9. Airborne particles were sampled at each of these locations by continuously drawing air through a glass fiber filter. The filters were collected every
2 weeks, field surveyed for total radioactivity to detect any unusual occurrences, held for at least 7 days at the analytical laboratory, and then analyzed for total beta radioactivity. The holding period was necessary to allow for the decay of short-lived, naturally occurring radionuclides that would otherwise obscure detection of longerlived radionuclides potentially present from Hanford emissions. Field measurements of radioactivity are taken to obtain data that might indicate changes in environmental trends which could warrant attention before the more detailed and sensitive laboratory analyses are completed. In addition, filters from selected locations were also analyzed for total alpha radioact itv.

For most radionuclides, the amount arioactive material collected on the filter during the 2-week period was too small to be measured with reasonable accuracy. The accuracy of sample analysis was increased by combining two biweekly samples into a monthly composite sample for each location. The monthly composites for a few nearby locations were then combined to form a quarterly or annual geographical composite (Table 4.8). Each composite (except for the ALE Field Lab sample, which was not routinely analyzed) was analyzed for numerous specific gamma-emitting radionuclides (Appendix E), then combined into quarterly or annual composites and analyzed for strontium and plutonium (DOE 1991b). Selected quarterly or annual composites were also analyzed for uranium isotopes.

Gaseous ${ }^{1: 11}$ was sampled at selected locations by drawing air through a cartridge containing activated charcoal. These cartridges were located downstream of the particle filter and were exchanged biweekly or monthly. Sampling was performed near operating facilities to maximize the potential for detecting releases and at locations of potential public exposure. Monthly ${ }^{1: 31} \mathrm{I}$ samples were archived and were not routinely analyzed. These samples were collected to provide additional data in the event of an accident or unusual release. Iodine-129 was sampled using the same technique with a low background 


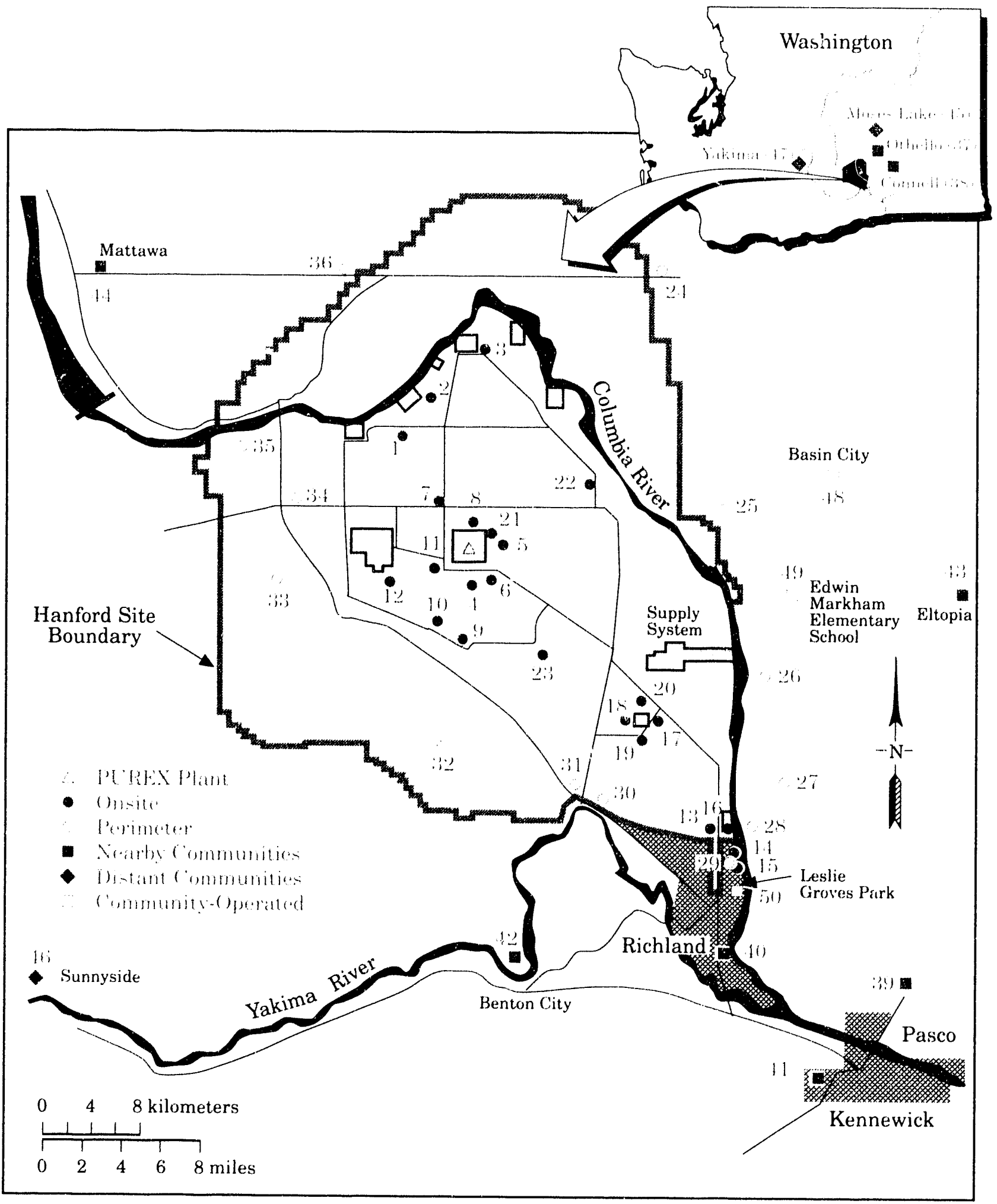

59203058.10

Figure 4.1. Air Sampling Locations, 1991 (see Table 4.8 for location key) 
Table 4.8. Air Sampling Locations and Sample Composite Groups

Composite Group $\quad$ Sampling Location $\quad \begin{gathered}\text { Map }^{(i)} \\ \text { Location }\end{gathered}$

\begin{tabular}{|c|c|c|}
\hline \multicolumn{3}{|l|}{ Onsite } \\
\hline \multirow[t]{3}{*}{100 Areas } & $100-\mathrm{K}$ & 1 \\
\hline & $100-\mathrm{N}$ & 2 \\
\hline & $100-\mathrm{D}$ & 3 \\
\hline \multirow{3}{*}{ 200-East Are: } & $S$ of 200 -East & 4 \\
\hline & $\mathrm{E}$ of 200 -East & 5 \\
\hline & 200-East SE & 6 \\
\hline \multirow[t]{2}{*}{ North of 200 Areas } & Rt. $11 \mathrm{~A}, \mathrm{Mi} .9$ & 7 \\
\hline & $\mathrm{N}$ of 200 -East & 8 \\
\hline \multirow{3}{*}{$\begin{array}{l}\text { 200-West, South } \\
\text { and East }\end{array}$} & SW of $B / C$ Cribs & 9 \\
\hline & Army Loop Camp & 10 \\
\hline & GTE Building & 11 \\
\hline 200-West & 200-West SE & 12 \\
\hline \multirow[t]{3}{*}{300 Area } & 300 Trench & 13 \\
\hline & 300 Water intake & 14 \\
\hline & 300-South Gate & 15 \\
\hline $300 \mathrm{NE}$ & $300 \mathrm{NE}$ & 16 \\
\hline \multirow[t]{4}{*}{400 Area } & 400-East & 17 \\
\hline & 400-West & 18 \\
\hline & 400-South & 19 \\
\hline & 400 -North & 20 \\
\hline B Pond & B Pond & 21 \\
\hline Hanford Townsite & Hanford Townsite & 22 \\
\hline Wye Barricade & Wye Barricade & 23 \\
\hline \multicolumn{3}{|l|}{ Perimeter } \\
\hline \multirow[t]{2}{*}{ Northeast Perimeter } & Berg Ranch & 24 \\
\hline & Ringold Met. Tower & 25 \\
\hline \multirow[t]{2}{*}{ East Perimeter } & W. End of Fir Road & 26 \\
\hline & Pettett Farm & 27 \\
\hline \multirow[t]{2}{*}{ Southeast Perimeter } & Byers Landing & 28 \\
\hline & Battelle Complex & 29 \\
\hline
\end{tabular}

(a) See Figure 4.1 . 
Table 4.8. Air Sampling Locations and Sample Composite Groups (contd)

Composite Group

Prosser Barricade

ALE Field Lab

West Perimeter

Northwest Perimeter
Sampling Location

Horn Rapids Rd. Substation Prosser Barricade

ALE Field Lab

Rattlesnake Spring Yakima Barricade

Vernita Bridge

Wahluke Slope

$$
\text { Map'n' }
$$$$
\text { Location }
$$

30

31

32

33

34

35

36

Othello

37

38

39

40

41

Richland

Kennewick

42

43

44

Mattawa

Mattawa

Moses Lake

45

$\begin{array}{lll}\text { Sunnyside } & \text { Sunnyside } & 46\end{array}$

$\begin{array}{lll}\text { Sunnyside } & \text { Sunnyside } & 46\end{array}$

$\begin{array}{lll}\text { Yakima } & \text { Yakima } & 47\end{array}$

Basin City Elementary School

Edwin Markham

North Franklin

County

Basin City

49

Leslie Groves Park

Richland

1
3 6 8 9 1 42 43 4

Distant Communities

Elementary School County

50

(a) See Figure 4.1. 
Table 4.9. Sampling Frequency by Location for Air Samples Collected in 1991 (see Table 4.8 and Figure 4.1)

\begin{tabular}{|c|c|c|c|c|c|c|c|}
\hline Locations & $\begin{array}{l}\text { Total } \\
\text { Beta }\end{array}$ & $\begin{array}{l}\text { Total } \\
\text { Alpha }\end{array}$ & $\begin{array}{c}\text { Particulates }{ }^{(* 1)} \\
{ }^{8: 9} \mathrm{Sr}^{9,10} \mathrm{Sr} \\
{ }^{2: 3} \mathrm{Pu},{ }^{2: 39,24(1)} \mathrm{Pu}\end{array}$ & $\begin{array}{c}\text { Gamma } \\
\text { Scar't" }^{(1)}\end{array}$ & Uranium & $1: 31 \mathbf{I}^{\left(\mathrm{C}^{\prime}\right)}$ & $\begin{array}{c}\text { Gases } \\
{ }^{129} \mathrm{I}\end{array}$ \\
\hline Onsite & 23 & 21 & $11 / 23$ & $11 / 23$ & $9 / 17$ & $3 / 6$ & 1 \\
\hline Perimeter & 13 & 9 & $6 / 12$ & $6 / 12$ & $3 / 6$ & $5 / 5$ & 2 \\
\hline $\begin{array}{l}\text { Nearby } \\
\text { Communities }\end{array}$ & 8 & 2 & $5 / 8$ & $5 / 8$ & 0 & $1 / 2$ & 0 \\
\hline $\begin{array}{l}\text { Distant } \\
\text { Communities }\end{array}$ & 3 & 3 & $3 / 3$ & $3 / 3$ & $3 / 3$ & $2 / 2$ & 1 \\
\hline $\begin{array}{l}\text { COES } \\
\text { Station }\end{array}$ & 3 & 3 & $3 / 3$ & $3 / 3$ & $3 / 3$ & $3 / 3$ & 0 \\
\hline
\end{tabular}

(a) Number of location-composited samples/total number of individual locations contained in the composites. For example, 10/23 indicates 10 composite groups that are made up of 23 individual locations, or between 2 and 3 individual locations per composite on the average. The individual locations making up composite groups are listed in Table 4.8.

(b) Appendix E lists the specific radionuclides analyzed using gamma scans.

(c) Number of locations analyzed routinely/number of locations sampled routinely. (See "Sample Collection and Analysis," in this section.)

(d) Community-operated environmental surveillance.

petroleum charcoal cartridge. Samples were collected monthly and combined to form quarterly composite samples for each location.

Atmospheric water vapor was collected for ${ }^{3} \mathrm{H}$ analysis by continuously passing air through cartridges containing silica gel, which were exchanged every 4 weeks. The trapped water was removed from the silica gel and analyzed.

A detailed description of sampling and analytical techniques is provided in the Hanford Site Environmental Monitoring Plan (DOE 1991b). Field sampling for ${ }^{14} \mathrm{C}$ (as $\mathrm{CO}_{2}$ ), ${ }^{85} \mathrm{Kr}$, and nitrogen dioxide $\left(\mathrm{NO}_{2}\right)$ was discontinued in 1991 . These constituents were used primarily as indicators of activity at the PUREX Plant, which reduced operations in 1990.

Air samples were also collected at three COESS located at the Basin City Elementary School in
Basin City, Edwin Markham Elementary School in North Franklin County, and Leslie Groves Park in Richland (see Figure 4.1, and Tables 4.8 and 4.9). These samples were collected by local teachers using the same equipment, procedures, and analytical laboratory as the Hanford Surface Environmental Surveillance Program. This work was part of a DOE-sponsored program to improve public awareness of Hanford environmental monitoring programs and the effects of Site operations.

\section{Results}

\section{Radiological Results}

Air sampling results for onsite, Site perimeter, nearby communities, distant communities and COESS for total beta, total alpha, and specific radionuclides are summarized in Table 4.10. 


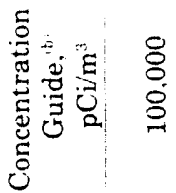

요

ஓ

ㅇ

\&

\&

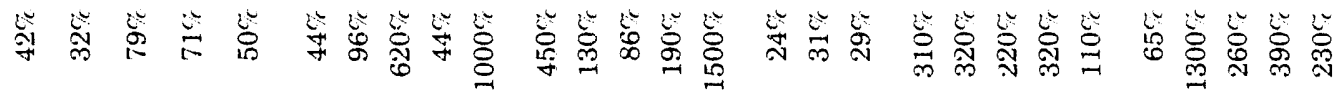

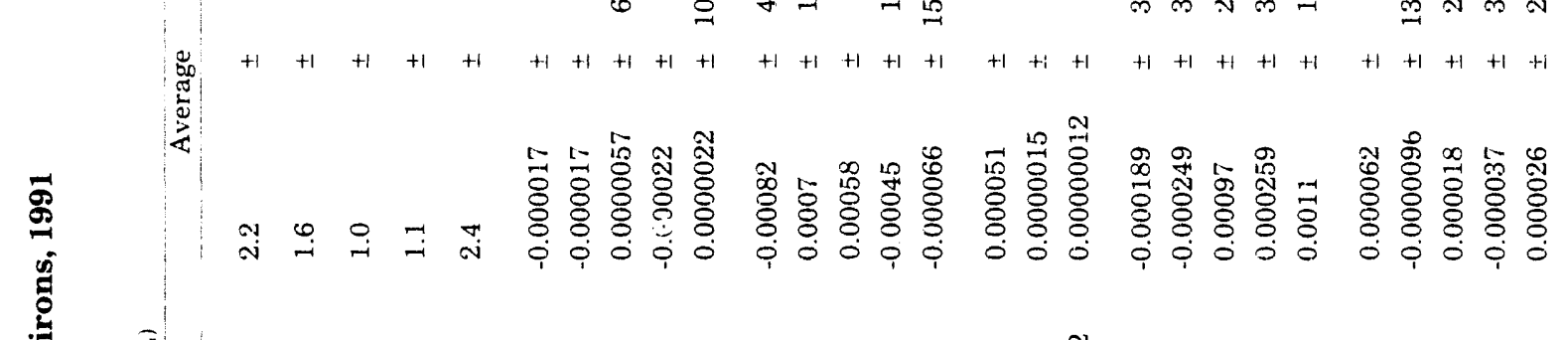

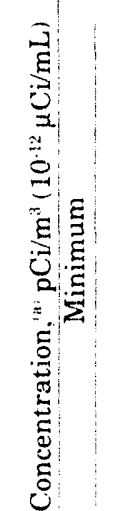

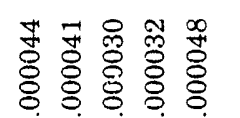

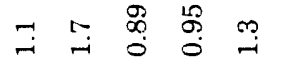

000000

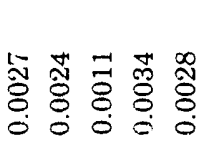

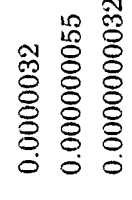

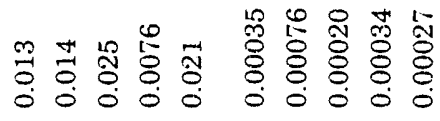

1.

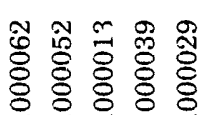

$+1+1+1$

$+1+1+1+1+1+1+1+1+1+1$

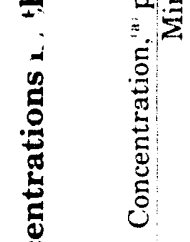

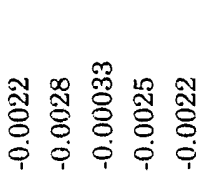

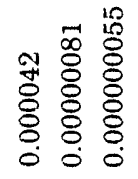

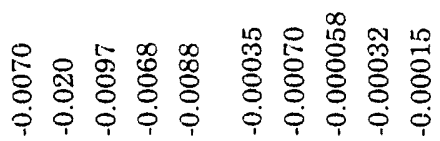

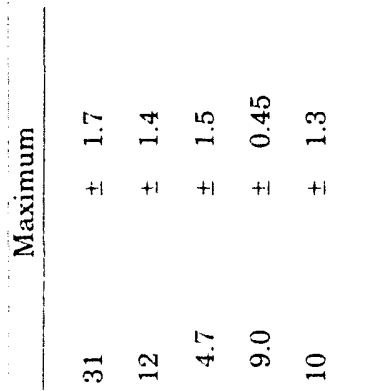

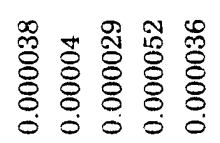

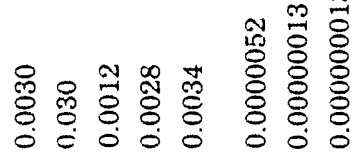

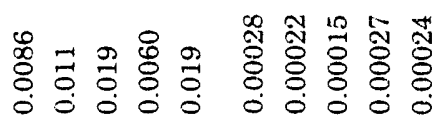

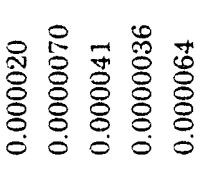

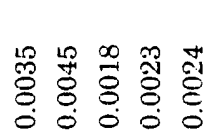

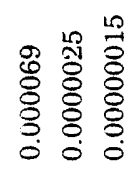

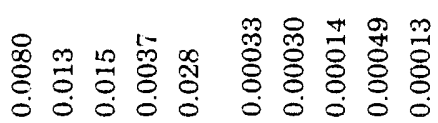

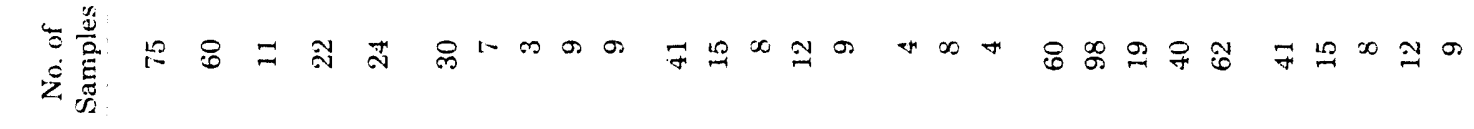

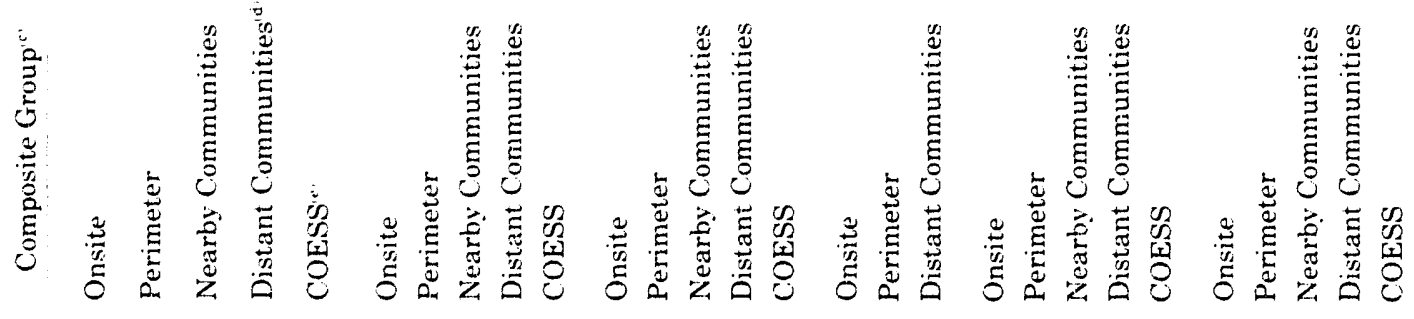
:

$\stackrel{5}{h}$

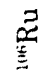




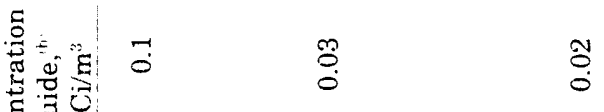

过

$\sum_{\substack{1 \\ 0}}$

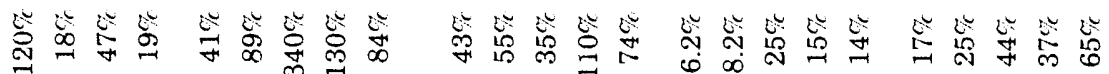
递 $+1+1+1+1+1+1+1+1+1+1+1+1+1+1+1+1+1+1+1+1+1+1+1+1$

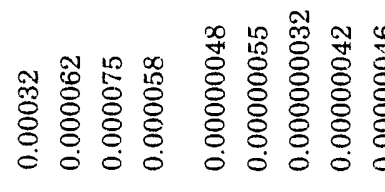

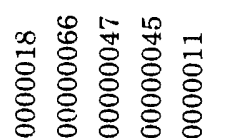

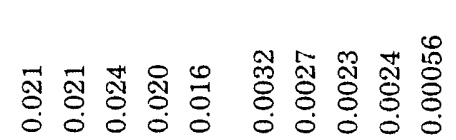

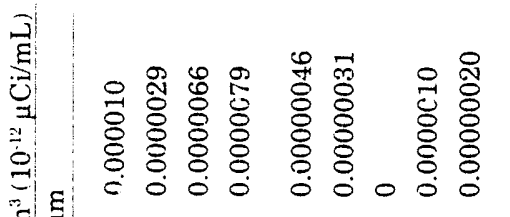

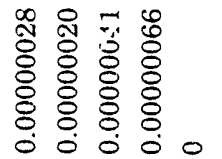

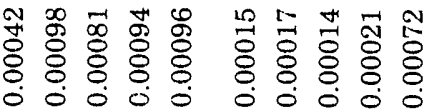

ह $+1+1+1+1+1+1+1+1$

$+1+1+1+1+1$

$+1+1+1+1+1+1+1+1+1+1$

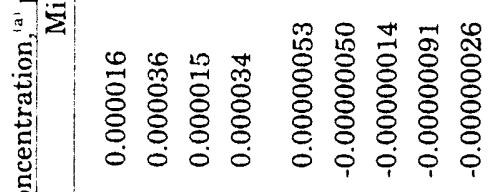

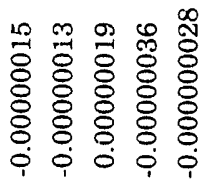

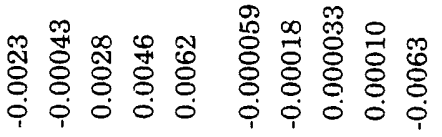

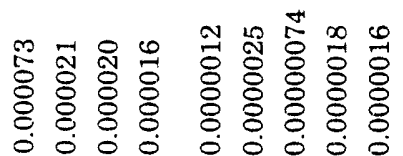

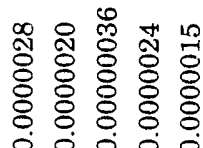

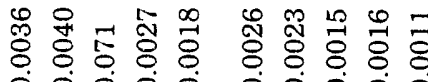

$+1+1+1+1+1+1+1+1+1$

$+1+1+1+1+1$

$+1+1+1+1+1+1+1+1+1+1$

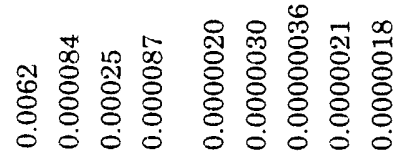

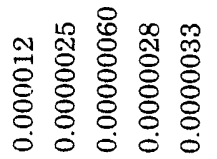

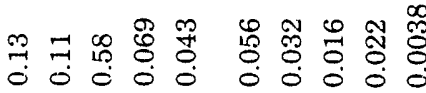

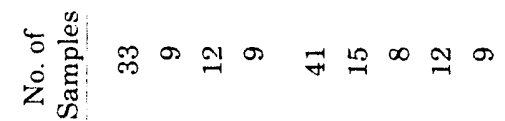

F⿻ㄱㄱㅇㅛ $\infty$

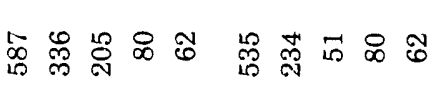

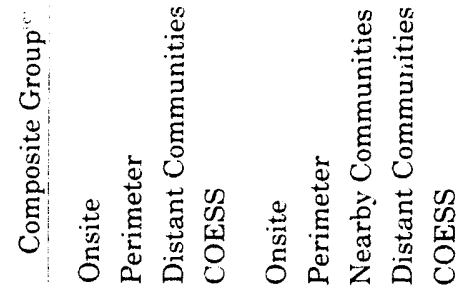

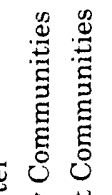

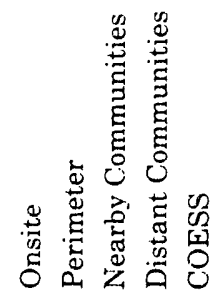

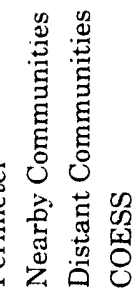

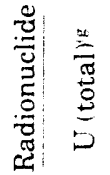

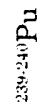

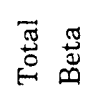

竞毫

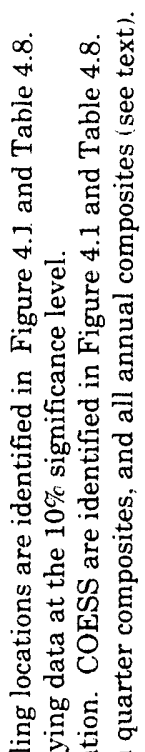

焉造

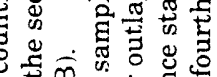

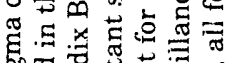

क.

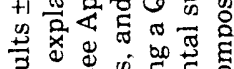

की

a

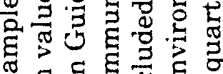

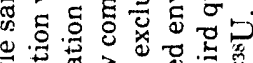

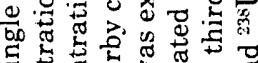

का

ह

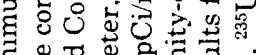

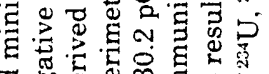

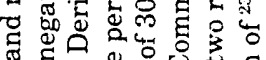

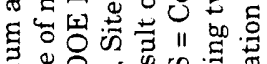

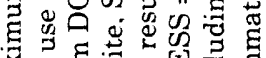

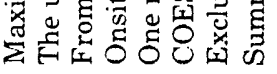

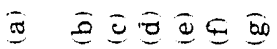


Numerous specific radionuclides (Appendix E) were analyzed in the monthly composite gamma energy analyses (DOE 1991b), but none of Hanford origin were detected consistently.

Total beta concentration in air for 1991, as shown in Figure 4.2, peaked during the winter, repeating a pattern of natural annual radioactivity fluctuations (Eisenbud 1987). As shown in Table 4.10, the average total beta and total alpha concentrations were about the same onsite as at the Site perimeter and in nearby and distant communities, indicating that the observed levels were predominantly a result of natural sources and world wide fallout. No significant differences were observed (one-tailed t-test, $5 \%$ significance level) between average Site perimeter and distant locations for either total beta or total alpha concentrations. An exception is an indication that elevated uranium concentrations in soil (Poston 1990) and air (see uranium air results) in the 300 Area are being reflected in the air total alpha concentrations at that location.

Most strontium-90 results for air samples collected onsite, at the Site perimeter, and in nearby and distant communities were below detectable concentrations during the first three quarters of the year (Table 4.10). In addition, during the same time period all six "Sr samples collected at the COESS were below the detection limit. However, abnormally high "si concentrations were reported for some quarterly composites collected during the third (East and Nrrtheast Perimeter stations) and fourth quarters ( 10 of 17 fourth quarter samples were greater than the maximum quarterly concentration measured at the distant stations) and for all 1991 annual composite samples (six of eight annual samples were greater than the maximum quarterly concentration measured at the distant stations). These apparently anomalous results are probably due to an error or sample contamination during the analytical process. No significant Hanford Site effluent source was reported for " $\mathrm{Sr}$ in 1991 (see Table 4.1, Section 4.1, "Effluent Monitoring"), and the unusual results are being reviewed. The questionable third quarter composites, all fourth quarter composites, and all annual composites have not been included in the data summary given in Table 4.10. Given the above limitations, all reported "'Sr air" concentrations were $<0.00002 \%$ of the DCG of $50 \mathrm{pCi} / \mathrm{m}^{3}$.

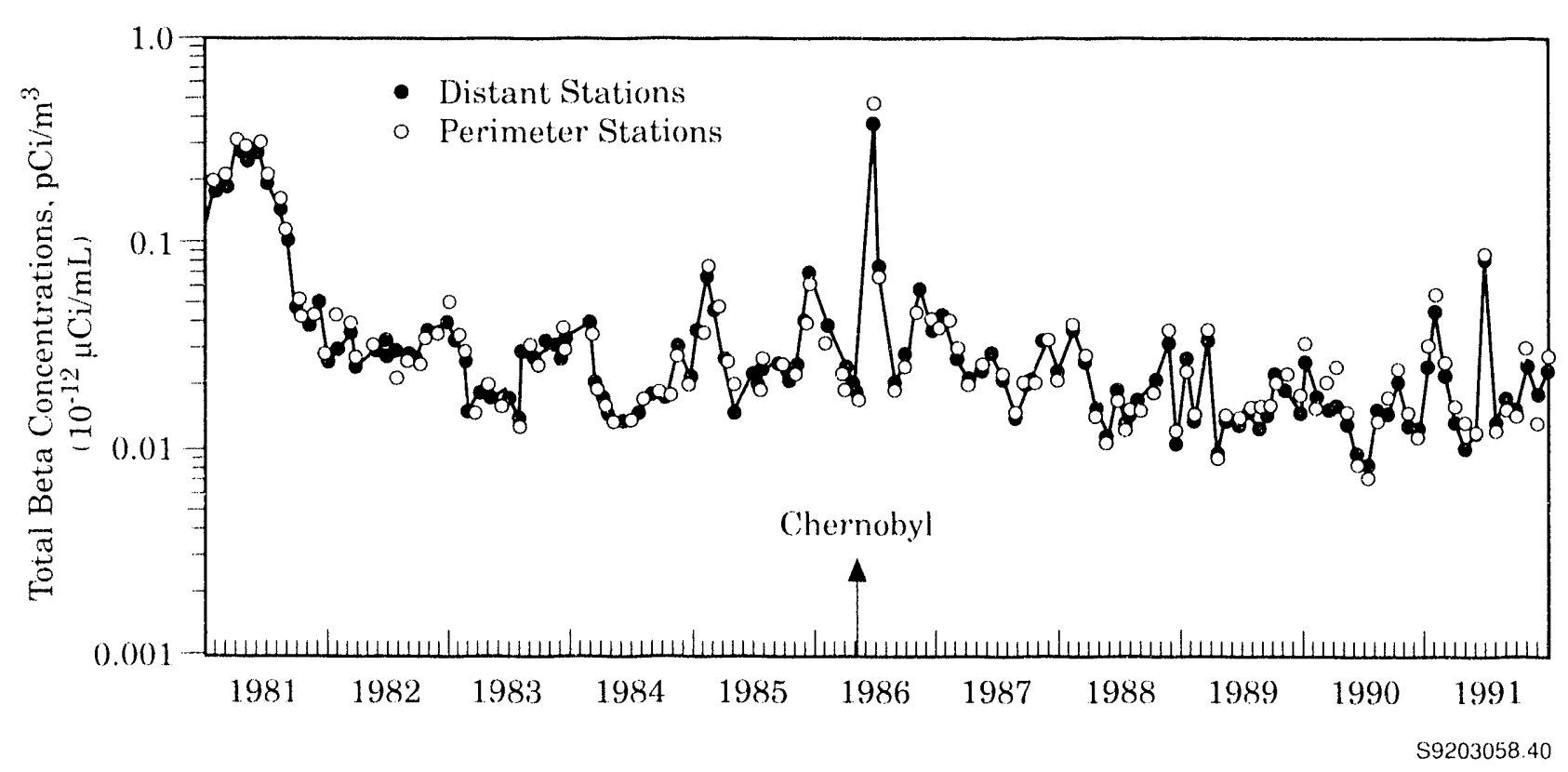

Figure 4.2. Monthly Average Total Beta Radioactivity in Airborne Particulate Samples, 1981 Through 1991 
Quarterly air sampling for ${ }^{129} \mathrm{I}$ began in July 1984. Iodine-129 was sampled onsite downwind of the PUREX Plant (200-East SE location), at two downwind perimeter locations, and at a distant community location (Yakima) in 1991. (Because of extremely low concentrations, results for some radionuclides are reported in $\mathrm{aCi} / \mathrm{m}^{3}$ rather than $\mathrm{pCi} / \mathrm{m}^{3}$. One $\mathrm{aCi} / \mathrm{m}^{3}=0.000001$ $\mathrm{pCi} / \mathrm{m}^{3}$.) Concentrations at the Site perimeter in 1991 were higher than those observed at Yakima (Figure 4.3), and the difference was statistically significant (one-tailed t-test, $5 \%$ significance level). The average onsite and Site perimeter concentrations decreased in 1989 in response to decreased PUREX Plant operations and remained at similar levels in 1990/1991. Onsite air concentrations of ${ }^{12 \%} \mathrm{I}$ were influenced by minor emissions $(0.048 \mathrm{Ci}$, Table 4.1$)$ from the PUREX Plant, storage of dissolved fuel rod solutions, and possible releases from waste storage tanks and cribs. The annual average ${ }^{129} \mathrm{I}$ concentration at the perimeter in $1991\left(1.5 \mathrm{aCi} / \mathrm{m}^{3} \pm\right.$ $31 \%$ ) was $0.000002 \%$ of the DCG of $70,000,000$ $\mathrm{aCi} / \mathrm{m}^{3}\left(70 \mathrm{pCi} / \mathrm{m}^{3}\right)$.

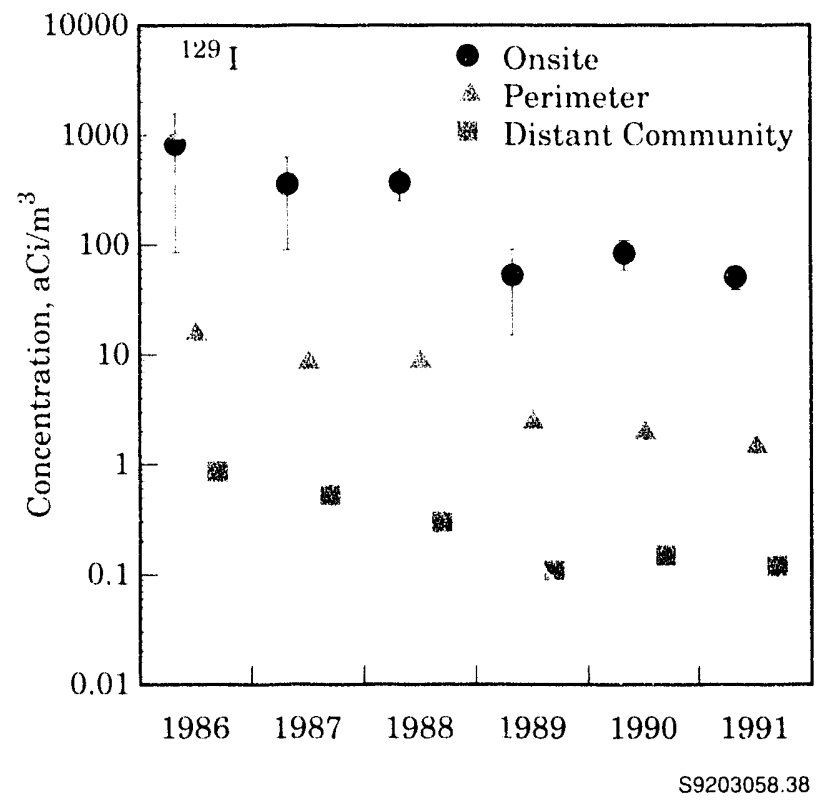

Figure 4.3. Annual Average Concentrations of Iodine-129 ( ${ }^{129}$ I) in Air near the Hanford Site, 1986 Through 1991. As a result of figure scale, some uncertainties (error bars) are concealed by point symbol.
Average concentrations of tritium in air measured at the Site perimeter were slightly higher than at distant locations for 1991; however, the differences were not statistically significant (onetailed t-test, $5 \%$ significance level). Tritium concentrations at the Site perimeter averaged 1.6 $\mathrm{pCi} / \mathrm{m}^{3} \pm 32 \%$, which was $0.0016 \%$ of the DCG of $100,000 \mathrm{pCi} / \mathrm{m}^{3}$. Figure 4.4 displays the average ${ }^{3} \mathrm{H}$ concentrations for onsite and perimeter locations, and distant communities from 1986 to 1991. Atmospheric ${ }^{3} \mathrm{H}$ releases totaling $85 \mathrm{Ci}(\mathrm{HT}+$ HTO) for 1991 (Table 4.1, Section 4.1, "Effluent Monitoring") were reported for the PUREX Plant and the 300 Area. The 300 Area had the highest mean onsite ${ }^{3} \mathrm{H}$ concentration $\left(3.4 \mathrm{pCi} / \mathrm{m}^{3} \pm 58 \%\right)$; however, this value was only $0.0034 \%$ of the DCG. Tritium releases in the 300 Area are associated with research and development activities (see Section 4.1, "Effluent Monitoring").

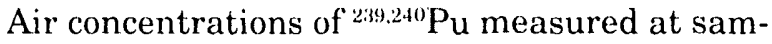
pling locations in 1991 were generally less than $2.0 \mathrm{aCi} / \mathrm{m}^{3}$. The 1991 average ${ }^{2: 39,240} \mathrm{Pu}$ concentrations for onsite, Site perimeter, and near and

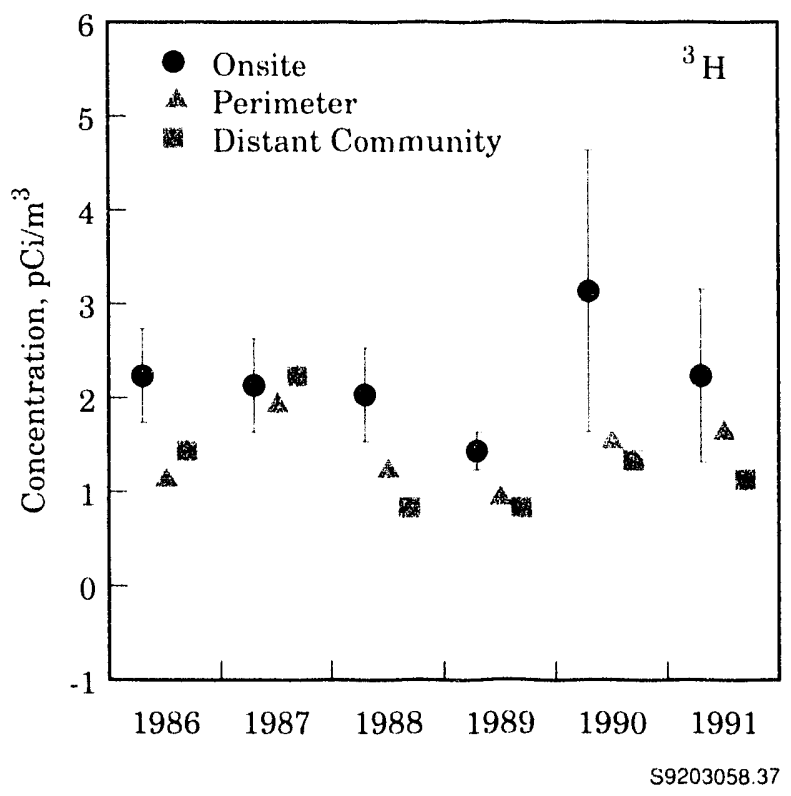

Figure 4.4. Annual Average Concentrations of Tritium $\left({ }^{3} \mathrm{H}\right)$ in Air near the Hanford Site, 1986 Through 1991 
distant community samples are shown in Table 4.10 and Figure 4.5. The 1991 Site perimeter annual concentration was $0.66 \mathrm{aCi} / \mathrm{m}^{3}$, which is $0.003 \%$ of the DCG of $20,000 \mathrm{aCi} / \mathrm{m}^{3}$. There was a significant difference (one-tailed t-test, $5 \%$ significance level/ between the average concentrations onsite compared to distant locations; however, there was no significant difference between concentrations at the Site perimeter and distant locations.

Uranium concentrations $\left({ }^{2: 34} \mathrm{U},{ }^{2: 35} \mathrm{U}\right.$, and $\left.{ }^{2: 3} \mathrm{U}\right)$ in airborne particulate matter in 1991 were similar at the Site perimeter and at distant communities (Table 4.10 and Figure 4.6), and there was no significant difference (one-tailed t-test, $5 \%$ significance level). Elevated uranium concentrations $\left[2: U\right.$ and ${ }^{2} U$ ) were reported for 300 Area air samples collected during the final two quarters of 1991. The maximum air concentration at the 300 Area $(2:-\mathrm{U})$ was $3,450 \mathrm{aCi} / \mathrm{m}^{3} \pm 1.6 \%$, which is $3.4 \%$ of the DCG of $100,000 \mathrm{aCi} / \mathrm{m}^{3}$.

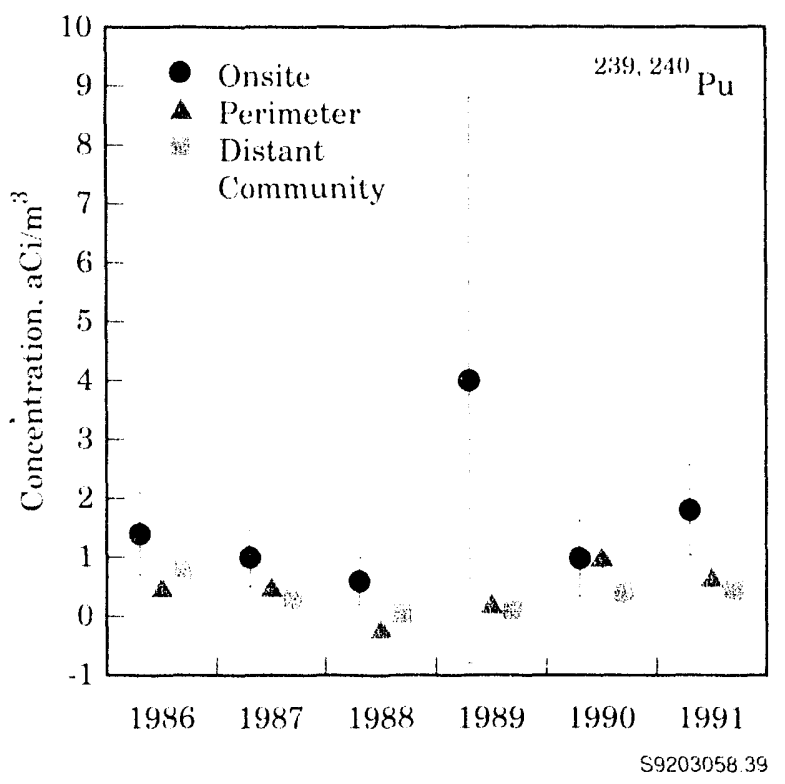

Figure 4.5. Annual Average Concentrations of Plutonium-239, $\left.240{ }^{(239,2411} \mathrm{Pu}\right)$ in Air at the Hanford Environs, 1986 Through 1991
Uranium concentrations measured at downwind Site perimeter locations were not elevated during this time period and were similar to those at the distant community station. The elevated 300 Area concentrations may be attributable to wind resuspension of soil contaminated from past Site operations in and around the 300 Area (Poston 1990). The 1991 annual average concentration for the Site perimeter was $62 \mathrm{aCi} / \mathrm{m}^{3} \pm$ $18 \%$, which was $0.06 \%$ of the DCG.

Ruthenium-106 and ${ }^{16 i} \mathrm{Cs}$ associated with airborne particulate matter, and ${ }^{1: 1}$ I collected on charcoal cartridges were routinely monitored through gamma energy analyses. Results were generally below detectable concentrations both on and off the Hanford Site. The results obtained for 1991 samples are included in Table 4.10. Even the maximum individual measurements for these radionuclides were less than $0.015 \%$ of their DCG.

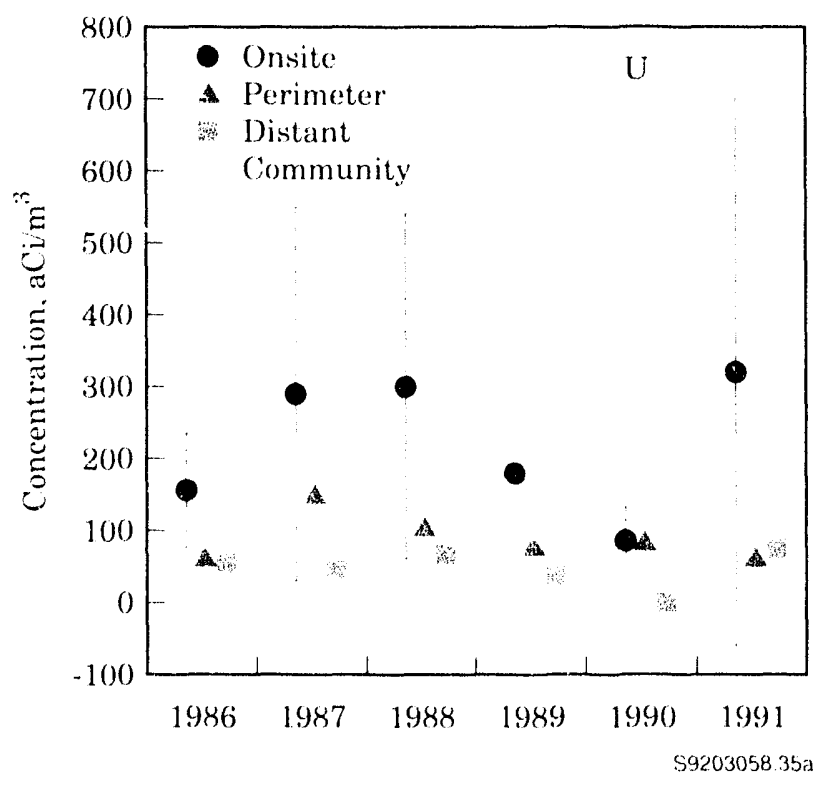

Figure 4.6. Annual Average Concentrations of Uranium $\left({ }^{2: 34} U,{ }^{235} U,{ }^{2: 34} U\right)$ in Air at the Hanford Environs, 1986 Through 1991 . As a result of figure scale, some uncertainties (error bars) are concealed by point symbols. 


\subsection{Surface-Water Surveillance}

Surface water on and near the Hanford Site is monitored to determine the potential affects of Hanford operations. Surface water at Hanford includes the Columbia River, riverbank springs, ponds located on the Hanford Site, and offsite water systems directly east of and across the Columbia River from the Hanford Site. Table 4.11 summarizes the sample locations, sample type, frequency, and analyses included in the surfacewater surveillance activities during 1991. Sample locations are shown in Figure 4.7 as vell. This section describes the surveillance effort and summarizes the results for these aquatic environments. Detailed analytical results are contained in Bisping (1992).

\section{Columbia River}

The Columbia River, second largest river in North America, is used as a source of drinking water at onsite facilities and communities located downstream of Hanford. In addition, the river near the Hanford Site is used for a variety of recreational activities, including hunting, fishing, boating, water skiing, and swimming. Water from the Columbia River downstream of Hanford is also used extensively for crop irrigation. The Hanford Reach is currently under consideration for designation as a National Wild and Scenic River as a result of congressional action in 1988 (see Section 2.3).

Pollutants, both radiological and nonradiological, are known to enter the river along the Hanford Site. In addition to direct discharges of liquid effluents from Hanford facilities, contaminants in ground water from past discharges to the ground are known to seep into the river (Dirkes 1990; McCormack and Carlile 1984). Effluents from each direct discharge point are routinely monitored and reported by the responsible operating contractor; they are summarized in "Effluent Monitoring," Section 4.1. Direct discharges are identified and regulated for nonradiological constituents under the National Pollutant Discharge Elimination System (NPDES). The NPDES-permitted discharges at Hanford and the regulated parameters are listed in Table B.7, Appendix B.
The State of Washington has classified ihe stretch of the Columbia River from Grand Coulee Dam to the Washington-Oregon border, which includes the Hanford Reach, as Class A (Excellent). Water quality criteria and water use guidelines have been established in conjunction with this designation (Table B.1, Appendix B). The State of Washington and EPA drinking water standards (DWS) used in evaluating radionuclide concentrations in Coiumbia River water are provided in Table B.2, Appendix B.

\section{Sample Collection and Analysis}

Samples of Columbia River water were collected throughout 1991 at the locations shown in Figure 4.7. Samples were collected upstream of Hanford facilities at Priest Rapids Dam and near the Vernita Bridge to provide background data from locations unaffected by Site operations. Samples were collected from the 300 Area water intake and the Richland Pumphouse to identify any increase in contaminant concentrations at these locations downstream of Hanford operations. The Richland Pumphouse is the first downstream point of river water withdrawal for a public drinking water supply. The river sampling locations and the methods used for sample collection are discussed in detail in the Hanford Site Environmental Monitoring Plan (DOE 1991b).

Radiological analyses of water samples included total alpha, total beta, gamma scan, ${ }^{3 \mathrm{H}},{ }^{\text {"m }} \mathrm{Sr}$, ${ }^{9 \cdot 9 \mathrm{~T}} \mathrm{~T}$, ${ }^{129} \mathrm{I},{ }^{239} \cdot{ }^{2441} \mathrm{Pu}$, and isotopic uranium ${ }^{2034} \mathrm{U},{ }^{23.5} \mathrm{U}$, and ${ }^{2: 34} U$ ). Alpha and beta measurements provided a general indication of the radioactive contamination. Gamma scans provided the ability to detect numerous specific radionuclides (Appendix E). Specific radiochemical analyses and, in some cases, special sampling techniques were used to determine the concentrations of ${ }^{3} \mathrm{H},{ }^{90} \mathrm{Sr},{ }^{, ! \cdot} \mathrm{Tc},{ }^{12 *} \mathrm{I}$, ${ }^{2: 34} \mathrm{U},{ }^{2: 35} \mathrm{U},{ }^{2: 34} \mathrm{U}$, and ${ }^{2: 312,2411} \mathrm{Pu}$ in river water during the year. Radionuclides of interest were selected based on their presence in effluent discharges or ground water near the river, and their importance in determining water quality, verifying effluent control and effluent monitoring systems, and determining compliance with applicable standards. 
Table 4.11. Surface-Water Surveillance, 1991

$$
\text { Locition Sample Type Frequency Analyses }
$$

\section{Columbia River - Radiological}

Priest Rapids Dam and Richland

Priest Rapids Dam, Richland, and $30(0)$ Area Water Intake

Priest Rapids Dam, Richland, and $3(1)$ Area Water Intake

Columbia River - Nonradiological

Vernita and Richland

Vernita and Richland

Onsite Ponds

West Lake

B Pond

FFTF Pond

\section{Offsite Water}

Ringold Hatchery,

Mathews Corner.

White Bluffs Shallow,

White Bluffs Deep, and

Alexander Farm

Riverview Canal

Grab $3^{\prime \prime \prime}$

A

\section{Riverbank Springs}

100-N, Hanford Townsite,

Grab
Alpha, beta, Lo 'H, gamma scan, "Sr. wrT: $U^{\text {wh }}$

Camma scan

$\mathrm{Pu}^{\text {tht }}$

Gamma scaan

[?i) $1, \mathrm{Pu}^{(\mathrm{w})}$
$M^{(e r}$
$Q^{\prime e r}$

Thermograph

Grab

Grab

M

Cirab

Q

A

Alpha, beta, 'H, U, ${ }^{\text {(h) }}$ gamma scan, ${ }^{|\cdot 4|}$ and 300 Area

(a) $\mathrm{A}=$ annually; $\mathrm{M}=$ monthly; $\mathrm{Q}=$ quarterly; Comp = composite.

(b) Isotopic uranium

(c) Filter/resin samples collected as scheduled; results were not available for inclusion in this report

(d) Isotopic plutonium.

(e) Monthly analyses are performed by the Hanford Environmental Health Foundation. Numerous water quality analyses are performed by the U.S. Geological Survey (USGS) in conjunction with the National Stream Quality Accounting Network (NASQAN) Program. Thermograph stations are operated and maintaned by the USGS.

(f) Three samples during irrigation season. 


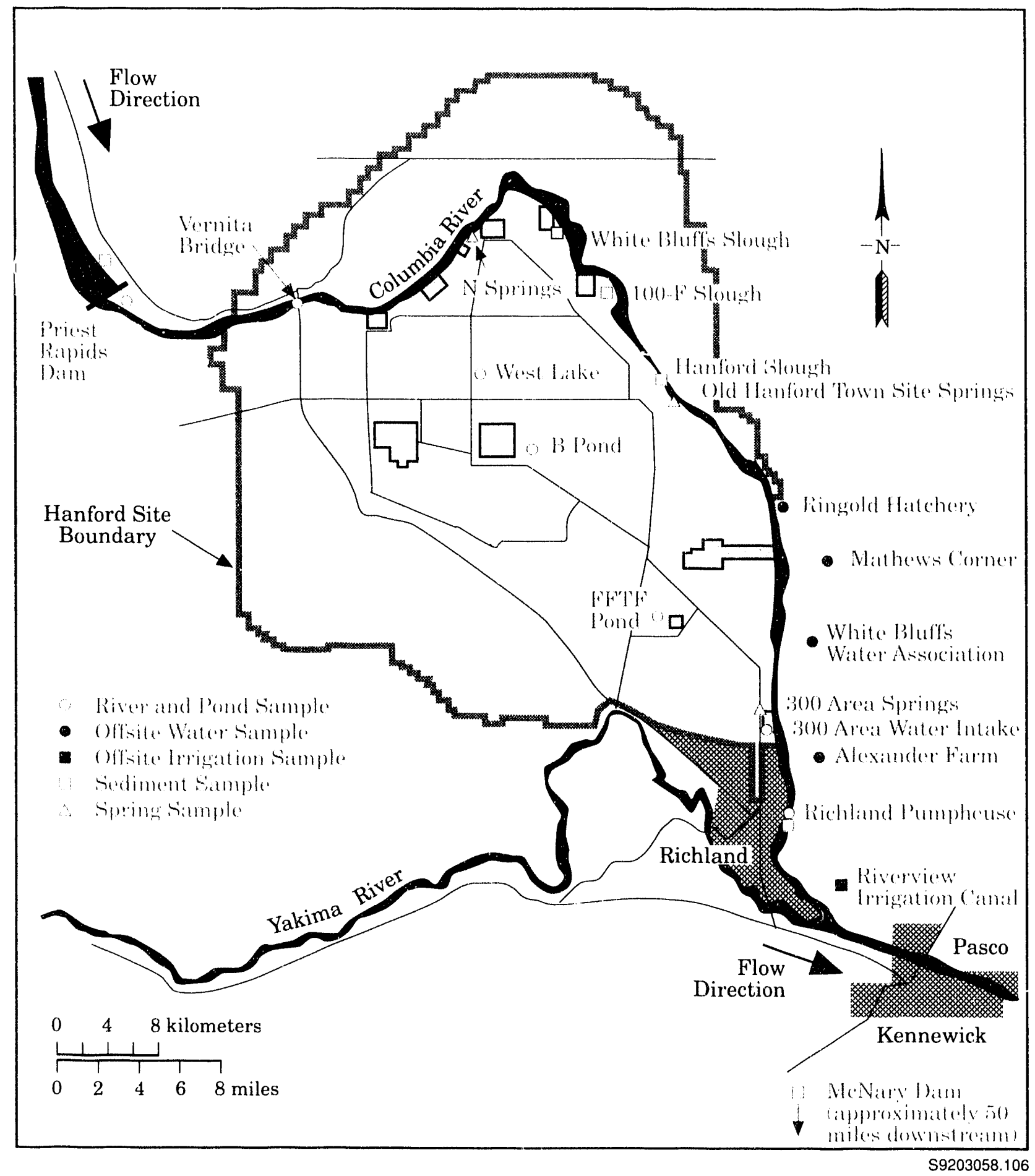

Figure 4.7. Onsite and Offsite Water and Sediment Sampling Locations, 1991 
Samples of Columbia River water were also collected by PNL from the shoreline near the Vernita Bridge and the Richland Pumphouse for analyses of various nonradiological water quality parameters. Analyses performed during 1991 included $\mathrm{pH}$, nitrate, total coliform and fecal coliform bacteria, and biological oxygen demand. All of these parameters are indicators of the quality of Columbia River water.

In addition to monitoring conducted by PNL, nonradiological water quality measurements were also taken by the U.S. Geological Survey (USGS) at Vernita Bridge and Richland (USGS 1988). The USGS samples were collected every 2 months at Vernita Bridge and quarterly at Richland. Analyses for numerous physical, biological, and chemical constituents were performed at the USGS laboratory in Denver, Colorado. In addition to sampling, the USGS provided continuous river temperature monitoring, both upstream of the Site and at Richland, and provided flow rate measurements at Priest Rapids Dam.

Annual samples of Columbia River sediment were collected during 1991 at locations shown in Figure 4.7. Offsite sanıples were collected upstream of the Hanford Site behind Priest Rapids Dam, below the Site at Richland, and approximately 50 miles downstream of the Site at McNary Dam. Samples were also collected along the Hanford Reach from sloughs at White Bluffs, 100-F Area, and the Hanford townsite. Samples were obtained from approximately $15 \mathrm{~cm}$ ( $6 \mathrm{in}$.) of the top sediment material using a dredge sampler. Analyses of the sediment samples include

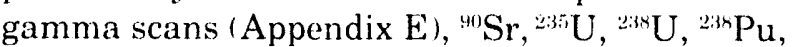
and ${ }^{2342,240} \mathrm{Pu}$.

\section{Radiological Results for River Water}

Results of the radiological analyses of Columbia River water samples collected at Priest Rapids Dam, the 300 Area, and the Richland Pumphouse during 1991 are contained in Bisping (1992). Significant results are discussed and illustrated in the following paragraphs, with comparisons to previcus years provided. Levels throughout the year were extremely low, essentially undetectable without the use of special sampling techniques and sensitive analytical procedures. Radionuclides consistently measurable in river water during 1991 were ${ }^{3} \mathrm{H},{ }^{91} \mathrm{Sr},{ }^{234} \mathrm{U},{ }^{2335} \mathrm{U}$, and ${ }^{2: 34} \mathrm{U}$. Tritium and "Sr exist in worldwide fallout, as well as in effluents from Hanford facilities. Uranium, as well as ${ }^{3} \mathrm{H}$, occurs naturally in the environment in addition to being present in Hanford effluents.

Total alpha and total beta measurements are useful indicators of the general radiological quality of the river and provide an early indication of changes in the levels of radioactive contamination. The 1991 average alpha and beta concentrations in Columbia River water at Priest Rapids Dam, the 300 Area, and the Richland Pumphouse were approximately $5 \%$ of the applicable DWS of 15 and $50 \mathrm{pCi} / \mathrm{L}$, respectively. Figures 4.8 and 4.9 iliustrate the annual average total alpha and total beta concentrations, respectively, at Priesi Rapids Dam and the Richland Pumphouse during the past 6 years. The 1991 alpha concentrations were similar to those previously reported. T'otal beta concentrations during 1991 were also similar to those observed during recent years. Statistical analyses (paired sample comparison and t test of differences) of alpha and beta concentrations at Priest Rapids Dam and the Richland Pumphouse indicated the differences

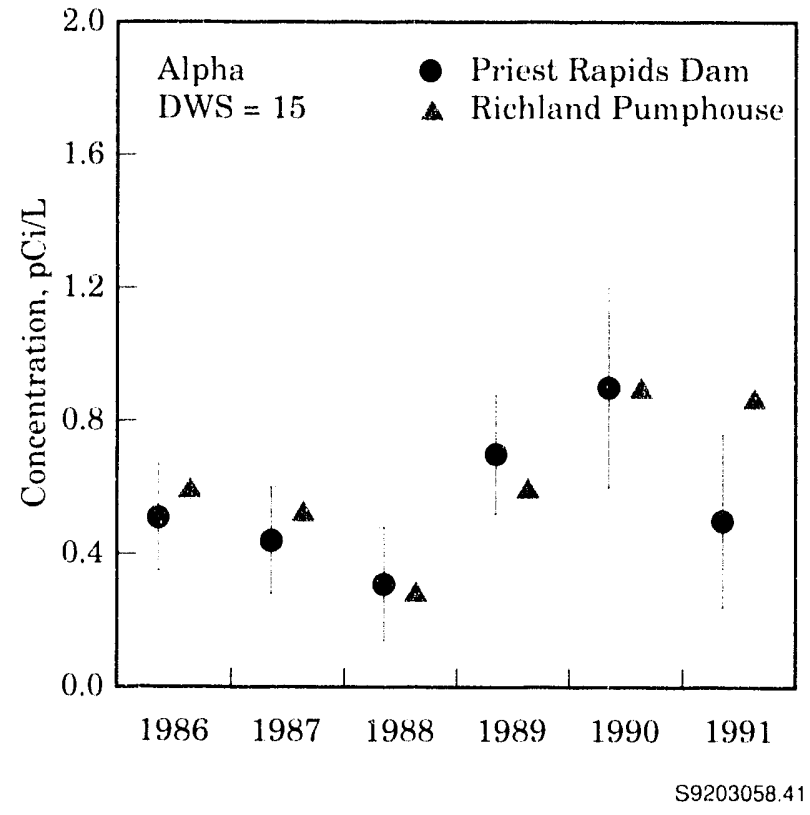

Figure 4.8. Annual Average Total Alpha Concentrations in Columbia River Water, 1986 Through $199 \mathrm{i}$ 


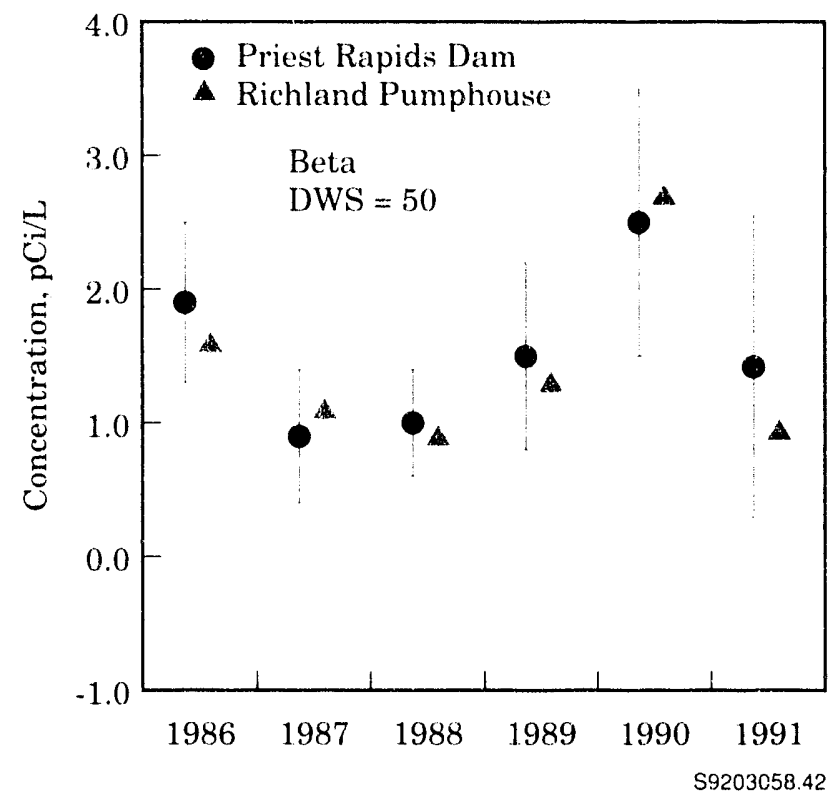

Figure 4.9. Annual Average Total Beta Concentrations in Columbia River Water, 1986 Through 1991

were not significant ( $5 \%$ significance level) (Snedecor and Cochran 1980).

Annual average ${ }^{3} \mathrm{H}$ concentrations at Priest Rapids Dam and the Richland Pumphouse during 1991 were $45 \mathrm{pCi} / \mathrm{L} \pm 4 \%$ and $112 \mathrm{pCi} / \mathrm{L} \pm 21 \%$, respectively. Figure 4.10 compares the annual average ${ }^{3} \mathrm{H}$ concentrations at Priest Rapids Dam and the Richland Pumphouse from 1986 through 1991. Tritium concentrations in Columbia River water continued to decline during 1991. Tritium concentrations are decreasing more rapidly than expected solely as a result of radioactive decay (12-year half-life). Studies conducted following the U.S. Pacific nuclear weapons tests indicated that the effective residence time of tritium deposited on the North American continent is approximately 5.7 years (NCRP 1979). The difference between the ${ }^{3} \mathrm{H}$ concentrations at Priest Rapids Dam and the Richland Pumphouse was significant (paired sample comparison, $t$ test of differences, $5 \%$ significance level). Tritium sources entering the river were effluent releases from the 100-N Area and ground-water seepage into the river along the Site (see "Effluent Monitoring," Section 4.1, and "Ground-Water Protection and

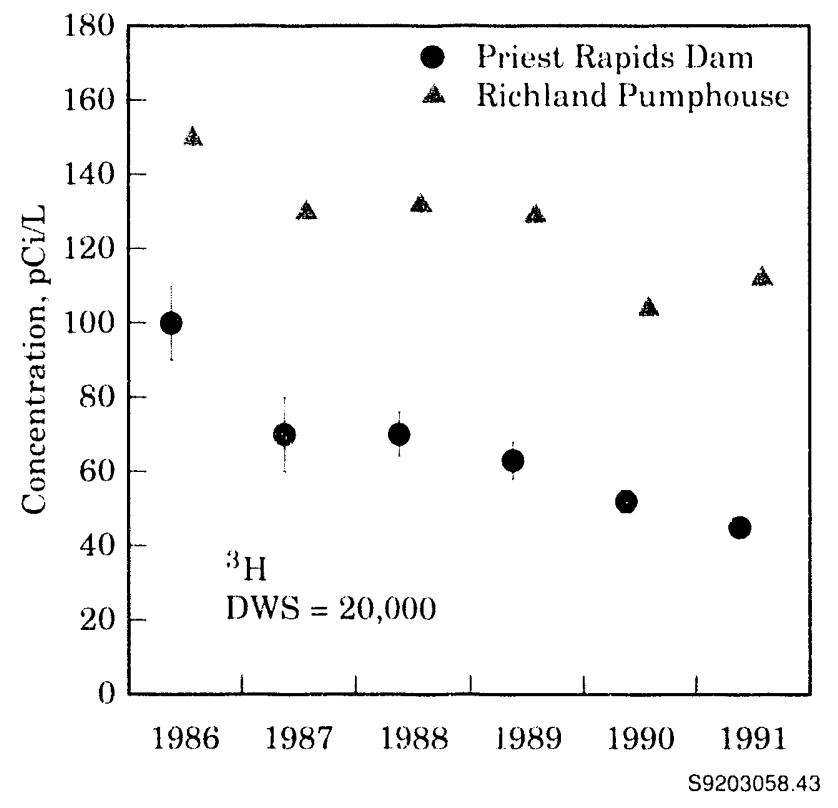

Figure 4.10. Annual Average Tritium ( $\left.{ }^{3} \mathrm{H}\right)$ Concentrations in Columbia River Water, 1986 Through 1991. As a result of figure scale, some uncertainties (error bars) are concealed by point symbol.

Monitoring Program," Section 5.0). All "H concentrations were $1 \%$ or less of the State of Washington and EPA DWS of $20,000 \mathrm{pCi} / \mathrm{L}$.

Annual average "Sr concentrations at Priest Rapids Dam and the Richland Pumphouse during 1991 were $0.09 \mathrm{pCi} / \mathrm{L} \pm 24 \%$ and $0.09 \mathrm{pCi} / \mathrm{L} \pm 23 \%$, respectively. Figure 4.11 shows the annual average ${ }^{9} \mathrm{Sr}$ concentrations at these locations from 1986 through 1991, indicating a slight decline over the years. The difference between the " $\mathrm{Sr}$ concentrations throughout the year at these locations was not significant (at the 5\% significance level). The primary source of "Sr attributable to Hanford entering the Columbia River has been the 100-N Area liquid waste disposal facilities, which are known to discharge to the river via ground-water seepage. Strontium-90 concentrations in Columbia River water during 1991 remained below the State of Washington and EPA DWS of $8 \mathrm{pCi} / \mathrm{L}$ (approximately $1 \%$ ).

Annual average uranium concentrations in river water during 1991 at the Richland Pumphouse and Priest Rapids Dam were similar. Annual average uranium concentrations at the Richland 


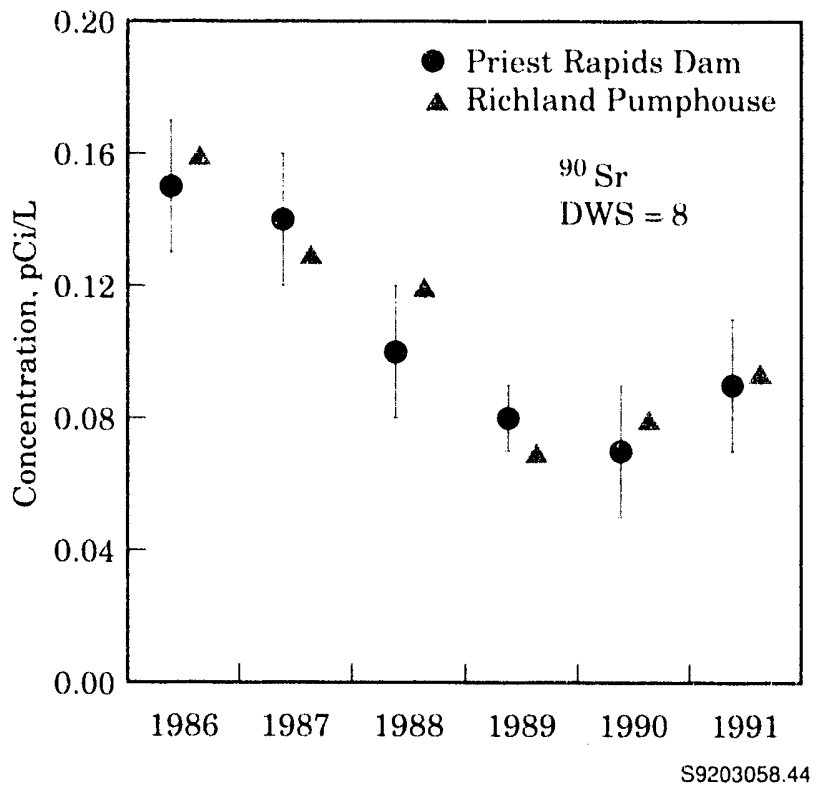

Figure 4.11. Annual Average Strontium-90 $\left({ }^{90} \mathrm{Sr}\right)$ Concentrations in Columbia River Water, 1986 Through 1991

Pumphouse and Priest Rapids Dam for 1986 through 1991 are shown in Figure 4.12. There was no consistently measurable contribution to Columbia River water uranium concentrations at the Richland Pumphouse attributable to Hanford operations. Differences during the year were not statistically significant (5\% significance level). Although there is no direct discharge of uranium to the river, uranium is present in the ground water beneath the 300 Area as a result of past operations (see "Ground-Water Protection and Monitoring Program," Section 5.0) and has been detected at elevated levels in riverbank springs in this area (Dirkes 1990; McCormack and Carlile 1984). There is currently no DWS directly applicable to uranium. However, uranium concentrations in the river during 1991 were below those that would result in doses exceeding the State of Washington and EPA DWS of $4 \mathrm{mrem} /$ year, which is applicable to anthropogenic radionuclides.

During 1991, ${ }^{61} \mathrm{Co},{ }^{99} \mathrm{Tc},{ }^{1066} \mathrm{Ru},{ }^{131} \mathrm{I},{ }^{134} \mathrm{Cs}$, and ${ }^{137} \mathrm{Cs}$ were not consistently found in measurable quantities in the Columbia River at Priest Rapids Dam, the 300 Area water intake, or the Richland Pumphouse. The approximate minimum detectable concentrations (see Appendix B) for ${ }^{67} \mathrm{Co}$, ${ }^{99} \mathrm{Tc}$,

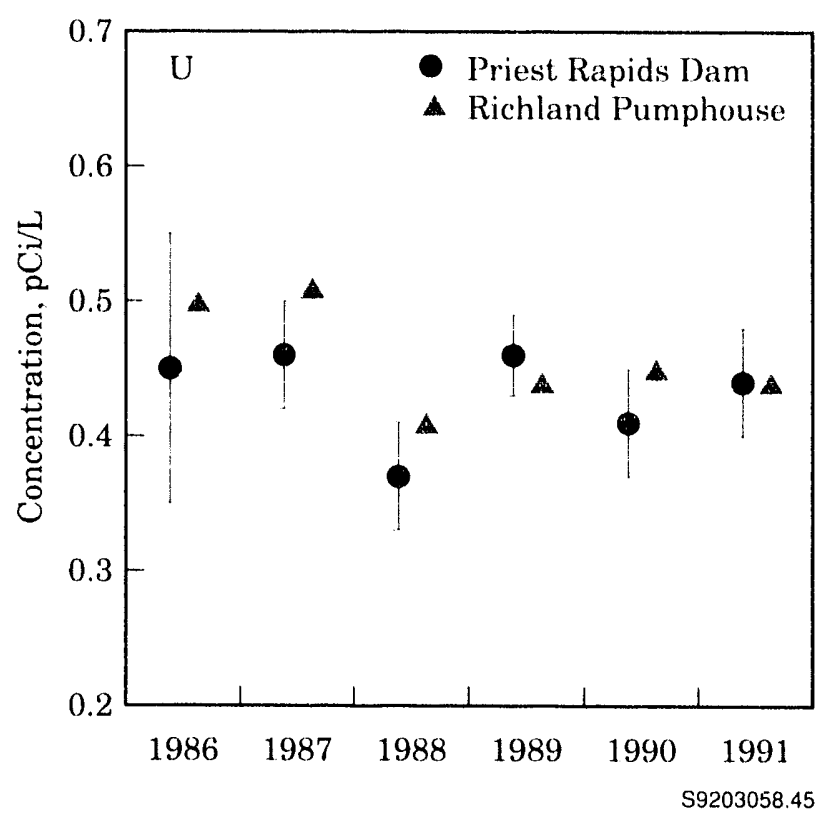

Figure 4.12. Annual Average Uranium Concentrations in Columbia River Water, 1986 Through 1991

\footnotetext{
${ }^{106} \mathrm{Ru},{ }^{131} \mathrm{I},{ }^{134} \mathrm{Cs}$, and ${ }^{137} \mathrm{Cs}$ during 1991 were 1.5 , $0.5,10.0,1.0,1.5$, and $1.5 \mathrm{pCi} / \mathrm{L}$, respectively.
}

Filter/resin water samples were not submitted for analyses during 1991, as in 1990, because of limitations in the availability and capability of analytical resources. Iodine-129, the primary radionuclide of interest measured by these samples, enters the river along the Hanford Site through the seepage of contaminated ground water (Dirkes 1990; McCormack and Carlile 1984). Similarly, ${ }^{239,2410} \mathrm{Pu}$ concentrations are obtained from filter/resin collection systems. No annual average ${ }^{129} \mathrm{I}$ or ${ }^{239,240} \mathrm{Pu}$ concentrations were avail. able to be reported as a result of the limitations in the availability and capability of analytical services.

\section{Nonradiological Results for River Water}

Nonradiological water quality data were compiled by PNL and the USGS during 1991. As a result of a quality assurance (QA) audit, which identified QA problems within the analytical laboratory used by PNL, samples collected by PNL were discontinued during August 1991. Further 
evaluation of the laboratory practices determined past data to be reliable; however, no data were obtained during the latter half of 1991. A number of parameters measured have no regulatory limits. These parameters are, however, useful as indicators of water quality. Specific water quality measurement results are reported in Bisping (1992). In 1991, the PNL and USGS results were in agreement and were comparable to results from recent years. Applicable standards for Class Adesignated water were met. There was no indication during 1991 of any deterioration of the water quality along this stretch of the Columbia River resulting from Hanford operations. Potential sources of pollutants not associated with Hanford include irrigation return water and seepage associated with extensive irrigation north and east of the Columbia River.

Figure 4.13 shows Vernita Bridge and Richland results for the period 1986 through 1991 for several water quality parameters with respect to the applicable standards. The $\mathrm{pH}$ measurements above and below the Site were in close agreement and were within the acceptable range for Class A waters. Turbidity, fecal coliform, and dissolved oxygen concentrations during 1991 were in compliance with Class A requirements at both locations as well.

The annual average flow rate of the Columbia River was $3,990 \mathrm{~m}^{3} / \mathrm{s}$ (141,000 cfs) during 1991, slightly higher than those of recent years. The monthly average flow rates at Priest Rapids Dam are shown in Figure 4.14. The peak monthly average flow occurred during June $\left(5,380 \mathrm{~m}^{3 / 3} \mathrm{~s}\right.$, $190,000 \mathrm{cfs}$ ), and the lowest average monthly flow occurred during September $\left(2,390 \mathrm{~m}^{3} / \mathrm{s}, 84,400\right.$ cfs). Daily average flow rates varied from 1,595 to $6,710 \mathrm{~m} / 3 / \mathrm{s}(56,300$ to $237,000 \mathrm{cfs})$ during 1991 .

Average monthly Columbia River water temperatures at Priest Rapids Dam and the Richland Pumphouse are shown in Figure 4.15. The major source of heat to the Columbia River in the Hanford Reach is solar radiation (Dauble et al. 1987). River temperatures and the differences between Priest Rapids Dam and the Richland Pumphouse temperatures during 1991, in the absence of reactor operations, were similar to those in the past (Price 1986). Monthly average temperatures were higher at the Richland Pumphouse than at Priest Rapids Dam from March through August
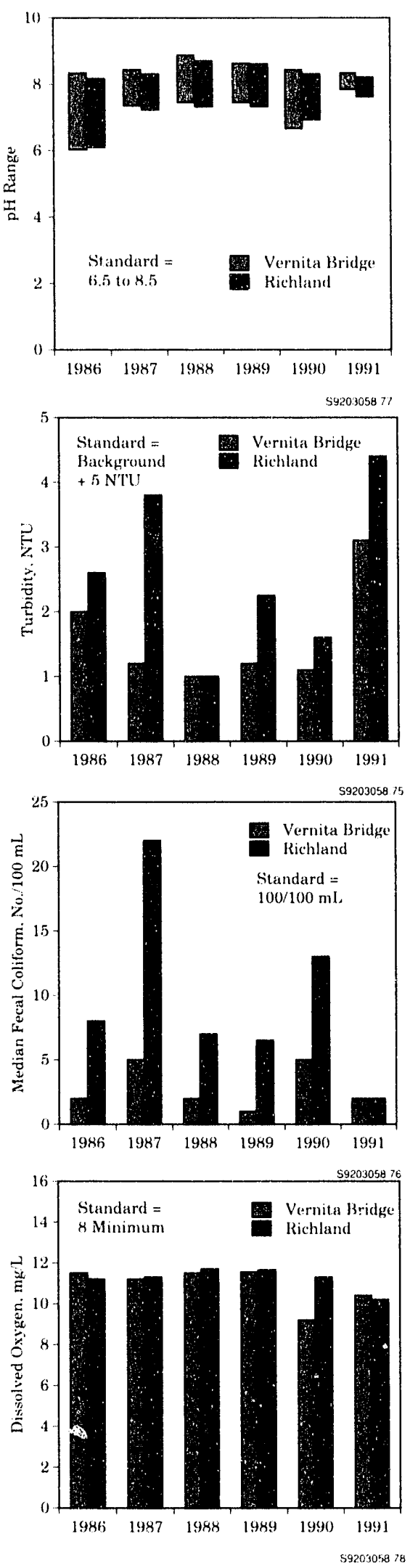

Figure 4.13. Columbia River Water Quality Measurements, 1986 Through 1991 


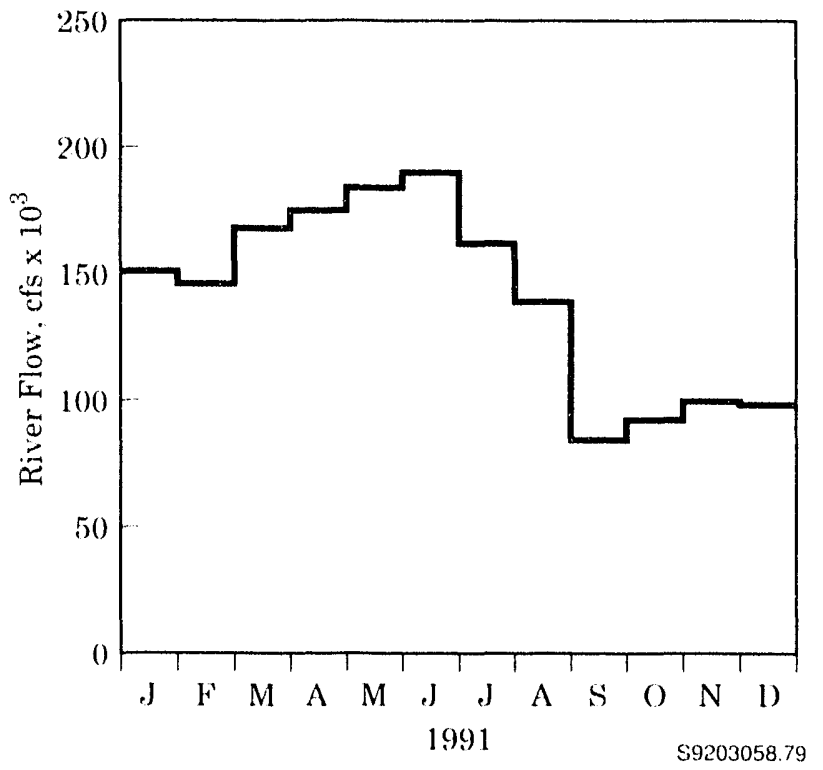

Figure 4.14. Monthly Average Columbia River Flow Rates During 1991 (measured at Priest Rapids Dam)

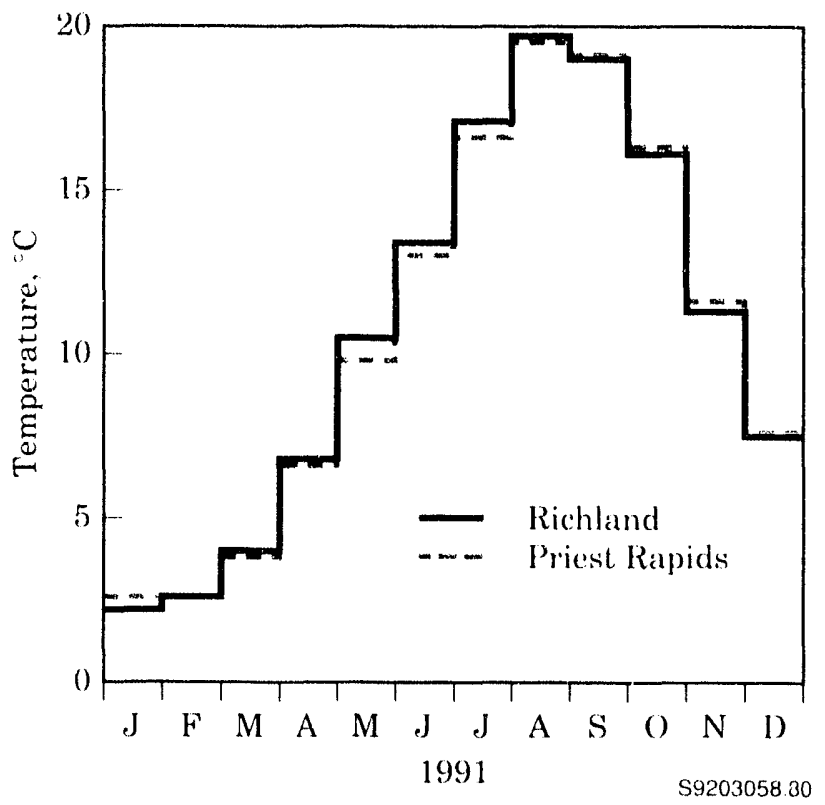

Figure 4.15. Monthly Average Columbia River Water Temperatures During 1991

1991. Cooler monthly average temperatures were observed at the Richland Pumphouse during September through January. Monthly average temperatures were the same during February.
Temperatures along the Hanford Reach were in compliance with applicable state Class A water quality requirements during the year.

\section{Radiological Results for Sediments}

Surface sediments in the Columbia River are known to contain low levels of radionuclides of Hanford origin and from nuclear weapons testing fallout (Beasley 1981; Robertson and Fix 1977; Woodruff et al. 1991). Analytical results for surface sediment (top $15 \mathrm{~cm}$ ) samples collected during 1990 and 1991 are reported in Bisping (1992). Results for 1990 are included in the 1991 report because they were not available for the 1990 report.

In general, the level of radioactivity in surface sediments behind McNary Dam was slightly higher than that behind Priest Rapids Dam during 1990 and 1991. Radionuclide concentrations in sediments collected from the sloughs along the Hanford Reach and at Richland were generally comparable to those observed upstream of Hanford at Priest Rapids Dam. The exception to this is uranium, which is present in sediments along the Hanford Reach at levels comparable to those at McNary Dam.

Figure 4.16 shows the concentrations of selected radionuclides in Columbia River sediment at Priest Rapids Dam and McNary Dam for 1989 through 1991. 'The concentrations of "ill $\mathrm{Co}$ during 1990 and 1991, which were below the detection level $(0.05 \mathrm{pCi} / \mathrm{g})$ in sediments behind Priest Rapids Dam, were highest in sediments collected from McNary pool. The levels of "ill $\mathrm{Co}$ in surface sediments behind McNary Dam have been relatively stable over the past 3 years. The concen-

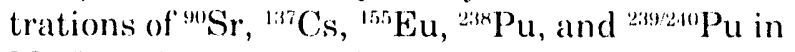
McNary Dam pool sediment are consistently slightly higher than at other sediment sample locations (Figure 4.7). The differences are very small, with the uncertainties in the concentrations at all locations generally overlapping.

\section{Riverbank Springs}

The seepage of ground water into the Columbia River has been known to occur for many years. Riverbank spring discharges were documented along the Hanford Reach long before the startup 

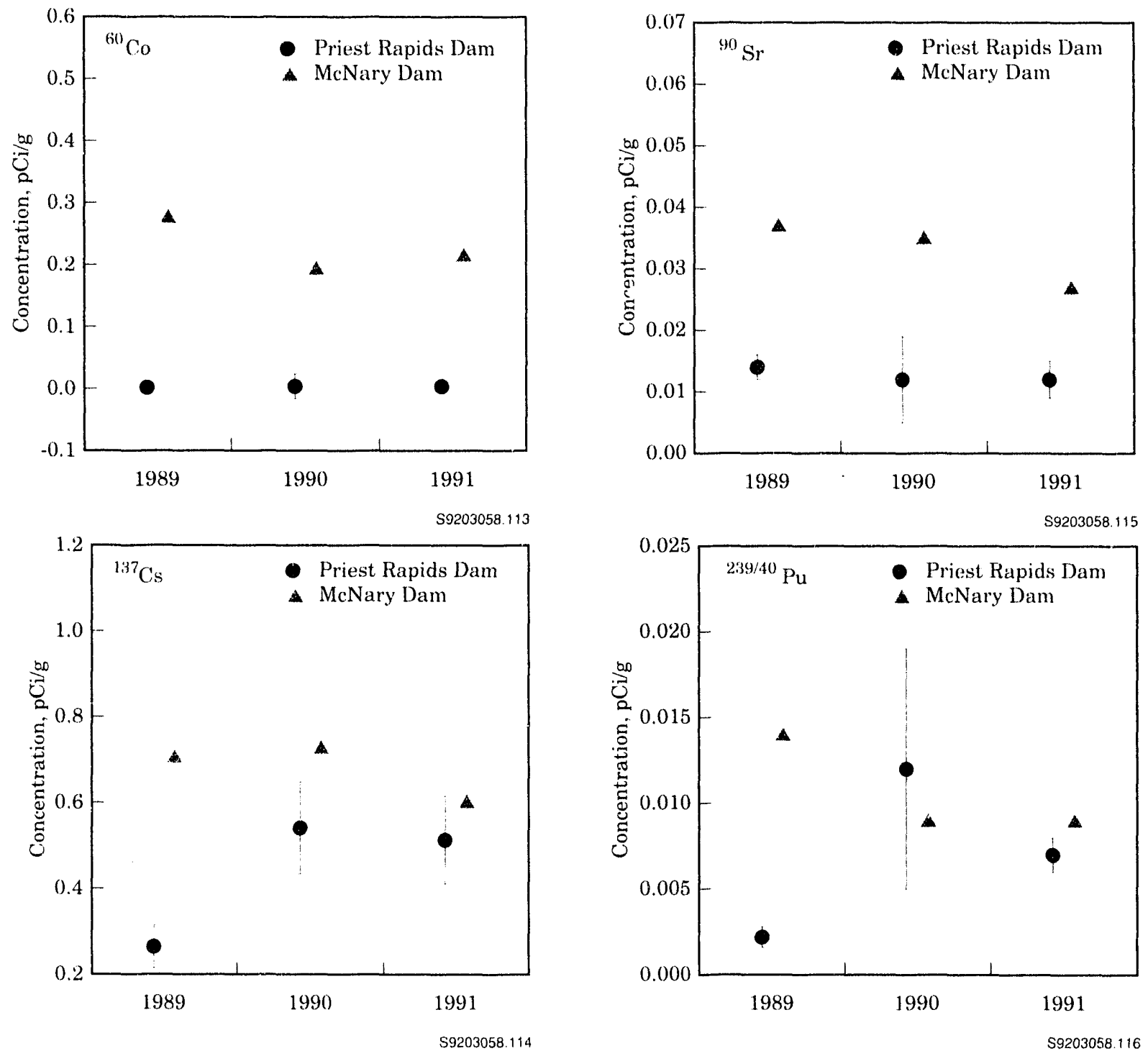

Figure 4.16. Radionuclide Concentrations in Columbia River Sediments at Priest Rapids Dam and McNary Dam, 1989 Through 1991. As a result of figure scale, some uncertainties (error bars) are concealed by point symbol.

of Hanford operations (Jenkins 1922). These relatively small springs flow intermittently, apparently influenced primarily by the changes in the river level. Contaminants associated with these ground-water discharges have been documented to enter the river along the Hanford Reach (Dirkes 1990; DOE 1992c; McCormack and Carlile 1984).

\section{Sample Collection and Analysis}

Samples of ground-water seepage were collected during 1991 at the locations identified in Figure 4.7. Sample collection methods are described in the Hanford Site Environmental Monitoring Plan (DOE 1991b). The analyses, limited to radiological constituents in 1991, were selected based on findings of previous riverbank spring investigations and reviews of contaminant concentrations observed in nearby ground-water monitoring wells. At a minimum, riverbank spring samples collected during 1991 were analyzed for total alpha, total beta, gamma scan, and ${ }^{3} \mathrm{H}$. Uranium, ${ }^{90} \mathrm{Sr}$, and ${ }^{19} \mathrm{Tc}$ analyses were included for those locations where these constituents are known to exist in the local ground water as a result of past operations at Hanford. 


\section{Results}

Hanford-origin contaminants were detected in spring water entering the Columbia River along the Hanford Site during 1991. The type and concentrations of contaminants in the spring water, reported in Bisping (1992), were similar to those known to exist in the ground water near the river as a result of past operations at Hanford. The location and extent of the contaminated discharges agreed with recent riverbank spring investigations, ground-water monitoring results, ground-water model predictions, and results of seep sampling conducted by others (DOE 1992c).

Radionuclide concentrations were below DOE Derived Concentration Guides (DCGs, see Appendix B), with the exception of "Sr near the 100-N Area. Tritium, while below the DCG, was detected at concentrations above the EPA DWS in several springs. All other radionuclide concentrations were below DWSs.

Figure 4.17 provides selected radionuclide concentrations in N Springs (Figure 4.7) for the years 1988 through 1991. Apparent in this figure is the general decrease in radionuclide concentrations during recent years. The concentration of "Sr was higher in 1991 than 1990; however, it remained below those observed in earlier years. The decrease is attributable to the closure of the 1301-N Liquid Waste Disposal Facility (LWDF) in 1985 and startup of the new 1325-N LWDF, which is located farther from the river. In addition, the volume of water discharged to the 1325-N LWDF was reduced as a result of the retired status of the $\mathrm{N}$ Reactor in 1987.

Concentrations of radionuclides of concern in the riverbank springs near the Hanford townsite for the years 1988 through 1991 are provided in Figure 4.18. The levels of contaminants observed in this seepage in recent years have been relatively consistent and comparable to those known to exist in the ground water near the river at this location as a result of past operations.

Figure 4.19 shows the concentrations of constituents of concern in the 300 Area riverbank springs from 1988 through 1991. In general, the levels have remained relatively stable in recent years. However, notable increases in the total alpha, ${ }^{3} \mathrm{H}$
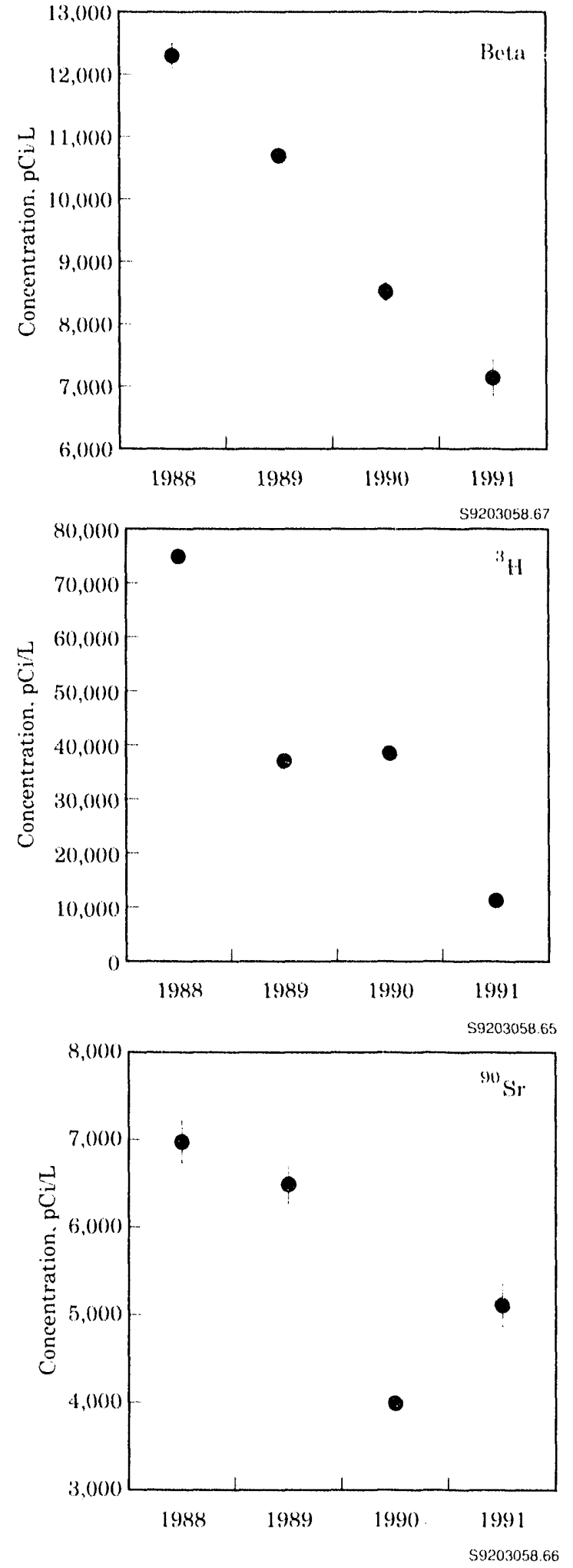

Figure 4.17. Radionuclide Concentrations in $\mathbf{N}$ Springs, 1988 Through 1991. As a result of figure scale, some uncertainties (error bars) are concealed by point symbol. 

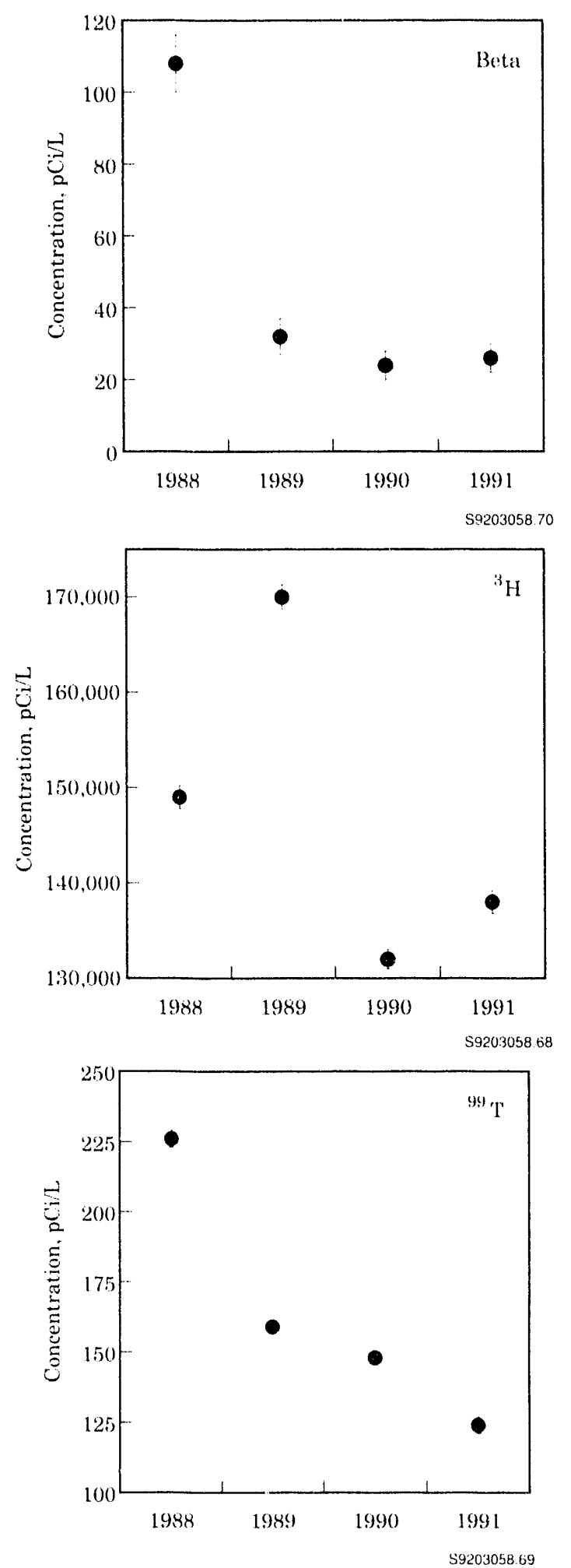

Figure 4.18. Radionuclide Concentrations in Riverbank Springs Near the Hanford Townsite, 1988 Through 1991. As a result of figure scale, some uncertainties (error bars) are concealed by point symbol. and uranium concentrations during 1991 are apparent. The increase in "H may be attributable to the expansion of the contaminated groundwater plume emanating from the 200 Areas. This plume reached the river just north of the 300 Area during recent years (Dirkes 1990). The concentration of uranium in the spring water during 1991 was within the range observed in the ground water beneath the 300 Area (Section 5.0) as a result of past operations in the 300 Area. The elevated alpha concentration is likely associated with the high concentration of uranium.

\section{Onsite Ponds}

Three onsite ponds (see Figure 4.7) located near operating areas were sampled periodically during 1991. B Pond, located near the 200-East Area, was excavated in the mid-1950s for disposal of process cooling water and other liquid wastes occasionally containing low levels of radionuclides. West Lake, located north of the 200-East Area, is recharged from ground water (Gephart et al. 1976). West Lake has not received direct effluent discharges from Site facilities. The Fast Flux Test Facility (FFTF) Pond, located near the 400 Area, was excavated in 1978 for the disposal of cooling and sanitary water from various facilities in the 400 Area.

Westinghouse Hanford Company is responsible for monitoring effluents discharged to the ponds and for operational surveillance of the ponds (Brown et al. 1990). Although the ponds were inaccessible to the public and did not constitute a direct offsite environmental impact during 1991, they were accessible to migratory waterfowl, creating a potential biological pathway for the dispersion of contaminants (see "Wildlife Surveillance," Section 4.5). Periodic sampling of the ponds also provided an independent check on effluent control and monitoring systems.

\section{Sample Collection and Analysis}

During 1991, grab samples were collected quarterly from each pond. Unfiltered aliquots were analyzed for total alpha and total beta activities, gamma-emitting radionuclides, " $\mathrm{H}$, and " $\mathrm{Sr}$. 

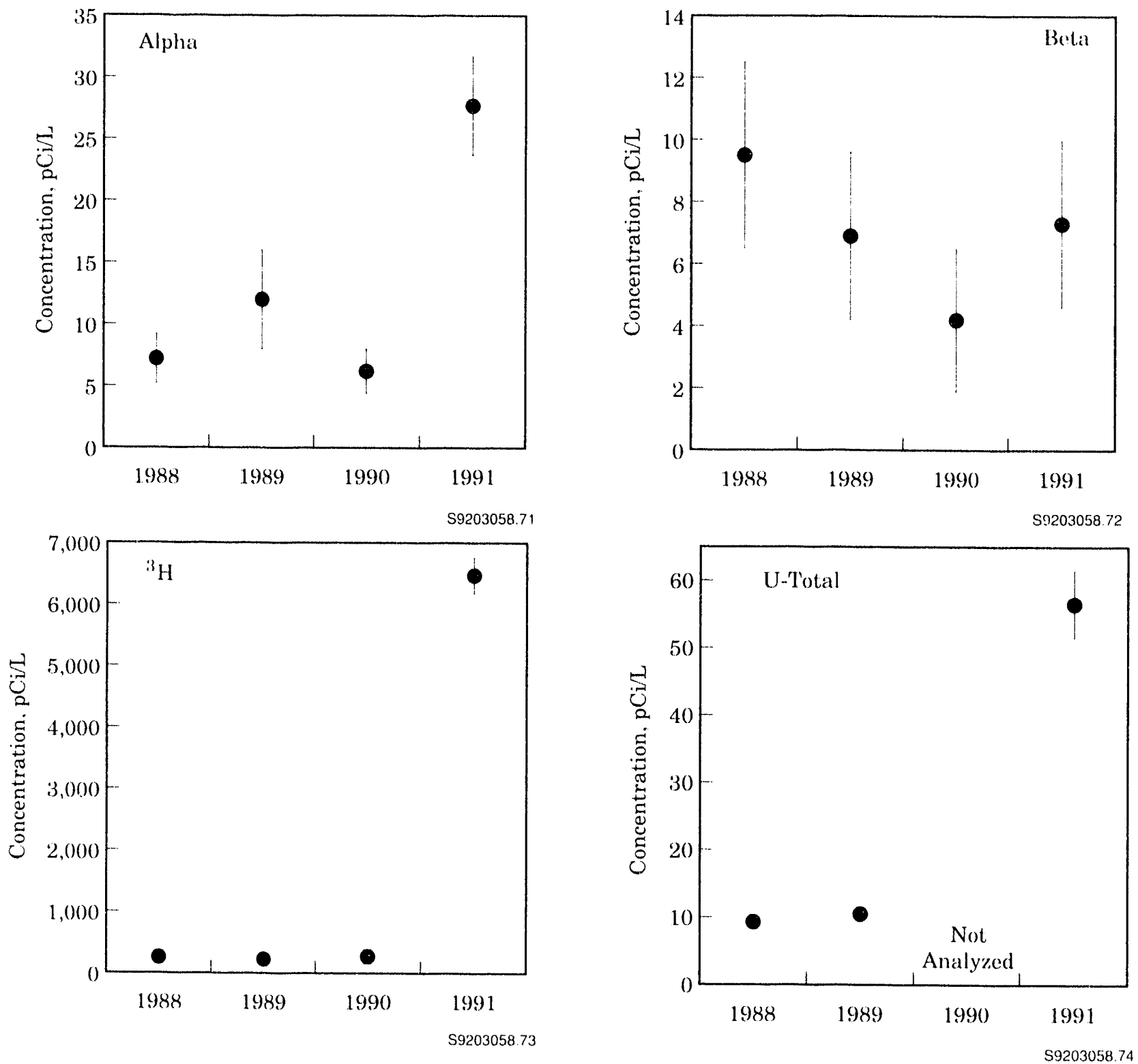

Figure 4.19. Constituents of Concern in 300 Area Riverbank Springs, 1988 to 1991. As a result of figure scale, some uncertainties (error bars) are concealed by point symbol.

\section{Results}

Analytical results from pond samples collected during 1991 are summarized in Bisping (1992). Maximum, minimum, and average concentration values are provided for various radionuclides in each pond. In all cases, radionuclide concentrations in onsite pond water were below applicable DCGs. Further discussion of individual constituents and comparisons with results obtained during previous years are provided below.
Annual average radionuclide concentrations in B Pond for the years 1986 through 1991 are shown in Figure 4.20. Radionuclide concentrations in B Pond water during 1991 were comparable to those observed during the previous 5 years. Total alpha and beta concentrations during the year were within the range observed during the previous 5 years and, as in past years, near the analytical detection limit. Concentrations of " $\mathrm{Sr}$ were comparable to those observed during the previous 5 years. Tritium concentrations in B Pond remained in the range observed 

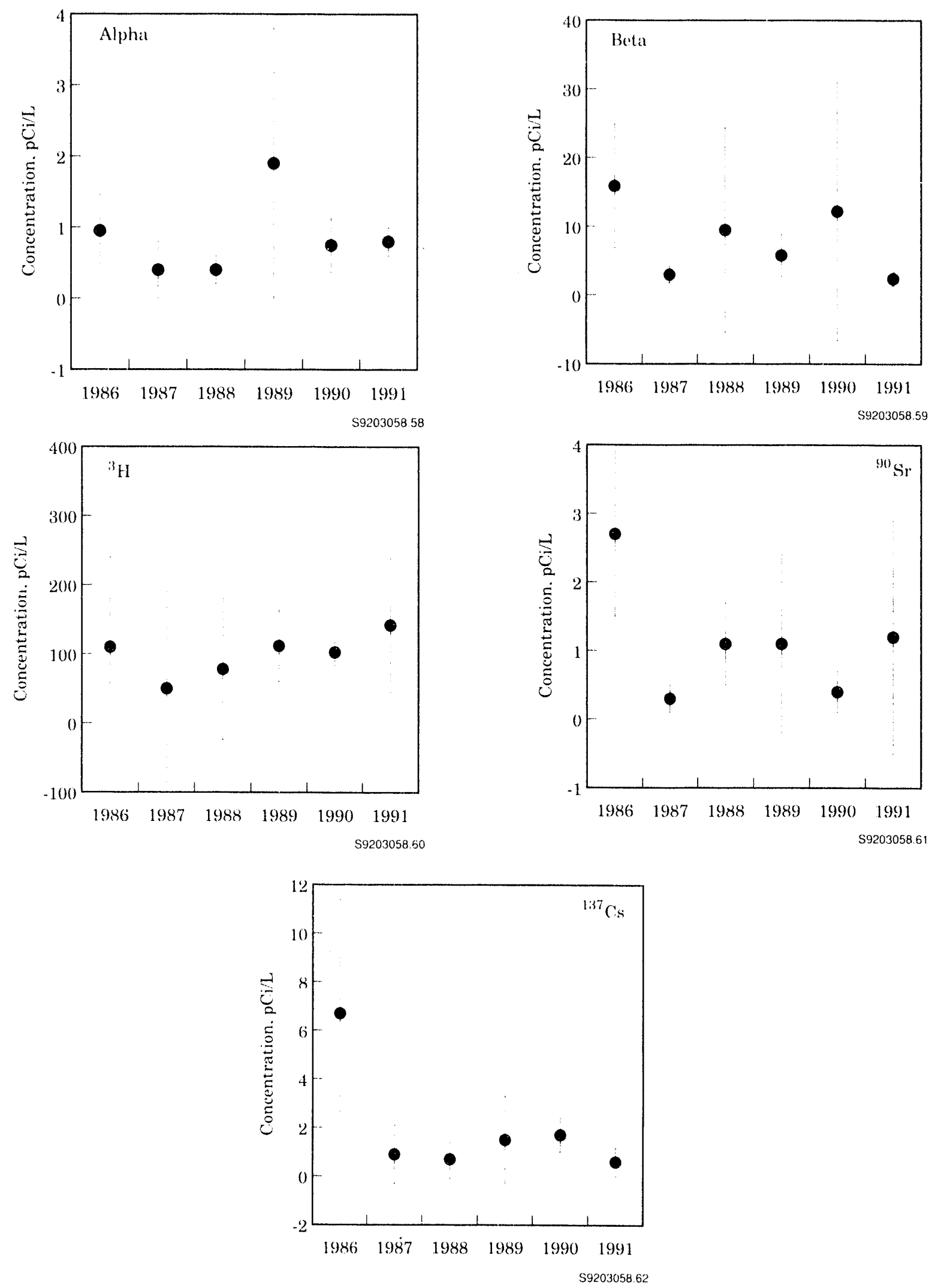

Figure 4.20. Annual Average Radionuclide Concentrations in B Pond, 1986 Through 1991 
during recent years. Cesium-137 concentrations were generally below the detection level, $1.5 \mathrm{pCi} / \mathrm{L}$, during 1991 and similar to recent years.

Figure 4.21 shows the annual average total beta and ${ }^{3} \mathrm{H}$ concentrations in FFTF Pond during the years 1986 through 1991. As in the past, total alpha, ${ }^{22} \mathrm{Na}$, and ${ }^{91} \mathrm{Sr}$ concentrations were below the detection levels $(1.5,6.0,0.06 \mathrm{pCi} / \mathrm{L}$, respectively) during the year. Total beta concentrations in FFTF Pond water were slightly lower than those reported during the previous 5 years. The concentrations of ${ }^{3} \mathrm{H}$ were comparable to those measured in FFTF Pond in the past. The tritium concentrations observed in FFTF Pond are indicative of the levels of tritium known to exist in the ground water beneath the 400 Area, from which the 400 Area obtains its water (Woodruff et al. 1991).

The 1986 through 1991 annual average contaminant concentrations in West Lake are shown in Figure 4.22. Average total alpha and total beta concentrations during 1991 were similar to those observed in the past. Total alpha and total beta concentrations in West Lake, which is recharged from ground water (Gephart et al. 1976), continued to be higher than the alpha and beta levels

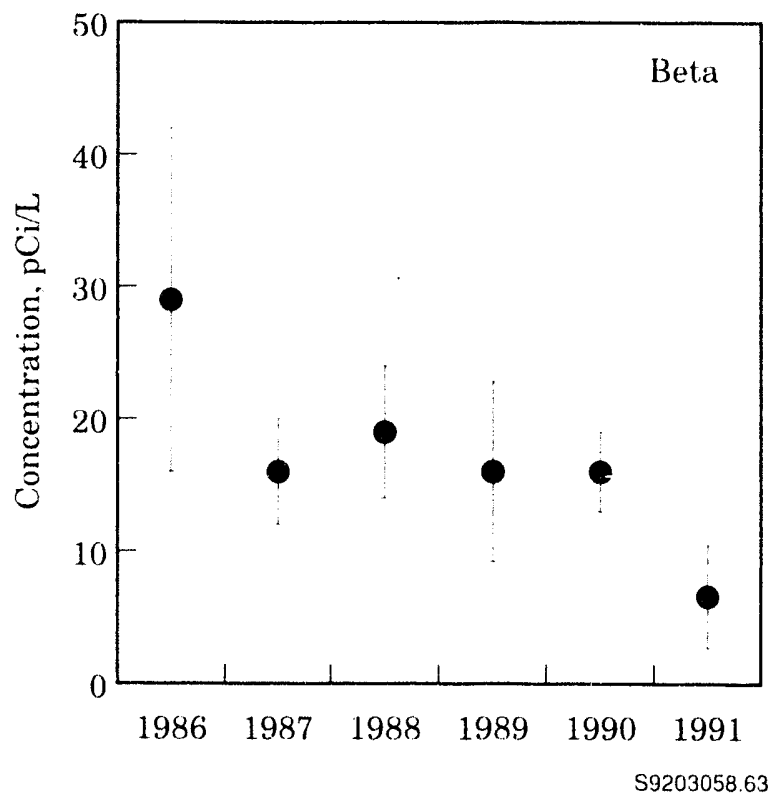

found in the other onsite ponds. These elevated levels are believed to result from high concentrations of naturally occurring uranium (Poston 1991; Speer et al. 1976). Annual average uranium concentrations were slightly elevated during 1991 and substantiate the elevated total alpha and total beta measurements. Strontium-90 concentrations during 1991 were higher than those observed during the previous 5 years, well within the range observed in the ground water near this pond. Tritium concentrations in West Lake, which have been decreasing in recent years, were the lowest observed in the past 6 years and remained similar to those observed in the local ground water. Gamma-emitting radionuclides remained below the analytical detection levels (approximately $1 \mathrm{pCi} / \mathrm{L}$ for ${ }^{6 i 1} \mathrm{Co}$ and ${ }^{137} \mathrm{Cs}$ ).

\section{Offsite Water}

Water samples were collected from four water systems directly east of and across the Columbia River from the Hanford Site during 1991. Samples were also collected from an irrigation canal that obtains water from the Columbia River downstream of Hanford. Sampling was conducted to document the levels of radionuclides in the water used by the public and as a result of public

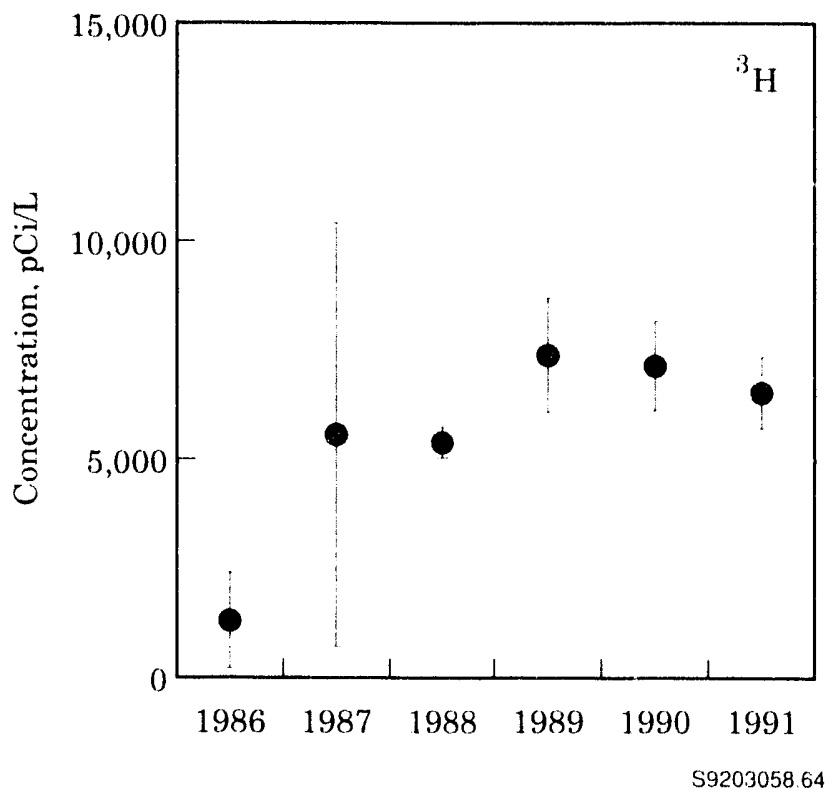

Figure 4.21. Average Total Beta and Tritium $\left({ }^{3} \mathrm{H}\right)$ Concentrations in FFTF Pond, 1986 Through 1991 

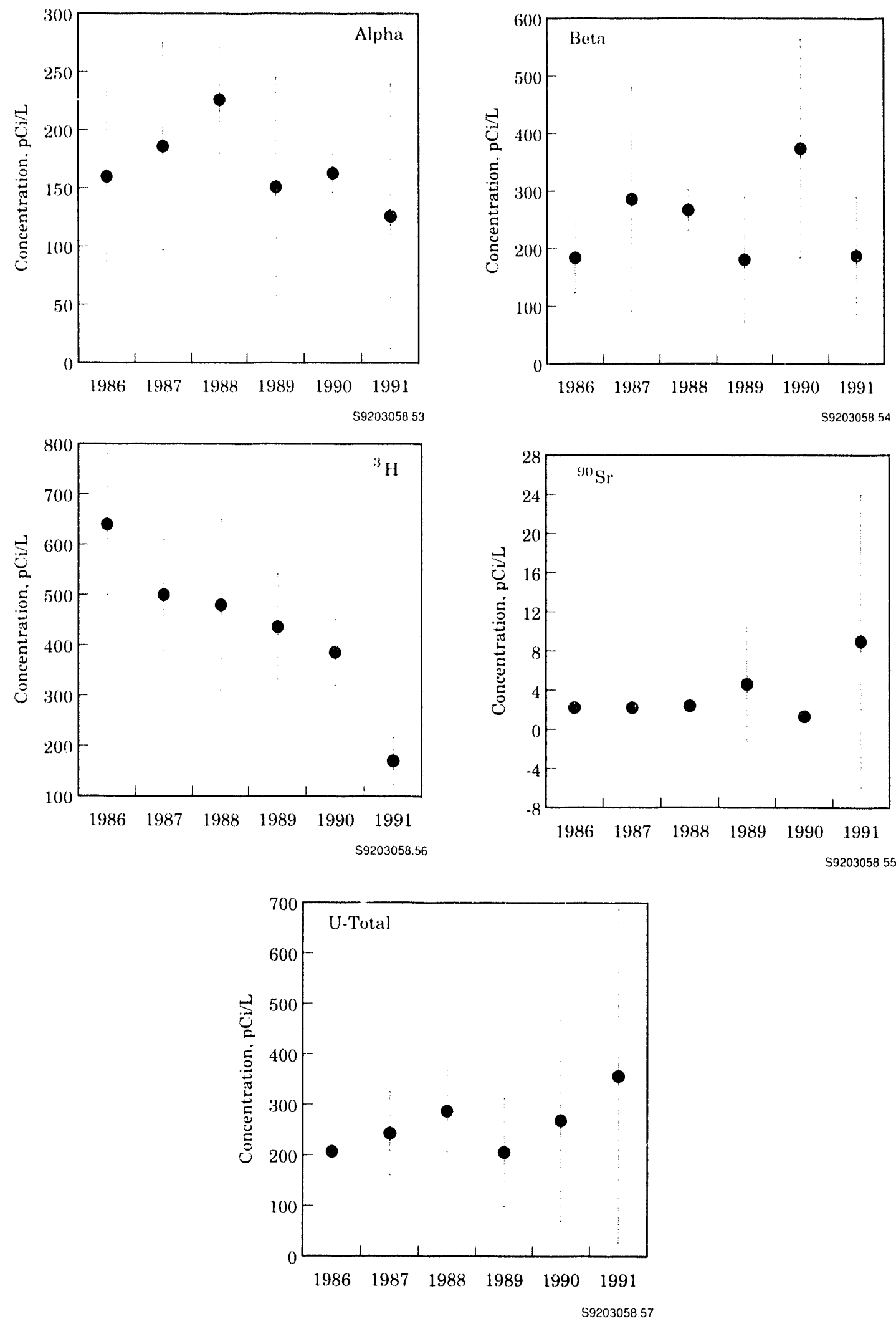

Figure 4.22. Annual Average Radionuclide Concentrations in West Lake, 1986 Through 1991. As a result of figure scale, some uncertainties (error bars) are concealed by point symbol. 
concerns about the potential for Hanfordassociated contaminants being present in offsite water. Consumption of food irrigated with Columbia River water from downstream of the Site has been identified as one of the primary pathways contributing to the dose to the hypothetical maximally exposed individual (Jaquish and Mitchell 1988I.

\section{Sample Collection, Analysis, and Results}

Grab samples were collected quarterly from four offsite domestic water supplies during 1991 I see Figure 4.7). Analyses of these samples included total alpha, total beta, gamma scan, ${ }^{3} \mathrm{H},{ }^{1299} \mathrm{I},{ }^{234} \mathrm{U}$, ${ }^{235} \mathrm{U}$, and ${ }^{2: 3 *} \mathrm{U}$. Results are presented in Bisping (1992). Alpha and beta concentrations are attributable to natural uranium concentrations in the ground water of this area. The concentrations observed in the offsite water supplies were comparable to those reported by the State of Washington (WDSHS 1987). Iodine-129 concentrations were within the range previously reported in offsite water. Annual average radionuclide concentrations in offsite water during 1991 were within applicable DWSs.

The Riverview irrigation canal was sampled three times during the irrigation season. These samples were analyzed for total alpha, total beta, gamma emitters, ${ }^{3 \prime} \mathrm{Sr},{ }^{234} \mathrm{U},{ }^{23.5} \mathrm{U}$, and ${ }^{234} \mathrm{U}$. Results are presented in Bisping (1992). Strontium-90 was the radionuclide of most concern because it has been identified as one of the primary contributors to the calculated hypothetical dose to the public via the water pathway (Jaquish and Bryce 1989). The average concentration of "'Sr during $1991,0.07( \pm 29 \%) \mathrm{pCi} / \mathrm{L}$, was similar to that reported for the Columbia River at Priest Rapids Dam and the Richland Pumphouse. 


\subsection{Food and Farm Product Surveillance}

Alfalfa and a number of foodstuffs, including milk, vegetables, fruits, wine, wheat, beef, chickens, and eggs, were collected at several locations surrounding the Hanford Site (Figure 4.23). Samples were collected primarily from locations in the prevailingly downwind directions (south and east of the Site) where airborne effluents from Hanford could be expected to be deposited. Samples were also collected in generally upwind directions somewhat distant from the Site to provide information on background radioactivity. This section describes sample collection and the radiological analyses perforn.ed and summarizes results. Detailed analytical results are available in Bisping (1992). The potential dose to members of the public from the consumption of local food and farm products is addressed in Section 4.8, "Potential Radiation Doses from 1991 Hanford Operations." Results for liquids are reported in $\mathrm{pCi} / \mathrm{L}$, plant material in $\mathrm{pCi} / \mathrm{g}$ dry weight, and animal products in $\mathrm{pCi} / \mathrm{g}$ wet weight. Many samples had concentrations that were less than detectable. In those cases, an upper limit is reported; there is a $\sim 98 \%$ probability that the actual value is less than the upper limit.

The program is designed to sample several downwind locations for comparison to generally upwind or distant locations (Figure 4.23). This sampling approach provides the basis for addressing the potential influence of Hanford Site releases. Specific details of the sampling design including location and radionuclides analyzed are reported in Bisping (1991) and DOE (1991) and have been summarized in Table 4.12. Gamma scans and ${ }^{90} \mathrm{Sr}$ analyses were routinely performed for nearly all products. Selected farm products were specifically analyzed for additional radionuclides including ${ }^{3} \mathrm{H},{ }^{129} \mathrm{I},{ }^{131} \mathrm{I}$, ${ }^{99} \mathrm{Tc}$, uranium, and plutonium.

\section{Milk}

\section{Sample Collection and Analysis}

Samples of raw, whole milk were collected from East Wahluke and Sagemoor area dairy farms near the Site perimeter in the prevailingly downwind directions to evaluate possible Hanford impacts (Figure 4.23). Milk samples were also collected from dairy farms near Sunnyside and Moses Lake to indicate the general background concentrations of radionuclides. Samples were routinely collected every other week throughout the year from the Sagemoor and Sunnyside areas, and monthly from other areas. A talysis of 1991 samples by the analytical laboratory started in February 1991. Some early samples of milk. collected in January 1991 were not analyzed for ${ }^{131}$ I because of its short half-life and the length of time the samples had been archived.

Tritium analyses were conducted on one sample per month, ${ }^{90} \mathrm{Sr}$ analyses were conducted on one sample per quarter, and ${ }^{129} \mathrm{I}$ analyses were condicted on two biannual composite samples. Gamma scans of milk were performed on samples from each location at frequencies varying from biweekly to quarterly.

\section{Results}

Iodine- 129 contributed about $30 \%$ of the dose to the maximum exposed individual (MEI) through the consumption of food products (see Section 4.8 ). Iodine-129 was identified by highresolution mass spectroscopy in all 8 samples tested. In recent years, the levels of ${ }^{129} \mathrm{I}$ in milk collected from Sagemoor and East Wahluke (downwind locations) have persisted at levels 2 to 4 times greater than levels measured in Sunnyside (Figure 4.24); however, concentrations 


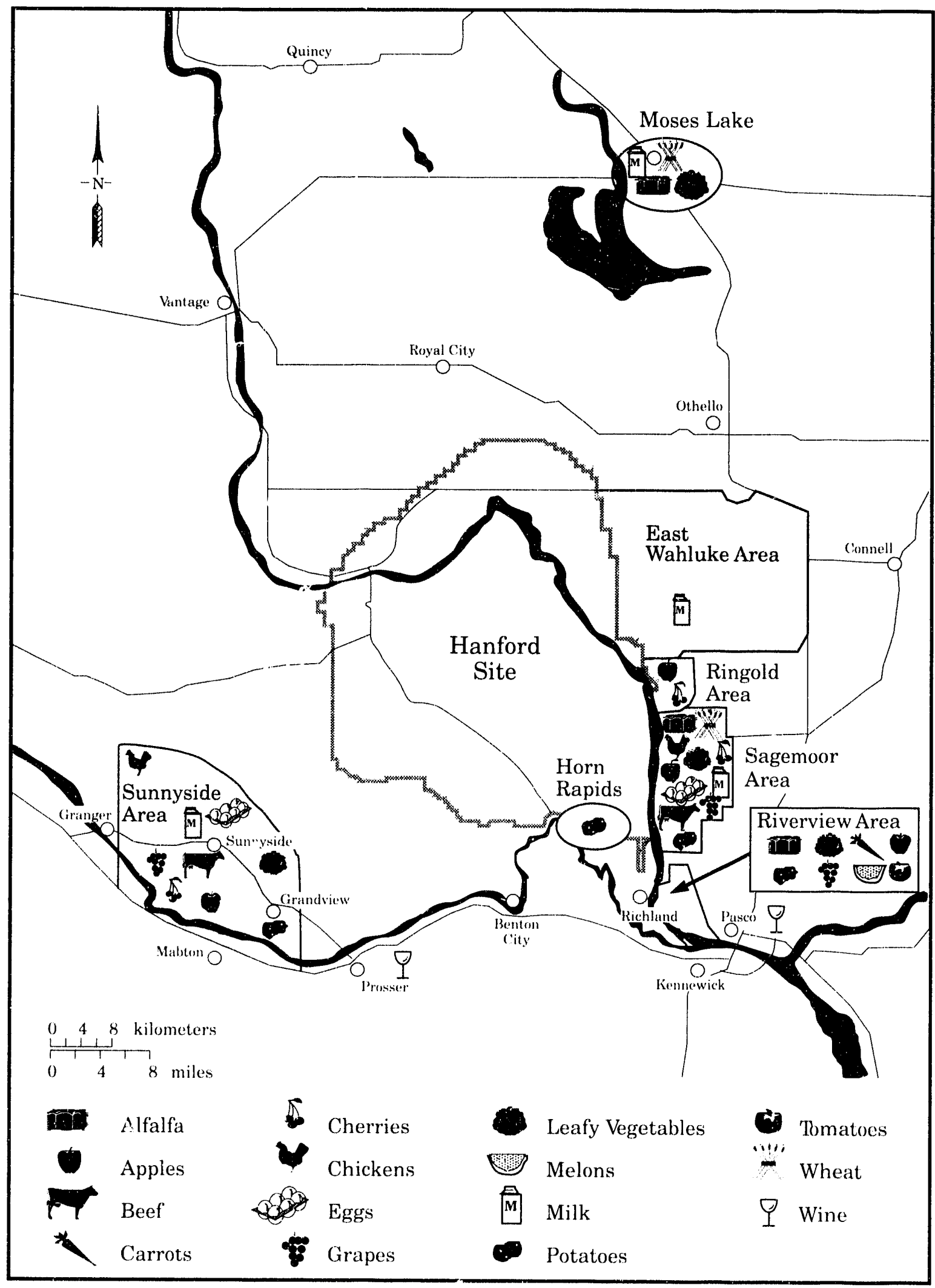

S9203058.12b

Figure 4.̇̇̇. Food and Farm Product Sampling Locations, 1991 
Table 4.12. Numbers of Locations, Sampling Frequency, and Analyses Performed for Food and Farm Products for $1991^{(a)}$

\begin{tabular}{|c|c|c|c|c|c|c|c|c|c|c|}
\hline \multirow[b]{2}{*}{ Media } & \multicolumn{2}{|c|}{ Number of Locations } & \multirow{2}{*}{$\begin{array}{l}\text { Sampling } \\
\text { Frequency }\end{array}$} & \multicolumn{7}{|c|}{ Number of Locations Analyzed } \\
\hline & Upwind & Downwind & & ${ }^{3} \mathrm{H}$ & Gamma & ${ }^{90} \mathrm{Sr}$ & ${ }^{99} \mathrm{Tc}$ & $129,131 \mathrm{I}$ & $\underline{\mathrm{U}}$ & $\mathrm{Pu}$ \\
\hline Milk & 2 & 2 & $\mathrm{M}, \mathrm{Q}$, or $\mathrm{SA}$ & 4 & 4 & 4 & 0 & 4 & 0 & 0 \\
\hline $\begin{array}{l}\text { Eggs, Meat } \\
\text { and Poultry }\end{array}$ & 1 & 2 & $\mathrm{SA}$ or $\mathrm{A}$ & 0 & 3 & 3 & 0 & 0 & 0 & 0 \\
\hline Vegetables & 2 & 3 & A & 0 & 5 & 5 & 4 & 2 & 2 & 2 \\
\hline Fruit & 1 & 3 & A & 4 & 4 & 4 & 0 & 2 & 0 & 3 \\
\hline $\begin{array}{l}\text { Wheat and } \\
\text { Alfalfa }\end{array}$ & 1 & 2 & A & 0 & 3 & 3 & 0 & 0 & 0 & 2 \\
\hline Wine & 2 & 2 & A & 4 & 4 & 0 & 0 & 0 & 0 & 0 \\
\hline
\end{tabular}

(a) Media may include multiple varieties for each category. Not all analytes are assayed at all locations or for each variety of media.

(b) $\mathrm{M}=$ monthly; $\mathrm{Q}=$ quarterly; $\mathrm{SA}=$ semi-annually; $\mathrm{A}=$ annually.

were low. Concentrations of ${ }^{129}$ I tended to be higher in milk samples collected from locations adjacent to Hanford (East Wahluke and

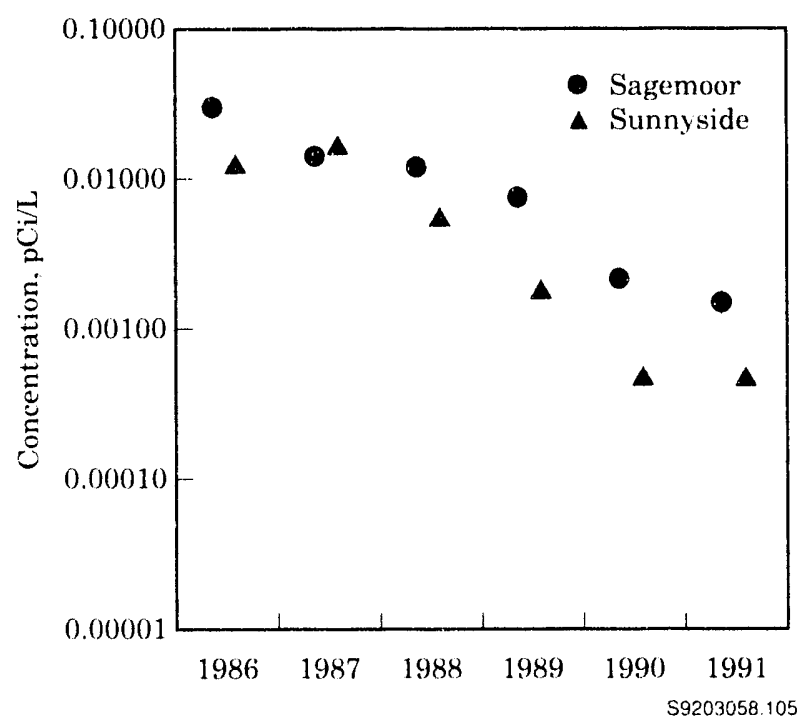

Figure 4.24. Average ( \pm 2 standard error of the mean) Iodine-129 ( $\left.{ }^{129} \mathrm{I}\right)$ Concentrations in Milk at Sagemoor and Sunnyside, 1986 Through 1991. As a result of figure scale, some uncertainties (error bars) are concealed by point symbol. Uncertainties for 1986, 1987, and 1989 averages for Sunnyside samples continue to below zero.
Sagemoor) when compared to those collected at distant control locations (Moses Lake and Sunnyside) as shown in Table 4.13.

About $6 \%$ of the 36 milk samples collected and analyzed for ${ }^{137} \mathrm{Cs}$ in 1991 contained detectable concentrations (above $6.53 \mathrm{pCi} L$ ), and no other gamma emitters were consistently detectable (see Appendix E). However, $88 \%$ of all milk samples analyzed for "Sr in 1991 contained measurable levels with no apparent differences between upwind and downwind locations (Table 4.13). Both ${ }^{91} \mathrm{Sr}$ and ${ }^{137} \mathrm{Cs}$ are expected to some degree in milk samples because of the presence of these radionuclides in worldwide fallout and movement through the air-pasture-cow-milk food chain. Figure 4.25 shows the 5 -year record for ${ }^{\text {: }} \mathrm{Sr}$ in milk samples from all sampling areas. The influence of the 1986 Chernobyl incident on ${ }^{90} \mathrm{Sr}$ in milk is evident in 1987 data; otherwise, concentrations of ${ }^{91} \mathrm{Sr}$ have remained relatively constant over the past 4 years. Tritium was identified in about $40 \%$ of the 27 samples analyzed, with maximum concentrations near a detection limit of $280 \mathrm{pCi} / \mathrm{L}$. There was no apparent difference between results upwind and downwind of the Site (Table 4.13). 
Table 4.13. Radionuclide Concentrations (pCi/L) in Milk Samples, 1991

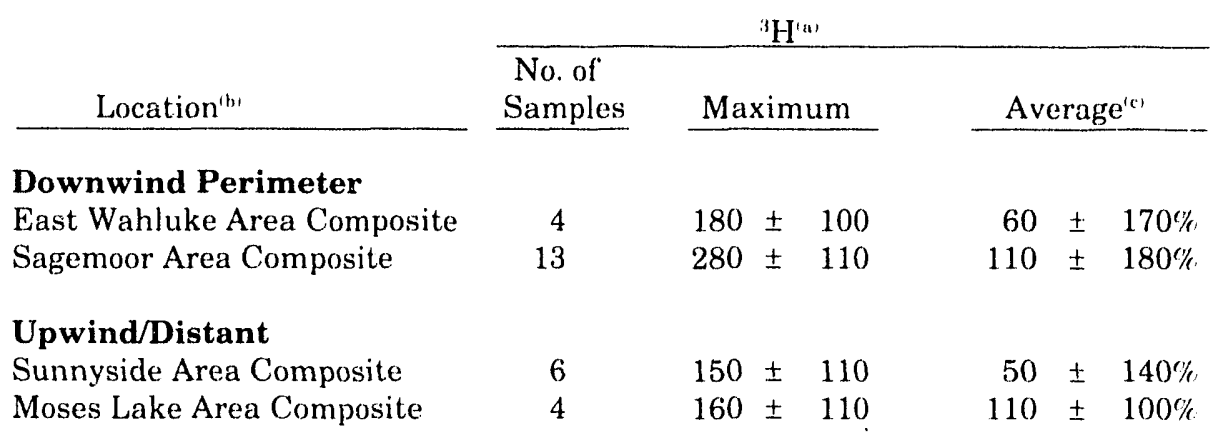

\begin{tabular}{|c|c|c|c|c|c|c|}
\hline \multirow{2}{*}{ Location't) } & \multicolumn{3}{|c|}{${ }^{90} \mathrm{Sr}^{\prime \prime \prime \prime}$} & \multicolumn{3}{|c|}{$129]^{(a, d, d}$} \\
\hline & $\begin{array}{l}\text { No. of } \\
\text { Samples }\end{array}$ & Maximum & Average ${ }^{(\cdot)}$ & $\begin{array}{l}\text { No. of } \\
\text { Samples }\end{array}$ & Maximum & Average \\
\hline \multicolumn{7}{|l|}{$\begin{array}{l}\text { Downwind Perimeter } \\
\text { East Wahluke Area }\end{array}$} \\
\hline Composite & 4 & $0.71 \pm 0.45$ & $0.60 \pm 30 \%$ & 2 & $0.00132 \pm 0.00010$ & $0.00100 \pm 3 \%$ \\
\hline Sagemoor Area Composite & 4 & $0.71 \pm 0.33$ & $0.58 \pm 30 \%$ & 2 & $0.00185 \pm 0.00013$ & $0.00150 \pm 5 \%$ \\
\hline \multicolumn{7}{|l|}{ Upwind/Distant } \\
\hline Sunnyside Area & 4 & $3.24 \pm 1.82$ & $1.0 \pm 300 \%$ & 2 & $0.00068 \pm 0.00002$ & $0.00048 \pm 5 \%$ \\
\hline Moses Lake Area Composite & 4 & $1.2 \pm 0.30$ & $1.0 \pm 40 \%$ & 2 & $0.00027 \pm 0.00005$ & $0.00022 \pm 4 \%$ \\
\hline
\end{tabular}

(a) Maximum values \pm 2 sigma counting errors. The error for averages is \pm 2 times the standard error of the calculated mean, expressed as a percent.

(b) Locations are shown in Figure 4.23.

(c) Error values greater than $100 \%$ indicate that the range of probable results includes zeru.

(d) Iodine-129 concentrations determined by mass spectroscopy on two biannual composite samples.

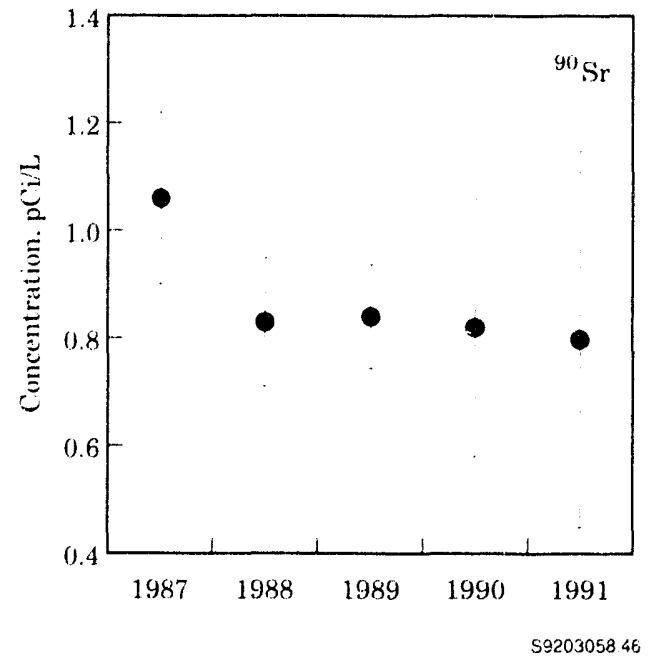

Figure 4.25. Annual Average Strontium-90 ( $\left.{ }^{90} \mathrm{Sr}\right)$ Concentrations in Milk for All Sampling Locations, 1987 Through 1991. Values are means \pm 2 times the standard error.
A total of 27 milk samples were collected and analyzed for ${ }^{1: 31}$ I during the last 10 months of 1991. No atmospheric releases of ${ }^{1: 31} \mathrm{I}$ from Hanford were reported for 1991 (see Table 4.1), and ${ }^{131}$ I was not detected in any milk sample.

\section{Vegetables}

\section{Sample Collection and Analysis}

Samples of leafy vegetables (cabbage, broccoli leaves, beet tops, or turnip greens), tomatoes, carrots, and potatoes, were obtained during the summer from gardens and farms located within the sampling areas (see Figure 4.23). Leafy vegetables are sampled because of the potential deposition of airborne contaminants; however, they may also receive deposition from overhead irrigation. Three replicate samples of each 
vegetable were collected at each sampling location. All were analyzed for ${ }^{9} \mathrm{Sr}$ and gammaemitting radionuclides; in addition, potatoes from selected locations were analyzed for ${ }^{239.240} \mathrm{Pu}$ and uranium isotopes. Samples were collected from the Riverview and Horn Rapids areas to assess potential contamination from the irrigation of crops at those locations. Irrigation water for Horn Rapids and Riverview is drawn from the Columbia River downstream from Hanford.

\section{Results}

Strontium-90 was identified in most leafy vegetable samples but with no apparent difference between distant and nearby locations. The concentrations were variable and near detection $(\sim 0.005 \mathrm{pCi} / \mathrm{g})$ in 1991 and similar to those in previous years (Figure 4.26). All analytical results for ${ }^{137} \mathrm{Cs}$ were below detection $(\sim 0.02 \mathrm{pCi} / \mathrm{g})$, and no other gamma emitters (Appendix E) were consistently detectable.

Potatoes from the Riverview, Sagemoor, Horn Rapids, and Sunnyside areas, and tomatoes and carrots from the Riverview area, did not have

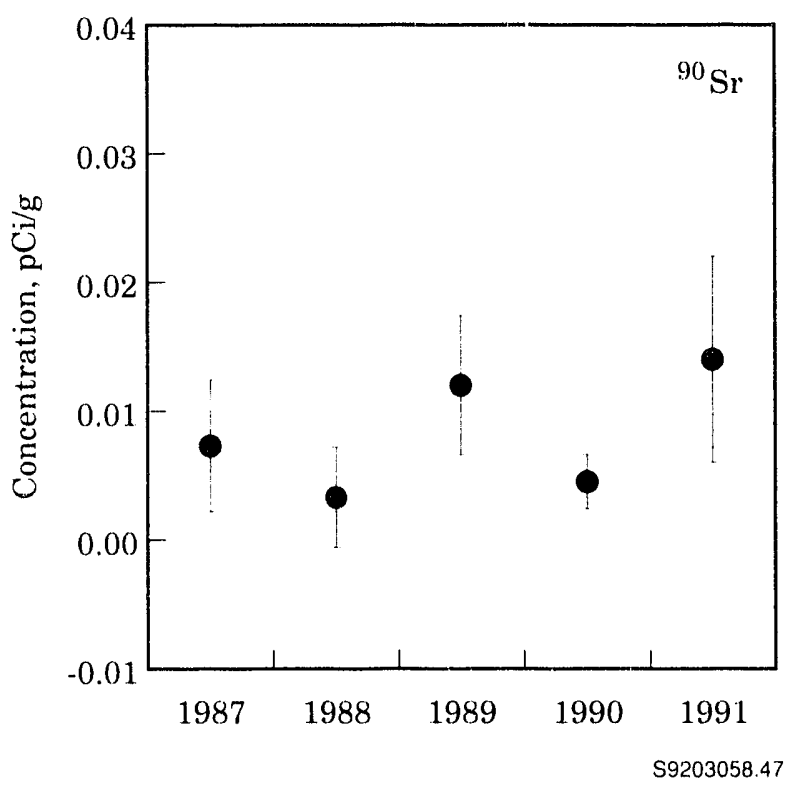

Figure 4.26. Annual Average Strontium-90 ("'Sr) Concentrations in Leafy Vegetables for All Sampling Locations, 1987 Through 1991. Values are means \pm 2 times the standard error. detectable amounts of ${ }^{90} \mathrm{Sr},{ }^{235} \mathrm{U},{ }^{238} \mathrm{Pu},{ }^{239,240} \mathrm{Pu}$, or gamma emitters (Appendix E). Concentrations of ${ }_{234} \mathrm{U}$ and ${ }^{238} \mathrm{U}$ were about $0.0005 \mathrm{pCi} / \mathrm{g}$ for each isotope in potatoes grown in Sunnyside and Horn Rapids. Uranium is found naturally in soil and can also be present in phosphate fertilizers.

\section{Fruit}

\section{Sample Collection and Analysis}

Samples of apples, cherries, grapes, and melons were collected during harvest from the areas shown in Figure 4.23 (not all types were collected in each area). Each sample consisted of three replicates. The edible portions were analyzed for ${ }^{3} \mathrm{H},{ }^{90} \mathrm{Sr}$, gamma emitters (Appendix $\mathrm{E}$ ) and, for selected samples, ${ }^{129} \mathrm{I}$ and ${ }^{239,240} \mathrm{Pu}$. Tritium was analyzed in the condensate collected from fruit samples.

\section{Results}

Iodine-129, ${ }^{238} \mathrm{Pu}$, and ${ }^{239,240} \mathrm{Pu}$ were not detected in any fruit samples. Strontium-90 was detected in some grapes and apples collected at Sagemoor (highest values were $0.015 \pm 30 \% \mathrm{pCi} / \mathrm{g}$ and 0.004 $\pm 30 \% \mathrm{pCi} / \mathrm{g}$, respectively). All analyses for gamma emitters of potential Hanford origin, including ${ }^{137} \mathrm{Cs}$, were less-than-detection except for a single apple sample collected at Ringold that had $0.008 \pm 60 \% \mathrm{pCi} / \mathrm{g}{ }^{137} \mathrm{Cs}$. Tritium was detected in some fruit samples at concentrations close to background ( 200 to $300 \mathrm{pCi} / \mathrm{L}$ ). Radionuclide concentrations in fruit samples collected upwind from the Hanford Site did not differ from those in samples collected near the downwind perimeter, indicating no significant impact from Hanford operations.

\section{Wine}

\section{Sample Collection and Analysis}

Locally produced red and white wines (1991 vintage grapes) were analyzed for tritium and gamma-emitting radionuclides. The wines were made from grapes grown at individual vineyards in the Columbia Basin downwind of the Site and 
in the Yakima Valley upwind of the Site. Three samples of each wine were obtained from each area. Samples were split with the Washington State Department of Health (DOH).

\section{Results}

The results for ${ }^{3} \mathrm{H}$ in wine indicate no difference between locations except that the Yakima Valley red was higher than the Columbia Basin red. The IT analyses for ${ }^{3} \mathrm{H}$ were higher than those reported by the Washington Department of Health (DOH) for all samples (Table 4.14). However, the concentrations for the IT analyses were close to the expected analytical detection limit of $300 \mathrm{pCi} / \mathrm{L}$. The differences in the results are attributed to differences in analytical laboratory methodologies and techniques. The ${ }^{137} \mathrm{Cs}$ results do not indicate any accumulation of this radionuclide in wine. Collectively, these results do not indicate any impact of Hanford operations on wine. While there is no tritium standard for wine; the standard for drinking water is $20,000 \mathrm{pCi} / \mathrm{L}$.

\section{Wheat and Alfalfa}

\section{Sample Collection and Analysis}

Samples of ripened wheat and mature alfalfa were collected from the areas shown in Figure 4.23. Three replicate samples of wheat and alfalfa were collected at each location and analyzed for ${ }^{90} \mathrm{Sr}$ and gamma emitters (Appen$\operatorname{dix} \mathrm{E}$ ). Wheat samples from the Sagemoor and Sunnyside areas were also analyzed for ${ }^{239,240} \mathrm{Pu}$.

\section{Results}

Strontium-90 was detected at near background $(\sim 0.005 \mathrm{pCi} / \mathrm{g})$ concentrations in all samples of alfalfa. The 1990 Hanford Site Environmental Report (Woodruff et al. 1991) noted that alfalfa collected from Richland and Riverview was irrigated with Columbia River water and concentrations of ${ }^{90} \mathrm{Sr}$ were slightly elevated when compared to samples from locations that had not been irrigated with water from the Hanford Reach. Values of ${ }^{90} \mathrm{Sr}$ for all 1991 samples were lower than concentrations reported in recent years (Figure 4.27); however, two trends were apparent. The concentrations of "Sr are decreasing and over the last 4 years, the difference between the irrigation groups is decreasing. No gamma emitters potentially of Hanford origin were consistently detected. Cesium-137 was identified at background concentrations (maximum value was $0.013 \pm 60 \% \mathrm{pCi} / \mathrm{g}$ ) in one of nine samples. Strontium-90 was detected in wheat but did not show any association with proximity or downwind direction from Hanford. Plutonium was not detected $(<0.0006 \mathrm{pCi} / \mathrm{g})$ in wheat samples collected at Sagemoor.

\section{Beef, Chickens, and Eggs}

Samples of locally produced beef, poultry, and eggs were collected from the areas shown in Figure 4.23. Concentrations of gamma emitters potentially of Hanford origin (Appendix E) in beef, eggs, and poultry samples were less than detection. Specifically ${ }^{611} \mathrm{Co}$ and ${ }^{137} \mathrm{Cs}$ were less than $\sim 0.03$ and $0.05 \mathrm{pCi} / \mathrm{g}$, respectively. Similarly, "Sr concentrations were also less than detection (about $0.005 \mathrm{pCi} / \mathrm{g}$ ). 
Table 4.14. Concentrations of Tritium $\left({ }^{3} \mathrm{H}\right)$ and Cesium-137 $\left({ }^{137} \mathrm{Cs}\right)$ in Columbia Basin (downwind) and Yakima Valley Wines (upwind), 1991. (Values are the mean of 3 replicate samples \pm 2 times the standard error as a percent in $\mathrm{pCi} / \mathrm{L}$.)

\begin{tabular}{|c|c|c|c|c|c|c|c|c|c|}
\hline \multirow{4}{*}{$\begin{array}{l}\text { Variety } \\
\text { Red }\end{array}$} & \multirow{4}{*}{$\begin{array}{l}\text { Location } \\
\text { Yakima Valley } \\
\text { Columbia Basin }\end{array}$} & \multirow{2}{*}{\multicolumn{2}{|c|}{$\frac{\mathrm{DOH}}{{ }^{3} \mathrm{H}}$}} & \multicolumn{6}{|c|}{ PNL } \\
\hline & & & & \multicolumn{3}{|c|}{${ }^{3} \mathrm{H}$} & \multicolumn{3}{|c|}{${ }^{137} \mathrm{Cs}$} \\
\hline & & 80 & $\pm 90 \%$ & 580 & \pm & $20 \%$ & 1.9 & \pm & $170 \%$ \\
\hline & & 100 & $\pm 80 \%$ & 250 & \pm & $10 \%$ & -1.5 & \pm & $120 \%$ \\
\hline \multirow[t]{2}{*}{ White } & Yakima Valley & 120 & $\pm 30 \%$ & 360 & \pm & $30 \%$ & -1.2 & \pm & $150 \%$ \\
\hline & Columbia Basin & 90 & $\pm 40 \%$ & 420 & \pm & $50 \%$ & 0.4 & \pm & $280 \%$ \\
\hline
\end{tabular}

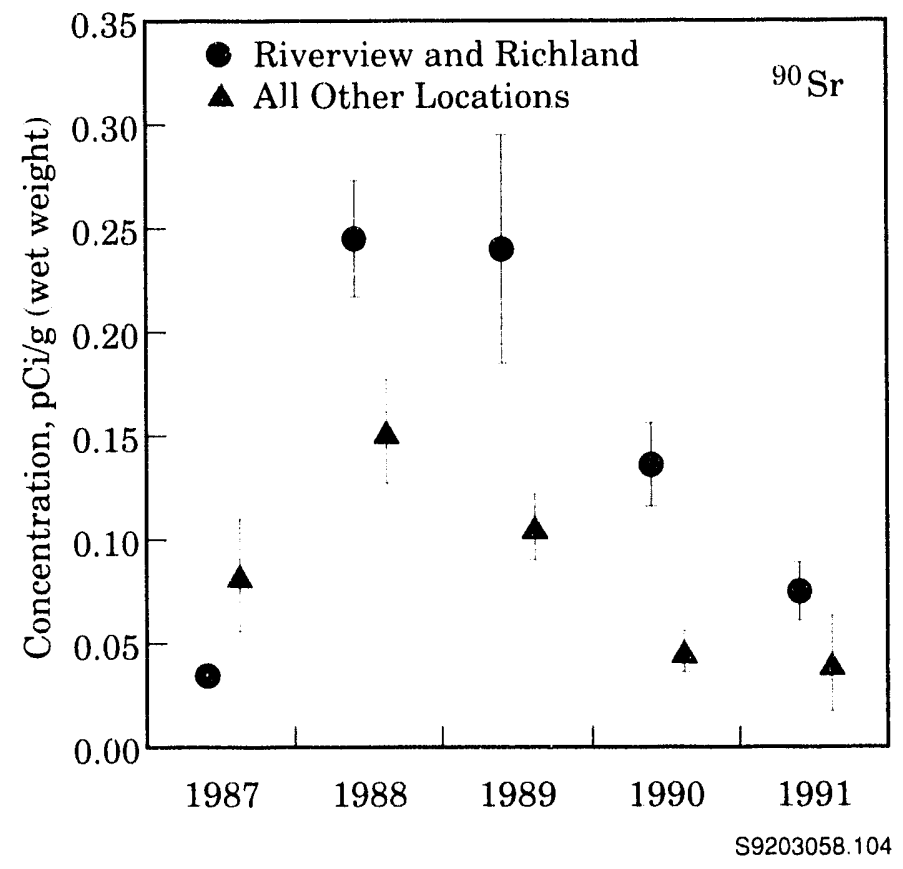

Figure 4.27. Strontium-90 ( $\left.{ }^{90} \mathrm{Sr}\right)$ Concentrations in Alfalfa Collected at Riverview and Richland (irrigated with Columbia River water) and All Other Sampling Locations, 1987 Through 1991. Values are means \pm 2 times the standard error. As a result of figure scale, some uncertainties (error bars) are concealed by point symbol. 


\subsection{Wildlife Surveillance}

A number of fish and wildlife species inhabit the Columbia River and Hanford Site. Wildlife have access to several areas that contain some radioactive contamination and fish can be exposed to contamination in spring water entering the river along the shoreline. It is important therefore to monitor fish and wildlife. Fish and some wildlife species may be harvested, and monitoring data provides a measure of the potential dose associated with these activities. Detection of radioactivity in fish and wildlife may indicate that wildlife are entering restricted areas or that radioactivity is migrating out of restricted areas. Consequently, many of the collection sites are located adjacent to restricted areas (Figure 4.28). Samples are collected once annually during the season of harvest for game species. All results are reported on a wet weight basis.

When radioactivity is detected in fish or wildlife, it is important to estimate what part of that radioactivity originated at Hanford. Therefore a number of background samples of wildlife and fish have been collected from distant locations for this purpose. However, only the results from bass collected from the Sunnywide area were available for comparison.

Strontium-90 and ${ }^{1: 37} \mathrm{Cs}$ have been the most important and frequently analyzed radionuclides in fish and wildlife. However, a much larger number of radionuclides (see Appendix E) are analyzed, but are not reported unless detected. Cesium is particularly important because it is chemically similar to potassium and accumulates in the muscle tissue of fish and wildlife. Strontium is chemically similar to calcium; consequently, it accumulates in hard tissues high in calcium like bone, antlers, and clam shells. Plutonium was monitored in liver because it accumulates in that organ and is therefore a sensitive indicator. A complete list of the media sampled, number of sampling locations, sampling frequency, and radionuclides analyzed is shown in Table 4.15. The locations of wildlife sample collections are indicated in Figure 4.28.

\section{Deer}

Samples taken from deer accidently killed on roadways (sampled from areas identified in Figure 4.28 ) indicate the general levels of radionuclides in Hanford Site deer. Muscle was sampled and analyzed for ${ }^{137} \mathrm{Cs}$ in all deer. Bone was analyzed for "Sr and liver tissue was analyzed for ${ }_{238} \mathrm{Pu}$ and ${ }^{239 ., 240} \mathrm{Pu}$ in the two deer taken from the 100-N Area.

Results were generally nondetectable (4 of 6 samples) for ${ }^{137} \mathrm{Cs}(<0.006 \mathrm{pci} / \mathrm{g})$ in muscle samples. The maximum concentration of ${ }^{1: 37} \mathrm{Cs}$ was $0.007 \mathrm{pCi} / \mathrm{g}$ in a deer collected in the 200 Areas. The ${ }^{90} \mathrm{Sr}$ concentrations in deer bone range from 1.0 to $1.2 \mathrm{pCi} / \mathrm{g}$ in 1991 and were less than the 0.7 - to $58-\mathrm{pCi} / \mathrm{g}$ levels reported in 1990 . The lower values indicate that the deer sampled were not exposed to elevated levels of "'Sr, and may reflect the removal of contaminated vegetation from the $100-\mathrm{N}$ Area shoreline. Concentrations of $1 \mathrm{pCi} / \mathrm{g}$ of ${ }^{\text {"N }} \mathrm{Sr}$ in bone are considered attributable to fallout. Concentrations exceeding $10 \mathrm{pCi} / \mathrm{g}$ may indicate exposure to elevated levels of ${ }^{90} \mathrm{Sr}$ in the environment. The concentrations of ${ }^{2: 39: 30} \mathrm{Pu}$ in $100-\mathrm{N}$ Area deer liver were $<0.0001 \mathrm{pCi} / \mathrm{g}$.

A study was initiated in 1991 to evaluate the feasibility of monitoring exposure to ${ }^{91} \mathrm{Sr}$ by sampling deer antlers. Antlers collected from two deer from the $100-\mathrm{N}$ Area had 0.39 and $0.68 \mathrm{pCi} / \mathrm{g}$ ${ }^{90} \mathrm{Sr}$, compared to a range of 0.10 to $0.24 \mathrm{pCi} / \mathrm{g}$ ${ }^{9} \mathrm{Sr}$ in deer antlers collected from the Hanford townsite, which is not known to have surface contamination. Levels in antlers are not expected to be as high as in bone because they contain a single season's accumulation, whereas bone accumulates ${ }^{90} \mathrm{Sr}$ for the lifetime of the deer.

\section{Fish}

Whitefish and carp were collected from the Columbia River near the 300 Area and selected 100 Area locations. Fish were filleted and muscle 


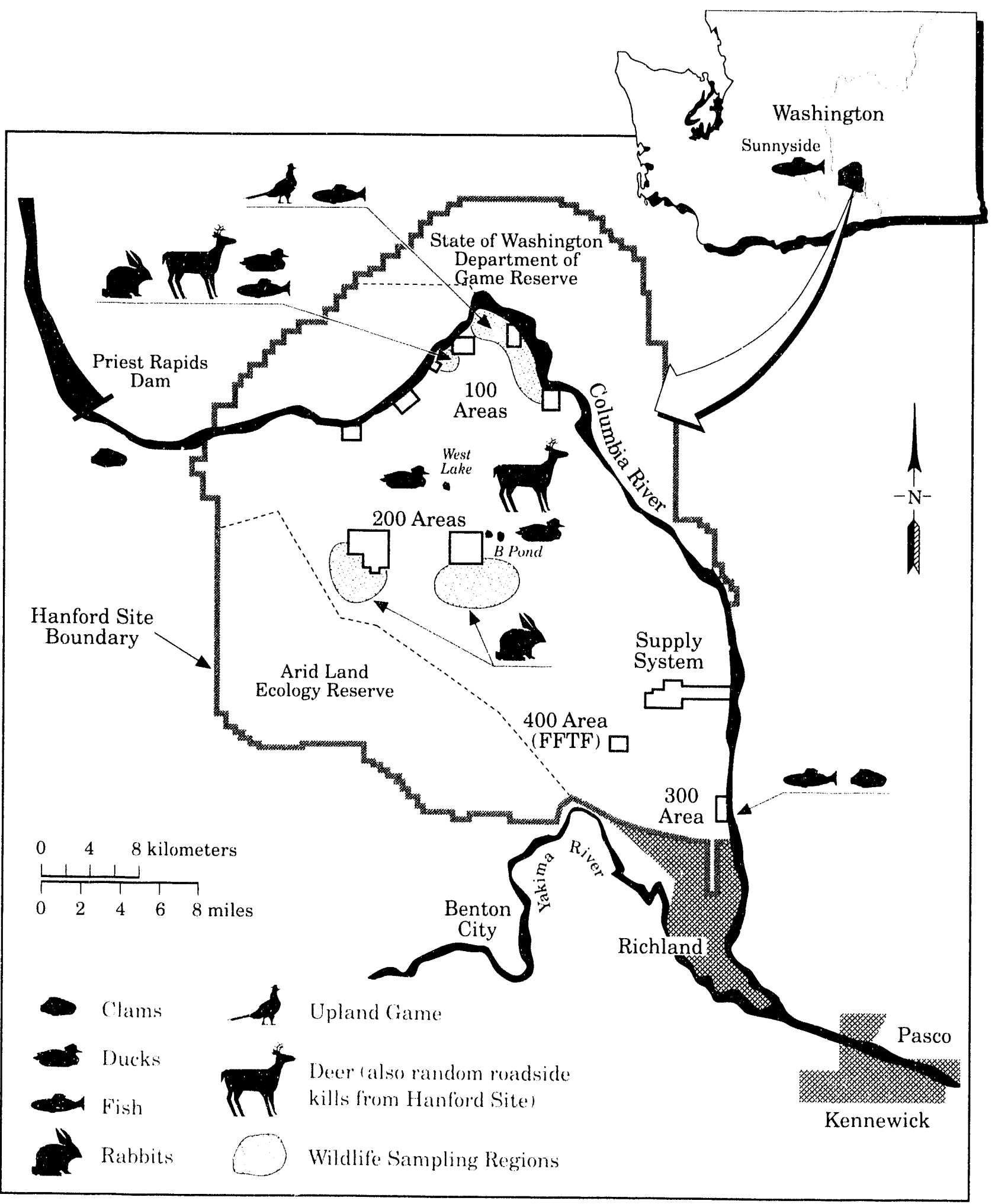

S9203058.11

Figure 4.28. Wildlife Sampling Areas, 1991 
Table 4.15. Number of Species and Locations Sampled and Analyzed for Fish and Wildlife, 1991

\begin{tabular}{cccc} 
& Number of & Onsite & \multicolumn{2}{c}{ Number of Locations Analyzed } \\
Media & Species & Locations & Gamma ${ }^{90} \mathrm{Sr}^{\left({ }^{(a)}\right.} \stackrel{99 \mathrm{Tc}}{\mathrm{U}} \mathrm{Pu}^{(\mathrm{b})}$
\end{tabular}

$\begin{array}{lcc}\text { Fish } & 3 & 1 \text { to } 3 \\ \text { Clams } & 1 & 2 \\ \text { Ducks } & 1^{\left({ }^{\prime \prime}\right.} & 3 \\ \text { Upland Gamebirds } & 1^{(d)} & 1 \\ \text { Deer } & 1 & 3 \\ \text { Rabbits } & \\ \text { (a) Analyzed in bone and some muscle samples. } \\ \text { (b) Analyzed in liver only. } \\ \text { (c) Usually mallards. } \\ \text { (d) Usually pheasants. }\end{array}$

and carcass (bone) samples obtained. All carcass samples were analyzed for ${ }^{90} \mathrm{Sr}$. All muscle samples were analyzed for ${ }^{60} \mathrm{Co},{ }^{90} \mathrm{Sr}$, and ${ }^{137} \mathrm{Cs}$; muscle samples from 300 Area fish were also analyzed for ${ }^{99} \mathrm{Tc}$ and ${ }^{2 ; 34,235,238} \mathrm{U}$. Bass samples were not collected from the Columbia River in 1991; however, background results were reported for samples from a pond near Sunnyside (Figure 4.29).

A total of seven whitefish were collected in 1991 , five from near the 100-D Area and two from near the 300 Area. Muscle sample concentrations of ${ }^{60} \mathrm{Co},{ }^{90} \mathrm{Sr}$, or ${ }^{137} \mathrm{Cs}$ were generally not detectable. The maximum concentrations detected for ${ }^{60} \mathrm{Co}$ and ${ }^{1: 37} \mathrm{Cs}$ were $0.056 \pm 90 \% \mathrm{pCi} / \mathrm{g}$ and $0.06 \pm$ $50 \% \mathrm{pCi} / \mathrm{g}$, respectively. Strontium-90 was not detected in any sample $(<0.009 \mathrm{pCi} / \mathrm{g})$. All carcass samples at both locations had detectable concentrations of ${ }^{4} \mathrm{Sr}$ that ranged from $0.003 \pm$ $100 \% \mathrm{pCi} / \mathrm{g}$ to $0.017 \pm 24 \% \mathrm{pCi} / \mathrm{G}$ with no distinctive differences with location with the exception that the maximum was in a 100-D Area sample.

Nine carp samples were collected in 1991, 4 from near the 100-N Area and 5 from near the 300 Area. Concentrations of ${ }^{610} \mathrm{Co}$, ${ }^{91} \mathrm{Sr}$, and ${ }^{1: 77} \mathrm{Cs}$

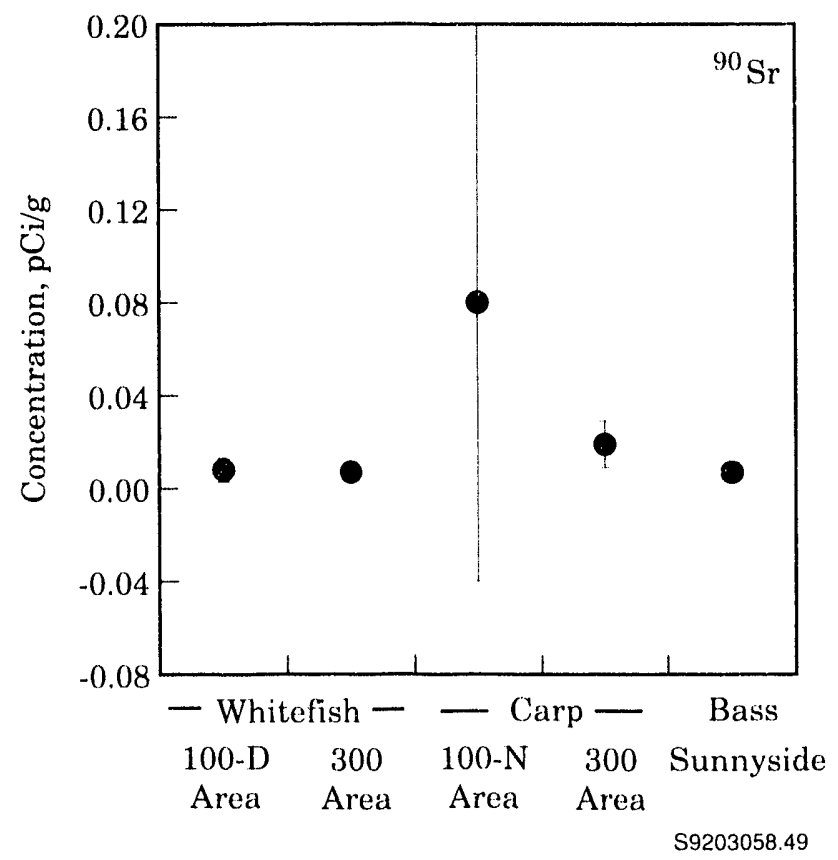

Figure 4.29. Mean Concentrations of Strontium90 ("1) $\mathrm{Sr}$ ) in Whitefish and Carp Carcasses Collected from the Columbia River, and Bass from Sunnyside, 1991. Values are means \pm 2 times the standard error. As a result of figure scale, some uncertainties (error bars) are concealed by point symbol. 
were also generally not detectable in carp muscle. Maximum concentrations were $0.007 \pm 90 \% \mathrm{pCi} / \mathrm{g}$, $0.045 \pm 30 \% \mathrm{pCi} / \mathrm{g}$, and $0.008 \pm 40 \% \mathrm{pCi} / \mathrm{g}$, respectively. All carcass samples at both locations had detectable concentrations of ${ }^{\text {s }} \mathrm{Sr}$, with the range in the $100-\mathrm{N}$ Area samples $(0.010$ to $0.26 \mathrm{pCi} / \mathrm{g})$ being distinctly higher than the 300 Area samples $(0.006$ to $0.036 \mathrm{pCi} / \mathrm{g})$. This is consistent with the elevated levels of " $\mathrm{Sr}$ in the $100-\mathrm{N}$ Area springs and clam shells, and the suspected consumption of clams, including shells, by carp.

The above results consistently indicate the presence of " $\mathrm{Sr}$ in fish carcasses, and the difference between 300 Area and 100-N Area carp samples, as shown in Figure 4.29, suggest an influence from 100 Area operations. Comparison of the 100-N Area carp carcass samples with the Sunnyside bass carcass samples (Figure 4.29) also suggests an impact from Hanford, but is not conclusive because of the different feeding habits of the two species. Although bass were not collected from the Hanford Reach in 1991, comparison can be made between the Sunnyside background bass carcass samples, which had an average concentration of $0.007 \pm 40 \% \mathrm{pCi} / \mathrm{g}$, and the $1990100-F$ Slough bass carcass samples, which had a mean concentration of $0.03 \pm$ $30 \% \mathrm{pCi} / \mathrm{g}$. This strongly suggests a Hanford influence, and analyses of background carp and whitefish samples are planned.

While it appears that bass and carp were exposed to 100 Area releases, as indicated by the presence of strontium in carcasses (bone), no radionuclides were consistently detectable in muscle. This is reflected in the dose estimates (Section 4.8) for the maximally exposed individual (MEI), which indicates that consumption of Columbia River fish contributed only $9 \%$ of the 0.02 -mrem MEI dose, with the primary contributors being ${ }^{137} \mathrm{Cs}$ and "Sr.

\section{Clams}

Clams were sought in the $100-\mathrm{N}$ and 300 Areas but were only found in the 300 Area in sufficient quantity for analysis. Concentrations of ${ }^{6 i} \mathrm{Co}$ and ${ }^{1.7} \mathrm{Cs}$ were less than 0.005 and $0.008 \mathrm{pCi} / \mathrm{g}$, respectively, in the 300 Area clam tissue sample.
Uranium was present at about $0.1 \mathrm{pCi} / \mathrm{g}$. A clam shell collected from the shoreline of the $100-\mathrm{N}$ Area in 1990 was analyzed in 1991 for ${ }^{(i)} \mathrm{Co}$, ${ }^{\text {M }} \mathrm{Sr}$, and ${ }^{137} \mathrm{Cs}$. The shell had $266 \pm 20 \% \mathrm{pCi} / \mathrm{g}$ "' $\mathrm{Sr}$; however, ${ }^{167} \mathrm{Co}$ and ${ }^{137} \mathrm{Cs}$ concentrations in the shell were less than detertion $(\sim 0.4 \mathrm{pCi} / \mathrm{g}$ and 0.2 $\mathrm{pCi} / \mathrm{g}$, respectively).

\section{Waterfowl}

Duck samples consisting of primarily mallard ducks were collected from B Pond near the 200 Areas, West Lake, and the Columbia River adjacent to the 100-N Area (see Figure 4.28). The mean concentration ( \pm 2 standard error) of ${ }^{1: 37} \mathrm{Cs}$ (Figure 4.30 ) detected in the breast meat of mallard ducks collected from B Pond was $0.8 \pm$ $50 \%) \mathrm{HCi}^{\prime} \mathrm{g}$. Results from West Lake were more variable $(0.05 \pm 200 \% \mathrm{pCi} / \mathrm{g})$. Cesium-137 was not detected in ducks collected from the Columbia River near the 100-N Area. Muscle samples from West Lake, B Pond, and the Columbia River near the 100-N Area were analyzed for " ${ }^{\prime \prime} \mathrm{Sr}$, but none was detected $(<0.005 \mathrm{pCi} / \mathrm{g})$ with the exception of one duck collected from B Pond. The concentration was $0.13 \pm 20 \% \mathrm{pCi} / \mathrm{g} \% \mathrm{Sr}$ and exceeded all other values by a factor of a hundred. The concentration of "Ty' $\mathrm{T}$ in B Pond duck muscle was $<0.26 \mathrm{pCi} / \mathrm{g}$.

\section{Rabbits}

Muscle samples from 100-N Area cottontail rabbits were analyzed for ${ }^{137} \mathrm{Cs}$ and other gammaemitting radionuclides, bone samples were analyzed for "Sr, and liver samples were analyzed for ${ }^{2339.2+11} \mathrm{Pu}$. The concentration of ${ }^{91} \mathrm{Sr}$ in bone samples (maximum value, $81 \mathrm{pCi} / \mathrm{g}$ ) indicated exposure to relatively high "Sr contamination compared, for example, to the 200-West Area where samples were as low as $0.53 \pm 20 \% \mathrm{pCi} / \mathrm{g}$. The gamma spectroscopy analysis indicated the presence of $14 \pm 4 \% \mathrm{pCi} / \mathrm{g}{ }^{6 i t} \mathrm{Co}$ and $0.14 \pm 80 \%$ $\mathrm{pCi} / \mathrm{g}{ }^{137} \mathrm{Cs}$ in the muscle of an individual rabbit. The same rabbit had $1.0 \mathrm{pCi} / \mathrm{g}^{2: 4,2+11} \mathrm{Pu}$ in liver tissue. These concentrations exceed the levels normally observed in rabbit samples and indicate exposure to elevated environmental levels of radioactivity. 


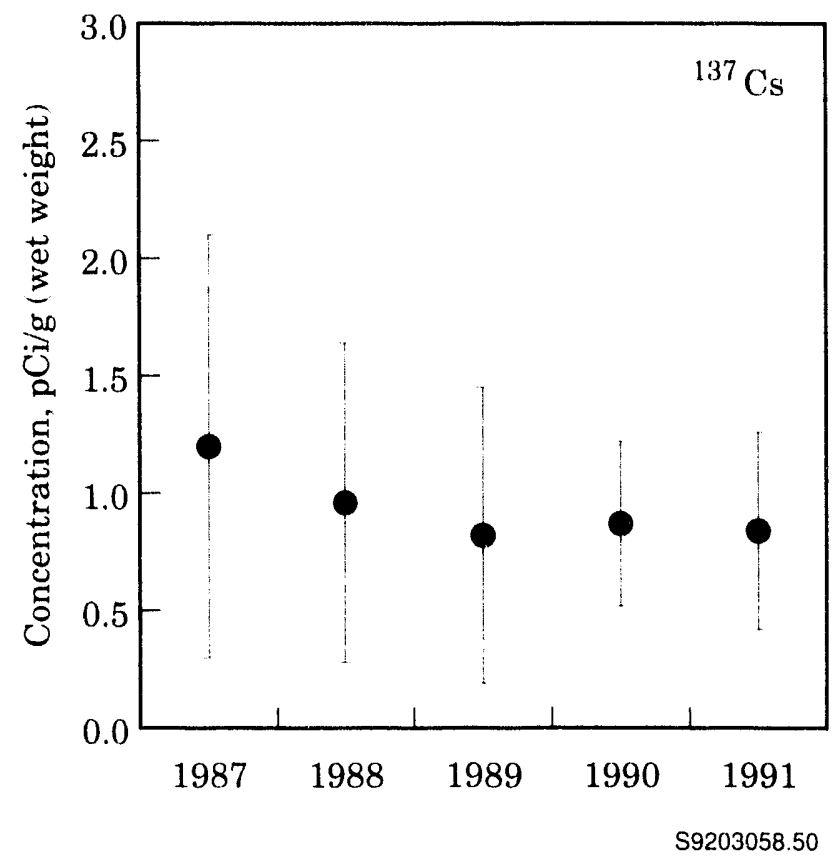

Figure 4.30. Mean Concentrations of Cesium-137 $\left.{ }^{(137} \mathrm{Cs}\right)$ in Mallard Duck Muscle Collected from B Pond, 1987 Through 1991. Values are means \pm 2 times the standard error.
Two of four jackrabbits collected from the 200East Area had detectable ${ }^{137} \mathrm{Cs}$ in muscle tissue. The highest concentration was $0.05 \pm 40 \% \mathrm{pCi} / \mathrm{g}$. Plutonium in liver was also detected in two of the four liver samples at close to the detection limit of $0.0006 \mathrm{pCi} / \mathrm{g}$. Concentrations of ${ }^{90} \mathrm{Sr}$ in jackrabbit bune ranged from 8 to $49 \mathrm{pCi} / \mathrm{g}$, indicating exposure to elevated environmental concentrations.

\section{Gamebirds}

Pheasants were collected from the 100-D to $100-\mathrm{F}$ Areas. Breast muscle was analyzed for ${ }^{60} \mathrm{Co}$ and ${ }^{137} \mathrm{Cs}$. Three of eight pheasants had detectable levels of ${ }^{1: 37} \mathrm{Cs}$ that ranged from $0.013 \pm 80 \%$ to $0.035 \pm 70 \% \mathrm{pCi} / \mathrm{g}$ ( 2 sigma counting error). In comparison, domestic chickens had less than $0.03 \mathrm{pCi} / \mathrm{g}$ (see Section 4.4). 


\subsection{Soil and Vegetation Surveillance}

Surface soil samples were collected from 26 locations during 1991, 16 on and 10 off the Hanford Site. Perennial vegetation (shrubs) was collected from 20 locations during 1991, 13 on and 7 off the Hanford Site. The purpose of the sampling was to detect any build up of radionuclides from deposition of airborne effluents released from Hanford facilities. The samples were collected at relatively undisturbed, nonagricultural sites so that natural deposition and build up processes could be assessed.

Radionuclide contributions from Hanford operations were assessed by comparing results from samples taken 1) onsite with those collected offsite, and 2) around the Site perimeter with those collected at distant locations. Results were also compared to results obtained from the same location in previous years.

\section{Sample Collection and Analysis}

Soil and vegetation samples were collected at the locations shown in Figure 4.31. Most onsite sampling locations were near major operating areas, where any effects from operations would be expected to be most apparent. Most of the offsite samples were collected around the Site perimeter and in a generally downwind direction where any offsite effects would be expected to be maximized. Some offsite samples were collected in upwind and distant locations to establish background concentrations. Downwind is generally considered to be a southeasterly direction while upwind is to the north to northwest from the Hanford Site. Table 4.16 shows the number and frequency of soil and vegetation samples collected in 1991 , and the types of analyses performed.

The soil samples were composites of five soil cores ( $2.5 \mathrm{~cm}$ deep by $10 \mathrm{~cm}$ diameter) taken from the same location. Perennial vegetation samples consisted of new growth taken from predominate species (e.g., rabbitbrush and sagebrush) and were collected at the same general locations as the soil samples. Sample aliquots were analyzed for gamma-emitting radionuclides, ${ }^{90} \mathrm{Sr},{ }^{238} \mathrm{U}$, and ${ }^{2: 39,240} \mathrm{Pu}$. Selected samples were also analyzed for ${ }^{241} \mathrm{Am}$. Gamma-emitting radionuclides that are looked for in the gamma scans are listed in Appendix E.

\section{Soil Results}

Of the radionuclide analyses performed, only ${ }^{911} \mathrm{Sr},{ }^{137} \mathrm{Cs},{ }^{239.240} \mathrm{Pu}$, and total uranium were consistently detectable. Soil concentrations for these radionuclides were evaluated by comparing all onsite to all offsite locations, and by comparing background locations to locations on the downwind (southeastern) perimeter. The comparisons were made using nonparametric statistics (Mielke 1984). Three of the five samples analyzed for ${ }^{241} \mathrm{Am}$ from onsite, perimeter, and offsite locations had detectable concentrations with the maximum concentration of $2.5 \times 10^{-2} \mathrm{pCi} / \mathrm{g}$ being found onsite.

Onsite concentrations of ${ }^{90} \mathrm{Sr},{ }^{137} \mathrm{Cs},{ }^{239,240} \mathrm{Pu}$, and uranium did not differ from those concentrations found offsite when the comparison was made between these two groups. Figure 4.32 shows median, maximum, and minimum values for 1991 and the preceding 5 years. Concentrations in 1991 onsite soil samples did not significantly differ from those obtained in previous years. However, comparisons with 1990 results can not be made because only one onsite sample was analyzed in that year, and that sample was from a location (near and east of the 200-West Area) known to have concentrations higher than are typical for the Site.

Statistical comparisons of 1991 results for onsite and offsite samples as groups did not show a difference. However, comparison of concentrations for two subgroups, the perimeter locations (Ringold, Sagemoor, Byers Landing, Riverview, and Yakima Barricade), which are primarily downwind, versus the distant (background) locations (Moses Lake, Yakima, and Sunnyside) 


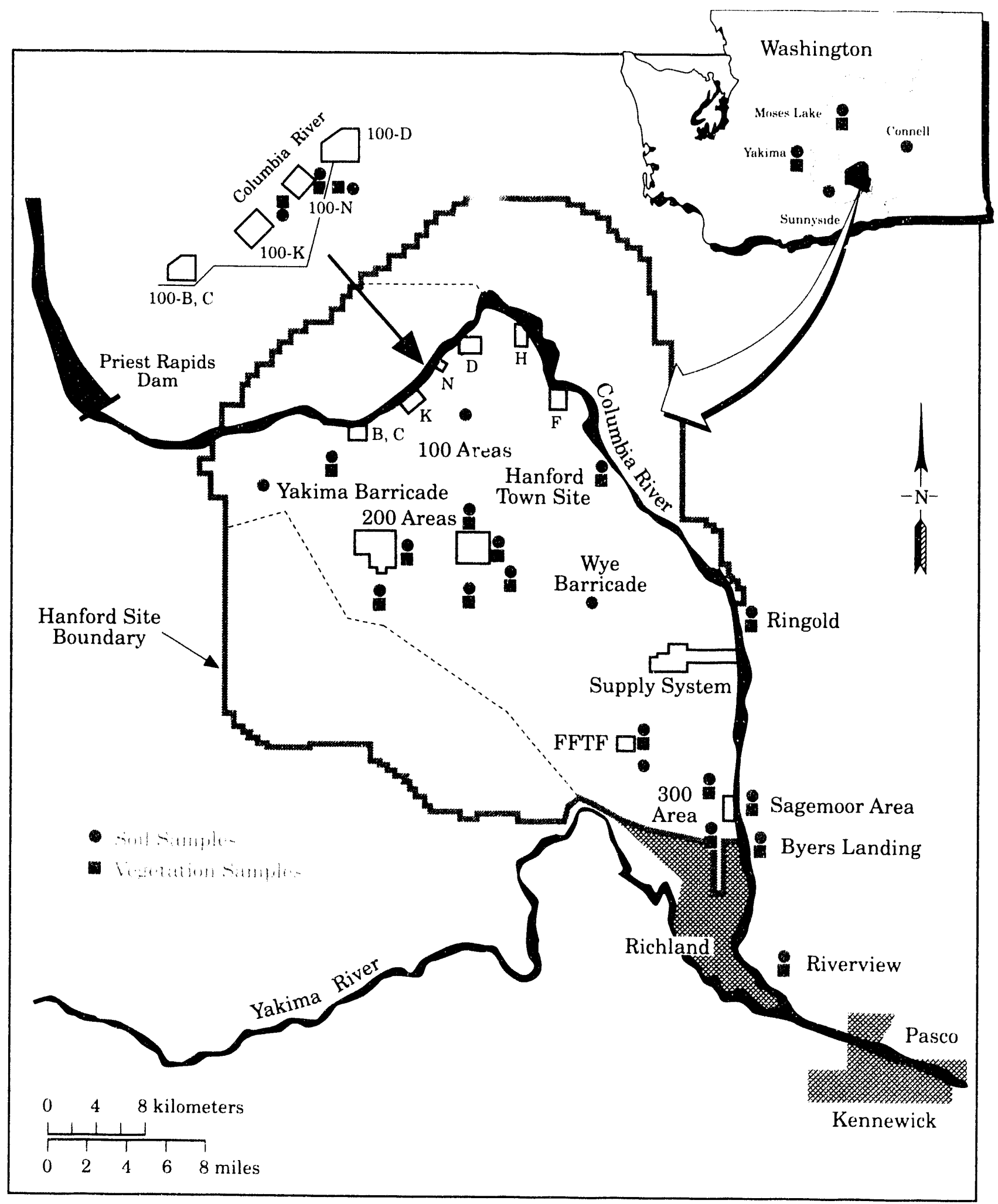

59203058.8

Figure 4.31. Sampling Locations for Soil and Vegetation, 1991 
Table 4.16. Soil and Vegetation Samples Collected in 1991

General Location

Number

Frequency $^{(\mathbf{a})}$

Analytes ${ }^{(b)}$

Soil

Onsite

100-N Area 4

200 Areas

300 Area

400 Area

600 Area

6

1

2

3

Offsite

Near

Distant

\section{Vegetation}

Onsite

100-N Area

200 Areas

300 Area

400 Area

600 Area

Offsite

Near

Distant
3

6

1

1

2

5

2
A
A
A
A

A to $3 \mathrm{y}$

A to $3 y$

A or $5 \mathrm{y}$

\author{
${ }^{90} \mathrm{Sr}$, gamma scan, $\mathrm{U}, \mathrm{Pu}$ \\ ${ }^{90} \mathrm{Sr},{ }^{241} \mathrm{Am}$, gamma scan, $\mathrm{U}, \mathrm{Pu}$ \\ ${ }^{90} \mathrm{Sr}$, gamma scan, $\mathrm{U}, \mathrm{Pu}$ \\ ${ }^{90} \mathrm{Sr}$, gamma scan, $\mathrm{U}, \mathrm{Pu}$ \\ ${ }^{90} \mathrm{Sr}$, gamma scan, $\mathrm{U}, \mathrm{Pu}$
}

(a) A = Annually.

$3 y=$ once every 3 years.

$5 \mathrm{y}=$ once every 5 years.

(b) Not all samples are analyzed for all analytes.

indicated a significant difference in concentrations of ${ }^{91} \mathrm{Sr},{ }^{137} \mathrm{Cs}$, and total uranium (greater than 5\% significance) as shown in Figure 4.33. These differences appear to be a result of unusually low distant sample concentrations rather than increases in perimeter concentrations, with the exception of uranium. The increase in the perimeter uranium concentrations compared to distant concentrations is likely partially a result of local variations in natural soil concentrations. The uranium results in Figure 4.33 are based on analytical methods that changed during the time period, and the apparent increasing trend may be substantially a result of this factor. While the differences discussed above were measurable using modern analytical techniques, the

potential doses from such concentrations are small compared to public dose standards and have been considered in the total Site doses reported in Section 4.8 .

Analytical results for the individual samples summarized in this report are tabulated in Bisping (1992).

\section{Vegetation Results}

The radionuclide analyses performed on vegetation samples are listed in Table 4.16. Of these, only ${ }^{90} \mathrm{Sr},{ }^{137} \mathrm{Cs},{ }^{239,240} \mathrm{Pu}$, and total uranium were consistently detectable. Concentrations of these 

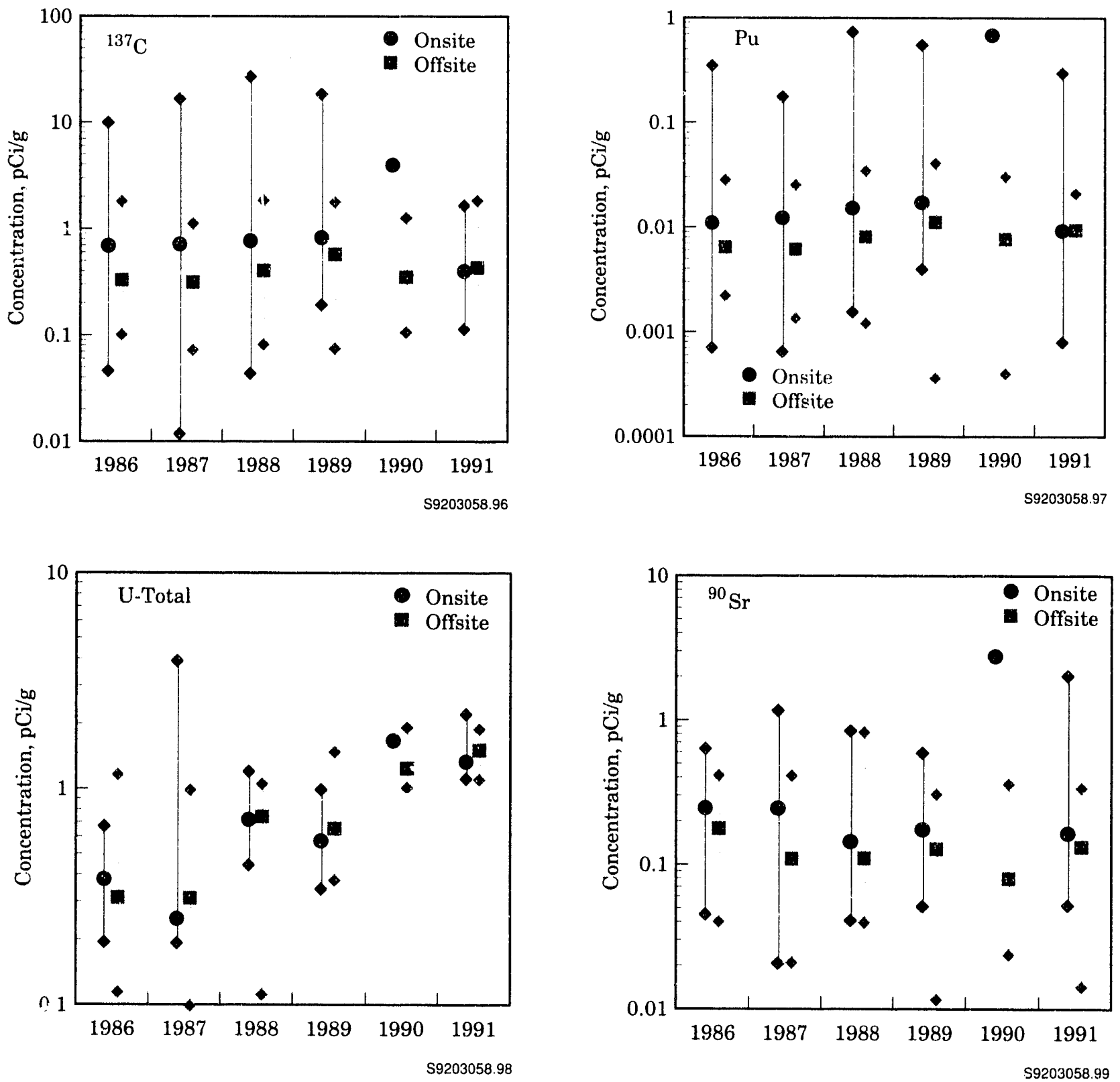

Figure 4.32. Median, Maximum and Minimum Strontium-90 ( $\left.{ }^{90} \mathrm{Gr}\right)$, Cesium-137 $\left({ }^{137} \mathrm{Cs}\right)$, Plutonium-239,240 $\left({ }^{238.240} \mathrm{Pu}\right)$, and Uranium Concentrations Measured in Soil On and Off the Hanford Site, 1986 Through 1991. Units are $\mathrm{pCi} / \mathrm{g}$ (dry weight). As a result of figure scale, some uncertainties (error bars) are concealed by point symbol.

radionuclides in vegetation were evaluated by comparing all onsite to all offsite locations, and by comparing background locations to locations on the downwind (southeastern) perimeter. The comparisons were made using nonparametric statistics (Mielke 1984).
Concentrations of ${ }^{137} \mathrm{Cs}$ and ${ }^{239,240} \mathrm{Pu}$ in 1991 were statistically higher in the onsite group of locations compared to the offsite group. Concentrations of ${ }^{90} \mathrm{Sr}$ and uranium were not statistically different between the two groups. Figure 4.34 shows median, maximum and minimum values 

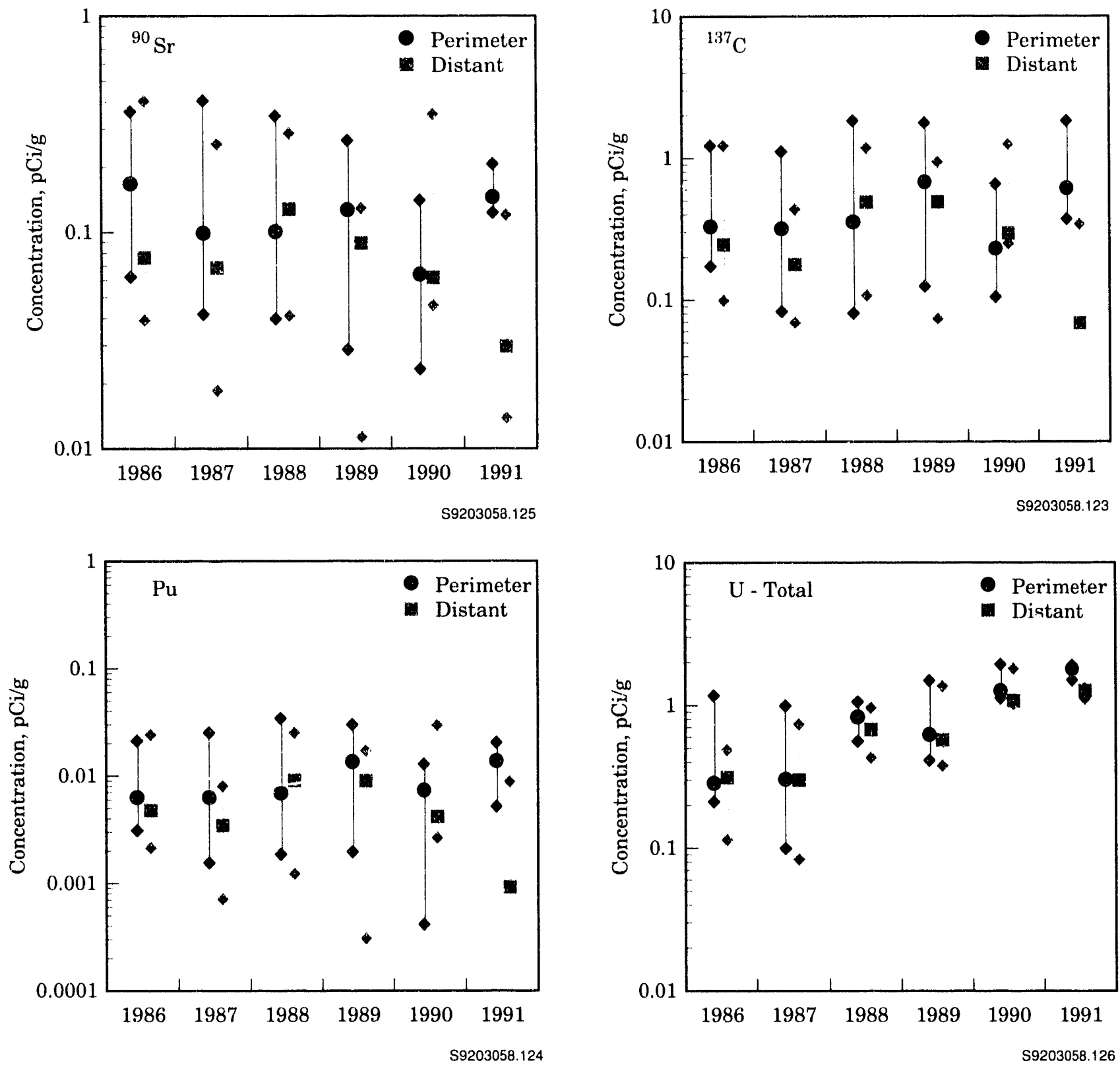

Figure 4.33. Median, Maximum and Minimum Strontium-90 $\left({ }^{80} \mathrm{Sr}\right)$, Cesium-137 $\left({ }^{137} \mathrm{Cs}\right)$, Plutonium-239,240 $\left({ }^{239,240} \mathrm{Pu}\right)$ and Uranium Concentrations Measured in Soil at the Hanford Site Perimeter and Distant Locations, 1986 Through 1991. As a result of figure scale. Some uncertainties (error bars) are concealed by point symbol.

for 1991 and the preceding 5 years. The increased ${ }^{137} \mathrm{Cs}$ value in 1986 is attributed to fallout from the Chernobyl incident.

The 1991 concentrations of ${ }^{90} \mathrm{Sr}$ and ${ }^{239.240} \mathrm{Pu}$ in vegetation at the Site perimeter were not statistically different (at the 5\% significance level) than those at the background locations. Cesium-137 concentrations for these groups were generally not detectable and had a maximum concentration of about $0.05 \mathrm{pCi} / \mathrm{g}$. Uranium concentrations at the perimeter and background 

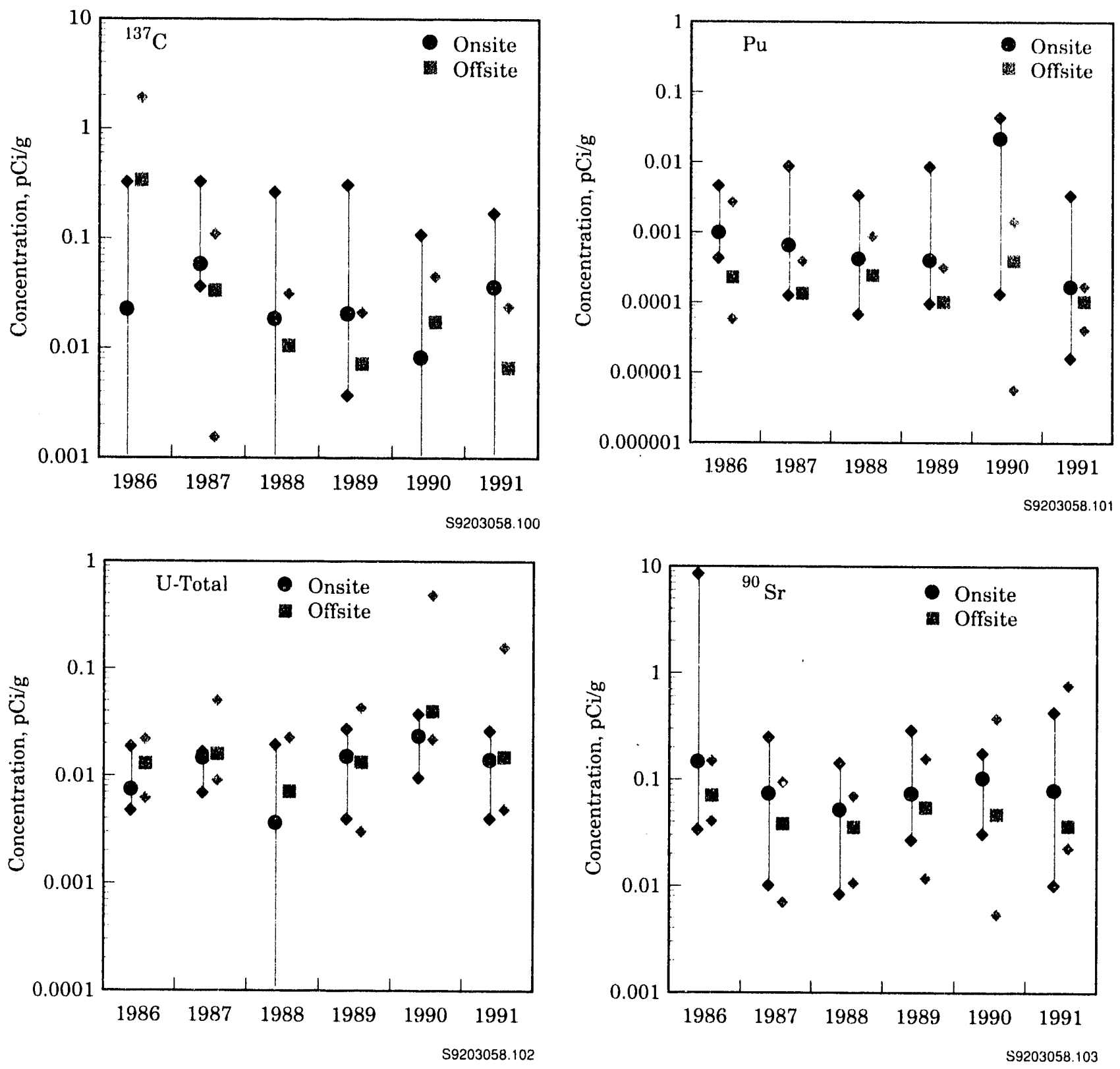

Figure 4.34. Median, Maximum and Minimum Strontium-90 $\left({ }^{94} \mathrm{Sr}\right)$, Cesium-137 $\left({ }^{137} \mathrm{Cs}\right)$, Plutonium-239,240 $\left({ }^{239,240} \mathrm{Pu}\right)$, and Uranium Concentrations Measured in Vegetation at Onsite and Offsite Locations, 1986 Through 1991. Units are $\mathrm{pCi} / \mathrm{g}$ (dry weight).

locations were not compared statistically because the results were analyzed under different contracts and methods.
Analytical results for the individual samples summarized in this report are tabulated in Bisping (1992). 


\subsection{External Radiation Surveillance}

Environmental radiation fields vary significantly from one location to another because of differences in the terrestrial and cosmic components of natural background radiation. The differences are most influenced by ${ }^{40} \mathrm{~K}$, ${ }^{232} \mathrm{Th}$, and ${ }^{238} \mathrm{U}$, which are the primary components contributing to terrestrial natural background radiation. Terrestrial natural background radiation is one of the components of the total natural background radiation dose each person receives (nominally 300 $\mathrm{mrem} / \mathrm{yr}$, see Figure 4.43, Section 4.8, "Potential Radiation Doses from 1991 Hanford Operations"). Environmental radiation fields can also be influenced by the presence of artificially produced radionuclides, such as those deposited as fallout from past atmospheric nuclear weapons testing or those produced and released to the environment during the creation or use of nuclear fuel. External radiation dose rates from natural and humanmade sources were measured at a number of locations on and off the Hanford Site using thermoluminescent dosimeters (TLDs). In addition, external radiation and contamination surveys were performed at a number of locations on and around the Hanford Site. This section discusses how external radiation was measured, how surveys were conducted, and the results of these measurements.

\section{External Radiation Measurements}

An environmental TLD station consists of three dosimeters, each mounted approximately $1 \mathrm{~m}$ (3.3 ft) above the ground (except for two stations that are intentionally submerged in the Columbia River). Each dosimeter consists of a card holding four LiF (TLD 700) chips and one $\mathrm{CaF}_{2}$ :Dy (TLD 200) chip. The chips are covered by approximately $1 \mathrm{~mm}(0.04 \mathrm{in}$.) of plastic. Measurements are taken at all stations quarterly, except for those at the $100-\mathrm{N}$ shoreline locations, where they are taken monthly because of elevated radiation levels. The 12 TLD 700 chips at each location are analyzed to determine the average environmental dose rate. The three TLD 200 chips are included to permit dose rate determinations in the event of a radiological emergency.

The TLDs were placed at numerous locations onsite, around the Site perimeter, in nearby and distant communities, and along the Hanford Reach of the Columbia River (Figures 4.35 and 4.36). All community and most of the onsite and perimeter TLDs were located at air monitoring stations; however, none of the Columbia River shoreline TLD locations were adjacent to air monitoring stations. These placements were based on historical determinations of locations with the highest potential for public exposure (access areas, population centers downwind, etc.) from past operations and the potential for current public exposures. Placement of a TLD near an air sampler facilitates the confirmation of measurements.

Dose rates were recorded by TLDs at several shoreline locations along the Hanford Reach of the Columbia River (some accessible by the general public), and TLDs were submerged in the Columbia River at two locations (Coyote Rapids and Richland Pumphouse). Most of the shoreline TLD locations were in areas along the river where dose rates have historically been elevated with respect to typical background levels. These elevated levels were identified in an extensive shoreline study in 1979 (Sula 1980) and were attributed to the radioactivity in shoreline sediments (primarily ${ }^{60} \mathrm{Co}$ and ${ }^{154} \mathrm{Eu}$ ) as a result of liquid releases during past reactor operations in the 100 Areas. The submerged TLDs provided an estimate of external radiation dose rates that could be received by a person immersed in the river.

Dose rates were also recorded by TLDs at three community-operated environmental surveillance stations. These stations are located at Edwin Markham Elementary Schoul, Basin City Elementary School, and Leslie Groves Park, as shown in Figure 4.35. Each statior is managed by local school teachers and measures dose rates using both TLDs and portable survey instruments. 


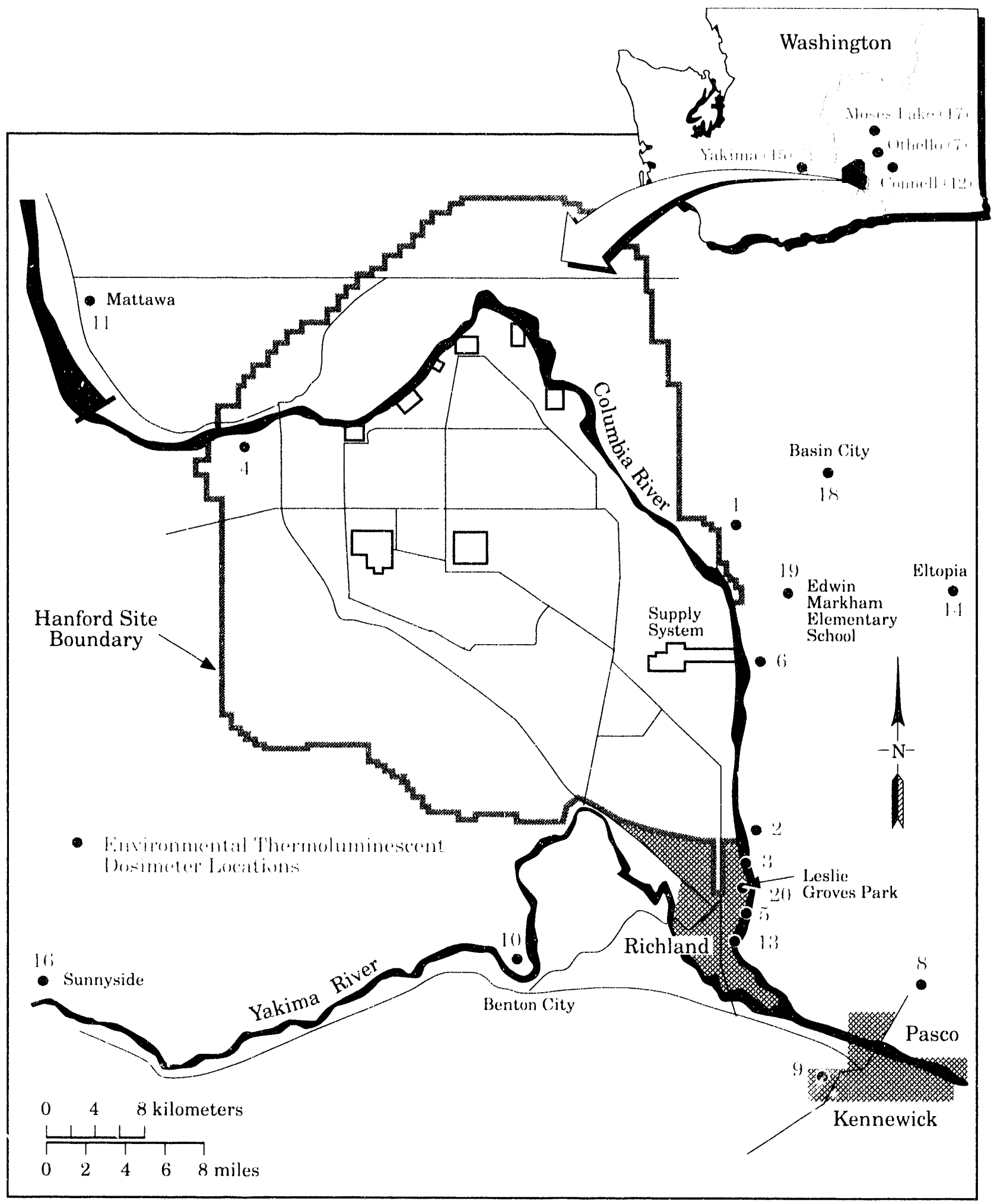

59203058.5

Figure 4.35. Thermoluminescent Dosimeter (TLD) Measurement Locations and Station Numbers for Perimeter and Community Sites, 1991 


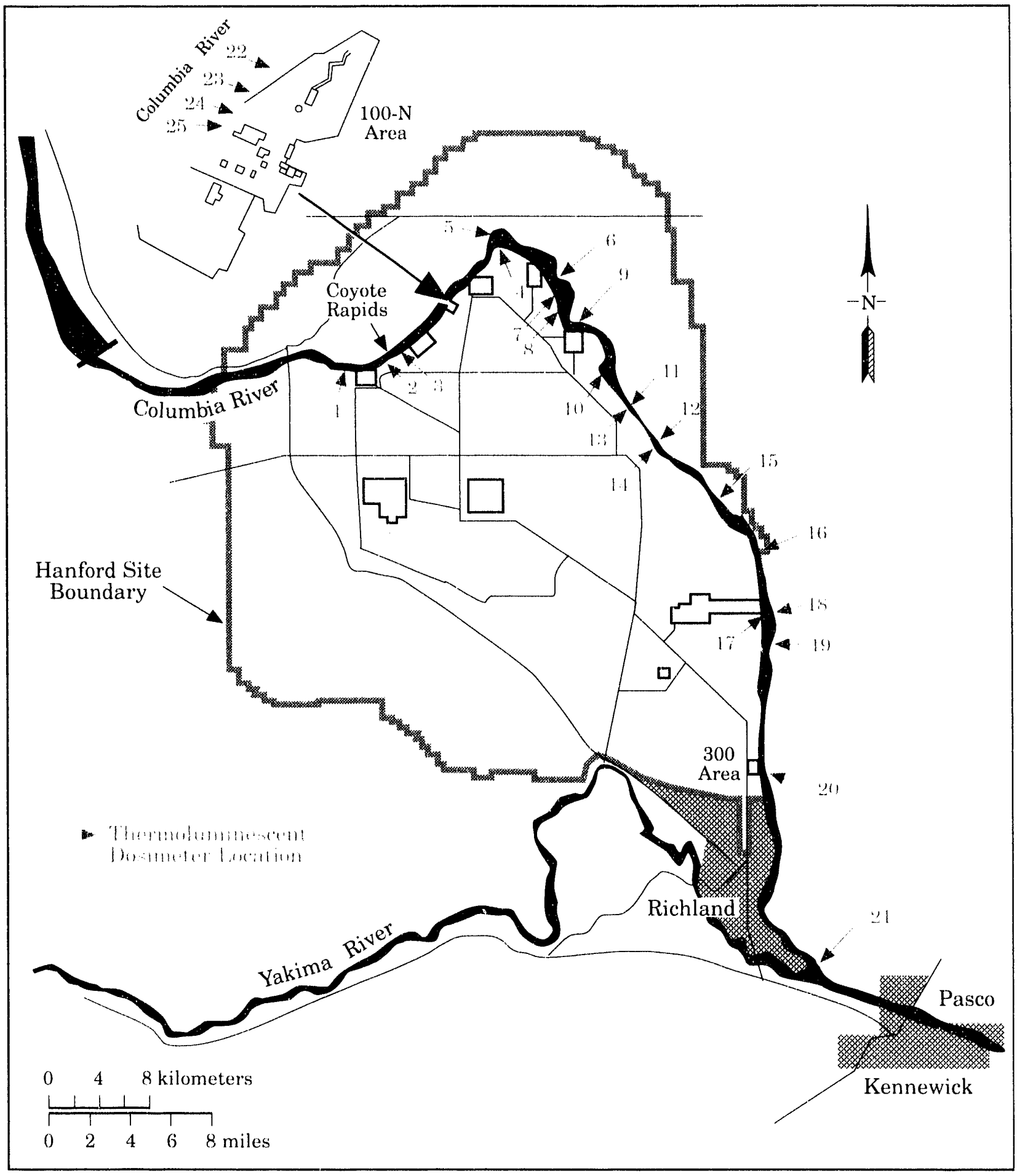

$\$ 9203058.6$

Figure 4.36. Thermoluminescent Dosimeter (TLD) Locations and Station Numbers on the Hanford Reach of the Columbia River, 1991 


\section{External Radiation Results}

Perimeter and offsite locations were monitored with TLDs primarily downwind of the Site and near population centers. Table 4.17 displays dose rates for the Site perimeter and nearby and distant communities. The dose rates were approximately $15 \%$ higher than those observed during 1990. An increase of the same magnitude was also observed at all other surveillance locations. This increase could be a result of two factors: either a uniform increase in natural background radiation occurred or a consistent measurement bias was applied to all TLD measurements in 1991 that was not applied in 1990. Increases in natural background radiation can occur as a result of a $10 \%$ annual variation in cosmic radiation as well as a $15 \%$ to $25 \%$ variation in terrestrial radiation, depending on soil moisture content (NCRP 1987). Average yearly TLD doses can also be affected by variations in the sensitivity of the individual TLDs zero-dose readings, fading, and random errors in the readout equipment or procedure. These uncertainties can result in variations in yearly average TLD doses of as much as $12 \%$ (Rathbun 1989).

The background external radiation dose rate, calculated from the annual average results from upwind distant locations (Sunnyside, Yakima, and Moses Lake only), was $88 \pm 3 \% \mathrm{mrem} / \mathrm{yr}$ as compared to the perimeter average of $100 \pm 6 \%$ $\mathrm{mrem} / \mathrm{yr}$. The difference between these average dose rates is due to both natural geographic variations in terrestrial radiation and variations resulting from human activities. Many of the perimeter sites are richer in naturally occurring deposits of radioactive potassium and thorium (Rathbun 1989). On the other hand, distant locations are near public buildings where the landscape has been altered by paving, gravel, etc. These alterations tend to lower the external radiation doses relative to natural conditions by shielding a small portion of the terrestrial radiation field. Although radiation at the distant locations is not ideal for comparison with radiation from unaltered sites, the choice of the distant site locations was considered necessary for reasons of security and accessibility.

Figure 4.37 shows average annual dose rates at perimeter and distant locations (all upwind and downwind) during 1991 and the previous 5 years. Some year-to-year natural variability is apparent. Natural variability is due to several factors as discussed above and year-to-year variacions of $10 \%$ are not unlikely (NCRP 1987). The belownormal precipitation during the past 5 years (approximately $12 \%$ less) may account for more

Table 4.17. Dose Rates Measured by Thermoluminescent Dosimeters at Perimeter and Community Locations, 1991

\begin{tabular}{|c|c|c|c|c|}
\hline \multirow[b]{2}{*}{ Location } & \multirow{2}{*}{$\begin{array}{c}\text { Map } \\
\text { Location }^{(b)} \\
\end{array}$} & \multicolumn{3}{|c|}{ Dose Rate, ${ }^{(a)} \mathrm{mrem} / \mathrm{yr}$} \\
\hline & & Maximum & Minimum & Average $^{(c)}$ \\
\hline Perimeter Stations & $1-6$ & $106 \pm 16 \%$ & $85 \pm 18 \%$ & $100 \pm 6 \%$ \\
\hline Nearby Communities & $7-14$ & $95 \pm 10 \%$ & $88 \pm 10 \%$ & $90 \pm 2 \%$ \\
\hline Distant Communities & $15-17$ & $91 \pm 8 \%$ & $86 \pm 7 \%$ & $88 \pm 3 \%$ \\
\hline $\begin{array}{l}\text { Community-Operated } \\
\text { Stations }\end{array}$ & $18-20$ & $88 \pm 5 \%$ & $77 \pm 12 \%$ & $81 \pm 9 \%$ \\
\hline
\end{tabular}

(a) Quarterly integrated readings in $\mathrm{mR}$ were converted to annual dose equivalent rates.

(b) Locations are identifi $\triangleq d$ in Figure 4.35.

(c) Averages \pm 2 times the standard error of the calculated mean (SEM). The averages and 2 SEM were computed using station averages rather than individual measurements. 


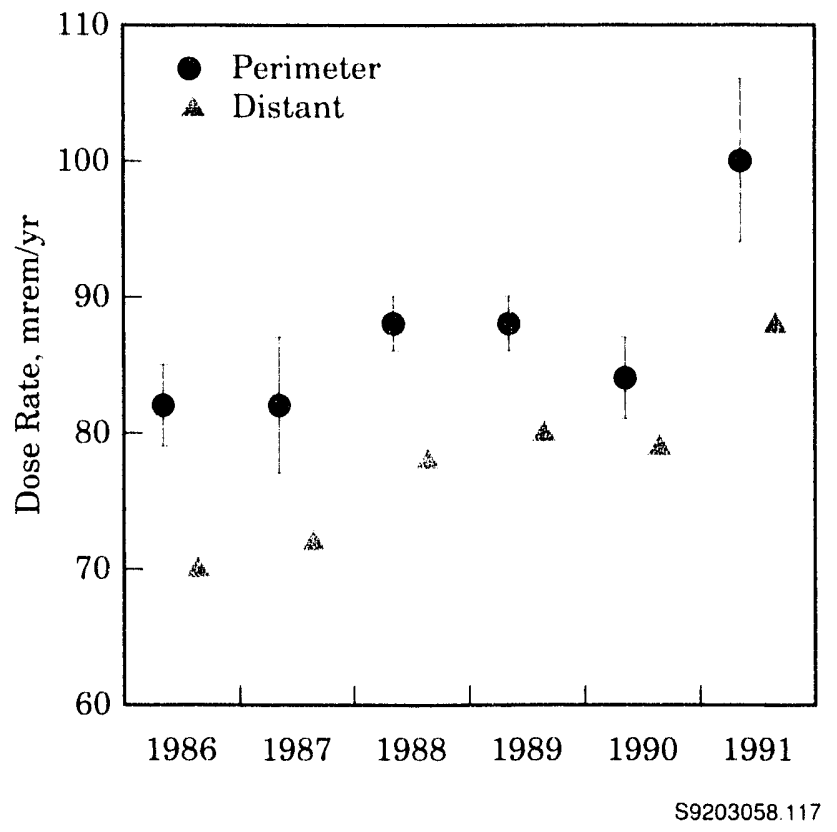

Figure 4.37. Annual Average Dose Rates at Perimeter and Distant Locations, 1986 Through 1991

radiation from the soil reaching the TLDs by increasing radon percolation rates and decreasing the shielding of gamma-ray emissions from natural radionuclides in the ground.
Figure 4.36 and Table 4.18 show the location of the TLDs on the Hanford Reach of the Columbia River and their average dose rates. An increase of approximately $15 \%$ between 1990 and 1991 was observed at all shoreline locations consistent with the general increase across the network. Dose rates at the shoreline of the 100-N Area were approximately two to three times greater than the typical shoreline dose rates. This increase is attributed to residual radioactivity from past waste management activities within the $100-\mathrm{N}$ Area. The shoreline in the $100-\mathrm{N}$ Area is not open for public use, but the adjacent river is open.

Dose rates from two immersed dosimeter locations indicated that swimmers at these locations would receive about one-half the external radiation dose rate of a person at a typical shoreline location. This difference is expected because they would be receiving less natural radiation from terrestrial sources.

Onsite external radiation was measured at locations shown in Figure 4.38 and listed in Table 4.19. Dose rates above background levels were observed at several locations during 1991. The average onsite dose was approximately $11 \%$ larger than the measured background. Rates in

Table 4.18. Dose Rates Measured by Thermoluminescent Dosimeter Along the Hanford Reach of the Columbia River, 1991

Location

Typical Shoreline Area"

100-N Area Shoreline $\mathrm{e}^{(\mathrm{d})}$

All Shoreline

Immersed in Columbia River ${ }^{(1)}$
Map

$\underline{\text { Location }^{(a)}}$

$1-21$

$22-25$

\begin{tabular}{|c|c|c|c|}
\hline Location ${ }^{(a)}$ & Maximum & Minimum & Average $^{(t)}$ \\
\hline $1-21$ & $131 \pm 22 \%$ & $88 \pm 5 \%$ & $103 \pm 5 \%$ \\
\hline \multirow[t]{3}{*}{$22-25$} & $356 \pm 40 \%$ & $184 \pm 9 \%$ & $268 \pm 37 \%$ \\
\hline & & & $125 \pm 21 \%$ \\
\hline & $65 \pm 15 \%$ & $57 \pm 31 \%$ & $61 \pm 13 \%$ \\
\hline
\end{tabular}

Dose Rate, $\mathrm{mrem} / \mathrm{yr}$

(a) All locations shown in Figure 4.36; immersion points at Richland Pumphouse and Coyote Rapids.

(b) Averages \pm 2 times the standard error of the calculated mean (SEM). The averages and 2 SEM were computed using station averages rather than individual measurements.

(c) Quarterly integrated readings in $\mathrm{mR}$ were converted to annual dose equivalent rates.

(d) Monthly integrated readings in $\mathrm{mR}$ were converted to annual dose equivalent rates. 


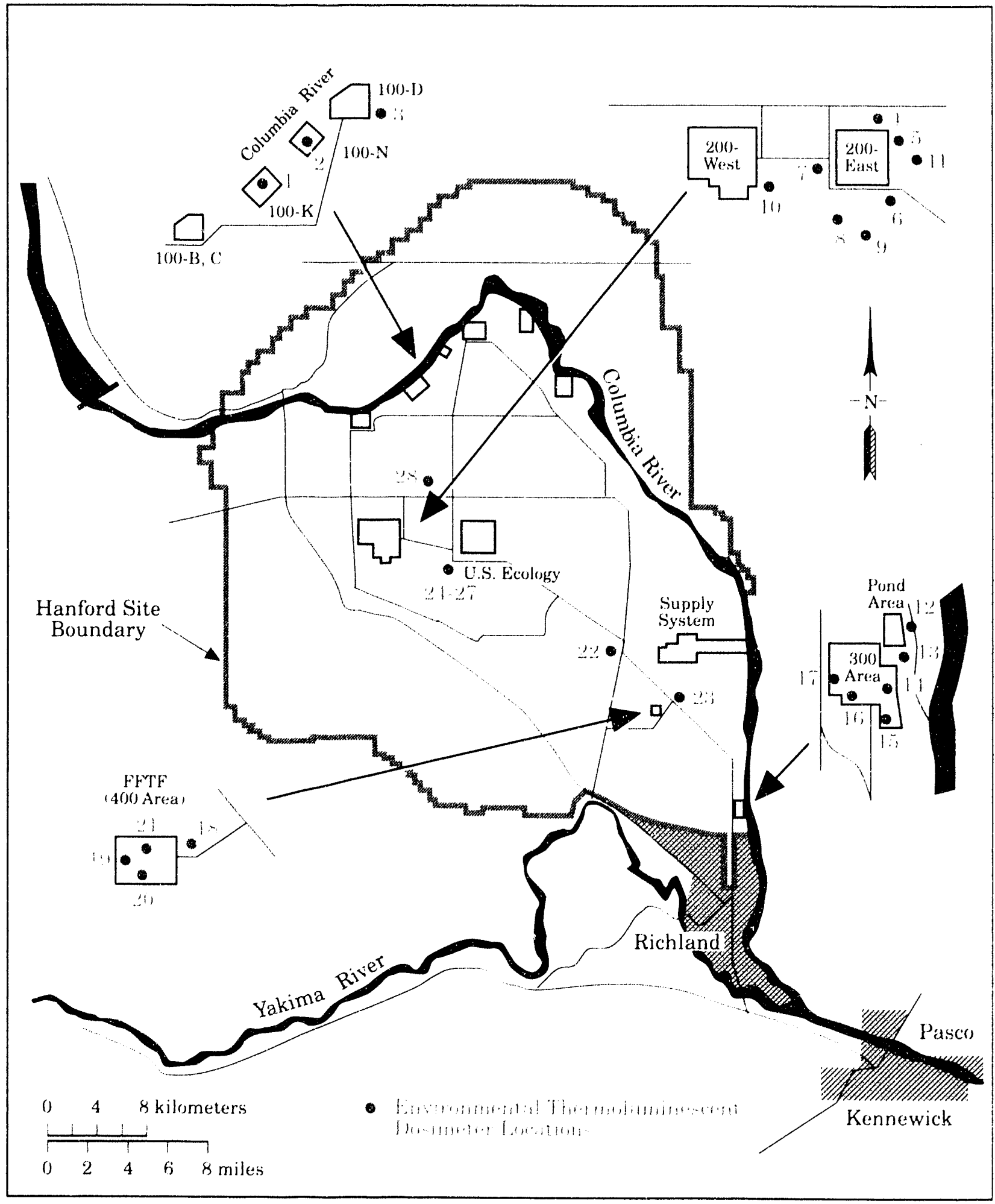

59203058.7

Figure 4.38. Thermoluminescent Dosimeter (TLD) Locations and Station Numbers on the Hanford Site, 1991 
Table 4.19. Dose Rates for 'Thermoluminescent Dosimeter Locations on the Hanford Site, 1991

\begin{tabular}{|c|c|c|c|c|}
\hline \multirow[b]{2}{*}{ Location } & \multirow{2}{*}{$\begin{array}{c}\text { Map } \\
\text { Location't. }\end{array}$} & \multicolumn{3}{|c|}{ Dose Rate, 'a' mrem/yr } \\
\hline & & Maximum & Minimum & Average \\
\hline 100 Areas & $1-3$ & $120 \pm 29 \%$ & $82 \pm 10 \%$ & $101 \pm 22 \%$ \\
\hline 200 Areas & $4-11$ & $104 \pm 29 \%$ & $83 \pm 20 \%$ & $94 \pm 5 \%$ \\
\hline 300 Area & $12-17$ & $99 \pm 13 \%$ & $89 \pm 7 \%$ & $95 \pm 3 \%$ \\
\hline 400 Area & $18-21$ & $95 \pm 16 \%$ & $85 \pm 10 \%$ & $90 \pm 5 \%$ \\
\hline 600 Area & $22-28$ & $170 \pm 11 \%$ & $90 \pm 21 \%$ & $109 \pm 21 \%$ \\
\hline All Onsite & & & & $98 \pm 7 \%$ \\
\hline
\end{tabular}

(a) Quarterly integrated readings in $\mathrm{mR}$ were converted to annual dose equivalent rates.

(b) Locations are identified in Figure 4.38.

(c) Averages \pm 2 times the standard error of the calculated mean (SEM). The averages and 2 SEM were computed using station averages rather than individual measurements.

excess of background observed near the $100-\mathrm{N}$, 200-East, and 300 Areas were attributed to direct radiation from waste handling and storage facilities. Some of the highest rates onsite are attributable to waste handling activities at U.S. Ecology (south of the 200-East Area), a non-DOE facility. Dose rates at the 400 Area FFTF Visitor Center and near the west perimeter of the 300 Area (two areas routinely visited by the public) were at typical background leveis.

\section{Radiation Surveys}

Various onsite roads and railroads, Columbia River shoreline, and perimeter locations were surveyed routinely during 1991 . Some public (offsite) roads were surveyed into north Richland. The frequency of surveys on specific routes for roads and railroads was based on their use and the potential for contamination. Specific routes and frequencies for surveys in 1991 were defined in a master schedule developed by PNL (Bisping 1991).

Roads and railroads (Figure 4.39) were surveyed routinely using mobile scintillation detectors. In
1991 one small area of low-level radioactive contamination [less than $1 \mathrm{ft}^{2}\left(0.09 \mathrm{~m}^{2}\right)$ ) was detected on an onsite road and at an onsite rail location. Contamination was reported to Westinghouse Hanford Company and was removed.

Portable instrument surveys were conducted routinely at many of the Columbia River shoreline TLD locations. These surveys provide a gross screening for elevated radiation fields. The shoreline surveys showed that radiation levels at these locations were comparable to levels measured in the last few years. Unlike many other monitoring results, road, rail, and shoreline results are not listed in Bisping (1992), but are kept in the Surface Environmental Surveillance Project files at PNL.

In 1988 , an extensive aerial radiological survey capable of detecting very small changes in gamma-ray radiation levels coming from groundlevel sources was performed over the Site and the surrounding areas (EG\&G 1990). The final report for this study was received and reviewed in October 1990 . The data indicated that the radionuclides and associated gamma radiation detected were generally consistent with those 


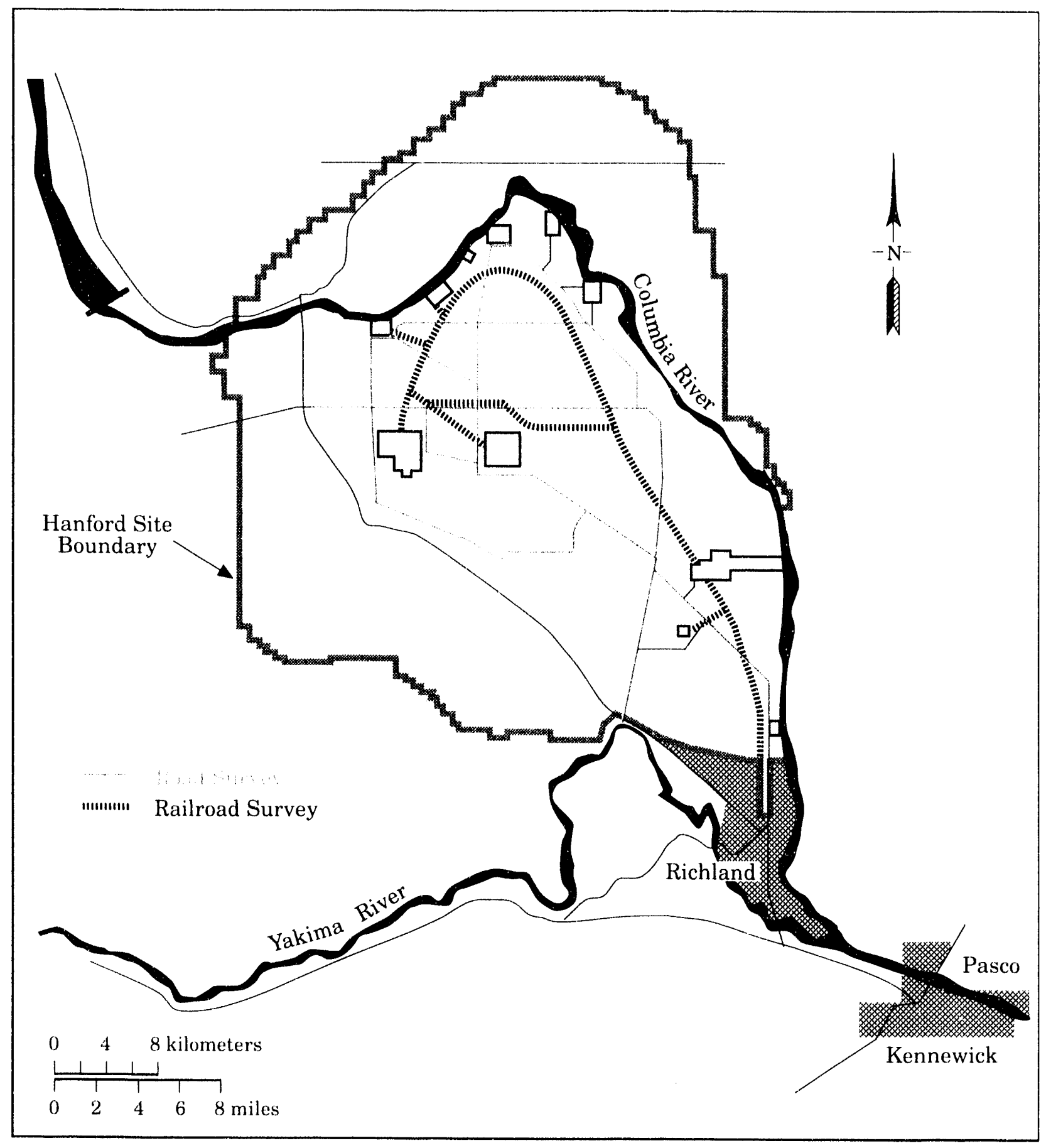

$\$ 9203058.4$

Figure 4.39. Road and Railroad Survey Routes, 1991 
expected from normal background sources and the past and present activities at the Site. The external exposure rates reported by this : agree well with the average exposure rate measured around the Site and at perimeter locations during the past few years. Some operating areas had external exposure rates approximately 100 times higher than typical background levels, but these areas are inaccessible to the public and are currently under operational safety controls. The study further showed that the total amount of publicly accessible land area known to have elevated external radiation levels from past Hanford operations (primarily areas on the Hanford Reach of the Columbia River) has decreased since a similar 1978 study (EG\&G 1978). Further declines in contaminated area are expected because of the decay of artificially produced radionuclides in some river sediments and changing Site operations. 


\subsection{Potential Radiation Doses from 1991 Hanford Operations}

Present and past operations at Hanford have resulted in the release of radionuclides into the surrounding environment. Members of the public have potentially been exposed to low levels of radiation from these effluents through a variety of pathways. The potential radiation doses' 'to to the public in 1991 from Hanford operations were calculated for the hypothetical maximally exposed individual (MEI) and for the general public residing within $80 \mathrm{~km}(50 \mathrm{mi})$ of the Hanford Site. These doses were calculated from effluent releases reported by the operating contractors, and radionuclide measurements in environmental media, using Version 1.485 of the GENII code (Napier et al. 1988a, 1988b, 1988c) and Hanford Site-specific parameters.

The potential dose to the MEI in 1991 from Hanford operations was $0.02 \mathrm{mrem}\left(2 \times 10^{4}\right.$ $\mathrm{mSv})$, compared to $0.03 \mathrm{mrem}\left(3 \times 10^{-4} \mathrm{mSv}\right)$ reported for 1990. The potential dose to the local population of 380,000 persons (Beck et al. 1991) from 1991 operations was 0.9 person-rem (0.009 person-Sv), compared to 2 person-rem (0.02 person-Sv) reported for 1990 . The 1991 average dose to the population was $0.002 \mathrm{mrem}$ $\left(2 \times 10^{-5} \mathrm{mSv}\right)$ per person. The current DOE radiation limit for an individual member of the public is $100 \mathrm{mrem} / \mathrm{yr}(1 \mathrm{mSv} / \mathrm{yr})$, and the national average dose from natural sources is $300 \mathrm{mrem} / \mathrm{yr}$ ( $3 \mathrm{mSv} / \mathrm{yr}$ ). The MEI potentially received $0.02 \%$ of the limit and $0.007 \%$ of the national average dose from natural sources. The average individual potentially received $0.002 \%$ of the standard and $0.0008 \%$ of the $300 \mathrm{mrem} / \mathrm{yr}$ received from typical natural sources.

During 1991, radionuclides reached the environment in gaseous and liquid effluents from present and past Hanford operations. Gaseous effluents were released from operating stacks and ventilation exhausts. Liquid effluents were released

(a) Unless stated otherwise the term "dose" in this chapter is the "effective dose equivalent" (see Glossary). from operating waste-water treatment facilities and in seepage of contaminated ground water into the Columbia River. These radioactive materials were then transported throughout the environment by wind and the Columbia River. Eventually, animals and people can be exposed to these radionuclides through external exposure, and inhalation and ingestion of contaminated air and foodstuffs. Because of the many variables involved in the transport of the radionuclides in the environment, differing living habits of people, and the fact that the exposure scenarios employed are conservative, the results of the evaluations are likely to be maximum estimates of the radiation doses potentially received by residents of the area surrounding the Hanford Site.

Potential radiation doses to the public from these releases were evaluated in detail to determine compliance with pertinent regulations and limits. The potential radiological impacts of 1991

Hanford operations were assessed in terms of the following:

- dose to a hypothetical MEI at an offsite location

- maximum dose rate from external radiation at a publicly accessible location on or within the Site boundary

- dose to an avid sportsman

- dose to the population residing within $80 \mathrm{~km}$ $(50 \mathrm{mi})$ of the operating areas

- dose rate potentially received by animals associated with contaminant releases to the Columbia River.

During 1991, the various unusual environmental occurrences listed in Section 2.4, "Environmental Occurrences," involved potential uncontrolled releases of radionuclides into the environment. However, no additional dose to the public resulted from such occurrences. 
To the extent possible, radiation dose assessments should be based on direct measurements of radiation dose rates and radionuclide concentrations in the surrounding environment. The amounts of most radioactive materials released during 1991 were generally too small to be measured directly once they were dispersed in the offsite environment. For many of the measurable radionuclides, it was difficult to identify the contributions from Hanford sources in the presence of those contributed from worldwide fallout and from naturally occurring uranium and its decay products. Therefore, in nearly all instances, potential offsite doses were estimated using environmental pathway models that calculate concentrations of radioactive materials in the environment from effluent releases reported by the operating contractors.

In the past, the differences in measured concentrations of certain radionuclides in samples of Columbia River water collected upstream and downstream of the Hanford Reach were used to estimate the doses to the public from these radionuclides entering the river with riverbank seepage of ground water. The only two radionuclides routinely found at greater concentrations than predicted from direct discharge from the 100 and 300 Areas have been " $\mathrm{H}$ and ${ }^{12 !} \mathrm{I}$.

Although the uncertainty associated with the radiation dose calculations has not been quantified, whenever Hanford-specific data were not available for parameter values (for example, plant uptake and consumption factors) conservative values were selected from the literature for use in environmental transport models. Thus, doses calculated using models should be viewed as maximum estimates of potential doses resulting from Hanford operations.

\section{Maximally Exposed Individual Dose}

The MEI is a hypothetical person who lives at a location and has a postulated lifestyle such that it is unlikely that other members of the public would receive higher doses. This individual's characteristics were chosen to maximize the combined doses from all realistic environmental pathways of exposure to radionuclides in Hanford effluents. In reality, such a combination of maximized parameters is unlikely to apply to any single individual.

The location selected for the MEI can vary from year to year depending on the relative importance of the several sources of radioactive effluents released to the air and to the Columbia River from Hanford facilities.

Historically, two separate locations in the Hanford environs have been identified as potential sites for the MEI: the Ringold area $26 \mathrm{~km}$ ( $16 \mathrm{mi}$ ) east of the 200 Areas separation facilities, and the Riverview irrigation district across the river from Richlaild (Figure 4.40). The principal differences between the two MEI locations are that Ringold is closer than Riverview to the Hanford facilities which had been the major contributors of airborne effluents, but the MEI at Ringold does not drink water derived from the Columbia River. The MEI at Riverview, although farther from the Hanford sources of airborne radionuclides, can be exposed to the one additional pathway of consumption of drinking water derived from the Columbia River.

In recent years, the calculated doses to an MEI at the two locations have been very nearly the same. For the 1990 calendar year, the dose calculated for the MEI at Ringold was about 5\% higher than that calculated for the MEI at Riverview. For the 1991 calendar year, the situation was reversed (i.e., the calculated dose to the MEI at Riverview was $5 \%$ higher than that calculated for the MEI at Ringold). The change resulted from the continued reduction of the quantity of radionuclides released to the atmosphere from Hanford facilities.

The following exposure pathways were included in the calculation of doses potentially received by the MEI for 1991: inhalation of and subınersion in air downwind of the Site, consumption of foods contaminated by radionuclides deposited on the ground from airborne materials and by irrigation with water from the Columbia River, direct exposure to radionuclides deposited on the ground, consumption of drinking water derived from the Columbia River, consumption of fish taken from 


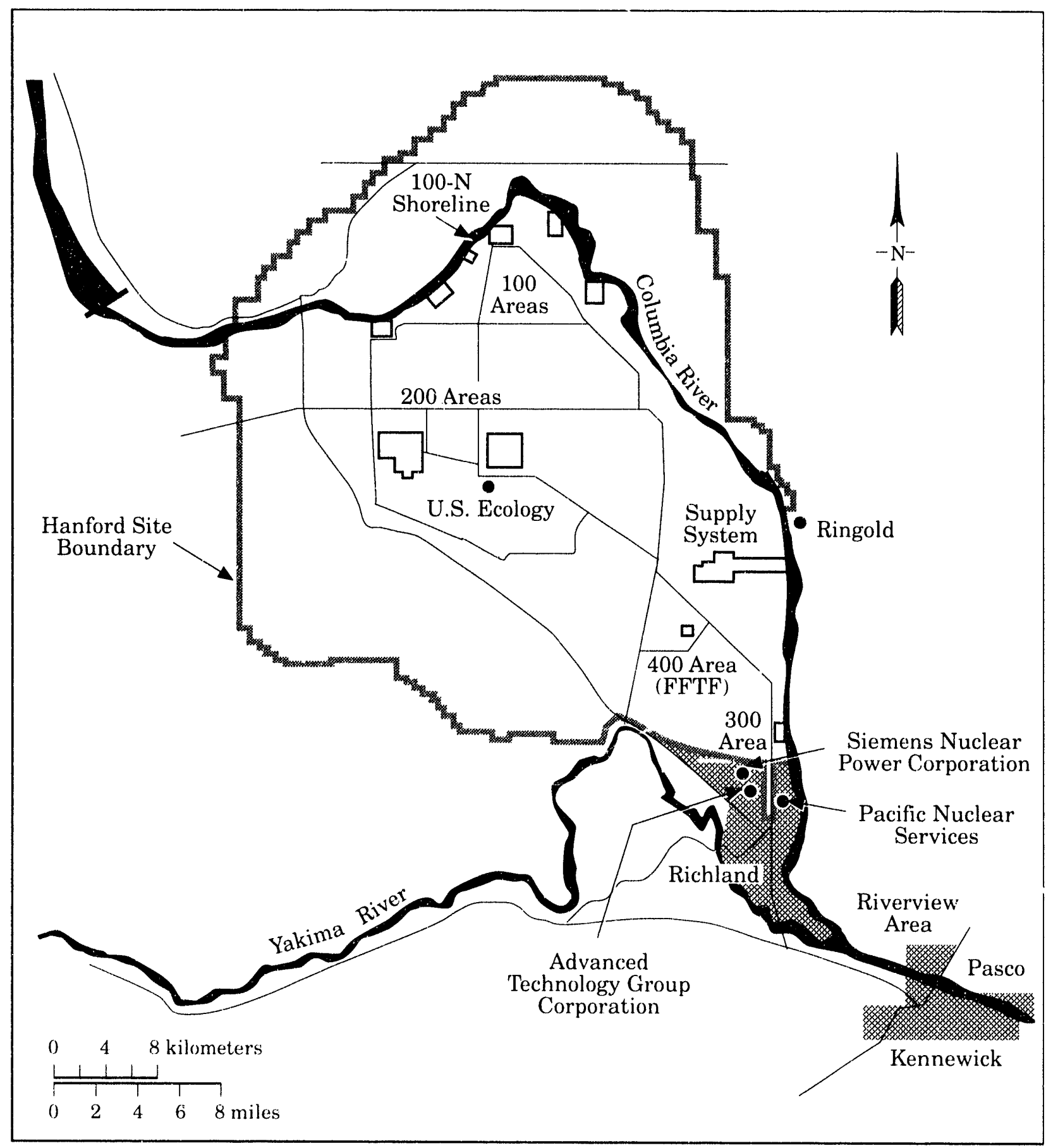

S9203058.121

Figure 4.40. Locations Important to Dose Calculations 
the Columbia River, and external radiation during recreation activities on the Columbia River and its shoreline. The MEI for 1991 was postulated to be an individual who:

- was a resident of the Riverview area

- consumed homegrown foodstuffs irrigated with Columbia River water

- used the Columbia River extensively for boating, swimming, and fishing, and consumed the fish caught

- drank water that was derived from the Columbia River via the Pasco municipal water system.

Doses to the MEI were calculated using the effluent data in Section 4.1, Tables 4.1 through 4.7, and measured quantities of ${ }^{3} \mathrm{H}$ and estimated quantities of ${ }^{129} I$ present in the Columbia River from riverbank springs as input to the GENII code. The calculated doses for the MEI are summarized in Table 4.20. These values include the potential doses received from exposure to liquid and airborne effluents during 1991, as well as the future dose from radionuclides that were deposited in the body during 1991 via inhalation and ingestion. As releases from facilities and the doses from these sources decrease, the contribution of diffuse sources, such as wind-blown contaminated soil, becomes relatively more significant. A preliminary upper estimate of the dose from diffuse sources is discussed in a following subsection (Comparison with Clean Air Act Standards). This contribution is not included in the MEI dose. Site-specific parameters for food pathways, diet, and recreational activity used for the dose calculations are contained in Appendix C.

The total dose to the hypothetical MEI in 1991 was calculated to be $0.02 \mathrm{mrem}\left(2 \times 10^{-4} \mathrm{mSv}\right)$ compared to 0.03 mrem $\left(3 \times 10^{-4}\right)$ in 1990 . The primary pathways contributing to this dose as determined by the computer calculations were:

- consumption of food containing radionuclides (primarily ${ }^{12 \%} \mathrm{I}$ ) deposited from the air $(37 \%$ of total dose)
- consumption of food irrigated with Columbia River water containing radionuclides (primarily $\left.{ }^{3} \mathrm{H}\right)(27 \%)$

- consumption of drinking water containing radionuclides (primarily ${ }^{\text {' }} \mathrm{H}$ ) from the Columbia River (19\%)

- consumption of fish containing radionuclides (primarily ${ }^{137} \mathrm{Cs}$ ) from the Columbia River $(13 \%)$.

The dose limit for any member of the public from all routine DOE operations is $100 \mathrm{mrem} / \mathrm{yr}$ ( $1 \mathrm{mSv} / \mathrm{yr}$ ). The dose calculated for the MEI was $0.02 \%$ of the DOE limit.

The doses from Hanford operations for the MEI for 1987 through 1991 are illustrated in Figure 4.41. During each year the doses were estimated using methods and computer codes that were state-of-the-art at the time. Doses were estimated for the location determined to potentially result in the highest dose to the MEI. In 1987 and 1988 both the computer code to calculate the doses and the location of the MEI changed. Therefore, some of the change in dose from year to year is a result of these factors. Specifically, the principal reason for the change between 1987 and 1988 was the change in the location for the MEI. Soldat (1989) presents a comparison of the doses for the 5-year period 1983 through 1987 as calculated by these different methods. After 1989, the differences in doses calculated for the MEI at the two locations, Ringold and Riverview, have become very small.

\section{Special Case Exposure Scenarios}

While characteristics that define the standard and historical MEI are selected to define a high exposure scenario that is unlikely to occur, they do not necessarily represent the highest conceivable dose scenario that could occur. Low probability exposure scenarios exist that could conceivably result in somewhat higher doses. Two 
Table 4.20. Doses to the Hypothetical Maximally Exposed Individual from 1991 Hanford Operations

\begin{tabular}{|c|c|c|c|c|c|c|}
\hline \multirow[b]{2}{*}{ Effluent } & \multirow[b]{2}{*}{ Pathway } & \multicolumn{5}{|c|}{$\begin{array}{l}\text { Operating Area Contribution } \\
\text { Doses, mrem }\end{array}$} \\
\hline & & $\begin{array}{c}100 \\
\text { Areas }\end{array}$ & $\begin{array}{c}200 \\
\text { Areas }\end{array}$ & $\begin{array}{c}300 \\
\text { Area }\end{array}$ & $\begin{array}{l}400 \\
\text { Area }\end{array}$ & $\begin{array}{l}\text { Pathway } \\
\text { Total }\end{array}$ \\
\hline \multirow[t]{3}{*}{ Air } & External ${ }^{(0)}$ & $5 \times 10^{-8}$ & $7 \times 10^{-6}$ & $2 \times 10^{-\varsigma}$ & $5 \times 10^{-5}$ & $6 \times 10^{-5}$ \\
\hline & Inhalation & $2 \times 10^{-6}$ & $8 \times 10^{-4}$ & $2 \times 10^{-4}$ & $2 \times 10^{-9}$ & 0.001 \\
\hline & Foods ${ }^{\text {di }}$ & $3 \times 10^{-7}$ & 0.004 & 0.001 & $6 \times 10^{-8}$ & 0.006 \\
\hline \multirow[t]{5}{*}{ Water } & Recreation (") & $2 \times 10^{-5}$ & $8 \times 10^{-i j}$ & $5 \times 10^{-7}$ & (f) & $2 \times 10^{-5}$ \\
\hline & Foods' & $4 \times 10^{-4}$ & 0.004 & $2 \times 10^{-4}$ & --- & 0.004 \\
\hline & Fish'h & 0.002 & $2 \times 10^{-4}$ & $2 \times 10^{-4}$ & --- & 0.002 \\
\hline & Drinking water & $3 \times 10^{5}$ & 0.003 & $1 \times 10^{-4}$ & -- & 0.003 \\
\hline & Total & 0.002 & 0.01 & 0.002 & $5 \times 10^{-5}$ & 0.02 \\
\hline
\end{tabular}

(a) To convert these dose values to $\mathrm{mSv}$, divide them by 100 .

(b) Values rounded after adding.

(c) Includes air submersion and exposure to ground-deposited radionuclides.

(d) Includes consumption of all foodstuffs contaminated via deposition from the air.

(e) External exposure during river recreation plus inadvertent ingestion of water while swimming.

(f) There are no releases to the river from the 400 Area.

(g) Includes consumption of all foodstuffs contaminated via irrigation water and external exposure to ground contaminated via irrigation.

(h) Consumption of fish taken from the Columbia River.

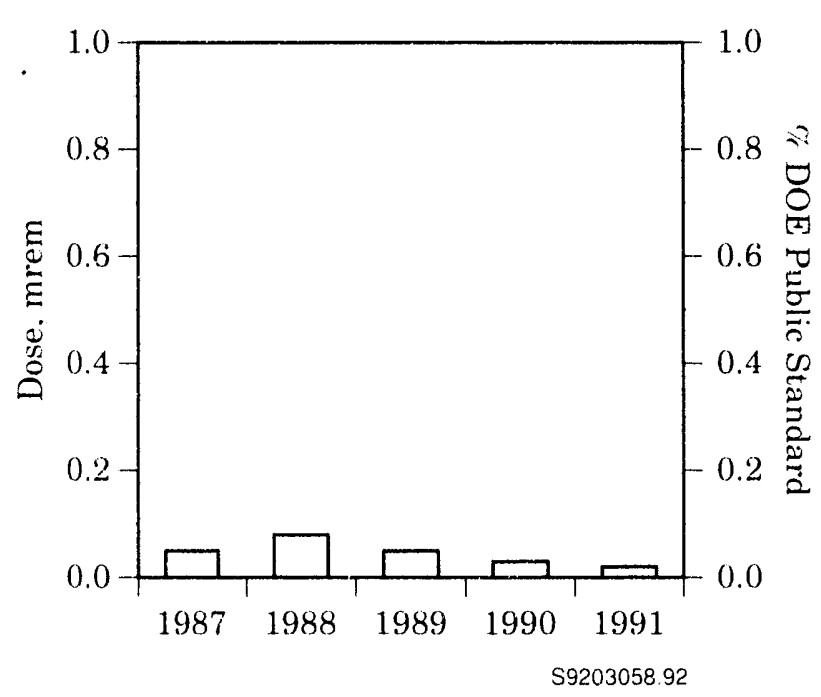

Figure 4.41. Calculated Effective Dose Equivalent to the Hypothetical Maximally Exposed Individual, 1987 Through 1991. potential scenarios include an individual who could spend time at the Site boundary location with the maximum external radiation dose rate, and a sportsman who might obtain contaminated wildlife that migrated from the Site. These special cases are discussed below, as well as the potential dose from consumption of drinking water at the FFTF Visitors Cente:.

\section{Maximum "Boundary" Dose Rate}

The "boundary" dose rate is the external radiation dose rate measured at publicly accessible locations on or near the Site. The "boundary" dose rate was determined from radiation exposure measurements using fixed radiation dosimeters (TLDs) at locations of expected elevated dose rates onsite and at representative locations offsite. These "boundary" dose rates 
should not be used to calculate annual doses to the general public because no one can actually reside at any of these "boundary" locations. However, these rates can be used to determine the dose to a specific individual who might spend some time at that location.

"Boundary" external radiation dose rates were measured in the vicinity of the $100-\mathrm{N}, 300$, and 400 (FFTF) Areas, as described in Section 4.7, "External Radiation Surveillance." The 200 Areas results were not used because these locations are not accessible to the general public. Radiation measurements made at the $100-\mathrm{N}$ Area shoreline (Figure 4.40) were consistently above background level and represent the highest measured "boundary" dose rate. The Columbia River provides public access to an area within a few hundred meters of the N Reactor and supporting facilities.

The annual average dose rate at the location with the highest exposure rate along the $100-\mathrm{N}$ shoreline during 1991 was $0.04 \mathrm{mrem} / \mathrm{h}\left(4 \times 10^{-4} \mathrm{mSv} / \mathrm{h}\right)$, or about $0.03 \mathrm{mrem} / \mathrm{h}$ above the average background dose rate of $0.01 \mathrm{mrem} / \mathrm{h}\left(1 \times 10^{-4} \mathrm{mSv} / \mathrm{h}\right)$ normally observed at offsite shoreline locations. Therefore, for every hour someone spent at the 100-N Area shoreline, the external radiation dose received from Hanford operations would be about $0.03 \mathrm{mrem}\left(3 \times 10^{-1} \mathrm{mSv}\right)$. This dose would be in addition to the annual dose calculated for the MEI at Riverview. In practice the public can approach the shoreline by boat, but they are legally restricted from stepping onto the shoreline.

The FFTF Visitors Center, located southeast of the FFTF Reactor building (Figure 4.40), provides public access to the 400 Area. Dose rates measured at this location during 1991 were essentially equal to normal background radiation levels in the vicinity of Hanford $10.01 \mathrm{mrem} / \mathrm{h}$ $\left(1 \times 10^{-1} \mathrm{mSv} / \mathrm{h}\right)$.

\section{Sportsman Dose}

Wildlife have access to areas of the Site that contain contamination and could thereby become contaminated. The potential also exists for contaminated wildlife to move offsite. For this reason, sampling is conducted onsite to estimate maximum contamination that might exist in animals hunted offsite. This is a unique and relatively low probability scenario that is not included in the MEI calculation.

Listed below are examples of the estimated radiation doses that could have resulted if wildlife, containing the maximum concentrations measured in onsite wildlife in 1991, migrated offsite, were hunted, and were consumed. These are very low doses, and qualitative observations suggest that the significance of this pathway is further reduced because of the relatively low migration offsite and the inaccessibility of onsite wildlife to hunters. Not all of the maximum values were observed in the same animal of each species sampled. However, the maximum values were compounded to arrive at an upper limit to the potential concentrations. These doses would be in addition to the MEI dose.

- The dose from eating $1 \mathrm{~kg}^{(a)}$ of meat containing the maximum concentrations of ${ }^{61} \mathrm{Co}$ and ${ }^{137} \mathrm{C}$ s measured in a deer collected onsite is estimated to be $5 \times 10^{-4} \mathrm{mrem}\left(5 \times 10^{-4} \mathrm{mSv}\right)$.

- The dose from eating $1 \mathrm{~kg}$ of meat containing the maximum concentrations of ${ }^{6 i} \mathrm{Co},{ }^{91} \mathrm{Sr}$, and ${ }^{137} \mathrm{Cs}$ measured in any duck collected onsite is estimated to be 0.2 mrem $(0.002$ $\mathrm{mSv}$ ).

- The dose from eating $1 \mathrm{~kg}$ of meat containing the maximum amount of ${ }^{61} \mathrm{Co}$ and ${ }^{17} \mathrm{Cs}$ measured in a pheasant collected onsite is estimated to be $1 \times 10^{.3} \mathrm{mrem}\left(1 \times 10^{-5} \mathrm{mSv}\right)$.

The methodology for calculating doses from consumption of wildlife are addressed in more detail in a recent report (Soldat et al. 1990).

\section{FFTF Visitors Center Drinking Water}

During 1991, ground water was used as a drinking water source at the FFTF Visitors Center (Figure 4.40). This water is sampled and analyzed throughout the year in accordance with

(a) $1 \mathrm{~kg}$ is approximately $2.2 \mathrm{lb}$. 
applicable drinking water regulations. Radionuclide concentrations during 1991 were well below applicable drinking water standards, but concentrations of ${ }^{3} \mathrm{H}$ and ${ }^{12}{ }^{\prime 2} \mathrm{I}$ were detected at levels above typical background values. Based on these measurements, the potential dose received by a member of the public from drinking $1 \mathrm{~L}$ ( $1 \mathrm{qt}$ ) of drinking water during a visit to the FFTF Visitors Center was calculated to be $6 \times 10^{-4}$ mrem $\left(6 \times 10^{-15} \mathrm{mSv}\right)$. The maximum organ dose (thyroid) was also calculated to be $6 \times 10^{-4} \mathrm{mrem}$ $\left(6 \times 10^{-15} \mathrm{mSv}\right)$. These doses are very small percentages of the EPA limit of 4 mrem $(0.04 \mathrm{mSv})$.

\section{Comparison with Clean Air Act Standards}

Limits for the radiation dose to the public from air pathways are provided in 40 CFR 61, Subpart H, of the Clean Air Act (EPA 1990). The regulation specifies that no member of the public should receive more than $10 \mathrm{mrem} / \mathrm{yr}$ $(0.1 \mathrm{mSv} / \mathrm{yr})$. The 1991 air emissions from Hanford facilities resulted in a calculated dose to the MEI of 0.007 mrem $\left(7 \times 10^{\circ} \mathrm{mSv}\right)$, which is $0.07 \%$ of the limit. Thus, the estimated annual dose from Hanford airborne effluent releases in 1991 was well below the Clean Air Act standard. The dose calculated to demonstrate compliance with the Clean Air Act is required to be generated using the CAP- 88 codes. The dose factors in these EPA codes, and certain assumptions, differ somewhat from those specified in DOE publications (DOE 1988a, 1988b). Nevertheless, the results from calculations performed with CAP-88 are similar to the doses to an MEI at Ringold from the air-pathways calculated using GENII |0.009 mrem $\left(9 \times 10^{\text {is }} \mathrm{mSv}\right) \mid$.

Since 1990 the Clean Air Act (40 CFR 61 Subpart $H$ ) required DOE to report radioactive air emissions and dose from diffuse sources as well as point sources. Diffuse source emissions are very difficult to measure directly and EPA has not specified or approved methodologies for assessing diffuse sources. However, a first approximation of the maximum potential offsite public dose from diffuse and other unmonitored sources was made using receptor location environmental surveillance measurements. The calculated upperbound estimate was 0.1 mrem or $1 \%$ of the limit
(DOE 1992e). This first approximation was made based on simplified but conservative assumptions, which if refined would be expected to reduce estimates of doses from these sources.

\section{Population Dose}

Pathways of exposure to the population from releases of radionuclides to the atmosphere include inhalation, air submersion, and consumption of contaminated food. Pathways of exposure associated with Hanford-generated radionuclides present in the Columbia River include consumption of drinking water, fish, consumption of irrigated foods, and external exposure during aquatic recreation. The regional population dose from 1991 Hanford operations was estimated by calculating the radiation dose to the population residing within an $80-\mathrm{km}(50-\mathrm{mi})$ radius of the onsite operating areas. Results of the dose calculations are shown in Table 4.21. Food pathway, dietary, residency, and recreational activity assumptions for these calculations are given in Appendix C.

The potential dose calculated for the population was 0.9 person-rem ( 0.009 person-Sv) in 1991 , compared to 2 person-rem $(0.02$ person-Sv) in 1990. The $80-\mathrm{km}(50-\mathrm{mi})$ population doses attributed to Hanford operations from 1987 through 1991 are compared in Figure 4.42.

Primary pathways contributing to the 1991 dose to the population were:

- consumption of foodstuffs contaminated with radionuclides (principally ${ }^{\mid 2 *}$ I) released with gaseous effluents primarily from the PUREX Plant stack (68\% of the total dose)

- inhalation of radionuclides (principally ${ }^{2} 3342,211 \mathrm{Pu}$ and ${ }^{2 \cdot 11} \mathrm{Am}$ ) that were released to the air from the PUREX Plant stack $(17 \%)$

- consumption of drinking water contaminated with radionuclides ( principally ${ }^{3} \mathrm{H}$ ) released to the Columbia River at Hanford (13\%).

The average per capita dose from 1991 Hanford operations, based on a population of 380,000 within $80 \mathrm{~km}(50 \mathrm{mi})$, was $0.002 \mathrm{mrem}\left(2 \times 10^{-5}\right.$ $\mathrm{mSv}$. This dose estimate may be compared with 
Table 4.21. Population Doses from 1991 Hanford Operations

\begin{tabular}{|c|c|c|c|c|c|c|}
\hline \multirow[b]{2}{*}{ Effluent } & \multirow[b]{2}{*}{ Pathway } & \multicolumn{5}{|c|}{$\begin{array}{l}\text { Operating Area Contribution } \\
\text { Doses, } \mathrm{mrem}^{(\mathrm{ub} b}\end{array}$} \\
\hline & & $\begin{array}{l}100 \\
\text { Areas } \\
\end{array}$ & $\begin{array}{c}200 \\
\text { Areas } \\
\end{array}$ & $\begin{array}{c}300 \\
\text { Area } \\
\end{array}$ & $\begin{array}{c}400 \\
\text { Area } \\
\end{array}$ & $\begin{array}{l}\text { Pathway } \\
\text { Total } \\
\end{array}$ \\
\hline \multirow[t]{3}{*}{ Air } & External' & $2 \times 10^{-5}$ & $9 \times 10^{-4}$ & $1 \times 10^{-6}$ & 0.007 & 0.008 \\
\hline & Inhalation & 0.001 & 0.2 & 0.01 & $3 \times 10^{-7}$ & 0.2 \\
\hline & Foods ${ }^{\prime d,}$ & $9 \times 10^{-5}$ & 0.6 & 0.05 & $7 \times 10^{6}$ & 0.6 \\
\hline \multirow[t]{5}{*}{ Water } & Recreation'(e) $^{(2)}$ & $7 \times 10^{-5}$ & $1 \times 10^{-4}$ & $4 \times 10^{-6}$ & (f) & $2 \times 10^{-4}$ \\
\hline & Foods' & $5 \times 10^{-4}$ & 0.004 & $2 \times 10^{-4}$ & -..- & 0.005 \\
\hline & Fish $^{\text {h' }}$ & $5 \times 10^{4}$ & $7 \times 10^{-5}$ & $7 \times 10^{5}$ & --- & $7 \times 10^{-4}$ \\
\hline & Drinking Water & 0.001 & 0.1 & $6 \times 10^{-4}$ & $--\cdot$ & 0.1 \\
\hline & Total & 0.004 & 0.8 & 0.07 & 0.007 & 0.9 \\
\hline
\end{tabular}

(a) To convert these dose values to $\mathrm{mSv}$, divide them by 100 .

(b) Values rounded after adding.

(c) Includes air submersion and exposure to ground-deposited radionuclides.

(d) Includes consumption of all foodstuffs contaminated via deposition from the air.

(e) External exposure during river recreation plus inadvertent ingestion of water while swimming.

(f) There are no releases to the river from the 400 Area.

(g) Includes consumption of all foodstuffs contaminated via irrigation water and external exposure to ground contaminated via irrigation.

(h) Consumption of fish taken from the Columbia River.

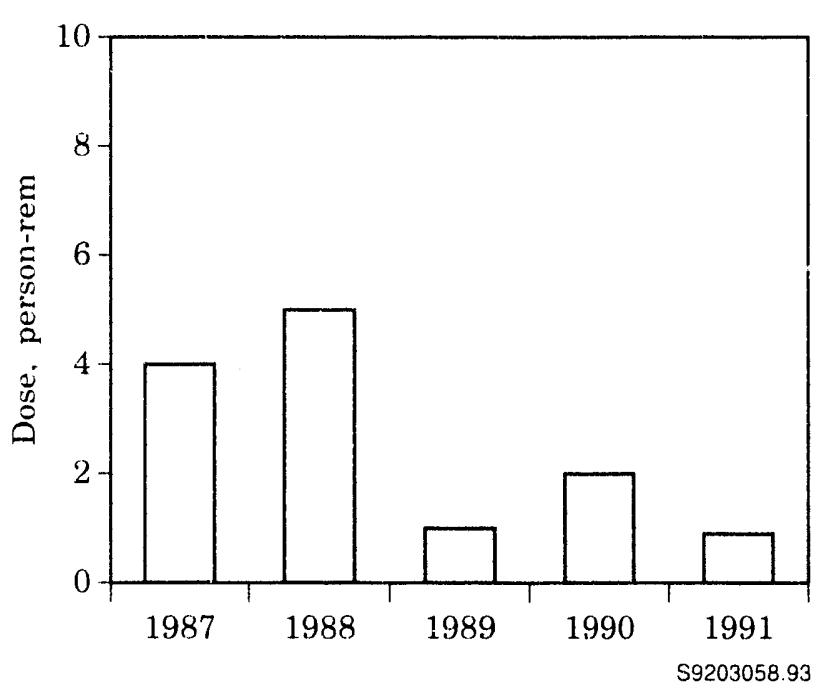

Figure 4.42. Calculated Effective Dose Equivalent to the Population Within $80 \mathrm{~km}(50 \mathrm{mi})$ of Hanford, 1987 Through 1991 doses from other routinely encountered sources of radiation, such as natural terrestrial and cosmic background radiation, medical treatment and $\mathrm{x}$ rays, natiral internal body radioactivity, and inhalation of naturally occurring radon. The national average radiation doses from these other sources are illustrated in Figure 4.43. The estimated per capita dose to individual members of the public from Hanford sources is a small fraction (approximately $0.0008 \%$ ) of the annual per capita dose (300 mrem) from natural background sources.

The doses to the MEI and to the 80-km (50-mi) population from Hanford effluents are compared to appropriate standards and natural background radiation in Table 4.22 . This table shows that the calculated doses from Hanford operations in 1991 are a small percentage of the standards and of natural background. 


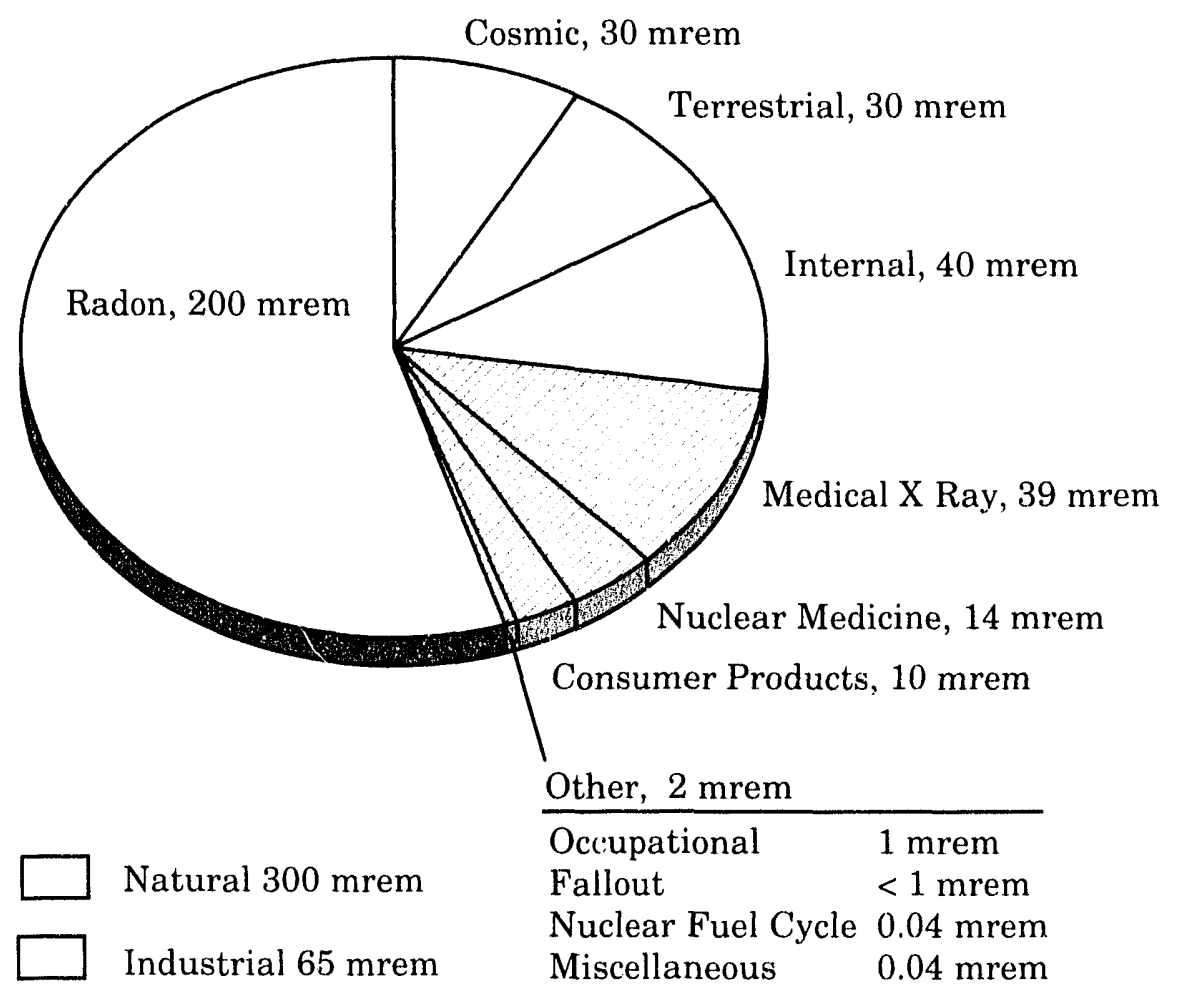

S9203058.94

Figure 4.43. National Annual Average Radiation Doses from Various Sources (mrem) (NCRP 1987)

Table 4.22. Summary of Doses to the Public in the Vicinity of Hanford from Various Sources, 1991

\section{Source}

All Hanford Effluentsith

DOE Limit

Percent of DOE Limit

Background Radiation

Hanford Doses Percent of

Background

Doses from Gaseous Effluents ${ }^{(\mathrm{cl}}$

EPA Air Standard

Percent of EPA Standard
Maximum Individual

$(\mathrm{mrem})^{(a)}$

0.02

100

$0.02 \%$

300

$0.007 \%$

0.007

10

$0.07 \%$ 80-km Population

(person-rem) $)^{(n)}$

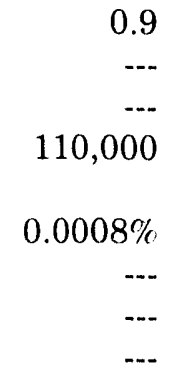

(a) To convert the dose values to mSv or person-Sv, divide them by 100 .

(b) Calculated with the GENII code.

(c) Calculated with the EPA CAP-88 code. 


\section{Doses from Other Than DOE Sources}

DOE maintains an awareness of other artificial sources of radiation (other than DOE artificial sources), which if combined with the DOE sources might have the potential to exceed a dose contribution to any member of the public of $10 \mathrm{mrem}(0.1 \mathrm{mSv})$. Various non-DOE industrial sources of public radiation exposure exist at or near Hanford. These include the low activity commercial radioactive waste burial ground at Hanford operated by U.S. Ecology, the nuclear generating station at Hanford operated by Washington Public Power Supply System ISupply System ), the nuclear fuel production plant operated by Siemens Nuclear Power Corporation, the commercial low-activity radioactive waste compacting facility operated by Allied Technology Group Corporation, and a commercial decontamination facility operated by Pacific Nuclear Services (Figure $4.40 \%$. With information gathered from the mentioned companies, it was conservatively determined that the total 1991 individual dose from their activities is the same order of magnitude as the MEI dose from Hanford DOE operations, $0.02 \mathrm{mrem}$ ( $2 \times 10^{-4} \mathrm{mSv}$ ). Therefore, the combined dose from Hanford area non-DOE and DOE sources to a member of the public for 1991 was well below any regulatory dose limit.

\section{Hanford Public Radiation Dose in Perspective}

Several scientific studies (NRC 1980; NRC 1990; UNSCEAR 1988/ have been performed to estimate the potential risk of developing detrimental health effects from exposure to low levels of radiation. These studies have provided vital information to those government and scientific organizations that recommend radiation dose limits and standards for public and occupational safety.

Although increased incidence of health effects from low doses of radiation has not actually been confirmed by the scientific community, most scientists accept the conservative hypothesis that low-level doses increase the probability that these effects will occur. Regulatory agencies conservatively (cautiously) assume that the probability of health effects at low doses (down to zero) is proportional to the probability of health effects that have been observed historically at much higher doses (atomic bomb victims, radium dial painters, etc.). Therefore, using conservative assumptions, one can infer that even the natural background radiation (which is many hundreds of times greater than radiation from Hanford releases) increases each person's probability or chance of developing a detrimental health effect.

Scientists do not agree about how to translate the available data on health effects into the numerical probability (risk) of detrimental effects from low-level radiation doses. Some scientific studies have even indicated that low-level radiation doses may be beneficial (HPS 1987). Because the rate of cancer and hereditary diseases in the general population may be caused by a multitude of sources (e.g., genetic defects, sunlight, chemicals, and background radiation), some scientists doubt that the risk from low-level radiation exposure will ever be determined accurately. The EPA has used a probability value of approximately 4 per 10 million ( $4 \times 10^{\circ}$ ) for the risk of developing a fatal cancer after receiving a dose of $1 \mathrm{mrem}$ $(0.01 \mathrm{mSv})$ in developing Clean Air Act regulations (EPA 1989). Recent data (NRC 1990) support the reduction of this risk value, possibly to zero, for certain types of radiation when the dose is spread over an extended time.

Government agencies are trying to determine what level of risk is safe for members of the public exposed to pollutants from industrial activities (for example, DOE facilities, nuclear power plants, chemical plants, and hazardous waste sites. All of these industrial activities are considered beneficial to people in some way, such as providing electricity, national defense, waste disposal, and consumer products. These government agencies have a complex task in establishing environmental regulations that maintain levels of risk safe to the public without unnecessarily reducing the needed productivity of the industry. 
The public is subjected to some incremental risks from exposure to industrial pollutants (radiological and nonradiological). These risks can be kept in perspective by comparing them to the increased risks involved in other typical activities. For instance, two added risks that an individual receives from flying on an airline are the risks of added radiation dose (stronger cosmic radiation field at higher altitude) and the possibility of being in an aircraft accident. Table $4.23 \mathrm{com}$ pares the estimated risks from various radiation doses to the risks of some activities encountered in everyday life.

Another way of looking at the risk of detrimental health effects from Hanford radioactive releases is shown in Table 4.24. Listed are some activities considered approximately equal in risk to the hypothetical risk from the potential radiation dose received by the MEI from Hanford releases in 1991.

\section{Dose Rates to Animals}

Conservative (upper) estimates have been made of the potential radiation dose to "native aquatic animal organisms," in accurdance with a DOE Order 5400.5 interim requirement for management and control of liquid discharges. The computer code CRITR (NCRP 1991) was used to calculate radiation doses for several possible exposure modes, including exposure to water entering the Columbia River from springs near

Table 4.23. Estimated Risk from Various Activities and Exposures ${ }^{(a)}$

Activity or Exposure Per Year

Riding or driving in a passenger vehicle (300 miles)

Home accidents

Drirking 1 can of beer or 4 ounces of wine per day (liver cancer/cirrhosis)

Pleasure boating (accidents)

Firearms, sporting (accidents)

Smoking 1 pack of cigarettes per day (lung/heart/other diseases)

Eating 4 tablespoons of peanut butter per day (liver cancer)

Eating 90 pounds of charcoal-broiled steaks (gastrointestinal-tract cancer)

Drinking chlorinated tap water (trace chloroform--cancer)

Taking contraceptive pills (side effects)

Flying as an airline passenger (cross country roundtrip--accidents)

Flying as an airline passenger (cross country roundtrip--radiation)

Natural background radiation dose ( $300 \mathrm{mrem}, 3 \mathrm{mSv}$ )

Dose of $1 \mathrm{mrem}(0.01 \mathrm{mSv})$

Dose to the maximally exposed individual living near Hanford in 1991 ( $0.02 \mathrm{mrem}, 0.0002 \mathrm{mSv}$ )
Risk of Fatality

Per Person

$\begin{aligned} & 2 \times 10^{-6(b)} \\ & 100 \times \times 10^{-6(b)} \\ & 10 \times 10^{-6} \\ & \times 10^{-6(b)} \\ & 10 \times 10^{-6(b)} \\ & 3600 \times 10^{-6} \\ & 8 \times 10^{-6} \\ & 1 \times 10^{-6} \\ & 3 \times 10^{-6} \\ & 20 \times 10^{-6} \\ & 8 \times 10^{-6(b)} \\ & 0 \text { to } 5 \times 10^{-6} \\ & 0 \text { to } 120 \times 10^{-6} \\ & 0 \text { to } 0.4 \times 10^{-6} \\ & 0 \text { to } 0.008 \times 10^{-6}\end{aligned}$

$100 \times 10^{-6 i b l}$

$6 \times 10^{-6 i \mathrm{~h}}$

$10 \times 10^{-6 i b)}$

$8 \times 10^{\circ}$

$1 \times 10^{-6}$

$20 \times 10^{-6}$

$8 \times 10^{-6 i t h}$

0 to $120 \times 10^{-6}$

0 to $0.008 \times 10^{-6}$

(a) These values are generally accepted approximations with varying levels of uncertainty; there can be significant variation as a result of differences in individual lifestyle and biological factors (Ames et al. 1987; Atallah 1980; Dinman 1980; Wilson and Crouch 1987; Travis and Hester 1990).

(b) Real actuarial values. Other values are predicted from statistical models. For radiation dose, the values are reported in a possible range from the least conservative $(0)$ to the current, accepted most conservative value. 
Table 4.24. Activities Comparable in Risk to that from the 0.02-mrem Dose Calculated for the 1991 Maximally Exposed Individual

Driving or riding in a car $2 \mathrm{~km}(1.2 \mathrm{mi})$

Smoking $1 / 60$ of a cigarette

Flying $5 \mathrm{~km}$ ( $3.1 \mathrm{mi}$ ) on a commercial airline

Eating $11 / 3$ tablespoons of peanut butter

Eating one 0.3 -kg (12-ounce) charcoal-broiled steak

Drinking about $1.9 \mathrm{~L}$ ( 2 quarts) of chlorinated tap water

Being exposed to natural background radiation for about 40 minutes in a typical terrestrial location

Drinking about one-third of a can of beer or one-fourth a glass of wine per week for a year

the 100-N Area, and internally deposited radionuclides measured in samples of fish and waterfowl collected from the Columbia River and in samples of waterfowl and terrestrial animals collected onsite.

Because the volumetric flow of the springs at the $100-\mathrm{N}$ Area is so low, no aquatic animal can live directly in this seepage water. Exposure to the radionuclides from the springs cannot occur until the water has been noticeably diluted in the Columbia River. The unlikely assumptions were made that a few clams, fish, and waterfowl might spend their entire life adjacent to the shoreline where the springs enter the river, and that in this region spring water had only been diluted 10 to 1 by the river. Based on these extremely conservative assumptions, the highest estimated dose rate was for a duck that spent its entire lite next to the seepage area and consumed only fish that had also spent their entire life there. The estimated dose rate for such a hypothetical duck was $1 \mathrm{rad} / \mathrm{d}$. This dose rate was calculated using very unlikely concentrations of exposure to arrive at an upper limit for the potential dose. It is highly unlikely that any native aquatic animal organism received a dose as high as the $1 \mathrm{rad} / \mathrm{d}$ limit given in DOE Order 5400.5.

Doses were also estimated for clams, fish, and waterfowl exposed to Columbia River water containing a mixture of all the radionuclides reaching the Columbia River from Hanford sources during 1991. Once again the highest potential dose was for a fish-eating duck, $3.0 \times 10^{-6} \mathrm{rad} / \mathrm{d}$.

Dose estimates based on the maximum concentrations of radionuclides measured in animals collected onsite ranged from $1.0 \times 10^{-6}$ for whitefish, pheasants, and deer to $1.0 \times 10^{-4} \mathrm{rad} / \mathrm{d}$ for rabbits and ducks. 


\section{Ground-Water Protection and Monitoring Program}




\subsection{Ground-Water Protection and Monitoring Program}

The strategy for protecting ground water at the Hanford Site is presented in the Hanford Site Groundwater Protection Management Program (DOE 1989c). Two of the key elements of this strategy are to 1 ) protect the unconfined aquifer from further contamination, and 2) conduct a monitoring program to provide an early warning when contamination of ground water does occur. The monitoring program at Hanford has also been designed to allow an assessment of the distribution and movement of existing ground-water contamination.

\section{Ground-Water Protection}

The effort to protect ground-water quality is being implemented through programs to minimize wastes being discharged to the soil column and through site remediation activities being carried out in accordance with an agreement between the Washington State Department of Ecology, the U.S. Department of Energy (DOE), and the U.S. Environmental Protection Agency (EPA). This agreement, called the Tri-Party Agreement, provides a framework for remediation of the Hanford Site over a 30-year period.

\section{Soil Column Discharge Reduction}

In 1987 Congress directed DOE to prepare a Plan and Schedule to Discontinue Disposal of Liquids Into the Soil Column at the Hanford Site (DOE 1989d). This document presents an implementation plan for providing alternative treatment and disposal of contaminated effluent discharged to the soil on the Hanford Site. The 33 major waste streams that have been identified will be addressed in two phases. Phase I projects are con-. sidered higher priority, and cessation or alternative treatment and disposal systems will be implemented by 1995 for those streams. Phase II streams will be dealt with after completion of Phase I projects.
Minimization of Hanford liquid effluents will be accomplished by reducing the volume of discharge and reducing the amount of contaminant being released. Volumes will be reduced by eliminating or discontinuing some streams and reconfiguring some facilities. Three of the 33 major liquid effluent streams have been eliminated, and four have been discontinued. Facility reconfiguration usually involves replacement of equipment that generates the liquid effluent. As a result of these waste reduction activities, the total monthly flow rate for the 33 streams has been reduced from 350 million gallons per month in 1989 to 300 million gallons per munth at the end of 1991.

Chemical and radiological contaminants in the liquid effluent have also been reduced through the implementation of administrative controls and engineered barriers. The effect of these controls will be quantified through a liquid effluent sampling program planned for 1992 .

\section{Site Remediation Activities}

The Hanford Site contains approximately 1,100 identified waste management units to be characterized and remediated and/or permitted during the next 28 years. These units include various types of liquid waste disposal sites, solid waste burial grounds, underground tanks, and unplanned release sites. To deal with this number of waste units, the Hanford Site was subdivided into four aggregate areas (Figure 5.1) each of which is included on the EPA National Priorities List. The four aggregate areas are divided into a total of 78 operable units. Each operable unit will be investigated and remediated as described in the Tri-Party Agreement.

Investigations involving ground-water characterization have been initiated at four operable units and two aggregate areas. The status of these characterizations follows. 


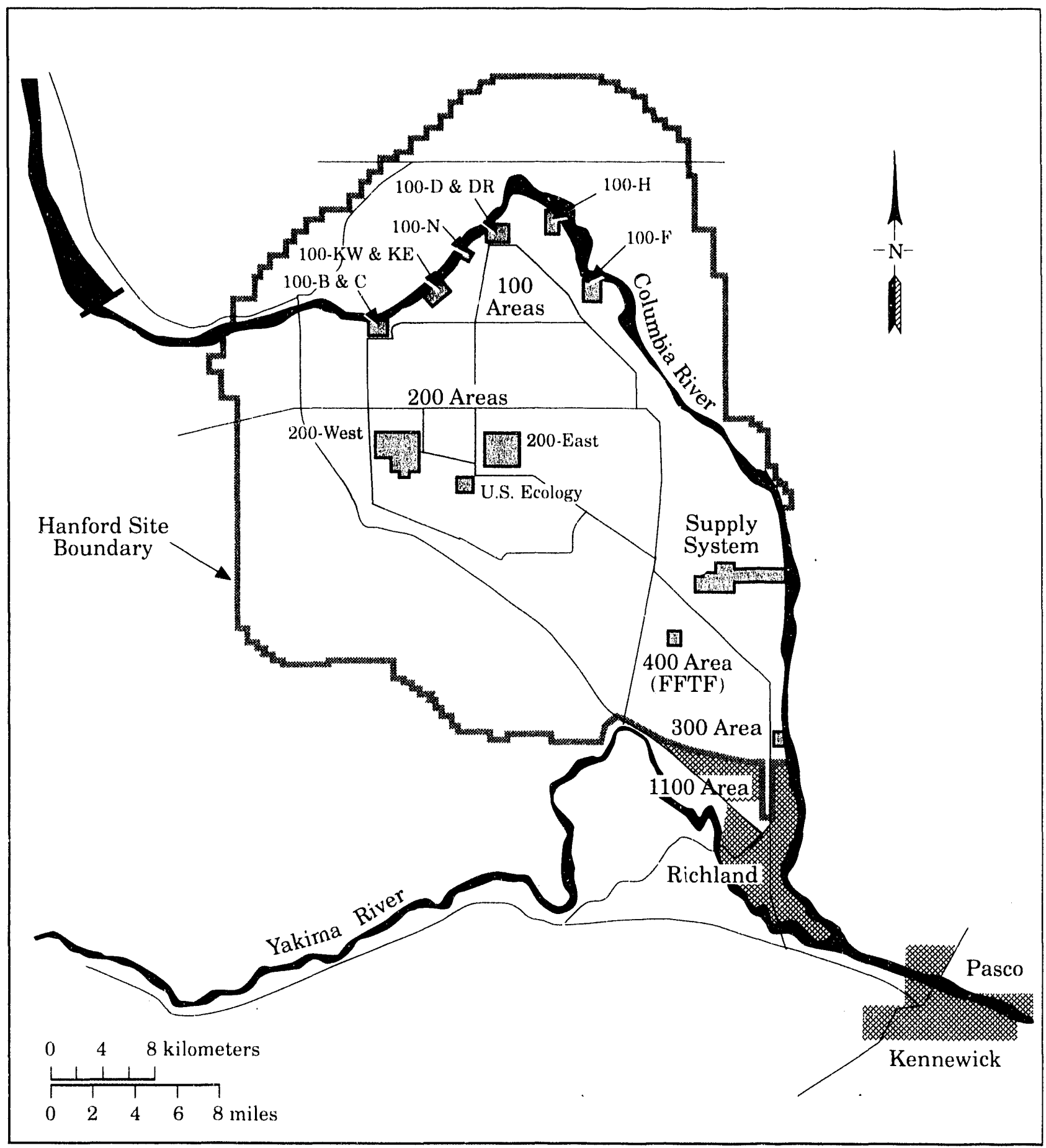

S9203058.15

Figure 5.1. Location of 100, 200, 300 and 1100 Aggregate Areas of the National Priorities List for the Hanford Site 


\section{Operable Unit Investigations}

The 1100-EM-1 Operable Unit consists of seven waste sites associated with vehicle maintenance operations. It received a high priority because it is located near wells used by the City of Richland for the city water supply system. Characterization activities have shown no contamination in the aquifer near the City of Richland wells. Ground water beneath one of the seven waste sites (the Horn Rapids Landfill) has been found to be contaminated with trichloroethylene, nitrate, and gross beta at concentrations above the drinking water standards. The source of this contamination appears to be from outside the Hanford Site (Brown 1992).

Thirteen waste management units in the northern part of the 200-East Area have been grouped in the 200-BP-1 Operable Unit. These units received waste from the $U$ Plant uranium reclamation process and 241-BY Tank Farm operations. Nine ground-water monitoring wells were drilled near the BY tank farm by the end of 1991. Ground-water samples have been collected from these new wells and previously existing wells for four quarters.

Work has been also been initiated on the $300-F F-5$ Operable Unit. This unit underlies the 300 Area and includes all ground water affected by waste disposal operations in the 300 Area. Potential contaminants of concern include organic solvents, radionuclides, metals, and anions. Ground-water samples were collected from 63 wells including 19 new wells in the fall of 1991 . Results from analysis of the samples are not yet available.

The 100-HR-3 Operable Unit includes the ground water underlying the 100-H Area, 100-D Area, and the region between these two. Construction of new characterization wells was initiated during 1991; however, no ground-water samples were collected from the new wells during the year.

\section{Aggregate Area Studies}

Integrated ground-water investigations for the 200 and 100 Areas began in September 1991. This effort involves synthesis of existing data and collection of some new data from existing wells. Results of these studies will be used to direct detailed investigations in each of the 100 and 200 Areas.

\section{Expedited Response Action Program}

An Expedited Response Action is a way to accelerate cleanup of waste sites. These actions can be taken if a benefit can be gained by starting the action before completion of the entire remedial investigation/feasibility study process. Three sites at Hanford have been selected for treatment as Expedited Response Actions. These sites are the 618-9 Burial Ground, the 300 Area Process Trenches, and the 200-West Area carbon tetrachloride contamination (Brown 1992).

The 618-9 Burial Ground contained drums of organic solvent suspected of containing uranium. These drums were disposed of at the site just west of the 300 Area during the 1950s. During the response action, the trench at the burial ground was excavated. One hundred and twenty drums were found; 42 contained contaminated liquids. In addition, a large amount of debris was also unearthed. Approximately 5,678 L (1,500 gal) of liquid were recovered. The liquid was sampled and analyzed. The results indicate the liquid is hexone and other solvents. Initial approval has been obtained for disposal of the liquid through incineration offsite. Final remedial actions at the site have been proposed and are being reviewed.

The 300 Area Process Trenches are an active liquid disposal facility in the 300 Area. Two trenches are located approximately $300 \mathrm{~m}(1,000 \mathrm{ft})$ west of the Columbia River. The trenches received radioactive and hazardous chemical waste from operations in the 300 Area. The discharge of hazardous wastes to the trenches ended in 1985 but up to 2.2 million L (500,000 gal) of water from heating and cooling systems in the buildings in the 300 Area goes to the trenches every day. Sediment in the trenches contained uranium, cadmium, nickel, lead, mercury, copper, chromium, silver, trichloroethylene, and chloroform.

Removal of contaminated sediment from the trenches began in July 1991 and was completed by October 1,1991 . This material was removed 
to prevent the clean water that continues to be disposed of in the trench from mobilizing contaminants and transporting them to the ground water and ultimately to the Columbia River.

Carbon tetrachloride contamination has keen found in the vadose zone and ground water near the Plutonium Finishing Plant in the 200-West Area. It is estimated that the bulk of the carbon tetrachloride came from and remains near three specific disposal sites near the plant. An estimated 600 to 900 tons of carbon tetrachloride was disposed of in these sites during their operational life. An Expedited Response Action is planned to remove the bulk of carbon tetrachloride from the soils above the ground water. This action is intended to remove the source of contaminants responsible for the carbon tetrachloride observed in ground water in the 200-West Area. Initial site characterization activities including a vapor extraction test have been completed. Based on the results of the test, a vapor extraction system will be designed to remove the carbon tetrachloride (Brown 1992).

\section{Ground-Water Monitoring}

Ground-water monitoring is being performed at the Hanford Site as an integral part of the Hanford Site ... oundwater Protection Management Program (DOE 1989c). The program includes monitoring at active waste disposal facilities to comply with the Resource Conservation and Recovery Act (RCRA), operational monitoring in and adjacent to reactor and chemical rocessing facilities, and environmental surveiliance to assess the impact of Hanford operations on ground water both onsite and offsite independently of the operating contractors' programs.

\section{Sample Collection and Analysis}

Ground-water samples were collected from 528 monitoring wells for these monitoring programs curing 1991. The monitoring frequency for the wells was selected based on regulatory requirements, proximity to waste sources, and the characteristies of the ground-water flow system at the sampled location. Three hundred and four of the wells were sampled once, 113 were sampled twice, 101 were sampled approximately quarterly, and 10 wells were sampled more frequently during the year.

These samples were collected as part of the Hanford Ground-Water Environmental Surveillance Program and other ground-water monitoring programs. Wells included in the Hanford Ground-Water Surveillance Network are shown in Figures 5.2 through 5.5. Ground-water monitoring was conducted at the facilities shown in Figure 5.6 to comply with RCRA. The RCRA monitoring is the responsibility of the contractor operating each facility.

Although these programs are managed by different organizations, all samples are collected by sampling teams following a single set of procedures. Samples were analyzed by PNL and subcontractor laboratories. A common database is used to store ground-water chemistry data so that each monitoring program has access to data collected by other programs.

Most ground-water monitoring wells on the Site are 10 to $20 \mathrm{~cm}$ in diameter and are constructed of steel casing. Several small-diameter $(5-\mathrm{cm})$ wells are sampled for radionuclides only. Monitoring wells for the unconfined aquifer are constructed with well screens or perforated casing generally in the upper 3 to $6 \mathrm{~m}$ of the aquifer. This construction allows sample collection near the top of the aquifer, where maximum concentrations for some radionuclides were measured at a few locations on the Hanford Site (Eddy et al. 1978). Wells monitoring the confined aquifer have screens or perforated casing within the monitored aquifer. Wells drilled before 1985 were generally con-structed with carbon steel casing. Wells recently constructed for RCRA monitoring projects and CERCLA characterizations have been constructed with stainless steel casing.

Samples were collected following documented sampling procedures (PNL 1989) based on EPA guidelines (EPA 1986). Analytical techniques used are described in the Hanford Site Envirnnmental Monitoring Plan (DOE 1991b). The pecies analyzed for are listed in Table 5.1. 


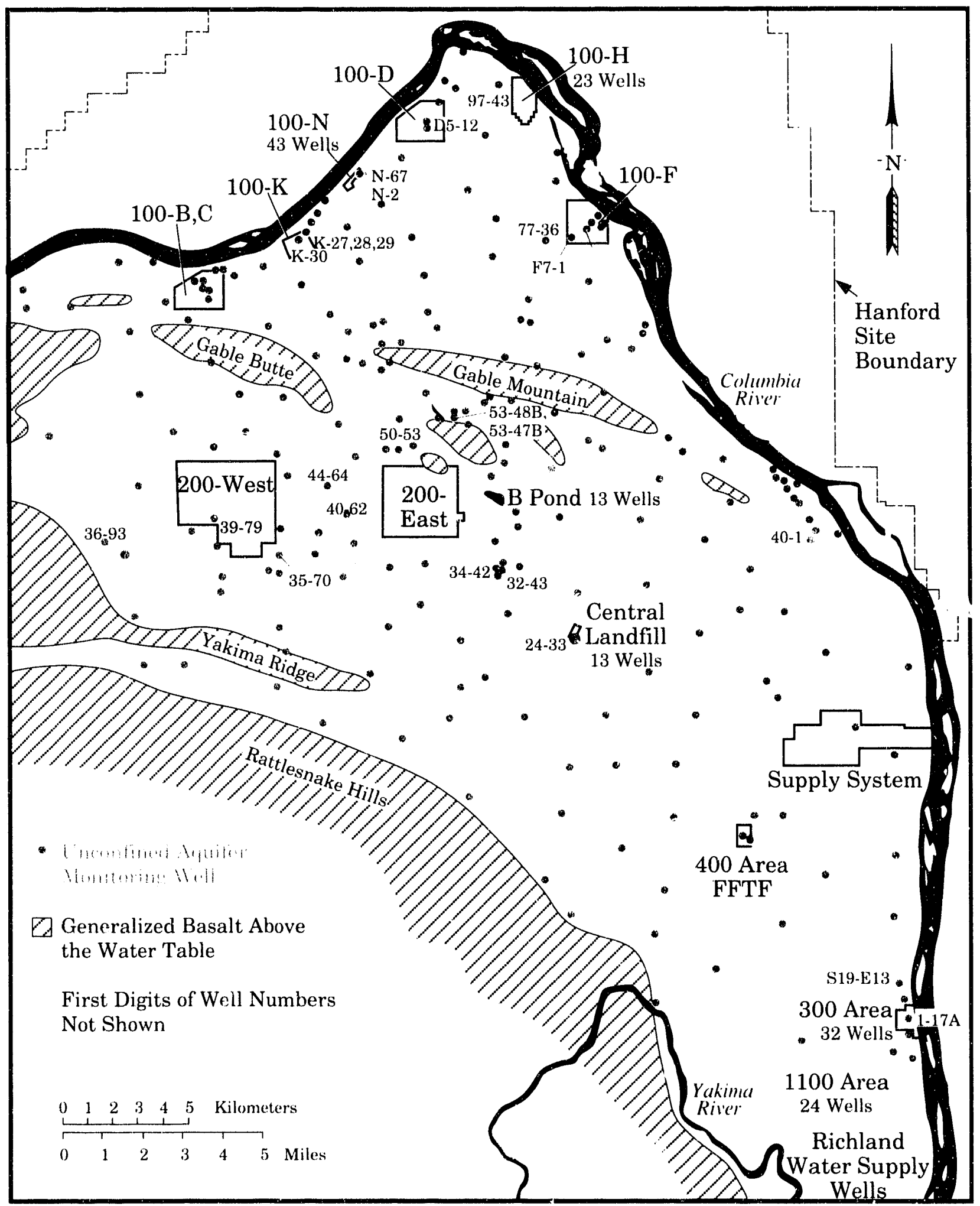

S9203058.107

Figure 5.2. Hanford Site Unconfined Aquifer Monitoring Well Locations, 1991. Numbered well locations are discussed in the text. 


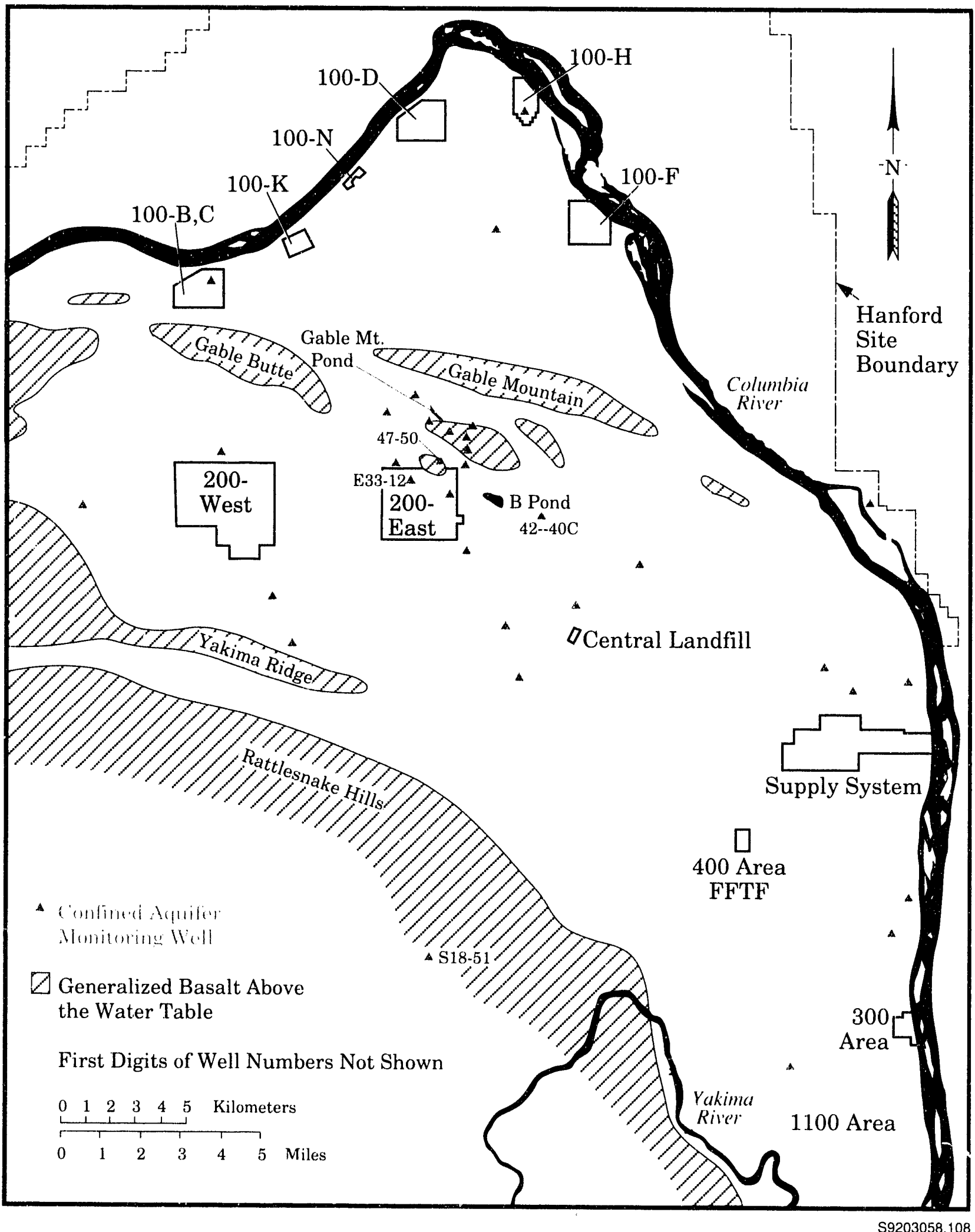

Figure 5.3. Hanford Site Confined Aquifer Monitoring Well Locations, 1991. Numbered well locations are discussed in the text. 


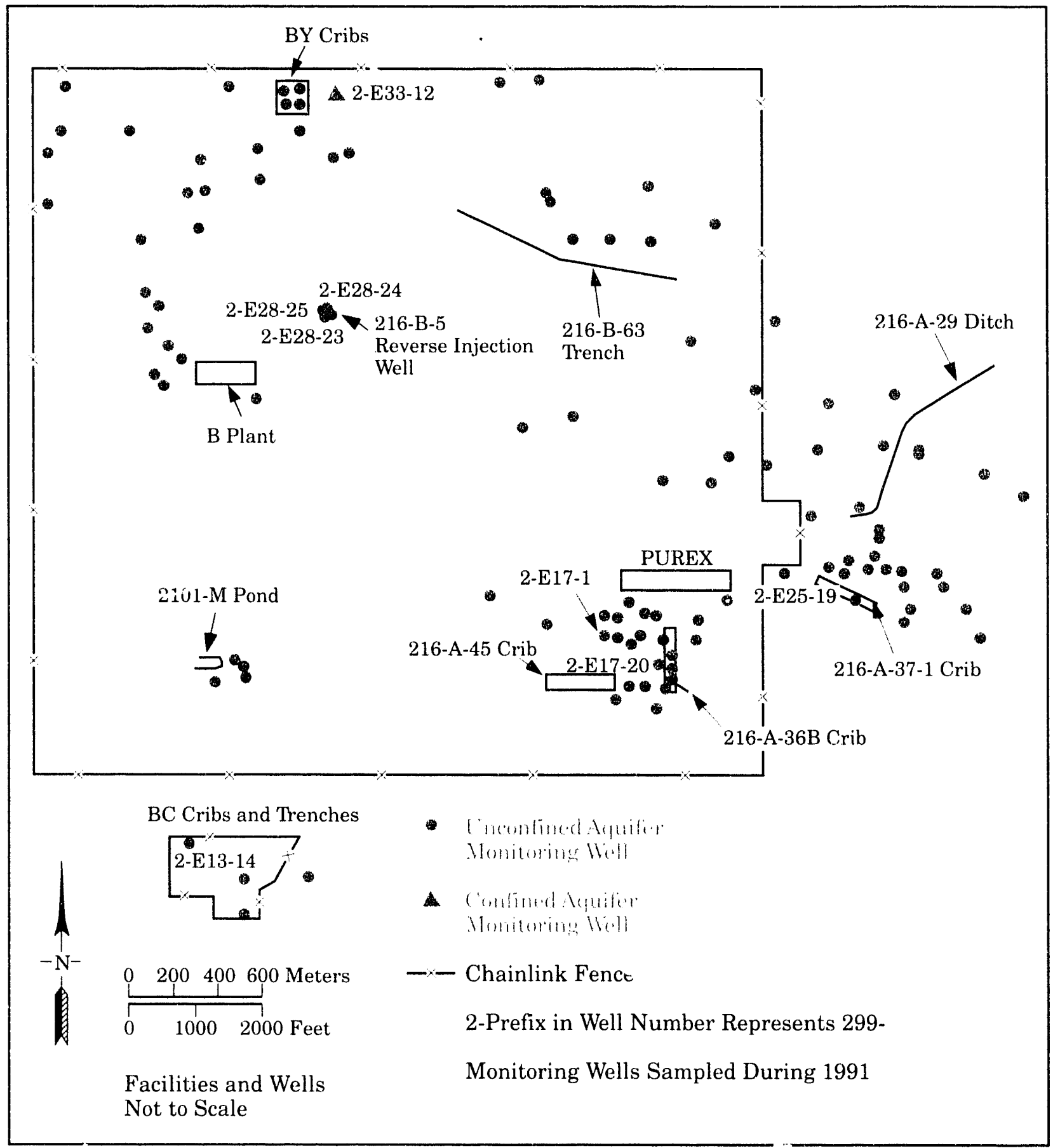

$\$ 9203058.112$

Figure 5.4. Monitoring Well Locations in the 200-East Area, 1991. Numbered :vell locations are discussed in the text. 


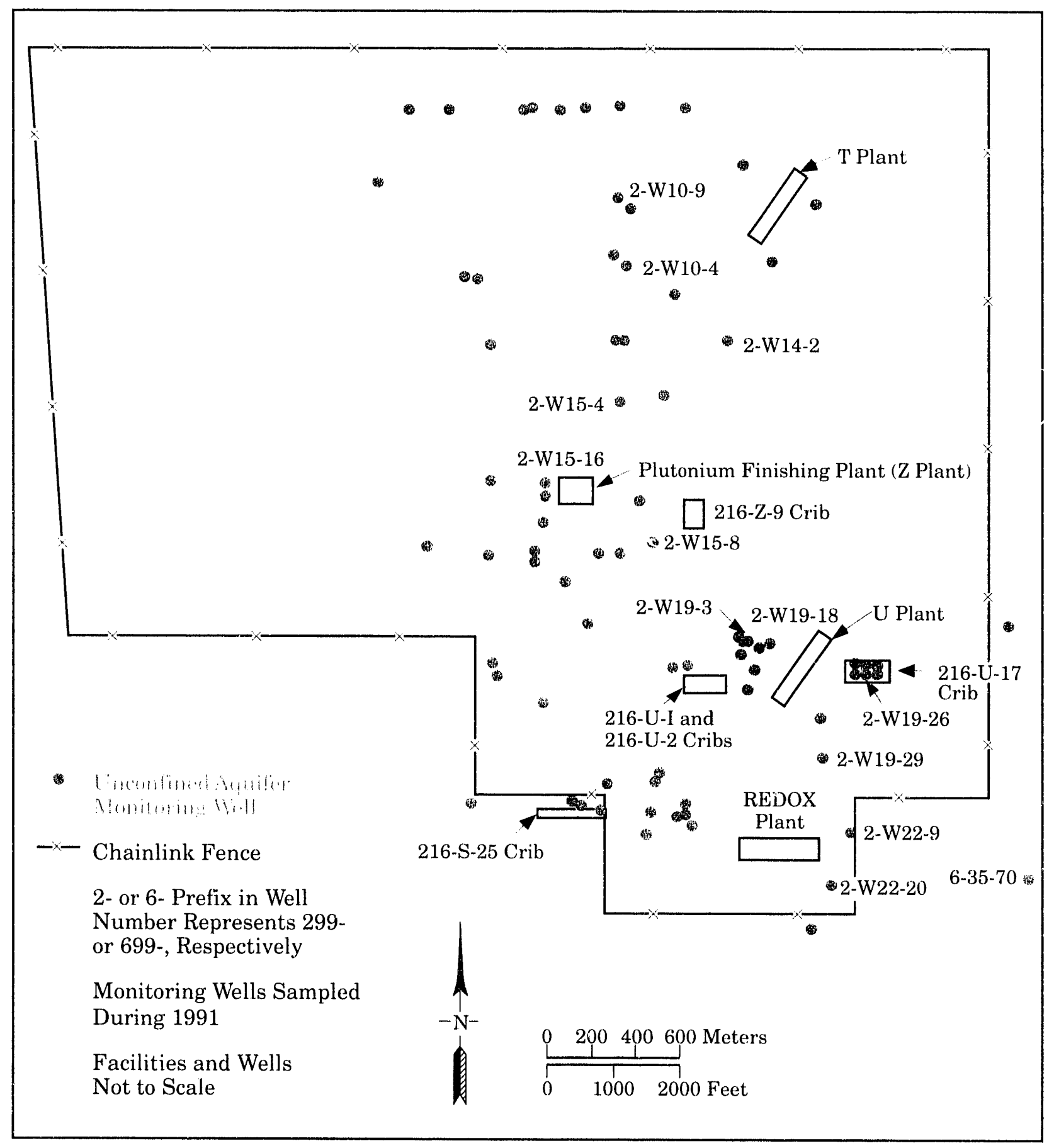

S9203058.111

Figure 5.5. Monitoring Well Locations in the 200-West Area, 1991. Numbered well locations are discussed in the text. 


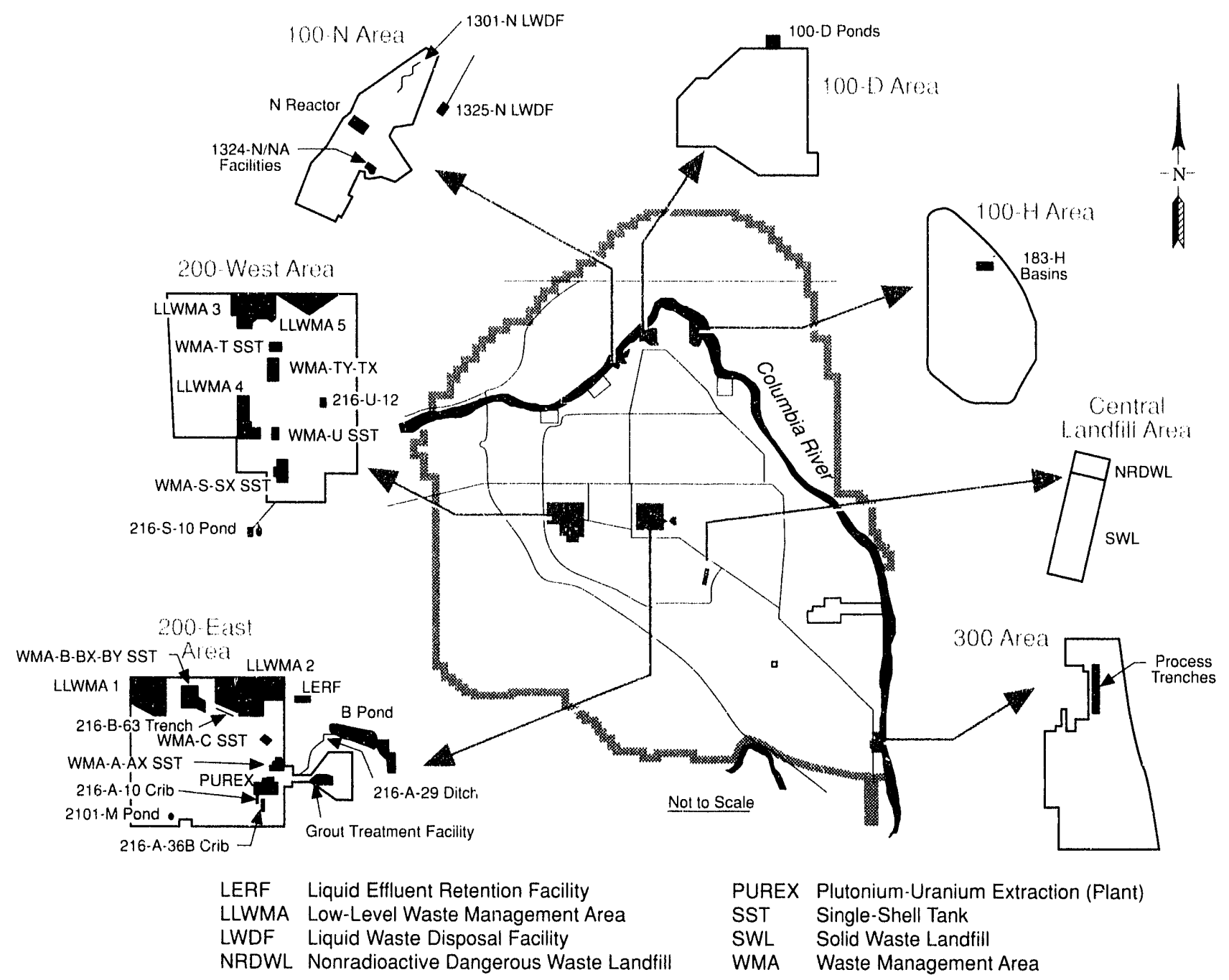

S9203058.16

Figure 5.6. Locations of RCRA Ground-Water Monitoring Projects and Landmarks on the Hanford Site

\section{Radiological Analysis}

Most ground-water samples for the Hanford Ground-Water Environmental Surveillance Program were analyzed for tritium. Selected samples were subjected to more extensive radiological analysis by alpha-, beta-, gamma-counting techniques, and in many cases accompanied by selective radiochemical separations. Uranium analyses were performed by a laser fluorescence method. A list of radionuclides analyzed is presented in Table 5.1. The radiological monitoring network for most areas on the Hanford Site is shown in Figures 5.2 and 5.3. Figures 5.4 and
5.5 show environmental surveillance and RCRA monitoring wells in the 200-East and 200-West Areas, respectively. Figure 5.6 shows RCRA ground-water monitoring projects throughout the Hanford Site.

\section{Chemical Analysis}

The RCRA monitoring wells and a subset of the radiological monitoring network used for operational monitoring and environmental surveillance were used for chemical surveillance. Chemical sampling wells were selected primarily for their proximity to known active and inactive chemical 
Table 5.1. Radionuclides and Chemicals Analyzed for in Ground Water

Radiological

Parameters

${ }^{3} \mathrm{H}$

${ }^{10} \mathrm{Co}$

${ }^{90} \mathrm{Sr}$

${ }^{99} \mathrm{Tc}$

${ }^{103} \mathrm{Ru}$

${ }^{106} \mathrm{Ru}$

${ }^{125} \mathrm{Sb}$

${ }^{129} \mathrm{I}$

${ }^{131} \mathrm{I}$

${ }^{137} \mathrm{Cs}$

${ }^{241} \mathrm{Am}$

Total Alpha

Total Beta

Plutonium Isotopes

Uranium Isotopes

Uranium (total)
Chemical Parameters

$\mathrm{pH}$ (field and laboratory)

Conductance (field)

Alkalinity

Total Carbon

Total Organic Carbon

Total Organic Halogens

$\mathrm{B}, \mathrm{Be}, \mathrm{Na}, \mathrm{Mg}, \mathrm{Al}, \mathrm{K}, \mathrm{Co}, \mathrm{Si}$

$\mathrm{C}$ a, $\mathrm{V}, \mathrm{Cr}, \mathrm{Mn}, \mathrm{Fe}, \mathrm{Ni}$

$\mathrm{Cu}, \mathrm{Zn}, \mathrm{Sr}, \mathrm{Ag}, \mathrm{Cd}, \mathrm{Sb}, \mathrm{Ba}$

$\mathrm{F}, \mathrm{Cl}, \mathrm{NO}_{3}^{-}, \mathrm{PO}_{4}^{-3}, \mathrm{SO}_{4}^{-2}, \mathrm{NO}_{2}^{-}$

$\mathrm{As}, \mathrm{Se}, \mathrm{Pb}, \mathrm{Tl}$

$\mathrm{Hg}$

$\mathrm{CN}^{-}$

$\mathrm{NH}_{3}$

Volatile Organic Constituents

Semi-Volatile Organic Constituents

Table 5.2. Major Chemical anu Radiological Ground-Water Contaminants and Their Link to Site Operations

Facilities Type

Reactor Operations

Irradiated Fuel Processing

Plutonium Purification

Fuel Fabrication
Area

100

200

200

300
Constituents

tritium, ${ }^{60} \mathrm{Co},{ }^{90} \mathrm{Sr}, \mathrm{Cr}^{+6}, \mathrm{SO}_{4}^{-2}$

tritium, ${ }^{137} \mathrm{Cs},{ }^{90} \mathrm{Sr},{ }^{129} \mathrm{I},{ }^{99} \mathrm{Tc}, \mathrm{NO}_{3}^{-}, \mathrm{Cr}^{+6}$, $\mathrm{CN} \cdot \mathrm{F} \cdot \mathrm{U}, \mathrm{Pu}$

$\mathrm{Pu},{ }^{241} \mathrm{Am}, \mathrm{NO}_{3}^{-}, \mathrm{CCl}_{4}, \mathrm{CHCl}_{3}$

$\mathrm{U},{ }^{99} \mathrm{Tc}, \mathrm{Cr}^{+6}$, Trichloroethylene, $\mathrm{Cu}$ 
disposal sites. Table 5.2 lists major contaminants found in each area. The list of chemicals analyzed for is presented in Table 5.1.

\section{Results}

Ground-water monitoring information obtained for the RCRA monitoring program is reported by DOE (DOE 1992a) and for drinking water supplies on the Hanford Site by Hanford Environmental Health Foundation (Thurman 1991). Information gathered in support of the CERCLA program are reported in Remedial Investigation reports. Detailed discussions of all monitoring results for the year are reported in another document (for example, Evans et al. 1992). Highlights of those results are discussed below.

Concentrations of radionuclides and chemicals in ground water were compared to EPA's drinking water standards (DWS) and DOE's Derived Concentration Guides (DCG) (Tables B.2, B.3, and B.6, Appendix B). Onsite drinking water supply wells at the Fast Flux Test Facility (FFTF) are discussed in Section 4.8, "Potential Radiation Doses from 1991 Hanford Operations." Drinking water standards are more restrictive than the DCG because the DWS are based on an annual dose to the affected organ of $4 \mathrm{mrem} / \mathrm{yr}$ and the DCG are based on an effective dose equivalent of $100 \mathrm{mrem} / \mathrm{yr}$ (see "Applicable Standards and Permits and Environmental Compliance Documentation," Appendix B). The DCGs are available only for radionuclides. Derived Concentration Guides are presented in DOE Order 5400.5.

\section{Radiological Monitoring Results for the Unconfined Aquifer}

Radiciulclides analyzed for in ground water are listed in Table 5.1. Ruthenium-103, ${ }^{106} \mathrm{Ru}$, and ${ }^{131}$ I have relatively short half-lives and historically have been detected near operating reactors or liquid waste disposal facilities near active fuel reprocessing facilities. These radionuclides have not been observed in concentrations above the DWS, and in general, have not been detected since soon after the shutdown of N Reactor and the PUREX Plant. Alpha and beta are used as indicators of radionuclide distribution and are not discussed in detail because the radionuclides contributing to these measurements are discussed. The distribution of ${ }^{3} \mathrm{H}$, ${ }^{611} \mathrm{Co},{ }^{90} \mathrm{Sr}$, ${ }^{99} \mathrm{Tc}$, ${ }^{125} \mathrm{Sb},{ }^{129} \mathrm{I},{ }^{1: 37} \mathrm{Cs}$, uranium, and plutonium, will be discussed in the following section. Americium241 is also mentioned in association with other radionuclides. The type of operation resulting in the release of these radionuclides to the ground water are listed in Table 5.2. The table also lists the locations where these operations were performed.

Tritium. Tritium is present in many waste streams discharged to the soil column and is the most mobile radionuclide onsite. As a result, ${ }^{3} \mathrm{H}$ reflects the extent of contamination in the ground water from Site operations and is the radionuclide most frequently monitored at the Hanford Site. Figure 5.7 shows the 1991 distribution of ${ }^{3} \mathrm{H}$ in the unconfined aquifer resulting from over 47 years of Site operations. Contours of ${ }^{3} \mathrm{H}$ concentrations were based on the analysis of ground-water samples collected from monitoring wells.

Tritium concentrations greater than the 20,000$\mathrm{pCi} / \mathrm{L}$ DWS were detected in portions of the 100-D, 100-K, 100-N, 200-East, 200-West, 400, and 600 Areas. Well 199-K-30 continued to contain the highest ${ }^{3} \mathrm{H}$ concentration within the 100 Areas with a maximum concentration of $798,000 \mathrm{pCi} / \mathrm{L}$, similar to the high for $1990 \mathrm{but}$ somewhat lower than the maximum of $1,220,000$ $\mathrm{pCi} / \mathrm{L}$ in 1988 . Well $199-\mathrm{K}-27$ also showed a decrease in ${ }^{3} \mathrm{H}$ concentrations relative to 1990 , down to 40,400 in April 1991 from a high of 134,000 in 1990. Wells $199-\mathrm{K}-28$ and 199-K-29, located between and near the other two wells, remained at relatively low ${ }^{3} \mathrm{H}$ concentr ations (2,000 and $6,000 \mathrm{pCi} / \mathrm{L}$, respectively).

Concentrations greater than the 2,000,000-pCi/L DCG were detected in four wells in the 200-East Area. The highest ${ }^{3} \mathrm{H}$ concentrations in the 200-East Area continued to be in wells near cribs that have received effluent from the PUREX Plant. Tritium concentrations greater than the DCG were present in wells near the 216-A-10, 216-A-36B, 21 $1^{r}-\mathrm{A}-37-1$, and $216-\mathrm{A}-45$ cribs. The ground-water ${ }^{3} \mathrm{H}$ concentration measured in well 299-E25-19 was $2,140,000 \mathrm{pCi} / \mathrm{L}$ in 1991 . That concentration is approximately half that measured a year earlier. The highest " $\mathrm{H}$ level observed in 1991 was $3,360,000 \mathrm{pCi} / \mathrm{L}$ in well 


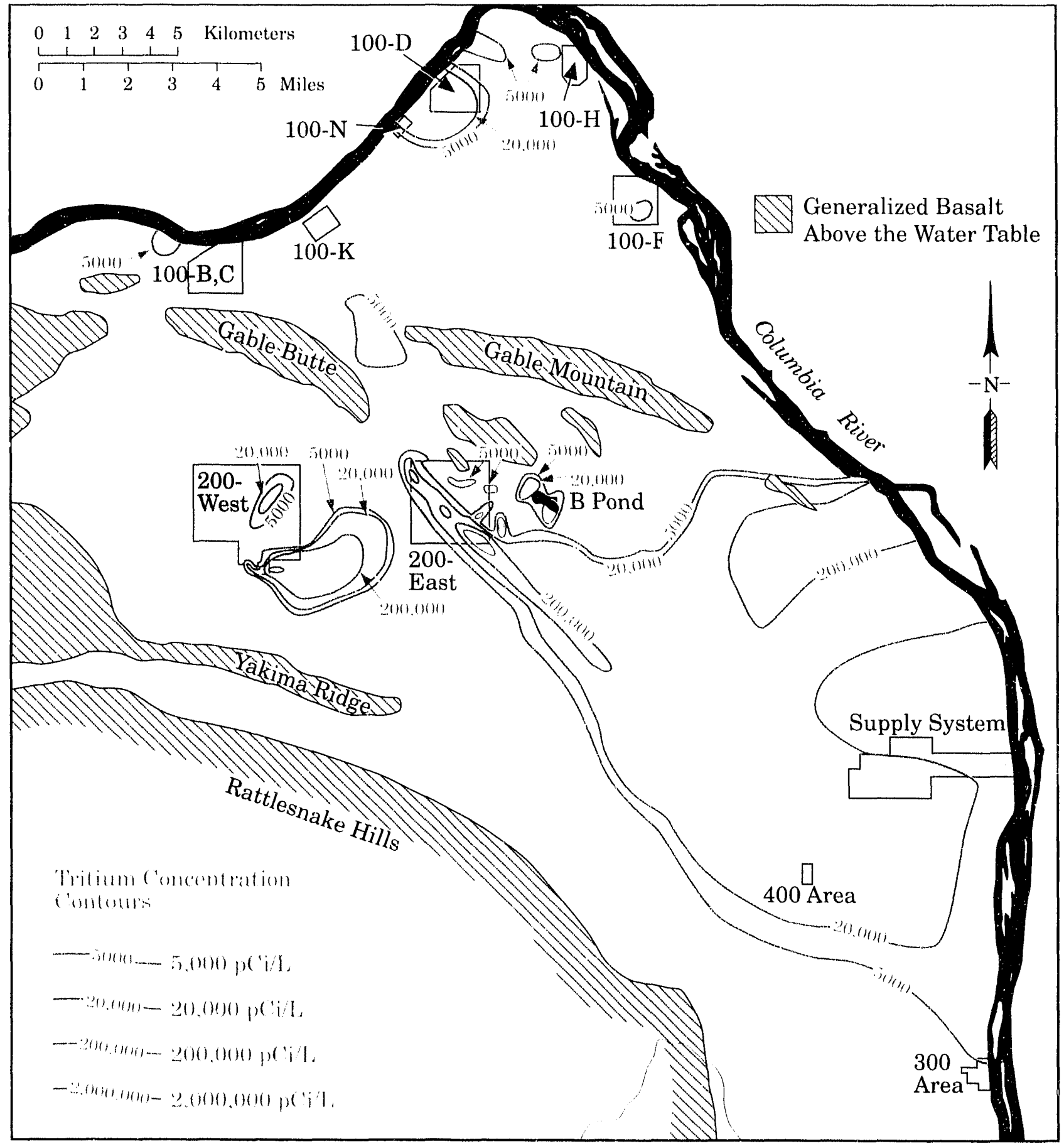

S9203058.14

Figure 5.7. Tritium $\left({ }^{3} \mathrm{H}\right)$ Concentrations in the Hanford Site Unconfined Aquifer, 1991 
299-E17-20. Tritium concentrations exceeding the DWS continued to occur in most other wells affected by these cribs.

The movement of the widespread " $\mathrm{H}$ plume (see Figure 5.7) extending from the southeastern portion of the 200-East Area to the Columbia River was consistent with patterns noted earlier (Woodruff et al. 1991; Evans et al. 1992). Separate ${ }^{3} \mathrm{H}$ pulses associated with the two episodes of PUREX operations can be distinguished in the plume. The 200,000- to 2,000,000-pCi/L lobe east of the 200-East Area near the Columbia River is a result of discharges to ground water during the operation of the PUREX Plant from 1956 to 1972. Following an 11-year shutdown, plant operation began again in 1983 and ceased in December 1988. Elevated ${ }^{3} \mathrm{H}$ concentrations measured in several wells (for example, wells 699-32-43, and 699-24-33) downgradient from the 200-East Area represent the formation of a second pulse of " $\mathrm{H}$ moving away from PUREX waste disposal facilities. Large-scale movement of the leading edge of this plume is best observed in well 699-24-33, which clearly shows arrival of the plume in early 1987 following the passage of the plume from the earlier campaign. The first plume had reached much higher levels in the mid 1960s. A trend plot of " $\mathrm{H}$ concentrations in well 699-24-33 is shown in Figure 5.8. By contrast, a trend plot of the "H concentrations in well 699-40-1 located near the shore of the Columbia River (Figure 5.9) shows the arrival in the early 1970s of the plume from the first campaign with no discernable effect as yet from the second plume.

The eastern portion of the plume continues to move to the east-southeast and discharge into the Columbia River. Figure 5.10 shows the trend of "H concentrations in well 699-S19-E13, located just north of the 300 Area. In recent years, this well has shown a steady increase in ${ }^{3} \mathrm{H}$, having reached a new maximum value of $9,110 \mathrm{pCi} / \mathrm{L}$ in December 1991. The plume is not expected to move much farther south because of the influence of the Yakima River on ground-water flow in this area. The Yakima River is at a higher elevation than the ground water in this area, which is in

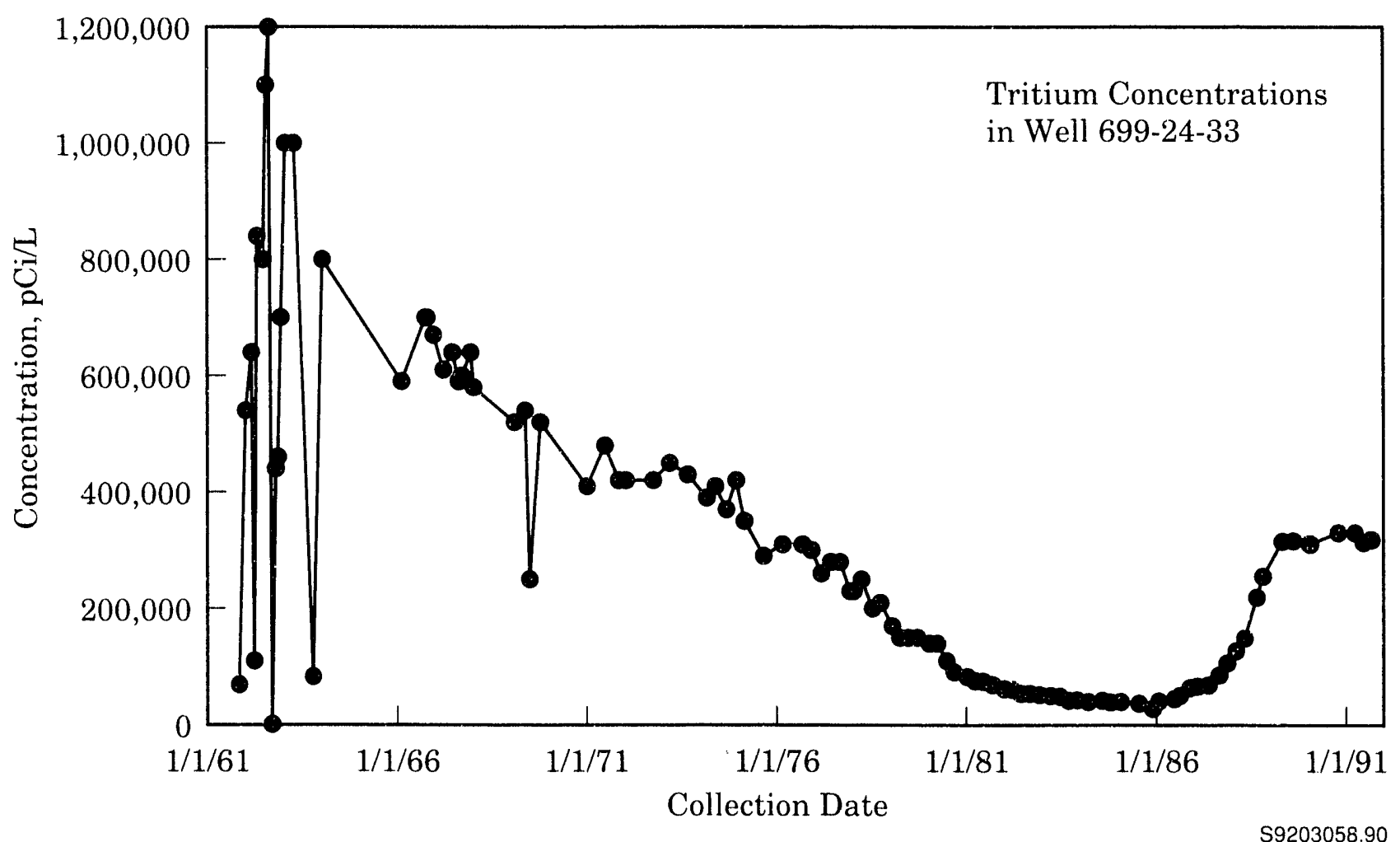

Figure 5.8. Trend Plot of Tritiun ( $\left.^{3} \mathrm{H}\right)$ Concentrations in Well 699-24-33 


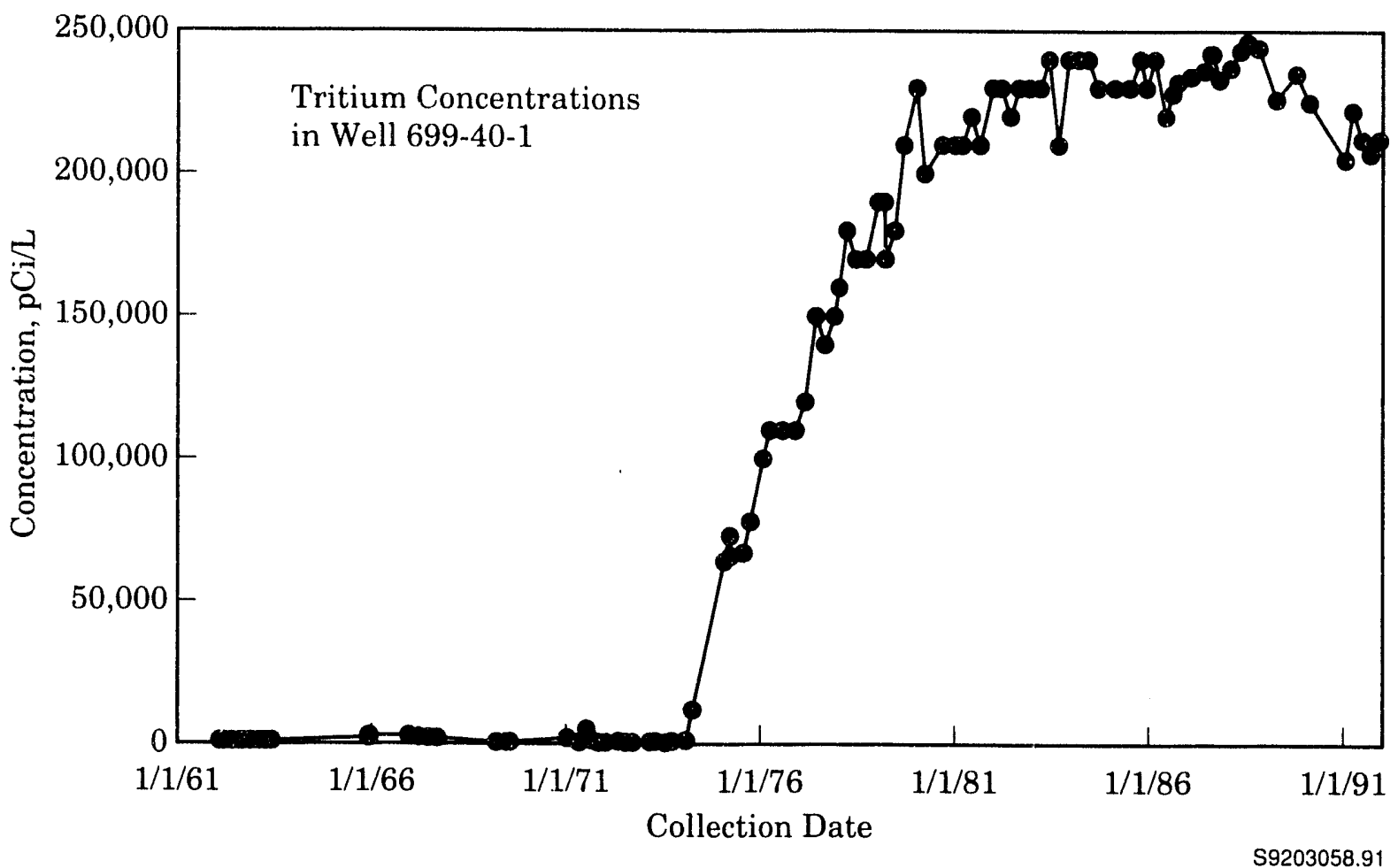

Figure 5.9. Trend Plot of Tritium $\left({ }^{3} \mathbf{H}\right)$ Concentrations in Well 699-40-1

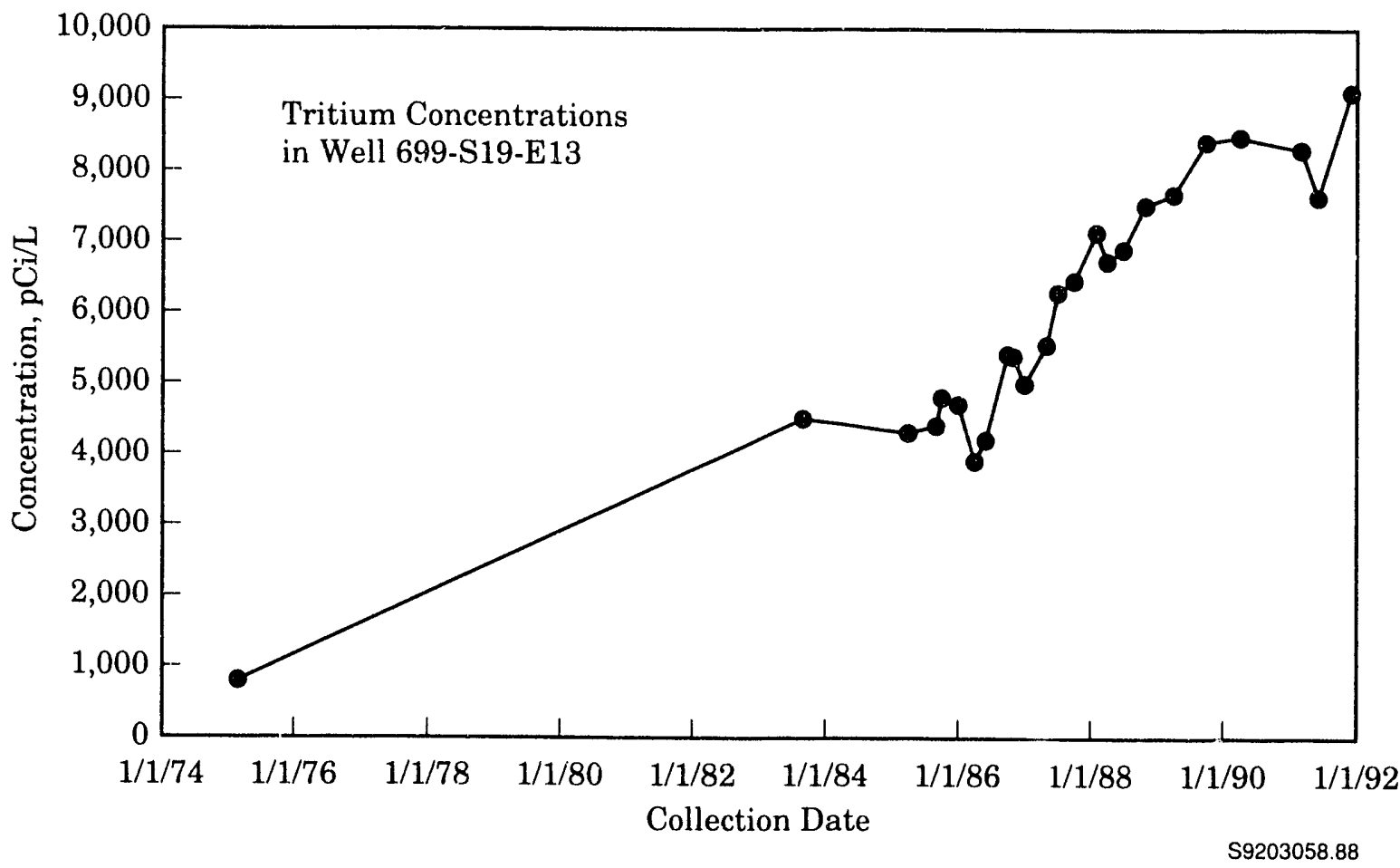

Figure 5.10. Trend Plot of Tritium $\left({ }^{3} \mathrm{H}\right)$ Concentrations in Well 699-S19-E13 
turn at a higher elevation than the Columbia River (Newcomer et al. 1991). As a result, ground water flows from west to east, limiting the extent of southward movement of the contaminant plume.

The configuration of the western portion of the plume closely matches previous predictions of the direction of contaminant movement from the 200-East Area (Freshley and Graham 1988). Movement to the south may be enhanced by the spreading ground-water mound beneath B Pond. This mound is spreading as a result of increased discharge of steam condensate and process cooling water to B Pond since 1984 when Gable Mountain Pond was deactivated.

The movement of ${ }^{3} \mathrm{H}$ plumes in the 200-West Area was also consistent with previous observations. The plume extending from near the Reduction Oxidation (REDOX) Plant in the southern part of the 200-West Area continued to move slowly to the east and north. Only one well in the 200-West Area (299-W22-9) continued to show ${ }^{3} \mathrm{H}$ levels in excess of the DCG during 1990; however, that well contained the highest ${ }^{3} \mathrm{H}$ levels of any ground-water monitoring wells on the Site. That well was not sampled in 1991; however, results from early 1992 indicate the ${ }^{3} \mathrm{H}$ concentration has remained above 4 million $\mathrm{pCi} / \mathrm{L}$. Movement of the "'H plume extending north and east from the REDOX Plant was indicated by changes in the ${ }^{3} \mathrm{H}$ concentrations in several wells in the plume. Concentrations in well 699-35-70 continued to decrease slightly, suggesting that peak concentrations may have moved beyond this well. Figure 5.11 shows the ${ }^{3} \mathrm{H}$ concentrations in well 699-35-70 since the mid 1960 s with the passage of the ${ }^{3} \mathrm{H}$ plume in evidence. The current ${ }^{3} \mathrm{H}$ concentrations in the well are about five-fold below the peak concentration corrected for radioactive decay since the peak occurred in 1976. Plume movement in that area is slow because of low hydraulic conductivity in the unconfined aquifer; however, some perceptible movement is still occurring. Concentrations in wells near the center of the plume remained relatively constant. The northernmost extent of the plume appeared to be near well 699-40-62. Well 699-44-64, north of well 699-40-62, has shown a small but steady increase over the last 24 months, reaching a new high of $814 \mathrm{pCi} / \mathrm{L}$ in April 1990.

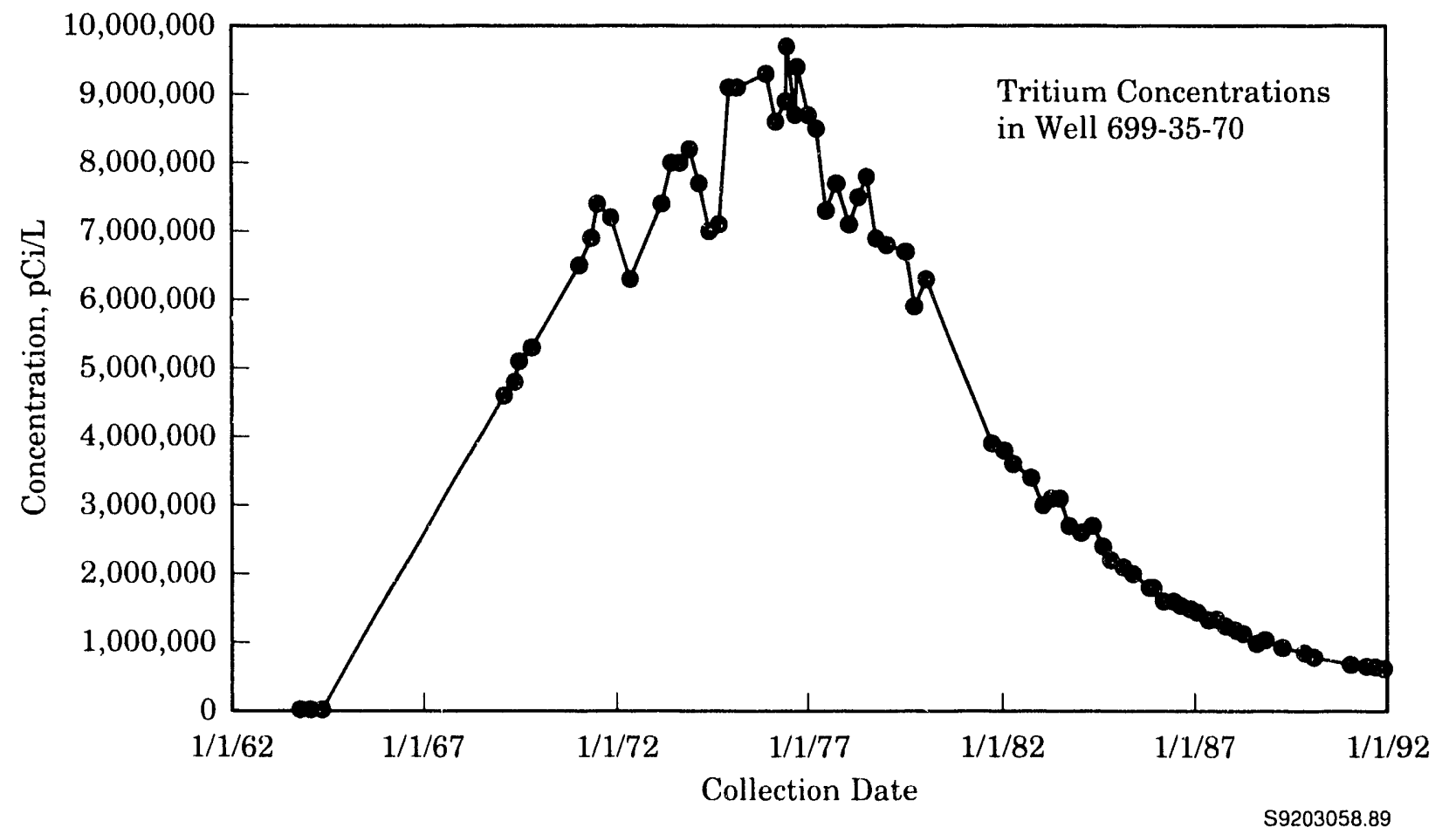

Figure 5.11. Trend Plot of Tritium $\left({ }^{3} \mathrm{H}\right)$ Concentrations in Well 699-35-70 
Cobalt-60. All "'Co concentrations were consistently near or below the detection limit $120 \mathrm{pCi} / \mathrm{L}$, for wells monitored in 1991 except in a region north of the 200 Areas affected by waste disposed of in the BY cribs (Figure 5.12।. The highest level of ${ }^{51} \mathrm{Co}$ in 1991 was found in well 699-50-53 $1449 \mathrm{pCi} / \mathrm{L})$. Cobalt-60 in this area appears to be highly mobile, probably because of the presence of a soluble cobalt-cyanide or ferrocyanide l complex associated with the plume originating in the BY cribs.

Strontium-90. Concentrations of ${ }^{4} \mathrm{Sr}$ were above the $8-\mathrm{pCi} / \mathrm{L}$ DWS in wells in the $100-\mathrm{B}$, 100-D, 100-F, 100-K, 100-N, 200-East, and 600 Areas. Concentrations of ${ }^{31} \mathrm{Sr}$ were greater than the 1,000-pCi/L DCG in the $100-\mathrm{N}$ and 200East Areas, ranging up to $6,060 \mathrm{pCi} / \mathrm{L}$ in the 100-N Area (well 199-N-67), significantly reduced from the maximum of $23,400 \mathrm{pCi} / \mathrm{L}$ reached in March 1989. A trend plot of "Sr concentrations in well 199-N-67 is given in Figure 5.13, showing the continuing decrease in "' $\mathrm{Sr}$ in that well. Concentrations: of "' $\mathrm{Sr}$ ranged up to $3,150 \mathrm{pCi} / \mathrm{L}$ in the 200-East Area near the 216-B-5 Reverse Injection Well. Concentrations of "Sr above the DWS (maximum of $171 \mathrm{pCi} / \mathrm{L}$ in well $699-53-48 \mathrm{~B}$ ) but less than the DCG were detected in several wells near Gable Mountain Pond. Strontium-90 contamination in that area resulted from the accidental discharge of radioactive waste to Gable Mountain Pond during its early use. Strontium90 has since migrated through the sedimentary column to the ground water, which is relatively close to the surface at that location. Initial breakthrough occurred in 1980 in some areas and later in others. Trend plots showing "'Sr breakthrough for several representative Gable Mountain Pond monitoring wells are shown in Figure 5.14. Well 699-53-47B appears to show a slightly increasing trend. Areas with "Sr above the DWS are shown in Figures 5.12 and 5.15.

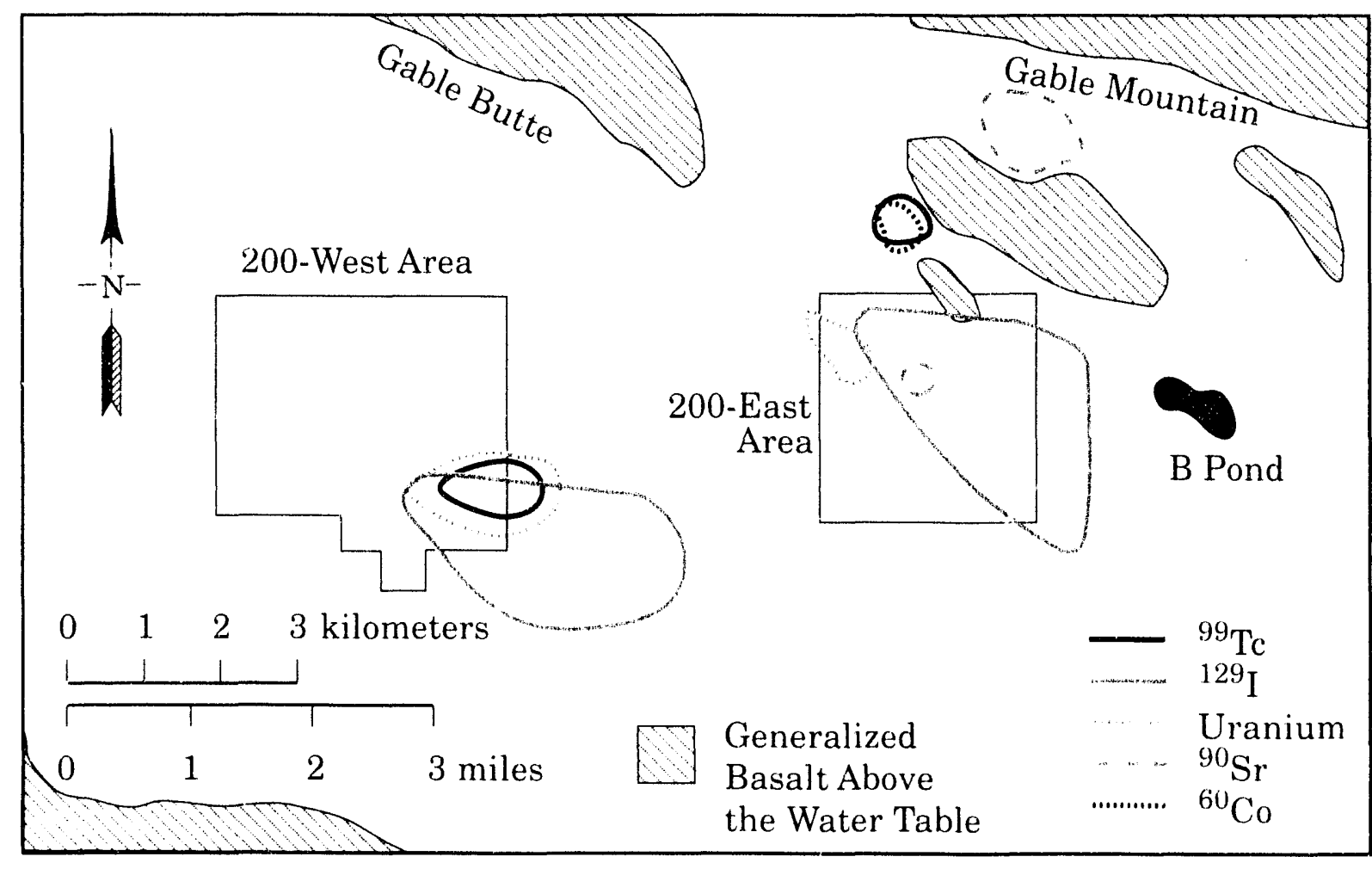

S9203058.19

Figure 5.12. Distribution of Radionuclides Except Tritium at Concentrations Above the Drinking Water Standard in the Vicinity of the 200 Areas, 1991 


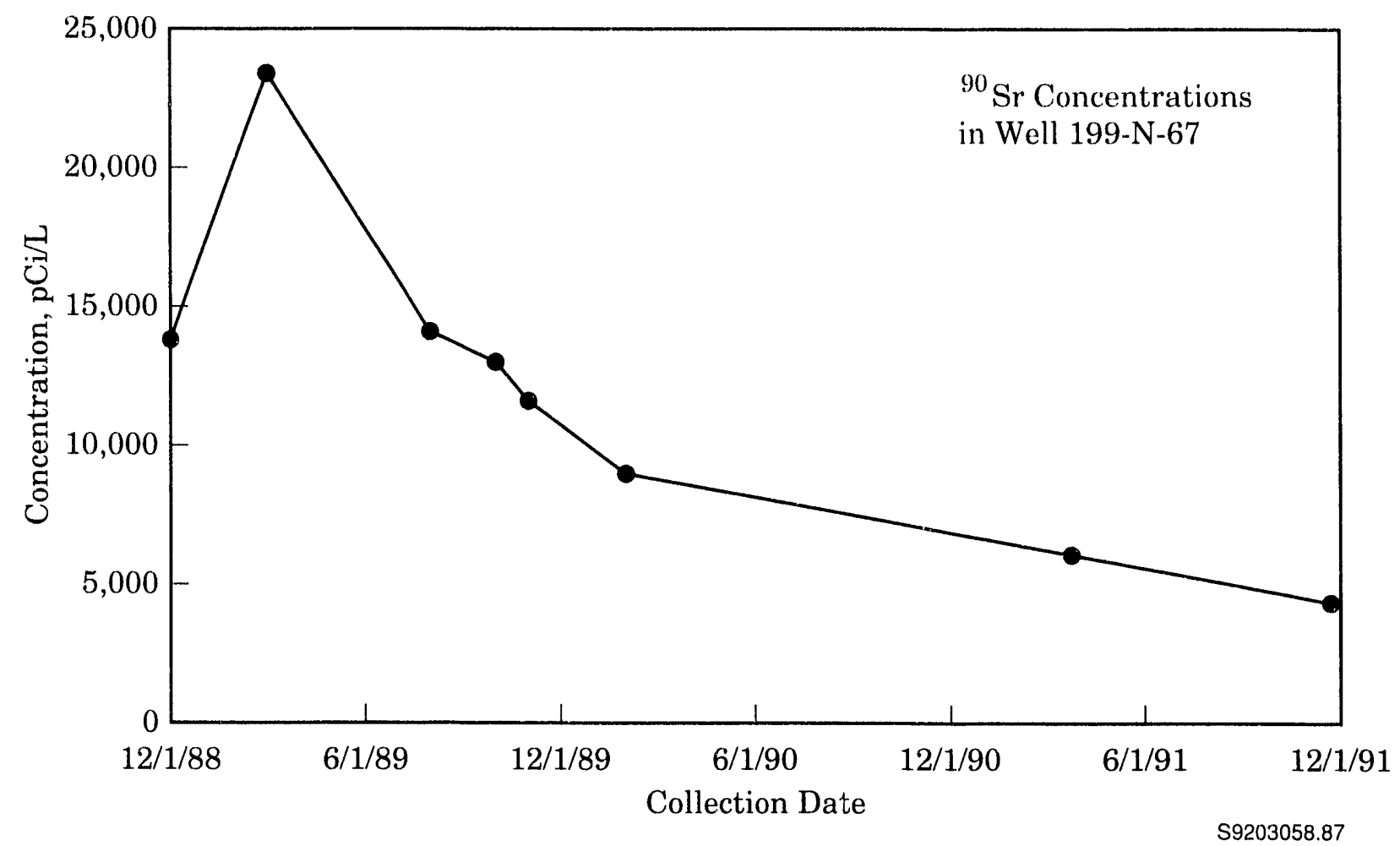

Figure 5.13. Trend Plot of Strontium-90 $\left({ }^{90} \mathrm{Sr}\right)$ Concentrations in Well 199-N-67

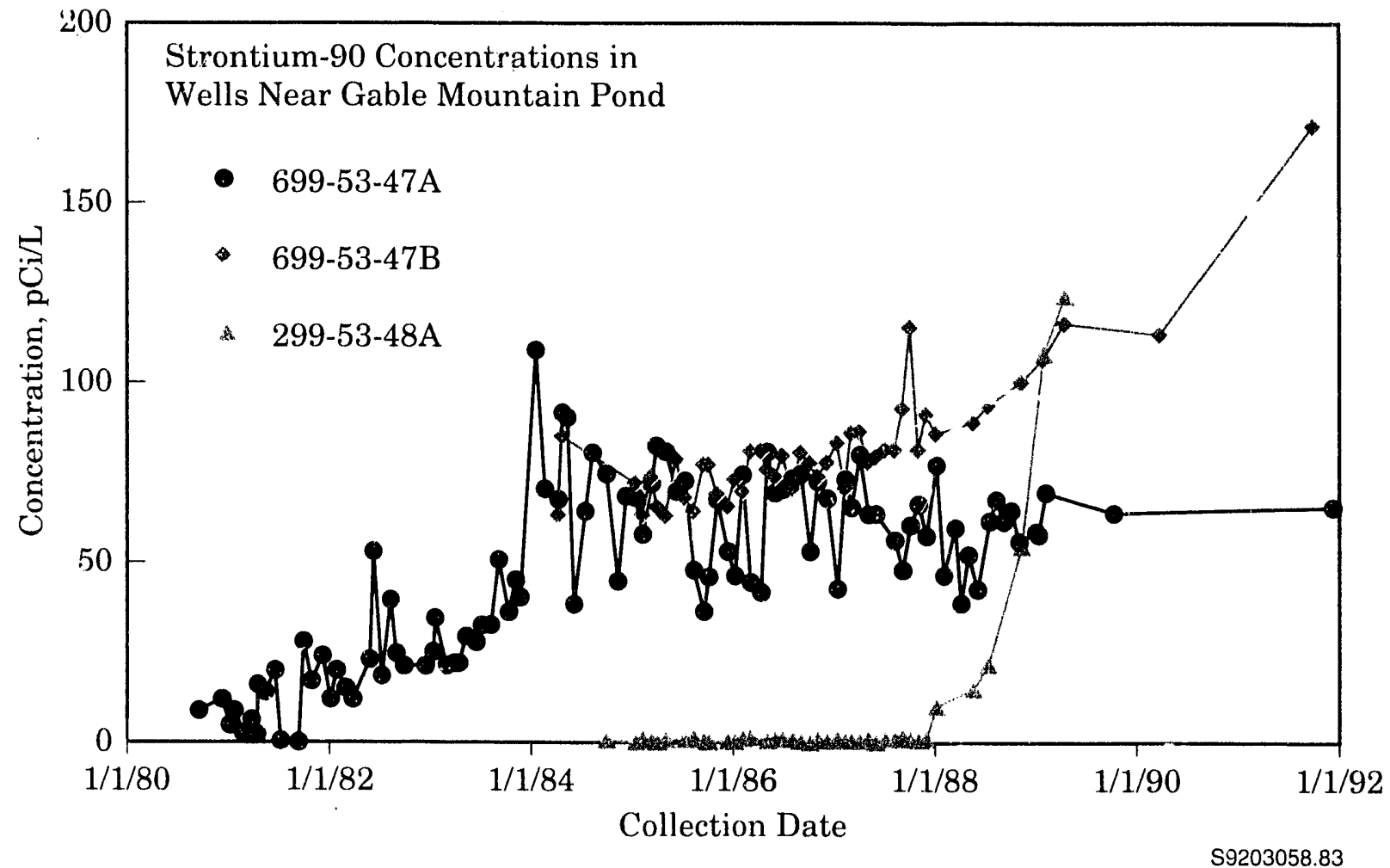

Figure 5.14. Trend Plot of Strontium-90 ("in) Concentrations in Wells Near Gable Mountain Pond 


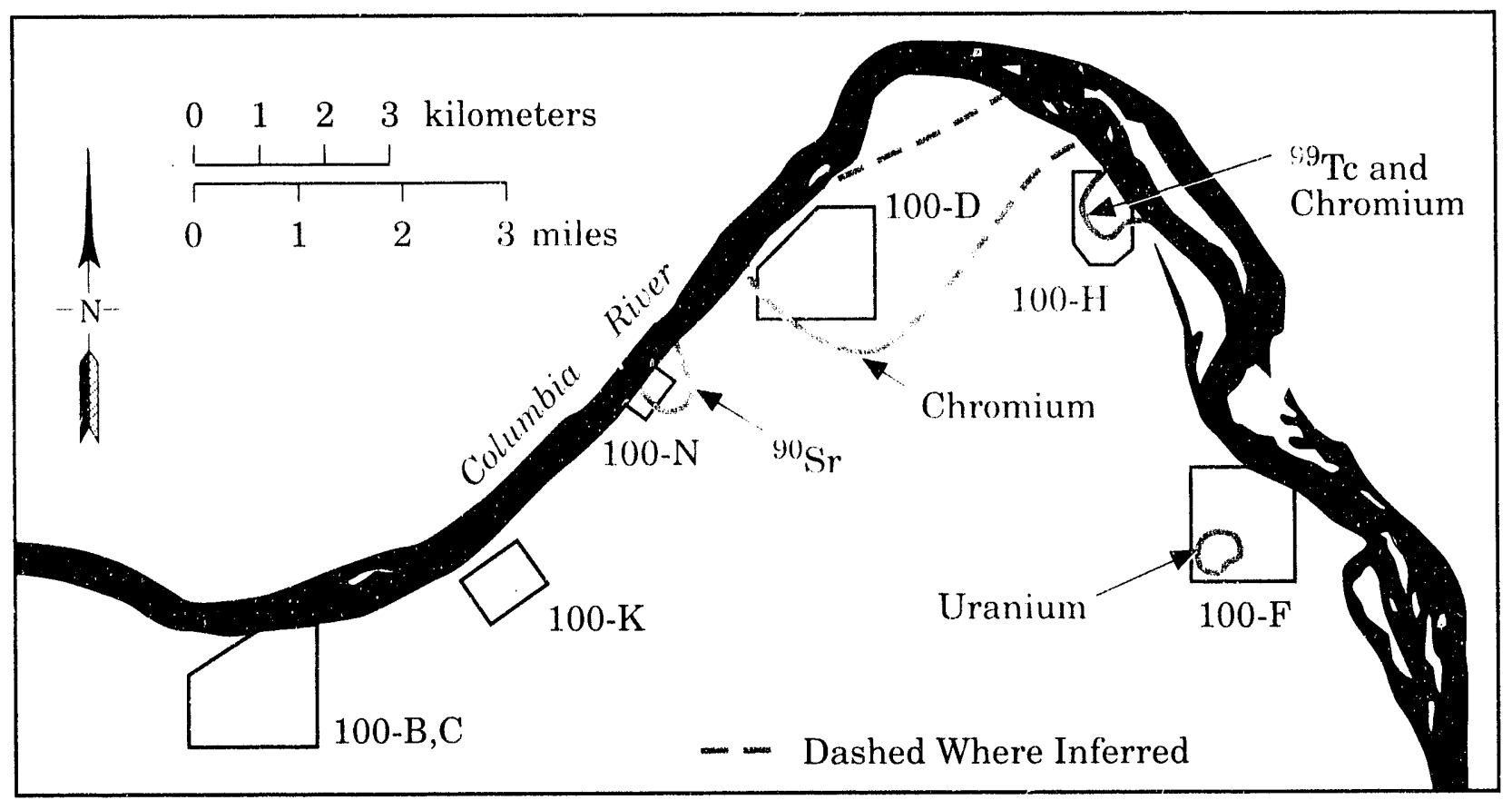

S9203058.17

Figure 5.15. Distribution of Radionuclides and Hazardous Chemicals at Concentrations Above the Drinking Water Standard in the Vicinity of the 100 Areas, 1991

Technetium-99. Concentrations of ${ }^{99} \mathrm{Tc}$ greater than the $900-\mathrm{pCi} / \mathrm{L}$ DWS were detected in wells in the 100-H, 200-East, and 200-West Areas and in portions of the 600 Area. These locations are identified on Figures 5.12 and 5.15. Concentrations did not exceed the $100,000-\mathrm{pCi} / \mathrm{L}$ DCG in any well sampled in 1991.

Antimony-125. Antimony-125 $\left.{ }^{(125} \mathrm{Sb}\right), \mathrm{a}$ gamma emitter, has been measured in the past in a few wells in $\mathrm{N}$ and $\mathrm{K}$ Areas. Concentrations measured in samples from these two areas have been as high as $305 \mathrm{pCi} / \mathrm{L}$ near the 1325-N LWDF in 1987. In 1991, however, the maximum concentrations observed were $103 \mathrm{pCi} / \mathrm{L}$ in samples collected from one $100-\mathrm{K}$ Area well and $30 \mathrm{pCi} / \mathrm{L}$ in samples from several 100.N Area wells. The DWS for ${ }^{125} \mathrm{Sb}$ is $300 \mathrm{pCi} / \mathrm{L}$, and the $\mathrm{DCG}$ is $60,000 \mathrm{pCi} / \mathrm{L}$.

Iodine-129. The presence of ${ }^{129} \mathrm{I}$ in ground water is significant, because of its relatively low DWS ( $1 \mathrm{pCi} / \mathrm{L})$, its potential for accumulation in the environment as a result of long-term releases from nuclear fuel reprocessing facilities (Soldat 1976 ), and its relatively long half-life ( 16 million years). At Hanford, the main contributor of ${ }^{12 \%} \mathrm{I}$ to ground water has been liquid discharges to cribs in the 200 Areas. Assay of that isotope by highsensitivity, direct-counting methods requires long counting times with correspondingly low analytical throughput. The highest concentrations observed onsite are downgradient from the REDOX and PUREX Plants. The highest ${ }^{129} I$ concentration observed in 1991 in Hanford ground water was $44 \mathrm{pCi} / \mathrm{L}$ found in well 699-35-70. Many wells sampled in the 200-West, 200-East, and 600 Areas had concentrations somewhat above the DWS (Figure 5.12); however, none were above the DCG ( $500 \mathrm{pCi} / \mathrm{L})$.

Cesium-137. Concentrations of ${ }^{1: 57} \mathrm{Cs}$ were below the detection limit $(23 \mathrm{pCi} / \mathrm{L})$ except in three wells located near the 216-B-5 Reverse Injection Well (Figure 5.4). The 216-B-5 reverse well received an estimated $31.8 \mathrm{Ci}$ of ${ }^{137} \mathrm{Cs}$ (decayed through April 1, 1986) during its operation from 1945 to 1947 (Stenner et al. 1988). The DWS for ${ }^{1: 37} \mathrm{Cs}$ is $200 \mathrm{pCi} / \mathrm{L}$, and the $\mathrm{DCG}$ is $3,000 \mathrm{pCi} / \mathrm{L}$. The area with ${ }^{1: 37} \mathrm{Cs}$ above the DWS is depicted in Figure 5.12. Most of the wells 
located near the 216-B-5 Reverse Injection Well were not sampled in 1991 because of newly implemented restrictions on entry to radiation protection zones.

Uranium. The highest uranium levels in Hanford ground water occurred in wells adjacent to the inactive $216-\mathrm{U}-1$ and $216-\mathrm{U}-2$ cribs (Figure 5.5). Uranium concentrations in these wells have been decreasing over the last 4 years following remediation activities associated with those cribs. The total uranium concentration in well 299-W 19-3 dropped from 11,500 pCi/L in January 1987 to $737 \mathrm{pCi} / \mathrm{L}$ in April 1990. Well 299-W19-3 and other several other key wells near the 216 U-1 and 216-U-2 cribs were not sampled for uranium in 1991 because of programmatic reductions in the operational ground-water monitoring program; however, samples were collected from well 299-W19-18, which is located downgradient of the cribs. This well showed a maximum of $897 \mathrm{pCi} / \mathrm{L}$ in early 1991. Uranium levels in that well and others nearby appear to have stabilized. A trend plot of uranium concentrations for well 299-W1918 is shown in Figure 5.16. In addition, a newly installed well farther downgradient from the cribs near U Plant itself (299-W19-29) was sampled for the first time in 1991 with a maximum value of $2,240 \mathrm{pCi} / \mathrm{L}$ reported. It thus appears that the plume center has shifted somewhat to the east consistent with known ground-water flow in that part of the Site.

A plume of uranium exists in the unconfined aquifer beneath the 300 Area in the vicinity of uranium fuel fabrication facilities and inactive waste sites known to have received uranium waste. The extent of the plume was limited to an area downgradient from active and inactive LWDFs. Uranium concentrations in welis in and adjacent to the 300 Area ranged up to $362 \mathrm{pCi} / \mathrm{L}$ during 1991. These concentrations were similar to those measured in previous years. An Expedited Response Action performed on the 300 Area Process Trenches in mid-1991 was aimed at reducing the uranium source in that area. Use of the trenches was resumed following completion of the remedial action. Uranium levels in well 399-1-17A appear to have been reduced following that action; levels apparently stabilized

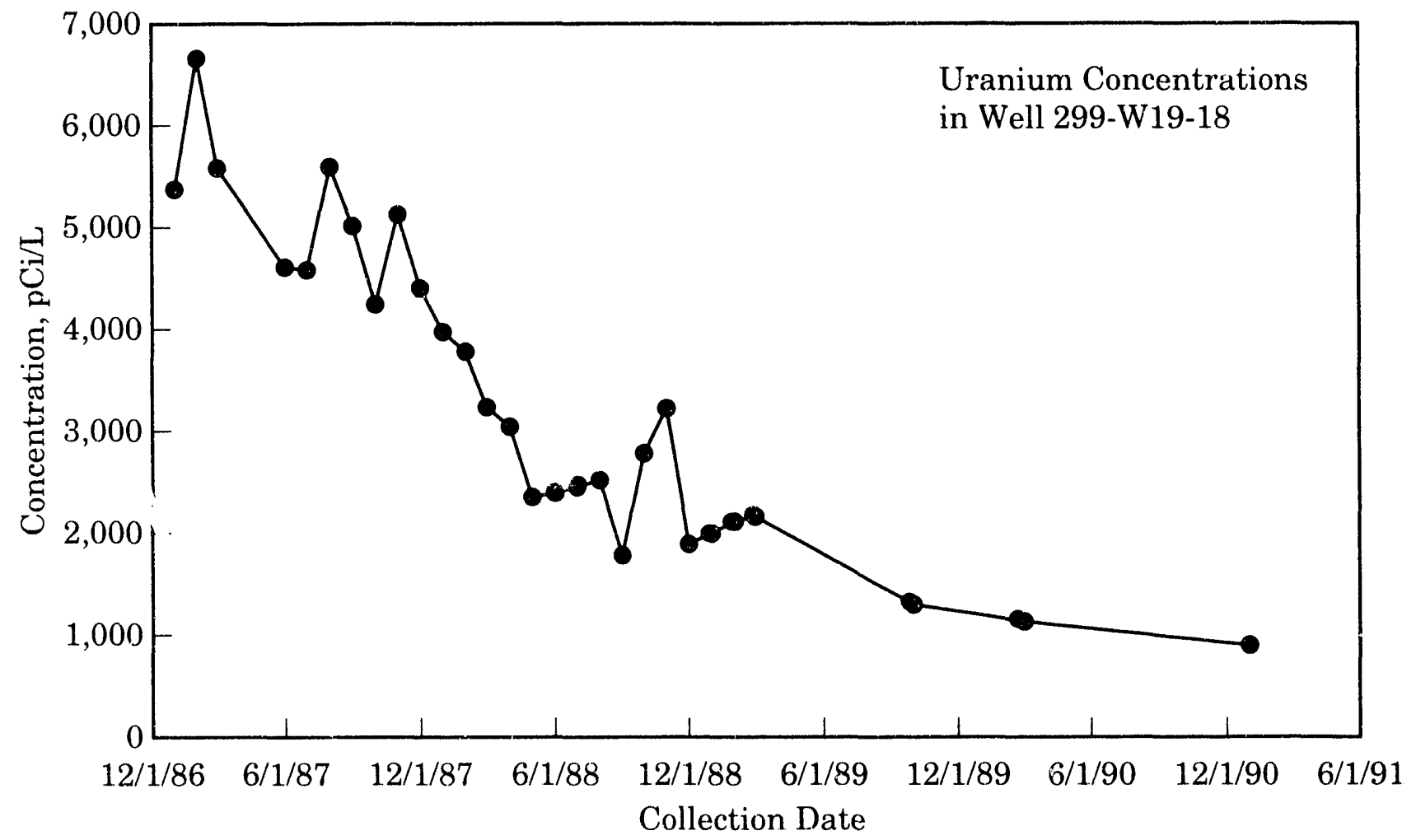

Figure 5.16. Trend Plot of Uranium Concentrations in Well 299-W19-18 
about a factor of 10 below the maximum values seen in 1990. A trend plot showing the uranium concentrations in that well is shown in Figure 5.17. Well 399-1-17A is located near the down-gradient discharge point for the 300 Area Process Trenches. That well has shown cyclic variations in the uranium level in the past. It is thus too early to conclusively ascertain if the remedial action was completely effective.

Plutonium. A survey of plutonium in ground water was undertaken during 1991 . The survey covered 132 wells including most of the usable wells in the 200 Areas and a few selected 600 Area wells. Concentrations of $239.240 \mathrm{Pu}$ were below the detection limit in all wells, except for one well located near the 216-B-5 Reverse Injection Well (Figure 5.4) and one well in the 200 -West Area. Plutonium is generally considered to bind strongly to sediments and thus has limited mobility in the aquifer. Ground water sampled at well 299-E28-23 contained $21.7 \mathrm{pCi} / \mathrm{L}$ of ${ }^{233.241} \mathrm{Pu}$ in 1990 . That well could not be sampled in 1991 because of newly implemented restrictions on entry to radiation protection zones. Ground water at well 299-E28-25 contained $13.3 \mathrm{pCi} / \mathrm{L}$ in 1991 , similar to the levels seen in the past 2 years. Plutonium was detected in 1989 in another nearby well, 299E28-24, and ranged up to $144 \mathrm{pCi} / \mathrm{L}$ in 1990. That well vas not sampled in 1991. Plutonium238 has been detected at much lower levels in all three wells. The 216-B-5 Reverse Injection Well received an estimated $244 \mathrm{Ci}$ of ${ }^{233.2411} \mathrm{Pu}$ during its operation from 1945 to 1947 (Stenner et al. 1988). The $\mathrm{DCG}$ of $300 \mathrm{pCi} / \mathrm{L}$ for ${ }^{23{ }^{4}} \mathrm{Pu}$ was reduced to $30 \mathrm{pCi} / \mathrm{L}$ effective February 1990 . There is no explicit DWS for ${ }^{234} \mathrm{Pu}$; however, the gross alpha DWS of $15 \mathrm{pCi} / \mathrm{L}$ would be applicable at a minimum. Alternately, if the DCG (which is based on a 100-mrem dose standard) is converted to the 4-mrem dose equivalent used for the DWS, $1.2 \mathrm{pCi} / \mathrm{L}$ would be the relevant guideline.

Plutonium-239,240 was detected for the first time in May 1990 in a well located in the 200-West Area (299-W15-8). That well monitors the 216-Z-9 crib, which received a large burden of

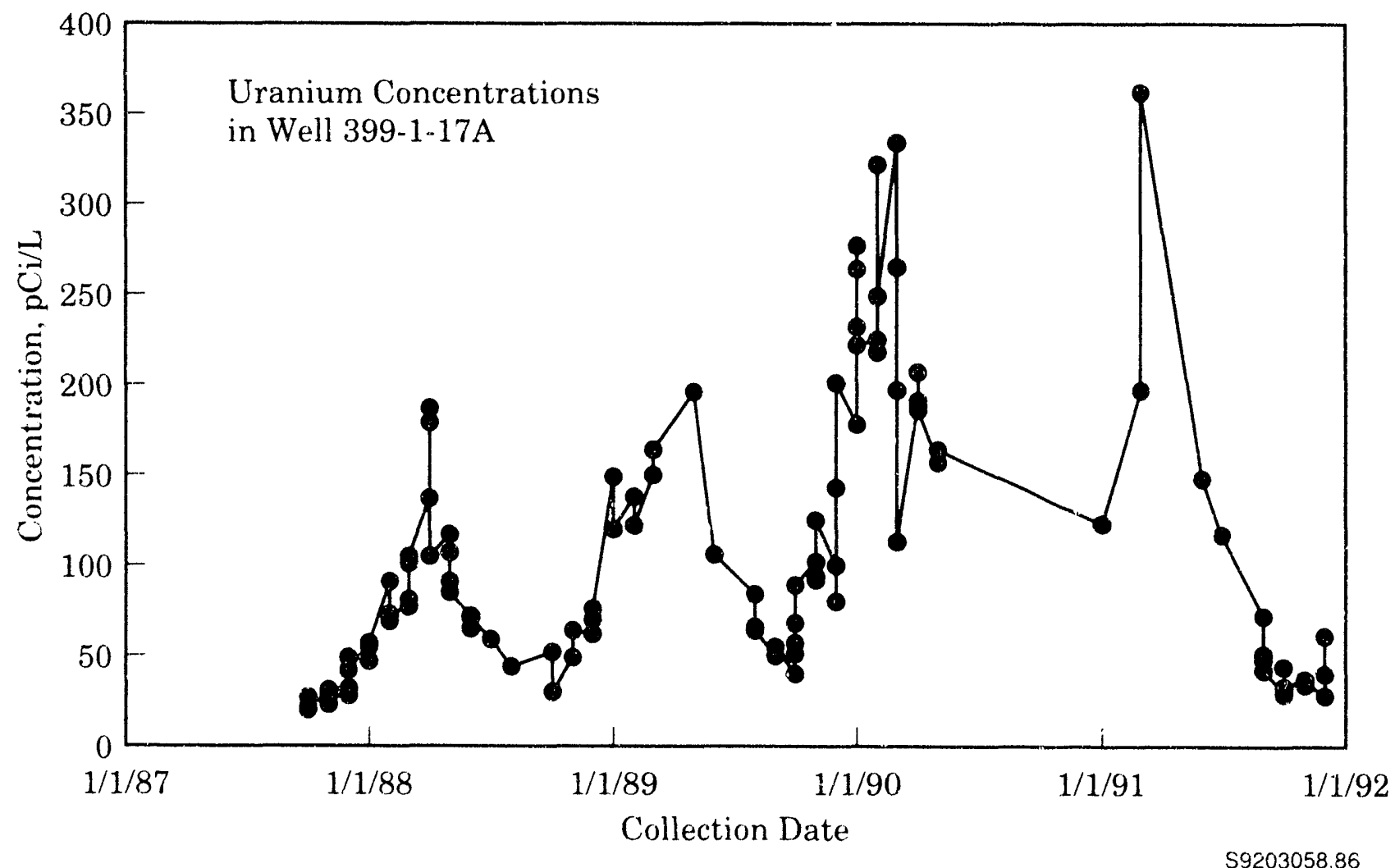

Figure 5.17. Trend Plot of Uranium Concentrations in Well 399-1-17A 
plutonium and americium from Z Plant liquid effluent streams. No previous transuranic measurements were available for this well. As the data were received just before termination of the analytical contract with United States Testing, Inc., it was not possible to verify the ouservation. The measured concentration of ${ }_{239.2411} \mathrm{Pu}$ was $8.3 \mathrm{pCi} / \mathrm{L}$. Plutonium-238 was also detected in the same sample $(0.14 \mathrm{pCi} / \mathrm{L})$. The :vell was resampled on November 14, 1991. Unfiltered, acidified samples were collected in the normal manner for transuranic analysis. In addition, a filtered, acidified sample was collected for plutonium assay. The unfiltered samples confirmed the presence of ${ }^{239: 240} \mathrm{Pu}(1.9 \mathrm{pCi} / \mathrm{L})$, ${ }^{238} \mathrm{Pu}(0.03 \mathrm{pCi} / \mathrm{L})$, and ${ }^{241} \mathrm{Am}(5.9 \mathrm{pCi} / \mathrm{L})$. No plutonium was found in the filtered samples, confirming that the transuranic fraction is associated with particulate material.

\section{Chemical Monitoring Results for the Unconfined Aquifer}

Chemical analyses performed on ground-water samples by various monitoring programs at Hanford are listed in Table 5.1. These analyses have identified seven hazardous chemicals occurring in ground water at concentrations above existing or proposed federal drinking water standards. These are $\mathrm{NO}_{3,}, \mathrm{CN}, \mathrm{F}, \mathrm{Cr}^{+i}$, carbon tetrachloride, chloroform, and trichloroethylene.

A number of the constituents measured such as conductance, total carbon, total organic carbon, and total organic halogens are used as indicators of contamination. These will not be discussed in detail in this report because the specific contaminant contributing to these parameters will be discussed. Other chemicals listed in Table 5.1 are indicators of the nat ural chemical composition of ground water and in general are not contaminants from operations at Hanford. These include alkalinity, pH, $\mathrm{Na}, \mathrm{Mg}, \mathrm{K}, \mathrm{Al}, \mathrm{Si}, \mathrm{Ca}, \mathrm{Mn}, \mathrm{Fe}, \mathrm{Cl}$, and $\mathrm{SO}_{4}^{-2}$. The analytical technique used to determine the concentration of metals in ground water provides results for a number of constituents that are rarely observed above background concentrations such as $\mathrm{V}, \mathrm{Ni}, \mathrm{Cu}, \mathrm{Zn}, \mathrm{Sr}, \mathrm{Ag}, \mathrm{Cd}, \mathrm{Sb}, \mathrm{Ba}, \mathrm{Be}$, and $\mathrm{B}$. Table 5.1 lists several additional analyses ( $\mathrm{Hg}, \mathrm{As}, \mathrm{Se}, \mathrm{Pb}$, and $\mathrm{Tl}$ ) performed on samples from selected locations where wastes containing these materials may have been disposed.
The following section presents additional information on the seven constituents occurring in ground water at concentrations above existing or proposed drinking water standards.

Nitrate Concentrations. Most ground-water samples collected in 1991 were analyzed for nitrate. Nitrate was measured at concentrations greater than the DWS ( $45 \mathrm{mg} / \mathrm{L} \mathrm{NO}_{3}$ ion) in wells in all operational areas except the 400 Area.

Although nitrate is associated primarily with process condensate liquid wastes, other liquids discharged to ground also contain nitrate. Nitrate contamination in the unconfined aquifer reflects the extensive use of nitric acid in decontamination and chemical reprocessing operations. Nitrate, like ${ }^{3} \mathrm{H}$, can be used to define the extent of contamination because nitrate is present in many waste streams and is mobile in ground water. The distribution of nitrate on the Hanford Site is shown in Figure 5.18. The nitrate distribution shown in Figure 5.18 is similar to previous evaluations.

Although most nitrate observed onsite is the result of Hanford operations, elevated nitrate concentrations in wells to the west of the Site appear to be the result of increasing agricultural activity in Cold Creek Valley. There is no known source of nitrate in that area associated with Site operations, and wells located between well 699-36-93 and Hanford waste disposal facilities show no evidence of plume passage. Nitrate levels have fluctuated considerably in those wells over the past 30 years and again appear to be increasing, particularly in w 11 699-36-93. A trend plot of nitrate data associated with well 699-36-93 near the Yakima Ridge is shown in Figure 5.19. Nitrate levels have been near or above the DWS in that well since 1985 .

The highest nitrate concentrations in the 200East Area continued to be found near LWDFs that received effluent from PUREX operations. Nitrate concentrations in wells near the 216-A-10 and $216-\mathrm{A}-36 \mathrm{~B}$ cribs have generally tended to decrease in the past few years but remained above the DWS even though these facilities were removed from service in 1987. 


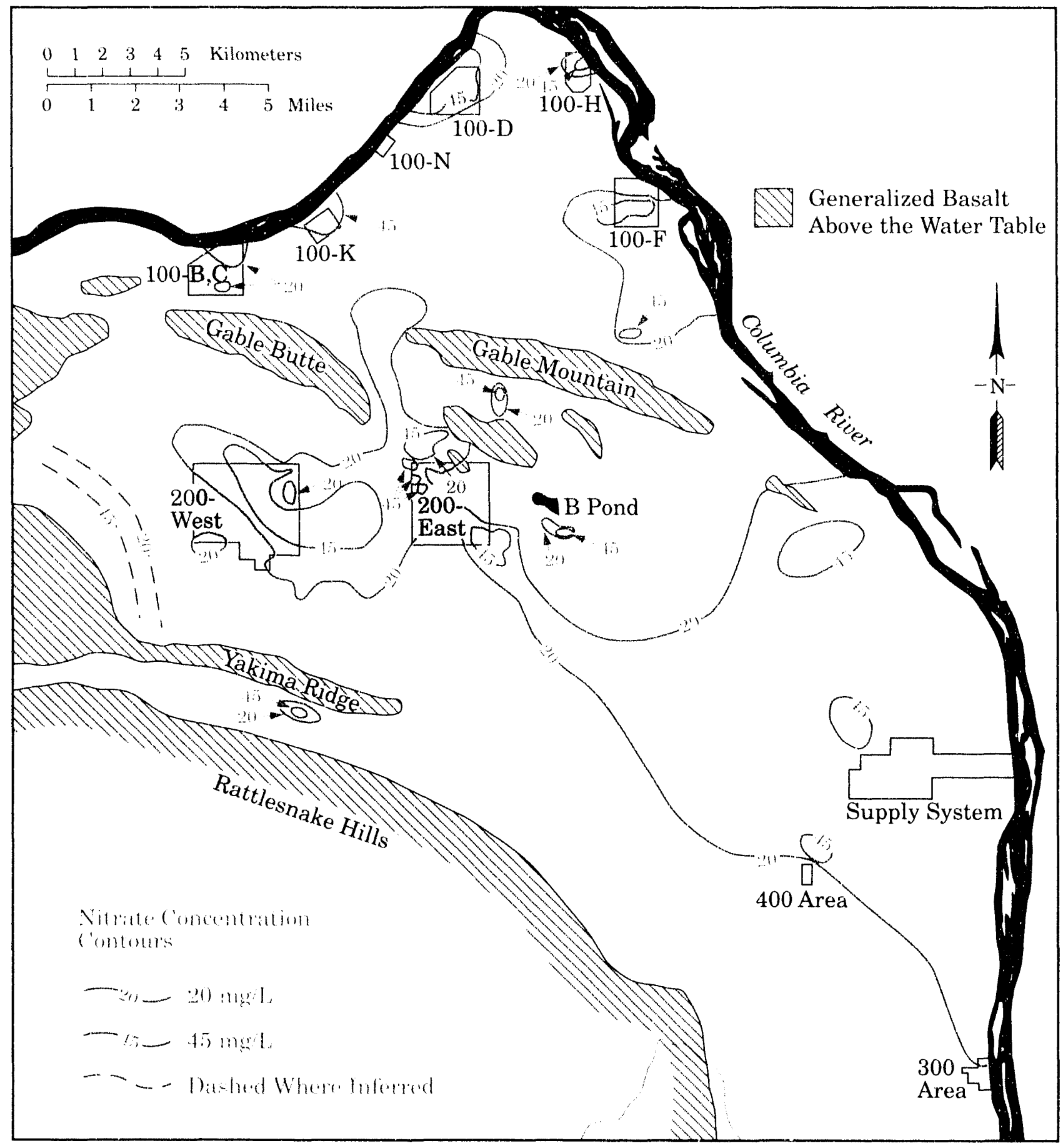

$\$ 9203058.13 a$

Figure 5.18. Nitrate $\left(\mathrm{NO}_{3}{ }^{-}\right)$Concentrations in the Hanford Site Unconfined Aquifer, 1991 


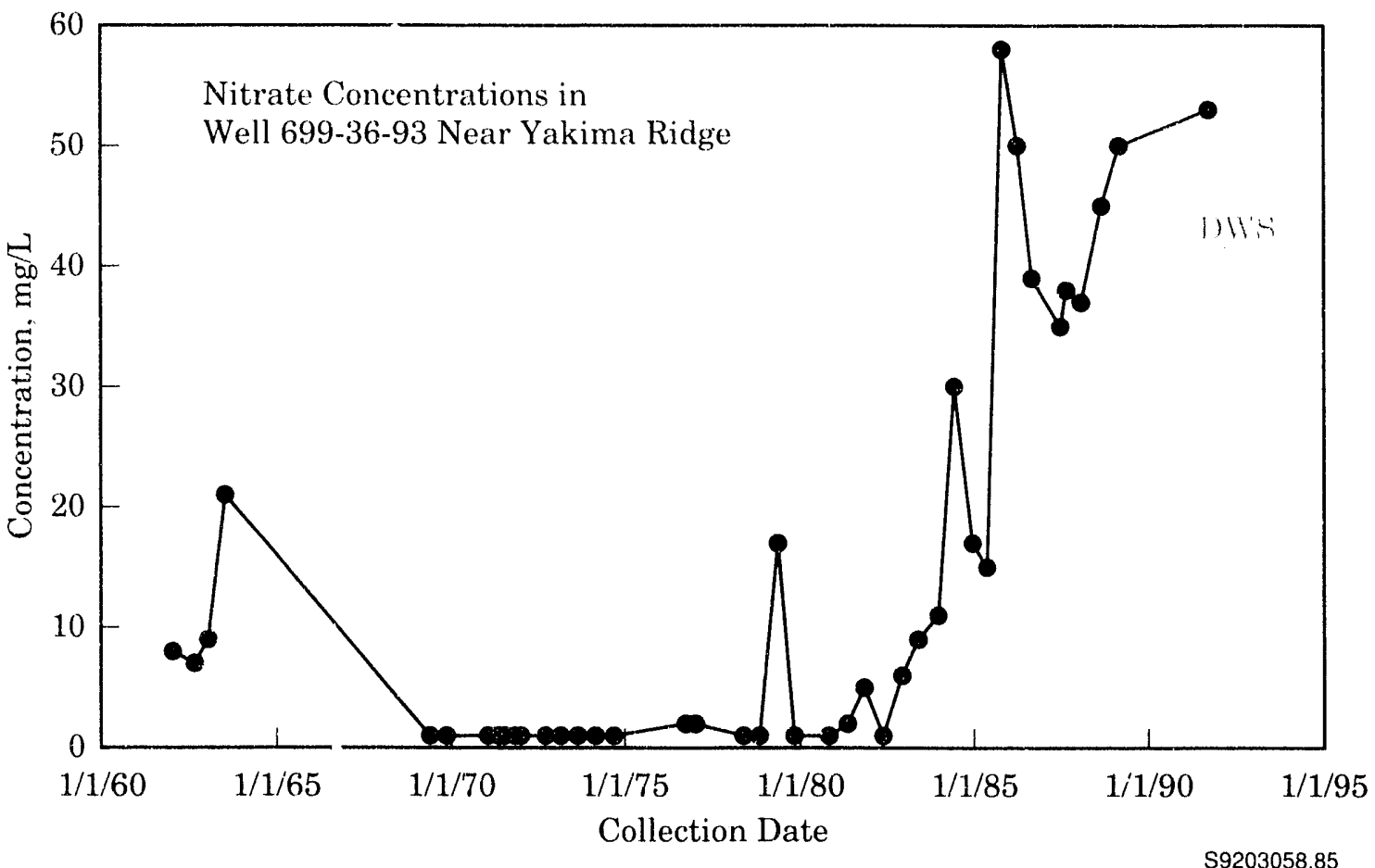

Figure 5.19. Trend Plot of Nitrate Concentrations in Well 699-36-93

The configuration of the nitrate plume emanating from the 200-East Area shows the influence of two periods of PUREX operation and recent changes in the operation of $B$ Pond. The location of $B$ Pond is shown in Figure 5.2. Increases in the volume of process cooling water discharged to $\mathrm{B}$ Pond may have resulted in the expanding area of lower nitrate concentrations in ground water to the east and south of that facility (see Figure 5.18).

Nitrate concentrations above the DWS were widespread in ground water beneath the 200-West Area. Highest concentrations were centered in three locations: 1) wells near U Plant, 2) wells in the northwestern part of the 200-West Area, and 3) wells near the 216-S-25 crib. The highest nitrate concentrations across the Site continued to be found in wells east of U Plant near the 216U-17 crib. The presence of nitrate in wells near this crib was observed before February 1988 when the crib went into operation. The source of nitrate is believed to be wastes disposed of in the 216-U-1 and $216-\mathrm{U}-2$ cribs. These cribs received over 1 million $\mathrm{kg}$ of nitrate during their operation from 1951 to 1967 (Stenner et al. 1988). Nitrate concentrations in wells located near the $216-\mathrm{U}-1$ and 216-U-2 cribs west of U Plant continued to decrease, with concentrations in several of the wells dropping below the DWS. For example, the nitrate concentration in well 299-W19-18 located near U Plant has dropped below the DWS as shown in Figure 5.20.

Several wells in the northwestern part of the 200-West Area continued to contain nitrate at concentrations greater than the DWS. These wells are located near several inactive LWDFs that received waste from early $\mathrm{T}$ Plant operations. Maximum concentrations in these wells in 1991 ranged up to $791 \mathrm{mg} / \mathrm{L}$ in well $299-\mathrm{W} 15-4$, similar to that observed in recent years.

Cyanide Concentrations. In past monitoring activities, cyanide was detected in samples collected from wells in and directly north of the 200-East Area. The cyanide source is believed to 


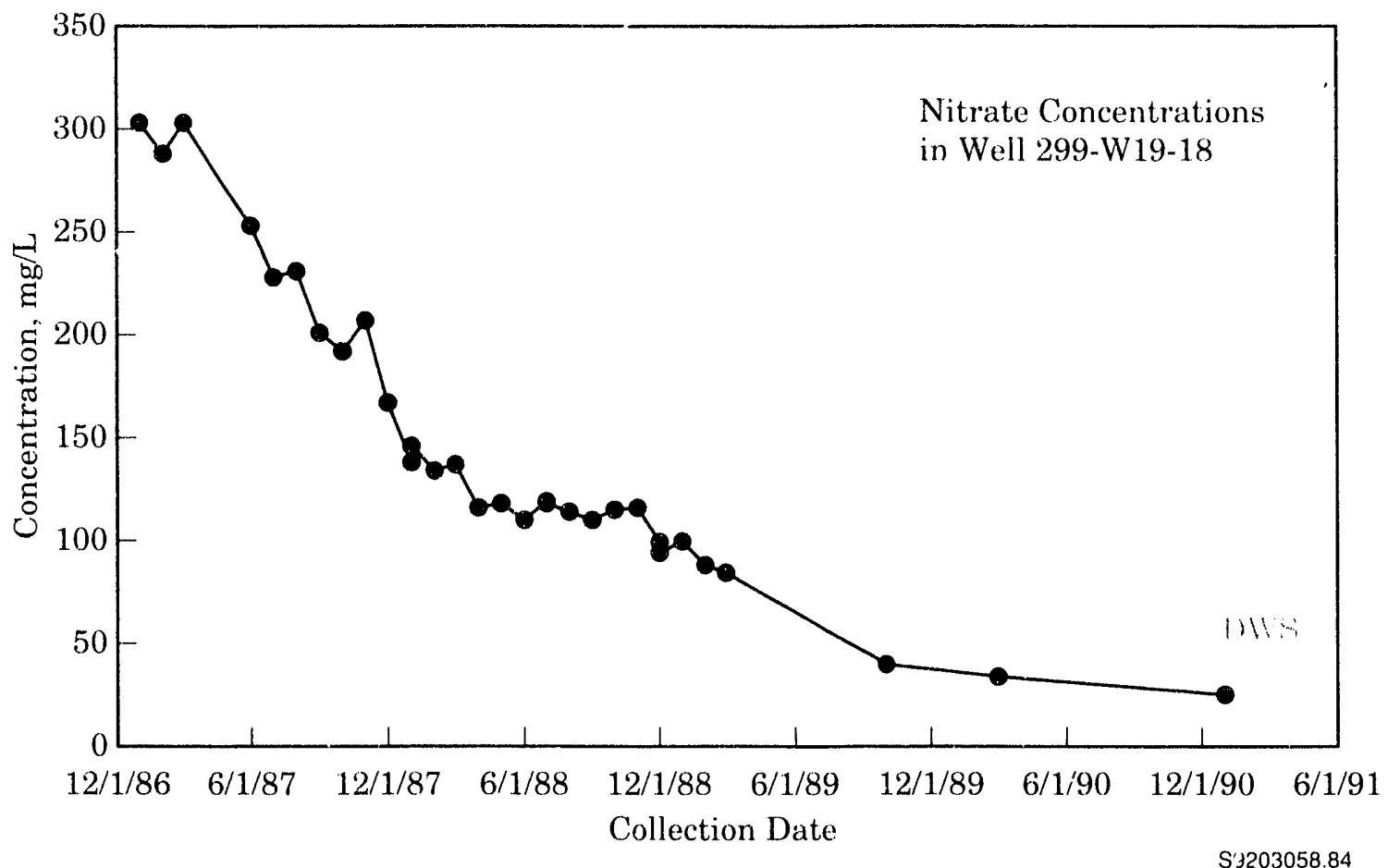

Figure 5.20. Trend Plot of Nitrate Concentrations in Well 299-W19-18

be wastes containing ferrocyanide disposed of in the BY cribs. Samples taken in 1991 by routine monitoring programs had a maximum cyanide concentration of $760 \mu \mathrm{g} / \mathrm{L}$ (well 699-50-53). Wells containing cyanide also contained concentrations of several radionuclides, including ${ }^{(6)} \mathrm{Co}$. Although ${ }^{\text {ii" }} \mathrm{Co}$ is normally immobile in the subsurface, it appears to be chemically complexed and mobi . lized by cyanide or ferrocyanide. A more extensive study of cyanide was performed for the 200 BP-1 Remedial Investigation. However, the data are still being reviewed. Cyanide also has been detected in four widely spaced wells in the 200-West Area; the highest level reported in 1991 was $70 \mu \mathrm{g} / \mathrm{L}$ in well 299-W14-2, essentially identical to the previous measurement made in 1988. No formal DWS has been established for cyanide. A standard of $200 \mu \mathrm{g} / \mathrm{L}$ has been proposed by the EPA.

Fluoride Concentrations. Fluoride concentrations above the DWS occurred in a few wells in the 200-West Area near T Plant. The maximum concentration in 1988 was $12.8 \mathrm{mg} / \mathrm{L}$ in well 299-W15-4. Because of considerations asscciated with disposal of purgewater, no 200-West Area wells in the fluoride plume were sampled in 1989 or 1990 . Well 299-W15-4 showed a fluoride concentration of $7.0 \mathrm{mg} / \mathrm{L}$ in 1991, somewhat lower than the previous maximum. All wells sampled outside the 200-West Area contained fluoride levels below the DWS. The DWS for fluoride is $2.0 \mathrm{mg} / \mathrm{L}$. A map depicting the fluoride plume above the DWS in the 200-West Area is shown in Figure 5.21.

Chromium Concentrations. Chromium has been found in ground water from wells in the 100-B, 100-D, 100- H, and 100-K Areas. In addition, at least one well in the 100-F Area had detectable hexavalent chromium. The highest measured chromium concentrations onsite in recent years have been found in well 199-D5-12. This well was not sampled for chromium in 1991. Detectable chromium was also found in various parts of the 600 Area, particularly near the 100-D 


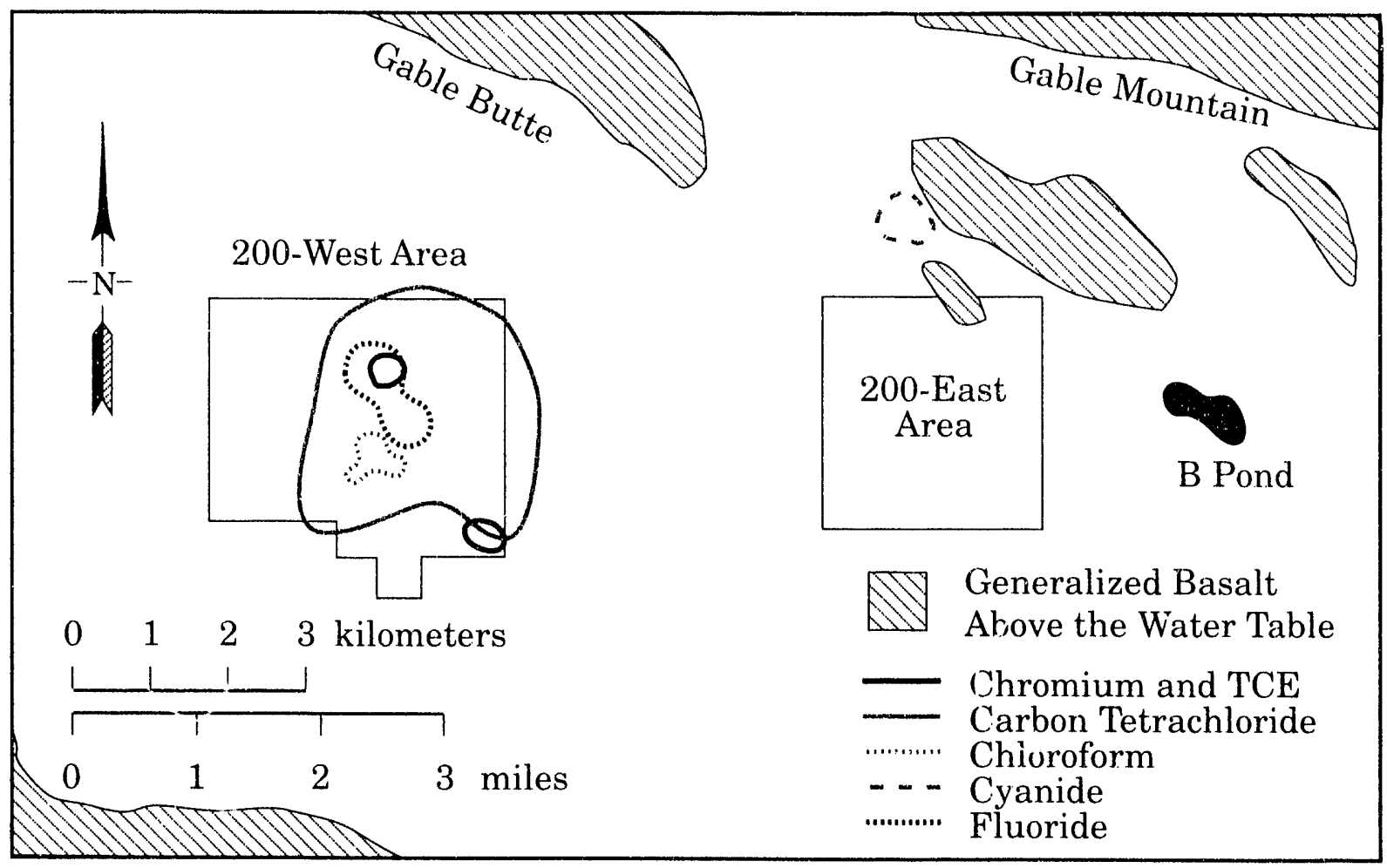

S9203058.18

Figure 5.21. Distribution of Hazardous Chemicals Except Nitrate Above the Drinking Water Standard in the Vicinity of the 200 Areas, 1991

and 100-H Areas. The highest concentration was found in well 699-97-43 (approximately $1 \mathrm{~km}$ west of the $100-\mathrm{H}$ Area) at $160 \mu \mathrm{g} / \mathrm{L}$, about three times the DWS of $50 \mu \mathrm{g} / \mathrm{L}$. Chromium contamination has been found at several locations in the 200-West Area. The 1991 chromium concentration in well $299-\mathrm{W} 10-9(135 \mu \mathrm{g} / \mathrm{L})$ was similar to earlier measurements. The maximum chromium concentration found in the 200-West Area during 1991 was $350 \mu \mathrm{g} / \mathrm{L}$ in well $299-W 22-20$, also similar to previous measurements. Ground-water samples from at least 10 other 200 -West Area wells have shown detectable chromium. A few wells in the 200-East Area also showed evidence of minor chromium contamination. The highest level found was in well 299-E13-14, with a chromium concentration of $73 \mu \mathrm{g} / \mathrm{L}$ in August 1991, essentially identical to the last measurement taken in 1988. A map showing the distribution of chromium contamination in the 200-West Area is shown in Figure 5.21. The chromium distribution in the 100 Areas is shown in Figure 5.15.

\section{Carbon Tetrachloride Concentrations.}

Carbon tetrachloride contamination was found in the unconfined aquifer beneath much of the 200West Area. The contamination is believed to be from waste disposal operations associated with Z Plant before 1973. A concentration of $8,100 \mu \mathrm{g} / \mathrm{L}$ was found in a well near Z Plant first monitored in October 1988 (well 299-W15-16). Carbon tetrachloride concentrations in well 299-W15-16 were somewhat lower in 1991, reaching a maximum of $5,400 \mu \mathrm{g} / \mathrm{L}$. Numerous other wells in the area had carbon tetrachloride levels ranging from 1,000 to $5,000 \mu \mathrm{g} / \mathrm{L}$. The distribution of carbon tetrachloride in the 200-West Area above the DWS is shown in Figure 5.21. The carbon tetrachloride distribution in the 200 -West Area ground water has remained relatively stable since the presence of the contaminant plume was first noted in 1987. The only discernable exception is the western or southwestern edge of the plume, which has shown considerable movement over the past 4 to 5 years. 
Figure 5.22 shows the trends in carbon tetrachloride concentrations with time for four wells located at the east, west, north, and south boundaries of the plume. Well 699-39-79 shows a major increase during 1987 and 1988, suggesting that the plume moved past this location. This level was followed by a slight decrease, suggesting nassage of the leading edge of the plume at that location. The other three locations show little change. The maximum contaminant level, or target concentration, of carbon tetrachloride for remediation under the Comprehensive Environmental Response, Compensation, and Liability Act and the Superfund Amendments and Reauthorization Act is $5 \mu \mathrm{g} / \mathrm{L}$. The DWS is also $5 \mu \mathrm{g} /$ L. In addition to carbon tetrachloride, significant amounts of other chlorinated hydrocarbon solvents were found in 200-West Area ground water, including trichloroethylene and chloroform. A chloroform concentration of $1,540 \mu \mathrm{g} / \mathrm{L}$ was measured in well 299-W-15-8 in May 1990. The chloroform plume appears to be associated with but not exactly coincident with the carbon tetrachloride plume. The DWS for chloroform is 100 $\mu \mathrm{g} / \mathrm{L}$ (total trihalomethanes). The location of the chloroform plume is also shown on Figure 5.21.

Trichloroethylene Concentrations. Trichloroethylene contamination in excess of the $5 \mu \mathrm{g} / \mathrm{L}$ DWS was found at several sites in 1991. Trichloroethylene was found in 600 Area wells on the west side of the 100-F Area. The highest level reported in 1991 was $30 \mu \mathrm{g} / \mathrm{L}$ in well 69977-36. Trichloroethylene concentrations in that well appear to be constant with time. The trichloroethylene concentration in well 199-F7-1 has been somewhat variable, rising to $35 \mu \mathrm{g} / \mathrm{L}$ in 1990 , two to three times previous measurements, but decreasing to $19 \mu \mathrm{g} / \mathrm{L}$ in 1991 . Several wells at the Solid Waste Landfill (SWL) contained trichloroethylene close to but slightly below the DWS. Solid Waste Landfill wells had shown trichloroethylene concentrations above the DWS in previous years. These wells also continued to

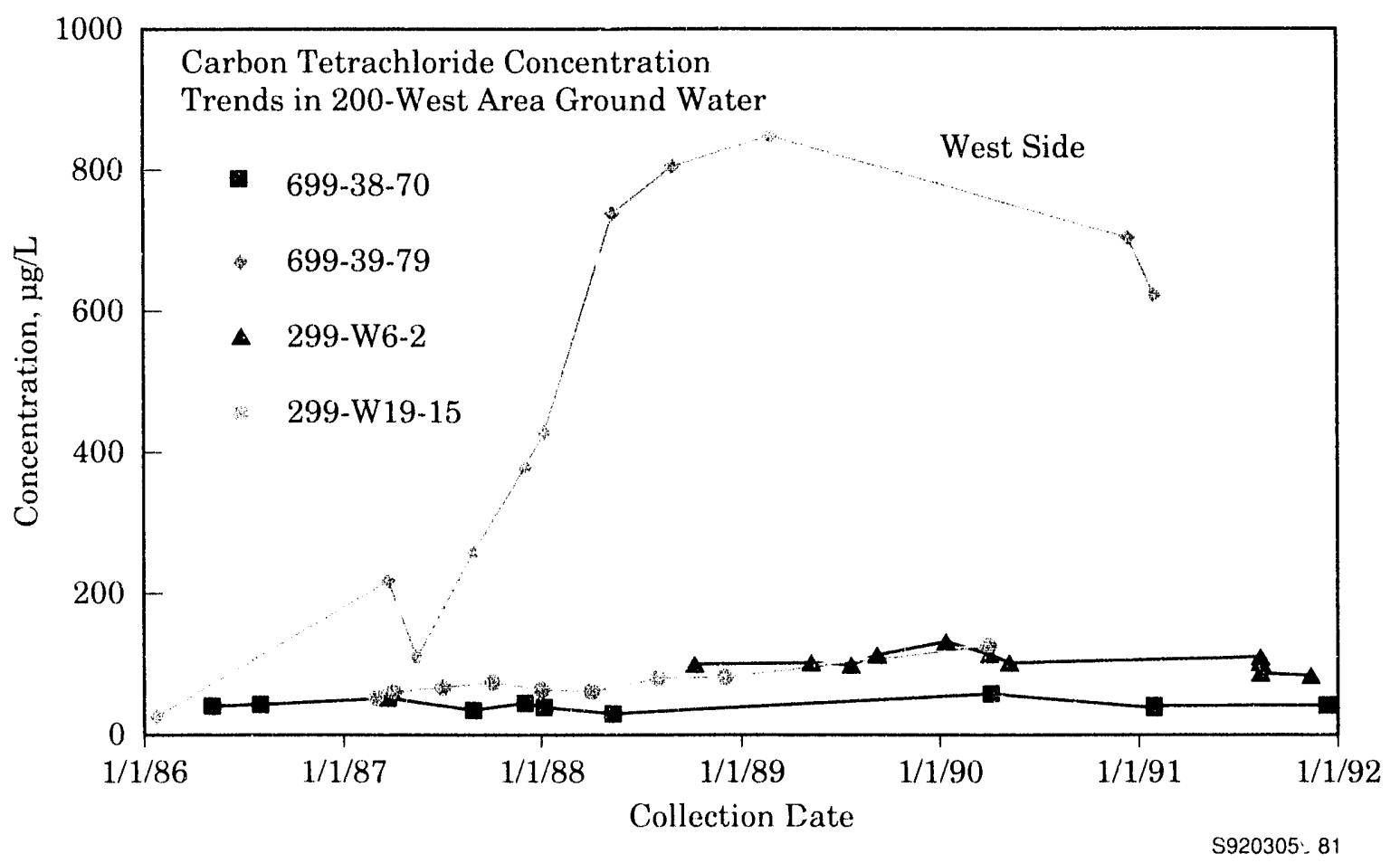

Figure 5.22. Trend Plot of Carbon Tetrachloride Concentrations Near the 200-West Area 
show levels of perchloroethylene just above the $5-\mu \mathrm{g} / \mathrm{L}$ DWS. Trichloroethylene and some of its partial degradation products / primarily cisdichloroethylene (1,2-DCE) | were found in wells monitoring the lower portion of the unconfined aquifer in the 300 Area near the North Process Pond. Maximum concentrations in 1991 were $12 \mu \mathrm{g} / \mathrm{L}$ trichloroethylene and $110 \mu \mathrm{g} / \mathrm{L} \mathrm{DCE}$ in well 399-1-16B. Similar levels were found in nearby well 399-1-16C, which monitors the upper portion of the confined aquifer. Trichloroethylene had not previously been observed in well 3991-16A, which monitors the upper portion of the unconfined aquifer; however, a trichloroethylene concentration of $2.5 \mu \mathrm{g} / \mathrm{L}$ was found in well $399-1$ $16 \mathrm{~A}$ in 1991. Trichloroethylene contamination had been detected at levels exceeding the DWS in two locations inside the 200-West Area near T Plant and REDOX Plant. The maximum level found in 1991 in the well near REDOX Plant (299-W22-20) was $34 \mu \mathrm{g} / \mathrm{L}$. The maximum trichloroethylene level found in the T Plant area (well 299-W 10-4) was $23 \mu \mathrm{g} / \mathrm{L}$. The trichloroethylene distribution in the 200-West Area is depicted on Figure 5.21.

\section{Radiological and Chemical Monitoring Results for the Confined Aquifer}

The uppermost (Rattlesnake Ridge) confined aquifer was monitored to determine the extent of ground-water interaction between the confined and unconfined aquifers. Intercommunication between aquifers has been previously identified by Gephart et al. (1979) and Graham et al. (1984). Ground-water samples from selected confined aquifer wells have been analyzed for a variety of radionuclides and hazardous chemicals. In most cases, no indication of contamination was observed. Detection of radionuclides in well 299E33-12 in the past is attributed to contamination by high-salt waste that migrated by density flow into the borehole when it was open to both the unconfined and the confined aquifer during drilling (Graham et al. 1984). Samples were not collected from this well during 1990 or 1991 as a result of various programmatic interruptions.

Intercommunication between the Rattlesriake Ridge confined aquifer and the unconfined aquifer north of the 200-East Area was indicated in the past by nitrate concentrations in well 69947-50. This well is located near an erosional window (an area where the confining layer is absent) in the confining basalt flow (Graham et al. 1984). Elevated levels of " $\mathrm{H}(3,830 \mathrm{pCi} / \mathrm{L})$ have also been measured in ground water from the Rattlesnake Ridge interbed in well 69942-40C. Elevated levels of ${ }^{12 \prime} \mathrm{I}(0.15 \mathrm{pCi} / \mathrm{L})$ have previously been observed in the same well. Well 699-47-50 and 699-42-40C were not sampled in 1990 or 1991 as a result of a variety of programmatic interruptions. 
Quality Assurance 


\subsection{Quality Assurance}

A comprehensive quality assurance (QA) program, including various quality control ( $Q C)$ practices, was maintained to ensure the quality of data collected through the surveillance programs. QA plans were maintained for all surveillance activities, defining the appropriate controls and documentation required to meet the guidance of the American Society of Mechanical Engineers (ASME) NQA-1 QA program document (U.S. nuclear industry's standard, ASME 1989) and DOE Orders.

In the surface- and ground-water surveillance programs, sufficient environmental data are obtained to minimize reliance on only a few results. New data collected were compared with both recent results and historical data to ensure that deviations from previous conditions were identified and promptly evaluated. Samples were collected using approved and documented procedures to ensure corisistency. Samples were analyzed by documented standard analytical procedures. Analytical data quality was verified by a continuing program of internal laboratory $\mathrm{QC}$, participation in interlaboratory cross-checks, replicate sampling and analysis, submittal of blind standard samples and blanks, and splitting samples with other laboratories.

$\mathrm{QC}$ for ground-water surveillance also included procedures for 1) documenting instrument calibrations and procedures used in the field and laboratory, 2) scheduling maintenance of wells to ensure well integrity, 3 ) inspecting wells using downhole video cameras and other devices, and 4) using dedicated sampling pumps to avoid cross-contamination.

This section discusses specific measures taken to ensure quality in project management, sample collection, and analytical results. Where appropriate, the surface- and ground-water surveillance, and effluent monitoring projects are discussed separately.

\section{Project Management Quality Assurance}

The surveillance programs and related programs, such as processing of thermoluminescent dosimeters (TLDs) and dose calculations, are subject to the overall QA program of the Pacific Northwest Laboratory (PNL). This program implements the requirements of RL Order RL 5700.1A, "Quality Assurance," and is based on ASME NQA-1, Quality Assurance Program Requirements for Nuclear Facilities (ASME 1989). The program is defined in the PNL QA manual (PNL 1991). The manual provides guidance for implementation by addressing $18 \mathrm{QA}$ elements. These are:

1. Organization

2. Quality Assurance Program

3. Design Control

4. Procurement Document Control

5. Instructions, Procedures, and Drawings

6. Document Control

7. Control of Purchased Items and Services

8. Identification and Control of Items

9. Control of Processes

10. Inspection

11. Test Control

12. Control of Measuring and Test Equipment

13. Handling, Storage, and Shipping

14. Inspection, Test, and Operating Status

15. Control of Nonconforming Items

16. Corrective Action

17. Quality Assurance Records

18. Audits.

Each surveillance project has a current QA plan that describes the specific QA elements that apply to the project. These plans are approved and monitored by the QA organization within PNL, which conducts surveillances and audits to verify compliance with the plans. Work performed through contracts, such as sample analysis, must meet the same QA requirements. Audits 
of potential equipment and services suppliers are conducted by the PNL Process Quality Department before awarding contracts for services or approving purchase requisitions having significant impact on a project's quality.

\section{Sample Collection Quality Assurance}

Surface- and ground-water samples were collected by staff trained to conduct sampling according to approved and documented procedures. Continuity of sampling location identities was maintained through documentation. Samples for ground-water hazardous chemical monitoring were sealed with e idence tape to prevent tampering and were transported to the laboratory in accordance with the chain-of-custody procedures required by the EPA for Resource Conservation and Recovery Act (RCRA) monitoring programs.

\section{Analytical Results Quality Assurance}

Routine radiochemical analyses for environmental surveillance samples were performed by International Technology Corporation's (IT) Richland laboratory. Analytical quality at the laboratory was evaluated in a number of ways. IT's Richland laboratory participated in the U.S. Department of Energy's (DOE's) Quality Assessment Program and the U.S. Environmental Protection Agency's (EPA's) Laboratory Intercomparison Studies. PNL conducted an additional QC program. IT's Richland laboratury also maintained an internal QC program, which PNL audited and reviewed. Other audits and comparisons were conducted on specific types of samples. A final QC check of data was performed by a computerized screening of results against criteria. Anomalous results are reported, and discrepancies resolved and documented. Additional information on these efforts is provided in the following subsections.

\section{U.S. Department of Energy and Environmental Protection Agency Comparison Studies}

IT's Richland laboratory participated in the DOE Quality Assessment Program and EPA's Laboratory Intercomparison Studies Program. These programs provide standard samples of various environmental media (water, milk, air filters, soil, and foodstuffs) containing specific amounts of ons or more radionuclides that are unknown by the participating laboratory. After sample analyses, the results were forwarded to DOE and EPA for comparison with known values and results from other laboratories. Both EPA and DOE have established criteria for evaluating the accuracy of results (Jarvis and Siu 1981; Sanderson 1985). Summaries of the 1991 results for the programs are provided in Tables 6.1 and 6.2 . Over $93 \%$ of the results during the year were within the typically used "3-sigma control limits" ( \pm 3 standard errors of the mean). This level of performance was determined to be acceptable and was among the best of participating radiochemistry laboratories.

\section{Pacific Northwest Laboratory Evaluations}

In addition to DOE and EPA interlaboratory $\mathrm{QC}$ programs, a QC program was maintained by PNL to evaluate analytical contractor precision and accuracy and to conduct special intercomparisons. This program included the use of blind samples and replicate samples. Blind standard QC samples and blanks were prepared and submitted to check the accuracy and precision of IT's analyses. The methods used to determine accuracy and precision acceptability were taken from the EPA and DOE (Jarvis and Siu 1981; Sanderson 1985). Reviews of the results reported to date indicate that accuracy and precision performance were consistent with IT's performance in the DOE and EPA Laboratory Intercomparison Studies Program and were acceptable. 
Table 6.1. International Technology Corporation Performances on DOE Quality Assessment Program Samples in 1991

\begin{tabular}{|c|c|c|c|}
\hline Sample Media & Radionuclides & $\begin{array}{l}\text { Number } \\
\text { of Results } \\
\text { Reported }\end{array}$ & $\begin{array}{l}\text { Number } \\
\text { Within Control } \\
\text { Limits }^{(a)}\end{array}$ \\
\hline Air Filters & $\begin{array}{l}{ }^{7} \mathrm{Be},{ }^{54} \mathrm{Mn},{ }^{57} \mathrm{Co},{ }^{60} \mathrm{Co},{ }^{90} \mathrm{Sr},{ }^{134} \mathrm{Cs}, \\
{ }^{137} \mathrm{Cs},{ }^{144} \mathrm{Ce},{ }^{239} \mathrm{Pu},{ }^{234} \mathrm{U},{ }^{238} \mathrm{U}\end{array}$ & 22 & 22 \\
\hline Soil & $\begin{array}{l}{ }^{40} \mathrm{~K},{ }^{90} \mathrm{Sr},{ }^{137} \mathrm{Cs},{ }^{238} \mathrm{Pu},{ }^{239} \mathrm{Pu}, \\
{ }^{234} \mathrm{U},{ }^{238} \mathrm{U},{ }^{241} \mathrm{Am}\end{array}$ & 15 & 14 \\
\hline Vegetation & $\begin{array}{l}{ }^{40} \mathrm{~K},{ }^{90} \mathrm{Sr},{ }^{137} \mathrm{Cs},{ }^{238} \mathrm{Pu},{ }^{239} \mathrm{Pu}, \\
{ }^{241} \mathrm{Am},{ }^{234} \mathrm{U},{ }^{238} \mathrm{U}\end{array}$ & 13 & 13 \\
\hline Water & $\begin{array}{l}{ }^{3} \mathrm{H},{ }^{54} \mathrm{Mn},{ }^{57} \mathrm{Co},{ }^{60} \mathrm{Co},{ }^{90} \mathrm{Sr},{ }^{134} \mathrm{Cs}, \\
{ }^{137} \mathrm{Cs},{ }^{144} \mathrm{Ce},{ }^{239} \mathrm{Pu},{ }^{241} \mathrm{Am},{ }^{234} \mathrm{U},{ }^{238} \mathrm{U}, \\
\mathrm{U} \text { (mass) }\end{array}$ & 26 & 23 \\
\hline
\end{tabular}

(a) Control limits from Sanderson (1985).

Table 6.2. International Technology Corporation Performances on EPA Intercomparison Program Samples in 1991

\begin{tabular}{|c|c|c|c|}
\hline Sample Media & Radionuclides & $\begin{array}{l}\text { Number } \\
\text { of Results } \\
\text { Reported }\end{array}$ & $\begin{array}{l}\text { Number } \\
\text { Within Control } \\
\text { Limits }^{(a)}\end{array}$ \\
\hline Water & $\begin{array}{l}\text { Total Alpha, Total Beta, } \\
{ }^{51} \mathrm{Cr},{ }^{65} \mathrm{Zn},{ }^{60} \mathrm{Co},{ }^{106} \mathrm{Ru}, \\
{ }^{131} \mathrm{I},{ }^{133} \mathrm{Ba},{ }^{134} \mathrm{Cs},{ }^{137} \mathrm{Cs}\end{array}$ & 29 & 28 \\
\hline Water & ${ }^{2266} \mathrm{Ra},{ }^{228} \mathrm{Ka},{ }^{238} \mathrm{U}, \mathrm{U}$ (nat), & 22 & 21 \\
\hline Water & ${ }^{89} \mathrm{Sr},{ }^{90} \mathrm{Sr}$ & 12 & 12 \\
\hline Water & ${ }^{3} \mathrm{H}$ & 2 & 2 \\
\hline Milk & ${ }^{89} \mathrm{Sr},{ }^{90} \mathrm{Sr},{ }^{131} \mathrm{I},{ }^{137} \mathrm{Cs}$ & 6 & 4 \\
\hline Air Filters & $\begin{array}{l}\text { Gross Alpha, Gross Beta } \\
{ }^{90} \mathrm{Sr},{ }^{137} \mathrm{Cs}\end{array}$ & 8 & 5 \\
\hline
\end{tabular}

(a) Control limits from Jarvis and Siu (1981). 
Replicate samples were also routinely collected and analyzed to check sampling and analysis precision. Replicate data showed similar results as those of previous years. The variation in results, as expressed by the coefficient of variation, was generally less than $20 \%$ for samples with activities greater than the minimum detectable amount.

\section{Laboratory Internal Quality Control Programs}

IT's Richland laboratory was required to maintain an internal QC program, and PNL audited and reviewed their compliance with this program. The internal QC program involved routine calibrations of counting instruments, yield determinations of radiochemical procedures, frequent radiation check source and background counts, replicate and spiked samples analyses, maintenance of control charts to indicate analytical deficiencies, and analyses of reagents to ensure purity of processing chemicals. Available calibration standards traceable to the National Institute of Standards and Technology were used for radiochemical calibrations.

The PNL Process Quality Department conducted a formal audit of IT in April 1991 and a limited scope surveillance in November 1991. The deficiencies identified during these oversight activities were promptly addressed by IT and subsequently verified by PNL.

Internal laboratory $\mathrm{QC}$ program data were summarized by IT in quarterly reports to PNL. These reports indicated that during 1991 approximately $30 \%$ of all analyses performed were QC analyses, including blanks, spikes, and duplicates. The results of these analyses and the observations noted in each report were found to indicate an acceptably functioning QC program.

Verification of minimum detectable concentration (MDC) requirements for specific radionuclidemedia combinations (for example, "Sr in air) was initiated with the IT contract. MDC verification is conducted (when requested) for up to five radionuclide-media combinations for analyses performed during the previous month. Equation 37 from Chapter 6 in EPA 520/1-80-012 (EPA 1980 ) is used in the MDC calculations, which involves the use of factors such as the average counting efficiencies and background for detection instruments, length of time for background and sample counts, sample volumes, radiochemical yields, a predesignated uncertainty multiplier, and other factors. The MDC verification is used to document historical performance to project detection goals. As of this report writing, 10 MDC verification reports had been completed for 50 s adionuclide-media combinations, indicating that 39 MDCs had been achieved. Eight of the eleven radionuclide-media combinations not meeting MDC requirements involved " $\mathrm{H}$ analysis.

\section{Sample-Specific Audits and Comparisons}

Additional audits and comparisons were conducted on several specific types of samples. The State of Washington routinely collected samples of various environmental media and measured external radiation levels at multiple locations during 1991. The results from the state monitoring program were reviewed and indicated good agreement between TLD measurements (approximately $10 \%$ variation), total beta measurements in air (approximately $20 \%$ variation), and ${ }^{\prime \prime} \mathrm{Sr}$ measurements in alfalfa (approximately $10 \%$ variation). Additional data from other media were unavailable at the time this report was prepared.

The Surface Environmental Surveillance Project also "split" duplicate samples in 1991 of various locally grown farm products with the U.S. Food and Drug Administration (FDA) for analytical intercomparison. Gamma scans and ${ }^{3} \mathrm{H}$ and ${ }^{\prime \prime} \mathrm{Sr}$ analyses were performed by PNL and the FDA, and the results produced by both laboratories were compared. All gamma scans and "H results from both laboratories indicated the levels in these samples were less than their detection capabilities (not detectable by either laboratory). Strontium-90 was detected at low levels (near the detection limits) in eight samples by IT and in seven samples by the FDA laboratory, indicating the results from each were in acceptable agreement.

Quality control for environmental TLDs included the audit exposures of three environmental TLDs to known values of radiation (between 14 to 
$28 \mathrm{mR}$ ), which were routinely processed quarterly. A summary of 1991 results is shown in Figure 6.1. On average, the TLD measurements were biased $9 \%$ lower than the known values. The average percent bias was calculated from

$$
\frac{\sum\left[\frac{\text { measured - know n value }}{\text { known value }} \times 100 \%\right]}{\text { Number of TLDs }}
$$

This average bias is slightly larger than the bias observed during 1990 biased $7 \%$ lower) and is considered to be acceptable for these very low exposure levels.

\section{Effluent Monitoring}

Laboratory analyses of most Hanford Site environmental samples, including effluent monitoring samples, are performed on site by the 222-S Analytical Laboratory. This laboratory operates under the QA criteria described below. Other samples collected from stacks operated by PNL are analyzed by offsite laboratories contracted under equivalent $\mathrm{QA}$ requirements.

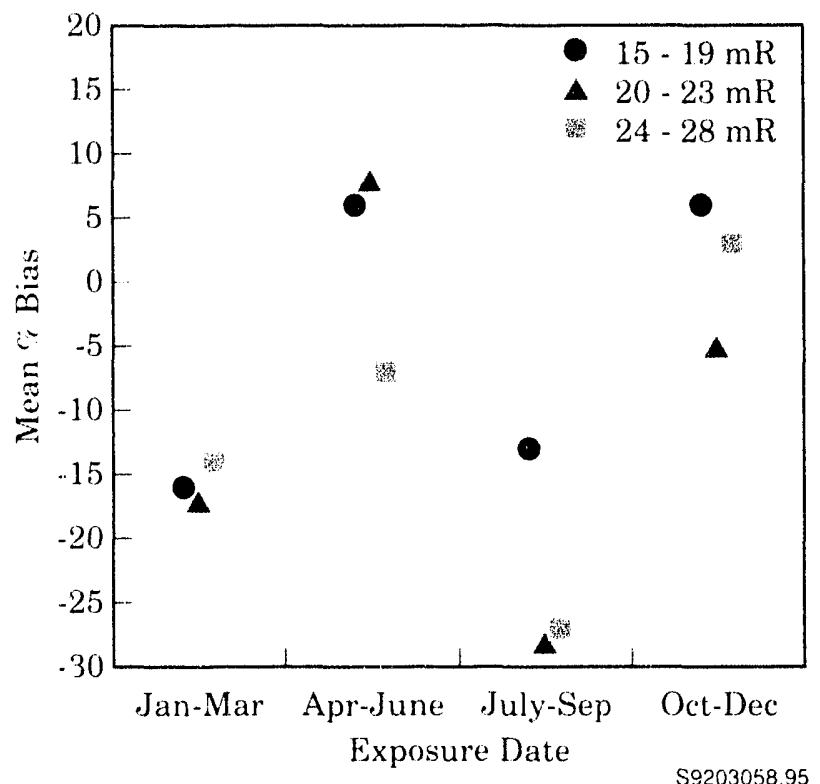

Figure 6.1. Comparison of Thermoluminescent Dosimeter Results With Known Exposures
The American Society for Testing and Materials (ASTM) C 1009-89, Standard Guide for Establishing a Quality Assurance Prograr, for Analytical Chemical Laboratories within the Nuclear Industry, is a consensus document that interprets the 18 elements of NQA-1 for applicability to analytical chemical laboratories. These 18 elements are organized into the 9 functions identified by ASTM and represent the basic components of a laboratory QA program. The QA requirements for analyses of radioactive effluent samples are those established by NQA-1 and the C 1009 document.

The quality assurance program is formally reviewed for adequacy and revised annually. Assessments of program adequacy are documented. Laboratories adhering to NQA-1 and the $\mathrm{C} 1009$ document are supposed to participate in both the EPA and DOE Environmental Monitoring Laboratory intercomparison programs.

Training in QA is required for each laboratory employee. Classes are taught in company-level policies, laboratory safety and analysis techniques, specific laboratory procedures, and selected development topics. Training and qualification records are retained to document employee qualifications and management certification of qualification.

Analytical measurements and routine laboratory support activities are described by written procedures and directions to ensure accuracy, consistency, and safety. Laboratory supporting documents explain the technical background for laboratory activities. Laboratory directions give precise procedural steps for laboratory activities. Laboratory procedures give procedural steps with technical and explanatory information. The directions and procedures are prepared, used, and controlled in compliance with approved manuals.

Existing laboratory record systems provide complete docurnentation of all work done in the laboratory, from sample receipt to report of analytical results. All laboratory records are controlled by a records management system that allows tracking and retrieval of records. 
References 


\subsection{References}

10 CFR 1021, "Compliance with the National Environmental Policy Act." U.S. Department of Energy, Code of Federal Regulations.

40 CFR 52.21, "Prevention of Significant Deteric ration of Air Quality." U.S. Environmental Protection Agency, Code of Federal Regulations.

40 CFR 61, "Natural Emission Standard for Hazardous Air Pollutants; Standards for Radionuclides." U.S. Government Printing Office, Code of Federal Regulations.

40 CFR 761, "Polichlorinated Biphenyls (PCBs) Manufacturing, Processing, Distribution in Commerce, and Use Prohibitions." U.S. Environmental Protection Agency, Code of Federal Regulauiions.

40 CFR 1500-1508, "Regulations for Implementing the Procedural Provisions of the National Environmental Policy Act." U.S. Environmental Protection Agency, Code of Federal Regulations.

Ames, B. N., R. Magaw and L. S. Gold. 1987. "Ranking Possible Carcinogenic Hazards." Science 236:271-280.

American Society of Mechanical Engineers (ASME). 1989. Quality Assurance Program for Nuclear Facilities, ASME NQA-1-1989

Edition. American Society of Mechanical Engineers, New York.

American Society for Testing Materials (ASTM). 1989. Standard Guide for Establishing a Quality Assurance Program for Analytical Chemical Laboratories Within the Nuclear Industry. ASTM C 1009-89. American Society for Testing Materials, Philadelphia, Pennsylvania.

Atallah, S. 1980. "Assessing and Managing Industrial Risk." Chemical Engineering 9/8/80:94-103.
Beasley, T. M., L. A. Ball, and J. E. Andrews III. 1981. "Hanford-Derived Plutonium in Columbia River Sediments." Science 214(20):913-915.

Beck, D. M., B. A. Napier, M. J. Scott, A. G. Thurman, M. D. Davis, D. B. Pittenger, S. F. Shindle, and N. C. Batishko. 1991. Hanford Area 1990 Population and 50-Year Projections. PNL-7803. Pacific Northwest Laboratory, Richland, Washington.

Benton-Franklin-Walla Walla Counties Air Pollution Control Authority. 1980. General Regulation 80-7. Air Pollution Control Authority, Richland, Washington.

Bisping, L. E. 1991. Environmental Surveillance Master Sampling Schedule. PNL-7619, Pacific Northwest Laboratory, Richland, Washington.

Bisping, L. E. 1992. Hanford Site Environmental Data for Calendar Year 1991-Surface and Columbia River. PNL-8149, Pacific Northwest Laboratory, Richland, Washington.

Bjornstad, B. N., and K. R. Fecht. 1989. "PreWisconsin Glacial-Outburst Floods: Pedogenic and Paleomagnetic Evidence from the Pasco Basin and Adjacent Channeled Scabland." Geological Society of America Program 21(5):58 (Abstract).

Brown, M. J., R. K. P'Pool, and S. P. Thomas. 1990. Westinghouse Harford Company Effluent Discharges and Solid Waste Waste Management Report for Calendar Year 1989: 200/600 Areas. WHC-EP-0141-2, Westinghouse Hanford Company, Richland, Washington.

Brown, M. C. 1992. Quarterly Briefing Book on Environmental and Waste Management Activities. WHC-SP-0434-13, Westinghouse Hanford Company, Richland, Washington. 
Chatters, J. C. (ed). 1989. Hanford Cultural

Resources Management Plan. PNL-6942, Pacific Northwest Laboratory, Richland, Washington.

Chatters, e. C., S. K. Campbell, G. D. Smith, and P. E. Minthorn, Jr. 1992. "Bison Procurement at Tsulim: A 2100-Year-Old Kill Site on the Columbia Plateau." Submitted to Plains

Anthropoligist.

Coony, F. M., D. B. Howe, and L. J. Voight. 1988. Westinghouse Hanford Company Effluent Releases and Solid Waste Management Report for 1987: 200/600/1100 Areas. WHC-EP0141, Westinghouse Hanford Company, Richland, Washington.

Cushing, C. E. (ed.). 1991. Hanford Site National Environmental Policy Act (NEPA) Characterization. PNL-6415, Rev. 4, Pacific Northwest Laboratory, Richland, Washington.

Dauble, D. D., R. M. Ecker, L. W. Vail, and D. A. Neitzel. 1987. Downstream Extent of the N Reactor Plume. PNL-6310, Pacific Northwest Laboratory, Richland, Washington.

Diediker, L. P., C. L. Manley, and D. J. Rokkan. 1992. Radionuclide Air Emissions Report for the Hanford Site. DOE/RL-92-30, U.S. Department of Energy, Richland, Washington.

Dinman, B. D. 1980. "The Reality and Acceptance of Risk." Journal of the American Medical Association (JAMA) (11):1226-1228.

Dirkes, R. L. 1990. 1988 Hanford Riverbank Springs Characterization Report. PNL-7500, Pacific Northwest Laboratory, Richland, Washington.

DOE - See U.S. Department of Energy.

Eberhardt, L. E., R. G. Anthony, and W. H. Rickard. 1989. "Survival of Juvenile Canada Geese During the Rearing Period." Journal of Wildlife Management 53:372-377.
Eddy, P. A., D. A. Myers, and J. R. Raymond. 1978. Vertical Contamination in the Unconfined Groundwater at the Hanford Site, Washington. PNL-2724, Pacific Northwest Laboratory, Richland, Washington.

Eisenbud, M. 1987. Environmental Radioactivity from Natural, Industrial, and Military Sources. Third Edition, Chapter 5, Academic Press Inc., New York.

EG\&G Energy Measurements (EG\&G). 1978. An Aerial Radiological Survey of the U.S. Department of Energy's Hanford Site. Date of Survey: May/June 1978, Richland, Washington. EGG-1183-1828, The Remote Sensing Laboratory, EG\&G Energy Measurements for the U.S. Department of Energy, Las Vegas, Nevada.

EG\&G Energy Measurements (EG\&(x). 1990. An Aerial Radiological Survey of the Hainford Site and Surrounding Area. Date of Survey: July/August 1988, Richland, Washington. EGG-10617-1062, The Remote Sensing Laboratory, EG\&G Energy Measurements for the U.S. Department of Energy, Las Vegas, Nevada.

Emery, R. M., and M. C. McShane. 1980. "Nuclear Waste Ponds and Streams on the Hanford Site: An Ecological Search for Radiation Effects." Health Physics 38:787-809.

EPA - See U.S. Environmental Protection Agency.

ERDA - See U.S. Energy Research and Development Administration.

Evans, J. C., R. W. Bryce, and D. J. Bates. 1992. Hanford Site Ground-Water Monitoring for 1990. PNL-8073, Pacific Northwest Laboratory, Richland, Washington.

Federal Register Title 50, p. 17 (50 FR 17); "Endangered and Threatened Wildlife and Plants." Department of the Interior, 1986. 
Federal Register, Title 52, p. 47662 (52 FR 47662); "Compliance with the National Environmental Policy Act (NEPA); Amendments to the Department of Energy National Environmental Policy Act Guidelines." (December 15, 1987.)

Federal Register, Title 56, p. 60985 (56 FR 60985 ); "Opportunity for Public Comment, Programmatic Environmental Impact Statement for Reconfiguration of the Nuclear Weapons Complex," Department of Energy, November 29, 1991. (Vol. 56, No. 230.)

Freshley, M. D., and M. J. Graham. 1988. Estimation of Ground-Water Travel Time at the Hanford Site: Description, Past Work, and Future Needs. PNL-6328, Pacific Northwest Laboratory, Richland, Washington.

Gard, H. A. 1992. "A Fish-Eye's View: Salmonid Ber havior as a Means of Predicting Archaeological Fishing Site Locations." Archaeology in Washington. Vol. 4:33-38.

Gee, G. W. 1987. Recharge at the Hanford Site: Status Report. PNL-6403, Pacific Northwest Laboratory, Richland, Washington.

Gephart, R. E., P. A. Eddy, R. C. Arnett, and G. A. Robinson. 1976. Geohydrologic Study of the West Lake Basin. ARH-CD-775, Atlantic Richfield Hanford Company, Richland, Washington.

Gephart, R. E., R. C. Arnett, R. G. Baca, L. S. Leonhart, and F. A. Spane, Jr. 1979. Hydrologic Studies Within the Columbia Plateau, Washington: An Integration of Current Knowledge. RHO-BWI-ST-5, Rockwell Hanford Operations, Richland, Washington.

Graham, M. J., M. D. Hall, S. R. Strait, and W. R. Brown. 1981. Hydrology of the Separations Area. RHO-ST-42, Rockwell Hanford Operations, Richland, Wasnington.

Graham, M. J., G. V. Last, and K. R. Fecht. 1984. An Assessment of Aquifer Intercommunication in the B Pond - Gable Mountain Pond Area of the Hanford Site. RHO-RE-ST12P, Rockwell Hanford Operations, Richland, Washington.
Hajek, B. F. 1966. Soil Survey: Hanford Project in Benton County, Washington. BNWL-243, Pacific Northwest Laboratory, Richland, Washington.

Health Physics Society (HPS). 1987. Health Physics Society Official Journal: Special Issue on Radiation Hormesis. Vol. 52, No. 5.

Hanford Federal Facility Agreement and Consent Order. 1989 (as amended). 89-10, Rev. 1, Washington State Department of Ecology, U.S. Environmental Protection Agency, a':d the U.S. Department of Energy.

Jaquish, R. E., and P. J. Mitchell. 1988. Environmental Monitoring at Hanford for 1987. PNL-6464, Pacific Northwest Laboratory, Richland, Washington.

Jaquish, R. E., and R. W. Bryce. 1989. Hanford Site Environmental Report for Calendar Year 1988. PNL-6825, Pacific Northwest Laboratory, Richland, Washington.

Jarvis, A. B., and L. Siu. 1981. Environmental Radioactivity Laboratory Intercomparison Studies Program: Fiscal Year 1980-81. EPA600/4-81-004, U.S. Environmental Protection Agency, Las Vegas, Nevada.

Jenkins, O. P. 1922. Underground Water Supply of the Region About White Bluffs and Hanford. State of Washington, Department of Conservation and Development, Olympia, Washington.

Last, G. V., B. N. Bjornstad, M. P. Bergeron, R. W. Wallace, D. R. Newcomer, J. A. Schramke, M. A. Chamness, C. S. Cline, S. P. Airhart, and J. S. Wilbur. 1989. Hydrogeology of the 200 Areas Low-Level Burial Grounds - An Interim Report. PNL-6820, 2 volumes, Pacific

Northwest Laboratory, Richland, Washington.

Ledgerwood, R. K. 1992. Summaries of Well Construction Data and Field Observations for Existing 100 Aggregate Area Operable Unit Resource Protection Wells. WHC-SDER-T'I-006, Westinghouse Hanford Company, Richland, Washington 
Manley, C. L. 1992. Environmental Release for Calendar Year 1990. WHC-EP-0527, Westinghouse Hanford Company, Richland, Washington.

McCormack, W. D., and J. M. V. Carlile. 1984. Investigation of Ground-Water Seepage from the Hanford Shoreline of the Columbia River. PNL-5289, Pacific Northwest Laboratory, Richland, Washington.

Mielke, P. W. 1984. Handbook of Statistics. P. R. Krishnaigh, and P. K. Sen, eds, pp. 813-830, North Holland Publishing Company, Amsterdam.

Napier, B. A., R. A. Peloquin, D. L. Strenge, and J. V. Ramsdell. 1988a. Conceptual Representation. Volume 1 of GENII - The Hanford Environmental Radiation Dosimetry Software System. PNL-6584, Vol. 1, Pacific Northwest Laboratory, Richland, Washington.

Napier, B. A., R. A. Peloquin, D. L. Strenge, and J. V. Ramsdell. 1988b. User's Manual. Volume 2. of GENII - The Hanford Environmental Radiation Dosimetry Software System. PNL-6584, Vol. 2, Pacific Northwest Laboratory, Richland, Washington.

Napier, B. A., R. A. Peloquin, D. L. Strenge, and J. V. Ramsdell. 1988c. Code Maintenance Manual. Volume 3 of GENII - The Hanford Environmental Radiation Dosimetry Software System. PNL-6584, Vol. 3, Pacific Northwest. Laboratory, Richland, Washington.

National Council on Radiation Protection and Measurements (NCRP). 1979. Tritium in the Environment. Report No. 62, NCRP, Washington, D.C.

National Council on Radiation Protection and Measurements (NCRP). 1987. Ionizing Radiation Exposure of the Population of the United States. Report No. 93, NCRP, Bethesda, Maryland.

National Council on Radiation Protection and Measurements (NCRP). 1991. Effects of Ionizing Radiation on Aquatic Organisms. Report No. 109, NCRP, Bethesda, Maryland.
National Research Council (NRC), Committee on the Biological Effects of Ionizing Radiation. 1980. The Effects on Populations of Exposure to Low Levels of Ionizing Radiation. National Academy Press, Washington, D.C.

National Research Council (NRC), Committee on the Biological Effects of Ionizing Radiation 1990. Health Effects of Exposure to Low Levels of Ionizing Radiation. National Academy Press, Washington, D.C.

Newcomer, D. R., K. D. Pohlod, and J. P. McDonald. 1991. Water-Table Elevations on the Hanford Site, 1990. PNL-7693, Pacific Northwest Laboratory, Richland, Washington.

Pacific Northwest Laboratory (PNL). 1989. Procedures for Ground-Water Investigations. PNL-6894, Pacific Northwest Laboratory, Richland, Washington.

Pacific Northwest Laboratory (PNL). 1991.

Quality Assurance Manual. PNL-7000, Pacific Northwest Laboratory, Richland, Washington.

Peterson, R. E. 1992. Hydrologic and Geologic Data Available for the Region North of Gable Mountain, Hanford Site, Washington. WHC-SD-EN-TI-006, Westinghouse Hanford Company, Richland, Washington.

Poston, T. M. 1990. A Survey for Elevated Levels of Uranium North of the 300 Area on the Hanford Site. PNL-7271, Pacific Northwest Laboratory, Richland, Washington.

Poston, 'T. M., K. R. Price, and D. R. Newcomer. 1991. An Evaluation of the Chemical, Radiological, and Ecological Conditions of West Lake on the Hanford Site. PNL-7662, Pacific Northwest Laboratory, Richland, Washington.

Presidential Executive Order 11988, "Floodplain Management." May 24, 1977. 42 FR 26951 (May 25,1977 ).

Presidential Executive Order 11990, "Protection of Wetlands." May 24, 1977. 42 FR 26961 (May 25,1977 ). 
Price, K. R. 1986. Environmental Monitoring at Hanford for 1985. PNL-5817, Pacific Northwest Laboratory, Richland, Washington.

Public Law 100-605, November 4, 1988 [H.R.3614], "An Act. To Authorize a Study of the Hanford Reach of the Columbia River, and for Other Purposes."

Public Law 101-510 Section 3137, "Safety Measures for Waste Tanks at Hanford Nuclear Reservation," November 5, 1990. (Note: This is section 3137 of the National Defense Authorization Act for Fiscal Year 1991. This does not have a USC number.)

Rathbun, L. A. 1989. The Determination of the Penetrating Radiation Dose at Hanford. PNL-7124, Pacific Northwest Laboratory, Richland, Washington.

Revised Code of Washington (RCW) 17.21, "Washington Pesticide Application Act 1961," as amended.

Robertson, D. E., and J. J. Fix. 1977. Association of Hanford Origin Radionuclides with Columbia River Sediment. BNWL-2305, Pacific Northwest Laboratory, Richland, Washington.

Sanderson, C. G. 1985. Semi-Annual Report of the Department of Energy, Operational Safety, Health and Environment Division, Quality Assessment Program Data Report. EML-439, Environmental Measurements Laboratory, U.S. Department of Energy, New York.

Secretary of Energy Notice (SEN) 15-90, from James D. Watkins, "National Environmental Policy Act," February 5, 1990.

Snedecor, G. W., and W. G. Cochran. 1980. Statistical Methods. 7th ed. Iowa State University Press, Ames, Iowa.

Soldat, J. K. 1962. A Compilation of Basic Data Relating to the Columbia River Section 8 - Dispersion of Reactor Effluent in the Columbia River. HW-69369, General Electric, Richland, Washington.
Soldat, J. K. 1976. "Radiation Doses from Iodine-129 in the Environment." Health Physics. 30:61-70.

Soldat, J. K. 1989. Offsite Radiation Doses from Hanford Operations for the Years 1983 Through 1987: A Comparison of Results Calculated by Two Methods. PNL-7135, Pacific Northwest Laboratory, Richland, Washington.

Soldat, J. K., K. R. Price, and W. H. Rickard. 1990. Methodology Used to Compute Maximum Potential Doses from Ingestion of Edible Plants and Wildlife Found on the Hanford Site. PNL-7539, Pacific Northwest Laboratory, Richland, Washington.

Speer, D. R., J. J. Fix, and P. J. Blumer. 1976. Environmental Surveillance at Hanford for CY-1975. BNWL-1979, Pacific Northwest Laboratory, Richland, Washington.

Stenner, R. D., K. H. Cramer, K. A. Higley, S. J. Jette, D. A. Lamar, T. J. McLaughlin, D. R. Sherwood, and N. C. Van Houten. 1988. Hazard Ranking System Evaluation of CERCLA Inactive Waste Sites at Hanford. PNL-6456, Pacific Northwest Laboratory, Richland, Washington.

Stone, W. A., J. M. Thorp, O. P. Gifford, and D. J. Hoitink. 1983. Climatological Summary for the Hanford Area. PNL-4622, Pacific Northwest Laboratory, Richland, Washington.

Sula, M. J. 1980. Radiological Survey of Exposed Shorelines and Islands of the Columbia River Between Vernita and the Snake River Confluence. PNL-3127, Pacific Northwest Laboratory, Richland, Washington.

Thurman, P. A. 1991. Hanford Sanitary Water Quality Surveillance, CY 1990. HEHF82, Hanford Environmental Health Foundation, Environmental Health Sciences, Richland, Washington.

Travis, C. C., and S. T. Hester. 1990. "Background Exposure to Chemicals: What Is the Risk?" Risk Analysis 10(4). 
United Nations Scientific Committee on the Effecis of Atomic Radiations (UNSCEAR). 1988. Sources, Effects and Risks of Ionizing Radiation. Report E.88.1X.7, United Nations, New York.

U.S. Department of Energy (DOE). 1996. Environmental Assessment, Reference Repository Location, Hanford Site, Washington. DOE/RW-0070, U.S. Department of Energy, Washington, D.C.

U.S. Department of Energy (DOE). 1987a. Effluent Information System (EIS)/Onsite Discharge Information System (ODIS). DOE/ID-187 (87), Idaho Operations Office, Idaho Falls, Idaho.

U.S. Department of Energy (DCE). 1987b. Final Environmental Impact Statement, Disposal of Hanford Defense High-Level, Transuranic and Tank Wastes. DOE/EIS0113, U.S. Department of Energy, Richland, Washington.

U.S. Department of Energy (DOE). 1988a. Internal Dose Conversion Factors for Calculation of Dose to the Public. DOE/EH-0071, U.S. Department of Energy, Washington, D.C.

U.S. Department of Energy (DOE). 1988b. External Dose-Rate Conversion Factors for Calculation of Dose to the Public. DOE/EH0070, U.S. Department of Energy, Washington, D.C.

U.S. Department of Energy (DOE). 1989a. Draft Environmental Impact Statement, Decommissioning of Eight Surplus Production Reactors at the Hanford Site. DOE/RL-0119D, U.S. Department of Energy, Richland, Washington.

U.S. Department of Energy (DOE). 1989b. Environmental Restoration and Waste Management Site-Specific Plan for the Richland Operations Office: Detailed Information. DOE/RL-89-10, U.S. Department of Energy, Richland, Washington.
U.S. Department of Energy (DOE). 1989c. Hanford Site Groundwater Protection Management Program. DOE/RL 89-12, U.S. Department of Energy, Richland, Washington.

U.S. Department of Energy (DOE). 1989d. Plan and Schedule to Discontinue Disposal of Liquids Into the Soil Column at the Hanford Site. Richland Field Office, Richland, Washington.

U.S. Department of Energy (DOE). 1990a. Hanford Tier-Two Emergency and Hazardous Chemical Inventory. DOE/RL 90-2, U.S. Department of Energy, Richland, Washington.

U.S. Department of Energy (DOE). 1990b. Environmental Restoration and Waste Management Five-Year Plan, Fiscal Years 1992-1996. DOE/S-0078P, U.S. Department of Energy, Washington, D.C.

U.S. Department of Energy (DOE). 1990c. Hanford Site Stream-Specific Reports: Waste Management Advanced Effluent Technology Unit. WHC-EP-0342, prepared for U.S. Department of Energy by Westinghouse Hanford Company, Richland, Washington.

U.S. Department of Energy (DOE). 1990d. The Hanford Site Environmental Restoration and Waste Management Five-Year Plan Activity Data Sheets. DOE/RL-89-17, U.S. Department of Energy, Richland, Washington.

U.S. Department of Energy (DOE). 1990e. Tiger Team Assessment of the Hanford Site. DOE/EH-0139, U.S. Department of Energy, Washington, D.C.

U.S. Department of Energy (DOE). 1991a. Environmental Guide for Radiological Effluent Monitoring and Environmental Surveillance. DOE/EH-()173T, U.S. Department of Energy, Washington, D.C.

U.S. Department of Energy (DOE). 1991b. Hanford Site Environmental Monitoring Plan. DOE/RL 91-50, U.S. Department of Energy, Richland, Washington. 
U.S. Department cf Energy (DOE). 1991c. Toxic Chemical Release Inventory. DOE/RL91-29, Department of Energy, Richland, Washington.

U.S. Department of Energy (DOE). 1991d. U. S. Department of Energy Richland Operations Office, Environmental Protection Implementation Plan. DOE/RL-91-49, U.S. Department of Energy, Richland, Washington.

U.S. Department of Energy (DOE). 1992a. Annual Report for RCRA Ground water Monitoring Projects at Hanford Site Facilities for 1991. DOE/RL-92-03, Department of Energy, Richland, Washington.

U.S. Department of Energy (DOE). 1992b. Hanford Site Annual Dangerous Waste Report for 1991. Department of Energy, Richland, Washington.

U.S. Department of Energy, Richland Field Office (RL). 1992c. Sampling and Analysis of $\mathbf{1 0 0}$ Area Springs. U.S. Department of Energy, Richland, Washington.

U.S. Department of Energy (DOE). 1992d. 1991 Tier Two Emergency and Hazardous Chemical Inventory. DOE/RL-92-10, Department of Energy, Richland, Washington.

U.S. Department of Energy (DOE). 1992e. Radionuclide Air Emissions Report for the Hanford Site, Calendar Year 1991. DOE/RL92-0030, U.S. Department of Energy, Richland, Washington.

U.S. Department of Energy (DOE). 1992f. Engineering Evaluation of the 618-9 Burial Ground Expidited Response Action. DOERL 91-38, Department of Energy, Richland, Washington.

U.S. Department of Interior (DOI). 1986.

Endangered and Threatened Wildlife and Plants. Federal Register, 50 FR, Part 17.

U.S. Energy Research and Development Administration (ERDA). 1975. Final Environmental
Impact Statement of Waste Management Operations, Hanford Reservation, Richland, Washington, 2 vols. ERDA-1538, U.S. Energy Research and Development Administration. Washington, D.C.

U.S. Environmental Protection Agency (EPA). 1980. Upgrading Enviroumental Radiation Data: Health Physics Suciety Committee Report HPSR-1 (1980). EPA 520/1-80-012, U.S. Environmental Protection Agency, Washington, D.C.

U.S. Environmental Protection Agency (EPA). 1982. Test Metbods for Evaluating Solid Waste: Physical/Chemical Methods. 2nd ed. SW-846, Office of Solid Waste and Emergency Response, Washington, D.C.

U.S. Environmental Protection Agency (EPA). 1986. Environmental Radiation Data. Report 46 Revised Edition, September 1986, EPA 520/5-87-004, Office of Radiation Programs, Eastern Environmental Radiation Facility (EERF), Montgomery, Alabama.

U.S. Environmental Protection Agency (EPA). 1989. Risk Assessment Methodology: Draft Environmental Impact Statement for Proposed NESHAPS for Radionuclides, Vol. 1, Background Information Document. EPA 520/1-89-005, Environmental Protection Agency, Washington, D.C.

U.S. Environmental Protection Agency (EPA). 1990. National Emission Standard for Hazardous Air Pollutants; Standards for Radionuclides. 40 CFR 61, U.S. Government Printing Office, Washington, D.C.

U.S. Geological Survey (USGS). 1988. Water Resources Data Washington Water Year 1986. Report WA-86-1, U.S. Geological Survey, Denver, Colorado.

Washington Administrative Code (WAC) 16-228 Pesticide Regulations, Washington State Department of Agriculture, 1990. 
Washington Administrative Code (WAC) 173-201. Water Quality Standards for Waters of the State of Washington, Washington State Department of Ecology, 1982.

Washington Administrative Code (WAC) 246-247, Raciation Protection--Air Emissions, Washington State Department of Health, 1990.

Washington Natural Heritage Program. 1990.

Endangered, Threatened, and Sensitive Vascular Plants of Washington. Department of Natural Resources, Olympia, Washington.

Washington State Department of Ecology (WDOE) 1982. Water Quality Stundards for Waters of the State of Washington. Washington Administrative Code, Chapter 173. 201, Olympia, Washington.

Washington State Department of Ecology (WDOE). July 1986 (Amended). Dangerous Waste Regulations. Washington Adminisira tive Code, Chap ers 173-303, Olympia, Washington.
Washington State Department of Social and Health Services (WDSHS). 1987. Environmental Radiation Program, Twenty-Fourth Annual Report. Office of Radiation Protection, Olympia, Washington.

Westinghouse Hanford Company (WHC). 1990. Hanford Site Stream-Specific Report. WHC-EP0342, Westinghouse Hanford Company, Richland, Washington.

Wilson, R., and E. S. C. Crouch. 1987. "Risk Assessment and Comparisons: An Introduction." Science 236 ( 4799$): 267-270$.

Woodruff, R. K., R. W. Hanf, M. G. Hefty, and R. E. Lundgren, eds. 1991. Hanford Site Environmental Report for Calendar Year 1990. PNL-7930, Pacific Northwest Laboratory, Richland, Washington. 


\section{U.S. Department of Energy Orders}

DOE Order 5000.3A. 1990. "Occurrence Reporting and Processing of Operations Information."

DOE Order 5400.1. 1988. "General Environmental Protection Program."

DOE Order 5400.5. 1990. "Radiation Protection of the Public and the Environment."
DOE Order 5440.1D. 1991. "National Environmental Policy Act Compliance Program."

DOE Order 5484.1. 1981. "Environmental Protection, Safety, and Health Protection Information Reporting Requirements."

DOE Order 5820.2A. 1988. "Radioactive Waste Management." 


\section{Acts}

American Antiquities Preservation Act see: Antiquities Act of 1906, June 8, 1906, ch. 3060, 34 Stat. 225 (Title 16, secs. 431, 432, 433).

\section{American Indian Keligious Freedom Act.}

Public Law 95-341, August 11, 1978, 92 Stat 469, Title 42.

\section{Archaeological Resources Protection Act.} Public Law 96-95, October 31, 1979, 93 Stat 721. Title 16.

Clean Air Act. Public Law 88-206, as amended, 42 USC 7401 et seq.

Clean Water Act. Public Law 95-217, Deceriver 27, 1977, 91 Stat. 1566 and Public Law 96-148.

\section{Comprehensive Environmental Response,} Compensation, and Liability Act (CERCLA). Public Law 96-150, December 11, 1980, 94 Stat 2767, Title 26.

Endangered Species Act. 1973. Public Law 93-205 through 100-707.
Federal Insecticide, Fungicide, and Rodenticide Act. 1975. Public Law 94-51 through 94-140.

National Environmental Policy Act (NEPA). 1969. Public Law 91-190, as amended, 42 USC 4321 et seq.

National Historic Preservation Act. Public Law 89-665, October 15, 1966, 80 Stat 915-919, Title 16.

Resource Conservation and Recovery Act. Public Law 94-580, October 21, 1976, 90 Stat 2795, Title 42.

Safe Drinking Water Act. Public Law 93-523, December 16, 1974, 88 Stat 1660, Title 21.

Superfund Amendments and Reauthorization Act. Public Law 99-499, October 17, 1986, 100 Stat 1613, Title 10.

Toxic Substances Control Act. Public Law 94-469, as amended, 15 USC 2601 et seq. 
Appendixes 
Appendix A Glossary 


\section{Appendix A}

\section{Glossary}

activation product - Material made radioactive by exposure to radiation from a source such as a nuclear reactor's neutrons.

air submersion dose - Radiation dose received from external exposure to radioactive materials present in the surrounding atmosphere.

aquifer - Permeable geologic unit that can transmit significant quantities of water.

background radiation - Radiation in the natural environment, including cosmic rays from space and radiation from naturally occurring radioactive elements in the air, in the earth, and in our bodies. In the United States, the average person receives about 300 millirems (mrem) of background radiation per year.

bankstorage - Hydrologic term that describes river water that flows into and is retained in permeable stream banks during periods of high river stage. Flow is reversed during periods of low river stage.

becquerel (Bq) - Unit of activity equal to one nuclear transformation per second ( $1 \mathrm{~Bq}=1 / \mathrm{s}$ ). The conventional unit of activity, the curie, is related to the becquerel according to $1 \mathrm{Ci}=3.7 \mathrm{x}$ $10^{111} \mathrm{~Bq}$.

boundary dose rate - Dose rate measured or calculated at publicly accessible locations on or near the Hanford Site.

composite sample - Sample formed by mixing discrete samples taken at different points in time or from different locations.

confined aquifer - An aquifer bounded above and below by less permeable layers. Ground water in the confined aquifer is under a pressure greater than atmospheric pressure. continuous sample - Sample formed by the continuous collection of the medium or contaminants within the medium during the entire sample period.

controlled area - An area to which access is controlled to protect individuals from exposure to radiation or radioactive and/or hazardous materials.

cosmic radiation - High-energy subatomic particles and electromagnetic radiation from outer space that bombard the earth. Cosmic radiation is part of natural background radiation.

curie (Ci) - A unit of radioactivity equal to 37 billion $\left(3.7 \times 10^{10}\right)$ nuclear transformations per second.

decay - The decrease in the amount of any radioactive material with the passage of time, due to the spontaneous emission from the atomic nuclei of nucleons or either alpha or beta particles, often accompanied by gamma radiation. When a radioactive material decays, the material may be converted to another radioactive species (decay product) or to a nonradioactive material.

Derived Concentration Guides (DCG) - Concentrations of radionuclides in air and water that an individual could continuously consume, inhale or be immersed in at average annual rates, without receiving an effective dose equivalent of greater than $100 \mathrm{mrem} / \mathrm{yr}$.

detection level - Minimum amount of a substance that can be measured with a $99 \%$ confidence that the analytical result is greater than zero.

dispersion - Process whereby effluents are spread or mixed as they are transported by ground water or air. 
dosimeter - Portable device for measuring the total accumulated exposure or absorbed dose from ionizing radiation fields.

Effective Dose - See "Effective Dose Equivalent" under "Radiation Dose."

effluent - Liquid or gaseous waste streams released from a facility.

effluent monitoring - Sampling or measuring specific liquid or gaseous effluent streams for the presence of pollutants.

exposure - Subjecting a target (usually living tissue) to radiation or chemicals. Also used as a term describing external radiation air ionization (see "Roentgen").

fallout - Radioactive materials that are released into the earth's atmosphere following a nuclear explosion or atmospheric release and that eventually fall to earth.

fission - A nuclear reaction involving the splitting or breaking apart of a nucleus into at least two other nuclei, accompanied with a release of various types of energy. For example, when a heavy atom, such as uranium, is split, large amounts of energy including radiation and neutrons are released along with the new nuclei (which are fission products).

fission products - Elements formed from fissioning. Many fission products are radioactive.

glaciofluvial sediments - Sedimentary deposits consisting of material transported by, suspended in, or laid down by the meltwater streams flowing from melting glacier ice.

grab sample - A sample that is randomly collected or "grabbed" from the collection site.

ground water - Subsurface water that is in the pore spaces of soil and geologic units.

gray (Gy) - Unit of absorbed dose in the International System of Units (SI) equal to 1 joule per kilogram. $1 \mathrm{~Gy}=100 \mathrm{rad}$. half-life - Length of time in which a radioactive substance will lose one half of its radioactivity by decay. Half-lives range from a fraction of a second to billions of years, and each radionuclide has a unique half-life.

ion exchange - The reversible exchange of one species of ion for a different species of ion within a medium.

irradiation - Exposure to radiation.

isotopes - Different forms of the same chemical element that are distinguished by different numbers of neutrons in the nucleus. A single element may have many isotopes; some may be radioactive and some may be nonradioactive (stable). For example, the three isotopes of hydrogen are protium, deuterium, and tritium.

maximally exposed individual - A hypothetical member of the public residing near the Hanford Site who, by virtue of location and living habits, could receive the highest possible radiation dose from radioactive effluents released from Hanford.

mean - Average value of a series of measurements.

The mean, $\overline{\mathrm{X}}$, was computed as:

$$
\bar{x}=\frac{1}{n} \sum_{i=1}^{n} x_{i}
$$

where $\mathrm{X}_{\mathrm{i}}$ is the ith measurement and $\mathrm{n}$ is the number of measurements.

median - Middle value in a set of results when the data are ranked in increasing or decreasing order.

millirem (mrem) - A unit of radiation dose equivalent that is equal to one one-thousandth (1/1000) of a rem. According to DOE standards, an individual member of the public may receive no more than 100 mrem per year from a site's operation. This limit does not include radiation received for medical treatment or the approximately 300 mrem that people receive annually from natural background radiation. 
minimum detectable concentration - Smallest amount or concentration of a radioactive or nonradioactive element that can be reliably detected in a sample.

noble gas - Any of a group of chemically and biologically inert gases that includes argon, krypton, and xenon. These gases are not retained in the body following inhalation. The principal exposure pathways from radioactive noble gases are direct external dose from the surrounding air (see "Air Submersion Dose").

offsite locations - Sampling and measurement locations outside the Hanford Site boundary.

onsite locations - Sampling and measurement locations within the Hanford Site boundary.

outfall - End of a drain or pipe that carries waste water or other effluents into a ditch, pond, or river.

plume - The cloud of a pollutant in air, surface water, or ground water formed after the pollutant is released from a source.

plutonium - A heavy, radioactive, anthropogenic metallic element consisting of several isotopes. One important isotope is ${ }^{234} \mathrm{Pu}$, which is produced by the irradiation of ${ }^{234} \mathrm{U}$. Routine analysis cannot distinguish between the ${ }^{2 * 1} \mathrm{Pu}$ and ${ }^{240} \mathrm{Pu}$ isotopes; hence, the term ${ }^{23: 2.2411} \mathrm{Pu}$ as used in this report is symbolic of the presence of one or both of these isotopes in the analytical results.

radiation - The energy emitted in the form of rays or particles, such as those thrown off by transforming (disintegrating) atoms. For this report, radiation refers to ionizing types of radiation; not radiowaves, microwaves, radiant light, or other types of non-ionizing radiation. The ionizing rays or particles typically consist of alpha, beta, or gamma radiation.

- alpha radiation - Least penetrating type of radiation. Alpha radiation can be stopped by a sheet of paper or the outer dead layer of skin, and can cause biological damage only if sufficient quantities are emitted inside the body.
- beta radiation - One form of radiation emitted from a nucleus during radioactive decay. Beta radiation can be stopped by an inch of wood or a thin sheet of aluminum, and may cause biological damage if a sufficient amount is internal, or occasionally external, to the body.

- external radiation - Radiation originating from a source outside the body.

- gamma radiation - Form of electromagnetic, high-energy radiation emitted from a nucleus. Gamma rays are essentially the same as $x$ rays. They require heavy shielding, such as concrete or steel, to be stopped, and may cause biological damage when originating internally or externally to the body in sufficient amounts.

- internal radiation - Radiation originating from a source within the body as a result of the inhalation, ingestion, skin absorption, or implantation of natural or anthropogenic radionuclides in body tissues (e.g., uranium dust in the lungs, radioiodine in the thyroid).

radiation dose - For the purpose of this report, radiation doses are defined as follows:

- absorbed dose - Amount of energy deposited by radiation in a given amount of material. Absorbed dose is measured in units of "rads" or "grays."

- collective effective dose equivalent - Sum of the effective dose equivalents for individuals composing a defined population. The units for this are "person-rem" or "personsievert."

- committed dose equivalent - Total dose equivalent accumulated in an organ or tissue in the 50 years following a single intake of radioactive materials into the body.

- dose equivalent - Product of the absorbed dose, the quality factor, and any other modifying factors. The dose equivalent is a quantity for comparing the biological effectiveness 
of different kinds of radiation on a common scale. The unit of dose equivalent is the rem. A millirem is one one-thousandth of a rem.

- effective dose equivalent - A value used for estimating the total risk of potential health effects from radiation exposure. This estimate is the sum of the committed effective dose equivalent ( deposition of radionuclides in the body and the effective dose equivalent from external radiation received during a year.

radioactivity - Property possessed by some isotopes of elements of emitting radiation (such as alpha, beta, or gamma rays) spontaneously in their decay process to stable element isotopes.

radioisotope - Radioactive isotope of a specified element. Carbon-14 is a radioisotope of carbon. Tritium is a radioisotope of hydrogen.

- long-lived radioisotope - A radionuclide that decays at such a slow rate that a quantity will exist for an extended period (typically many years).

- short-lived radioisotope - A radionuclide that decays so rapidly that a given quantity is transformed almost completely into decay products within a short period (typically less than a few monthsi.

radionuclide - Radioactive atomic species or isotope of an element. There are several hundred known radionuclides, both anthropogenic and naturally occurring. Radionuclide and radioisotope are terms that are sometimes used interchangeably, although they are theoretically different terms.

rem - Acronym for roentgen equivalent man; a unit of dose equivalent that indicates the potential for impact on human cells.

risk - The probability that a detrimental health effect will occur.

roentgen - Unit of $x$-ray or gamma radiation exposure in air, typically used for describing external radiation levels. An exposure of 1 roentgen $(R)$ is approximately equal to a 1-rem dose to human tissue. sievert (Sv) - Unit of dose equivalent in the International System of Units (SI) equal to 100 rem.

spent fuel - Nuclear fuel that has been exposed in a nuclear reactor; this fuel contains uranium, activation products, fission products, and plutonium.

standard deviation - An indication of the dispersion or variability of a set of results around their average.

standard error of the mean - An indication of the dispersion or variability of an estimated mean from the average of other estimates of the same mean.

The standard error of $\overline{\mathrm{X}}$ was computed as

$$
\mathrm{SE}=\sqrt{\frac{\mathrm{s}^{2}}{\mathrm{n}}}
$$

where $S^{2}$, the variance of the $n$ measurements, was computed as

$$
\mathrm{S}_{\mathrm{M}}^{2}=\frac{1}{\mathrm{n}-1} \sum_{\mathrm{i}=1}^{\mathrm{n}}\left(\mathrm{X}_{\mathrm{i}}-\overline{\mathrm{X}}\right)^{2}
$$

This estimator, $\mathrm{S}^{2}$, includes the variance among the samples and the counting variance. The estimated $\mathrm{S}^{2}$ may occassionally be less than the average counting variance.

taxon - A group oí organisms constituting one of the categories or formal units in taxonomic classification (i.e., kingdom, phylum, class, order, family, genus, or species) and characterized by common characteristics in varying degrees of distinction.

\section{thermoluminescent dosimeter (TLD) - A} material that, after being exposed to beta and/or gamma radiation, emits light when processed and heated. The amount of light emitted is proportional to the amount of radiation (dose) to which the TLD has been exposed.

unconfined aquifer - An aquifer containing ground water that is not confined above by relatively impermeable rocks. The pressure at the top of the unconfined aquifer is equal to that of the atmosphere. At Hanford, the unconfined 
aquifer is the uppermost aquifer and is most susceptible to contamination from Site operations.

uncontrolled area - Area on or near a nuclear facility to which public access is not restricted.

vadose zone - underground area from the surface to the top of the water table or aquifer.

water table - Theoretical surface represented by the elevation of water surfaces in wells penetrating only a short distance into the unconfined aquifer. whole-body dose - Radiation dose that involves exposure of the entire body. Whole-body dose typically refers to external radiation exposure.

wind rose - Star-shaped diagram showing how often winds of various speeds blow from different directions, usually based on yearly averages. 
Appendix B

Applicable Standards and Permits 


\section{Appendix B}

\section{Applicable Standards and Permits}

Operations at the Hanford Site must conform to a variety of governmental standards and permits designed to ensure the biological and physical quality of the environment for either public health, ecological, or aesthetic considerations. The primary environmental quality standards and permits applicable to Hanford operations in 1991 are listed in the following tables. The State of Washington has promulgated water quality standards for the Columbia River, WAC, 173-201. The Hanford Reach of the Columbia River has been designated as Class A (Excellent). This designation requires that the water be usable for substantially all needs, including drinking water, recreation, and wildlife. Class A water standards are summarized in Table B.1. Drinking water standards promilgated by the U.S. Environmental Protection Agency (EPA) in 40 CFR 141 are summarized in Tables B.2 and B.3. Tri-Counties Air Pollution Control Authority air quality standards are shown in Table B.4. Applicable radiation standards pursuant to the Clean Air Act for sources of radionuclide emissions to the air, 40 CFR 61, are summarized in Table B.5. Environmental radiation protection standards are published in DOE Order 5400.5, "Radiation Protection of the Public and the Environment." This DOE order establishes new limits for public radiation dose and gives guidance for keeping radiation exposures to members of the public as low as reasonably achievable (ALARA). These standards are based on guidelines recommended by authoritative organizations, such as the International Commission on Radiological Protection and the National Council on Radiation Protection and Measurements. The DOE has initiated a policy for creating and implementing public radiation protection standards that are generally consistent with the standards used by the U.S. Nuclear Regulatory Commission (NRC) in regulating and licensing non-DOE nuclear facilities (i.e., nuclear power plants). Table B.5 shows the radiation standards from DOE Order 5400.5. These standards govern allowable public exposures to ionizing radiation from DOE operations.

In Order 5400.5, the DOE established Derived Concentration Guides (DCGs) that reflect the concentrations of individual nuclides in water or air that would result in an effective dose equivalent of 100 mrem per year caused by ingestion of water or inhalation of air at average annual intake rates. Table B.6 lists selected DCGs of particular interest at the Hanford Site. The DCGs are useful reference values but do not generally represent concentrations in the environment that ensure compliance with either the DOE, the Clean Air Act, or drinking water dose standards.

Permits required for regulated releases to water and air have been issued by the EPA under the National Pollutant Discharge Elimination System (NPDES) of the Clean Water Act and the Prevention of Significant Deterioration (PSD) requirements of the Clean Air Act. Also, under authority granted by the Clean Air Act, the Washington State Department of Health has issued a permit for Hanford radioactive air emissions. Permits for collecting wildlife for environmental sampling are issued by the Washington State Department of Wildlife and the U.S. Fish and Wildlife Service. Current permits are listed in Table B.7. 
Table B.1. Washington State Water Quality Standards for the Hanford Reach of the Columbia River

Parameter
Fecal Coliform
Dissolved Oxygen
Temperature
pH
Turbidity
Toxic, Radioactive, or
Deleterious Materials

Aesthetic Value
Permissible Levels
1) $\leq 100$ organisms $/ 100 \mathrm{~mL}$
2) $\leq 10 \%$ of samples may exceed 200 organisms $/ 100 \mathrm{~mL}$

$>8 \mathrm{mg} / \mathrm{L}$

1) $\leq 20^{\circ} \mathrm{C}\left(68^{\circ} \mathrm{F}\right)$ due to human activities

2) When natural conditions exceed $20^{\circ} \mathrm{C}$, no temperature increase of greater than $0.3^{\circ} \mathrm{C}$ allowed

3) Increases not to exceed $34 /(T+9)$, where $T=$ highest existing temperature in ${ }^{\circ} \mathrm{C}$ outside of dilution zone.

1) 6.5 to 8.5 range

2) $<0.5$ unit induced variation

$\leq 5 \mathrm{NTU}^{\prime \prime \prime \prime}$ over background turbidity

Concentrations shall be below those of public health significance, or which cause acute or chronic toxic conditions to the aquatic biota, or which may adversely affect any water use.

Shall not be impaired by the presence of materials or their effects, excluding those of natural origin, which offend the senses of sight, smell, touch, or taste.

(a) NTU = nephelometric turbidity units. 
Table B.2. Radiological Drinking Water Standards: U.S. Environmental Protection Agency, National Primary Drinking Water Regulations (40 CFR 141); and State of Washington, Rules and Regulations of the State Board of Health Regarding Public Water Systems (WAC 248-54)

\section{Contaminant}

Total Alpha (excluding uranium)

Combined ${ }^{226} \mathrm{Ra}$ and ${ }^{228} \mathrm{Ra}$

Radium-226 (State of Washington only)

Beta and Gamma Radioactivity

From Anthropogenic Radionuclides
Limit

$$
\begin{aligned}
& 15 \mathrm{pCi} / \mathrm{L} \\
& 5 \mathrm{pCi} / \mathrm{L} \\
& 3 \mathrm{pCi} / \mathrm{L}
\end{aligned}
$$

Annual average concentration shall not produce an annual dose from anthropogenic radionuclides equivalent to the total body or any internal organ dose greater than $4 \mathrm{mrem} / \mathrm{yr}$. If two or more radionuclides are present, the sum of their annual dose equivalents shall not exceed $4 \mathrm{mrem} / \mathrm{yr}$.

Compliance may be assumed if annual average concentrations of total beta, ${ }^{3} \mathrm{H}$, and ${ }^{91} \mathrm{Sr}$ are less than 50 , 20,000 , and $8 \mathrm{pCi} / \mathrm{L}$, respectively.

The following list provides the annual average concentrations for anthropogenic radionuclides of interest. These radionuclides are assumed to yield an annual dose of $4 \mathrm{mrem}$ to the indicated organ.

\begin{tabular}{|c|c|c|}
\hline$\underline{\text { Radionuclide }}$ & Critical Organ & Concentration, $\mathrm{pCi} / \mathrm{L}$ \\
\hline${ }^{3} \mathrm{H}$ & Whole body & 20,000 \\
\hline${ }^{14} \mathrm{C}$ & Fatty tissue & 2,000 \\
\hline${ }^{611} \mathrm{Co}$ & GI (LLI) $)^{\text {tal }}$ & 100 \\
\hline${ }^{89} \mathrm{Sr}$ & Bone & 20 \\
\hline${ }^{49} \mathrm{Sr}$ & Bone marrow & 80 \\
\hline${ }^{90} \mathrm{Sr}$ & Bone marrow & 8 \\
\hline${ }^{95} \mathrm{Zr}$ & GI (LLI) & 200 \\
\hline${ }^{45} \mathrm{Nb}$ & GI (LLI) & 300 \\
\hline${ }^{999} \mathrm{Tc}$ & GI (LLI) & 900 \\
\hline${ }^{1113} \mathrm{Ru}$ & GI (LLI) & 200 \\
\hline${ }^{1196} \mathrm{Ru}$ & GI (LLI) & 30 \\
\hline${ }^{125} \mathrm{Sb}$ & GI (LLI) & 300 \\
\hline${ }^{129} \mathrm{I}$ & Thyroid & 1 \\
\hline${ }^{131} I$ & Thyroid & 3 \\
\hline${ }^{1: 34} \mathrm{Cs}$ & GI $(S)^{(b)}$ & 20,000 \\
\hline${ }^{137} \mathrm{Cs}$ & Whole body & 200 \\
\hline
\end{tabular}
Data are taken from the National Interim Primary Drinking Water Regulations, Table IV-2A (EPA 1976).

(a) Gastrointestinal tract (lower large intestine)

(b) Stomach. 
Table B.3. Chemical Drinking Water Standards: U.S. Environmental Protection Agency, National Primary Drinking Water Regulations (40 CFR 141); and State of Washington, Public Water Supplies (WAC 248-54)

\section{Chemical \\ Constituent}

$\begin{array}{lr}\mathrm{As} & 50 \mu \mathrm{g} / \mathrm{L} \\ \mathrm{Ba} & 1 \mathrm{mg} / \mathrm{L} \\ \mathrm{CCl}_{4} & 5 \mu \mathrm{g} / \mathrm{L} \\ \mathrm{Cd} & 10 \mu \mathrm{g} / \mathrm{L} \\ \mathrm{Cr} & 50 \mu \mathrm{g} / \mathrm{L} \\ \mathrm{Cu} & 1 \mathrm{mg} / \mathrm{L} \\ \mathrm{F} & 2 \mathrm{mg} / \mathrm{L} \\ \mathrm{Hg} & 2 \mu \mathrm{g} / \mathrm{L} \\ \mathrm{NO}_{3}^{-} & 45 \mathrm{mg} / \mathrm{L} \\ \mathrm{Pb}^{-} & 50 \mu \mathrm{g} / \mathrm{L} \\ \mathrm{Se} & 10 \mu \mathrm{g} / \mathrm{L}\end{array}$

Table B.4. Benton-Franklin-Walla Walla Counties (Tri-Counties) Air Pollution Contiol Authority Ambient Air Quality Standards' ${ }^{\text {(a) }}$

$\begin{array}{cccc}\text { Parameter } & \text { Type of Standard }{ }^{b .} & \text { Sampling Period } & \text { Permissible Level } \\ \mathrm{NO}_{2} & \text { Secondary and primary } & \text { Annual average } & 0.05 \mathrm{ppmv}\end{array}$

(a) Benton-Franklin-Walla Walla Counties Air Pollution Control Authority (1980).

(b) Primary standards for ambient air quality define levels of air quality to protect the public health. Secondary standards define levels of air quality to protect the public welfare from any known or anticipated adverse effects of a pollutant. 
Table B.5. Radiation Standards for Protection of the Public from All Routine DOE Activities

\section{RADIATION DOSE LIMITS ${ }^{(a)}$}

ALL PATHWAYS [limits from DOE Order 5400.5]

The effective dose equivalent for any member of the public from all routine DOE activities' ${ }^{\text {'b }}$ shall not exceed the values given below.

\begin{tabular}{|c|c|c|}
\hline & \multicolumn{2}{|c|}{ Effective Dose Equivalent ${ }^{(\mathrm{c})}$} \\
\hline & mrem/yr & $(\mathrm{mSv} / \mathrm{yr}$ \\
\hline Routine Public Dose & 100 & (1) \\
\hline Potential Authorized Temporary Public Dose ${ }^{(d)}$ & 500 & (5) \\
\hline
\end{tabular}

DOSE TO NATIVE AQUATIC ANIMAL ORGANISMS FROM LIQUID DISCHARGES IInterim Limits from DOE Order 5400.5]

Radioactive material in liquid wastes discharged to natural waterways shall not cause an absorbed dose $^{\prime \prime \prime}$ to native aquatic animal organisms that exceeds $1 \mathrm{rad}$ per day (10 $\mathrm{mGy}$ per day).

DRINKING WATER PATHWAY ONLY [Limits from 40 CFR 141 and DOE Order 5400.5]

Radionuclide concentrations in DOE-operated public drinking water supplies shall not cause persons consuming the water to receive an effective dose equivalent greater than 4 mrem $(0.04 \mathrm{mS}, \mathrm{v})$ in a year. DOE activities shall not cause private or public drinking water systems downstream of the facility discharge to exceed the radiological drinking water limits in 40 CFR 141 (Table B.2).

AIR PATHWAYS ONLY [Limits from 40 CFR 61]

Public Dose Limit at Location of Maximum

Effective Dose Equivalent
mrem/yr
(mSv/yr)

10

Annual Air Concentration as a Consequence of

Routine DOE Activities'br

(a) Radiation doses received from natural background, residual weapons testing and nuclear accident fallout, and medical consumer product exposures are excluded from the implementation of these dose limits.

(b) "Routine DOE activities" implies normal, planned activities and does not include actual or potential accidental or unplanned releases.

(c) Effective dose equivalent is expressed in rem (or millirem) with the corresponding value in sievert (or millisievert) in parentheses.

(d) Authorized temporary annual dose limits may be greater than $100 \mathrm{mrem} / \mathrm{yr}$ (but cannot exceed $500 \mathrm{mrem} / \mathrm{yr}$ ) if unusual circumstances exist that make avoidance of doses greater than 100 mrem to the public impracticable. The $\mathrm{RL}$ is required to request and receive specific authorization from $\mathrm{DO}^{\mathrm{S}_{-}} \mathrm{HQ}$ for an increase from the routine public dose limit to a temporary annual dose limit.

(e) Absorbed dose is expressed in rad (or millirad) with the corresponding value in gray (or milligray) in parentheses. 
Table B.6. Derived Concentration Guides ${ }^{(a, b, b)}$

\begin{tabular}{|c|c|c|}
\hline Radionuclide & $\begin{array}{c}\text { Water, } \\
\mathrm{pCi} / \mathrm{L} \\
\left(10^{-9} \mu \mathrm{Ci} / \mathrm{mL}\right) \\
\end{array}$ & $\begin{array}{c}\text { Air, } \\
\mathrm{pCi} / \mathrm{m}^{3} \\
\left(10^{-12} \mu \mathrm{Ci} / \mathrm{mL}\right)\end{array}$ \\
\hline${ }^{3} \mathrm{H}$ & $2,000,000$ & 100,000 \\
\hline${ }^{14} \mathrm{C}$ & 70,000 & 500,000 \\
\hline${ }^{51} \mathrm{Cr}$ & $1,000,000$ & 60,000 \\
\hline${ }^{54} \mathrm{Mn}$ & 50,000 & 2,000 \\
\hline${ }^{60} \mathrm{Co}$ & 5,000 & 80 \\
\hline${ }^{65} \mathrm{Zn}$ & 9,000 & 600 \\
\hline${ }^{85} \mathrm{Kr}$ & $N S^{(d)}$ & $3,000,000$ \\
\hline${ }^{90} \mathrm{Sr}$ & 1,000 & 50 \\
\hline${ }^{99} \mathrm{Tc}$ & 100,000 & 2,000 \\
\hline${ }^{103} \mathrm{Ru}$ & 50,000 & 2,000 \\
\hline${ }^{106} \mathrm{Ru}$ & 6,000 & 30 \\
\hline${ }^{125} \mathrm{Sb}$ & 60,000 & 1,000 \\
\hline${ }^{129} \mathrm{I}$ & 500 & 70 \\
\hline${ }^{131} I$ & 3,000 & 400 \\
\hline${ }^{137} \mathrm{Cs}$ & 3,000 & 400 \\
\hline${ }^{144} \mathrm{Ce}$ & 7,000 & 30 \\
\hline${ }^{234} \mathrm{U}$ & 500 & 0.09 \\
\hline${ }^{235} \mathrm{U}$ & 600 & 0.1 \\
\hline${ }^{238} \mathrm{U}$ & 600 & 0.1 \\
\hline${ }^{238} \mathrm{Pu}$ & 40 & 0.03 \\
\hline${ }^{239} \mathrm{Pu}$ & 30 & 0.02 \\
\hline${ }^{240} \mathrm{Pu}$ & 30 & 0.02 \\
\hline
\end{tabular}

(a) Concentration of a specific radionuclide in water or air that could be continuously consumed or inhaled at average annual rates and not exceed an effective dose equivalent of $100 \mathrm{mrem} / \mathrm{yr}$. An exception is the limit for ${ }^{85} \mathrm{Kr}$, which is based on the skin dose limit of 5 rem from immersion in a plume.

(b) Values in this table represent the lowest, most conservative derived concentration guides considered potentially applicable to Hanford operations, and may be adjusted upward (larger) if accurate solubility information is available.

(c) From DOE Order 5400.5.

(d) NS = No standard. 
Table B.7. Environmental Permits

\section{Clean Water Act Permit}

NPDES Permit No. WA-000374-3, issued to the DOE Richland Field Office (RL) by Region 10 of the EPA, covers nonradioactive discharges to the Columbia River from eight outfalls. The following are measurements required for NPDES-permitted discharges at Hanford:

\begin{tabular}{|c|c|c|c|}
\hline \multirow[b]{2}{*}{ Measurement } & \multicolumn{3}{|c|}{ Location } \\
\hline & $\begin{array}{c}\text { 100-K Area } \\
\text { (2 discharges) }\end{array}$ & $\begin{array}{c}\text { 100-N Area } \\
\text { (5 discharges) }\end{array}$ & $\begin{array}{c}300 \text { Area } \\
\text { (1 discharge) }\end{array}$ \\
\hline Flow Rate & $\mathrm{X}$ & $\mathrm{X}$ & $\mathrm{X}$ \\
\hline Suspended Solids & $\mathrm{X}$ & $\mathrm{X}$ & $\mathrm{X}$ \\
\hline Temperature & $\mathrm{X}$ & $\mathrm{X}$ & $--^{(a)}$ \\
\hline $\mathrm{pH}$ & $\mathrm{X}$ & $\mathrm{X}$ & $\mathrm{X}$ \\
\hline Chlorine & $\mathrm{X}$ & $\mathrm{X}$ & -.- \\
\hline Oil and Grease & $\cdots$ & $\mathrm{X}$ & -- \\
\hline Heat Discharged & -- & $\mathrm{X}$ & $-\cdots$ \\
\hline Settleable Solids & $-\cdots$ & $\ldots$ & $\mathrm{X}$ \\
\hline Iron & -.- & $\mathrm{X}$ & -.. \\
\hline Ammonia & -.. & $\mathrm{X}$ & -.. \\
\hline Chromium & -.. & $\mathrm{X}$ & --- \\
\hline
\end{tabular}

(a) Dashed line indicates no measurement required.

\section{Clean Air Act Permits}

PSD Permit No. PSD-X80-14, issued to RL by Region 10 of the EPA, covers emission of $\mathrm{NO}_{\mathrm{x}}$ to the atmosphere from the Plutonium Uranium Extraction (PUREX) Plant and the Uranium Oxide ( $\left.\mathrm{UO}_{3}\right)$ Plant. No expiration date.

Radioactive Air Emission Permit No. FF-01, issued to RL by the DOH under authority granted by the Clean Air Act, covers operations on the Hanford Site having a potential to emit radioactive airborne effluents. Initially issued August 15, 1989, the permit is for a 2-year perind.

\section{Wildlife Sampling Permits}

Scientific Study or Collection Permit No. 201, issued by Washington State Department of Wildlife to Pacific Northwest Laboratory (PNL) for 1991, covers the collection of wildlife, including gamefish, for environmental monitoring purposes. Renewed annually.

Scientific Collection Permit No. 91-35, issued by Washington State Department of Fisheries to PNL for 1991 , covers the collection of food fish and shellfish for environmental monitoring purposes. Renewed annually.

Federal Fish and Wildlife Permit No. 671877, issued by U.S. Fish and Wildlife Service by U.S. Fish and Wildlife Service to PNL, covers the collection of migratory wildlife. Renewed biannually.

Copies of the regulations concerning these permits may be obtained from the following organizations:

State of Washington

Department of Ecology

Olympia, WA 98504
U.S. Department of Energy

Richland Field Office

Richland, WA 99352

U.S. Environmental Protection Agency

Region 10

1200 Sixth Avenue

Seattle, WA 98101 


\section{References}

40 CFR 61, "National Emissions Standard for Hazardous Air Pollutants; Standards for Radionuclides." U.S. Government Printing Office, Code of Federal Regulations.

40 CFR 141, "National Primary Drinking Water Regulations." U.S. Government Printing Office, Code of Federal Regulations.

Benton-Franklin-Walla Walla Counties Air Pollution Control Authority. 1980. General Regulation 80-7. Air Pollution Control Authority, Richland, Washington.

Clean Air Act. Public Law 88-206, as amended, 42 USC 7401 et seq.

Clean Water Act. Public Law 95-217, December 27, 1977, 91 Stat. 1566 and Public Law 96-148.

DOE Order 5400.5. 1990. "Radiation Protection of the Public and the Environment."

U.S. Environmental Protection Agency (EPA). 1976. National Interim Primary Drinking Water Regulations. EPA-570/9-76-003, Office of Water Supply, Washington, D.C.
U.S. Environmental Protection Agency (EPA). 1990a. National Primary Drinking Water Regulations. 40 CFR 141, U.S. Government Printing Office, Washington, D.C.

U.S. Environmental Protection Agency (EPA). 1990b. National Emission Standard for Hazardous Air Pollutants; Standards for Radionuclides. 40 CFR 61, U.S. Government Printing Office, Washington, D.C.

Washington Administrative Code (WAC) 173-201, Water Quality Standards for Waters of the State of Washington, Washington State Department of Ecology. 1982.

Washington Administrative Code (WAC) 248-54, Public Water Supplies, Washington State Department of Social and Health Services. 1983.

Washington State Department of Ecology (WDOE). 1982. Water Quality Standards for Waters of the State of Washington. Washington Administrative Code, Chapter 173-201, Olympia, Washington.

Washington State Department of Social and Health Services (WDSHS). August 1983 (Revised). Public Water Supplies. Washington Administrative Code, Chapter 248-54, Olympia, Washington. 
Appendix C

Dose Calculations 


\section{Appendix C}

\section{Dose Calculations}

The radiation dose that the public could have potentially received in 1991 from Hanford operations was calculated in terms of the "effective dose equivalent." These dose quantities are given in units of millirem (mrem) [millisievert $(\mathrm{mSv})]^{(\mathrm{a})}$ for individuals and in units of person-rem (person-Sv) for the collective dose received by the total population within an $80-\mathrm{km}(50 \mathrm{mi})$ radius of the Site. These quantities provide a way to express the radiation dose, regardless of the type or source of radiation or the means by which it is delivered. The values given in this report may be compared to standards for radiation protection (Table B.5, Appendix B). This appendix describes how the doses in this report were calculated.

Radionuclide release rates from Hanford Site activities are usually too low to be measured in offsite air, drinking water, and food crops. Therefore, in most cases, the dose calculations were based on measurements made at the point of release (stacks and effluent streams), and environmental concentrations were estimated from these effluent measurements by environmental transport models.

The transport of radionuclides from the environment to the body is predicted by empirical models of exposure pathways. These pathways account for inhalation or ingestion of radionuclides present in air, water, and foods. Radionuclides taken into the body may be distributed among different organs and retained for various times. In addition, long-lived radionuclides deposited on the ground become possible sources for long-term external exposure and uptake by agricultural products. Dietary and exposure parameters were then applied to calculate radionuclide intakes and radiation doses to the public. Standardized computer programs were used to perform the calculations. These programs contain internally consistent mathematical models that use sitespecific dispersion and uptake parameters.

(a) 1 rem $(0.01 \mathrm{~Sv})=1000$ mrem $(10 \mathrm{mSv})$.
These programs are incorporated in a master code, GENII (Napier et al. 1988a, 1988b, 1988c), which employs the dosimetry methodology described in ICRP Reports (1979a, 1979b, 1980, 1981a, 1981b, 1982a, 1982b). The assumptions and input data used in these calculations are described below.

\section{Types of Dose Calculations Performed}

\section{Revised DOE Guidance for Dose Calculations}

Calculations of radiation doses to the public from radionuclides released into the environment are performed to demonstrate compliance with applicable standards and regulations.

Beginning in 1985, the DOE required that estimates of radiation exposure to the general public be in terms of the "effective dose equivalent." The effective dose equivalent is representative of the total risk of potential health effects from radiation exposure. The adoption and use of the effective dose equivalent was previously recommended by the ICRP (1977). In addition to implementing the effective dose equivalent requirement for offsite population dose calculations, the DOE has also adopted the revised biokinetic models and metabolic parameters for radionuclides given by the ICRP for estimating radiation dose. As in the past, when concentrations of radionuclides in the environment are too low to measure, then DOE specifies that the doses are to be calculated from effluent data using environmental transport and dosimetry models.

Estimated radiation doses from DOE operations have previously been reported in terms of the dose equivalent (or simply, dose), which is a measure of the energy absorbed by tissue (rads), multiplied by a radiation quality factor, and modified 
by any other necessary factors. Under this system, standards for radiation protection were presented in terms of the critical organ dose limits and were expressed in rem (or mrem).

The calculation of the effective dose equivalent takes into account the long-term (50-year) internal exposure from radionuclides taken into the body during the current year. The effective dose equivalent is the sum of individual committed (50-year) organ doses multiplied by weighting factors that represent the proportion of the total health-effect risk that each organ would receive from uniform irradiation of the whole body. Internal organs may also be irradiated from external sources of radiation. The external exposure received during the current year is added to the committed internal dose to obtain the total effective dose equivalent. In this report, the effective dose equivalent is expressed in rem (or millirem), with the corresponding value in sievert (or millisievert) in parentheses. The numerous transfer factors used for pathway and dose calculations have been documented in GENII (Napier et al. 1988a, 1988b, 1988c).

The following types of radiation doses were estimated:

\section{1. "Boundary" Whole-Body Dose Rate} ( $\mathrm{mrem} / \mathrm{h}$ and $\mathrm{mrem} / \mathrm{yr}$ ). The external radiation dose rates during the year in areas accessible by the general public were determined from measurements obtained in proximity to operating facilities.

\section{2. "Maximally Exposed Individual" Dose}

(mrem). The maximally exposed individual is a hypothetical member of the public who lives at a location and has a postulated lifestyle such that it is unlikely that other members of the public would receive higher doses. All potentially significant exposure pathways to this hypothetical individual were considered, including the following:

- inhalation of airborne radionuclides

- submersion in airborne radionuclides

- ingestion of foodstuffs contaminated by radionuclides deposited on vegetation and the ground by both airborne deposition and irrigation water drawn from the Columbia River downstream of the $\mathrm{N}$ Reactor

- exposure to ground contaminated by both airborne deposition and irrigation water

- consumption of sanitary water derived from the Columbia River

- ingestion of fish taken from the Columbia River

- recreation along the Columbia River, including boating, swimming, and shoreline activitiess.

3. 80-km Population Doses (person-rem). Regulatory limits have not been established for population doses. However, evaluation of the collective population doses to all residents within an $80-\mathrm{km}(50-\mathrm{mi}$ ) radius of Hanford Site operations is required by DOE Order 5400.5 . The $80-\mathrm{km}(50 \cdot \mathrm{mi})$ population dose represent the summed products of the individual doses for the number of individuals involved for all potential exposure pathways.

The pathways assigned the maximally exposed individual were assumed to be applicable to the offsite population with the addition of drinking water drawn from the Columbia River. Consideration was given, however, to the fraction of the offsite population actually affected by each pathway. The exposure pathways for the population are as follows:

- Drinking Water. The cities of Richland and Pasco obtain their municipal water directly, and Kennewick indirectly, from the Columbia River downstream from the Hanford Site. A total population of approximately 70,000 in the three cities drinks water derived from the Columbia River.

- Irrigated Food. Columbia River water is withdrawn for irrigation of small vegetable gardens and farms in the Riverview district of Pasco in Franklin County. Enough food is grown in this district to feed an estimated 2,000 people. Commercial crops are also irrigated by Columbia River water in the Horn Rapids area of Benton County. 
- River Recreation. These activities include swimming, boating, and shoreline recreation. An estimated 125,000 people reside adjacent to the river within $80 \mathrm{~km}(50 \mathrm{mi})$ of the Hanford Site and are assumed to be affected by these pathways.

- Fish Consumption. Population doses from the consumption of fish obtained locally from the Columbia River were calculated from an estimated total annual catch of $15,000 \mathrm{~kg} / \mathrm{yr}$ (without reference to a specified human group of consumers).

\section{Data}

The data that are needed to perform dose calculations based on measured effluent releases include information on initial transport through the atmosphere or river, transfer or accumulation in terrestrial and aquatic pathways, and public exposure. By comparison, radiation dose calculations based on measured concentrations of radionuclides in food require data describing only dietary and recreational activities and exposure times. These data are discussed in the following sections.

\section{Population Distribution and Atmuspheric Dispersion}

Geographic distributions of the population residing within an $80-\mathrm{km}(50-\mathrm{mi})$ radius of the four Hanford Site operating areas are shown in the Hanford Site Environmental Data for Calendar Year 1991 - Surface and Columbia River (Bisping 1992). These distributions are based on 1990 Bureau of Census data (Beck et al. 1991). These data influence the population dose by providing estimates of the number of people exposed to radioactive material releases and their proximity to the points of release.

Atmospheric dispersion data are also shown in the Hanford Site Environmental Data for Calendar Year 1991 - Surface and Columbia River
(Bisping 1992). These data describe the transport and dilution of airborne radioactive material, and influence doses to the maximally exposed individual and public by estimating the amounts of radionuclides being transported through the air to specific locations.

\section{Terrestrial and Aquatic Pathways}

Important parameters affecting the movement of radionuclides within potential exposure pathways, such as irrigation rates, growing periods, and holdup periods, are listed in Table C.1. Certain parameters are specific to either the lifestyles of "maximally exposed" or "average" individuals.

\section{Public Exposure}

The potential offsite radiation dose is related to the extent of external exposure to or intake of radionuclides that are released from Hanford Site operations. Tables C.2 through C.4 give the parameters describing the diet, residency, and river recreation assumed for "maximally exposed" and "average" individuals.

\section{Dose Calculation Documentation}

The Hanford Dose Overview Panel has the responsibility for defining standard, documented computer codes and input parameters to be used for radiation dose calculations for the public in the vicinity of the Hanford Site. Only those procedures, models, and parameters defined by the Hanford Dose Overview Panel were used to calculate the radiation doses. The calculations were then reviewed by the Dose Overview Panel. Summaries of dose calculation documentation for this report are shown in the Hanford Site Environmental Data for Calendar Year 1991 - Surface and Columbia River (Bisping 1992). 
Table C.1. Food Pathway Parameters Used in 1991 Dose Calculations

\begin{tabular}{|c|c|c|c|c|c|}
\hline & \multicolumn{2}{|c|}{ Holdup, days 'al } & \multicolumn{2}{|l|}{ Growing } & \multirow{2}{*}{$\begin{array}{c}\text { Irrigation } \\
\text { Rate, } \\
\mathrm{L} / \mathrm{m}^{2} / \text { month }\end{array}$} \\
\hline & $\begin{array}{l}\text { Maximally Exposed } \\
\text { Individual }\end{array}$ & $\begin{array}{l}\text { Average } \\
\text { Individual }\end{array}$ & $\begin{array}{l}\text { Period, } \\
\text { days }\end{array}$ & $\begin{array}{l}\text { Yield, } \\
\mathrm{kg} / \mathrm{m}^{2}\end{array}$ & \\
\hline Leafy Vegetables & 1 & 14 & 90 & 1.5 & 150 \\
\hline Other Vegetables & 5 & 14 & 90 & 4 & 170 \\
\hline Fruit & 5 & 14 & 90 & 2 & 150 \\
\hline Cereal & 180 & 180 & 90 & 0.8 & 0 \\
\hline Eggs & 1 & 18 & 90 & 0.8 & 0 \\
\hline Milk & 1 & 4 & & & \\
\hline Hay & $(100)^{\mathrm{thr}}$ & $(100)$ & 45 & 2 & 200 \\
\hline Pasture & $(0)$ & $(0)$ & 30 & 1.5 & 200 \\
\hline Red Meat & 15 & 34 & & & \\
\hline Hay & $(100)$ & $(100)$ & 45 & 2 & 200 \\
\hline Grain & $(180)$ & $(180)$ & 90 & 0.8 & 0 \\
\hline Poultry & 1 & 34 & 90 & 0.8 & 0 \\
\hline Fish & 1 & 1 & -.. & -.- & --- \\
\hline Drinking Water & 1 & 1 & --- & --- & --- \\
\hline
\end{tabular}

(a) Holdup is the time between harvest and consumption.

(b) Values in ( ) are the holdup in days between harvest and consumption by farm animals.

Table C.2. Dietary Parameters Used in the 1991 Dose Calculations

Consumption, $\mathrm{kg} / \mathrm{yr}$
Maximaally
Exposed
Individual

\begin{tabular}{|c|c|c|}
\hline Leafy Vegetables & 30 & 15 \\
\hline Other Vegetables & 220 & 140 \\
\hline Fruit & 330 & 64 \\
\hline Grain & 80 & 72 \\
\hline Eggs & 30 & 20 \\
\hline Milk $^{(a)}$ & 270 & 230 \\
\hline Red Meat & 80 & 70 \\
\hline Poultry & 18 & 8.5 \\
\hline Fish & 40 & $--^{(b)}$ \\
\hline Drinking Water ${ }^{(a \prime)}$ & 730 & 440 \\
\hline
\end{tabular}

(a) Units L/yr.

(b) Average individual consumption not identified; radiation doses were calculated based on estimated total annual catch of $15,000 \mathrm{~kg}$. 
Table C.3. Residency Parameters Used in the 1991 Dose Calculations

\begin{tabular}{lcc} 
& \multicolumn{2}{c}{ Exposure, $\mathrm{h} / \mathrm{yr}$} \\
\multicolumn{1}{c}{ Maximally } \\
Parameter & $\begin{array}{c}\text { Exposed } \\
\text { Individual }\end{array}$ & $\begin{array}{c}\text { Average } \\
\text { Individual }\end{array}$ \\
Ground Contamination & 4,383 & 2,920 \\
Air Submersion & 8,766 & 8,766 \\
Inhalation & & \\
Iut & 8,766 & 8,766
\end{tabular}

(a) Inhalation rates: Adult $270 \mathrm{~cm}^{3} / \mathrm{s}$.

Table C.4. Recreational Parameters Used in the 1991 Dose Calculations

\begin{tabular}{lcc} 
& \multicolumn{2}{c}{ Exposure, $\mathrm{h} / \mathrm{yr}^{(\mathrm{a})}$} \\
Maximally \\
$\begin{array}{c}\text { Exposed } \\
\text { Individual }\end{array}$ & $\begin{array}{c}\text { Average } \\
\text { Individual }\end{array}$ \\
Sarameter & 500 & 17 \\
Bhoreline & 100 & 5 \\
Swimming & 100 & 10
\end{tabular}

(a) Assumed river water travel times from $100-\mathrm{N}$ to the point of aquatic recreation were $8 \mathrm{~h}$ for the maximally exposed individual and $13 \mathrm{~h}$ for the average individual. Correspondingly lesser times were used for other locations. 


\section{References}

Beck, D. M., B. A. Napier, M. J. Scott, A. G. Thurman, M. D. Davis, D. B. Pittenger, S. F. Shindle, and N. C. Batishko. 1991. Hanford Area 1990 Population and 50-year Projections. PNL-7803. Pacific Northwest Laboratory, Richland, Washington.

Bisping, L. E. 1992. Hanford Site Environmental Data for Calendar Year 1991 - Surface and Columbia River. PNL-8149, Pacific Northwest Laboratory, Richland, Washington.

International Commission on Radiological Protection (ICRP). 1977. ICRP Publication 26, Recommendations of the International Commission on Radiological Protection. Annals of the ICRP, Vol. 1, No. 3, Pergamon Press, Elmsford, New York.

International Commission on Radiological Protection (ICRP). 1979a. ICRP Publication 30, Part 1, Limits for Intakes of Radionuclides by Workers. Annals of the ICRP, vol. 2, No. 3/4. Pergamon Press, Elmsford, New York.

International Commission on Radiological Protection (ICRP). 1979b. ICRP Publication 30, Supplement to Part 1, Limits for Intakes of Radionuclides by Workers. Annals of the ICRP, Vol. 3, No. 1-4, Pergamon Press, Elmsford, New York.

International Commission on Radiological Protection (ICRP). 1980. ICRP Publication 30, Part 2, Limits for Intakes of Radionuclides by Workers. Annals of the ICRP, Vol. 4, No. 3/4, Pergamon Press, Elmsford, New York.

International Commission on Radiological Protection (ICRP). 1981a. ICRP Publication 30, Supplement to Part 2, Limits for Intakes of Radionuclides by Workers. Annals of the ICRP, Vol. 5, No. 1-6, Pergamon Press, Elmsford, New York.
International Commission on Radiological Protection (ICRP). 1981b. ICRP Publication 30, Part 3 Including Addendum to Parts 1 and 2, Limits for Intakes of Radionuclides by Workers. Annals of the ICRP, vol. 6, No. 2/3, Pergamon Press, Elmsford, New York.

International Commission on Radiological Protection (ICRP). 1982a. ICRP Publication 30, Supplement A to Part 3, Limits for Intakes of Radionuclides by Workers. Annals of the ICRP, Vol. 7, No. 1-3, Pergamon Press, Elsmford, New York.

International Commission on Radiological Protection (ICRP). 1982b. ICRP Publication 30, Supplement $B$ to Part 3 Including Addendum to Supplements to Parts 1 and 2, Limits for Intakes of Radionuclides by Workers. Annals of the ICRP, Vol. 8, No. 1-3, Pergamon Press, Elmsford, New York.

Napier, B. A., R. A. Peloquin, D. L. Strenge, and J. V. Ramsdell. 1988a. Conceptual Representation. Volume 1 of GENII - The Hanford Environmental Radiation Dosimetry Software System. PNL-6584, Vol. 1, Pacific Northwest Laboratory, Richland, Washington.

Napier, B. A., R. A. Peloquin, D. L. Strenge, and J. V. Ramsdell. 1988b. User's Manual. Volume 2 of GENII - The Hanford Environmental Radiation Dosimetry Software System. PNL-6584, Vol. 2, Pacific Northwest Laboratory, Richland, Washington.

Napier, B. A., R. A. Peloquin, D. L. Strenge, and J. V. Ramsdell. 1988c. Code Maintenance Manual. Volume 3 of GENII - The Hanford Environmental Radiation Dosimetry Software System. PNL-6584, Vol. 3, Pacific Northwest Laboratory, Richland, Washington. 


\section{Appendix D}

\section{RCRA and CERCLA Monitoring Documents}




\section{Appendix D}

\section{RCRA and CERCLA Monitoring Documents}

The following lists Resource Cration and Recovery Act (RCRA) ground-water monitoring publications for 1991:

- U.S. Department of Energy (DOE). 1991. Quarterly Report of RCRA Groundwater Monitoring Data for January 1, 1991 Through March 31, 1991. DOE/RL 91-26, U.S. Department of Energy, Richland, Washington.

- U.S. Department of Energy (DOE). 1991. Quarterly Report of RCRA Groundwater Monitoring Data for April 1, 1991 Through June 30, 1991. DOE/RL 91-47, U.S. Department of Energy, Richland, Washington.

- U.S. Department of Energy (DOE). 1991. Quarterly Report of RCRA Groundwater Monitoring Data for July 1, 1991 Through September 30, 1991. DOE/RL 91-57, U.S. Department of Energy, Richland, Washington.

- U.S. Department of Energy (DOE). 1992. Quarterly Report of RCRA Groundwater Monitoring Data for October 1,
1991 Through December 31, 1991. DOE/ RL 92-26, U.S. Department of Energy, Richland, Washington.

- U.S. Department of Energy (DOE). 1992. Annual Report of RCRA Groundwater Monitoring Projects at Hanford Site Facilities for 1991. DOE/RL 92-03, U.S. Department of Energy, Richland, Washington.

Below is a list of Comprehensive Environmental Response, Compensation, and Liability Act (CERCLA) groundwater monitoring publications for 1991.

- Westinghouse Hanford Company (WHC). 1991. Interim Groundwater Data Summary Report for the 1100-EM-1 Operable Unit for 1990. Westinghouse Hanford Company, Richland, Washington.

- Westinghouse Hanford Company (WHC). 1991. Groundwater Data Quality Report for the 1100-EM-1 Operable Unit for First and Second Quarter 1991. Westinghouse Hanford Company, Richland, Washington. 


\section{Appendix E}

\section{Radionuclides Detected by Gamma Spectroscopy (Gamma Scan)}




\section{Appendix E}

\section{Radionuclides Detected by Gamma Spectroscopy (Gamma Scan)}

One of the more common forms of radiation is gamma radiation. Gamma radiation is emitted by many radionuclides. Gamma spectroscopy, sometimes called a gamma scan, is used in the environmental surveillance program to detect the presence of the radionuclides shown in Table E.1. These radionuclides may be natural or result from Hanford activities. They include activation products formed by the absorption of a neutron by a stable element and fission products that occur following fission (splitting) of nuclear fuel radionuclides like ${ }^{235} \mathrm{U}$ or ${ }^{239} \mathrm{Pu}$. These radionuclides may not be discussed in the main body of this report if they are below detection levels.

Table E.1. Radionuclides Analyzed by Gamma-Spectroscopy

\begin{tabular}{l}
\multicolumn{1}{c}{ Radionuclide } \\
\hline Beryllium-7 \\
Sodium-22 \\
Sodium-24 \\
Potassium-40 \\
Manganese-54 \\
Cobalt-58 \\
Cobalt-60 \\
Iron-59 \\
Zinc-65 \\
Zirconium/Niobium-95 \\
Molybdenum-99 \\
Ruthenium-103 \\
Ruthenium-106 \\
Antimony-125 \\
Iodine-131 \\
Cesium-134 \\
Cesium-137 \\
Barium/Lanthanum-140 \\
Cerium-141 \\
Cerium/Praseodymium-144 \\
Europium-152 \\
Europium-154 \\
Europium-155
\end{tabular}

Europium-155
Symbol

${ }^{7} \mathrm{Be}$

${ }^{22} \mathrm{Na}$

${ }^{24} \mathrm{Na}$

${ }^{40} \mathrm{~K}$

${ }^{54} \mathrm{Mn}$

${ }^{54} \mathrm{Co}$

${ }^{60} \mathrm{Co}$

${ }^{59} \mathrm{Fe}$

${ }^{65} \mathrm{Zn}$

${ }^{95} \mathrm{Zr} / \mathrm{Nb}$

${ }^{99} \mathrm{Mo}$

${ }^{103} \mathrm{Ru}$

${ }^{106} \mathrm{Ru}$

${ }^{125} \mathrm{Sb}$

${ }^{131} \mathrm{I}$

${ }^{134} \mathrm{Cs}$

${ }^{137} \mathrm{Cs}$

${ }^{140} \mathrm{Ba} / \mathrm{La}$

${ }^{141} \mathrm{Ce}$

${ }^{144} \mathrm{Ce} / \mathrm{Pr}$

${ }^{152} \mathrm{Eu}$

${ }^{154} \mathrm{Eu}$

${ }^{155} \mathrm{Eu}$ 


\section{Distribution}

No. of

Copies

\section{Hanford Site Contractors}

Pacific Northwest Laboratory (PNL)

Westinghouse Hanford Company (WHC)

Hanford Environmental Health

Foundation ( $\mathrm{HEHF}$ )

Kaiser Engineers Hanford (KEH)

DOE, EPA, State and Federal Agencies, Other DOE Sites, Other Companies, or Nuclear Facilities

DOE Richland Operations Office (RL) DOE Headquarters (DOE-HQ)

Environmental Protection Agency (EPA)

Washington State Agencies

Oregon State Agencies

Other DOE Sites and Federal Agencies,

Other Companies or Nuclear Facilities

Libraries, Universities, and

Schools

226
No. of

Copies

Public and Elected Officials

25
Professional Organizations, Public Interest Groups, and

Native American Officials

Farmers Contributing Samples for Analyses

Owners and/or Administrators of Islands in the Hanford Reach of the Columbia River (Excluding DOE)

Community-Operated

Environmental Surveillance

Station Managers

Interested Citizens and Others 

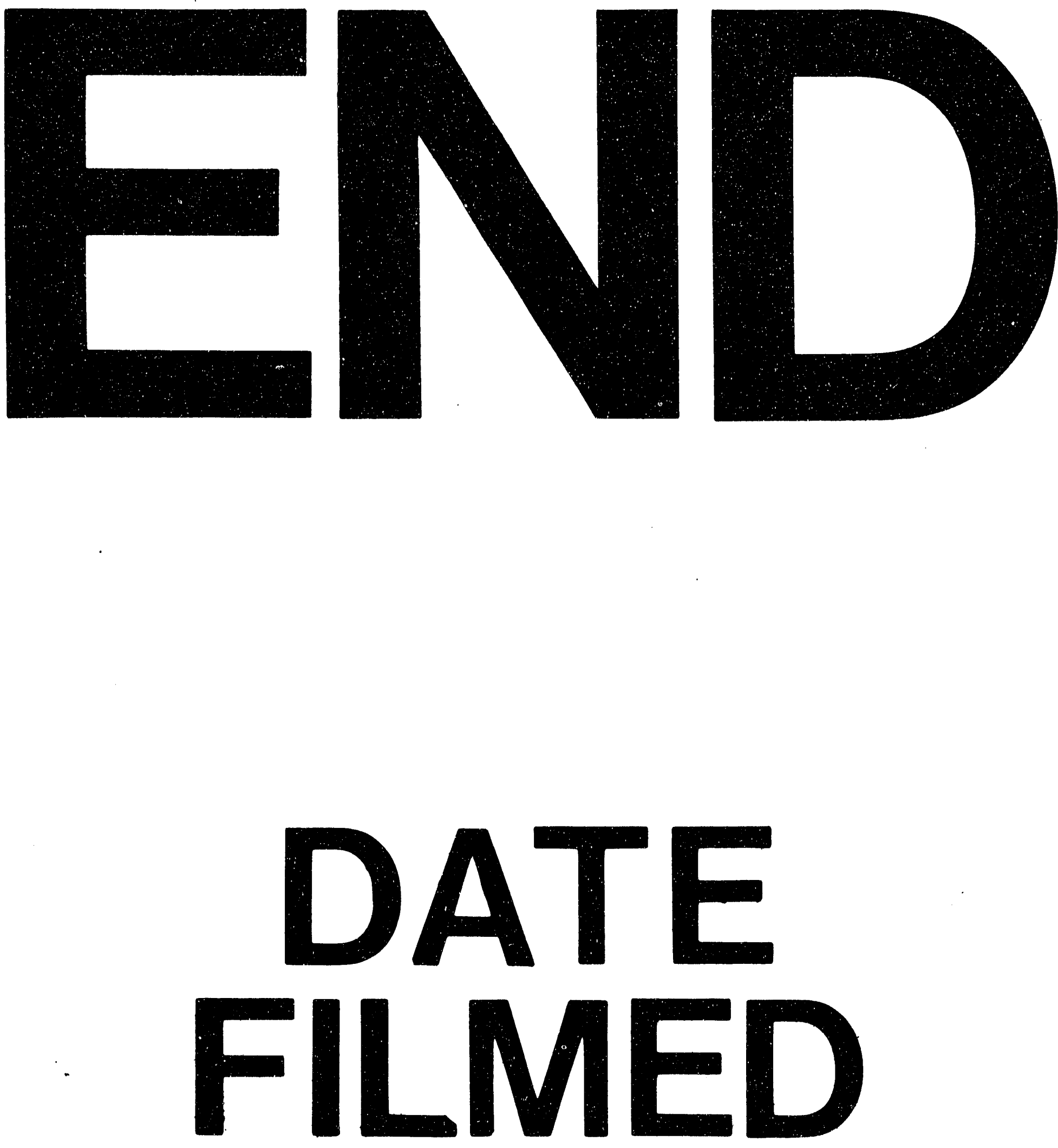

1

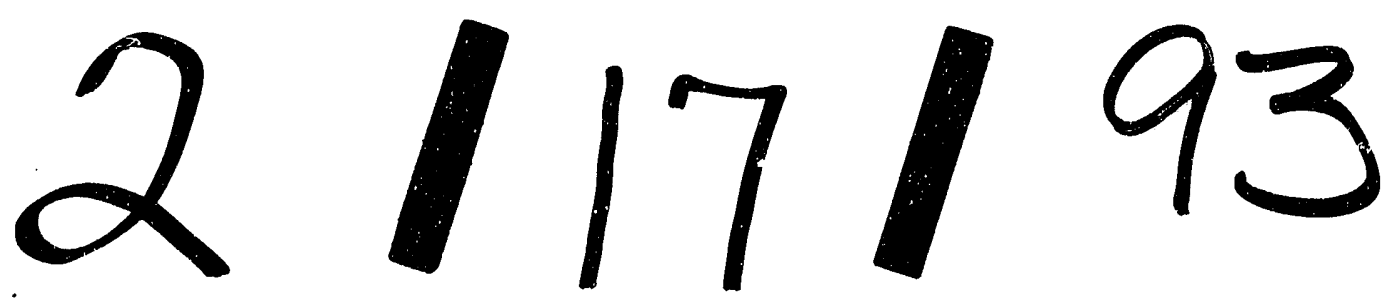


